\title{
Revalidatie van gedragsdeviaties bij cerebraal gestoorden : een medisch-psychologisch onderzoek naar mogelijkheden van gedragstherapie
}

Citation for published version (APA):

Schuerman, J. A. (1977). Revalidatie van gedragsdeviaties bij cerebraal gestoorden : een medischpsychologisch onderzoek naar mogelijkheden van gedragstherapie. [Doctoral Thesis, Maastricht University]. Rijksuniversiteit Limburg. https://doi.org/10.26481/dis.19770923js

Document status and date:

Published: 01/01/1977

DOI:

10.26481/dis.19770923js

Document Version:

Publisher's PDF, also known as Version of record

Please check the document version of this publication:

- A submitted manuscript is the version of the article upon submission and before peer-review. There can be important differences between the submitted version and the official published version of record.

People interested in the research are advised to contact the author for the final version of the publication, or visit the DOI to the publisher's website.

- The final author version and the galley proof are versions of the publication after peer review.

- The final published version features the final layout of the paper including the volume, issue and page numbers.

Link to publication

\footnotetext{
General rights rights.

- You may freely distribute the URL identifying the publication in the public portal. please follow below link for the End User Agreement:

www.umlib.nl/taverne-license

Take down policy

If you believe that this document breaches copyright please contact us at:

repository@maastrichtuniversity.nl

providing details and we will investigate your claim.
}

Copyright and moral rights for the publications made accessible in the public portal are retained by the authors and/or other copyright owners and it is a condition of accessing publications that users recognise and abide by the legal requirements associated with these

- Users may download and print one copy of any publication from the public portal for the purpose of private study or research.

- You may not further distribute the material or use it for any profit-making activity or commercial gain

If the publication is distributed under the terms of Article $25 \mathrm{fa}$ of the Dutch Copyright Act, indicated by the "Taverne" license above, 


\section{REVALIDATIE VAN GEDRAGSDEVIATIES}

\section{BIJ \\ CEREBRAAL GESTOORDEN}

(Rehabilitation of Behaviour Disorders

in Patients suffering from Cerebral Damage).

J. A. SCHUERMAN

with an English summary

mit einer Zusammenfassung in Deutscher Sprache avec un résumé en Français 


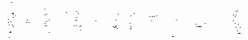

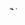




\title{
REVALIDATIE VAN GEDRAGSDEVIATIES
}

\author{
BIJ \\ CEREBRAAL GESTOORDEN \\ (Rehabilitation of Behaviour Disorders \\ in Patients suffering from Cerebral Damage).
}

Een medisch-psychologisch onderzoek naar mogelijkheden van gedragstherapie.

ACADEMISCH PROEFSCHRIFT

TER VERKRIJGING VAN DE GRAAD VAN DOCTOR IN DE GENEESKUNDE AAN DE RIJKSUNIVERSITEIT LIMBURG, OP GEZAG VAN DE RECTOR MAGNIFICUS DR. H. A. TIDDENS, HOOGLERAAR IN DE FACULTEIT DER GENEESKUNDE, VOLGENS BESLUIT VAN HET COLLEGE DER DEKANEN IN HET OPENBAAR TE VERDEDIGEN OP VRIJDAG 23 SEPTEMBER 1977 DES NAMIDDAGS OM 4 UUR PRECIES, IN DE AULA DER UNIVERSITEIT.

door

\section{J. A. SCHUERMAN}

geboren te Goes 


\section{PROMOTOR: $\quad$ PROF. DR. J. J. C. B. BREMER CO-PROMOTOR: PROF. DR. P. E. BOEKE REFERENTEN: DR. B. NIEUWENHUIJSE DR. J. MOL}

.The day may not be far off when behavioral disorders will be treated not in hospitals or mental hygiene clinics but in comprehensive "learning centers", where clients will be considered not patients suffering from hidden psychic pathologies but responsible people who participate actively in developing their own potentialities". 


\section{VOORWOORD}

Bij de voltooiing van dit proefschrift maak ik graag van de gelegenheid gebruik een woord van erkentelijk heid te richten tot allen die aan het tot stand komen hebben bijgedragen.

In de eerste plaats moet hier genoemd worden dat deze studie alleen mogelijk is geweest dankzij de coöperatie van vele tientallen patiënten, die tijdens hun opname in het revalidatiecentrum aan diverse onderzoeken hebben deelgenomen. Mijn gedachten in deze heb ik proberen te verwoorden in de opdracht en het motto van deze dissertatie.

Hooggeleerde Bremer, het valt mij moeilijk mijn dank jegens $U$ in woorden uit te drukken. Uw kritische bijsturing op het pad der revalidatiepsychologie was onmisbaar. Dat ik onder uw leiding de diverse denkbeelden heb mogen verwoorden beschouw ik als een voorrecht. De vele kontakten, die hierbij hebben plaats gevonden, waren voor mij steeds een stimulans tot verdergaan. De wijze waarop $U$ tenslotte het manuscript hebt doorgewerkt heeft mijn bijzondere waardering.

Hooggeleerde Boeke, hoewel de geografische afstand, althans in Nederland bezien, nauwelijks groter had kunnen zijn, bestond bij mij de indruk dat er op enig ander gebied van distantie geen sprake was. Integendeel, bij voortduring was tijdens onze gesprekken bij mij de zekerheid aanwezig, dat $U$ vanuit $U$ w ervaring volledig begrip had voor theoretische en praktische problemen, die in een klinische setting kunnen optreden.

Zeergeleerde Nieuwenhuyse, de kennis die $U$ mij op het gebied van het experimentele design en de cognitiepsychologie in korte tijd wist over te dragen alsmede Uw kanttekeningen en aanvullingen bij deze studie zijn van grote waarde geweest. UW samenwerking in deze heeft naar mijn gevoel onze reeds jarenlang bestaande relatie eens te meer bestendigd.

Zeergeleerde $\mathrm{Mol}$, het deed mij bijzonder veel genoegen dat $\mathrm{U}$ naast $\mathrm{U} w$ deelname aans ons zeer recent aangevangen research projekt eveneens $U w$ kritische aandacht vanuit neuro-fysiologische visie op deze studie heeft willen richten.

Hooggeleerde Fordyce, dankzij Uw publikaties en later schriftelijke en persoonlijke kontakten heeft $\mathrm{U}$ aan mij de weg gewezen voor de toepassing van leertheorie in de revalidatie.

U, Hoogleraren, Lektoren en Leden van de wetenschappelijke staf van de Fakulteit der Saciale Wetenschappen der Gemeentelijke Universiteit te Amsterdam, betuig ik gaarne mijn dank voor het onderwijs, dat ik door colleges, praktika en bewerken wan doktoraal onderwerpen van $U$ heb mogen ontvangen. Met name de benaderings: wijze van Prof. Dr. J. Barendregt heeft mij later bij studie en werk bij voortduring geïnspireerd.

De directeur van de Lucasstichting voor Revalidatie te Hoensbroek, de heer C. W. de Ruijter en de dirigerend geneesheer van het Revalidatiecentrum „Hoensbroeck", de revalidatie-arts $\mathrm{H}$. J. te Riele ben ik bijzonder erkentelijk voor de bijstelling van allerlei ideeën en methodieken vanuit het standpunt van de medische revalidatie en vanuit organisatorische- en beleidsaspekten.

Aparte aandacht wil ik hierbij besteden aan alle leden van afdeling IV van het revalidatiecentrum te Hoensbroek.

De samenwerking met de heer $P$. Bakker, teamleider en revalidatie-arts van het eerste uur, zal mij steeds voor ogen staan als een open diskussierelatie. De vele gesprekken met hem hebben er in niet geringe mate toe bijgedragen, dat allerlei probleemstellingen en denkbeelden helder en scherper geëxpliciteerd konden worden. 
De algemene gedachtengang. dat revalidatie voor een deel opnieuw leren zou kunnen inhouden, werd mede opgenomen door de heer C. Pons, in 1973 assistent-revalidtie-arts van afdeling IV, en drie jaren later voortgedragen door mevrouw P. Hoenderdaal. Beide artsen ben ik zeer erkentelik voor hun spontane wijze van reageren en hun bereidheid tot uitproberen van een nog onvolledig werkmodel.

Nadrukkelijk wil ik stilstaan bij de aktiviteiten van de onderwijsdeskundige mevrouw Van Pelt en de onder haar ressorterende therapie-assistenten. De grote bereidheid lot het meedenken en meewerken inzake de op te zetten funktie-restauratie moet met grote wardering genoend worden. De verwardiging van materiaal en het uivveren van de trainingen was een niet te onderschatten opgave die door hen allen met groot enthousiasme en nawkeurigheid werd gerealiseerd.

Een bijzonder woord wan wardering zow ik willen uitspreken voor zuster Gadiot en het verplegendenteam, dat in staat was nast hun disciplinegebonden aktiviteiten woh ruimte te bieden voor werk zamheden welke voortkwamen uit een totaal andere denkwereld.

Eenzelfde witspraak geldt in niet mindere mate voor:

de logopedisten mevrouw $\mathrm{C}$. Sipkema-Van Geel, pater B. wan Wel en mejuffrouw M. Beekmans:

de fysiotherapeuten de heren J. Halfens en J. Kurvers;

de arbeidstherapeuten mejuffrouw $W$. Heystek, de heer $K$. wan Rooden en mejuflirow $\mathrm{T}$. Lutgerink:

de maatschappelijk werkers, de heren J. Kupers, J. Vernooy en mejuffrouw $M$. Hennekens:

de bezigheidstherapeuten mejufrouw $M$. Brekelmans en mevrouw Van Helden; de sport en spel-therapeuten de heren H. Dobbelstein en T. Grendel.

Zij allen waren bereid de hun aangeboden ideeen, instrumenten en modifikatietechnieken binnen eigen vakgebied uit te proberen en hun steun te verlenen aan nieuwe ontwik kelingen.

De dames M. Ploum, C. Kleykers-Roukens en M. Eussen verdienen de hoogste lof voor werkzaamheden van zeer uiteenlopende aard. Zij waren niet slechts in staat daadwerkelijk mee te werken bij programma-uitwoering en de verzameling van diverse empirische gegevens, maar bowendien hebben zij het gepresteerd dit manuscript op een accurate wijze te typen, ondanks een toch reeds volbezette dagtaak.

Mijn collega's de heren F: Riga en J. Koekkoek en de stagiaires, de dames E. Hermens en $K$. Beers ben ik zeer erkentelijk voor hun samenwerking tijdens de realisering van deze studie en het geduld dat zij in verscheidene opzichten moesten opbrengen in verband met de overbezeting van andere leden van de afdeling psychologie.

Het kontakt met diverse medewerkers van de Medische Fakulteit te Maastricht heb ik altijic zeer op prijs gesteld. In het bijzonder denk ik hierbij aan de samenwerking met Drs. L. Strijbosch, die de statistischebewerking en komputerverwerking heeft geleid, en de regelmatige gesprekken met de leden van de capaciteitsgroep Medische Psychologie.

Hoewel mijn ouders helaas geen getuige konden zijn van de realisatie van deze studie, meer ik hier mijn grootste waardering uit te moeten spreken voor hum opvoeding die mij nast vele, hier niet te noemen levenswaarden, ook de waarde vant een academische opleiding heef doen ervaren.

In niet geringe mate gaat mijn dank uit naar mijn wrouw, die mij niet slechts op direkte, maar vooral op indirekte wijze heeft bijgestaan in de tot standkoming van deze dissertatie. 


\section{INHOUDSOPGAVE}

1. Introduktie: Naar een revalidatie-leermodel . . . . 11

1.1. Algemene inleiding . . . . . . . . . . . . . . . . . . . . 12

1.2. Voorgeschiedenis . . . . . . . . . . . . . . . . . . 13

1.2.1. Uitgangssituatie . . . . . . . . . . . . . . . . 13

1.2.2. De "probleemgroep". . . . . . . . . . . . . . 14

1.2.3. Inventarisatie der problematiek van patienten met contusio cerebri...................... . . 15

1.2.4. Literatuurverkenning. . . . . . . . . . . . . . 16

1.2.5. Behoefte aan "basisfilosofie". . . . . . . . . 17

1.2.6. Samenvatting. . . . . . . . . . . . . . . . 18

13. Revalidatie en leren . . . . . . . . . . . . . . . . . . . 18

1.3.1. Inleiding . . . . . . . . . . . . . . . 18

1.3.2. Pijlers van de revalidatie . . . . . . . . . . . . . . 20

1.3.3. Leerparadigmata in de revalidatie . . . . . . . . . . . 23

1.3.4. Keuze van verklarings-en behandelingsmodel in de revalidatie . . . . . . . . . . . . . . . . 25

1.3.5. Het revalidatie-leetproces bezien vanuit het operante
paradigma . . . . . . . . . . . . . . . . . . 26

1.3.5.1. Krisishantering. . . . . . . . . . . . 28

1.3.5.2. Assimilatie van handicap. . . . . . . . . . . . 29

1.3.5.3. Motivatie tot (her)leren . . . . . . . . . . . 31

1.3.5.4. Beklijving van handicap-adekwaat gedrag . . . . 32

1.3.6. Samenvatting . . . . . . . . . . . . . . . . . 33

2. Een voorlopige revalidatiestrategie. . . . . . . . . 35

2.1. Contusio-problematiek bezien vanuit een neobehavioristisch referentiekader. . . . . . . . . . . . . . . . . . . . 36

2.1.1. Inleiding. . . . . . . . . . . . . . . . . . 36

2.1.2. Inventarisatiebronmen . . . . . . . . . . . . . . . . 36

2.1.3. Resultaten van de inventarisatie . . . . . . . . . . . 39

2.1.4. Bespreking der resultaten van de inventarisatic. . . . . . 42

2.1.5. Samenvatting . . . . . . . . . . ... . . . . 46

2.2. Samenstelling van een voorlopige assessmentprocedure . . . . . 47

2.2.1. Inleiding. . . . . . . . . . . . . . . . . . . . . . 47

2.2.2. De psychologische onderzoekprocedure (PO). . . . . . 48

2.2.2.1. Samenstelling . . . . . . . . . . . . . . . 48

2.2.2.2. Assessmentuitvoering . . . . . . . . . . . . . 49

2.2.3. De gedragsobservatieschaal Contusio Cerebri (GOCC) . , 50

2.2.3.1. Samenstelling van de items. . . . . . . . . . . 50

2.2.3.2. Assessment door gedragsobservatoren . . . . . . 51

2.2.3.3. Assessmentuitvoering . . . . . . . . . . . 52

2.2.4. Samenvatting". . . . . . . . . . . . . . . . . 54

2.3. Opzet van een voorlopige modifikatiestrategie . . . . . . . . . 54

2.3.1. Inleiding . . . . . . . . . . . . . . . . . . 54

2.3.2. Situatie en probleemgedrag .. . . . . . . . . . . . . 55

2.3.2.1. Situaties warin gedragsdeviaties gesignaleerd kunnen worden. . . . . . . . . . . . . . 55

2.3.2.2. Konstatering van gedragsdeviaties. . . . . . . . 58 
2.3.3. Gedragstherapeutische technieken t.b.v. de modifikatie van probleemgedrag

\section{Uitvoering en evaluatie van een experimentele revalida-} tiestrategie

3.1. Uitvoering van modifikatie en assessment

3.1.1. Inleiding

3.12 Gedragsworming bij zero-gedrag

3.1.3. Toename van gedrag . . . . . . . . . . . 70

3.1.4. Behoud wan gedrag onder toenemende stimuluscomplexiteit 71

3.1.5. Reduktie van excessief gedrag . . . . . . . . . . . 72

3.1.6. Samenvatting . . . . . . . . . . . . . . 74

3.2. Statistische bewerking der Gedragsobservatieschal Contusio Cerebri

3.2.1. Inleiding . . . . . . . . . . . . 74

3.2.2. Dataverzameling. . . . . . . . . . . . . 75

3.2.3. Bewerking der gegevens. . . . . . . . . 76

3.2.3.1. Zwakheden in schaalkonstruktie . . . . . . 76

3.2.3.2. Inter- en intrabeoordelaarsbetrouwbaarheid. . . . 78

3.2.4. Overwegingen inzake faktoranalyse. . . . . . . . 79

3.2.5. Bespreking der resultaten . . . . . . . . . . . . . . . 80

3.2.6. Samenvatting . . . . . . . . . . . . 81

3.3. Evaluatie van modifikaties ter vorming, toename en reduktie van gedrag.

3.3.1. Inleiding

3.3.2. Datapresentatie . . . . . . . . . . . . . . 82

3.3.3. Gedragsvorming. . . . . . . . . . . . . . . 83

3.3.4. Toename van gedrag . . . . . . . . . . . . . . . . 89

3.3.5. Gedragsreduktie . . . . . . . . . . . . . . . . . . 97

3.3.6. Bespreking der resultaten . . . . . . . . . . . . 113

3.3.6.1. Rekenkundige bewerking der resultaten . . . . 114

3.3.6.2. Statistische bewerking der resultaten. . . . . 115

3.3.7. Modifikatie van gedragsdeviaties bij patiënten, die buiten de kategorie contusio cerebri vallenı. . . . . . . . 116

3.3.8. Samenvatting . . . . . . . . . . . . . . 118

3.4. Evaluatie van de modilikatieprocedure ter gedragsbehoud onder toenemende stimuluscomplexiteit

3.4.1. Inleiding.

3.4.2. Assessment en modifikatie.

3.4.3. Samenstelling en kondities van experimentele en kontrolegroep.

3.4.4. Vergelijking van training versus geen trainingkondities.

3.4.4.1. Formulering der hypothesen

3.4.4.2. Toetsing der hypothesen . . . . . . . . . . 130

3.4.5. Bespreking der resultaten . . . . . . . . . . . . . 131

3.4.6. Samenvatting . . . . . . . . . . . . . 132 


\section{Heroriëntatie}

4.1. Assessment. . . . . . . . . . . . . . . . . 136

4.1.1. Inlëding. . . . . . . . . . . . . ..... 136

4.1.2. Assessment wan gedragstekorten in de premorbide situatie " 138

4.1.3. Assessment van gedragstekorten in de klinische testsituatie " 139

4.1.3.1. Probleemstelling ............... 139

4.1.3.2. De neuropsychologische benadering van Mark . . 142

4.1.3.3. De cognitiepsychologische benadering van Guilford 146

4.1.3.4. Ontwikkelingspsychologische benaderingen. . . . 148

4.1.3.5. Overzicht . . . . . . . . . . . . . . . 148

4.1.4. Assessment van gedragstekorten in klin ische observatiesituatie

4.1.4.1. Probleemstelling . . . . . . . . . . . . 149

4.1.4.2. Samenstelling van enkele gedragsobservatieschalen. 152

4.1.4.3. Aansluiting tussen test en gedragsobservatieschaal. 156

4.1.5. Assessment van gedragstekorten in de nabehandelingssituatie 159

4.1.6. Assessment van gedragstekorten in de thuissituatie . . . . 160

4.1.7. Assessment van gedragsbelemmeringen . . . . . . . . . 161

4.1.7.1. Probleemstelling . . . . . . . . . . . . . . . 161

4.1.7.2. Gedragsaspekten ter observatie . . . . . . . . , 162

4.1.8. Samenvalting! . . . . . . . . . . . . . . . . . 163

4.2. Modifikatie. . . . . . . . . . . . . . . . . . 164

4.2.1. Inleiding. . . . . . . . . . . . . . . . . . . . . . 164

4.2.2. Modifikatie van gedragstekorten uit de premorbide situatie. 165

4.2.3. Modifikatie wan gedragstekorten vanuit de klinische testsituatie . . . . . . . . . . . . . . . . . . . . 165

4.2.3.1. Probleemstelling . . . . . . . . . . . . . . . 165

4.2.3.2. Het effekt van funktietrainingen. . . . . . . . . 166

4.2.3.3. Indeling naar theoretische uitgangspunten . . . 167

4.2.3.4. Indeling nar praktische uitgangspunten . . . . . 170

4.2.4. Modifikatie van gedragstekorten vanuit de klinische observatiesituatie . . . . . . . . . . . . . . . . . . 176

4.2.4.1. Probleemstelling . . . . . . . . . . . . . . . 176

4.2.4.2. Gedragskorrektie naar methodiek . . . . . . . . 177

4.2.5. Modifikatie van gedragstekorten in denabehandelingssituatie 181

4.2.6. Modifikatie van gedragstekorten in de thuissituatie . . . 183

4.2.7. Modifikatie wan gedragsbelemmeringen . . . . . . . . . 186

4.2.7.1. Probleemstelling. . . . . . . . . . . . . . 186

4.2.7.2. Reduktie van excessief gedrag in de diverse siluaties 186

4.2.8. Samenvatting . . . . . . . . . . . . . . . . 192

\section{Naar een revalidatie-leerproces . . . . . . . . . . 195}

5.1. Overwegingen inzake assessment. . . . . . . . . . . . . . . 196

5.1.1. Inleiding. . . . . . . . . . . . . . . . . . . . . 196

5.1.2. Assessment van gedragstekorten in de klinische testsituatie. 196

5.1.2.1. Algemene zienswijze. . . . . . . . . . . . . . 196

5.1.2.2. Ontwerp van een funktietaxonomie. . . . . . . 197

5.1.2.3. Van ontwerp naar operationalisering. . . . . . . 200

5.1.3. Assessment van gedragstekorten in de klinische obsërvatiesituatie 
5.1.4. Assessment van gedragstekorten in andere kriterimmsituaties

5.1.5. Integratic van funkties en wardigheden ter assessment. . 205

5.1.6. Assessment van ged ragsbelemmeringen . . . . . . . . . 206

5.1.7. Samenvatting.................. 209

5.2. Overwegingen inzake modifikatie . . . . . . . . . . . . 210

5.2.1. Inleiding . . . . . . . . . . . . . . . . . . . . 210

5.2.2. Modifkatie van gedragstekorten... . . . . . . . . 210

5.2.3. Modifikatie van gedragsbelemmeringen . . . . . . . . 212

5.2.3.1. Terugblik . . . . . . . . . . . . . . 212

5.2.3.2. Bestissingsprocedure . . . . . . . . . . 213

5.2.4. Samenvatting. . .. . . . . . . . . . . . . . 217

5.3. Conceptual framework" . . . . . . . . . . . . . 2 217

5.3.1. Inleiding. . . . . . . . . . . . . . . . . . . 217

5.3.2. Praktische realiseringsmogelijkheden . . . . . . . . 218

5.3.2.1. Poging tol konkretisering van leermodel. . . . . 218

5.3.2.2. Poging tot integratie van ziekte-en leermodel. . 220

5.3.3. Research in de revalidatie . . . . . . . . . . . . . . . 222

5.3.3.1. Algenene overwegingen . . . . . . . . . 222

5.3.3.2. Nabeschouwing. . . . . . . . . . . . . . . 224

5.3 .4 . Samenvatting . . . . . . . . . . . . . . 225

6. Algemene samenvattingen . . . . . . . . . . . . 227

6.1. Summary. . . . . . . . . . . . . . . . . . . . . . . . 228

6.2. Zusammenfassung. . . . . . . . . . . . . . . . . 233

6.3. Résumé . . . . . . . . . . . . . . . . . . . 238

6.4. Samenvatting. . . . . . . . . . . . . . . . . . . 243

Referenties.

\section{Bijlagen}

Bijlage 1 Gedragsobservatieschaal Contusio Cerebri(GOCC)-Aanwijzingen voor de beoordelaar - ltems . . . . . . . . . . . . . 258

Bijlage 2 Voorbewerkingstabellen inzake GOCCascores. Verzameling 1 (dec. 1975) en verzameling 2 (dec. 1976) . . . . . . . . . 263

Bijlage 3 Inter-en intrabeordelarsbetrouwbaatheidscoefficient inzake GOCC Verzameling 1 (dec. 1975) en verzameling 2 (dec. 1976)

Bijlage 4 Verzameltabel inzake gedragsvorming, gedragstoename en gedragsreduktie

Bijlage 5 Toetsing van de procedures ter gedragsvorming, gedragstoename en gedragsreduktie . . . . . . . .

Biflage 6 Verzameltabel inzake behoud van gedrag onder toenemende stimuluscomplexiteit

Bijlage 7 Toetsing van de procedure tot gedragsbehoud onder toenemende stimuluscomplexiteit 
HOOFDSTUK 1

\section{INTRODUKTIE}

Naar een revalidatie-leermodel 


\subsection{Algemene inleiding}

Een eerste doel van een revalidatieprograma lijkt te zin: het (opnieuw) doen optreden van een bepaald gedrag (met een bepaalde regelmat, sterkte enz.) in een omgeving, waar dit verondersteld wordt op te moeten treden. Deze omgeving is in eerste instantie het revalidatiecentrum zelf. De ontwikkeling van nieuw gedrag veronderstelt een leerproces en dit kan slechts gerealiseerd worden indien de kondities voor dit leren in de persoon en/of omgeving a anwezig zijn. Het leren van nieuw gedrag zal niet of trager verlopen, indien en naarmate kondities in persoon en/ of omgeving tegenwerken. Een van deze tegenwerkende faktoren bestaat uit aktueel gedrag, dat incompatibel is met het aan te leren gedrag, als dat aktuele gedrag bovendien voor patiënt en/of omgeving een zodanig bekrachtigende waarde heeft dat het aan te leren gedrag absoluut geen kans heeft om op te treden. De kans hierop is des te groter naarmate het nieuwe gedrag minder bekrachtiging ondervindt, hetgeen zondermeer veelal het geval is. Als tweede doelstelling zou derhalve konstatering en eliminatie van deze blokkades in de nieuwe gedragsvorming kunnen worden gezien. Deze blokkades kunnen optreden in de persoon, in de revalidatie-omgeving, in het thuismilieu en eveneens in processen in het organisme zelf. De principes van gedragsvorming bij gedragstekorten en de opheffing van belem meringen bijblokkades in het leerproces gelden in alle fasen van de revalidatie.

Wanneer een gehandicapte patiënt bijvoorbeeld een depressie in het revalidatiecentrum heeft verwerkt, maar thuis door allerlei omgevingsinvloeden weer in deze depressie terugvalt, dan is het revalidatieprogramma mis/ukt, tenzij er verdere aktiviteiten worden ondernomen. Een revalidatieprogramma lijkt beperkt te zijn in cle mate, waarin het de niet-therapie-omgeving kan beinvloeden, teneinde de waarschijnlijkheid van optreden van revalidatie-adek waat gedrag te verhogen. Alle inspanning is weinig zinvol als de patiënt, thuisgekomen, terugvalt in revalidatieinadekwat gedrag. Om deze weinig zinvolle inspanning te voorkomen, dient speciale aandacht besteed te worden aan revalidatiebevestigende reakties in dit thuis- of werkmilieu. Daarmee is de derde revalidatiedoelstelling aangegeven: het ondersteunen van nieuw gevormd gedrag in het thuismilieu en de eliminatie van faktoren, die gedragsbeklijwing tegenwerken. Het nieuwe, adekwate gedrag moet immers met name op (kunnen) treden in de leefwereld van de ontslagen patient, anders kan men zich de inspanning beter besparen.

De vorming van nieuw gedrag, de eliminatie van gedragsbelemmeringen en de beklijving van nieuw gedrag in het thuismilieu vergen een behoorlike inspanning, een afstemming en coördinatie van alle werkers in de revalidatie op patiẻnt en op elkat. In vele gevallen zall dit er op neerkomen, dat de diverse therapeuten, maar ook het thuismilieu een nieuw gedrag t.a. . de patient moeten gaan ontwikkelen. De noodzakelijke gedragsverandering bij deze revalidatiemedewerkers en personen uit het thuismilieu vereist een bijzondere aandacht. Het ontwikkelen van procedures die deze gedragsverandering mogelijk maken en verder ondersteunen wordt als vierde revalid tiedoelstelling gezien.

De drievoudige gedragsmodifikatie (bij patient, de medewerkers in de revalidatie en de personen in het thuismilieu) lijkt een uitermate gekompliceerd, marar desalniettemin noodzakelijk leerproces te zijn, wazrbij alle onderdelen regelmatig moeten worden bijgesteld en doorlopende evaluatie behoeven. Als vijfde en laatste doelstelling wordt derhal ve een kontinue empirische wetenschappelijke ondersteuning van alle gedragsmodifikatieprocedures aangevoerd.

Het opnieuw leren heeft dus niet slechts betrekking op de patiënt, maar eveneens op het personeel in het centrum en het thuismilieu. Het leerproces moet niet slechts 
optreden in het revalidatiecentrum, maar moet ook daarbuiten worden gekon. tinueerd. Het leerproces behoeft een voortdurende bijsturing, evaluatie en verdere afstemming op gestelde doelen.

Uitgaande wan een nadere precisering van deze leerprocessen bijdiverse kategorieen van personen en in diverse situaties kunnen de voorwaarden tot leren, de leermethoden, de doelstellingen, de vorm, de organisatie van het centrum en de externe kontakten buiten het centrum worden gestruktureerd.

Het is de doelstelling van deze studie om bovenstaande gedachtengang in theorie en praktijk te expliciteren en d.m.v. empirische toetsing te ondersteunen in de hoop en verwachting dat naast de medische en paramedische aktiwiteiten ruim baan gemaakt kan worden voor .revalidatie als leerproces".

\subsection{Voorgeschiedenis}

\subsubsection{Uitgangssituatie}

Het "klimaat" waarin deze studie kon ontstaan, is te kenschetsen met"

1e. De jeugd van het centrum. In 1970 werd het centrum. dat voorheem een verpleegtehuis was, als revaludatie-instituut geopend. Niet alleen de staf, maar in feite elk personeelslid was bezield wan de gedachte eigen ideeën en initiatieven te ontplooien om "hun" centrum en "de" revalidatie te helpen opbouwen. Hoewel aanvankelijk de stroom van ideeèn en initiatieven leidde tot een veelheid aan richtingen, bleek deze zich gelleidelijk aan te kanaliseren binnen duidelijker beddingen.

2e. Eigen gerichtheid. Dankzij wellicht een technische voorgeschiedenis ging onze interesse hoofdzakelijk uit naar die gebieden in de psychologie, welke zich enigszins konden beroepen op empirisch wetenschappelijke ondersteuning. De aanwezigheid van empirisch geverifieerde leerwetten richtte de keuze wat betreft therapeutische interventie op de gedragstherapie en stimuleerde tot het zoeken naar mogelijk heden juist deze gedragstherapie ook in de rewallidatie toe te kunnen passen.

3e. De revalidatie zelf. Uitgangspunt van deze studie is de visie, dat een der pijlers van de revalidatie het ,opnieuwleren" representeert en wel bezien vanuit leertheoretisch kader. De geleidelijke ontwikkeling van deze visie betekende dat niet slechts het medisch handelen, mar eveneens het handelen vanuit het zgn. leermodel zijn plaats ging vinden binnen het totaal der revalidatie-aktiviteiten. Hierdoor konden vanuit leerprincipes diverse gedragstherapeutische toepassingsmogelijkheden gerealiseerd worden ten behoeve van revalidanten.

4e. De probleemgroep. Zoals vaker in de loop der geschiedenis is gebleken, krijgt de gedragstherapie in een setting alleen een reële kans bij een moeilijke of vergeten groep patiënten (Ayllon 1968). Pas indien verscheidene thertapieen op deze groep tevergeefs geprobeerd zijn, krijgt de gedragstherapeut - die alles op een minder humane wijze zou bekijken - een kans. "Probleempatienten " zijn er in een grote verscheidenheid aanwezig in de revalidatic, maar in de groep der patiënten met contusio cerebri in het bijzonder.

Se. Last but not least wordt het team genoemd, dat gecoördineerd door de revalidatie-arts, de bereidheid, interesse en fexibiliteit heeft opgebracht een 
nieuwe benaderingswigze in hun toch al overbelaste aktivireiten te incorporeren. Hoewel in eerste instantie wat aarzelend en voorzichtig, werd de "draad" geleidelijk aan door verscheidene teamleden opgenomen en trachtte ieder op zijn beutt toepassingsmogelijkheden te vinden binnen het eigen werkterrein.

\subsubsection{De ,probleemgroep"}

In de jaren 1970-1973 manifesteerde zich de groep van patiënten met contusio cerebri ats een speciale probleemgroep binnen de revalidatie. In de aard van de aandoeningen die in het algemeen ter revalidatie werden aangeboden, voltrok zich geleidelijk een verandering. Enerzijds leek er een vermindering op te treden van het aantal patiènten met hemiparese, multiple sclerose e.d., terwijl er anderzijds een toerime ontstond van het aantal aangeboden patiënten met dwarslesie en contusio cerebri.

Terwijl over de revalidatie van dwarslesiepatiënten reeds vele publikaties het licht zagen en er zelfs specialal daarop gerichte tijdschriften bestonden, beperkte de literatu ur over patiënten met hersenletsel zich, althans in Nederland, vrijwel tot puur medische zaken qua diagnostiek en behandeling. Overigens worden deze zaken ook op het medische vlak tot nu toe niet uitputtend behandeld. Een oorzaak hiervan is mede het feit dat het begrip "contusio" zeer wijd is en gepaard gaat met een eindeloze variatie van symptomen. "Het is onmogelijk een beschrijving te geven van de symptomen van de contusio cerebri" (Van "t Hooft, 1975 p. 52) en „er bestaat geen specifieke behandeling hiertegen. Het komt erop neer dat een spontane genezing moet worden afgewacht, enerzijds door een zo zorgvuldig mogelijke verpleging anderzijds door de profyluxe en zo nodig de behandeling van komplikaties" (Van 't Hooft, 1975 p. 66).

Voor een revalidatiecentrum betekende dit dat het patienten kreeg aangeboden op basis van zeer onduidelijke behandelingsindikaties. Een prognose inzake algemene levensk ans was meestal nog wel te geven; wat betreft echter het herstel van de fysieke en nog meer van de psychische funkties was dit uiterst moeilijk. Er bestond geen overzichtelijke diagnostische procedure ten aanzien van diverse funktionele stoornissen.

Tijdens de revalidatiebehandeling moesten herhaaldelijk koerswijzigingen aangebracht worden op basis van onduidelijke informatie en op basis van een volledig gemis aan een te volgen strategie. Voorzover er spake was van enige behandeling was dit een zak van trial and error, watarbij de error in de meerderheid was.

De hierboven gesignaleerde toestand noodzaakte tot bezinning op eigen handelen. Teneinde te trachten in de algehele situatie rondom de patiënten met contuso cerebri enige struktuur te brengen werd op 20 augustus 1973 in het revalidatiecentrum een studie- en werkgroep geformeerd, samengesteld wit een arts, klinisch psycholoog, fysiotherapeut, logopedist, arbeidstherapeut en verpleegkundige. De doelstelling van deze werkgroep was tweeledig:

1e. Interne inventarisatie van de contusio-problematiek wia de bestudering van 25 statussen van ontslagen patiënten met contusio cerebri. lledere deelnemende discipline werd verzocht vanuit eigen gezichtpunt mogelijke kriteria te signateren inzake diagnostiek en therapie en te letten op lacunes in strategie en rapportering.

2e. Externe inventarisatie van de contusio-problematiek. Een aantal instituten en personen waarvan aangenomen kon worden dat deze zich met de behandeling van hersentraumata bezighielden, werden benaderd. Te weten: werkgroepen in 
Nederland, ziekenhuismaurologen, huisartsen en matschappelijk werkenden in

de regio Zuid-Limburg.

Daamaast werd en literatutustudie ondernomen inzake de diagnostiek en behandeling van de patiënten met contusio cerebri.

\subsubsection{Inventarisatie der problematiek van patiënten met contusio cerebri}

le. Bestudering van de statussen leverde de volgende bevindingen op (Bakker 1974):

a. Fysiotherapie: Uit teamverslagen is het verloop van de fysiotherapievorderingen niet te halen. Na enkele maanden verschuift het aksent van het verslag nat psychosociale problemen.

b. Arbeidstherapie: Van een algemeen vastgesteld programma is zelden sprake. Nazorg komt in de verslaggeving weinig an de orde. De rol van de arbeidstherapie is gericht op motorisch gebied en niet op het terrein van observatie of algemene begeleiding.

c. Medisch: Inkonsistente berichtgeving in akute fase, dutur coma wordt weinig vermeld. Inkonsistentie t.a.w. verslaggeving teambespreking en in ontslagbrieven door wisselende notulist. Therapie is somatisch gericht. Vage bloemlezingen over het gedrag, waarin woorden als "agressief" en "initiatiefloos" veel worden gebezigd. Over premorbide gedragsstruktuur blitk weinig bekend, evenals over de follow up. Zeer wisselende verbliffsduur die niet korreleert met de ernst van fysiek en/of psychisch letsel

d. Psychologie: Uit de teamverslagen komt een subjektief onbevredigd en bevredigd behandelde groep naar voren. De onbevredigd behandelde groep wordt als minder "gemotiveerd" en als meer .atgressief" omschreven. De uitspraken gedaan tijdens de teambesprekingen waren zeer gevarieerd. Niet minder dan 120 adjektiva konden worden vastgesteld. Gebruikte diagnostische procedures zijn beperkt tot algemene intelligentie (WAIS), concentratie (Bourdon), geheugen (Benton) en perceptie (Frostig).

2e. Kontakten buiten het centrum.

a. Kontakten met werkgroepen in Nederland. Uit de schriftelijke en mondelinge kontakten tijdens de inventarisatieperiode, werd de indruk verkregen dat dezk groepen op ongeveer gelijk niveau stonden met de eigen werkgroep "Hoensbrouck".

b. Kontakten met ziekenhuizen en neurologen in de regio Zuidalmburg leverden als resultaat op:

- de motorische uitval bij de contusio werd als a-specifiek omschreven. Als grove indeling bleek het meest gangbaar, de indel ing na lok alisatie van de in werking wan het trauma in de zin van occipital, frontalallet.

- Zo men al van het contusio-syndroom kon spreken dan zou dit toch bepald kunnen worden door het psychisch disfunktioneren.

- uit het doornemen van 25 contusio-statussen in een ziekenhuis konden slechts onvolledige gegevens betrokken worden.

Er was slechts in $20 \%$ van het a antal gevillen EEG of laboratorium-onderzock verricht, terwijl juist deze onderzoekingen volgitas deskundigen voor diagnostiek en therapie wezenlijk zijn vanwege hun prognostische waarde met name op lange termijn, dus belangrijk voor de revalidatie.

- Frontale beschadiging zou - volgens deze statusverslagen - meer psychische stoomissen veroorzaken.

c. Kontakten met nazorg. 
- een onslagprocedure met regeling van nazorg werd slechts in de helft van de gevallen gevolgd. Deze bestond uit: gesprekken met de familie om deze voor te bereiden op het ontsllag van de patient, maatschappelijk werk werzoeken verdere begeleiding te verzorgen, on tslagbrief aan arts, het leggen van kontakten met GMD-GAB-SPD en overdracht aan dagverblijven verzorgen.

- vaak blijkt dat herintegratie in gezin en werk mislukt. De patiënt blijkt zo veranderd te zijn, dal de omgeving niet weet hoe zij hierop moeten inspelen. Maar al te vaak valt een totale ontwrichting van het gezin te signaleren.

- Het maatschappelijk werk lijkt niet geprepareerd te zijn woor de begeleiding van de ontslagen patiënt met contusio cerebri en zijn gezinsleden. In persoonlijke kontakten met maatschappelijk werk kwam af en toe naar voren dat men nogal moeite onderwond met het zich in de persoon van de gehandicapte (en zeker in die van de contusio) te verplaatsen. „Het leek alsof men te doen had met geheel andere mensen dan warmee men gewend was te werken".

\subsubsection{Literatuurverkenning}

Bij de opgave de meest relewante literatuurbronnen te vinden die vanuit een psychologisch referentiekader de problematiek benaderen, leverde een schriftelijk kontakt met de Temple University Philadelphia Pennsylvania een goed spoor. Onder auspiciên van de American Psychological Association werd aldaar in 1970 een literatuuronderzoek gepubliceerd (Glenn, Snelbecker en Mason 1970).

Dit onderzoek had tot doel via literatuurstudie te weten te komen in hoeverre diverse disciplines betrokken waren bij hersenbeschadigingen. Deze disciplines waren: klinische psychologie, pedagogiek, neurologie, pediatrie, huisartsengeneeskunde, psychiatrie, revalidatie- en schoolpsychologie. Per discipline werden ca. 7 recente boeken bestudeerd, waarbijgelet werd op een drietal kriteria: mate van behoefte aan diagnostiek, geïnteresseerdheid in de revalidatie pogingen tot herscholing en herintegratie in de maatschappij bij de patiënt met hersenbeschadiging. De auteurs van het rapport kwamen tot de volgende konklusie: „dat van genoemde disciplines, in feite de revalidatie de meeste interesse toont in gestandaardiseerde psychologische diagnostiek in kombinatie met gedragsobservatieschalen en rapporteringen uit het dagelijkse leven. De diagnoses variëren van „brain damage” tot gedetailleerde neurofysiologische stoornissen en psychofunktionele defektlokalisaties. Er is een diversiteit aan planning variërende van algemene tot zeer gedetailleerde leerprogramma's. Pogingen tot herscholing en herintegratie in het milieu zijn aanwezig".

Het rapport signaleert verder de volgende problemen:

1e. De relatie hersenen-ged rag is zo complex dat het uiterst moeilijk is vast te stellen, welke funkties er al dan niet zijn aangetast. Bezoekers wan symposia e.d. gaan vaak teleurgesteld naaz huis, aangezien het vakjargon zo specialistisch is dat de aanwezige disciplines elkaar niet begrijpen.

2e. In de meeste settings lijken diverse specialisten vanuit diverse disciplines en vanuit diverse uitganspunten te werken. Glenn c.s. onderscheiden drie groeperingen:

a. de groep die zich met name richt op de ontwik keling van de gestandaardiseerde diagnostische strategieën t.b.v. de determinatie van de relatie hersenengedrag.

b. de neurofysiologische groepen.

c. de groep die betrokken is bij revalidatieplanning en uitvoering van trainingsen onderwijsprogramma's. 
3e. Interdisciplinaire kommunikatiestoonissen en het gemis aan een duidelijke basisfilosofie werden gezien als de oorzaken van het uitblijen van duidelijke behandelingsplannen ter behandeling van hersentraumata.

Gegeven Glenn"s literatuurbevindingen zou het zoekveld van de relevante literatuur dus beperkikunnen worden tot publikathes vanuit het gebied van de revalidatie zelf. Deze konklusie leidde tot de selektie van literatuur uit zgn. Rehabilitation Abstracts van 1973 $/ / m$ 1976, en tot informatiewerving bijeen tiental universiteiten in de USA met een revalidatie-afdeling. Bovendien leek het noodzakelijk om te werken vanuit éen algemeen geaksepteerd referentiekader, teneinde kommunikatiestoornissen binnen het team te voorkomen.

\subsubsection{Behoefte aan "basisfilosofie"}

Deze behoefte alan of eventueel de noodzaak van éen referentiekader welke door Glenn c.s. werd gesignaleerd, dringt zich zowel in theorievorming alsook in de dagelijkse praktijk van de revalidatie steeds meer op.

1e. Over het algemeen blijken omschrijvingen van hel begrip revalidatie alles omvattend te willen zijn en ondanks lange of puntige formulering. blijven ze toch te vaag.

2e. In 1975 ontstond het rapport "Model Centrum" (Van Rooyen 1976) waarin o.a. deze basisfilosofie onder de loep werd genomen. Het was een redilijk doorwrocht stuk, maar de kritieken die er op volgden, kwamen steeds weer terug op het onvermogen van de samenstellers éen algememe gedachtengang te formuleren, en daaruit konklusies voor de werkzaamheden te trekken.

3e. In het revalidatiecentrum "Hoensbroek" ontstond naar aanleiding van dit rapport een studiegroep "Revalidatiefilosofie" waarvan tot op dit moment niet duidelijk is of de inspanning wan deze groep een nuttig rendement zal hebben.

4e. Binnen een centrum varieert de denkwijze per afdelingsteam en binnen elk team weer per teamlid, maar al deze variaties worden zelden geëxpliciteerd.

Het gehele ,bedrijf" loopt of lijkt soepel te verlopen, zolang ieder teamlid zelfstandig op eigen territorium mag funktioneren. Komt men echter tot een poging om de eigen denk- en handelwijze te expliciteren, teneinde bijvoorbeeld een nieuw probleemgebied grondiger aan te pakken, dan blijkt dat ieder zijn eigen "geloof" hanteert. Dan pas komen de verschillende meningen, opvattingen en werk wijzen naar voren en dreigt men in het slop te geraken, waarvoor de studie der Temple University waarschuwt (Glenn 1970).

Een team van deskundigen dat een speciale patiëntengroep in diverse aspekten wil begeleiden, moet echter gesteund zijn in zijn wijze van handelen door een algemeen geaksepteerd referentiekader. Om echter deze basisvisie te doen ontstaan, lijkt het zinvoller niet tot diskussie over te gaan, maar een geheel andere weg in te slaan. Het denken over een revalidatiewijze en het effektueren van deze gedachtengang is - althans wolgens leertheoretische principes - in beide opzichten ungedrag" resp. covert en overt gedrag. Om een gedragsverandering te bewerkstelligen werd en wordt valk te veel waarde toegekend aan het gesprek als het medium bij uitstek. Intussen is uit evaluatieonderzoek van psychotherapie gebleken, dat dit stellig niet zo maar zondermeer kan worden aangenomen. Integendeel, er zijn aanwijzingen dat vele gedragsveranderingen eerder d.m. v. konditioneringsvormen wordei bewerkstelligd en dat ook in de zgn. verbale therapie konditioneringselementen aan wezig zijn (Kanfer en Philips 1970 p.371). Om gedragsverandering te realiseren dient men tenminste kennis te hebben van deze principes en deze ook systematisch en 
doelbewust te hanteren. Dit geldt waarschijnlijk eveneens voor het bewerkstelligen van een gemeenschappelijke basisflosofie. Deze principes komen elders in deze studie uitgebreid ter sprake. Het is hier niet de plaats om dus een "handreiking" te verrichtien die ons naar deze zo gewenste( ?) gemeenschappelijkheid van denken, zou kunnen voeren.

Hier zij slechts de problematiek rondom de basisfilosofie gesignaleerd.

\subsubsection{Samenvatting}

In het voorgalande werd een schets gegeven van de voorgeschiedenis en uitgangssituatie die ten grondslag lag aan deze studie.

1. In eerste instantie werd zowell bij direktie als personeel een bereidheid en enthousiasme gekonstateerd om in het centrum effektieve revalidatiemogelijkheden te realiseren. Er bestond echter geruime onzekerheid omtrent het gehele revalidatiegebeuren, hetgeen ondermeer tot uiting kwam in een sterke behoefte aan een basisfilosofie. Dit enthousiasme en deze onzekerheid resulteerden in een veelvoud aan ideeên, stromingen, visies, filosofieën en aktiviteiten.

2. Indien in zulk een situatie nog een nieuwe visie wordt gepresenteerd dan kan deze nieuweling, of een plaats krijgen naast andere visies, of volledig afgewezen worden of overgenomen worden. De eerste mogelijkheid lijkt het meest waarschijnlijk, de laatste daarentegen vrijwel uitgesloten, tenzij deze visie zich richt op een ".probleemgroep" waar niemand goed raad mee weet. Wanneer er dan "per ongeluk" enkele suksessen geboekt worden, lijkt er althans een eerste bereidheid tot overname gevormd.

3. Deze bereidheid tot overname $k$ wam verder tot uitdrukking in een bezinning op de problematiek rondom de patiënten met contusio cerebri. Er werd een werk en studiegroep geformeerd, die enkele belangrijke informaties opleverde:

a. De therapie en de bewerking wan gegevens, bleek een tamelijk inkonsistente aangelegenheid te zijn.

b. De behandeling was hoofdzakelijk somatisch gericht, terwijl men toch de indruk had dat, met name psychische faktoren, de problematiek bepaalden.

c. Een literatuurstudie, die suggereerde dat men voor een eventuele oplossing, zich zou dienen te oriënteren op publikaties vanuit revalidatiecentra in het buitenland en met name vanuit de USA.

4. Mede dankzij deze bezinning op eigen werk wijze $\mathrm{k}$ wam een diskussie rond een mogelijk nieuwe revalidatiegedachte op gang. Deze studie zal in de volgende bladzijden verslag geven van deze ontwikkeling in theoretisch en praktisch opzicht.

\subsection{Revalidatie en Leren}

\subsubsection{Inleiding}

De ontwikkeling van principes en procedures warmee men tracht een proces te verklaren of te veranderen, wordt grotendeels verklaard door het model dat men ondersteunt. Indien men als voorbeeld neemt de poging om ,inadek wat" gedrag van de mens in interaktie met de medemens te verklaren en te wijzigen, dan lijkt dit model aansluiting te moeten vinden bij de ,persoonlijkheidstheorie" danwel de .mensvisie" die men aanhangt. De eerste opvattingen inzake psychopathologie żagen anomalieën wan menselijk gedrag als beïnvloed door "boze geesten". De behandeling die hierop volgde, was dan ook gericht op hun ".uitdrijving". 
Hippocrates was een der eersten die het woord "bezeten" anders kodeerde. Hij verving het demonisch concept door het woord "ziekte" en de behandeling werd voltrokken d.m.v. dieet, hydrotherapie, aderlating en andere methoden.

Hoewel de psychologische methoden gaandeweg deze eerste pogingen tot wijzigin. gen van deviant gedrag vervingen, bleef de analogie met het , ziektemodel" lange tijd voortbestaan. Herin bleven dus gedragsuitingen, die door de omgeving als deviant werden gekodeerd, gezien als uiting van een dieperliggende oorzaak. De kodering van Hippocrates veranderde nauwelijks en werd "geestesziekte".

Volgens Bandura (1970 p.2) blijft in onze tijd een kwasi-ziektemodel gehanteerd: „Het deviante gedrag blijft gezien als een symptoom warbij, vanwege deze dieperliggende oorzaak, uitdrukkelijk gewaarschuwd wordt tegen symptoombehandeling. De oorzaak van deviantie word gezocht in een groot a antal faktoren als "verdrongen impulsen", "psychische complexen", "Iatente tendenties", "zelfdynz" miek" en andere benamingen die doen denken an duivels van vroegere tijden. Zo te zien is er weinig veranderd. Door het blijven hanteren van het ziektemodel, namelijk door uiterlijk warneembare devianties toe te schrijven aan een innerlijk in het organisme schuilende oorzaak, werd - aldus vervolgt Bandura - alleen het woord "demon" vervangen door "psychische energie". Ook de behandeling bleef gericht op de uitbanning van geesten d.w.z. niet op het probleem zelf, maar op de veronderstelde interne ,agents" die uitgedreven moeten worden door "thatharsis", "afreageren", "het verwerven wan inzicht door een uitgebreid interpretatie-proces". Direkte modifikatie van het zgn. symptoomgedrag wordt niet slechts als ineffektief; maar als buitengewoon gevaarlijk gezien, aangezien dit "werkelijk gerichte behandeling" in de weg zou staan en het symptoom toch, eventueel na tijdelijke afwezigheid, in een andere worm en in ernstiger mate weer terug zou komen.

Preoccupatie met interne respons producerende krachten resulteerde in een verwarlozing van externe variabelen. Een organisme dat volledig bepaald zou zijn van „binnenuit" moet ongevoelig zijn voor omgevingsstimuli en voor de gevolgen wan zijn aktiviteiten. Een dergelijk organisme zal niet lang voortbestaan", aldus Bandura (1970 p.3.). Gegeven het feit dat de mens in zijn totaliteit veel meer is dan wie dan ook ooit zal kunnen verwoorden, zal bij het verklaringsmodel van het menselijk funktioneren, dat hier zal worden gehanteerd noodzakelijkerwijs een sterke reduktie van de nimmer te benaderen werkeligheid worden doorgevoerd.

"Menselijk gedrag houdi in, een aantal met elkaar in relatie staande en elkaar kontrolerende systemen" aldus Bandura (1970 p.62) die het gedrag bepaald ziet door:

1e. externe stimulussituaties

2e. interne informatieverwerkende processen en koderingssystemen

3e. externe respons bek rachtigende feedbackprocedures

Aan deze visie van Bandura valt low te voegen:

$4 \mathrm{e}$. het niveau watr het organisme door leerprocessen via een voortdurende interaktie met zijn ongeving op weet te funktioneren.

De relaties tussen deze kontrolerende systemen kunnen weergegeven worden als: $\mathrm{S} \rightarrow \mathrm{O} \rightarrow \mathrm{R} \rightarrow \mathrm{K} \rightarrow \mathrm{C}$ (Kanfer F.H. en Philips J S. 1970 p.54)

Het gedrag ( $R$ ) van de mens wordt bepadd door de voorafgaande situatie of de stimulusconfiguratie (S) die inwerkt en verwerk $₫$ wordt door het organisme (O), de gevolgen of de konsekwenties op dit gedrag zelf (C) en van de aard der relatie tussen $R$ en $C$, de kontingentie ( $K$ ).

Er bestaan diverse verklaringsmodellen die alle een verschillend aksent platsen op de relatieve in $R$. Deze verklaringsmodellen worden ook waak weergegeven in de vorm valn 
paradigmata. Voor een nadere verklaring moet werwezen worden naar handboeken op dil gebied. Inzake leertheorie in het algemeen zij verwezen naar Deese J. and Hulse S. (1967) wat betreft gedragstherapie naar de Moor W. en Orlemans J.W. (1972). Voor defnities inzake veel gebruikte en essentiele concepten in lleertheorie en gedragstherapie kan ten overvloede worden geattendeerd op Linschoten J. (1964 p.396-399) of De Groot A.D. (1959) waar de definitie van "gedrag" aan de orde komt. De term "leren" wordt wellicht het duidelijkst omschreven door Hilgard E.R. (1956 p.3) of door Lundin R.W. (1967 p.265). Een zekere basiskennis inzake leertheorie wordt in het nawolgende verondersteld.

Ongeacht het relatieve alksent op de kontrolerende systemen en onalhankelijk van het verkozen paradigma, bestaat er over het algemeen een consensus inzake de opvatting dat het merendeel van het menselijk gedrag geleerd is.

In deze paragraf wordt vooral ingegaan op het leren bij de gedragsvorming in het revalidatie-gebeuren. Maar all te veel wordt voorbijgegaan aan deze rol van het leren in de revalidatie, waardoor een breed stuk van potentiele mogelijkheden in de revalidatie gewoon niet wordt gerealiseerd. Dit tekort is te bezien als een ingebouwde handicap in de revalidatie en is ongeveer te vergelijken met de blinde die de kreupele weer probeert te leren lopen. Uit de diversiteit van de leerparadigmata zal een paradigma gekozen moeten worden, dat de meeste perspektieven biedt voor de populatie wan patiënten die ter revalidatie worden aangeboden. Binnen dit behandelingsmodel verdienen de hierin verdiskonteerde leerprincipes de aandacht. Tensllotte moeten de behandelingsmogelijkheden vanuit dit gekozen behandelingsmodel in thet kort worden aangegeven en verduidelijkt. Met andere woorden: Vanuit het meest effektief beoordeelde leerparadigma zal het revalidatieproces naar toepassingsmogelijkheden en werkwijzen worden geanalyseerd.

\subsubsection{Pijlers van de revalidatie}

De zogenamam clientêle wan de medische revalidatiecentra bestaat op de eerste plaats unt mensen die als konsekwentie van een lichamelijke handicap een funktioneel nadeel hebben in het verrichten van allerlei taken en aktiviteiten waarmee ze in hun leefwereld worden gekonfronteerd. In het onlangs verschenen rapport inzake het revalidatiecentrum (Van Rooyen 1976) wordt de revalidant gedefinieerd als de "tijdelijk of blijvend primair motorisch gehandicapte, die kampt met funktie- en inwoegingsstoornissen voortkomend uit zijn primaire handicap, en die de bereidheid heeft zich te revalideren".

Het revalidatieproces wordt vervolgens gedefinieerd als: "een complex van onderling samenhangende en zoveel mogelijk op de individuele postrevalidatieverwachtingen afgestemde aktiviteiten, dat wordt vastgesteld vanuit een multifunktionele bendering van de revalidant door een team van in revalidatie gespecia liseer den en dat wordt uitgevoerd in een volledig samenspel tussen revalidanten het team met als uiteindelijk doel: de revalidant in staat stelten een optimale graad van zellstandigheid en welzijn te bereiken om zoveel rollen in zijn leven te vervullen als in zijn omstandigheden mogelijk zijn en anderszijds zujn lewen zo weinig mogelijk gekonditioneerd te doen zijn door het bestaande lichazmsgebrek": Zo gedefinieerd zijn de aktiviteiten voor zowel revalidant als centrum in twee gescheiden terreinen op te splitsen, namelijk:

le. Het beperken, verminderen, verlangzamen of elimineren van de fysieke handicap. Deze aktiviteiten lijken hoofdzakelijk besloten te liggen in het medisch taken pakket. De behandelingen van lysieke handicaps, per traditie een essentielle lunktie van de revalidatie, zijn te zien als het manipuleren wan de 
O-variabelen. Aangezien deze studie zich wat betreft de $\mathrm{O}$-variabelen beperkt tot de behandeling van psychische funktiestoornissen zal op de behandeling van de fysieke handicap in de revalidatie niet verder worden ingegaan, hoewel ook op dit gebied de leertheorieên toepasbaar zijn.

2e. Exn complex van aktiviteiten gericht op post-revalidatieverwachtingen inzake zelfstandigheid en het (opnieuw) vervullen van talrijke rollen zodanig dat betrokkene weer opgenomen kan worden in de maatschappij met een optimaal niveau van funktioneren binnen de handicap. Dit betekent een on wik kelen van nieuw gedrag, tengevolge van de handicap en de verandere levenssituatie.

Te Riele H. (1975-1) vergelijkt de revalidant met het kind dat vanaf zijn geboorte een lange weg moet gaan om met behulp van velen geleidelijk aan een volwassen mens te worden. Zo staat eveneens de gehandicapte door het verlies van diverse funkties voor een nieuwe situatie, een nieuw uitgangspunt van waruit hij opnieuw moet leren leven. Het revalidatieproces is op deze wijze bezien een opnieuw leren, waarbij revalidant, hulpverleners, thuismilieu en de hele maatschappij betrokken dienen te worden. Uirgaande van een nadere precisering van dit leerproces binmen de revalidatie kumen de voorwgarden tot leren. de leermethoden, de doelstellingen, de vorm, de organisatie van het centrum en de externe kontakten buiten het centrum worden gestruktwreerd".

In een artikel "Revalidatie" wordt ook t.a.v. de huisarts dit revalidatie-leerproces opnieuw beklemtoond (Te Riele H. 1975-2).

Ook Bakker P. (1976) drukt zich op soortgelijke wijze uit:

„De bekende omschrijvingen van het begrip revalidatie geven ons weinig houvast. In een steeds weer zich opdringende wens om allesomvattend te zijn, blijven ze, lang of puntig geformuleerd, toch te vaag. Wij tenderen naar een haast oversimplistisch uitgangspunt: Revalideren is een opmieuw leren. Aan revalidatie gaat iets vooraf, een ziekte of een ongeval, dat de geleidelijke groei, het geleidelijk leren doorbreekt. De mens ondergaat een vaak sprongsgewijze, plotselinge verandering en zo ook zijn omgeving. Het bestaande interaktiepatroion muteert. Wanneer we het zo zouden durven benaderen. word revalidarie een leerproces; een leerproces re voltrekken aam de persoon èn zijn omgeving, een opnieuw leren vanuil een ander, wieuw en nog ombekend staripuni".

Te Riele en Bakker zijn overigens de eerste revalidatie-artsen in Nederland die zich als zodamig weten op te stellen en hierdoor een uitgesproken positie innemen en uitdrukkelijk "kleur bekennen".

Ze zijn hierbij in het goede gezelschap van Fordyce W.E. (1971 - 2) where can be little doubt that the major change in Rehabilitation since the Princeton Conference of 1958 is the emergence of intervention strategies based on learning principles. In order to realize this different frame of reference in rehabilitation there are three tactical steps to be taken. 1st: Reconceptualizing rehabilitation from the perspective of a learning based conceptual model. 2 nd. Carrying out a proper analys is of tacticall situations in order to identily behavior to be modified. 3rd: Preparing the professional staff for application of these methods".

In Nederland werd vanuit psychologisch gezichtspunt het belang van leren in de revalidatie beklemtoond door Schuerman (1974 p. 98) "Wanneer iemand in een revalidatiecentrum terecht komt, dan blijkt plotseling een soms lang vergeten aktiviteit enorm belangrijk te gaan worden: Hij moet weer gaan leren".

Achtereenvolgens wordt de aandacht gevestigd op het leren van nieuw gedrag, het leren verwerken van een handicap, mar eveneens wordt stilgestaan bij het thuismilieu dat nieuw gedrag moet gaan ontwikelen. Dat het revalidatie-leerproces niet eindigt wanneer de patient het centrum heeft verlaten, wordt eveneens 
alangegeven door Trieschman (1974). "Rehabilitation does not end at the moment of discharge from the Rehabilitation Center, but rather begins when the person practizes the techniques he has learned in the certer and applies them in copying with his own world."

Volgens Fordyce (1971-1) zijn er in het revalidatie-gebeuren minimaal 4 redenen te signaleren warom dit leren in de revalidatie zo uitermate belangrijk is:

1e. Als iemand een rysieke handicap krijgt dan is er een onmiddelijke verandering in zujn gedragspotentieel of gedragstepertain. De handicap (b.v. een amputatie of een dwarslesie) werandert niet alleen wat de patiënt kán doen, mar ook wat hij môt doen. Hij kan echter pas nieuwe dingen doen als hij dat leert. Dit betekent: verwerwen van de vaardigheid danwel gedrag vormen dat op de juiste plaats, op de juiste tijd, en met een bepaalde frek wentie moet worden toegepast. Zowel de verwerwing alsook de vergroting van de mogelikheden tot optreden op de juiste plaats en tijd zijn gedragsveranderingsprocessen en derhalve als leerprocessen te beschouwen.

2e. Raakt iemand gehandicapt dan zijn sommige vroegere gedragingen niet meer goed en geschikt. Dat gedrag moelt worden geelimineerd of verminderd. In aanvulling daarop moet de patiënt nieuw gedrag leren dat wel bij de handicap past. De vaststelling van het gedrag dat geélimineerd moet worden, alsook de poging tot eliminatie. gaan ervan uit, dat er iets afgeleerd moet worden om plaats te maken voor de konditie voor het anteren van ander gedrag.

3e. Handicaps kunnen meestal niet volledig worden geellimineerd, er resteert een residu, ze blijven bestaan of ze keren terug. Dit in tegenstelling tot de gemiddelde medische praktijk. Dit verschil heeft een groot cantal betek emissen voor de patient, familie, de stal of de verpleging die moet optrekken met de patiênt. Chronische ziekteprocessen zoals bij cen handicap vereisen een permanente gedragsverandering voor patiënt én omgeving. Het gedrag dat "geindiceerd" wordl vanwege de handicap is meestal van lage frekwentie waarde, sterkte of intensiteit voor de patiënt.

Tenslotte is de wooruitgang zeer langzaam in vergelijking met de ervaring van patiěnt met vroegere akute ziektes. Dit alles bij elkaar is dus een wel zeer bijzonder proces, een weinig aantrek kelijk leerproces, maar wel stereotiep voor de revalidatie. Het vereist een bujzondere instelling, een kennis van het leerproces volgens welke een dergelijke gedragsverandering kan worden gerealliseerd.

4e. De handicap moet door patiënt en omgeving eveneens op "psychisch" niveau worden verwerkt en wel zodanig dat na verloop voor beide partijen een emotioneel stabiel evenwicht mogelijk wordt. Tot voor kort werden dat soort a anpassingsproblemen gezien wanuit het zgn. .ziektemodel". D.w.z. het gedrag (bw. depressie, agressie, passiviteit, ontkenning e.d.) dat door anderen werd gezien als (nog) niet aangepast, werd geinterpreteerd als onder kontrole staande van intra-psychische faktoren binnen het organisme. Deze visie is zoals in 1.2.2. werd toegelicht voortgekomen uit het traditionele medische model, warbij symptomen altijd werden geinterpreteerd als veroorzak pathologische kondities.

Het ziektemodel werd dus toegepast op aanpassingsstoornissen naar analogie van de toepassing op lichamelijke stoornissen. Ongelukkig genoeg werd vrijsnel vergeten dat het slechts een analogie was en het werd op den duur gezien als de realiteit. De konsekwentie hiervan was dat bij een gekonstateerde "slechte" aanpassing de oorzaak gezocht werd in onjuist gerichte, ten onrechte aanwezige, met elkar in konflikt zijnde onderliggende gevoelssystemen of 
psychische energieèn. De behandeling hiervan kon dan ook alleen maar plaatsvinden door verandering van onderliggende gevoelens d.m. $v$ een of andere vorm van gesprekstherapie hetgeen een vaak langdurige bemoeienis impliceerde, nog afgezien van de onbruikbatheid van deze benadering bij handicaps zoals bepaalde cerebrale traumata. Er zijn echter altematieve beschrijvende modellen mogelijk, die het medisch model als interventiestrategie gedeeltelijk terzijde schuiven en juist hierdoor tot nu toe ongekende mogelijkheden bieden, ook woor bovengenoemde patiëntengroep.

De depressie, agressie, ed. zijn nl, ook nog eens gedrag van de patient en derhalve volgens de leertheorie ook modificeerbaar door externe kondities ( $\mathrm{S}, *$ K-en C-variabelen).

Inplats van de "psycho-dynamica" (O-variabele, voor zover" wetenschappelijk aksepteerbaar, moet toch minimaal plaats geboden worden aan de mogelijkheid dat het gekonstateerde onaangepaste gedrag te zien is als het resultaat van een verkeerde wijze van interaktie tussen patiënt en omgeving. Deze moet worden veranderd, maar niet door een jarenlange behandeling, maar door er een andere wijze van interaktie voor in de plats te zetten.

M.a.w. het onaangepaste gedrag moet door verandering van omgevingskontingenties worden afgeleerd, zodat het mogelijk wordt door stimulerende kontingenties gedragsverandering hier voor in de plaats te brengen.

Resumerend kan dus gesteld worden dat het belang van het leren in het revalidatieproces niet genoeg kan worden benadrukt. Gemeend wordt dat men niet kan volstaan met het aankondigen, konkluderen of citeren: "dat de patiënt moet leren... enz." en verder in afwachting verkeren. Om werkelijk leren te doen optreden moeten de werkers in het revalidatiecentrum ervan bewust worden, dat leren niet zomaar zonder meer zal optreden. Men dient zich daadwerkelijk af te vragen om welke vorm van leren het gaat bij een bepalalde patient, of er potenties aanwezig zijn voor deze leervorm en of de omgevingskondities wel optimaal zijn. Men zou zich moeten beraden of het, indien noodzakelijk, ook mogelijk is dat de omgevingskondities optimaal worden voor deze speciale patiënt. Tenslotte dient men welk leerproces dan ook inderdaad „op gang te brengen”.

Hoe een en ander te realiseren valt, zal hopelijk uit het verdere betoog duidelijk worden.

\subsubsection{Leerparadigmata in de revalidatie}

Reeds eerder werd vermeld dat het bij de huidige stand van wetenschappelijk onderzoek op dit moment niet goed mogelijk is een keuze te doen voor een allesomvattend leerparadigma, dat al het op leren gebaseerde gedrag verklatart en een indikatie vormt voor éen behandelingsstrategie. Bij een keuze kan men zich dan ook niet zozeer laten bepalen door deze theoretische stand van zaken, mar dient men zich eerder te laten leiden door praktische overwegingen, het "type" van patiënten dat ter revalidatie word angeboden en eigen ervaringen tot nu toe. Bij deze overwegingen zullen achtereenvolgens de diverse leerparadigmata met het ong op hun toepasbarheid, de specifieke mogelijkheden en de behoeften van de revalidatiepatiënt, worden bezien.

Het klassieke conditioneringsparadigma lijkt als verklarings-en behandelingsmo. del met name toepasbar te zijn op patiënten, welke als gevolg van een verkeerde konditionering een niet-reële angst ontwikkeld hebben voor situaties of objekten. De potentiële toepasbaarheid lijkt dus in de revalidatie bijzonder groot voor die 
patienten welke geen vermijdingsgedrag kunnen tonen, dankzij hun toestand van immobiliteit of hun onvermogen een bepaalde therapie te weigeren. In de revalidatie is tot nu toe relatiel weinig toepassing van dit konditioneringsparadigma opgetreden. En verklaring hiervoor zou kunnen bestaan uit de overweging dat de uitvoering van diverse therapieen op zichzelf een desenstiserende of bekrachtigende werking zou hebben, waarbij de patiënt a.h.w. „over de angst heen geholpen wordt". Anderzijds bestaat de mogeljkheid dat de therapeut resp. het team niet *alert" is voor dit soort angsten en onvoldoende geinformeerd is over de frek wentie van fobieèn in het dagelijks leven en in de revalidatie.

Het twee-laktoren-paradigma lijkt toepasbaar op patienten die na een verkeerde konditionering een niet-reele angst van hun ongeval hebben overgehouden en eveneens in staat zijn daadwerkelijk gevolg te geven aan hun neiging tot vermijden. Als modifikatie zou een kombinatie van desensitisatie en assertiviteitstraining overwogen kunnen worden, dus de kombinatie van klassieke en operante technieken. In de jaren 72-76 werd deze gedragsmodifikatie in totaal tweemaal met sukses toegepast. Als een verklaring van dit sporadisch gebruik kunnen soortgelijke overwegingen aangevoend worden als boven vermeld. De toepasbaarheid lijkt in de revalidatie eveneens erg groot te zijn.

Het operante paradigma houdt rekening met de diskriminatieve stimulus, de konsekwenties en kontingenties van het gedrag. Het zou zich minder richten op de vorming wan nieuw gedrag op basis van reeds bestaande reflexen, maar wel uitdrukkelijk op de vorming en modifikatie van instrumenteel gedrag. Een bel angrijk kenmerk van het paradigma is juist het aksent op de omgevingsvariabelen en de negatie of beter gezegd, het niet relevant achten wan $\mathrm{O}$-variabelen.

Het leent zich derhalve voor die personen, waarbij nieuw instrumenteel gedrag gevormd dient te worden of warbij bestaand instrumenteel gedrag niet adekwaat is en gemodificeerd zou moeten worden. De patiënten die voor een dergelijke benaderingswijze in aanmerking komen, zijn zij die door hun konstitutie meer gevoelig zijn voor externe bekrachtigende kondities dan voor interne reinforcement. Dit vereist echter wel dat de omgeving, i.c. het revalidatieteam bereid en in staat is zich woor langere duur uniform op te stellen achter een bepaalde behandeling. Indien aan deze voorwaarden voldaan kan worden, dan lijkt het operante paradigma een behandelingsmodel te presenteren dat toepasbaar is op met name probleemgroepen als cerebraal gestoorden, konversie- of pijn patienten, kinderen en geretardeerden.

Het imitatie-paradigma houdt rekening met diverse stimuluskondities als modelgedrag van therapeut, maar ook wan patiènten en cle konsekwenties van dit gedrag voor het model. Het sluit niet unt dat ook thet gedrag van de observator, indien deze het model nabootst, bekrachtigd kan worden. In dit opzicht speelt ook het operante paradigma mee. Het is het eerste paradigma in deze reeks dat rekening wil houden met kenmerken en processen in de observator. Het lijkt in de revalidatie gebruikt te kunnen worden om angstreakties te modificeren en een grotere toepasbaarheid to hebben voor de vorming en modifikatie van instrumenteel gedrag, indien bijvoorbeeld verbale instrukties ontoereikend zijn. Het imilatieparadigma lijkt met name bruikbaar voor de behandeling van patiënten, die hetzij door konstitutie, hetzij tijdelijk in hun intellektuele vermogens gehandicapt of onvoldoende ontwikkeld zijn zoals cerebrale traumata, kinderen, geretardeerden. Het zou als zodanig en aanvulling of kombinatie kunnen vormen met het operante paradigma. Ook het model der "informatieverwerking" lijkt toepasbar in de revalidatie. Deze toepasbaarheid blijft echter beperkt tot enkele specialle groepen van patiënten, nl. de cerebralle stoornissen en de andere neurologische andoeningen. 
Dit model houdt beloften in als verklaringsmodel voor de cerebraal gestoorde pattient. Het is echter op dit moment nog niet duidelijk in hoeverre dit informatieverwerkende systeem aanwijzingen geeft voor een behandelingsstrategie buiten of naast de modifikaties die reeds vervat zijn in het operante model.

De cognitieve paradigma's welke de cognitieve herstrukturering van een waarnemingsveld beogen of een beroep doen op het vermogen tot self-control of self-reinforcement lijken in de revalidatie alleen toepasbaar bij die patiënten, welke meer bepaald worden door interne dan door externe reinforcement. Hoewel in de gedragstherapie de gedachte heerst dat principes van externe bekrachtiging overgenomen dienen te worden door principes van self-reinforcement, lijkt dit vooralsnog alleen mogelijk bij hen, die hiertoe over voldoende vermogens beschikken.

De theoretische basis woor de werking van deze konstrukties, alsmede van de therapeutische ondersteuning hiervoor, is overigens nog vrij zwak, maar dat wil niet zeggen dat verdere ontwikkeling hiervan - ook in de revalidatie - niet dient te worden beproefd. Voorwaarde hierbij is echter een gedegen empirisch onderzoek, ook in de revalidatie.

\subsubsection{Keuze van verklarings- en behandelingsmodel in de revalidatie}

Na voorafgaande, uiterst sumiere, uiteenzetting bestaat nu de opgave een keuze te doen inzake her verklarings- en behandelingsmodel binnen de revalidatie.

Aangezien de huidige stand van wetenschappelijke kennis wel een aantal paradigmata presenteert, maar geen uitspraak doet over éen bepaalde approach, lijkt deze keuze bepaald te moeten worden door de praktische toepasbaarheid en de patiêntenpopulatie. Deze overwegingen inachtnemend zijn een drietal behandelingsmodellen te noemen.

1e. Het klassieke paradigma en het twee-faktorenmodel lijken zich bij uitstek te lenen voor de behandeling van de patiënt met niet-reële angsten en onzekerheden in het gedrag tengevolge van een ongeval. De behandeling is hierbij uitsluitend individueel, d.w.z. éen therapeut begeleidt de patiënt gedurende vrij lange tijd.

2e. Het cognitieve paradigma gericht op herstrukturering en het bewerkstelligen van een toename van self-control is alleen toepasbaar op de patiënt die hiertoe de nodige vermogens bezit. Het zal de patiënt moeten zijn, die o.a. verbaal benaderbaar is, over de nodige .introspektieve" kwaliteiten beschikt, een redelijke tot goede intelligentie heeft en wellicht nog meer kwaliteiten bezit, die hem o.a. in staat stellen tot een relatief onafhankelijke individuele opstelling. De behandeling is hierbij eveneens therapeut-gebonden.

3e. Het operante paradigma op zich biedt mogelijkheden voor nieuwe gedragsvorming en gedragsmodifikatie bij een groot aantal patiënten in de revalidatie, waaraan niet persé de eisen van het cognitieve paradigma gesteld moeten worden. De behandeling is hierbij voornamelijk gericht op de hantering van de omgevingskontingenties, d.w.z. niet persé therapeut-gebonden. Aangezien revalidatie pretendeert een multidisciplinaire behandeling te zijn, lijkt dit paradigma bovendien een goede aansluiting te hebben bij de algemene revalidatiegedachte.

Van de genoemde drie behandelingsmodellen lijkt het operante paradigma vanuit pragmatisch gezichtspunt op dit moment de meest reële en grootste toepassingsmogelijkheden te bieden in de revalidatie.

$\mathrm{S}^{\mathrm{D}} \rightarrow \mathrm{R} \rightarrow \mathrm{K} \rightarrow \mathrm{C}$ 
Het model der informatieverwerking, het imitatiemodel, alsook het verklaringsmodel inzake de aard der menselijke motivatie, leveren geen uitdrukkelijke bijdrage inzake een toe te passen strategie.

Wel verschaffen ze informatie omtrent de soort diskriminatieve stimulus de volgorde van presentatie van deze stimulus en wellicht omtrent de bekrachtigende kondities volgende op de respons.

Voorbeeld: Bij het imitatieparadigma bestaat de empirisch ondersteunde bevinding dat de ene mens sneller imiteert dan de ander en dat niet ieder model gelijkelijk voor ieder persoon leidt tot imitatieleren. Met beide (en andere) mogelijkheden van imitatieleren dient dus rekening gehouden te worden inzake de aan te bieden stimulusconfiguratie. Het operante paradigma zelf verandert hierdoor echter niet wat betreft zijn behandelingsstrategie.

Resumerend:

Op pragmatische gronden wordt gekozen voor het operante paradigma als behandelingsmodel.

Als verklaringsmodellen, d.w.z informatie biedend voor de selektie der stimulus en reinforcement kondities kunnen het model der informatieverwerkende processen, het model van de sociale imitatie en de konditioneringsgeschieden is van de persoon hun bijdrage leveren.

De behandelingsmodellen der klassieke deconditionering en van het cognitieve leren lijken op dit moment minder toepasbaar en zijn slechts geëigend voor speciale patiëntengroepen zoals hierboven werd aangegeven.

Het operante paradigma en zijn specifieke toepassingsmogelijk heden in de revalidatie verdienen thans de aandacht.

\subsubsection{Het revalidatie-leerproces bezien vanuit het operante paradigma}

In de traditionele literatuur op het gebied van de psychologische revalidatie (zie o.a. Wright B.1960) wordt het revalidatieproces omschreven als het doorlopen van een aantal fasen. Hierbij worden dan termen als: „ontkenning, marchandering, depressie, agressie, integratie, assimilatie" e.d. gebezigd. Dit zou een soort reeks zijn, die de revalidant moet doorlopen, wil hij tot volledige verwerking van de handicap geraken. Daarnaast wordt ook verwezen naar .,persoonlijkheidsstruktuur" en "motivatie" als belangrijke determinanten die dit werwerkingsproces kunnen beinvloeden.

Wanneer men het revalidatieproces vanuit leertheoretisch perspek tief en met name vanuit het operante paradigma wil bezien, dan dienen deze termen, voorzover relevant, ook binnen deze context benaderd en verklatard te worden.

Bij deze behandeling van het revalidatieproces vanuit het operante paradigma moeten de volgende uilgangsvoorwaarden worden genoemd.

A. Het (onaangepaste) gedrag als reaktie op de handicap wordt uitdrukkelijk niet geïnterpreteerd vanuit een onderliggende psycho-pathologie of vanuit diepere lagen van de persoonlijk heid. Niet omdat deze niet zouden bestaan, maa omdat het operant paradigma daar waar het om opnieuw leren gaat, het aksent legt op de omgevingsk on tingenties.

B. Het eerste punt houdt tevens in, dat afgezien wordt van de poging om een bepaalde wijze van reageren op de revalidatie en het verwerken van de handicap te interpreteren als voorkomende uit de persoonlijkheidsstruktuur. 
C. Fysieke handicaps houden niet moodzakelijk gefixeerde gedragspatronem in. Er zijn slechts drie omstandigheden waaronder een systematische relatie is te veronderstellen tussen gedrag enerzijds en een speciale handicap anderzijds: a. Als de handicap optreedt ten gevolge van een bepaald gedrag (Voorbeeld: mensen die veel alcohol drinken kriggen vaak leverstoornissen, diabetici die weinig zorgvuldig zijn met hun dieet, krijgen visusstoornissen). De aard van het gedrag wordt dan veelal weinig nader gespecificeerd dan ,alcoholmisbruik" en "onzorgvuldigheid".

b. Als de handicap een direct causaal verband heeft tot het gedrag of de gedragsverandering. (bijvoorbeeld stoomissen in de linker hemisfeer en afasie). c. Als de handicap een konsistent effekt heeft op het gedrag van anderen (bijvoorbeeld gelaatsm isvormingen, blindheid, opvallende bewegingen). Als de handicap een konsistent effekt heeft op het gedrag van anderen, dan zuilen hun responsies het gedrag van de gehandicapte beinvloeden. De causale relatie ligt tussen het gedrag van de persoon en het gedrag van de omgeving t.o.v. hem. Er is echter geen reden om een onderliggend mechanisme te postuleren, die het geobserveerde gedrag produceert.

D. Ervan uitgaande, dat het niet nodig is zijn toevlucht te nemen tot persoonlijkheidskenmerken bij aanpassing an de handicap wordt het mogelijk de direkte weg te nemen naar observatie van gedragskonsekwentie-relaties: men richtzich dan op het gedrag, bij voorkeur objektief geobserveerd. Hierbij vraagt men zich af of dit gedrag onaangepast is bijwoorbeeld in die zin, dat het een revalidatieleerproces tegengaat of niet. Verder tracht men te weten te komen, waardoor dit eventueal onaangepaste gedrag wordt onderhouden en hoe men moet handelen om deze ondersteuning weg te nemen. Tegelijkertijd tracht men gedrag te ontdekken dat beter bij de handicap past en de ontwikkeling hierwan door aanleren te stimuleren met inschakeling van patient, therapie- en thuismilieu.

F. Het onderzoeks- en behandelingsplan in de revalidatie ziet er dan als wolgt uit:

1e. Beginobservatiefase: Is er probleemgedrag aanwezig? Zo ja, waruit bestall dit, wat of wanneer treed dit op? Zijn er bekrachtigende elementen (reinforcement) voor dit ongewenst gedrag?

2e. Overlegfase: Is er alternatief gedrag, dat bij voorkeur inkompatibel is met het probleemgedrag en dat revalidatie-ondersteunend is? Onderkenning van dit gedrag alsmede van de ondersteuning wan dit gedrag.

3e. Behandelingsfase: Door middel van het vestigen van goede relaties tussen patient en therapeut word de mogelijkheid van sociale bekrachtiging ingebouwd. Hierna wordt overgegaan tot extinklie van probleengedrag door konsekwente onthouding van bekrachtigende kondities. Tegelijk wordt getracht bijoptreden van het gewenste gedrag dit door bek rachtiging te ondersteunen. Hierbij kan eventueel gebruik gemakt worden van cen trapsgewijze opbouw (suksessieve approximatie), of andere shapingsproce. dures.

4e. Albouwfase: bij afname van probleemgedrag en ontstan van gewenst gedrag, zal dit gewenste gedrag in eerste instantie onderhouden moeten worden door een kontinu bekrachtigingsschema. Later zal echter voor de beklijwing wan dit gedrag overgegaan moeten worden op een variabel bekrachtigingsschema.

5e. Procesevaluatie: door voortgaande observatie in behandelings-en albouwfase wordt nagegaan in hoeverre de gevolgde strategie effektvol is. 
6e. Effektevaluatie: na afoouwlase dient de eindobservatie vergeleken te worden met de beginobservatie.

7e. Tijdens alle fasen dient therapie- en thuismillieu zoveel mogelijk samen te werken. Het thuismilieu dient expliciet in de behandeling betrokken te worden.

In het nawolgende zal getracht worden het werkmodel nader te differentiëren, aan de hand van de diverse veronderstelde stadia, die de patient heeft door te maken.

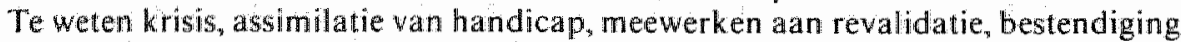
wan gedrag dat adekwaat is bij de handicap.

\subsubsection{Krisishantering}

Met krisis word hier bedoeld het psychotrauma, dat ontstat ten gevolge van het plotsaling gehandicapt raken.

Direkt na de gebeurtenis waaruit een bljwende handicap ontstaat, kan het gedrag een funktie zijin van:

a. de gedeeltelijke of bijna volledige afwezigheid van stimulus-input m.a.w. sensorische deprivatie, wat kan leiden tot desorganisatie.

b. De gehandicapte probeert zich de toekomst voor te stellen, wat kan leiden tot een geanticipeerde deprivatietoestand. Het idee dus, dat patiënt niet langer meer toegang heeft tot voor kort zinvolle, levenswullende arngelegenheden.

c. Tegelijkertijd heeft patiènt en thuismilieu onvoldoende informatie over revalidatie. Er is dus afwezigheid van bevestiging of ontkenning inzake geanticipeerde deprivatie.

d. Door het veelal langdurig in bed liggen is er onvoldoende mobiliteit zodat hierdoor weinig informatie valt te verwachten die de geanticipeerde deprivatie kan reduceren.

e. Van belang is verder het premorbide gedrag in het algemeen, en het gedrag inzake krisishantering in het bijzonder.

f. Momentane respons-repertoir. Wat kan patiënt op dit moment? Over welke leerfunkties beschikt hij?

g. Suggestibiliteit. Over het algemeen zijn patiënten in krises zeer gevoelig voor o.a. imitatialleren.

h. De betekenis die de handicap voor het therapie- en thuismilieu heeft.

Werkmodel bij krisishantering. (als voorbeeld).

Vermoedelijk zal onaangepast gedrag bij krisissituatie niet zozeer onderhouden worden door bepadde ondersteuningen vanuit patiënt of omgeving. Er lijkt eerder een tekort an gedrag of een ongericht gedrag te zullen bestaan. Wat ontbreekt is dan een nieuw soort gedrag of het richten, sturen, begeleiden van dit gedrag vanuit de omgeving. Alternatief gedrag: gerichte bezigheden, vragen proberen te stellen, aktieve therapièn e.d.

Stimulans voor alternatief gedrag: aandacht door omgeving, vermindering wan onzekerheden.

Verschathing van identifikatie-objekten (verpleging, bepaalde patiënten) en het trachten te bewerkstelligen van goede relaties.

D.m.v. identifikatie met modellen, indien aanwezig, stimuleren van trapsgewijze verkenning van omgering en mogeligheden, gerichte bezigheden en ondersteunende gesprekken trachten een verandering te bewerkstelligen in krisisgedrag. Voortgaande observatie door team moet eventuele moditikatie vaststellen. 


\section{3.5.2. Assimilatie van handicap}

Na verwerking van krisis staat de patiënt voor de opgave dat hijzijn handicap moet inpassen in zijn levenspatroon. Dit wordt de "assimilatiefase" genoemd (Fordyce 1971-1). Aan deze assimilatie zijn een aantal specifieke moeilijkheden te onderkennen. Faktoren die deze assimilatie in de weg staan, zijn de volgende:

A. aversief beleefde revalidatie

B. het rouwproces

C. premorbide gedrag

Ad A. De revalidatie kan als aversief ervaren worden. doordat de patient en omgeving de behandeling associeert met het toekomstig leven met handicap, dat door patiënt en/ of omgeving anticiperend als negatief gewaardeerd wordt, de pijn door handicap en therapie en de geanticipeerde deprivatie.

Gebruikelijke reaktiepatronen hierop zijn met name:

1. Vermijdingsgedrag (zich ontrekken aan behandeling)

2. En/of agressief gedrag

Beide reaktiepatronen worden in principe niet vaak langdurig gekontinueerd, aangezien dit een onttrekking aan alle positieve, prettige zaken tijdens het verblijf in het revalidatiecentrum betekent. Er is helaas een uitzondering, waardoor vermijdings- en agressiefgedrag bliff voortduren, namelijk in het geval dat de omgeving (thuis- en therapiemilieu) dit gedrag door middel van extra aandacht ondersteunt. In geval van aversief ondervonden revalidatie kan getracht worden het vermijdings- of agressiefgedrag te reduceren door:

1e. De aversieve kwaliteiten van het revalidatieklimaat te verminderen door goede patiënt-therapeutrelaties.

2e. De positieve konsekwenties van vermijdingsgedrag te beperken door konse$k$ wente onthouding van iedere bekrachtiging.

3e. De revalidatiedeelname te bevorderen door:

- aangeven van therapiedoel en het markeren van de stadia op de weg naar dat doel.

- bij vooruitgang, het verschaffen van stimulans en ondersteuning.

- deelname van familie bij selektieve ondersteuning.

\section{Werkmodel bij aversief ondervonden revalidatie (voorbeeld)}

Observatie: Welk gedrag treedt op? Hoe wordt dit gedrag ondersteund? Door het thuismilieu, dankzij irreële fantasieën, of door het therapiemilieu d.m.v. aandacht? Alternatief gedrag: deelname aan therapie, geen agressief gedrag. Ondersteuning: operante konditioneringsprincipes. Verschaffen van inzicht (eventueel). Faciliteiten verstrekken. Aangeven wat bereikt kan worden (fysiotherapie, arbeidstherapie). Doen deeinemen van familieleden en door bekrachtigingsschema"s. Het bewerkstelligen van goede relaties (met fysiotherapie, arbeidstherapie, logopedie, maatschappelijk werk).

Algemene behandeling: tracht door geregelde ondersteuning bij medewerking en inzet van patiënt en konsekwente onthouding van ondersteuning bij tegenwerking het vereiste gedrag te realiseren. Voortgaande observatie ten behoeve van evaluatie van effekt.

ad B. Vanuit leertheoretisch gezichtspunt wordt verdriet en depressie gezien als een tijdelijk tekort aan indrukken, gevoelsimpressies, die voor de patiênt het leven inhoud gaven.

Remedie hiertegen is te trachten het leven weer zinvol te maken en inhoud te geven. Bij de revalidatie moet de patiënt weer ontdekken, dat zijn toekomstig leven 
ondanks allerlei deprivaties toch zinvol en prettig kan zijn. Ditkan hijalleen ervaren door opnieuw aktief te worden en opnieuw te ervaren, dat er ook voor hen nog (self-)reinforeement bestaat.

Werkmodel bij het rouwproces. (als woorbeeld)

Observatie: toont de patient rouwgedrag en zo ja, welk?

Zijn er situaties te ontdekken, die de depressie ondersteunen, zowel in, het revalidatiecentrum als thuis?

Alternatief gedrag is: opgewekt gedrag, aktiviteit, belangstelling. Men is er niet op gericht om de depressie te behandelen, zodat patiënt weer aktief kan worden, men helpt de patient om weer aktief te worden, zadat hij de depressie het hoofd kan bieden. Wat waren of wat zijn woor deze patiënt bekrachtigers? Wat deed de patient vroeger; welke onderdelen hiervan kunnen nog gedaan worden? Wat zijn de imitatiemodellen en wal voor belangstellingen hadden deze? Bewerkstelligen van goede relaties. Verschaffen van modellen ter identifikatie of imitatie. Onderdelen van vroegere aktiviteiten binnen bereik van patiënt brengen.

Algemene behandeling bestata uit: a angeven van mogelijk heden wan het revalidatieproces met prestatie-units. Patiënt tot aktiviteit brengen. Eerst door middel van oude hobby's, die nog redelijk uitgewoerd kunnen worden, daarma kan geleidelijke overgang naar therapieèn plaatsvinden (selektieve ondersteuning). Soms dient tevens gebruik gemaakt te worden van medicamenteuze therapie of psychiatrisch consult, maar dan wel samen met geleidelijke introduktie van therapieverwante taken en ondersteuningskondities. Voortgaande observatie.

ad C. Extinkrie van premorbide gedrag dat niet verenigbaar is met handicap. Bepaalle gedragingen welke bestonden vór het ongeluk worden onverenigbaar met de handicap, zoals vaardigheden van het vroegere dagelijkse leven, beroepsaktiviteiten, vrijetijdsbesteding e.d. Veel van dit gedrag kan niet meer worden gerealiseerd, echter de patiëm kan hierover gaan dagdromen en fantaseren. Dit fantaserend gedrag blijkt in eerste instantie zekere bevrediging voor patiënt te geven, maar dit is slechts voor korte tijd. Er ontstaat wel een probleem als de omgeving rond patiënt (therapie- en thuismilieu) het lantasiegedrag ondersteunt door irreële beweringen, die suggereren, dat de handicap slechts tijdelijk zou zijn.

Het revalidatieprogramma moet erop gericht zijn om het ongewenste of inadekwate premorbide gedrag te vervangen door alternatief d.i. bij de handicap horend gedrag via optimale ondersteuningskondities. Ook de familie moet geîformeerd worden over datgene wat de patient nog zal kunnen doen aan het eind wan het program. Maar an informatie alleen hebben zij onvoldoende. Ook zij, net als iedereen. hebben behoefte aan positieve ondersteuning c.q. extinktie van hun gedrag ten opzichte van de patiënt.

Werkwodel bij extinktie premorbide gedrag (als voorbeeld)

Observatie: is er sprake van irreel gedrag, dagdromen, gebrek aan zelfkritiek en zo ja, in welke vorm?

Wordt dit vanuit thuis-en therapiemilieu ondersteund?

Alternatief gedrag: aanleren van zellkritiek, betrekkelijk nuchter denken over toekomst, zich verstaan met de realiteit.

ls er stimulans voor dit gedrag te vinden? Maatschappelijk werk kan bijdrage leveren door systematisch kontaky met de familie, naarmate de revalidatie vordert. Goede relaties vormen (verpleging, therapeuten), zodat adek waat gedrag wordt bekrachtigd en ongewenst gedrag bijv. "kritiekloos argumenteren" wordt gene- 
geerd. Doelgerichte begeleiding die erop gericht is het dagdroom-gedrag ed. te reduceren en het kritiekvol spreken over toekonst te stimuteren. Dit alles door gebruik te maken van modellen, van relaties, van selektieve ondersteuning door omgeving en familie. Voortgaande observatie ter tussentijdse effektbepaling.

\subsubsection{Motivatie tot (her)leren}

Het grootste probleem en het meest gebruikte begrip bij de revalidatie is "motivatie". De opvatting omtrent motivatie is bij het leermodel anders dan bij het ziektemodel. Bij het ziektemodel is motivatie niet een onderdeel van het gedrag, maar het is een gevolgtrekking ten aanzien van een innerljke toestand van patiënt, ontleend aan observatie wan het gedrag. De patiënt heet dàn gemotiveerd, als men ziet dat hij meedoet aan datgene, wat voor hem op het programma is geplatst. Hij is niet gemotiveerd als hij dat niet doet. Op deze manier gebruikt, voegt het begrip motivatie niets toe omtrent de patiënt noch aan een verder te volgen richting voor het programma. Voor nadere informatie omtrent het motivatieconcept wordt verwezen naar Cofer CN, Appley M (1967 p. 808-838)

Wanneer men het begrip motivatie vanuit het leermodel benadert krijgt men een enigszins andere formulering. Gedrag wordt bepaald - volgens de leertheorie - door de konsekwenties. Bij te weinig frek went gedrag moet er wat gedaan worden aan de konsekwenties van dat gedrag. Bij verkeerd (gericht) gedrag moeten de konse$k$ wenties van dit gedrag verminderd worden. Te weinig motivatie schijnt louter een kwestie te zijn van onvoldoende of van slecht gearrangeerde bekrachtiging (ondersteuning, goedkeuring, suksesvolle prestaties, vermindering van pijn, hoop voor toekomst etc.).

Twee redenen waarom motivatieproblemen zo vaak optreden in revalidatie:

1e. Meedoen aan revalidatie kan initieel aversief zijn.

2e. De bekrachtigers voor nieuw gedrag, dat angepast is aan de handicap zijn zwak. Vaak ziet men dat - voordat er enige valudigheid is verkregen met bijv. prothesen - bekrachtigers worden gezocht voor reeds vroeger beheerste substitutie-bewegingen. Er moeten dus eerst prothese-bewegingen ontstaan die kompetitief zijn met de vroegere bewegingen. Nu zijn deze prothese-bewegingen niet "natuurlijk" bekrachtigend, bovendien zijn ze van lage frek wentie niet krachtig en voor de patiënt initieel van weinig warde. Het is dus noodzakelijk - en dat is de essentie bij motivatie in de revalidatie - om goede therapeut patiëntrellaties te bewerkstelligen, waardoor er bekrachtiging mogelijk wordt van handicap-adek wa at ged rag. De patiènt gaat dus de handelingen verrichten, omdat hij de therapeut niet wil teleurstellen en deze behoefte om een prettige relatie niet te doorbreken vormt de overbrugging naar later komende ondersteu ningen.

Daarnaast moet aandacht besteed worden asn zgn. "langere termijn"-ondersteuningen of -waarden, die het handicap-aangepaste gedrag blijuend doen voortbestaan.

\section{Werkmodel (als voorbeeld)}

In geval van aversief beleefde revalidatie kan het werkmodel onder $1.3,5.2$. A gehanteerd worden.

Verder lijk t het aksent bij gebrek aan motwatie gelegd te moeten worden op de goede relatie russem patiënt en therapeut.

De psychologische afdeling zou in principe behulpzaam kunnen zijn bij het trapsgewijze indelen van een aan te leren vaardigheid, hell ontdekken van adek wate 
bekrachtiging of het kiezen van de .juiste persoon" voor deze intermenselijke relatie. Observatie: is er hier inderdad sprake wan gebrek aan motivatie? Zijn er tegenwerkende faktoren, gemis an goede relaties of moet eerder het thüsmilieu benaderd worden?

Het adekwat gedrag lijki bekend: .gemoliveerd meedoen".

Zijn er bepaalde personen war patient een goede relatie mee heeft?

Intensivering en verbetering van deze kontakten.

Trapsgewijze presentatie, waabijaksent valt op zeer veel stimulans en goedkeuring door kontaktpersoon bij in eerste instantie geringe voorutgang.

Voongaande observatie waarbij er ook opgelet wordt of verandering van motiwatie generaliseert naar andere dan strikt herapie-aktiviteiten.

\subsubsection{Beklijving van hamdicapmadekwaat gedrag}

Als een programma zich alleen bezighoud met het gedragsrepertoir van de patient en de familie negeert, dan zal de gedragsverandering die tot stand werd gebracht in de revalidatie, nadien niet lang blijven voortbestaan. De stappen, die genomen moeten worden om de familieleden te helpen hun gedrag te veranderen zijn hetzelfde als die voor de patiënt. De familie heeft daadwerkelijke hulp nodig om eigen gedrag en dat van de patiênt te modificeren, om te letten op de frekwentie van dil gedrag en om patronen van dit gedrag te veranderen door gebruik te maken van gerichte, toepasselijke stimulans of ondersteuningen.

\section{Werkmodel (als voorbeeld)}

Het bewerkstelligen van de beklijving van handicap-adekwaat gedrag lijkt in eerste instantie het terrein te zijn voor personen die hiertoe speciaal opgeleid zijn. Misschien zouden we de voorkeur geven a an maatschappelijk werkenden, mits deze zich zouden kunnen verenigen met de gedachte dat gedragsverandering ook door beinwloeding van de omgevingskondities kan en soms moet plaatsvinden en niet alleen door overigens goed bedoelde imzichtverstrekkende gesprekken. Voorllopig geven we de voorkeur aan non-professionals, met middelbare opleiding, die een speciale training in gedragstherapie wollgen.

Deze non-professionals dienen samen met de familie een aantal zaken te bespreken: a. de fasen binnen de assimilatie der handicap:

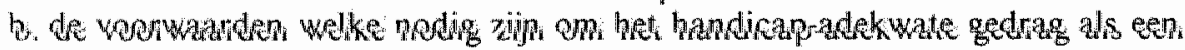
(mogelijk totaal) nieuw gedragspatroon te blijven ondersteunen.

c. het beklemtonen dat ook hun gedrag in relatie met gehandicapte aanzienlijk gewijzigd is of moet worden en dat men niet moet trachten naar het vroegere patroon terug te keren.

d. het bieden van steun aan de familieleden in hun anpassing aan de veranderde onstandigheden.

De 7 genoemde lasen wan het werkmodel zijn hierbij volledig of grotendeels ter verantwoordelijkheid van de non-professionals. In feite komt dit neer op gezinsthe"apewische aktiviteiten vanuit leertheoretisch gezichtspunt.

Observatie: loopt voortgande revalidatie goed of niet? Zijn er d.m.v. gesprekken, tegenwerkingen, misverstanden of i.d. te ontdekken? Is het mogelijk met het gezin een andere (betere) gedragsijn al te spreken?

Hoe kan deze gedragslijn bij patiènt en gezin wederzijds gesteund worden? Zijn er identifikatiemodellen binnen de familie of moeten er goede relaties ontstan tussen. non-professional en patiënt? Doorspreken, voorschrijven van gedragsregels, uit- 
proberen van programma, gedragsverandering in concreto in relatie met de patient. Evaluacie.

\subsubsection{Samenvatting}

In de revalidatie en misschien zelfs wel in de gehele gezondheidszorg, behoeft het medisch model aanvulling van het leermodel. Aangezien er meer paradigmata bestaan, werden deze bezien vanuit hun mogellike pragmatische betekenis voor de revalidatie. Drie leerparadigmata blijken een potentiële toepasbaarheid te hebben, uit welke drie het operante paradigma op dit moment de voorkeur verdient als behandelingsmodel. Drie verklaringsmodellen waarin O-variabelen betrokken zijin, worden medebepalend geacht voor de toepassing van het operante paradigma. De invloed van deze verklaringsmodellen wordt echter beperkt tot de selektie der diskriminatieve stimuli en de toe te passen bekrachtigende kondities.

Vanuit dit standpunt werd het revalidatieproces en enkele specifieke probleemgebieden nader bezien. De konsekwente doorvoering van deze principes is toepasbaar op een belangrijk grote patiëntengroep. De effekruering van het operante leermodel in de revalidatie vereist echter een herorièntatie van het huidige revalidatiebeleid. Het onderzoek waarover hiernavolgend zal worden gerapporteerd impliceert een principiè le haalbaarheid van een dergelijke heroriëntatie in een revalidatiecentrum. 
HOOFDSTUK 2

EEN VOORLOPIGE REVALIDATIE-STRATEGIE 


\subsection{Contusioproblematiek bezien vanuit een neobehavioristisch refe- rentiekader}

\subsubsection{Inleiding}

In het eerste hoofdstuk werd het revalidatiegebeuren bezien vanuit een neobehavioristich referentiekader. Opnieuw leren bleek een der pijlers van de revalidatie. Het operante model $\mathrm{k}$ wam mede vanuit pragmatisch standpunt en als aansluitend bij de algemene revalidatiegedachte, voorlopig als de meest relevante vorm van leren naar voren. Vanuit het revalidatieleermodel bleken diverse kategorieën in de revalidatie, zoals de zgn. verwerkingsfasen, het motivatie-concept e.d. effektief te kunnen worden geanalyseerd.

In dit hoofdstuk wordt teruggekomen op de patiënt met contusio cerebri om - zoals werd voorgesteld - te bezien in hoeverre het paradigma der operante konditionering perspektief kan brengen in de onduidelijke situatie waarin deze patiënt en het revalidatiecentrum zich bevinden.

Aan de hand van informatie vanuit patièntenstatussen wordt een "beeld" gegeven van de patiënt met contusio cerebri. Vervolgens wordt een voorlopige assessment en modifikatiestrategie ontworpen. De huidige stand van zaken maakt het niet goed mogelijk nu reeds een theoretisch model te ontwikkelen, waaruit duidelijke richtlijnen gedestilleerd kunnen worden voor assessment en behandeling van de diversiteit aan problemen, waarvoor de patiënt met contusio cerebri en zijn omgeving zich gesteld zien. Wanneer de doelstellingen in eerste instantie iets bescheidener worden gehouden, dan kan men tevreden zijn indien men zou kunnen komen tot een wat systematischer wijze van gegevens verzamelen en een wat meer gecoördineerde behandeling aan de hand van één duidelijk geëxpliciteerde strategie: de operante konditionering. Derhalve wordt in dit hoofdstuk gesproken over een voorlopige assessment en modifikatieprocedure. Een procedure dus, die alleen geldig mag zijn in een oriëntatiefase, waarbij in de daaropvolgende hoofdstukken wordt nagegaan in hoeverre dit operante model nader moet worden gekorrigeerd en aangevuld. Het zal later blijken dat er dankzij de hantering van een strakke behandelingsstrategie, die als voorlopige strategie werd opgezet, een betere theorievorming en behandelingswijze mogelijk is.

\subsubsection{Inventarisatiebronnen}

Aan het begin van iedere empirische cyclus in de reflektie staat een poging tot inventarisatie van op een bepaald moment beschikbare gegevens. Zoals in hoofdstuk 1 werd aangegeven bestond deze inventarisatie uit een bestudering van 25 statussen van ontslagen patiënten met contusio cerebri en wel door iedere discipline apart. Dat als nader te bestuderen probleemgroep de kategorie van de patiënten met contusio cerebri werd gekozen, wordt verklaard doordat met name deze groep de revalidatie met een aantal niet of nauwelijks op te lossen problemen konfronteert.

Deze inventarisatie zal, vanuit een referentiekader dat gedrag centraal stelt, in dit hoofdstuk nader worden toegelicht.

De 25 statussen vormden een der belangrijkste uitgangspunten wan waaruit een poging tot de konstruktie van een gedragsassessment werd ondernomen. Hierbij dient vermeld te worden dat deze 25 statussen geen representatieve gerandomiseerde steek proef vormden uit de populatie der patiënten met contusio cerebri. Het was eerder het enige materiaal dat direkt voor exploratie toegankelijk was. Gedurende 
de jaren dat het centrum zich van verpleegtehuis ontwik kelde tot revalidatiecentrum waren deze statussen de neerslag van de revalidatiepogingen gericht op de patienten met contusio cerebri. Als schoonheidsfout dient bovendien genoemd te worden dat deze verzameling zich niet mag beroepen op een homogene samenstelling, aangezien er enkele patiënten met cerebrowasculaire accidenten, subdurale hematomen en een enkele patient met een schotwond in voorkomen. Niettemin bestaat het merendeel uit patiënten met contusio cerebri en dit werd, gezien de bescheiden doelstelling, als voorlopig uitgangspunt akseptabel geacht.

Het statusmateriaal bestond in alle gevallen voor het merended uit een neerslag van teambesprekingen. Op de teambespreking vond de eerste informatieverzameling vanuit de disciplines plaats, welke vervolgens via verslaglegging in de status belandde. Met andere woorden de teambespreking ging wooraf aan de neerslag van de therapie-aktiviteiten in de status.

Bij beide vormen vam informatierapportage zijn kritische kanttekeningen te maken, echter de inventarisatie van deze informatie vormde de enge mogelijkheid van wadruit een meer gesystematiseerde gedragsobservatie kon worden opgezet.

De hoeveelheid informatie die in de statussen wordt aangetroffen blijk overweldigend. Niet slechts wat betreft de kwantiteit aan informatie, maar eveneens wat betreft de mogelijke gevolgtrekkingen.

De status als neerslag van onderzoek en behandeling werd meestal als volgt sámengesteld aatngetroffen:

1e. Een vrij uitgebreid intake-verslag van de revalidatie-arts als weergave van het eerste medische onderzoek, waarbij het aksent viel op somatische aspekten.

2e. Een verzameling korrespondentie van de specialisten, dia de patiënt hadden behandeld. Eveneens met aksent op fysieke toestand.

3e. Neerslagen van teambesprekingen, volgens datum gerangschikt. Elke teambespreking was samengesteld uit medische gegevens en informaties verstrekt door fysiotherapie, verpleging, arbeidstherapie (ergotherapie) logopedie, malaschappelijk werk en psychologie. Deze gegevens werden gevolgd door de weergave van de teamdiskussie en afspraken voor een verder te volgen behandelingskoers.

4e. De ontslagbrief, waarin de bereikte eindtoestand werd vermeld en gegevens omtrent verdere verwijzingen.

5e. Informaties inzake poliklinische follow-up onderzoeken.

De inhoudsanalyse van de velle gegevens uit de statussen vond plaats naar een drietal kriteria:

A. Patièntengegevens: deze zouden ook de medische gegevens genoemd kunnen worden, aangezien deze in hoofdzaak betrokken werden uit zgn, intakegesprekken en de korrespondentie met specialisten. Een moeilijkheid bij de verzameling van deze gegevens was, dat gezocht diende te worden vaar variabelen die zich per patient herhaalden. Wanneer er in een bepaalde status uitputtend over het ziektebeeld werd gesproken en er zodoende 10 wariabelen naar voren $k$ wamen, dan was het tamelijk frustrerend indien in een andere status - na eindeloos zoeken - slechts 3 wan de eerste 10 variabelen konden worden teruggevonden. Ter vaststelling van de al dan niet aan wezige homogeniteit van een groep moest uitgegaan worden van vergelijkbare gegevens en dit had derhalwe tot resultaat, dat hier slechts een zeer beperkt aantal genoemd kunnen worden. Er kon een onderscheid gemaakt worden in het gesiacht, leeftijd, tijd die verlopen was tussen het trauma en de opname in het revalidatiecentrum, duur van coma (danwel de tijd tussen trauma en de eerste 
gecontroleerde respons van de patient op een bepaalde stimulus), opnamedur en tenslotte moezaam, het type contusio en medikatie.

1. Assessment in $\mathrm{kwalitatief}$ opzicht: deze gegevens werden woomamelijk betrokken uit de opeenvolgende teambesprekingen. Het ging hierbij om de vragstelling ${ }_{\text {. }}$ Hoe drukt een bepaalde therapeut zich uit omtrent de patiênt?" - Buj de inventarisatie werden derhalve onderscheidingen gemaakt in de meningen van iedere discipline apart en de mening wan het team in zijn totaliteit. Hierdoor konden twee soorten variabelen worden onderscheiden:

a. Min of meer disciplinegebonden uitspraken (de fysiotherapeut doet een uitspraak over het looppatroon, de logopedist spreekt over de afasie, de arbeidstherapeut heeft een mening over de fijne motorische coördinatie etc.). Hier wordt gesproken over "min of meer" disciplinegebonden kriteria, aangezien de meningen hierover nogal verdeeld zijn en bijwoorbeeld in Amerika de ADL-training ook door fysiotherapeuten geschiedt, terwijl deze in ons land typisch het terrein zou zijn van de ergotherapeut en/of verpleging.

b. Het blijkt dat iedere discipline natast zijn min of meer typisch disciplinegebonden kriteria ook algemene uitspraken geeft over het gedrag van de patiënt. Dit soort uitspraken zijn t.o.W. de disciplinegebonden uitspraken in de meerderheid, hetgeen opvallend genoemd kan worden.

Deze uitspraken werden alle ontleend aan "gedragsobservaties" en geven een reële of vermeende gedragsdeviatie aan.

Voorlopig werden deze beschrijvingen in hun vaagheid, veetheid en diversiteit als gegevens ter verdere uitwerking gehanteerd.

C. Assessment in kwantitatief opzicht: Het leek van belang niet slechts de soort der uitspraken te kennen, maar eveneens de frekwentie van voorkomen en eventuele toe- of afname der gedragsdeviaties. Een eerste moeilijkheid die zich hierbij presenteerde was de, overigens vrij reële zaak, dat niet iedere patiënt even veelvuldig op de teambespreking werd gepresenteerd. Afhankelijk van de aandoening, de voor- of achueruitgang werd een patiënt soms gedurende 3 maanden om de 14 dagen besproken. Een andere patiënt verscheen de eerste 2 maanden iedere week op de , rol" en $\mathrm{kwam}$ daarna anderhalve mand niet meer op de besprekingen woor.

Teneinde ook hier een vergelijkbaarheid te verkrijgen werd de gemiddelde frekwentie van bespreken berekend. Dit leverde op dat in een tijdsbestek wan 2 manden iedere patient gemiddeld bij benadering driemaal werd besproken (range 5 per 2 maanden). De uitspraken inzake gedragsdeviaties zoals angegeven bij de kwalitatieve assessment werden over deze twee maanden gesommeerd en vervolgens over de totale verblijfsduur van de patiēnt.

Een wweede, niet zo vanzelfsprekende bevinding, was dat een klacht in eerste instantie well werd gesignaleerd, mar dat de stalus geen duidelike informatie gaf omtrent het verdere beloop hiervan. De toename van het aantall opmerkingen omtrent een bepalde gedragsdeviatie over de tijj genomen zou geînterpreteerd kunnen worden als een achteruitgang, als een toename van de deviatie zelf. Hoewel dit lang niet altijd zo duidelijk naar voren $\mathrm{k}$ wam, kon hier toch bij de inventarisatie rekening mee worden gehouden. Wanneer echter een gedragsdeviatie ophield te bestaan, dan werd dit vaak niet gesignaleerd. Ze $k$ wam niet meer ter sprake op de teambespreking - want deze is immers eerder gericht op het bespreken wan problemen - of, als dit wel voorkwam, werd dit niet genotuleerd. 
In een dergelijke situatie was het dus niet mogelik om aan de hand wan de statussen een uitspraak te doen, omtrent een eventuele afname of kontinuering van een bepaalde gedragsdeviatie.

Bij de inventarisatie werd het niet meer voorkomen van de klacht op de bespreking geinterpreteerd als het voortduren van dil eerder gesignaleerde defekt.

Alleen wanneer er duidelijk gesproken werd over verbetering van de bepaalde klacht werd dit als zodanig in de inventarisatie opgenomen.

\subsubsection{Resultaten van de inventarisatie}

In deze paragraaf worden de resultaten der statusinventarisatie gepresenteerd, na bewerkingen ter verbetering van de overzichtelijkheid.

Deze bewerkingen resulteerden in een aantal tabellen warbij de noodzakelijke toelichtingen onder de desbetreftende tabel worden vermeld.

arbel 1. Pallièntengegevens.

\begin{tabular}{|c|c|c|c|c|}
\hline Lefitigd tin gataces & M. & Md. & $\mathbb{R}$ & G.A. \\
\hline 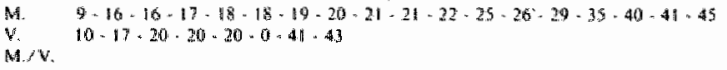 & $\begin{array}{l}24,33 \\
24,42 \\
24,36\end{array}$ & $\begin{array}{l}28 \\
20 \\
20\end{array}$ & $\begin{array}{l}37 \\
37\end{array}$ & $\begin{array}{r}7,85 \\
10,03 \\
8,23\end{array}$ \\
\hline
\end{tabular}

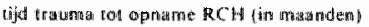

\begin{tabular}{|c|c|c|c|c|c|}
\hline 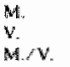 & $\begin{array}{l}1 \cdot 2-2-2 \cdot 2-2 \cdot 2 \cdot 2 \cdot 2 \cdot 4 \cdot 5 \cdot 6 \cdot 6 \cdot 8 \cdot 6 \cdot 82 \cdot 108 \cdot 120 \\
1 \cdot 1 \cdot 13-14-42 \cdot 240-333\end{array}$ & $\begin{array}{l}20,000 \\
92,90 \\
40,1: 4\end{array}$ & $\begin{array}{r}3 \\
14 \\
5\end{array}$ & $\begin{array}{l}120 \\
33 y \\
533\end{array}$ & $\begin{array}{r}27.72 \\
111,14 \\
43.85\end{array}$ \\
\hline
\end{tabular}

dutr coma fin dagens

\begin{tabular}{|c|c|c|c|c|c|}
\hline $\begin{array}{l}\mathrm{N} \text {. } \\
\mathrm{V} \\
\mathrm{M}, \mathrm{V} .\end{array}$ & $\begin{array}{l}3-3+7-2+7+7-10 \cdot 10-14-15-20-35-36-36-49-56-63=35 \\
7-3-7-14 \times 36-70-90\end{array}$ & $\begin{array}{l}32,76 \\
36,66 \\
34,06\end{array}$ & $\begin{array}{l}14,5 \\
14 \\
14\end{array}$ & $\begin{array}{l}69 \\
88 \\
88\end{array}$ & $\begin{array}{l}18,5,5 \\
28,85 \\
21,658\end{array}$ \\
\hline
\end{tabular}

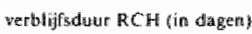

\begin{tabular}{|c|c|c|c|c|c|}
\hline $\begin{array}{l}\text { ML. } \\
W . \\
M .\end{array}$ & $\begin{array}{l}13 \cdot 24-26-60 \cdot 25-93-105-120 ; 120-120 \cdot 120 \cdot 135 \cdot 150 \cdot 180 \cdot 180-270-425 \cdot 700 \\
30-44-60-120-180-210-240\end{array}$ & $\begin{array}{l}162,100 \\
126,28 \\
152,60\end{array}$ & $\begin{array}{l}120 \\
120 \\
120\end{array}$ & $\begin{array}{l}688 \\
2111 \\
688\end{array}$ & $\begin{array}{c}105 \\
31,75 \\
9+, 52\end{array}$ \\
\hline
\end{tabular}

M. = manner $V=$ voow wen

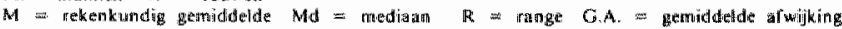

\begin{tabular}{|c|c|c|c|}
\hline bye conitusio & $N$ & medikature & \\
\hline 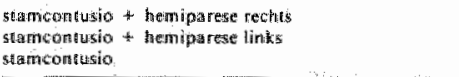 & $\frac{1}{3}$ & 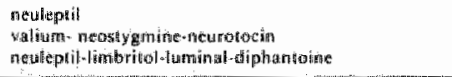 & $\therefore$ \\
\hline 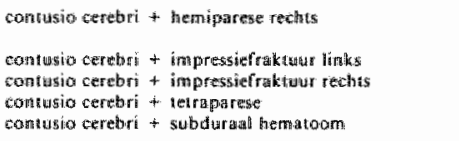 & $\begin{array}{l}6 \\
2 \\
2 \\
1 \\
1\end{array}$ & 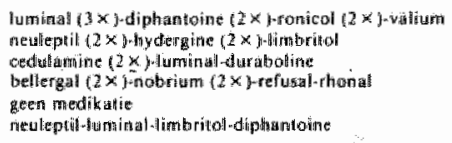 & \\
\hline 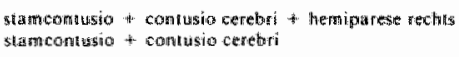 & 1 & 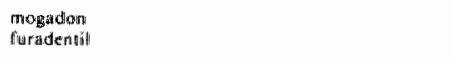 & \\
\hline 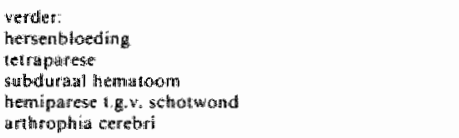 & $\begin{array}{l}2 \\
1 \\
1 \\
1 \\
1\end{array}$ & 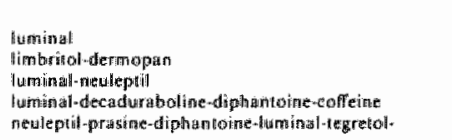 & \\
\hline
\end{tabular}




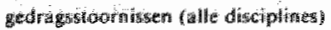

\begin{tabular}{|c|c|c|c|c|}
\hline$P=S$ & $N$ & $\mathbf{P}$ & $P-$ & $P$ 能。 \\
\hline ongennotiverd & 75 & 20 & 8 & 1 \\
\hline slordig in zelvertoryseg & $2 \pi$ & 15 & 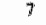 & 2 \\
\hline 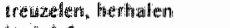 & 30 & 13 & 9 & 3 \\
\hline intakter & 30 & 14 & 4 & 2 \\
\hline will de bats spelen & 40 & 13 & 8 & 2 \\
\hline infantul, Hacher & 22 & 12 & 2 & 䧑 \\
\hline onrystig, ontremd & 22 & 14 & 4 & 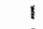 \\
\hline aldidache afd wingend & 21 & 12 & 5 & 0 \\
\hline 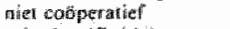 & 16 & $j$ & 4 & 19 \\
\hline gebrek zellh ritick & 16 & 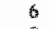 & 4 & 19 \\
\hline 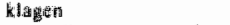 & 15 & 要 & 2 & 0 \\
\hline 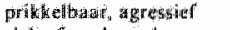 & 14 & 9 & 5 & 9 \\
\hline zich allondiend & 11 & 7 & i & 4 \\
\hline hutilctio & 11 & $g$ & 2 & 0 \\
\hline depressine & 11 & 10 & 2 & 0 \\
\hline onzellstandig & 10 & 5 & $\theta$ & 4 \\
\hline ant & 8 & 5 & 2 & 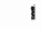 \\
\hline 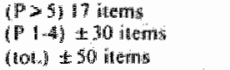 & 377 & 174 & 68 & 2 \\
\hline
\end{tabular}

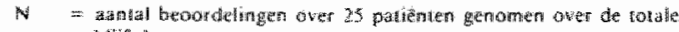
werblinfsidutur

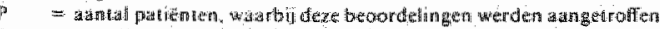

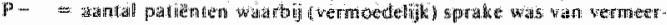

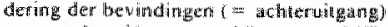

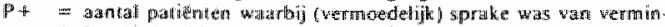

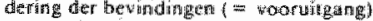

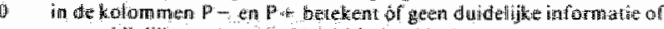

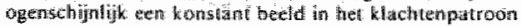

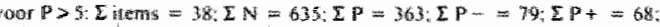
$\Sigma P 0=36 y-(99+6)=316$

$\Sigma\left(\|^{3}>5\right)=38$ iterns

$\Sigma_{1}\left(P_{1-4}\right)= \pm 180$ litems

$2(10 \%)= \pm 120$ itam

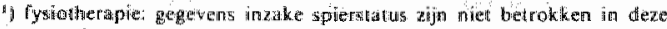
vereatiolints.

min of meer discipliske-gebondien bevindingent

\begin{tabular}{|c|c|c|c|c|c|c|c|c|c|}
\hline$p^{3}>15$ & $N$ & $\mathbf{P}$ & $\mathbf{P}$ & pt & $p>s$ & $N$ & P & P- & $P+$ \\
\hline 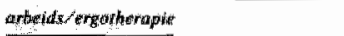 & & & & & priplinologicht ropporit & \multirow{7}{*}{$\begin{array}{r}23 \\
20 \\
14 \\
14 \\
8 \\
8 \\
6\end{array}$} & \multirow{7}{*}{$\begin{array}{r}13 \\
10 \\
18 \\
14 \\
7 \\
6\end{array}$} & \multirow{7}{*}{$\begin{array}{l}2 \\
0 \\
0 \\
0 \\
0 \\
0 \\
2\end{array}$} & \multirow{7}{*}{$\begin{array}{l}0 \\
0 \\
0 \\
0 \\
0 \\
0\end{array}$} \\
\hline \multirow{7}{*}{ 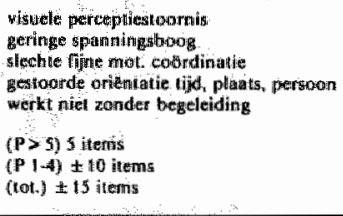 } & 28 & 14 & $\|$ & II & \multirow{7}{*}{ 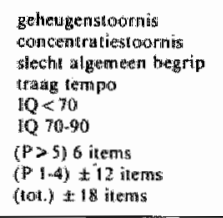 } & & & & \\
\hline & 17 & 12 & 3 & 4 & & & & & \\
\hline & 12 & 11 & 0 & $\$$ & & & & & \\
\hline & 10 & 5 & 0 & 2 & & & & & \\
\hline & 9 & 8 & i & 0 & & & & & \\
\hline & & & & & & & & & \\
\hline & 76 & 50 & 5 & 12 & & 5 & $5 s$ & 2 & 0 \\
\hline fysipherapies & \multirow{3}{*}{$\begin{array}{r}14 \\
12 \\
18\end{array}$} & \multirow{3}{*}{$\begin{array}{r}12 \\
120 \\
8\end{array}$} & \multirow{3}{*}{$\begin{array}{l}2 \\
0 \\
0\end{array}$} & \multirow{3}{*}{$\begin{array}{l}\$ \\
4 \\
3\end{array}$} & werptegrintig & \multirow[b]{2}{*}{8} & \multirow[b]{2}{*}{6} & \multirow[b]{2}{*}{0} & \multirow[b]{2}{*}{0} \\
\hline \multirow{3}{*}{ 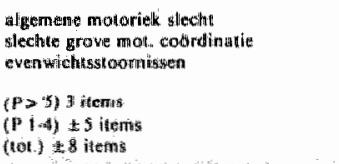 } & & & & & \multirow{3}{*}{ 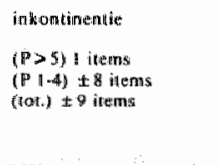 } & & & & \\
\hline & & & & & & \multirow[t]{2}{*}{$\$$} & \multirow[t]{2}{*}{8} & \multirow[t]{2}{*}{0} & \multirow[t]{2}{*}{0} \\
\hline & 34 & 30 & 2 & $n y$ & & & & & \\
\hline logagpentip & \multirow{5}{*}{$\begin{array}{r}89 \\
117 \\
8 \\
6\end{array}$} & \multirow{5}{*}{$\begin{array}{r}8 \\
13 \\
7 \\
5\end{array}$} & \multirow{5}{*}{$\begin{array}{l}0 \\
2 \\
0 \\
0\end{array}$} & \multirow{5}{*}{$\begin{array}{l}4 \\
7 \\
0 \\
1\end{array}$} & 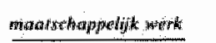 & \multirow{3}{*}{$\begin{array}{l}7 \\
7\end{array}$} & \multirow{3}{*}{$\begin{array}{l}9 \\
6\end{array}$} & \multirow{3}{*}{$\begin{array}{l}10 \\
3\end{array}$} & \multirow{3}{*}{0} \\
\hline afosie & & & & & \multirow{5}{*}{ 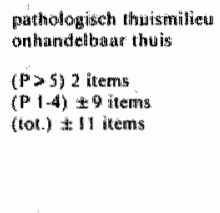 } & & & & \\
\hline sproken idgeneen stexhit & & & & & & & & & \\
\hline dyserthrimkh & & & & & & 16 & is: & 1 & 0 \\
\hline anditieve pereieptiastomomis.s & & & & & & tid & 13 & 3 & \\
\hline 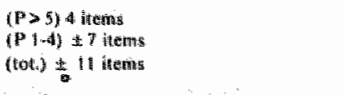 & 39 & 33 & 2 & $\| \geqslant$ & & & & & \\
\hline
\end{tabular}

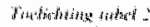

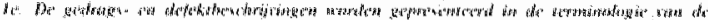

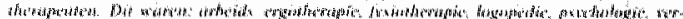

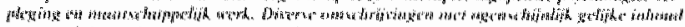

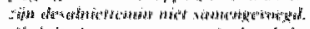

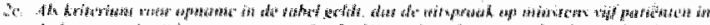

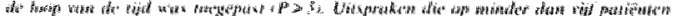

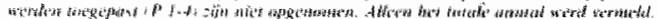




\begin{tabular}{|c|c|c|c|c|c|c|c|c|c|c|c|c|c|c|c|c|c|c|c|c|c|c|c|c|c|c|}
\hline & 1 & 2 & 3 & 4 & 5 & 6 & 7 & 8 & 9 & 10 & 11 & 23 & 13 & $(i 1)$ & 5 & 10 & & 13 & 10 & 20 & $2: 1$ & 3 & 27 & 20 & 25 & $4 N$ \\
\hline \multirow{4}{*}{ 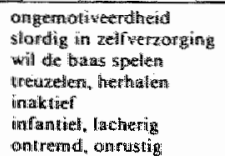 } & & & 2 & 1 & & 2 & 1 & & H & ii & 4 & I) & & 1 & & 3 & & ty & 3 & & & : & 1 & 1. & 3 & 27 \\
\hline & & 2 & 2 & 2 & & 1 & 2 & & 2 & 2 & 4 & & & & & 4 & & 3 & 21 & & & & 2 & $\therefore$ & 2 & 30 \\
\hline & 3 & H! & 3 & 1 & 3 & 2 & & & 焉 & 其 & 4 & 2 & 4 & & & & & & $2 !$ & & & 2 & i & & & 30 \\
\hline & & 2 & 5 & 1 & & & & & 2 & & 3 & $\$$ & & 1 & int & & 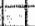 & T: & & & & 1 & & in & $T$ & 22 \\
\hline 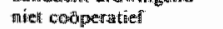 & & & & & & 2 & & & & 3 & 1. & & & & & 2 & & 6 & 1 & $i$ & & & & & & 10 \\
\hline debrelk asm tellontiek & & & 1 & & & & & & i & & & & & & & & & 8 & 3 & & & 2 & 1 & & & 16 \\
\hline kllugeter & & 2 & & & & & & 2 & & & 3 & 2 & 2 & & & & & & 2 & 2 & & & & & 1 & 15 \\
\hline priklacklbaar, angessilef & & 2 & & 1 & & 3 & & & & 2 & 11 & & 1 & & & 1 & & 2 & & & & 1 & & & & 14 \\
\hline ach afachderend & & & & & & 2 & & & 1 & 2 & & & & & & & & & 1 & 2 & & 2 & 1 & & & 11 \\
\hline hisisem & & 2 & & & & & & 2 & & & 1 & i) & 2 & & & & & & 1 & in & & & & & 1 & $-\frac{31}{11}$ \\
\hline
\end{tabular}

racedictiong rotuel io

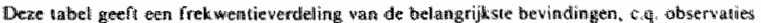

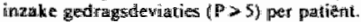

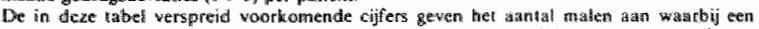

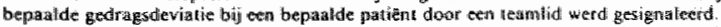

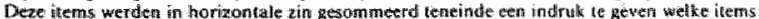

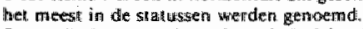

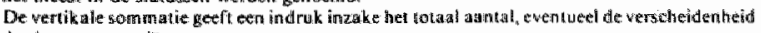
der tients per patioñ

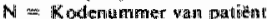

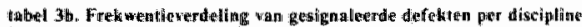

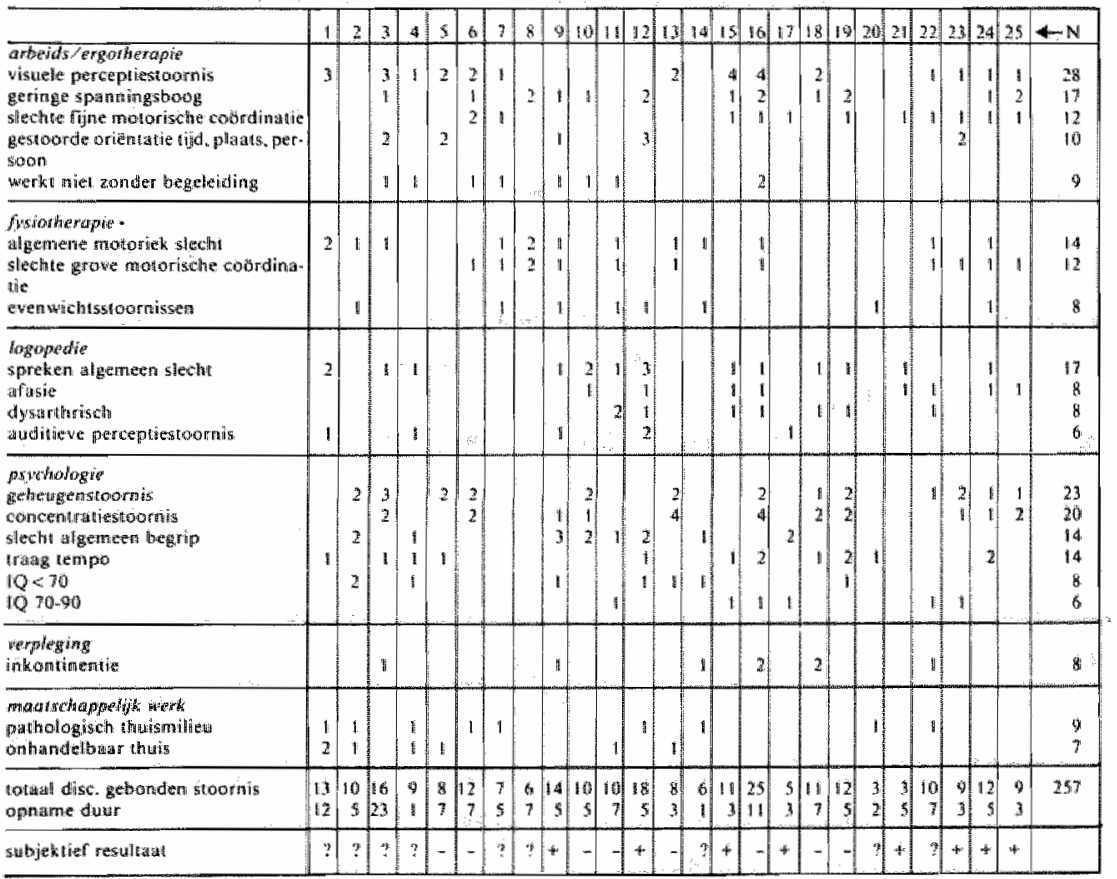

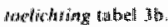

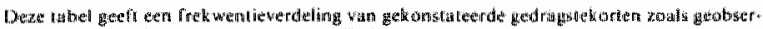

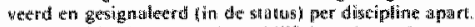

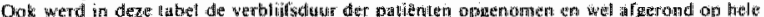

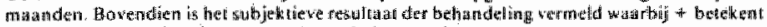

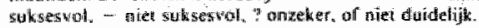

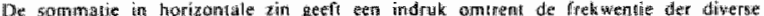
ged horter per partient wer.

No Rodenumber vart patient. 


\subsubsection{Bespreking der resulltaten van de inventarisatie}

Tabel 1 geeft de samenstelling weer van de patiêniengroep Hieruil blijkt:

le. Aantal mannen is bij benadering tweemaal zo groot als het aantal vrouwen. De gemiddelde leeftijd is bij mannen en vrouwen gelijk, nll. 24 jaar. De spreiding in leeftijd is echter bij beide groepen vrij groot nl. vanaf 10-45 jaar.

2e. Tijd van trauma tot opname is door enkele uitschieters vooral bij de wrouwelijke patiênten nogal uiteenlopend.

Bij mannen bedraagt deze tijd gemiddeld 20 maanden, bij vrouwen is deze tijd 92 maanden. Bij vrouwen en mannen tesamen gemiddeld 40 maanden, dus ca. $31 / 2$ jaar.

De range en gemiddelde afwijking zijn bij beide groepen vrij groot.

3e. De comaduur kon in 6 gevallen niet worden nagetrokken. Bij mannen en vrouwen lijkt de duur van het coma niet uitgesproken verschillend. Het gemiddelde van de totale groep bedraagt 34 dagen. Ook hier echter weer grote range en gemiddelde afwijking.

4e. Gemiddelde verblijfsduur ligt op 152 dagen, dus ca. 5 maanden met eveneens grote range en gemiddelde afwijking.

5e. De patiëntengroep bestaat uit 5 stamcontusio's (en hemisfeer beschadigingen); 12 contusio cerebri (en verdere aandoeningen); 2 mengvormen van stamcontusio en contusio cerebri; 6 patiënten, waarbij het beeld nogal atypisch was voor de contusio.

6e. Er werden 23 verschillende medikamenten aangewend, in diverse kombinaties, met als meest voorkomende medikatie resp. luminal $(10 \times)$ neuleptil $(7 \times)$, diphantoine $(6 \times)$ en limbritol $(4 \times)$.

\section{Tabel 2.}

Bij een eerste poging tot inventarisatie en eventuele voorzichtige interpretatie der gegevens dringt zich een moeilijkheid op inzake de terminologie. Een moeilijkheid die zich overigens nog wel enkele keren zal herhalen. Reeds bij een globale inspektie van de gegevens is het duidelijk dat er allerlei verschillen bestaan in de data van de "niet-disciplinegebonden uitingen" versus de "disciplinegebonden uitingen".

Dit geeft echter hoogstens aan dat de klachten gekonstateerd werden door een verzameling van diverse therapeuten in bepaalde situaties in vergelijking tot éen therapeut in een specifieke siluatie, het geeft voorlopig nog weinig informatie omtrent de patiént zelf.

Een onderscheid dat zich onwillekeurig opdringt is "de disciplinegebonden uitingen " in verband te brengen met cognitieve en motorische funktiestoornissen en de .niet-disciplinegebonden uitingen" met gedrag in interaktie met de medemens. Vanuit leertheoretisch standpunt gaat het echter in beide gevallen om gedrag. De konkludering dat de ..disciplinegebonden bevindingen" funktiestoomissen zijn, is een gevolgtrekking die eerst nog eens waargemaakt moet worden. Het is voorlopig onzeker of de benaming .ngedrag in interaktie" dit gedrag wel voldoende adek waat weergeeft. Daarbij komt bovendien de vraag of dit gedrag niet eveneens bepaald wordt door funtiestoormissen en omgekeerd.

In feite doen beide uitspraken over gedrag, zij het in verschillende situaties, namelijk: 1e. „De disciplinegebonden observaties” werden grotendeels uitgevoerd in een testsituatie waarbij de patiënt gekonfronteerd werd met een opgave en waarbij de betreffende therapeut beoordeelde of en hoe de patiënt deze opdracht uitvoerde. Dit is mu juist het gedrag waarop de fysieke revalidatie zich tot op 
heden voor het merendeel rich. Men zou het her doelgedrag wan de fusieke revalidatie kumner moemen.

2e. "De niet disciplinegebonden observaties" werden voor het merendeel uitgevoerd in een ,niet-testsituatie”. Het feit alleen al dat ze door een meerderheid der disciplines dus in allerlei situaties werden gesignaleerd en dan meestal nog in het voorbijgaan, geeft aan dat het hier om gedrag gaat, dat niet-testgebonden is. Het kwam bij diverse therapieên, maar ook op het dagverblijf naar voren en werd dan als hinderlijk door de omgeving onderwonden en als belemmerend voor een verdere therapietoepassing. Men zou het revalidariebelemmerend gedrag kunnen noemen.

Er lijken dus twee soorten onderscheidingen mogelijk te zijn: Enerzijds ".testgedrag " en ", niet-testgedrag” (onderscheid naar context of stimulus), anderzijds "revalidatiebevorderend doelgedrag" en "revalidatiebelemmerend gedrag" (onderscheid naar doelstelling).

Aan beide onderscheidingen zijn nadelen en onduidelijkheden verbonden. Het onderscheid naar "test"- en "niet-testgedrag” is wellicht belangrijk, maar het voegt niets toe aan "disciplinegebonden" en "niet-disciplinegebonden" observaties. Het onderscheid naar "revalidatiebevorderend" en "revalidatiebelemmerend gedrag" lijkt verwarrend. Het opheffen van belemmerend gedrag zou immers ook tot de doelstellingen van de revalidatie kunnen of moeten behoren.

Het onderscheid dat hier geintroduceerd wordt brengt aansluiting tussen leertheoretische principes èn revalidatie.

1e. De gehele revalidatie is in eerste instantie gericht op het konstateren van gedragstekorten. Men kan hierbij al dan niet onderliggende funktiestoornissen postuleren, echter het tekort kan alleen gekonstateerd worden in het gedrag van de persoon. Na de konstatering van een gedragstekort tracht men over te gaan tot eliminatie van het gedragstekort d.m.v. nieuwe gedragsvorming.

2e. Teneinde nieuwe gedragsvorming te realiseren is het nodig dat er een aantal voorwaarden aanwezig zijn. nl. die voorwaarden die het leren wan nieuw gedrag mogelijk maken en ondersteumen. Deze voorwaarden moeten aanwexig zijn in der persoon èn in de omgeving (revalidatie-thuis- en werkmilieu). Gedragsvorming wordt moeilijk, indien deze voorwaarden bij de persoon en/of de omgeving niet aanwezig zijn. Gedragsvorming (dus ook revalidatie) wordt onmogelijk indien er in plaats van de leervoorwaarden, kondities aanwezig zijn die nieuwe gedragsvorming belemmeren of tegenwerken. Men zou kumnen spreken van blokkeringen tor gedragsvorming of kortweg ..gedragsbelemmering". Een van deze gedragsbelemmeringen is de aanwezigheid van een zo dominerend gedragspatroon, dat er a.h.w. geen mogelijkheid meer is voor een ander ged rag of andere gedragsvorming. Hierbij dient aangetekend te worden, dat de nieuwe gedragsvorming in de revalidatie in een groot aantal gevallen weinig reinforcerend en vaak ook aversief is. Het gedrag dat nieuwe gedragsvorming tegengaat heeft voor de patiënt een hogere bekrachtigende waarde dan het nieuwe aan te leren gedrag. Dit kan zowel opgaan voor bijwoorbeeld "agressief” gedrag als "passief"gedrag. Beide gedragingen ontstaan zoveel gemakkelijker ondat ze veelal als reaktie op bijv, teleurstellingen, pijn, moeilijkheden, all heel vroeg zijn aangeleerd. Eenmaal aangeleerd staan ze vorming van het nieuwe gedrag dat van de patiènt verwacht wordt en dat mogelijk ook nog aversief wordt beleefd, in de weg. Vanuit gedragsvormend standpunt is hier een blokkering, die in dit geval bestat uit ongewenst gedrag dat met een te grote frekwentie (nl. meestal of altijd) optreedt, waardoor het nieuwe anderen van 
gedrag onmogelik word:. Gedragsbelemmeringen zinn echter niet beperkt tot excessief gedrag, voorkomende bij de patient zelf. Andere gedragsbelemmerin. gen kunnen aangetroffen worden in het revaldatiemilieu (te weinig bekrachtiging), het thuismilieu (onderstewning van het revalidatiebelemmerende gedrag) en eventued, howel hypothet sch, in het funkioneren wan het organisme zelf. (zie hoofdstuk 4 en 5 ).

Het antagonistische koppel: gedragswoming en de belemmeringen tot gedragsvorming resp. tussen willen en weerstand is in de psychologie reeds lang een vertrouwd idee, (zie bijv. Rümke 1951 p. 93 of Klages 1926)

Om deze tegenstelling te ontmoeten hoeft men overigens niet persé naar historische psychologische publikaties om te zien. In de hedendaagse fysiotherapeutische literatuur treft men soortgelijke uifspraken aan: , Abnormale gedragingen kunnen", aldus Kugel (1976 p. 260), ,zo genncorporeerd worden in het gedragspatroon, dat men normale gedragingen als aanstellerig ervaart en derhalve niet uivoert".

Uit bovenstaande, korte witeenzetting blikt dat de ideeën inzake gedragsvorming en ged ragsbelemmeringen, $z i j$ het in andere bewoordingen, in verleden en heden in werscheidene kaders worden aangetroffen. Uitspraken, voorkomende in de status en weergegeven in tabel 2 . kunnen dus, gebruk makend van leertheoretische indelingen, maar ook vanuit andere bronnen, in twee kategorieèn worden verdeeld.

Bij de werdere bewerking van tabel 2 en daaropvolgende assessment en madifikaties wordt derhalve een onderscheid gemaakt in:

1e. Tekorlen aan gewensi gedrag resp. gedragstekorten. Deze werden (wat tabel 2 betreft) gekonstateerd door de diverse disciplines apart en hadden hoofdzakelijk betrekking op somatische gedragstekortem. Dit impliceert dat er een grotere variëteit van gedragstekorten (bijvoorbeeld sociale vaardigheden) bestaan echter zij werden in destudie der statussen niet a angetroffen en derhalve ook niet opgenomen in de voorlopige assessmentprocedure.

2e. Gedragsbelemmeringen. Deze werden (wat tabel 2 betreft) gekonstateerd door de diverse disciplunes gezamenlijk èn door de maatschappelijk werkenden apart. Zoals deze in tabel 2 zijn geformuleerd hebben ze hoofdzakelijk betrekking op ongewenst gedrag (vanuit gedragsvormend standpunt) dat in te grote frekwentie (meestal, althj, tijdens pogingen tot gedragsvorming) optrad.

Dit impliceert dus eveneens dat er verschillende gedragsbelemmeringen kunnen bestaan, echter ook deze werden niet aangetroffen in de status en derhalve niet opgenomen in de voorlopige assessment.

Het onderscheid in gedragstekorten en gedragsbelemmeringen is leertheoretisch verantwoord en het leent zich uitstekend voor de bespreking van tabel 2 . In de revalidatie lijkt door de introduktie van "gedragsbelemmeringen" het aksent te zajn gelegd op een gebied dat tot nu toe niet de aandacht kreeg die het verdiende.

1e. Indien deze indeling naar gedragstekort en gedragsbelemmering wordt gehanteerd, dan blijkt het aantal items voor beide groepen gelijk te zijn, nl. 19-19. (17 gedragsbelemmeringen in de kliniek en 2 gekonstateerd door matschappelijk werk).

2e. We gedragsbelemmeringen, waarbij p $>5$ zijn:

ongemotiveerdheid, slordigheid, de baas willen spelen, treuzelen, herhalen, inaktiviteit, infantiel-lacherig gedrag, ontremd-onrustig gedrag, aandachtafdwingend, het niet-coöperatieve gedrag, gebrek aan zelfkritiek, klagen, prikkel- 
baarheid-agressiviteit, zich afzonderend gedrag, hullen, agressie, onzelfstandigheid, angst, pathologisch thuismilieu en onhandelbaarheid van patient in thuissituatie.

De gedragstekorten, waarbij $p \geqslant 5$ zijn:

visuele perceptiestoomis, beperkte spanningsboog, slechte fijne motorische coördinatie, gestoorde oriëntatie in thjd, plaats en persoon, werkt niet zonder begeleiding, algemeen slechte motoriek, slechte grove motorische coördinatie, evenwichtsstoornis, slechte algemene spraak, afasie, dysartrie, slecht algemeen begrip, auditieve perceptiestoornis, geheugenstoornis, concentratiestoornis, traag tempo, IQ onder gemiddelde, inkontinentie.

3e. Het aantal gedragsdeviaties over 25 patiënten genomen over de totale verblifscluur bedraagt voor de gedragsbelemmeringen $(377+16)=393$; voor de gedragstekorten 242. D.w.z. het aantal gedragsbelemmeringen bedraggt $1,6 \times$ het aantal gedragstekorten.

4e. Het aantal patienten warbij deze deviaties worden aangetroffen ( $P$ ) is wat betreft de gedragsbelemmeringen $(174+15)=189$ en wat betreft de gedragstekorten 174. D.W.z. hel aantal patiënten met gedragsbelemmeringen is nagenoeg even groot als het aantal patiënten met gedragstekorten. Dit behoeven niet noodzakelijk dezelfde patienten te zijn. ( $P$ is hierbij zoals tabel 2 aangeeft de sommatie der diverse deviaties over het antal patiënten).

Se. Het aantall patiënten warbij (vermoedelijk) sprake was van vermeerdering der deviaties (P-), bedragt voor de gedragsbelemmeringen $(68+3)=71$ en voor de gedragstekorten 11. D.w.z. een ca. 6 maal zo grote toename van patienten met gedragsbelemmerende faktoren in vergelijking met de toename van patiënten met gedragstekorten.

6e. Het aantal patiènten waarbij (vermoedelijk) sprake was van vermindering der klachlten $(\mathrm{P}+)$, bedragt voor de gedragsbelemmeringen 21 en voor de gedragstekorten 47. D.w.z. een ongeveer 2 mal zo grote verbetering van patiènten met gedragstekorten in vergelijking tot patiênten met belemmerende raktoren.

Tabel $3 a$. en $b$.

Deze tabel leent zich voor talloze overwegingen en konstateringen van tendenties. Het aantal gevallen biedt echter geen kans voor een zinvol gebruik van statistische toetsen. Er dient daarom voor gewaakt te worden voorbarige konklusies te trekken, derhalve worden de volgende gedachtengangen slechts als witspraken gepre. senteerd. Sommige hiervan zujn vanzelfsprekend, andere dadrentegen wellicht onverwacht.

A. Inzake het samen optreden van klachtenuitingen.

1e. "Pathologie in thuismilieu" hoeft niet samen te gan met "gestoord gedrag van patient thuis". De samenhang werd slechts in 3 van de 9 gevallen gekonstateerd.

2e. „Concentratiestoorn is" gaat in 9 van de 10 gevallen samen met "geheugenstoornis".

3e. a. "Auditieve perceptiestoornis" gat in 4 van de 5 gevallen samen met "slecht spreken in he algemeen".

b. "Dysartrie" gaat in 6 van de 7 gevallen samen met "slecht spreken in het algemeen".

c. Afasie" gaat in 6 van de 8 gevallen samen met .slech spreken in het algemeen". 
4e. a. "Evenwichtsstoomis" gaat in 6 van de 8 gevallen samen met "slechte algemene motoriek".

b. Slechte grove motorische coördinatie ${ }^{*}$ gat in 8 van de 10 gevallen samen met ,slechte algemene motoriek"

Se. a. ,Slechte fijne motorische coördinatie" gaat in 8 wan de 11 gevallen samen met „visuele perceptiestoorn is".

b. "Werkt niet zonder begeleiding" gat in 5 van de 8 gevallen samen met .geringe spanningsboog".

B. Inzake het falen van de revalidatie.

Een interessinte vraag lijkt te zijn, war nu het sukses of falen van de revalidatie bij patienten met contusio cerebri door bepaald wordt. Van 8 patienten kon met redelijke betrowwbaarheid uit de status gekonkludeerd. worden dat hun revalidatie suksesvol. was verlopen. Uit de statussen bleek nl. dat het aantal uitspraken van verbetering groot was en dat er geen uiklatingen meer voorkwamen omtrent eerder gekonstateerde deviaties. Van 8 patiënten kon overigens onder hantering van dezelfde kriteria het tegengestelde vastgesteld worden. Het aantal deviatie-uitspraken nam toe, terwijl over positieve bevindingen niet werd gerept. Van 9 patiënten is geen duidelijke konklusie mogelijk.

Indien men de 8 suksesvolle patienten vergelijkt met de 8 onbevredigd behandelde patienten, dan presenteert zich het volgende beeld.

Tabel 4: Vergelijking „suksessen" en "fallen"

\begin{tabular}{lrrrrrrrrr} 
suksessen $\mathrm{P}(+)$ & 9 & 12 & 15 & 17 & 21 & 23 & 24 & 25 & $\Sigma$ \\
\hline $\begin{array}{l}\text { ged ragsbelemmeringen } \\
\text { gedragstekorten }\end{array}$ & 14 & 18 & 2 & 1 & 0 & 12 & 9 & 7 & 63 \\
& 14 & 18 & 11 & 5 & 3 & 9 & 12 & 9 & 81 \\
Galen $\mathrm{P}(-)$ & 5 & 6 & 10 & 11 & 13 & 16 & 18 & 19 \\
\hline $\begin{array}{l}\text { gedragsbelemmeringen } \\
\text { gedragstekorten }\end{array}$ & 12 & 19 & 20 & 43 & 21 & 31 & 38 & 26 & 210 \\
\hline
\end{tabular}

$\mathrm{P}(+)$ en $\mathrm{P}(--)$ geef het (fiktieve) patièntennummer aan uit tabel 3. Gedragsbelemmeringen blijken vooral gesignaleerd te worden bijuitspraken door maatschappelijk werk en bij de niet-disciplinegebonden uitspraken uit tabel 3. Gedragstekorten zijn to herkennen onder klachtenuitingen voortkomend uit de disciplinegebonden uitspiaken wit tabel 3 .

Bij bestudering van tabel 4 blijkt:

18. Het antal gedragstekorten is voor beide groepen nagenoeg gelijk. Suksesvol behandelden kregen 81 uitspraken inzake gedragstekorten. Niet-suksesvol behandelden kregen 92 uitspraken inzake gedragstekorten.

2e. Het antal gedragsbelemmerende uitspraken is voor de niet-suksesvol behandelde groep a anzienlijk groter in vergelijking tot de suksesvol behandelde groep nl. $210: 63$ (faktor 3,3).

\subsubsection{Samenvatting.}

De status a Is neerslag van een teambespreking is op zichzelf een reduktie en een min of meer willekeurige verzameling van min of meer betrouwbare informaties. Het is derhalve wel een vreemd uitgangspunt om juist de status als basis te gebruiken voor het opzetten wan een mogelijk betere revalidatieprocedure. De status was echter het 
enige ruwe materiaal, dal direkt beschikbaar was. Informaties uit de status dienen derhalwe met reserve te moeten worden bezien en onder voorbehoud te worden geinterpreteerd. De eventueel hieruit voortkomende strategie kan allean een strategie in alle voorlopigheid zijn.

Na hergroepering van de gegevens uit de status konden een drietal overzichten worden gegeven inzake:

a. de samenstelling der groep patiènten met contusio cerebri, naar ard wan aandoening en andere parameters die hierbij relevant leken.

b. de soort en het aantal uitingen inzake gedragsdeviaties.

c. de verdeling van de deviaties over de patienten.

De onderverdeling der gedragsdeviatie-uitspraken in "gedragstekorten" zoals gekonstateerd door de diverse disciplines apart en "gedragsbelemmeringen" zoals gekonstateerd door de diverse disciplines tesamen, geeft een goed uitgangspunt voor de integratie van leertheorieën en behandelingsstrategieen in de revalidatie. De gedachte die aan deze indeling ten grondslag lag was de overweging dat revalideren in eerste instantie het opnieuw vormen van gedrag c.q. het aanleren van dit nieuwe gedrag is. Bij dit aanleren dienen allerlei kondities optimaal te zijn. Zijn deze voorwaarden niet vervuld, dan is er veelal sprake van belemmerende kondities, faktoren die het leren, het opnieuw vormen wan gedrag tegenwerken.

De gedragsbelemmeringen lijken uit diverse faktoren te kunnen bestan. Een daarvan is ongewenst gedrag dat excessief optreedt.

Na deze indeling in gedragstekorten en gedragsbelemmeringen konden een aantal voorlopige, maar opmerkelijke bevindingen uit de overzichtstabellen worden betrokken:

1e. Het aantal gedragsbelemmeringen is aanzienlijk groter dan het aantal gedragstekorten.

2e. Het aantal uitspraken inzake gedragsbelemmeringen neemt in de loop der revalidatieperiode meer toe dan het aantal uitspraken inzake gedragstekorten.

3e. Patienten die in de revalidatie als onbevredigd behandeld werden beschouwd tonen aanzienlijk meer gedragsbelemmeringen dan zij, die als suksesvol behandeld werden gezien. Bij deze groepen waren de gedragstek orten nagenoeg gelijk.

Als een voorlopig plausibele konklusie is te stellen, dat bij de revalidatie van patiènten met contusio cerebri een aantal gedragsbelemmeringen bestaan , die het opheffen wan gedragstekorten in de weg staat.

Herkenning van deze gedragsbelemmeringen en eliminatie ervan lijkt derhalve de primaire opgave te zijn voordat gedacht en gewerkt kan worden aan herstel of opnieuw vormen van gedrag.

Bij de groep der patiènten met contusio cerebri lijkt dit zelfs het eerste doel te zijn warop de revalidatie zich zou moeten richten.

\subsection{Samenstelling van een voorlopige assessmentprocedure}

\subsubsection{Inleidling}

In deze paragraat wordt teruggegrepen op datgene wat bij de verzameling der gegevens werd gekonstateerd. Een onregelmatige verzameling van weinig gestruktureerde subjektieve informatie kan geen basis vormen warop een strategie moet worden opgebouwd. Er dient dringend aandacht besteed te worden an een 
mogelijkheid om op een meer gestandardiserde wije, binnen regelmage rijdsintervallen, objektieve informatie te krijgen inzake relevante repeterende (dus dezelfide) kriteria.

Als gedrags variabelen warop de informatie betrekking moet hebben, werden bij de inventarisatie der contusio-problematiek reeds genoemd: enerzijs gedragstekorten en andersijds gedragsbelemmeringen.

Teneinde deze variabelen minder ahankelijk te maken wan een subjektieve hantering dienen ze nader uitgewerkt te worden. Dat geldt zondermeer voor de gedragsblemmeringen. Maar ook de gedragstekorten verdienen de aandacht, aangezlen niet zondermeer kan worden aangenomen dat de kriteria relevant zijn en dat de zo gewenste objektiviteit door ledere discipline in geljke mate wordt nagestreefo of geambieerd.

De regelmatige herhaling van informatiewerzamelen vormt hier een apart probleem. Deze bepadt in aanzienlijke mate welke variabellen yoor regelmatig gestandaardiseerde informatie kunnen worden bewerk. Dit zijn de niet-disciplinegebonden gedragsbelemmeringen, aangezien deze door geen enkele discipline als privé terrein worden beschouwd, en uiteraard gegevens vanuit het psychologisch rapport. Vanuit deze, eveneens weer door praktijkomstandigheden inzake toegankelijk heid gevormde invalshoek, wordt de voorlopige assessmentprocedure opgezet.

\subsubsection{De psychologische onderzoekprocedure}

Aangezien psychologische tests doorgaans gestanda ardiseerd zijn en bovendien met regelmatige tijdsintervallen door de afdeling psychologie afgenomen kunnen worden, werden deze als een eerste onderdeel in de voorlopige assessmentprocedure opgenomen.

\subsubsection{Samenstelling}

Bij de samenstelling van de psychologische onderzoekprocedure werd rekening gehouden met:

a. De kriteria welk genoemd werden onder inventarisatie der problematiek.

b. Met de ter beschikking staande gestandaardiseerde en genormeerde tests.

c. Voor zover dit enigszins kon, met de afnamemogelijkheid bij de soms zwaar gehandicapte revalidatiepatiënten.

\section{Algemene intelligentid,}

Aangezien het een ervaringsfeit is, dat intelligentiebepaling dm.v. eén test een onvolledig en vaak vertekend beeld oplevert, werd een kombinatie van twee intelligentietests voor iedere patiént met contusio cerebri nagestreefd. Afhankelijk van de handicap werd een keuze gemakkt uit: Raven Progressive Matrices; volwassen of kindervorm; WAIS-verbaal; WAIS-performance; WISC-verbaal; WISC performance; GIT en SON.

De normering werd betrokken uit de handleiding behorende bij de betreffende test. 2. Geheugen (korte termijn).

Literatuurgegevens en praktijkervaring suggereerden, dat er rekening moest worden gehouden met de modaliteit waarin de stimuli werden angeboden, de wijze wan stimuluspresentatie en de aard van de gewenste reproduktie. Derhalve werd hier onderscheid gemaakt in:

a. Recognitie: het presenteren van een aantal stimuli, de inprenting en de opslag hiervan, het herkennen van de stimuli uit verschillende tegelijkertijd aangeboden stimuli. 
a-1. Recognitie visueel: Eigen testontwikkeling (naar voorbeeld: geheugen voor plaatjes SON.)

a-2. Recognitie auditief: Eigen testontwikkeling

b. Recall: het presenteren van een aantal stimuli, inprenting en opslag hiervan en het reproduceren in een volgorde, die niet noodzakelijk overeen hoeft te komen met de presentatie.

b-1. Recall visueel: Benton

b-2. Recall auditief: 15-woordentest.

Onder korte termijn wordt verstaan: reproduktie 5 sekonden na presentatie. Normering voor a-1 en a-2 vond plats op 30 leerlingen van de opleidingen logopedie en arbeidstherapie in de leeftijdsgroepen 18-25 jaar met een GIT-IQ tussen de 100-120 punten.

In de gegeven omstandigheden diende genoegen genomen te worden met de normeringstekorten wat betreft de niet a-selekte steekproef, het te hoge IQ in relatie tot de gemiddelde patiënt met contusio cerebri en een te kleine groep woor vergaande statistische uitspraken.

\section{Concentratie.}

Als concentratie-aspekt werd de zgn. .attention span" gekozen "waarbij dus andere aspekten als "selektiviteit" en "focus" voorlopig buiten beschouwing bleven. Concentratie wordt hier gedefinieerd als het vermogen van een persoon om met een bepaalde taak bezig te zijn en te blijven, met een zekere snelheid, regelmatigheid en nauwkeurigheid. In ons land wordt hiervoor als onderzoekmethode De BourdonWiersmatest gebruikt, waarbij het volhouden van de taak een vereiste is en bet tempo per regel, het aantal fouten en de dispersie worden bepaald. Voorlopig werd gemeend ook deze Bourdon-Wiersma voor het genoemde concentratie-aspekt te kunnen hanteren.

Normering werd betrokken uit het akademisch ziekenhuis te Groningen, afdeling neurologie. Er bestaan hieromtrent enkele officiële publikaties.

\subsubsection{Assessmentuityoering}

Aangezien in de inventarisatie met name geheugen en concentratietekorten werden genoemd en er wat betreft de modifikatie hiervan enkele publikaties bestonden, werden deze gedragstekorten in aanmerking genomenvoor een poging tot gedragsvorming. Het intelligentieniveau gold hier slechts als een extra parameter. Een poging tot modifikatie van intelligentietekort werd nog niet ondernomen. De strategie ter modifikatie van geheugen-en concentratietekorten wordt onder 2.2.3. behandeld.

Als indlikatie voor geheugen resp. concentratietekort golld steeds de voorwaarde, dat betreffende patiënt vergeleken met zijn normeringsgroep duidelijk onderscoorde op geheugen en concentratietest, maar daarnaast toch een gemiddeld IQ $>90$ bezat. De effektassessment vond voor iedere patiënt om de drie maanden plaats. Aangezien vrijwel iedere behandeling minstens 5 à 6 maanden duurde, was er dus gelegenheid tot het afnemen van minimaal twee assessmentprocedures. De kans op testgewenning leek met een tussenperiode van drie maanden vrij gering. Hierdoor werd afgezien van het gebruik van paralleltests.

Vergelijking der scores vond plaats in decielen voor de geheugen en concentratietests: bij de intelligentietests werden de standaardscores vergeleken. Aangezien de onder 2.2.3. te behandelen observatie van gedragsbelemmeringen plaatswond in een 5-puntsschaal werd ter verkrijging wan overzichtelijkheid ook de geheugen-en 
concentratiedecielen en de intelligentiestandaardscores omgezet in een „punt” schaal.

Tabel 5 geeft een overzicht van deze omzetting.

Tabel 5: Omzetting van Testscores in ${ }_{4}$ puntt" schaal

\begin{tabular}{|c|c|c|c|c|c|c|c|c|}
\hline \multirow{4}{*}{$\begin{array}{l}\text { "punt"- } \\
\text { schaal }\end{array}$} & \multirow{4}{*}{$\begin{array}{c}\text { gem. } 1 \mathrm{Q} \\
\text { standaard- } \\
\text { scores }\end{array}$} & \multicolumn{4}{|c|}{ Geheugen-Units-Kort } & \multirow{2}{*}{\multicolumn{3}{|c|}{$\frac{\text { concentratie }}{\text { decielen }}$}} \\
\hline & & \multirow{2}{*}{\multicolumn{2}{|c|}{$\begin{array}{l}\text { decielen } \\
\text { recognitie }\end{array}$}} & \multirow{2}{*}{\multicolumn{2}{|c|}{$\frac{\text { decielen }}{\text { recall }}$}} & & & \\
\hline & & & & & & \multirow[b]{2}{*}{ tempo } & \multirow[b]{2}{*}{ disp. } & \multirow[b]{2}{*}{ fouten } \\
\hline & & vis. & audl. & vis. & aud. & & & \\
\hline 5,0 & $\left.<60^{\circ}\right)$ & v') & I') & I) & $\left.1^{4}\right)$ & (1) & 1) & (1) \\
\hline 4,5 & $60-70$ & II & 11 & II & II & III & II & III \\
\hline 4,0 & $70-80$ & III & III & 111 & IIII & III & III & 110 \\
\hline 3,5 & $80-90$ & IV & IV & IV & IV & IV & IV & IN \\
\hline 3,0 & $90-100$ & v & V & v & v & v & v & v \\
\hline 2,5 & $100-110$ & V1 & vi & vi & vI & VI & $\mathrm{V} 1$ & vi \\
\hline 2,0 & $110-120$ & VII & VII & vil & VIII & VII & VII & VIII \\
\hline 1,5 & $120-130$ & VIII & VIII & VIII & VIII & VIII & VIII & VIII \\
\hline 1,0 & $>130$ & $1 \mathrm{X}+\mathrm{x}$ & $1 x+x$ & $I X+x$ & $1 x+x$ & $11 x+x$ & $I X+X$ & $I X+X$ \\
\hline
\end{tabular}

\subsubsection{De Gedragsobservatieschaal Contusio Cerebri (GOCC)}

\subsubsection{Samenstelling van de items}

Ten behoeve van het onderzoek diende een betrouwbare en valide observatiemethode ontwikkeld te worden. Een dergelijk instrument moet uiteraard voldoen aan minimale voorwaarden.

Uitgaande van deze voorwaarden inzake de opzet van de schaal werd de samenstelling zelf als volgt uitgevoerd:

1e. Er werd uitgegaan van de 17 gedragsbelemmeringen, zoals die uit de inventarisatie van de problematiek bij de niet-discipline-gebonden uitingen naar voren kwamen.

2e Vervolgens werd in een drietal bestaande gedragsobservatieschalen gezocht of de 17 gedragsbelemmeringen hierin waren vertegenwoordigd. Deze schalen waren de WAV (Burger 1971), Graffelschaal (Burger 1966) en een schaal voor een psychiatrisch centrum (Marinkelle 1969).

3e. Indien een gedragsbelemmerend item in deze schalen werd aangetroffen, dan werden de omschrijvingen die deze bestaande schalen gebruikten genoteerd op een aparte lijst en wel iedere uitspraak op een aparte regel.

Hierbij werden alleen of hoofdzakelijk gedragsomschrijvingen geselekteerd en bijv. geen "selfreport". Op deze wijze ontstonden ca. 300 uitspraken die apart getypt werden op strookjes papier.

4e. De ca 300 strookjes met uitspraken werden vervolgens at random aangeboden an drie personen (niet-psychologen) met het verzoek: 
a. Deze te sorteren onder de hoofden die gewormd werden door de 17 gedragsbelemmeringen.

b. Vervolgens te trachten een volgorde in 4 stappen aan te brengen van "licht aanwezig" tot "de betreffende gedragsbelemmering is maximal aanwezig".

c. Tenslotte werd gevraagd "thet niet aamwezig zijn van bepatde klacht" in engen woorden te omschrijven.

5e. Als kriterium voor de opname van een uitspraak gold, dat deze uitspraak door twee van de drie personen overeenkomstig werd beoordeeld en gerangschikt.

6e. Voor twee soorten gedragsbelemmeringen waren zo veel uitspraken besehikbaar dat werd overgegaan tot opsplitsing namelijk in: Dwangmatig gedrag in resp, werk en zelfverzorging. Slordigheid in resp. werk en zelfverzorging.

7e. Tenslotte werden de gedragsbelemmeringen in twee groepen opgesplitst, met het oog op hun relevantie voor everituele modifikatiepogingen.

A. Gedrag dat in de regel: ,hulp, aandacht, medelijden, ondersteuning" vanuit de omgeving oproept.

I: Huilen

II : Angstig gedrag

III: Depressief gedrag

IV: Klagen

V: $\quad$ Onzelfstandig gedrag

VI: $\quad$ Afzonderings gedrag

VII: $\quad$ Opdringerig gedrag

VIII : $\quad$ Dwangmatig gedrag

IX: Euforie.

B. Gedrag dat in de regel ,afkeer, irritatie, agressie" spontaan vanuit de ongeving oproept.
$X:$
XI :
Slordigheid
XII:
Niet-coöperatief gedrag
XIV:
XV:
Onrustig, ontremd gedrag
XVI: XIII: Verbale en Motorische Agressie XVII: Gebrek a an zelfkritiek. XIII: Verbale en Motorische Agressie XVII: Gebrek aan zelfkritiek.
Dominant gedrag In ak tief, trang gedrag Ongemotiveerd gedrag

Dit onderscheid in A en B bleek in de praktijk - zoals te verwachten was - niet relevant (zie hoofdstuk 3 )

8e. Het resultaat van deze handelswijze werd tesamen met instrukties voor de beoordelaar (zie bijlage 1) als een boekje gepresenteerd aan het team.

N.B. De psychometrische aspekten van deze schaal worden in hoofdstuk 3 besproken.

\subsubsection{Assessment door gedragsobservatoren}

1e. Teneinde wederzijdse beifnvloeding te voorkomen dient observatie en rapportage buiten de groep te gebeuren. Dit betekent dat de observator aan de hand van 20 veel mogelijk geexpliciteerde gedragsomschrijvingen individueel en keuze doet uit alternatieven., deze keuze schriftelijk vastlegt en naar een central punt opstuurt.

2e. Daar het gedrag een funktie is van de voorgaande stimulus en de daaropvolgende omgevingskontingenties zal de patiënt in verschillende situaties geobserveerd dienen te worden. Op deze wijze wordt een indruk verk regen omtrent het voorkomen van gedrag binmen diverse situaties.

3e. Dientengevolge zullen er ook verschillende observatoren moeten zijn. Dit lijken bij voorkeur dezelfde personen te moeten zijn, die op ongeveer regelmatige en dezelfde tijdstippen de observatie uitvoeren en tot een indruk komen. 
4e. Hoewel het van belang is rekening te houden met de specifieke stimulussituatie moet wel in acht genomen worden dat deze aparte scoreverzameling het werk zal zijn van één hooguit twee observatoren, die dan toevallig in dezelfde plaats werkzaam waren. Het is hiernaast nodig en vermoedelijk meer betrouwbaar een indruk te krijgen van de totaalscore over verscheidene observatoren. Deze visie wordt ook ondersteund door Burger: „Door individuele beoordelingen te kombineren worden synthetische beoordeelaars gevormd, wier beoordelingen een hogere interbeoordeelaarsbetrouwbaarheid te zien geven en tot hogere validiteitscijfers kunnen leiden dan de beoordeling van individuele beoordelaars". (Burger 1966, p.1)

Aan bovenstaande richtlijnen en ideeën gevolg gevend werd een vast beoordelaarsteam samengesteld bestaande uit 3 verplegenden, 2 fysiotherapeuten, 1 logopediste, en 2 arbeids/ergotherapeuten. Deze 8 beoordelaars werden niet opgeleid, maar slechts verzocht zich dringend aan de instrukties te houden, die in de inleiding van de GOCC waren opgenomen (zie bijlage 1).

\subsubsection{Assessmentuitwoering}

ledere patiënt met contusio cerebri $k$ wam na een adaptatieperiode in aanmerking voor gedragsobservatie d.m.v. de "Gedragsobservatieschaal Contusio Cerebri (GOCC). Aangezien echter niet iedere patiënt evenveel therapiesessies per dag verkreeg, werd niet iedere patient door de 8 personen van het observatieteam geobserveerd. Er werd echter wel altijd naar gestreefd een minimum aantal van 5 observatoren per patiënt bij de observatie te betrekken. In total werden voor iedere patient drie observaties uitgevoerd, die eenmaal per 14 dagen plaats vonden.

Indien uit de observatie van de observatoren bleek dat er geen reden was om het gedrag van de patient voor een bepaalde situatie apart te bezien, dan werden de scores (lopende van 1-5) gesommeerd en gedeeld door het aantal observatoren (N.B. Zie inzake psychometrische overwegingen hoofdstuk 3).

Indien er toch reden bestond om de eventueel gekonstateerde gedragsbelemmerende faktoren per situatie apart te bezien dan vond evengoed sommatie en middeling plaats. De konstatering van deze stimuluskon trole vormde dan een aanwijzing voor het opstellen van eventueel te ondernemen modifikatie van gedragsbelemmeringen. Het resultaat van een driemalige observatie over 6 weken wordt in figuur 1 weergegeven.

Indien na 3 observaties bleek dat er een of meer gedragsbelemmeringen hoog, d.w.z. boven de 3 bleven, dan $\mathrm{kwam}$ de patiënt in aanmerking voor programmering van gedragsmodifikatie.

De gedragsmodifikaties zullen behandeld worden in 2.3 .2 de voorlopige revalidatiestrategic. Het lijkt hierbij nuttig nu reeds te vermelden dat er - evenals bij gedragsvorming - bij de gedragsmodifikatie van excessief gedrag een ",procesassessment" plaats vond. Deze procesassessment stond naast .effektassessment". De procesassessment ..begeleidde" a.h.w. de therapie van moment tot moment zoals in 3.1. zal blijken. De effektassessment der GOCC werd woor en na de therapie gerealiseerd. Voor de therapie bestond zij uit drie synthetische observaties, waarbij de latatste observatie het kriterium vormde voor verdere begeleiding. De meeste gedragsmodifikaties van excessief gedrag bleken niet langer dan 2 à 3 maanden te duren. Deze werden dan afgesloten met een GOCC-observatie. Indien een gedragsmodifikatie of gedragsvorming langer duurde werd daarna om de drie maanden een GOCC-observatie uitgevoerd. Op deze wijze werd zoveel mogelijk parallel gewerkt met de eerder besproken psychologische onderzoekprocedure. 
FIG. 1. Registratie van GOCC observaties
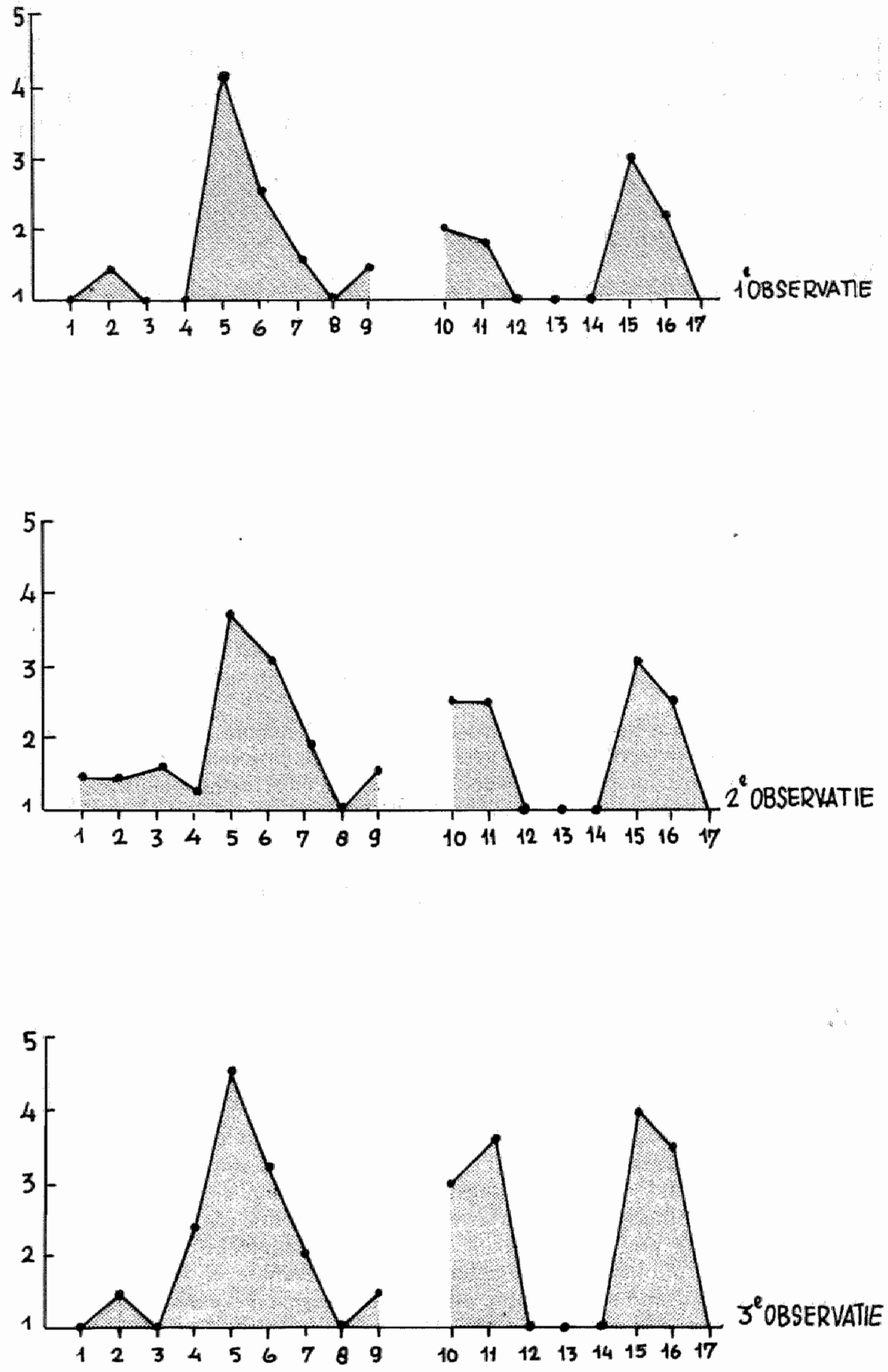


\subsubsection{Samenvatting}

De bewerking der gegevens uit de inventarisatie tot een voorlopige assessmentprocedure bleek niet onmiddellijk voor alle gegevens mogelijk. Enerzijds was er bij iedere aparte discipline een thechting aan eigen specialisatie, anderzijds leek het raadzaam om bij een poging tot herstrukturering niet direkt op een al te grote schaal op wijzigingen aan te dringen. Derhalve bleef een poging tot herziening der informatieverzameling beperkt tot het psychologische onderzoek en de observatiegegevens van de gedragsbelemmeringen die niet-disciplinegebonden waren. Dit resulteerde in een zogenaamde voorlopige assessmentprocedure, welke bestond uit twee delen:

1e. Een psychologisch onderzoek (PO) t.b.v. het vaststellen van gedragstekorten op het gebied van:

a. de algemene intelligentie

b. het geheugen op korte termijn en wel voor auditieve en visuele recognitie en recall

c. de concentratie: (tempo, regelmaat, fouten bij het uitvoeren van een taak).

2e. De Gedragsobservatieschaal Contusio Cerebri (GOCC). Deze bestond uit 17 gedragsbelemmerende kriteria, zoals aangetroffen bij de inventarisatie.

Zowel PO als GOCC werden zodanig opgezet, dat de resultaten van beide uitgedrukt konden worden in een 5-puntschaal, ter onderlinge vergelijking en eveneens latere statistische bewerkbaarheid.

Bij de afname der PO en GOCC werd er naar gestreefd een parallellopende verzameling van informatiewerving te verkrijgen, waardoor het effekt van een bepaalde vorm van begeleiding tegelijkertijd op beide schalen zichtbaar zou kunnen worden.

Naast deze effektassessment werd de procesassessment genoemd. Deze laatste vorm dient niet verward te worden met de eerstgenoemde. De procesassessment bedoelt het beloop van een strategie op de voet te volgen, de effektassessment beoogt de evaluatie van begin-en eindstand van de behandeling.

\subsection{Opzet voor een voorlopig modifikatiestrategie}

\subsubsection{Inleidling}

Bij de patiënt met contusio cerebri trachtte men in het verleden tot nieuwe gedragsvorming te komen. Indien na langdurig uitproberen bleek dat het optreden van nieuw gedrag mislukte, dan werd uitdrukkelijk stilgestaan bij allerlei kondities, die dit opnieuw leren blokkeerden. Het is niet goed duidelijk in hoeverre men in staat was tot inventarisatie en eliminatie van deze gedragsbelemmeringen, echter het aantal patienten met contusio cerebri, waarvan de revalidatie onbevredigend was verlopen bleek het aantal bevredigend behandelde patiënten minstens te evenaren. Bij cen surplus aan faktoren die gedragsvorming tegengaan, wordt de revalidatie maar al te snel als onmogelijk beschouwd. De desbetreffende patiënt wordt veelal ontslagen of vaker nog overgeplaatst naar een psychiatrisch ziekenhuis. De problematiek der dubbel gehandicapten wordt telkenmale in het revalidatiecentrum als een blijvend en voorlopig onoplosbaar gegeven ervaren. Toch wordt gemeend dat het revalidatiecentrum bij uitstek de plaats is om deze problematiek daadwerkelijk aan te pakken: 
Elimmatie van deze gedragsbelemmeringen (in de persoon, in de revalidatio-omgeving, in thet thuismilieu en eventueel eveneens in processen in het organisme zelf wordt hier gezien als een der doelstellingen van de revalidatie.

De principes van gedragsvorming bij gedragstekorten en de opheffing van gedragsbelemmeringen bij biokkades in het leerproces gelden in alle fasen van de revalidatie.

Uit deze overwegingen (waar in hoofdstuk 4 en 5 uitgebreider bij stil zal worden gestaan) volgt dat een revalidatie een twijfelachtige zaak wordt, indien deze zich slechts bezighoudt met gedragsvorming vanuit een eenzijdige aanpak. Er zijn meer benaderingen denkbaar en het is evengoed mogelijk dat er, eer men tot gedragsvorming $\mathrm{k}$ an overgaan, een gedragseliminatie moet worden nagestreefd.

De volgende paragraaf tracht een aanzet te vormen tot een modifikatiestrategie in alle voorlopigheid vanut een leertheoretisch denkkader. Allereerst wordt stilgestaan bij de situatie warin en de wijze waarop gedragstekorten en excessief gedrag, dat deze vorming tegengat, worden gesignaleerd.

Vervolgens wordt vanuit leertheoretisch standpunt aandacht besteed aan de reeds verscheidene keren genoemde gedragsdeviaties in de zin van gedragstekorten en excessieve gedragingen. De gedragstekorten komen in principe in anmerking voor korrektie in de zin van nieuwe gedragsvorming. Het excessieve gedrag wordt, zoals reeds werd aangegeven, in het kader van deze studie gezien als éen der gedrags. belemmeringen. Tenslotte wordt besloten met de behandeling van gedragstherapeutische technieken ter modifikatie van gedragstekorten en gedragsexcessen, zoals ze binnen deze studie werden toegepast.

\subsubsection{Situaties en probleemgedrag}

Gedragstekorten en gedragsbelemmeringen spelen zich af in een bepaalde context en worden over het algemeen op een specifieke manier door een omgeving gesignaleerd.

Bijeen poging om een veranderingsproces te realiseren zal aandacht moeten worden besteed aan context, wijze van signaleren van het probleemgedrag en de soort wan het probleemgedrag.

\subsubsection{Situaties waarin gedragsdeviaties gesignaleerd kunnen worden}

Er zijn een vijftall situaties, waarin of waaruit zowel tekorten als belemmeringen gesignaleerd kunnen worden.

1e. Premorbide gedragsgegevens in preklinische of de pre-opname situatie.

2e. Testsituatie in de kliniek.

3e. Gedrag buiten de testsituatie in de kliniek.

4e. Gedrag na klinische fase, maar vóór ontslag: nabehandelingssituatie.

5e. Na ontslag nar het thuis- of werkmilieu, de postopnamesituatie of kortweg "thunssituatie".

\section{ad. 1. Premorbidesituatie.}

Het premorbide gewoontegedrag is bij cerebraal gestoorden een weinig geexplow reerd terrein. Hoewel het in principe mogelijk lijkt waardevolle informatie te betrekken over de toestand yór het trauma is de wijze warop dit zou moeten gebeuren nog onzeker en wellicht ook moelijk te realiseren. Bij het opstellen van een strategie dient zeker ook rekening gehouden te worden met gedragstekorten die reeds in het thuis-, werk- of schoolmilieu werden gekonstateend. Het nadeel is hierbij 
dat het in een meerderheid der gewallen informatie zal zijn wit de tweede of derde hand. Vaak ook is bepald gedrag na het trauma ineens belangrijk geworden en heeft men geen idee hoe dit gedrag voór het trauma was, tenzij uiteraard dit bepaalde gedrag of gedragstekort opvallend duidelijk aanwezig was. Maar ook dan heeft men te maken met een speciale manier wan informatieverzameling, waarbij twijfel blifft bestaan omtrent de betrouwbarheid van deze hetero-anamnestische informatie. Gedragstekorten zouden misschien nog wel enigzins door thuis-of schoolmilieu kunnen woren aangegeven. Gedrag dat gedragsworming tegen werkt lijkt minder gemakkelijk te signaleren, zeker in die situatie waar het gedrag van personen uit het thuismilieu zelf mogelike nieuwe gedragsworming in de weg zow kunnen staan.

Uit de statusgegevens is geen of weinig systematische informatie inzake gedragstekorten en gedragsbelemmering in de preklinische situatie te putten.

\section{ad. 2. Testsituatie.}

Onder testsituatie wordt hier verstaan een gestandariseerde context warbij de patient wordt gewragd of gestimuleerd een bepaalde taak uil te voeren. Het niet kumnen witwoeren van de handeling wordt in dit verband als een gedragstekort van patiënt opgevat en soms gezien als een taak voor de therapeut $\mathrm{nl}$. te trachten dit tekort weg te werken d.m.v. nieuwe gedragsvorming. De test prestaties worden in het algemeen gezien als signalen die, mits goed geinterpreteerd, generalisaties toelaten voor de viet-testsituatie. Het getuigt echter van meer nauwkeurigheid om te zeggen dat het gedrag van de mens bepaald wordt door de kombinatie van gedragsmogelijkheden èn omgevingsinvloeden. Responsies op een testsituatie zijn één soort gedrag. Wat de persoon doet in een niet-testsituatie, kan een ander soort gedrag zijn. Deze twee soorten prestaties moeten eerst gekorreleerd worden voor er generalisaties en eventueel voorspellingen gedaan kunnen worden. Naarmate de testsituatie minder lijkt op de kriteriumsituatie wordt de generalisatie mogelijkheid en wordt de prediktieve validiteit van de test minder.

De nauwkeurigheid van generalisatie en voorspellingen hangen samen met de standaardisatie en normering wan de test (begrippen waarvan de bekendheid hier verondersteld wordt, of waarvoor verwezen kan worden naar Drenth 1966). Deze overwegingen gelden in principe voor alle disciplines in de revalidatie, dus niet slechts voor psychologisch onderzoek, maar eveneens op het terrein van geneeskunde, logopedie, arbeidstherapie, fysiotherapie ed. Revalidatieprogramma's worden gekonfronteerd met al de drie genoemde problemen: korrelatic van test-kriterium, de standaardisatie en normeringsmoeilijkheden. Het is zelden dat alle kriteria adekwaat zijn bepaald, waker is aan geen dezer kriteria de nodige aandacht geschonken. Talloze misverstanden zijn hiervan het gevolg.

Als voorbeeld: Een patiënt toont bij psychologisch onderzoek geen geheugenstoornissen, toch vergeet hij altijd op welk moment hij naar een beparalde therapie toe moet. Een ander onderzoek levert duidelijk stoornissen in ruimtelijke orientatie op, mar hoe is het dan mogelijk dat de patiënt well zijn weg weet te vinden in het doolhof van gangen in het revalidatiegebouw? De testsituatie is niet altijd de meest adekwate invalshoek voor het vaststellen van een gedragstekort en voor daar op aansluitende gedragsvorming. Er moet omgezien worden nar andere situaties.

\section{ad. 3. Klinische observatiesituatie.}

De uiteindelijke kriteriumsituatie is de leefrumte waar de patient na ontslag terecht zal komen. Deze situatie zal pas goed aan het licht brengen welke gedragstekorten de patiènt vertoont. Vaak komt ook voor dat een patiënt, na enige tijd te hebben verkeerd in zijn thuissituatie, opnieuw in een revalidatiecentrum wordt opgenomen 
ter gedragsworming van die tekorten, die eerst in zijn "werkelijke leven" worden gekonstateerd. Even zo vele malen echter blijkt ook een patiènt met contusio cerebri in thuis- of werkmilieu zo vast te lopen dat hij na het veroorzaken van diverse krises wordt overgeplaatst naar een psychiatrisch centrum of anderszins zogenaamd "beschut millieu".

Het is derhalve gewenst om extra kriterium-situaties in te bouwen, tussen test- en thuissituaties: de klinische observatie- en nabehandelings situaties. Deze klinische observatiesituatie zou idealiter informatie moeten geven omtrent het gedrag tussen testsituatie en de nabehandelingssituatie; ook hier hoopt men op een hoge prediktieve validiteit tussen klinische observatiegedragsprestaties en nabehandelingsgedragsprestaties.

Onder klinisch kriteriumgedrag zou men kunnen verstaan het gedrag van de patiënt op het dagverblijf, in kantine, op gangen, toilet, tuin, kamer etc. Onder klinisch kriterium valt bijvoorbeeld de vraag of patiënt in staat is de weg te vinden in het gebouw, liften zelfstandig te bedienen, gebruik van toilet te maken, zich redelijk sociaal weet op te stellen, een telefoongesprek kan uitvoeren enz. enz. enz. Het gedrag van de patiënt op de zaal, het dagverblijf, de rekreatie e.d. zou in principe ook in aanmerking kunnen komen voor konstateren van mogelijke gedragsbelemmeringen. Het is hierbij een eerste stap om te stellen, dat bijvoorbeeld het niet-coöperatieve gedrag van een patiënt op het dagverblijf hinderlijk werkt op de verpleging en andere patiënten stoort in hun revalidatie, waarbij somatische revalidatie van de patiënt zelf niet gestoord hoeft te zijn. Een tweede stap lijkt aanwezig, indien dit niet-coöperatieve gedrag niet beperkt blijft tot het dagverblijf, maar ook optreedt op plaatsen watar fysiotherapie, arbeidstherapie, e.d. wordt bedreven. In zulk een gevall lijkt sprake van gedragsbelemmeringen bij de patiënt zelf, die de fysieke revalidatie tegenwerken.

Een derde stap lijkt noodzakelijk te moeten worden toegevoegd, indien de gedragsvorming niet overwegend op het somatische funktioneren betrekking zou hebben. Stelt men zich als revalidatiecentrum ten doel ook bijv. sociale vaardigheden te vormen (tafelmanieren etc.), dan wordt het niet-coopperatieve gedrag een belemmering voor de vorming van dit sociale gedrag.

In alle drie gevallen is sprake van gedragsfaktoren, die belemmerend werken voor de gedragsvorming in het revalidatiecentrum.

Waar de testsituatie de laboratoriumsfeer vertegenwoordigt en een gedragspartikel op een sterk gekontroleerde manier pretendeert te meten, zou de klinische observatiesituatie gezien kunnen worden als een betere benadering van de realiteit wan het alledaagse leven. Hier zou men in principe een groot aantal gedragingen, weliswaar op een minder gestandariseerde manier, kunnen nagaan.

\section{ad. 4. Nabehandelingssituatie}

Zoals de naam reeds aangeeft is deze situatie een intermediair tussen de kliniek en de thuissituatie. In de klinische situatie worden pogingen aangewend tot nieuwe gedragsvorming, die door het trauma direkt noodzakelijk zijn. In de nabehandelingssituatie vindt eerder een voorbereiding plaats op bijvoorbeeld het arbeidsproces door het volgen van speciale cursussen. Hoewel ook dit als nieuwe gedragsvorming gezien kan worden is deze eerder afgestemd op noodzakelijke eisen vanuit een speciale positie in de maatschappij wan waaruit meer specifieke en gerichte .eisen" gesteld kunnen worden.

ad. 5. Thuissituatie.

He thuis- en werkmilieu wormt het definitieve kriterium voor de vraagstelling; . IIs 
de persoon, gegeven zijn handicap, in staat op een optimaal niveau te funktioneren?" Het thuis- en werkmilieu zal een doorslaggevende rol spellen inzake de "bekligwing"van het nieuw-gevormde gedrag d.w.z. het thuis-milieu kan het gedrag dat in het centrum werd aangeleerd gaan ondersteunen, tegenwerken of ontmoedigen. Hoewel hier het standpunt wordt ingenomen dat het thuismilieu tijdens de kinische fase participeert in de gedragsvorming, zal eveneens grote aandacht besteed moeten worden aan de zgn. "nazorg". Het lijkt niet een voudig om een goede informatic of observatie in het thuis- of werkmilieu te realiseren, die gericht is op gedragstekorten bij de patiènt en op gedrag van patiënt en/of zijn omgeving dat gedragsbeklijving ondersteunt of tegenwerkt.

Premorbide, klinische test-, klinische observatie-, nabehandeling-en thuissituatie komen alle in aanmerking voor de konstatering zowel van gedragstekorten bij de patiënt als van gedrag bij patiënt of omgeving dat gedragsworming resp. gedragsbeklijving tegengaat.

\subsubsection{Konstatering van gedragsdeviaties}

Hierna wolgend zal nader worden ingegaan op de wijze waarop gedragstekorten en gedragsbelemmeringen zijn te konstateren.

A. Gedragstekorten worden gekonstateerd:

1e. Door een systematische informatieverwerving.

2e. Doordat ze gesignaleerd worden door de patiënt of door de omgeving.

ad. 1. Systematisch informatieverwerving veronderstelt een plan of schema volgens welke deze exploratie zu kunnen worden opgezet enwel met betrekking tot de diverse vormen van menselijk funktioneren. Idealiter lijkt een dergelijk plan gesteund te moeten worder door één gemeenschappelijke visie, geldend voor alle disciplines. ledere discipline zou dan vanuit dit gezichtspunt kunnen trachten de te onderzoeken gedragsaspekten in kaart te brengen. Vervolgens zou iedere discipline zijn deelgebied kunnen exploreren, d.w.z. de gedragstekorten zouden per patiënt volgens dit ideaalschema per discipline kunnen worden nagegeaan. Tenslotte zou dan een rapportage moeten plaatsvinden waarbij iedere discipline zijn bevindingen rapporteert aan het team.

Van een dergelijke systematische exploratie alsmede van de ondersteunende voorwaarden daarvoor is vooralsnog geen sprake, noch wat betreft de klinische testsituatie, noch wat betreft de klinische observatiesituatie.

Klinische testsituatie.

Wanneer men de situatie beziet zoals deze zich op het terrein der psychologie presenteert en dan nog wel in de testsituatie, dan is deze toestand uitermate onbevredigend. Toch voeren, althans deeldisciplines in de psychologie, met name de psychologische funktieleer, reeds geruime tijd het streven naar objektiviteit, meetbaarheid en systematiek in hun vaandel. In de fundamentele research is men hierin in belangrijke mate gevorderd, zij het met beperking t.a.v. toepasbaarheid door de veelal specifieke onderizoekspopulaties. Deze bestaan doorgaans uit studenten aan universiteiten. Van enige overlap met revalidatiepopulaties is nog geen sprake en een taxonomie van testgedrag, waarmee gedragstekorten op een systematische wijze zouden kunnen worden geexploreerd is niet beschikbaar. Minstens gelijk waardige beperkingen lijken te gelden woor disciplines als fysiotherapie, ergotherapie en logopedie. Bijgeen der disciplines in de revalidatie bestaat een referentiesysteem, dat zou kunnen fungeren als kompas voor het in kaart brengen vau de diverse testgedragingen. Er zijn er verscheidene, alle met hun mogelijkheden, maar eveneens hun tekorten. Er bestaat in deze dus weinig (of geen) overeenstem- 
ming in de visie op en het onderzoek naar het menselijk funktioneren in een testsituatie.

Klinische observatiesituatie.

Wanneer het principe der systematische exploratie ook doorgevoerd wordt op het terrein wat het gedrag een funktie is van een wat meer complexe situatie dan treft men daar eenzelfde beeld. De gedragsobservatieschalen, als geeigend instrument tot het bestuderen van dit gedrag, worden aangetroffen ten behoeve van de populaties der psychiatrie en zwakzinnigenzorg, maar dan nog steeds vanuit hoofdzakelijk een referentiekader, $\mathrm{nl}$, het psychologisch denkframe.

Een gedragsobservatieschaal ten behoeve van revalidatiepatiënten werd in de Nederlandstalige en Angelsaksische literatuur nergens a angetroffen. Bijgebrek aan een dergelijk instrument is de informatie in de klinische observatiesituatie een verzameling van indrukken gebleven.

Systematische verzameling van de premorbide, de nabehandeling en thuismilieugedragsinformatie vond in de onderhavige onderzoek fase niet plats.

Ad. 2. De signalering van een gedragstekort door patient of omgeving. Wanneer men het principe van systematische exploratie prijs geeft, dan krijgen allerlei andere informatieve aktiviteiten vrij spel. De gegevens, die hieruit naar voren komen, wisselen sterk qua betrouwbaarheid. Het probleem is dat men nooit met zekerheid kan zeggen welke informatie betrouwbarar is. Het komt erop neer, dat men het gesproken woord van de goedwillende, maar op dat moment veelal labiele echtgenote als de onverdachte warheid aangeboden krijgt, kortom, dat de kans bestaat, dat een moeizame poging tot objektiviteit voor de zoveelste maal wordt verdrongen door het "invoelend vermogen" van diverse therapeuten tesamen.

\section{B. Konstatering van gedragsbelemmeringen.}

Gedragsbelemmeringen kwamen, eerst tijdens het werloop van de pogingen tot gedragsvorming naar voren en werden daarna eerst terloops en tenslotte welbewust en in grotere frekwentie door verscheidene teamleden gesignaleerd. Van een systematische exploratie was ook hier geen sprake. De GOCC kan bezien worden als een eerste poging tot een min of meer systematische exploratie. Dit observatiesysteem is echter een voorlopige benaderingswijze, voortgekomen uit de neerslagen van teambesprekingen.

\section{Resumerend.}

A. De verzameling van informatie inzake gedragstekorten bleek gerealiseerd te worden via twee , zoek wegen".

1. Een testsituatie. Onder afwezigheid wan een valide taxonomie werd hiver toch min of meer systematisch geexploreerd.

2. Een premorbide, klinische, nabehandeling- en thwissituatie. De signalering door de omgeving of vanuit de patiënt werd hier niet systematisch geêxploreerd.

B. De verzameling van informatie inzake gedragsbelemmeringen vond tot aan de invoering van de GOCC plaats op een niet systematische wijze. Deze belemmeringen bleken duidelijker naarmate het verblijf van de revalidant langer duurde. De invoering der GOCC betekende een verbetering in systematiek. Zij blijft echter slechts een deel-informatie van allle mogelijke gedragsbelemmeringen, zoals excessief ongewenst gedrag.

\subsubsection{Het probleemgedrag nader bezien}

Hoewel het uitermate verleidelijk is om bijwoorbeeld een gekonstateerd gedragste- 
kort in een testsituatie te koderen als .funktiestoornis" om vervolgens over te gaan tot "funktierestauratie", komen dergelijke stappen hier nog niet ter bespreking. Een dergelijke stap vereist immers meer kennis van zaken, o.a. het kunnen differentiëren wan psych ische funkties, het kunnen lokaliseren van een funktiestoornis binnen een walide taxonomie, het op de hoogte zijn van de diverse soorten trainingsprogramma's en het kunnen uitvoeren van een gekontroleerde "funktierestauratie" enz.

Dergelijke overwegingen gelden eveneens voor gedragsdeviaties in andere situaties. Vóór men genuancee rder over probleemgedrag (per situatie) kan spreken, dient men aandacht te scherken aan (pogingen tot) begripsomschrijwing, operationele definities, problemen van meetbaarheid e.d. Vóór men beweert probleemgedrag te kunnen veranderen, zal men dat toch eerst op gekontroleerde wijze moeten aantonen, will men tenminste niet belanden in messianisme e.d. Op populair wetenschappelijk niveau is de zaak ondertussen al lang geregeld. Hier spreekt men vrijelijk over "hoe wij denken leren en vergeten" (Vester 1976), waarbij de waarschuwing dat ,veel nog veronderstelling is" spoedig wordt vergeten bij het doorlezen van dit 25 e boek van de maand.

Op wetenschappelijk niveau maant men slechts tot de grootste voorzichtigheid, aangezien veel van het neurologisch apparaat nog onbekend is, van een valide taxonomie nog geen sprake is en ook de waarde van zgn. funktietrainingsprogramma's eerst nog moet worden aangetoond (Dumont 1973 p. 187, Deelman B. G., Elshout J. J., persoonlijke mededelingen). Vanuit het principe van spaarzalamheid inzake het gebruik van concepten wordt derhalve in dit hoofdstuk slechts gesproken over gedragsdeviaties binnen een bepaalde context. In hoofdstuk 4 en 5 zal een voorzichtige poging tot nadere nuancering van probleemgedrag worden ondernomen. Na deze bespreking vooraf valt het probleemgedrag per situatie nader te bezien.

Vanuit de leertheorie zijn er binnen het kader van het operant model een aantal indelingsprincipes bekend van waaruit de modifikatie van "inadek waat" gedrag in een bepaalde context en geëvalueerd volgens een waardesysteem kan worden ondernomen.

De meeste van deze principes richten zich op de behandeling van aanwezig gedrag dat, waardoor dan ook, is ontspoord. Het is dan ook niet verwonderlijk, dat de meeste prak tische toepassingen van leertheorieën - tot nu toe - worden aangetroffen op het gebied van neurotische en psychiatrische patiënten. Andere principes richten zich echter ook op de vorming van nieuw ged rag. Deze praktische toepassingen zijn vergeleken met de woorgenoemde groep wat beperkter en hebben wooral betrekking op de behandeling van kinderen en zwakzinnigen. Ten aanzien van gedragsdeviaties kan volgens het operante model het volgende onderscheid gemaakt worden: Zie o.a. Okma (1972 p. 9), Berni (1973 H.1, 2 en 7), Fordyce (1971 p. 30)

1e. Het gedrag treedt onder geen enkele stimuluskonditie en onder geen enkele bek rachtigende konsek wentie op. Er is geen gedrag. Wanneer dit voor alle kondities geldt, kan men zich afvragen of het organisme nog leeft: absoluut gedragstekort of zero-gedrag.

2e. Het ged rag treedt bij de juiste stimuluskonditie wel op, echter de frek wentie van optreden, dan wel de intensiteit is te gering. Er is te weinig gedrag voor die bepaalde context: relatief gedragstekort.

3e. Het gedrag treedt met voldoende intensiteit en onder goede frekwentie op, echter her treedt op bij een niet daarbij behorende, of niet volledig juiste stimuluskonditie. Er word dan gesproken van onvoldoende of onjuiste stimulusk ont role. 
4e. Hel gedrag treedt op bij een bepaalde stimuluskonditie met een te grote frekwentie of een te grote intensiteit Er is dan in die bepalde context sprake van excessief gedrag.

Se. Het gedrag treedt bij een bepaalde stimuluskonditie op met een juiste frek wentie en/of intensiteit.

Uit dit overzicht zal duidelijk zijn, dat een interwentie vanuit gedragstherapeutisch gezichtspunt gericht moet zijin op:

A. De gedragstekorten. Heronder vallen: 1. zero-gedrag, 2. relatief gedragstekort en 3. gedrag dat onder onvolledige stimuluskontrole staat.

B. De gedragsbelemmeringen. Bezien vanuit het gezichtspunt der gedragsvorming valt alleen punt 4 hieronder, $n$. excessief gedrag. Hiermee wordt bedoeld dat zowel bijvoorbeeld het optreden van agressief gedrag als ook inaktiviteit vanuit een poging tot nieuwe gedragsvorming in die situatie als excessief wordt gezien. De vorming van nieuw gedrag is er alleszins bij gebaat, indien zowel agressie als inaktiviteit totaal niet optreden en hun frekwentie dus - in die situatie - gelijk is an nul. Het wel optreden van deze en andere soorten van gedrag in een situatie waar dit in feite ongewenst is, a angezien de gedragsvorming belemmerd wordt, maakt hun aanwezigheid excessief voor die en geen andere situatie.

\subsubsection{Gedragstherapeutische technieken t.b.v. modifikatie.}

Het te modificeren gedrag werd konstateerbaar geacht in een vijftal situaties: premorbide, testklinische, observatieklinische, nabehandeling en thuissituatie. Niet alle situaties werden bij iedere patiënt als veld van informatie aangetroffen.

De wijze waarop het te modificeren gedrag kon worden gekonstateerd werd herleid tot een systematische exploratie (waarbij al dan niet een valide taxonomie aan wezig was) en een signalering ad hoc.

Het te modificeren gedrag kon ingedeeld worden naar: 1e. gedragstekorten, nl. zero-gedrag, relatief ged ragstekort, gedrag dat onder onvoldoende stimuluskontrole stond en 2e. gedrag dat gedragsvorming belemmerde: vanuit gedragsvormend gezichtspunt kon hier excessief gedrag onder geplaatst worden.

Gedragsdeviaties, gedefinieerd naar context, wijze van konstatering en ingedeeld naar leerprincipes vanuit het operante model lijken nu nader beschouwd te kunnen worden wat betreft de modifikatiestrategieên.

De gedragstherapeutische technieken, die hieraan ten grondslag liggen, werden ontleend aan: Kazdin A. E. (1973 p. 134-140), Sand P. L. (1970 p. 11-24), Berni R. (1971 p. 2180-2182), Hollon T. H. (1973 p. 65-68), Kanfer and Philips (1970 p. $241-318)$.

1e. Ter modifikatie wan zero-gedrag leent zich in principe: ,responsdifferentiatie" of , shaping".

Indien de gedragsfrekwentie $=0$ is, dan moet voor een bepaalde stimuluskonditie nieuw gedrag gewormd worden. Binnen het operante model worden de technieken, die hiertoe aangewend worden, benoemd met de verzamelnaam .shaping". De meest bekende zijn well verbale opdracht, imitatie "prompting" suksessieve approximatie. Meestal tracht men ook in deze genoemde volgorde te ontdekken of een bepaalde techniek effekt heeft of niet.

a. Verbale opdracht: Onder de gegeven stimuluskonditie wordi opdracht gegeven (of gevraagd) een taak uil te voeren. Indien dit lukt, volgt bekrach- 
tiging, waarbij de vorm der bekrachtiging aangepast zal zijn aan de persoon. b. Imitatie: Indien uitvoering van de taak na verbale opdracht niet lukt, wordt de diskriminatiewe stimulus (reeks) uitgebreid: Eerst verbale opdracht, gevolgd door het voondoen van het gewenste gedrag met tenslotte hel verzoek dit gedrag te imiteren. Bij sukses volgt bekrachtiging.

c. "Prompting": Samen met patient het gedrag uitvoeren. De diskriminatieve stimullus wordt: verbale opdracht, therapeut pakt handen of armen van patiënt en stuturt deze zodanig, dat de taak wordt uitgevoerd. Bij sukses volgt bekrachtiging.

d. Suksessieve approximatie met gebruikmaking van verbale opdracht, im tatie en/of prompting. Wanneer blijkt, dat de opdracht door middel van prompting niet kan worden gerealiseerd, wordt getracht deze taak onder te verdelen in deeltaken. ledere deeltaak word daarma apart geoefend, hetzij onder verbale opdracht, imitatie of prompting. Van belang is dat men daarbij met het laatste onderdeel der taak begint. De argumentering hierbij is, dat de persoon bekrachtiging en gedrag bij woorkeur zo snel en direkt mogelijk met elkaar in verband moet kunnen brengen.

e. Suksessieve approximatie onder differentiële bekrachtiging alleen. Hierbij wordt geen gebruik gemaakt van verbale-, imitatie-, of prompting cues. Men tracht de soort van spontaan optredende responsies in de bepaalde stimulussituatie door het principe der differentiële bekrachtiging dusdanig te versmallen, dat alleen thet gewenste soort gedrag woor die situatie resteert.

Deze eerste wier gedragsvormende principes hebben alle gemeen, dat de steun wan een begeleider noodzakelijk is. Uiteindelijk zal de persoon het zonder steun moeten stellen. Nadat de patiënt het gedrag met hulp beheerst wordt deze hulp dan ook geleidelijk aan weggenomen. Het langzaam afnemen van deze hulp wordt "fading" genoemd.

Alle onder "shaping" genoemde technieken hebben overigens het kenmerk der differentiële bekrachtiging: het gewenste gedrag (of delen hiervan) worden bekrachtigd, het ongewenste gedrag (of delen hiervan) worden geëxtingeerd. Kanfer and Philips (1970 p. 287) verduidelijken dit door te stellen: "Shaping employs differential reinforcement $a$ and differential ex tinction to gradually shift the topography and organization of a response into a new constellation of components. By applying differential reinforcement to one extreme subclass of a set of responses and extinction to all the other responses in the set, the more extreme subclass is differentially strengthened and becomes dominant. By successive applications of this procedure, complex behaviors can be established."

2e. In het geval dat het gedrag wel optreedt, maar met een te lage frekwentie of intensiteit wordt ter modifkatie kontingente bekrachtiging na optreden wan het gedrag toegepast.

Een van de belangrijkste empirisch ondersteunde leerprincipes is dat als gedrag in een situatie wordt gevolgd door positieve bekrachtiging, de frekwentie of de intensiteit van dat gedrag in die situatie zal toenemen. Een konsekwentie hiervan is, dat in de periode waarop het gewenste gedrag wordt bakrachtigd, eventueel ander gedrag inclusief de afwezigheid van gedrag moet worden genegeerd.

Indien men bijwoorbeeld wenst dat een patiènt, die ooit eens heeft laten zien dat hij met mes en vork kan eten, dit in de toekomst vaker gaat doen, dan zal men 
tijdens de maaltijd geen aandacht moeten besteden aan het eten met de handen, maar wel positieve reinforcement moeten geven op de momenten waarbij met mes en vork gegeten wordt.

Ook hier geldt dus het principe van de difierentiële bekrachtiging.

3e. In het geval dat het gedrag wel optreedt met goede frekwentie en intensiteit, maar niet onder de juiste stimuluskondities wordt ter modifikatie "fading" toegepast.

Voorbeelden van een dergelijk gemis aan stimuluskontrole zijn:

a. iemand die zich uitgebreid gaat voorstellen in de treincoupé aan alle medereizigers.

b. het kind dat wel zijn best doet als de onderwijzer in zijn buurt staat, maar ophoudt met werken als deze weg is.

c. de man die (na trauma) weer met veel moeite geleerd heeft zich uit te kleden en dit daarna overal demonstreert.

d. de persoon die wel de blokpatronen wan de Wechsler kan vormen als de nodige blokken voor hem eerst met de goede kant naar boven worden gelegd, maar dit niet kan als hij deze steun mist.

$\mathrm{Bij}$ de voorbeelden a. en $\mathrm{c}$. is zonder meer het vermogen tot stimulusdiskriminatie van belang. Bij de voorbeelden $\mathrm{b}$. en d. is hiernaast vereist het vermogen tot gemis aan stimulusfacilitatie. Stimulusfacilitatie staat nauw in verband met stimuluskontrole en vaak kunmen de effekten en mechanismen niet van elkaar worden onderscheiden (zie ook Kanfer and Philips 1971 p. 295).

De techniek, die gebruikt wordt om te trachten de respons onder de juiste kondities te doen optreden wordt "fading" genoemd.

Stimulusdiskriminatie: men beziet hierbij eerst onder welke kondities de respons wèl optreedt en verandert vervolgens geleidelijk aan stimuluselementen tot de nieuwe situatie onder behoud van de respons wordt bereikt. Het optreden van de respons wordt uiteraard bij voortduring bekrachtigd. Het optreden van de respons in de niet gewenste situaties (en dàt kan ook de oorspronkelijke situatie zijn, waarin de respons wel optrad,y wordt geëxtingeerd.

Ook hier dus weer het principe der differentiële bekrachtiging.

Vermindering van stimulusfacilitatie: Het woord "facilitatie" houdt in, dat er in de stimuluskonditie elementen zitten, die het optreden van de respons faciliteren. Wegname van de elementen maakt het optreden van de respons moeilijker. Een geheugenprestatie (het reproduceren van een aantal woorden) kan "gefaciliteerd" worden doordat de persoon eventueel door een gering aantal stimuli ,een geheugensteuntje”, ,een kapstok”, „een visueel beeld" kan ontdek ken. Dit faciliterende effekt kan wegvallen als het aantal te memoriseren eenheden groter wordt. „Fading" wil in dit geval zeggen, het in stand houden van de juiste respons (adek wate reproduktie) onder geleidelijke afname van facilitatie. Uiteraard zijn er meer en andere voorbeelden denkbaar. Het behoeft verder geen betoog, dat ook hierbij extinktie van inadekwate responsies optreedt m.a.w. het principe der differentiële bekrachtiging treedt ook hier op. (Hoewel in $\mathbb{H}$. 4 op deze materie verder wordt ingegaan, kan hier reeds opgemerkt worden, dat er een schijnbaar opmerkelijke verbetering van het geheugen wordt bereikt, door het ontwikkelen van een ,alertheid" voor en het gebruik wan faciliterende elementen (Lindeboom J. 1976). Hoewel een dergellike ontwikkeling uiteraard zeer waardevol is, is het een (dankbare) ..prothese". De geheugentraining, die volgens het fading-principe werkt, begint echter pas hierna. Immers na het vaststellen onder welke faciliterende kondities 
een persoon wet te onthouden, dient alsnog door langzame terugname of verwaging der facilitaties, de geheugenrespons op hetzelfde pill gehouden te worden ).

Zowel bij verbetering van stimulusdiskriminatie als bij vermindering van stimulusfacilitatie d.m.w. fading wordt aan de respons zelf niets veranderd. Het aksent ligt in beide gevallen op een zorgvuldige manipulatie van antecedente stimuli onder differentiele bekrachtiging ter behoud van de respons.

4e. In geval van excessief gedrag kan modifikatie ondernomen worden door versterking van de incompatibele respons.

De voorafgaande beschreven toepassingen van differentiele bekrachtiging hadden betrekking op het verbeteren of versterken van gewenst gedrag, dat een deficiet vormde in het gedragstepertoire van de patient. Wanneer de "probllematisclie" respons daarentegen een gedragsexces vertegenwoordigt dan is geen principicel andere strategie, maar wel een andere "gerichtheid" gewenst., d. w.z. meer nadruk op extinktie in eerste instantie.

De meest effek tieve manipulatie is hierbij de positieve bekrachtiging van gedrag dat onverenigbar is met het excessieve gedrag. Wanneer twee responsklassen kompetitief zijn en niet tegelijkertijd kunnen optreden, dan leidt versterking van de meer gewenste klasse tot een reduktie van de warschijnlijk heid van optreden wan de ongewenste symptomatische responsklasse. Het versterken van incompatibele responsen (ook wel counter konditionering genoemd) heef voordelen boven het "straffen" van het ongewenste gedrag, of het toepassen van alleen extinktie d.m.v. wegname der onderhoudende bekrachtigers:

a. Als een gedtag d.m.v. extinktie of "straf" verwijderd wordt, dan wordt datgene wat vervolgens de ontstane gedragsleemte gaat opvullen aan het toeval overgelaten.

b. Als lemand dankzij symptomatisch gedrag belangrijke bekrachtigende konsek wenties heeft ervaren, zonder dat hem alternatieve aangename bekrachtigende kondities worden geboden, dan mislukt de extinktie.

Het bekrachtigen van de incompatibele respons bevordert dus niet alleen een duidelijke opvalling van de leemte in het gedrag, maar voorkomt ook een gemis aan bekrachtigende kondities waardoor extinktie van symptomatisch gedrag effektiever wordt.

Resumerend kan gesteld worden dat wanuit het operante paradigma het principe der differentiele bekrachtiging en extinktie toepasbaar is voor: zero-gedrag, relatief gedragstekort, onjuiste stimuluskontrole en excessief gedrag. Volgens de gedragsvergelijking $\mathrm{S} \rightarrow \mathrm{O} \rightarrow \mathrm{R} \rightarrow \mathrm{K} \rightarrow \mathrm{C}$ liggen weliswaar de aangrijpingspunten voor thera peutische interventie voor de diverse behandelingen verschillend, het principe van bekrachtiging van gewenst en de extinktie van ongewenst gedrag blift echter gelden.

\subsubsection{Samenvatting}

Vanuit de gedachtengang, dat gedrag onder meer een funktie is van de voorafgaande stimulussituatie, werden de situaties warin bij patienten deviant gedrag werd gesignaleerd onderscheiden in:

1e. Premorbidesituatie.

$2 e$. Klinische testsituatie.

3e. Klinische observatiesituatie.

4e. Nabehandelingsituatie.

5e. Thuissituatie. 
Hoewel al deze situaties waardevolle gegevens zouden kunnen verstrekken inzake het gedrag van patiënt en omgeving konden zij niet alle als zodanig benut worden.

De wijze waarop gedragsdeviaties worden gesignaleerd werd beschreven. Deze signalering geschiedde in een meerderheid der bovengenoemde situaties dankzị de observatie van één of meer teamleden. Hoewel een meer systematische exploratie van de aanwezigheid van deviant gedrag gewenst zou zijn, lijkt de rea lisering hiervan een niet geringe opgave.

De indeling van gedragsdeviaties in gedragstekorten en excessieve gedragingen bleek ondersteuning te vinden vamuit de operante konditionering, die een soortgelijke verdeling toepast. Hiernaast werden vanuit deze leertheorie de gedragstekorten onderverdeeld in zero-gedrag, relatief gedragstekort en gedrag, dat onder onvoldoende stimuluskontrole staat. De modifikatietechnieken, welke aangereikt werden vanuit het operante model zijn:

le. Voor zero-gedrag: de diverse vormen van shaping.

2e. Voor relatief gedragstekort: selektieve bekrachtiging van het te vermeerderen gedrag.

3e. Ter handhaving van gedrag onder toenemende stimuluscomplexiteit: fading.

4e. Ter reduktie van excessief gedrag: differentiële bekrachtiging.

Alle, in deze studie gebruikte gedragsmodifikatietechnieken zijn te herleiden tot de bekrachtiging van het gewenste gedrag en de extinktie van ander, minder gewenst gedrag. 

HOOFDSTUK 3

\author{
UITVOERING EN EVALUATIE \\ van een \\ EXPERIMENTELE REVALIDATIESTRATEGIE
}




\subsection{Uitwoering van modifikatie en assessment}

\subsubsection{Inleîding}

In hoofdstuk 2. werd een indruk gegeven omtrent de samenstelling van een assessmentprocedure (d.m.v.gedragsobservatie en psychologisch onderzoek) en een wiertal modifikaties (reduktie van gedrag, toename van gedrag, gedragsvorming en behoud van gedrag onder toenemende stimuluscomplexiteit).

Het geheel werd gepresenteerd als een woorlopige revalidatiestrategie. Thans is de wijze waarop de diverse modifikaties werden uilgevoerd aan de orde alsmede hun samenhang met een voorafgaande, begeleidende en afsluitende assessment.

Vanuil het strikt experimentele karakter van deze voorlopige strategie maar eveneens met het oog op mogelijke konsek wenties is extra veel aandacht besteed aan assessmentuitvaering.

Achtereenvolgens zullen de diverse programmastappen worden behandeld die voorkomen bij:

Gedragsworming bij zero-gedrag

Toename van gedrag

Behoud van gedrag onder toenemende stimuluscomplexiteit

Reduktie van excessief gedrag

\subsubsection{Gedragsworming bij zero-gedrag}

1e. Efrektassessment.

a. Deze betreft de gedragsobservatie (dmv. GOCC) volgens synthetische beoordeling gedurende de $2 \mathrm{e}-, 3 \mathrm{e}-, 4 \mathrm{e}-, 5 \mathrm{e}-, 6 \mathrm{e}-$ en $7 \mathrm{e}-$ week na opname. Per patiënt werden 3 verzamelingen van observaties door minimaal 5 beoordelaars verk regen. ledere verzameling werd gemiddeld indien geen duidelijke a fwijkende scores bij een of twee beoordelaars werden gevonden. Wanneer aan de hand van deze GOCC of naar aanleiding van signaleringen ad hoc besloten werd tot een modifikatieprocedure, dan gold de laatste (dus $3 \mathrm{e}$ observatie) als uitgangsassessment.

b. Psychologisch onderzoek (PO). Hieronder bevonden zich altijd tests genoemd in 2.2. nl. intelligentieniveau, geheugen en concentratie. Hiernaast werden vaak ook andere tests afgenomen en werd geleidelijk aan het gehele arsenatal uitgebreid. Alleen genoemde tests behoorden echter bij de effektassessment en zijn bij de empirische toetsing betrokken. Afname van het $\mathrm{PO}$ vond plaats tussen de $4 \mathrm{e}$ en $7 \mathrm{e}$ week na opname.

2e. Vaststelling van probleemgedrag.

De konstatering van het probleemgedrag, in casu het totaal on tbreken van een bepaald soort gedrag, vond in dit geval niet plats aan de hand van de GOCC of PO. Het zero-gedrang, waar deze studie op was georiènteerd had betrekking op gedragstekorten als: patiënt komt nooit op tijd op therapie, vindt de weg niet van bed naar toilet, kleedt zich niet aan e.d. De signalering van de totale afwezigheid van een gedrag was een signalering ad hoc en gebeurde in de meerderheid der gevallen door de verpleegkundigen. De kriteriumsituatie waarin het gedragstekort werd vastgesteld was derhalve bijna steeds de klinische observatiesituatie.

3e. Vaststelling doelgedrag, modifikatieprocedures en bekrachtigende kondities. Het doelgedrag was bij de konstatering van zero-gedrag het komplement van het probleemgedrag. Wanneer een patiënt nooit op tijd komt, nimmer zijn 
prothese hanteert, de weg naar het toilet niet vindt ed, dian vloeit het te realiseren doelgedrag hier a.h.w. direkt uit voort:

De modifikatieprocedure bestond uit een vorm van shaping, warbuj het niveau van funktioneren van patiênt de worm welke hier moest worden toegepast, bepaalde. De voorbereiding van de shaping vereiste meestal het vervaardigen van een nauwgezet ,draaboek" waarbij voor iedere dag werd aangegeven welke aktiviteiten er door de modifikatiegroep uitgevoerd diende te worden, hoe en wanneer de bekrachtiging moest worden gegeven en op welke wijze de gedragingen van patient en begeleider moesten worden geregistreard.

$\mathrm{Bij}$ zero-gedrag was het soms moeilijk een adekwate bekrachtiging te vinden. Over het algemeen bleek sociale reinforcement in de zin van goedkeuring en aandacht redelijk te werken.

4e. Vaststelling van basislijn naar frekwentie of intensiteit wan voorkomen wan het probleemgedrag.

Dit was bijzero-gedrag niet eenvoudig. Het gedrag dat gevormd moest worden trad nooit op. Het probleem was juist dat het nooit optrad. Derhalve werd ter vaststelling van frekwentie of intensiteit van het probleemgedrag, altijd een soort afgeleid gevolg van dit probleemgedrag genomen. Bij voorbeeld: als patiënt de weg naar het toilet niet kon vinden dan gold als probleemgedrag, "het aantal malen natte kleding per etmad". Op deze wijze was het mogelijk een basislijn vast te stellen. Ook werd wel gebruik gemakakt van de zogenamde „time-sampling"-methode watabijop regelmatige tijdstippen de frek wentie van voorkomen van dit (afgelleide) probleengedrag werd nagegaan.

5e. Uitvoering der modifikatie en procesassessment.

De duur van de shapingsprocedure was uiteraard alhankelijk van doelgedrag, type patiënt, konsekwentheid der uitvoering e.d. Over het algemeen lag deze periode tussen 1 en 3 manden.

De witwoering wond plats door samenwerking van diverse disciplines, watrbij de verpleegkundigen valak een zeer belangrijk aandeel hadden. ledere stap van het ${ }$ draaiboek" werd dagelijks aan de hand van de vastgestelde shapingsprocedure door leden van diverse disciplines uitgevoerd. Bij swcces volgde bekrachtiging, bij falen geen. Na het bereiken van een bepaalde stap volgde $100 \%$ overlearning in de tijd, d.w.z. indien patiënt er 3 dagen over had gedaan om een bepaalde stap te bereiken, dan werd dit gedeelte van de training nog 3 dagen daarna voortgezet. Pas daarna werd overgegaan tot het aanleren van het volgende deel. ledere trial werd nauwgezet geregistreend wat betreft:

a. natam wan de begeleider (verondersteld werd, dat hierdoor een kompetitie. element geintroduceerd werd, waardoor mogelijke intermitterende reinforcement voor de begeleider zou kunnen gaan meespelen).

b. het al dan niet realiseren wan het (sub)doelgedrag.

c. het al dan niet toedienen van reinforcement.

6e Vaststelling van eindlijn van het probleemgedrag:

Na de vorming wan het doelgedrag was hel noodzakelijk nauwgezet te observeren en te registreren of het (afgeleide) probleemged rag nog optrad. Dit gebeurde opnieuw volgens de time-sampling-methode, $d$ w.z. op regelmatige tijdstippen (meestal het eerste kwartier van ieder uur) werd door de therapeut die in de buurt van patiënt was, geobserveerd of het probleemgedrag optrad. Over een gehele week betekende dat bij ca. 15 observatiek wartieren per dag, ongeveer 100 observaties. Per dag werd het gemiddelde bepaald.

7e Eflektassessment.

Na het eind der behandeling volgde opnieuw de effektassessment, zoals 
omschreven onder ad. 1. De GOCC werd éenmaal afgenomen volgens de synthetische beoordeling. Deze afname vond plaats na het bereiken van het doelgedrag en na de probleemassessment, en bestrek een periode van 2 weken. In deze 2 wekn werd eveneens het psychologische onderzoek afgenomen.

8e. Recapitulatie.

$\mathrm{Na}$ het realiseren wan de effektassessment werd in het team een nieuw doelgedrag (of het kontinueren van de poging het eerste doelgedrag te vormen) besproken.

Op deze wijze kreeg de behandeling een cyclisch verloop. Het was uiteraard ook mogelijk dat de behandeling na genoemde $1-3$ maanden werd beeindigd. Een en ander werd bepaald door het resp. sukselvol beëindigd zijn van de behandeling danwel het uitblijwen van enig gewenst resultaat.

Voorafgaande 8 fasen gelden mutatis mutandis bij alle andere modifikatieprocedures. Op enkelle inhoudelijke verschillen zal in het nu volgende worden ingegaan.

\subsubsection{Toename van gedrag}

1e. Effektassessment (geheel overeenkomstig 3.1.2.).

2e. Vaststelling van probleemgedrag.

Hierbijgold als probleemgedrag; in een bepaalde situatie is het gewenste gedrag wel aanwezig, de intensiteit of de frekwentie van voorkomen is te lag. Het infrekwente gedrag dat voorkwam tijdens de opzet en reallisering van deze studie bestond o.a. uit: een patiènt is in staat gedurende een korte tijd een taak uit te voeren, het zou gewenst zijn deze tijd op te voeren; patiënt is in staat zich aan te kleden, te wassen etc., maar doet het niet vaak genoeg. patient is over het algemeen slordig. mar hij is soms wel netjes, hoe is zijn netheid te vermeerderen? enz.

De signalering van dit infrek wente gedrag was een signalering ad hoc, zowel in de klinische observatiesituatie door verscheidene disciplines, alsook in de klinische testsituatie.

3e. Vaststelling doelgedrag, modifikatieprocedure, bekrachtiging.

Doelgedrag was in alle gevallen: toename van frekwentie en/of intensiteit van het reeds anwezige gedrag in de bepaalde situatie.

De modifikatie bestond uit de toepassing van selektieve reinforcement na optreden van het betreftende gedrag. Het programma der modifkative vertoonde gelijkenis met de gedragsvorming bij zero-gedrag (zie 3.1.2). Ter werhoging der frekwentie of intensiteit van optreden werden gedragsdoelstel. lingen of subdoelstellingen gemarkeerd. Bij de gedragsvorming (3.1.2) hadden deze stappen betrekking op uitbreiding van het gedragsrepertoir. Bij infrekwent gedrag was dit niet nodig, aangezien in principe het vereiste gedragsrepertoir reeds a anwezig was. De stappen of subdoelen hadden hier betrekking op het trapsgewijs verlengen van de tijd of het verhogen van de sterkte van de handeling.

De bekrachtiging zelf bestond voor alle gevallen welke in deze studie betrokken zijn uit tokens, die a an het eind van de dag, ochtend, middag of week, ingeruild konden worden voor goederen of privileges waar de patiënt veel waarde aan hechtte.

4e. Vasstelling basislijn van het probleemgedrag.

Bij de pogingen tot modifikatie van infrek went gedrag behoeft in tegenstelling tot zero-gedrag geen afgeleide vorm te worden gezocht. Het vaststellen van de 
basislin van het probleemgedrag gebeurde eveneens volgens de time-samplingprocedure zoals behandeld onder 3.1.2. punt 6 .

Se: Uitvoering van modifikatie en procesassessment.

In aansluiting op paragraaf 3.1.2. sub. Se. zij hier het volgende vermeld:

- Duur: 1-3 maanden

- Uitvoering: door alle disciplines

- Wijze van uitwoering verliep volgens stapsgewijze benadering van het vastgestelde doelgedrag (bijv. 10 minuten lang met een tak bezig kunnen zijn). Bij ledere gerealiseerde stap trad 100 \% overlearning op. Pas daarna overgang nat ar volgend gedragsdoel.

- De registratie betrof naam begeleider, realisering van het subdoel en al of geen toediening van bekrachtiging.

6e. Vaststelling van eindlijn (zie 3.1.2. - 6e).

7e. Effektassessment (zie 3.1.2. - 7e)

8e. Recapitulatie (zie 3.1.2. - 8e).

\subsubsection{Behoud van gedrag onder toenemende stimuluscomplexiteit}

1e. Effektassessment (zie 3.1.2. - 1e).

2e. Vaststelling van probleemgedrag.

Hierbij gold als probleemgedrag: Het gedrag treedt op met gewenste frekwentie en intensiteit onder bepaalde stimuluskondities, echter niet of minder korrekt onder andere stimuluskondities.

Het probleemgedrag dat onder deze studie viel en waarop een modifikatiepoging werd ondernomen, had alleen betrekking op geheugen-en/of concentratietekort.

Signalering van deze gedragstekorten trad op in de psychologische onderzoeksituatie. Hoewel gewerkt werd net een inadekwate taxonomie van gedragstekorten in de testsituatie werd wel systematisch geëxploreerd.

3e. Vaststelling van doelgedrag, modifikatieprocedure en bekrachtiging.

Als doelgedrag werd gesteld: het doen optreden van een korrekte geheugenrespons onder toenemende stimuluscomplexiteit. Onder korrekte geheugenrespons werd verstaan de recognitie van een eerder aangeboden stimulus uit verscheidene stimuli en de reproduktie van een aangeboden verzameling van stimuli. De stimuli konden hierbij van visuele of auditieve aard zijn. De modifikaties die in deze studie werden betrokken, betroffen de zgn. korte termijnopslag, d.w.z. recognitie of recall 5 sekonden na aanbieding.

$\mathrm{Bij}$., concentratietek ort" werd als doelgedrag gesteld: het doen optreden van een handeling met een bepaald tempo, regelmaat en fouten onder toenemende moeilikheidsgraad.

Als modifikatieprocedure werden zowel voor de geheugen-als concentratietraining een aantal moeilijkheidsgraden ontworpen. Voor de geheugentraining bestonden de parameters der moeiljkheidsgraad uit de hoeveelheid stimull, lengte, of complexiteit der stimuli en de bekendheid resp. kodificeerbaarheid der stimuli. Bij de concentratietraining werd de moeilijkheidsgraad voornamelijk bepaald door de samenstelling of de soort van het materiaal: het aanstrepen van bepaalde stimuli in een rij van andere stimuli, het sorteren of rangschikken van zeer eenvoudige stimuli etc.

Naast geleidelijk verhogen van de moeilijkheidsgraad werd tijdens de training gebruik gemaakt van overlearning. Pas indien patiënt een aantal oefeningen 
wan gelijke moeilijkheidsgraad onder bepaalde kondities kon uitvoeren werd overgegaan op een volgende moeilijkheidsgraad.

Bekrachtiging: Hoewel dit ook bij andere modifikatieprocedures het geval was, bleek dat met name de "relatievorming" bij de onderhavige procedure een belangrijke faktor was. Door patiënt en therapeut werd eerst een streefniveau vastgesteld, d.w.z. er werd aan de patiënt gevraagd welke moeilijkheidsgraad hij dacht te kunnen beheersen. Na de uitvoering werd onmiddellijke reedback gegeven omtrent het aantal goede prestaties en werd een patiënt de eventuele vooruitgang in een grafiek getoond. (zie verder 3.4)

4e. Vaststelling van basislijn van het probleemgedrag.

Deze vond plaats door met patiënt een aantal moeilijkheidsgraden door te nemen, waarbij uiteraard begonnen werd bij de eenvoudigste, en vervolgens verder gegaan werd naar moeilijker niveaus. De prestaties werden grafisch weergegeven. Horizontaal werd de tijd uitgezet en vertikaal de moeilijk heidsgraden. Na enige tijd bleek de patiënt in een bepaalde moeilijkheidsgraad te stagneren. Dit niveau vormde de basislijn en het uitgangspunt voor de training.

5e. Uitvoering van modifikatie en procesassessment.

De duur der modifikatie lag meestal minimaal op 5 à 6 maanden. Om vergelijkbaarheid der modifikaties mogelijk te maken vond echter de effektassessment steeds na 2 a 3 maanden plaats.

De uitvoering van de modifikatie in deze, vond plaats door onderwijskrachten, geassisteerd door speciaal hiertoe aangetrokken assistenten, waarbij meestal voor iedere patiënt een samensteld programma werd uitgevoerd in de visuele en auditieve modaliteit. De te trainen stappen werden gevorond door de diverse moeilijkheidsgraden.

Van iedere triall vond nauwgezette registratie plaats: de tijdens de training verkregen grafieken verschaften informatie aan de patiënt, de therapeut en het team.

6e. Vaststelling van eindlijn wan het probleemgedrag.

$\mathrm{Na}$ het doorlopen van een aantal moeilijkheidsgraden trad na enige tijd opnieuw een "stabilisatie" der prestaties op. Indien gedurende een week geen voortgang werd geboekt, werd aangenomen dat het maximale niveau voor de patiënt bereikt was. Aan dit kriterium voor stabilisatie werd echter eveneens de eis verbonden dat de horizontale lijn in de geregistreerde kurve zich zowel in de visuele als in de auditieve modaliteit moest presenteren.

7e. Efrektassessment (zie 3.1.2. - 7e).

8e. Recapitulatie (zie 3.1.2. - 8e).

\subsubsection{Reduktie van excessief gedrag}

1e. Effektassessment (zie 3.1.2. - 1e).

2e. Vaststelling van probleemgedrag.

De konstatering van het probleemgedrag in de vorm van excessief ongewenst gedrag vond plaats aan de hand der GOCC in de klinische observatiesituatie volgens een systematische exploratie. De GOCC signaleerde over het algemeen een verhoging bij verscheidene gedragskriteria. De selektie van het probleem. gedrag werd bepaald door o.a. de hoogte der score, de herhaling van een hoge score op het betreffende gedragskriterium, de bekendheid van een modifikatiestrategie bij het team.

3e. Vaststelling van doelgedrag, modifikatie en bekrachtiging.

Indien het probleemgedrag bekend was, werd gezocht naar gedrag, dat hiermee 
on verenigbaar was. Als doelgedrag werd gesteld: toename van dit incompatibele gedrag.

Aangezien het excessieve ongewenste ged rag in de regel door een intermitterend bekrachtigingsschema werd onderhouden, vereiste de extinktie hier bijuondere aandacht. Tegelijkertijd diende het incompatibele gedrag te worden bekrachtigd. Ter modifkatie werd nu zowel extinktie van probleemgedrag als bekrachtiging van inkompatibel gedrag gedurende 2-4 maanden kontinu toegepast. In extreme gevallen van excessief probleemgedrag diende de omgeving aanzienlijk gereduceerd te worden. Nadat gebleken was dat de modifikatieprocedure een verschuiving in het gedragsrepertoir tot gevolg had in de sterk gereduceerde omgeving werd onder handhaving van kontinue extinktie- en bekrachtigingsschema's overgegaan tot stimulusgeneralisatie. De patient werd geleidelijk aan in een diversiteit van stimulussituaties gebracht. Indien bleek dat het probleemgedrag niet of nauwelijks meer optrad, werd in de meer gevarieerde omgeving overgegaan op intermitterende schema's.

Een en ander vereiste een zorgvuldige planning, uit woering en registratie. Wat betreft de bekrachtiging werd in vrijwel alle op deze wijze behandelde gevallen gebruik gemaakt van een variëteit aan mogelijke bekrachtigingen (zie verder onder punt 5).

4e. Vaststelling van basislijn van het probleemgedrag en doelgedrag.

In vele gevallen werd een dubbele basislijn vastgesteld, namelijk de basislijn, die de frekwentie van voorkomen van het probleamgedrag aangal en die van het optreden van het incompatibele gedrag. Beide basislijnen werden samengesteld volgens de time-sampling-procedure. Bovendien werd aandacht besteed aan de stimuluskondities, die het probleemgedrag leken uit te lokken, alsmede aan de bekrachtiging, die het probleemgedrag in stand hield.

5e. Uitvoering van modifikatie en procesassessment.

Duur: 2-4 maanden.

De uitvoering werd verzorgd door alle disciplines. In verband met de extinktie werd getracht er voor te zorgen, dat patiènt alleen kontakt had met hen die op de hoogte waren wan deze procedures.

Bij patiënten met extreem probleemgedrag stuitte dit op allerlei hast onoverkomelijke moeilijkheden. Ieder moment bleek de kontinue extinktieprocedure in gevaar te kunnen verkeren. Aangezien een voortdurende begeleiding van de patiënt niet realiseerbaar was, werd in enkele gevallen overgegaan tot "relatief isolement". Met toestemming van naaste familieleden en zo mogelijk ook van patient zelf, werd deze in een kamer geplatst. Toegang tot de kamer hadden alleen die personen, die op de hoogte waren van de behandeling. Dit impliceerde dat de patiënt geen kontakt kon opnemen met personen die riet op de hoogte waren van vereisten ter extinktie. Overigens had de patient ondertussen meer sociaal kontakt dan enige andere patient, atangezien hij om het half uur door een lid van het team bezocht werd. Bij het binnenkomen werd de patiènt de diskriminatieve stimulus gepresenteerd, waarvan uit de time sampling bekend was geworden "dat deze het probleemgedrag uitlokle. Bij optreden van het nauwkeurig omschreven probleemgedrag werd de kamer zondermeer verlaten. Bij het achterwege blijwen van probleemgedrag en het optreden van het incompatibele gedrag volgde bekrachtiging. Deze bekrachtiging kon per patiënt variëren van verbale goedkeuring, langer sociaal kontakt. snoep, tokens tot kombinaties hiervan.

Registratie der procesassessment: ieder half uur werd dit bezoek herhaald watbij nauwkeurige registratie plaats vond van: 

a. de personen die de kamer binnen waren gegaan.
b. het al dan niet optreden wan het probleemgedrag.
c. het al dan niet kunnen uitvoeren van extinktie.
d. het eventueel optreden wan incompatibel gedrag.
e. het adekwat toepassen wan bekrachtiging na incompatibel gedrag.

Zodra aan de hand der dubbele grafieken duidelijk werd, dat de procedure "aansloeg" werd overgegaan tot stimulusgeneralisatie door de patiënt in aanraking te brengen met andere personen, o.a. familieleden en andere omgevingen. leder half uur werd echter de diskriminatieve stimulus a angeboden en volgde bekrachtiging en/of extinktie. Na geslaagde stimulusgeneralisatie werd overgegaan van een kontinu op een intermitterend bekrachtigingsschema totdat de bekrachtiging achterwege kon blijven.

6e. Eindilin van probleem-en doelgedrag.

Nadat via bovenstaande procedure het probleemgedrag vervangen was door het doelgedrag werd opnieuw de time-sampling-procedure toegepast: gedurende een week werd in het eerste kwartier van ieder uur de frek wentie van optreden van probleem èn het doelgedrag geobserveerd en geregistreerd.

7e. Effektassessment (zie 3.1.2. $-7 \mathrm{e}$ ):

8e. Recapitulatie (zie 3.1.2. - 8e).

\subsubsection{Samenvatting}

In het voorgaande werd weergegeven hoe modifikatie- en assessmentprocedures in hun onderlinge samenhang werden uitgevoerd.

Zowel gedragsvorming, gedragstoename, gedragsbehoud en gedragsreduktie bestonden uit de volgende programma stappen:

1e. Effektassessment:

a. GOCC-observatie volgens het principe der synthetische beoordeling.

b. Afname van het psychologisch onderzoek

2e. Vaststelling van het probleemgedrag

3e. Vaststelling van het doelgedrag, modifikatieprocedure en bekrachtigingswijze.

4e Vasistelling van basislijn ten behoeve van probleemassessment.

5e. Uitvoering van modifikatie en registratie (ten behoeve van procesassessment).

6e. Vaststelling van eindlijn ten behoeve van probleemassessment.

7e. Eflektassessment.

8e. Recapitulatie met eventueel opnieww vaststelling van doelgedrag voor een volgende cyclus.

\subsection{Statistische bewerking der Gedragsobservatieschaal Contusio}

\subsubsection{Inleiding}

De GOCC werd als een vast onderdeel opgenomen in de voorlopige assessmentprocedure. Mede op basis van de GOCC-scores werd de indikatie tot gedragsbehandeling gesteld. Bovendien verscharte de $\mathrm{GOCC}$ in een aantal gevallem informatie omtrent het probleem-en doelgedrag. Tenslotte vormde de GOCC een onderdeel van de zgn. effektassessment; warbuj uit de vergelijking van scores voor en na de behandeling een partieel oordeel omtrent het effekt der behandeling werd gevormd. In de loop van 3 jaren werd zodoende het gedrag van 104 patiënten aan de hand van de GOCC geobserveerd en beoordeeld. In een groot aantal gevallen 
werd de GOCC minstens tweemaal en vaak driemaal per patient toegepast. De GOCC-grafiek kwam tot stand door sommatie en middeling van de scores van minstens vijf onafhankelijke boordelaars. Indien een patiënt voor een behandeling in aanmerking was gekomen, werd deze na de behandeling nogmaals aan de hand der GOCC geobserveerd. Het zal duidelijk zijin, dat een dergelijke schaal die door verscheidene personen zo veelvuldig werd gehanteerd een nadere beschouwing vereist en verdient.

Voor statistische bewerking kwamen de volgende drie aspekten in aanmerking:

1e. Interbeoordelaarsbetrouwbaarheid: de mate van overeenstemming tussen de scores van de diverse beoordelaars.

2e. Intrabeoordelaarsbetrouwbaarheid: De mate van overeenstemming tussen de scores van eenzelfde beoordelaar in een periode, waarin geacht werd dat het gedrag der patiënt niet of nauwelijks veranderde.

3e. De mogelijkheid tot reduktie van de 17 items der GOCC tot een beperkter aantal door middel van faktoranalyse.

In het navolgende zal een verslag worden gegeven van dataverzameling en resultaten van deze statistische bewerkingen uitgevoerd door de afdeling informatieverwerking van de Medische Fakulteit te Maastricht (drs. L. Strijbosch) in samenwerking met het komputercentrum te Eindhoven.

\subsubsection{Dataverzameling}

Bij de dataverzameling werd uitgegaan van de volgende overwegingen:

a. De beoordelaars moeten per patiënt over alle in de bewerking te betrekken gegevens dezelfde personen zijn.

b. Deze beoordelaars moeten de patiënten in achtereenvolgende perioden en wel binmen 14 dagen hebben geobserveerd en beoordeeld.

c. Mede in verband met de te berekenen intrabeoordelaarsbetrouwbaarheid moet of de $1 \mathrm{e} e n 2 \mathrm{e}$ of de $2 \mathrm{e}$ en $3 \mathrm{e}$ waarnemingsperiode ter bewerking worden opgenomen. d. Het aantal patiënten dat door dezelfde beoordelaars binnen 14 dagen werd beoordeeld, moet bij voorkeur zo groot mogelijk zijn.

e. Het aantal beoordelaars dat eenzelfde patiënt binnen 14 dagen heeft beoordeeld moet bij woorkeur zo groot mogelijk zijn.

f. De beoordeling heeft bij woorkeur alleen betrekking op de contusio cerebri patiëntengroep.

Het bleek reeds snel dat vooral onder handhaving van de eerste overweging, het aantal patiëntengegevens dat voor bewerking in aarmerking $\mathrm{kwam}$, te beperkt zou zijn. Er waren wel steeds minimaal vijf observatoren per patiënt, maar om allerlei praktische redenen konden dit niet steeds dezelfde observatoren zijn. In verband met deze onbevredigende situatie werd besloten de te bewerken gegevens te verdelen in twee verzamelingen.

Eind 1975 was wit 42 geobserveerde patiënten bij 17 patiènten aan bovenstaande voorwaarden voldaan. Deze 17 patiënten waren alle door 5 dezelfde observatoren beoordeeld enwell tweemaal binnen een periode van 14 dagen, gedurende de $2 \mathrm{e}$ en 3e waarnemingsperiode. Deze patiënten behoorden overwegend tot de contusio cerebri populatie. Total $17 \times 17 \times 5 \times 2=2890$ GOCC-scores.

Eind 1976 was uit 96 geobserveerde patiênten bij 30 patiênten voldaan aan 
beoordeling door 5 dezelf de observatoren enwel tweemaal binnen een periode van 14 dagen gedurende de $2 e$ en $3 e$ warnemingsperiode. Deze patiënten behoorden overwegend tot de contusio cerebri populatie. Total $40 \times 17 \times 5 \times 2=6800$ GOC -sores.

Hierbij dient wel vermeld te worden dat bij de tweede patientenverzameling eveneens het merendeel van de eerste patientenverzameling was betrokken. In onderstaande tabellen wordt de samenstelling der patiëntengroepen weergegeven.

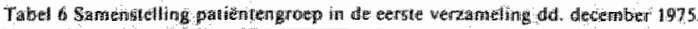

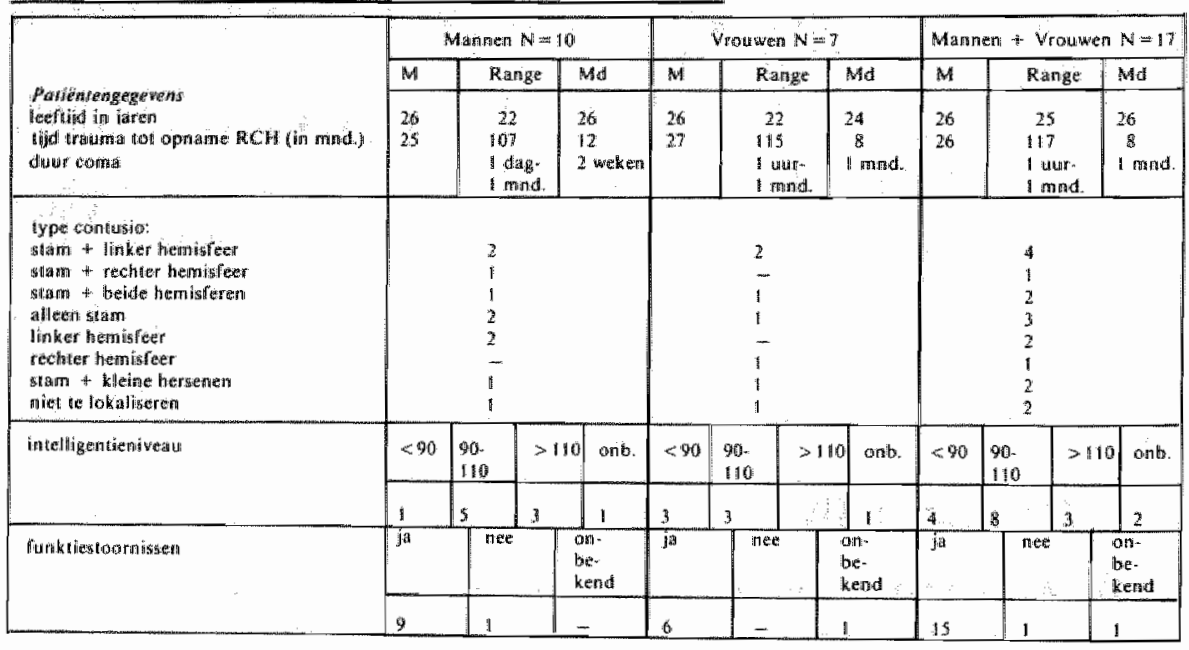

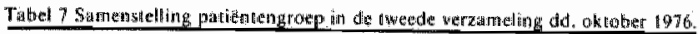

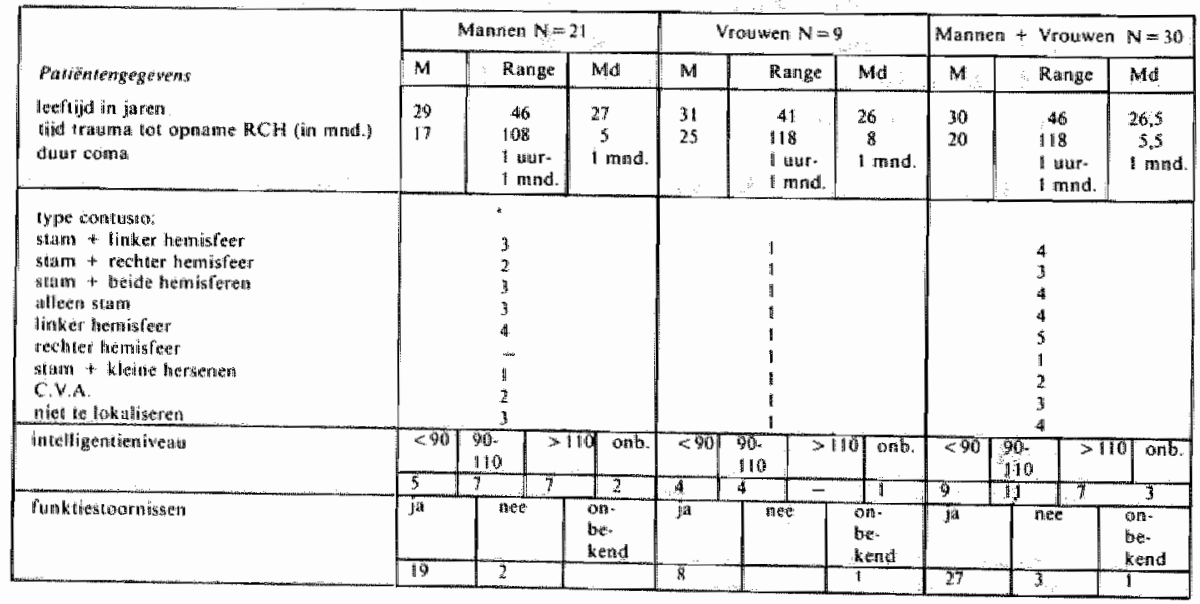

\subsubsection{Bewerking der gegevens}

\subsubsection{Zwakheden in schaalkonstruktie}

Bij de konstruktie der GOCC werd aan drie beoordelaars in eerste instantie gevraagd kaartjes met gedragsuitspraken te rangschikken in de volgorde: „licht aanwezig zijn van de klacht" en .. maximaal aanwezig zijn van de klacht". Vervolgens. 
werd getracht uitspraken te winden die de "afstand" tussen eerst genoemde punten owerbrugden in die zin, dat de uitspraken respektievelijk twee-en driemal zo enstig waren dan, "het licht aanwezig zijn van de klacht".

Op deze wijze werd geprobeerd een iets krachtiger schaal te konstrueren dan de ordinale schaal, nl. een intervalschaal. Tenslotte werd voor iedere uitsprak een amschrijving bedacht, warbij de desbetreflende klacht totaal niet a anwezig; c.q. tot nul gereduceerd was.

Ter kontrole werden alle kaartjes met "dummy-kaartjes" at random tweemaal aan de drie beoordelaars aangeboden met het verzoek de uitspraken te ondenen op een "ernst" schaal, van 0 tot 100. Aan de hand van deze resultaten werden diverse uitspraken bijgewerkt of herschreven. Het verkregen resultaat is een schaal, die bij benadering voldoet aan de eisen van een intervalschaal, hoewel hier vanuit psychometrisch standpunt bedenkingen tegen aan te voeren zijn.

Kerlinger (1972 p. 426 e.v.) besteedt aan dit psychometrische probleem de nodige aandacht: "Strictly speaking, the statistics that can be used with ordinal scales include rank-order coefficient correlations, $\rho$, Kendall's $W$, and the rank orderanalysis of variance, medians and percentiles. If only these statistics are legitimate, how can statistics like $r$, $t$ and $F$ be used with what are in effect ordinal measures? And they are used without a qualm by most researchers". Hiermee wordt door Kerlinger het probleem gesteld war men ondanks pogingen tot verbetering van de GOCC niet aan ontkomt. De GOCC is in feite een ordinale schaal, die echter in de praktijk gebruikt werd en in het vervolg van deze studie zal worden toegepast als een intervalschaal. Kerlinger ziet hier geen onoverkomelijk probleem in: „Yet, though most psychological scales are basically ordinal, we can with considerable assurance often assume an equality of interval".

De overwegingen inzake het gebruik wan ordinale schalen alls interval of ratioschalen zijn niet beperkt tot Kerlinger. Het probleem lijkt een algemeen probleem te zijn, dat door veel psychologen wordt ontmoet. Guilford was misschien een der eersten (1954), die deze kwestie naar woren heef gebracht ( $p .15$ en 16): „... . Experimental data often approach the condition of equal units sufficiently well that there is a tolerable error in applying the various statistics that call for them. This is one of those occassions for making use of approximations, in order that one may extract the most information from this data. This is often justified on the basis of evidence of the internal consistency of the findings and the validity of the outcomes. This does not excuse the investigator, however from being on the alert for intolerable approximations and for results and conclusions that are essential a function of this faulty application of statistics".

Andere auteurs die in hetzelfde verband genoemd kunnen worden zijn Boneau(1961 p. 260-261). Anderson (1961 p. 305-316) en Lord (1954 p. 264-265). Met Guilford, Lord, Anderson, Boneau en Kerlinger wordt hier een pragmatisch standpunt ingenomen. Met de ter beschikking stande hulpmiddelen werd als "voorlopig instrument" een schaal gekonstrueerd warvoor het principe van .de aanname der interval gelijkheid" akseptabel wordt geacht.

Uiteraard zin in deze studie de noodzakelijke maatregelen vereist om bij interpretatie der resultaten het risico te vermijden van te ver gaande konklusies. Deze matregelen bestaan uit het ." weevoudig bewerken“ der scores, zoals hiermavolgend zal worden toegelicht. 


\subsubsection{Inter-en intrabeoordelaarsbetrouwbaarheid}

Bij de bewerking der data werd uitgegan van de volgende dimensies:

Observatordimensie: varierend van $1-5$ (0-variabele)

iterndimensie: varierend van 1.17 (i-variabele)

tijddimensie: varierend van 1-2 (t-variabele)

patiéntimensie: varierend van $1-17$ in de eerste verzameling en van $1-30$ in de tweede verzameling (p-variabele).

Teneinde statistische bewerking mogelijk te maken en een dubbele kontrole te realiseren, werden de GOCC-scores, genoteerd per observator, per patiënt, per tijdstip en per item voorbewerkt door sommatie der GOCC-scores.

De sommatie der $\mathrm{GOCC}$-scores werd op twee manieren uitgevoerd.

\section{Sommatie over patienten.}

Op tijdstip $t_{1}$ werden per observatie-item, per observator, de GOCC-scores gesommeerd over alle patienten waaruit de verzameling bestond.
(A) Verzameling $1(p=17) ; t=1$ :
(17 somscores)
$\Sigma$ item $\times$ bij $\mathbb{H}_{1}=\Sigma_{1}^{17}$ pat. $[$ GOCC-sc] $=$
$\sum{ }_{1}^{7}$ pat [waarneming bij $t_{i}$ door $o_{y}$, op $i_{\mathrm{s}}$ over p.|.:pl
(B) Verzameling $2(\mathrm{p}=30) ; \mathrm{t}=1$ :
(30 somscores)
$\Sigma$ item $\times$ bij $t_{1}=\Sigma_{\|}^{*}$ pat. $[\mathrm{GOCC}-\mathrm{sc}]=$ $\Sigma(1)$ pat [waarneming bij $t_{\text {, door }} o_{y}$ op $i_{x}$

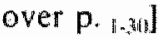

Op tijdstip t. werden per observatie item, per observator, de GOCC-scores gesommeerd over alle patienten waaruit de verzameling bestond.

(C) Verzameling $1(p=17) ; t=2$ :

(17 somscores)

(D) Verzameling $2(p=30) ; t=2$ :

( 30 somscores)
$\Sigma$ item $\times$ bij $t_{2}=\Sigma, 7$ pat $[$ GOCC-sc] $=$ $\Sigma_{1}{ }_{1}$ pat [W bij $t_{3}$ door $o_{4}$ op $i_{x}$ over p. $\left._{1-17}\right]$ $\Sigma$ item $x$ bij $t_{x}=\Sigma_{1}^{3 i}$ pat $[\mathrm{GOCC}-\mathrm{sc}]=$ $\Sigma_{1}^{30}$ pat [W bij $t_{2}$ door o op $i_{x}$ over p. 1-30]

2. Sommatie over de GOCC-items.

Op tijdstip t, werden per patiënt, per observator de GOCC wscores gesommeerd over alle GOCC-items.

(E) Verzameling $1(p=17) ; t=1$ :

(17 somscores)

(F) Verzameling $2(\mathrm{p}=30): \mathrm{t}=\|$ :

(17 somscores)
$\Sigma$ pat $\times$ bijt $t_{1}=\Sigma$, GOCC $[\mathrm{OOCC}-\mathrm{sc}]=$ $\Sigma i$ GOCC $\left[W\right.$ bij $t_{1}$ door o op $p_{x}$ over $\left.i_{\|=17}\right]$

$\Sigma$ pat $\times$ bijt $=\Sigma{ }_{1}^{17}$ GOCC $[\mathrm{OOCC}-\mathrm{sc}]=$ $\sum$ GOCCLW bij $t_{1}$ doot o op $p_{x}$ over $\left.i_{\| \bullet 17}\right]$

Op tijdstipt? werden per patiënt, per observator, de GOCC-scores gesommeerd over alle GOCC-items.

(G) Verzameling $1(\mathrm{p}=17) ; \mathrm{t}=2$ :

(17 somscores)

(H) Verzameling $2(p=30): t=2$;

(17 somscores)
$\Sigma$ pat $\times$ bijt $_{2}=\Sigma \sum_{1}^{7}$ GOCC [GOCC-sc] $=$ $\Sigma_{1}^{17}$ GOCC $\left[W\right.$ bij $t_{2}$ door $o_{y}$ op $p_{x}$ over $\left.\mathrm{i}_{1-17}\right]$

$\Sigma$ pat $\times$ bij $_{2}=\Sigma 1_{1}^{7}$ GOCC $[$ GOCC-sc] $=$ $\Sigma_{1}^{17} \mathrm{GOCC}\left[\mathrm{W}\right.$ bij $t_{2}$ door oy op $\mathrm{p}_{\mathrm{x}}$ over $i_{[-17]}$ 
Op deze wijze werden per verzameling vier sommatie-tabellen verkregen, als basis voor de bepaling van de inter-en intrabeoordelaarsbetrouwbaarheidscoëfficiënt. De interbeoordelaarsbetrouwbaarheidscoëfficiënten werden bij de sommatie over de GOCC-items berekend voor de beoordelaars onderling en woor iedere beoordelaar t.o.v. de gemiddelde beoordeling. Deze berekening werd uitgevoerd voor $t_{1}$ en $t_{2}$ apart. De interbeoordelaarsbetrouwbaarheidscoëfficiënten werden bij de sommatie over de patiênten alleen berekend voor de beoordelaars onderling. Ook deze berekeningen werden uitgevoerd voor $t_{1}$ en $t_{2}$ apart.

Daar de interbeoordelaarsbetrouwbaarheidscoëfficiënten gesommeerd over de GOCC-items, berekend voor de beoordelaars onderling, niet allen signifikant bleken te zijn, werd tevens deze coëfficiënt bepaald voor de gemiddelde waarden. De interbeoardelaarsbetrouwbaarheidscoëfficiënt gesommeerd over de patiënten was meestal wel zeer signifikant.

De intrabeoordelaarsbetrouwbaarheidscoëfficiënt werd (om dezelde reden) bij de sommatie over de GOCC-items berekend voor de beoordelatars onderling én voor de gemiddelde waarden, tussen tijdstip $t_{1}$ en $t_{2}$.

De intrabeoordellaarscoëficiènt werd bij de sommatie over de patiënten alleen uitgevoerd voor de beoordelaars onderling, tussen tijdstip $t_{1}$ en $t_{2}$.

Voor de berekening werd gebruik gemaakt van de produkt-moment-korrelatiecoëfficiënt (Spitz $1968 \mathrm{pg} 262$ ).

Tenslotte werd de signifikantie van al deze korrelaties bepaald door middel van de Student's t- toets (Spitz 1968 pg. 358). Hierbij werd een signifikantieniveau van $\alpha$ $=0,01$ gehanteerd onder een éenzijdige overschrijdingskans met Pearson's indices (Pearson c.s. 1956).

Voor een overzicht van de uitgevoerde voorbewerkingen wordt verwezen naar bijlage 2 .

De hieruit berekende korrelatiecoëfficiënten en toetsingsgrootheden zijn weergegeven in bijlage 3 .

\subsubsection{Overwegingen inzake faktoranalyse}

De gegevens ter berekening van faktorladingen werden ontleend aan de eerste verzameling d.d. december 1975. Dit leverde 6 faktoren op; die $99 \%$ der variantie dekten.

Terwijl via faktoranalyse een itemreduktie voor de GOCC werd nagestreefd, manifesteerde zich bij de gebruikers een tegengestelde tendens. Ondanks het feit dat er geen onduidelijkheid bleek te bestaan over de formulering van de GOCC-items werd er vanuit de praktijksituatie bij herhaling gesuggereerd dat de GOCC niet het probleemgedrag van alle patiënten met contusio cerebri zou dekken.

Toch werd met name vanuit de werpleegkundige sektor gesteld dat een rekonstruk tie van de GOCC-items grote verwarring zou stichten bij diverse beoordelaars. Men had behoefte aan stabilisatie van een observatiesysteem, dat ieder zich met de nodige moeite had eigen gemaakt.

Vanuit theoretisch standpunt is er dus een behoefte tot nadere precisering, betere begripsomschrijving, hergroepering en verdere validatie der GOCC.

Vanuit praktisch standpunt is er een drang tot behoud van het vertrouwde en bekende met hooguit enige aanvulling.

Vanwege deze ambivalentie werd vooralsnog afgezien wan de rekonstruktie van de GOCC.

Deze faktoranalyse maakte ondertussen wel duidelijk dat het onderscheid in de sub-groepen A en B (zie 2.2.3.) niet relevant was. Derhalve werd hiervan in deze studie geen verder gebruik gemaakt. 


\subsubsection{Bespreking der resultaten}

Voordat tot een bespreking der resultaten wondt overgegaan dient hier gesteld te worden dat de toegepast stallistische procedures slechts globale konklusies toelaten. In de toekomst dient onderzoek uitgevoerd te worden naar de betrou wbarheid van de items alzonderlijk omdat in de praktijk tenslotte ook over items afzondelijk en per patiént een uitspraak wordi gedaan. Dit geldt zowel voor inter-als intrabeoordelaarsbetrouwbararheid.

Aangezien het instrument zich ten tijde van deze studie in een ontwikkelingsfase bevond, werd de hier uitgevoerde procedure voorlopig voldoende geacht.

\section{Eerste verzameling}

De coefficienten voor inter-en intrabeoordelaarsbetrouwbaarheid berekend uit de sommatie over de patienten zin aile vrij hoog en signifikant $(\alpha=0,01$ en $\mathrm{d} . \mathrm{f}=15$ volgens de (-toets).

De interbeoordelaarsbetrouwbarheid berekend over de GOCC-items toont een minder overtuigend beeld. Indien afgezien wordt van de korrelatie van iedere beoordelaar met de gemiddelde beoordelaar, dan zijn bij $\mathrm{t}_{1}$ \& van de 10 korrelaties niet signifikant, bij $t_{2}$ zijn er 7 van de 10 korrelaties niet signifikant. Vooral de korrelaties wan de beoordelaars 1,2,3 en 5 met beoordelaar 4 komen hierbij als niet signifikant nat voren.

De korrelatie van alle beoordelaars met het gemiddelde zijn daarentegen zeer signifkant. De intrabeoordelaarsbetrouwbaarheid berekend uit de sommatie over de GOCC-items neemt een middenpositie in tussen beide vorige $(\alpha=0,01 \mathrm{en} \mathrm{d.f}$. $=15$ volgens de $t$-toets).

\section{Tweede verzameling}

De coëfliciënten voor inter-en intrabeoordelaarsbetrouwbaarheid berekend uit de sommatie over de patiënten zijn weer vrij hoog en signifkant. De warden gevonden in de tweede verzameling zijn op één uitzondering na alle hoger dan de waarden in de eerste verzameling $(\alpha=0,01$ en $d . f=28$ volgens de 1 -toets $)$.

De interbeoordelaarstbetrouwbaarheid berekend uit de sommatie over de GOCC. items toont weer een groot aantal niet signifikante korrelaties. Ook hiler zijn de korrelaties van alle observatoren met observator 4 vrijwel alle niet signifikant. De korrelatiecoefficiênten van alle observatoren met het gemiddelde zijn opnieuw zeer signifkant. Indien men de tweede verzameling met de eerste vergelijkt, vertoont de tweede verzameling geen hogere korrelatiecoefficienten dan de eerste. De intrabeoordetarsbetrouwbatheid ligt ook hier lets beter dan de interbeoordelaarsbetrouwbartheid $(\alpha=0,0 \|$ en $d . f=28$ volgens de t-toets).

Vergelijkt men de eerste verzameling met de tweede verzameling, dan blijkt in beide verzamelingen de intrabeoordelaarscoëficiènten van obervator 5 niet signifikant.

Uit deze resultaten vallen de volgende konklusies te trekken:

1e. Indien men aan een groep van vaste observatoren de opdracht geeft een groep patienten te beoordelen aan de hand der GOCC, dan bestat er

a. indien men alle patiènten eerst scoort op GOCC-item 1, en daarna deze scores over de patiënten sommeert, een grote mate van overeenstemming over de op deze wijze tot stand gekomen somscores. Eenzelfde konklusie geldt mutatis mutantus voor alle overige GOCC-items.

b. indien men é̉n patiènt scoort op GOCC-item 1, daarna op 2 enz. en vervolgens deze scores sommeert, een geringe mate wan overeenstemming 
tussen de verschillende beoordeladrs onderling over de op deze wijze tot stand gekomen somscores (over een gehele groep van patiënten genomen). De hoge korrelatiecoëfficiënten bij $\Sigma$, of $\Sigma$ iul pat. [GOCC] sc. in vergelijking tot de lagere korrelatiecoëfficiënten bij de $\Sigma_{1}^{17}$ GOCC [GOCC] sc. wordt wellicht verklaard doordat bij eerst genoemde wordt gesommeerd over eenzelfae variabele over een aantal patiènten hetgeen tot uitdrukking komt in één getal. Bij laatstgenoemde wordt gesommeerd over verschillende variabelen, die qua inhoud misschien moeilijker te sommeren zijn, waarbij de waarden elkaar ook per patiënt kunnen neutraliseren.

c. indien men de volgens b. tot stand gekomen somscores middelt, dan bestaat er (zoals overigens te verwachten was) een grote mate van overeenstemming tussen de verschillende somscores der aparte beoordelaars en de gemiddelde somscores.

2. De intrabeoordelaarsbetrouwbaarheidcoefficiënten zijn in het algemeen signifikant $(\alpha=0,01)$. Dit geldt voor de beide voorbewerkingen van beide verzamelingen.

3e. Een enkele observator is te kwalificeren als afwijkend t.o.v. de overige observatoren. Deze konstatering geldt alleen voor het geval waarbij de coëfficiënten berekend worden op basis van sommatie over de GOCC-items.

a. De interbeoordelaarsbetrouwbaarheidscoëfficiënten van de beoordelaars 1 , 2, 3 en 5 t.o.v. 4 is niet signifikant in beide verzamelingen.

b. De intrabeoordelaarsbetrouwbaarheid is voor observator 5 niet signifikant in beide verzamelingen.

\subsubsection{Samenvatting}

De basis voor een deel der modifikatieprodure is de GOCC, welke in de loop van drie jaren een toenemende mate van toepasbaarheid en bruikbaarheid bewees. Een kritische evaluatie van de GOCC leek derhalve een noodzakelijkheid en hiertoe werd een grote verzameling van scores aan een statistische bewerking onderworpen. Het aksent van deze bewerking werd gelegd op bepaling van inter-en intrabeoordelaarscoëfficiënten van 5 observatoren, betrokken op twee verzamelingen van resp. 17 en 30 patiënten. De belangrijkste resultaten kunnen als volgt geformuleerd worden:

1e. De intrabeoordelaarsbetrouwbaarheid van de vijf observatoren is goed te noemen, met uitzondering van de berekende waarde van één observator t.o.v. de overigen.

2e. De interbeoordelaarsbetrouwbaarheid van de vijf observatoren is redelijk tot goed, eveneens met uitzondering van de berekende waarden van eén observator t.o.v. de overigen.

3e. Genoemde uitzonderingen vormen een aanwijzing voor de beperking der observatorengroep, tot enkele vaste observatoren, die voortdurend informatie, opleiding en bijsturing behoeven.

4e. De interbeoordellarsbetrouwbaarheid is zeer goed, indien deze bepaald wordt op basis van sommatie over de patiënten per GOCC-item.

5e. De interbeoordelaarsbetrouwbarheid is minder goed, indien deze bepaald wordt op basis van sommatie over de GOCC-items per individuele patiënt. 


\subsection{Evaluatie van modifikatie ter vorming, toename en reduktie van gedrag}

\subsubsection{Inleiding}

In deze paragraaf zal de evaluatie wan de uitvoering zelf behandeld worden. Dit zal gebeuren in de vorm wan casuilstiek $\mathrm{nl}$. inzake de gedragsvorming, gedragstoenames en gedragsredukties. Als zodanig is dit een uitbreiding en nuancering van een pilotstudie, welke eerder werd gepubliceerd (zie Schuerman 1975, 1 en 2).

Deze paragraaf wordt afgesloten met een behandeling van de resultaten waarbij het slechts gaat om algemene tendenties. Een statistische bewerking is hierbij slechts beperkt mogelijk aangezien het aantal behandelingen gering is en er geen kontrolegroep gevormd kon worden.

\subsubsection{Datapresentatie}

De hiernavolgende casuïstiekbespreking richt zich uitsluitend op de behandeling van patiënten met contusio cerebri. Na de bespreking der resulaten zullen in 3.3.7. ook ervaringen inzake gedragsmodifikatie met anderszins cerebraal gestoorden worden betrokken.

Per behandeling zullen beknopt de bevindingen worden gepresenteerd wat betreft achtereenvolgens: gedragsworming ( $V$ ), gedragstoename ( $T$ ) en reduktie van gedrag (R).

Per patiênt met contusio cerebri zal achtereenvolgens aangegeven worden:

(1) Patiëntgegevens: geslacht, leeftijd, tijd interval tussen ongeval en opname in revalidatiecentrum, duur coma, type ziektebeeld, GOCC en gegevens van het psychologisch onderzoek.

Afgezien is van vermelding van EEG-bevindingen aangezien deze in de meerderheid der gevallen ontbraken. De medikatievermelding verviel op grond van de zeer gevarieerde en wisselende toepassing van diverse medikamenten.

(2) Probleemgedrag: probleemgedrag werd afgeleid uit de GOCC of uit signalering ad hoc. In verband met de probleemassessment werd gezocht naar een meetbaar kriterium dat het probleengedrag zo goed mogelijk weergaf of hiermee in direkte relatie stond.

(3) Doelgedrag: het doelgedrag was meestal een afgeleide van het probleemged rag. Het gaf aan watr het einddoel van de behandeling op gericht was.

(4) Behandelingsplan: het behandelingsplan omschrijft de weg waarlangs het doelgedrag wordt benaderd.

(5) Uitvoering: In de ,uitvoering" wordt zeer in het kort ingegaan op ondervonden moeilijkheden, suksessen en mislukkingen bij de realisering van de modifikatieprocedure.

(6) Probleemassessment

(7) Procesassessment

(8) ElTektassessment

Deze drie vormen van assessment geven de resultaten der behandeling in grafiekvorm weer.

(9) Resultaten bespreking

Bij de resultaten bespreking wordt ingegaan op:

a. afname of toename van probleemgedrag

b. de realisering van thet doelgedrag

c. de weerspiegeling van het effekt der procedure in GOCC en psychologisch onderzoek. 


\subsubsection{Gedragsvorming}

\section{Patient V-}

(1) Panerngegevens:

- 0,33 jaar

- lijd trauma to opname." $31 / 3$ matand

- duur coma: onbekend

- contusio cerebri

- niet testbaar m.b.v. psychologisch onderzoek

(2) Probleengedrag: Diverse stoornissen. Niet objektief vast te stellen. Als subjektier (voor verpleging en thüsmulieu meest storende gedrag: regelmatige urinelozing en defaecatie in hoek van slatapkamer. Vermoedelijke reden: kin toilet niet vinden door geheugen-en/of oriëntatiestoornis. Er bestond geen organische verklaring voor inkontinentie.

Definitie probleengedrag: Het aantal malen inkontinent per etmaal. Een week voor en een week nal de behandeling werd deze frekwentie van voorkomen nagegaan om 4.00, 8.00, $\| 2.00, \$ 6.00,20,00$ en 24.00 uur.

(3) Dovelgedrag: Bij ,aandrang" zelfstandig vanuit plats watar patiènt zich bevindt naar toilet kumnen gaan, alle noodzakelijke handelingen kunnen verrichten en weer teruggaan. Aangezien dit moeilijk konitroleerbaar te maken was, werd een meer specifieker doelged rag omschreven: Bij de diskriminatieve stimulus bestande uit de vraag: "Moet a natr het toilet?" moet patiënt in staat zijn (indien nodig) het toilet vanuit zijn bed (waar patiènt doorgaans verbleef) te kunnen vinden, alle noodzakelijke handelingen ter plekke to verrichten en weer zelfstandig naar het bed terug te kunnen gaam.

(4) Behandelingsplan: Suksessieve approximatie (volgens trajekt-bed-w.c.bed) met verbale instruktie, prompting, selektieve bekrachting en rading. De oefeningen vonden plats om de twee uur (net ., droge" periode) overdag en "s nachts. ledere deelhandeling werd altijcl begonnen met de vraag "moet u naar het toilet?" en bij suksesvolle trial beèindigd met sociale bekrachtiging (goedkeuring) volgens onderstaand behandelingsschema:

a. Begeleiding vanaf bed tot w.c.-brill - rest doet patient zelf - begeleiding natar het bed terug.

b. Begeleiding wanaf bed tot w.c.-deur - rest zell - begeleiding tot achter kamerdeur - rest zell.

c. Begeleiding vanaf bed tot halverwege de gang - rest zelf - begeleiding tot wór kamerdeur - resi zelf.

d. Begeleiding wan f bed tot achter kamerdeur - rest zetf - begeleiding vanaf w.c. tot halverwege gang - rest zell.

e. Begeleiding vanaf bed tot vóor kamerdeur - rest zelf - begeleiding $\mathrm{U} / \mathrm{m}$ sluiten van w.c.deur - rest zelf.

f. Instruktie . moet u natr het toilet?" - rest zelf (geen begeleiding terug natar bed ).

Bekrachtiging werd gegeven nadat ... rest zelr" in bovensta and schema inderdaad door patient kon worden gerealiseerd. Bij adrzelen of fallen tijdens ., rest zell' werd weer met prompting begonnen.

(5) Uiwering: Deze werd gerealliseerd door het verplegenden-tean over een periode van 7 weken (met onderbreking van een week ziekenliusopname). Voor en na de bellandeling vond probleemassessment en effektassessment plats, watoor de gehele behandeling ca. 9 weken duurde. Tijdens de behandeling vond procesassessment plaats. d.w.z. er werd geregistreerd of patient in statt was de deelhandelingen uit te voeren. 
(6) Problewmaseswnent:

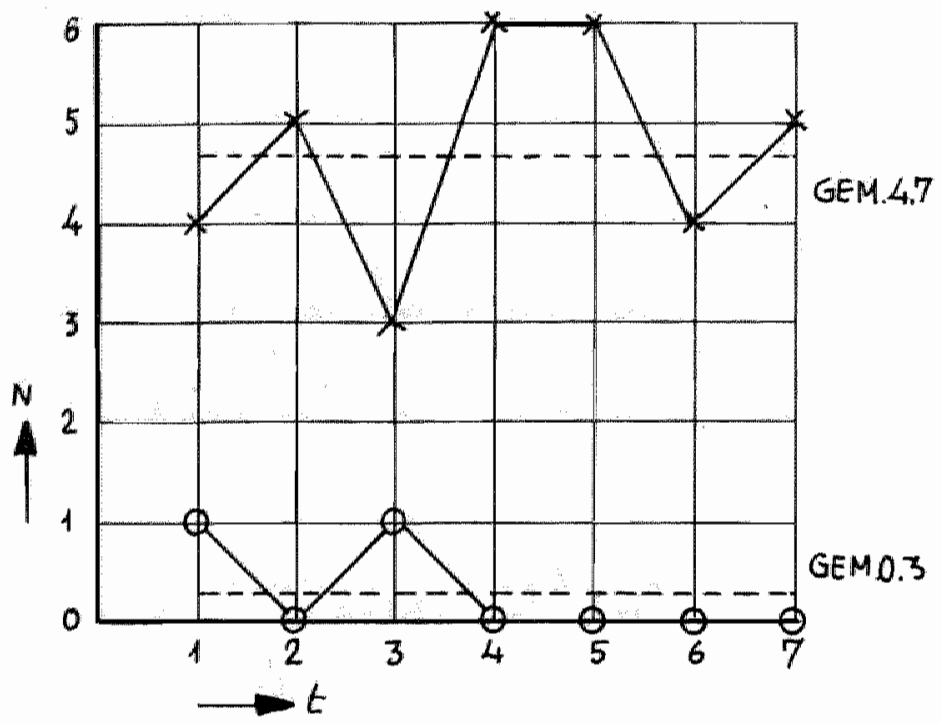

$i=$ tijd in dagen, gedurende observatieweek

$N=$ aamtal malen inkontinentie per etmaal;

6 observaties am de 4 uur

$x=$ voor behandelling

$a=$ na behandeling

(7) Procesassessment:

$\mathrm{P}=$ programmastappen

Afstand (A-B) (B-C) enz. op te vatten als verdeeld in percentages. Bereiken wan punt B wil zeggen $100 \%(=12 \times)$ suksesvol per etmat $1=$ tijd in weken

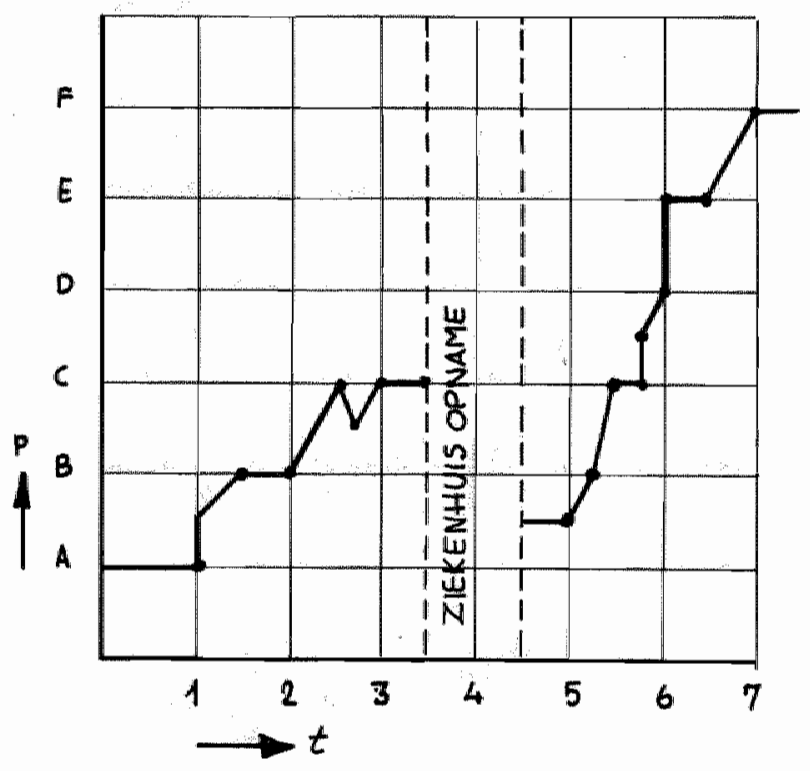


(8) Effektarsessment:

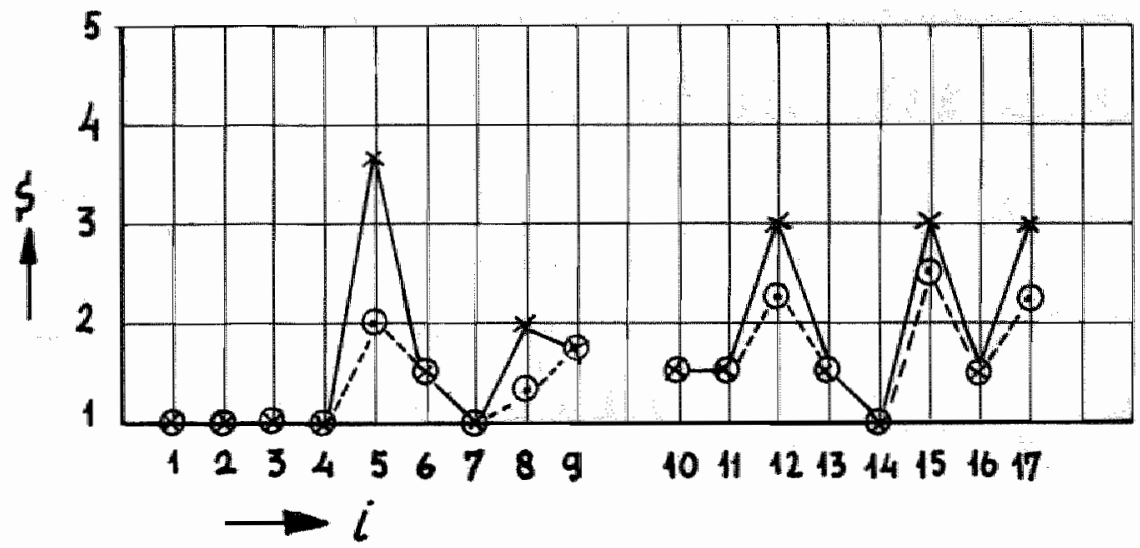

$x=$ voor behandeling

$0=$ na behandeling

$\mathrm{S}=\mathrm{GOCC}$-scores

$\mathrm{i}=\mathrm{GOCC}-\mathrm{item}$

psychologisch onderzoek niet mogelijk

(9) Resullaten:

(a) Afname van probleemgedrag (van 4.7 mal inkontinent per etmaal voór behandeling naar 0,3 matal per etmaal na behandeling): $(\sim 94 \%$ afname $)$.

(b) Procesalssessment: doelgedrag gereal iseerd in 7 weken.

(c) Alname van GOCC-score op observatie-item nr. 5 (onzelfstandig gedrag) (alleen afname of toename van $>1$ puntscore worden als betekenisvol gezien)

(d) Terugval na ziekenhuisopname, echter spoedig herstel op vroegere niveau na $11 / 2$ week training (zie procesassessment). 
(1) Patiengegevens:

- of 23 jadar

- Ijd Irama lot opname: 6 jaar, 8 manden (earst in diverse andere centra geweest)

- duir coma: onbekend

- silamcontusio en parese van de rechter lichamshellt van cerebrale aard

- ernstige geheugen- en concentratiestoornis. Na drie maanden geheugen- en concentratietraining werder geen verbeteringen in desbetreffende tests gekonstateerd. Dezer raining ging vooraf an de heronder behandelde gedragsvorming.

(2) Problegmgedrag. De signalering van het probleemgedrag vond ad hoc plats. Allerlei therapiecn werden door pitient niet bezocht en indien deze toch bezocht werden, dan kwam patient veel le lat. Op den duur werd hierin voorzien door patient door een verpleegkundige nat de therapieen te doen vergezellen. Bij verdere navraag ontstond de algemene indruk dat het hier ging om samengesteld probleemgedrag bestatande uit:

a. patient weet de weg niet in het centrum, kan zich deze ook niet inprenten.

b. patient vergeet op de tijd te letten en weet op een bepald tijdstip ook niet wat er op dat moment op het programma stat. Definitie probleemgedrag: Aantal malen nier op tijd op de juiste plats alanwezig zijn (zonder begeleiding). Plats en tijd werden voigens een konstant dagelijks schema wastgesteld: 9.15 utur zwembad: 10.15 uur afd. arbeidstherapie: 12. 15 uur verblijfsafdeling: 14.15 uur afd ergotherapie; 15.15 uur afd onderwijs: 16.15 uur verbliffisafdeling. Totad dus 6 kontrolemomenten en kontroleplatsen.

Voor en na behandeling werd gedurendle een week nagegata hoe grool de frekwentie was van aanwezigheid, .op juiste phats en op tijd".

(3) Dovelgedrag: Zonder hulp weten wat op een bepalal tijdstip wat betreft therapie moet gebeuren, nat betreffende plats gaan (met gebruk maken van lift, indien nodig) en op tijo ankomer.

(4) Behandelingplan: Dit viel witeren in twee onderdelen.

A. Trajekrbegeleiding. Er werden zes trajekten geselekteerd, die overeenkwamen met onder .probleengedrag" genoemde kontroleplatsen. Te weten: dagverbliff-zwembad; zwembad-arbeidstherapie; arbeidstherapie-dagverblijf; dagverblij-ergotherapie; ergotherapieonderwijs; onderwijs-dagverblijl. leder trajekt werd verwolgens onderverdeeld in 4 tot 6 onderting gelijke afstanden, wabbij zogenatame .herkenningspunten" wan te voren werden vastgesteld.

Als woorbeeld trajekt (a): van dagverblijf naar zwembad: herkemningspunten

- 6. lift idrukken op knop .,beneden”. Hiena zie je ..pilaren".)

- 5. plaren (na pilaren komt bocht walarna glazendeur).

- 4. glazendeur (na glazendeur kom musr, die twee rumten schedit).

- 3. muar: (voorbij de muur lïgt padium).

- 2. podum: (tegenover podium is middelste blauwe deur).

- 1. middelste blatue deur (geeft toegang rot het zwembad).

Training vond plats dlm. begeleiding watonder bij ieder herkennimgspunt verballe instruktie platstswond d.w.z. er werd geattendeerd op het herkenningspunt en gevratigd war patrent mata toe moest. De volgorde der begeleidingspunten verliep van 6-5-4-3-2-1. Nadat het trajekt op deze wijze onder begeleiding en verbale instruktie enige dagen was geofend, werd overgegatn op backward-fading. D.w.Z. de begeleiding vond niet meer plats van $6 \mathrm{~V} / \mathrm{m} 1$, matar van $6 \mathrm{~V} / \mathrm{m} 2$ (begeleidster stopt bij 2) en vervolgens van $6 \mathrm{t} / \mathrm{m} 3$, $6 \mathrm{~V} / \mathrm{m}, 6 \mathrm{~V} / \mathrm{ms}$.

Op deze wijze werd ieder trajekt dagelijks énmaal afgewerkt. M.a.w. er werden per dag 6 trajekten getraind.

B. Tijdsondersteuning: Herbij werd gebruik gemaakt van een .,parkeerwekkertie* en het inoefenen van een hepalde handelingssek wentic onder gebruik maken van een programmakatart. 
Handelingssekwentie:

- Patiẻnt kijkt op afdelingsklok

- Patientrit stelt wekkertje in om 8 uur, zodat het over ẻen uur afloopt

- Stopt wekker in rechterbroekzak

- Wekker loopt af orm 9 uut, patiènt kijkt op afdelingsklok, patiënt stelt wekker in zodat deze om 10.00 uur afloopt

- Stopt wekker in rechter broekzak

- Neemt kaarr uit linker borstzak

- Kijkt op kaart waar hij naar toe moet en stop kaart weer terug

- Gaat naar plaats van bestemming (in eerste instantie met begeleiding)

Backward-fading werd gerealiseerd door: instruktie op kaart te minimaliseren, kat wegnemen, wekker het laatste uur laten vervallen, geleidelijk de gehelle middág ten tenslotte volledig.

Als reinforcement werd een simpel kruisje gebruikt dat door de therapeut op een kart geplaatst wordt indien patiënt op het juiste moment op de juiste plaats" aanwezig was.

(5) Virbering: Deze werd volledig gerealiseerd door de begeleiding van éen psychologisch assistente, die telkens op het juiste moment aunwezig moest zijn. Tijdsondersteuning en trajektbegelleiding wonden direkt na elkaar plats. De gehele behandeling werd gereali. seerd in 5 weken.

(6) Problecmasueswment:

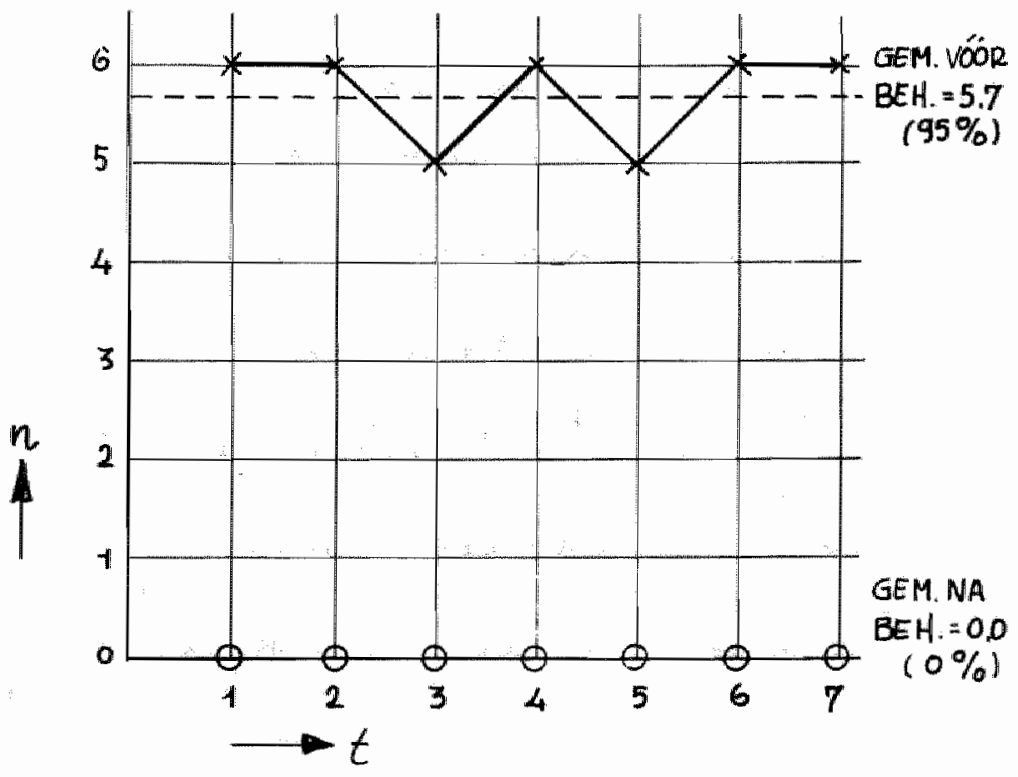

$\mathrm{n}=$ adntal malen niet op tijd op jüste plats

$t=$ lijd in dagen

$x=$ voór behandeling

$o=$ na behandeling. 
(7) Procesassesment: (voorbeeld trajekt a)

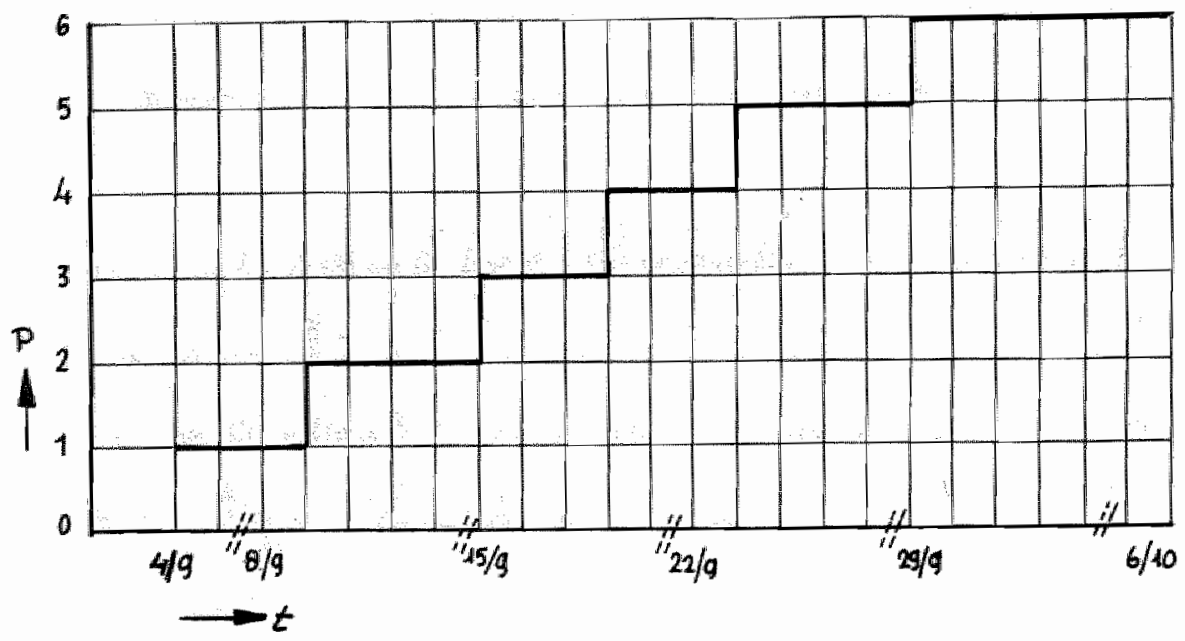

$p=$ programmastappen

(iedere stap werd $1 \times$ per dag geoefend)

$i=$ tijd in dagen

$v_{*}^{\prime \prime}=$ weekend-onderbreking

(voor de overige trajekten geldt eenzelfde soort grafiek)

(8) Effekrassessment:

$x=$ voor behandeling -

$o=$ na behandeling -

$\mathrm{s}=\mathrm{GOCC}$-score

$i=$ GOCC-item

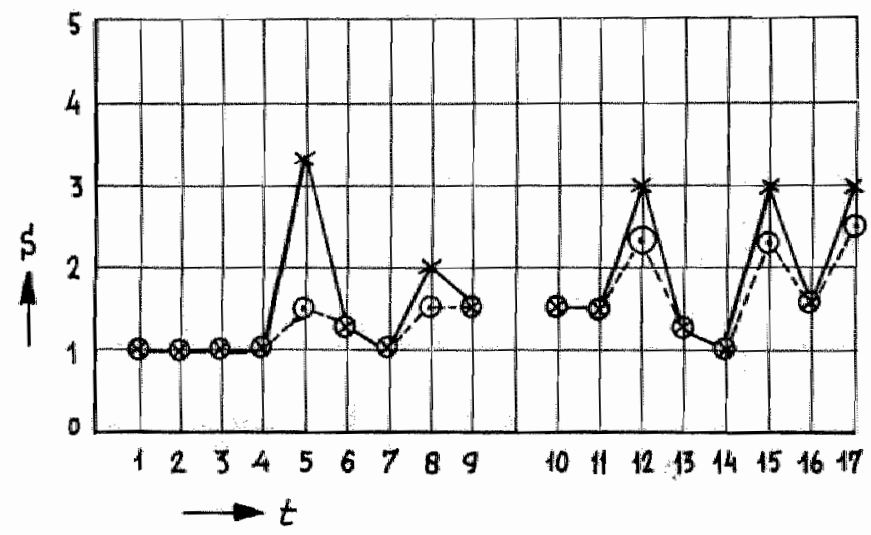

Geen verandering van scores op psychologisch onderzoek vóo en ma gedragsvorming (zie overzichtstabel bijlage 4)

(9) Resultaten:

(a) Afhame van probleemgedrag. Van 5,7 mad niet danwezig op juiste moment en plats vóo behandelimg tor 0,0 niet aanwezig na behandeling.

(b) Procesassessment: Doelgedrag van 6 trajektbegeleidingen en 6 tijdsondersteuningen gerealiseerd in 5 weken.

(c) Effektassessment: Afname der GOCC-scores op item nr. 5 (onzelfstandiggedrag). 


\subsubsection{Toename van gedrag}

\section{Patient Tra}

(1) Patiengegenens:

- O", 16 jaar

- tijd trauma tot opname rewalitatiecentrum: $11 \%$ matand

- duur coma: 5 maanden

- contusio cerebri en hemiplegie links

- moeilijk testbatar met psychologisch onderzoek mede in verband met sterke motorische stoornissen; spreekt zeer moeilijk en werkt traag: vermoedelijk geheugen-en concentratiestoornissen: $1 \mathrm{Q}$ weinig betrouwbar; volgens $G O C \mathrm{C}$ zijn er gedragsbelemmeringen.

(2) Probleemgedrag: De GOCC signaleerde o.a. gedragsbelemmeringen op het gebied van inaktiviteit en traagheid. Dit werd door diverse disciplines bevestigd. Vanuit fysotherapie en ergotherapie kwam de mening naar voren dat deze inaktiviteit en traagheid geen zuiver motorische basis zou hebben. Het probleemgedrag zou globaal gedefinieerd kunnen worden als het langzaam uitwoeren van een aantal handelingen, terwijl dat in principe sneller zou kunnen. Ter nadere definitie werden vijf aktiviteiten geselekteerd om de basislijin van het probleemgedrag te bepalen. Te weten: fysiotherapie; 40 meter lopen; verpleging: aankleden; sport en spel: 6 breedte banen zwemmen: onderwijs: cijfers leggen: logopedie: lezen van 50 tweelettergrepige woorden.

Vóór en na de behandelling werden de diverse handelingstijden beparald.

(3) Doelgedrag: Het werhogen wan het tempo op de wiff genoemde gebieden in die zin dat voor de strikt omschreven aktiviteiten minder tijid vereist zou gaan worden.

(4) Behandelingsplan: Na het vaststellen van de basislijn van het probleemgedrag (per aparte aktiviteit) werd door iedere discipline het eerste niveaw vastgesteld van watuit het doelgedrag benaderd zou worden. Dit beginniveau van het doelgedrag lag lager (d.w.z. minder tijd ter beschikking) in vergelijking met de basislijn wan het probleemgedrag. Indien patiënt het eerste doelniveau behaalde, verdiende hij per suksesvolle akliviteit één token en een verbale goedkeuring. Per week konden dus 25 tokens verdiend worden als alle aktiviteiten iedere dag eenmaal werden uitgevoerd. Indien patiënt 20 tokens per week verdiende betekende dit (als reinforcement) dat hij zijn loopsteunen mee naar huis mocht nemen om thuis te oefenen. (Dit bleek voor patient eem enorme bekrachtiging te zijn). Het doelniveau werd iedere week opnicuw bezien en lager gesteld. Het aantal vereiste tokens bleer gehandhaafd.

(5) Uimoering. Deze werd genealliseerd door vaste medewerkers wit 5 verschillende disciplines: fysiotherapie, verpleging, sport en spel, onderwijs en logopedie. De behandeling duurde 6 weken, waarbij dagelijks op 5 aktiviteiten werd geofend. Het bleek niet altijd mogelijk om iedere week het doelniveau te verlagen. Enerzijds bestond soms de indruk dat patient bepaalde aktiviteiten niet sneller kon uitvoeren. Anderszijds had men het idee dat patient werkte tot het minimum aantal tokens was verdiend en het daarna wel geloolde. Na drie weken werd besloten als eis te stellen dat patiënt alle tokens $(25)$ per week moest behalen. Een belangrijke vraag was; in hoeverre het op deze wijze verhoogde tempo ook zou generalliseren naar andere aktiviteiten.

Na 7 weken behandeling werd een week observatie ingelast zonder bekrachtigende kondities. Het tempo nam in deze week weer af, maar bereikte niet de basislin van het probleemgedrag. Hierna werd overwogen meer aktiviteiten ter tempobekrachtiging in thet programma te verdiskonteren. Een gesprek met familieleden thuis wees er ondertussen op. dat van die zijde weinig inzicht en medewerking te verwachten was. (Patiënt werd bijvoorbeell thuis met aankleden geholpen, terwijl hij dit in de kliniek zelfstandig wist te doen). Aangezien bovendien bekend was, dat patiënt binnen afzienbare tijd in een ziekenhuis zou worden opgenomen, werd wan verdere behandeling afgezien. 
(6) Problemassessment:

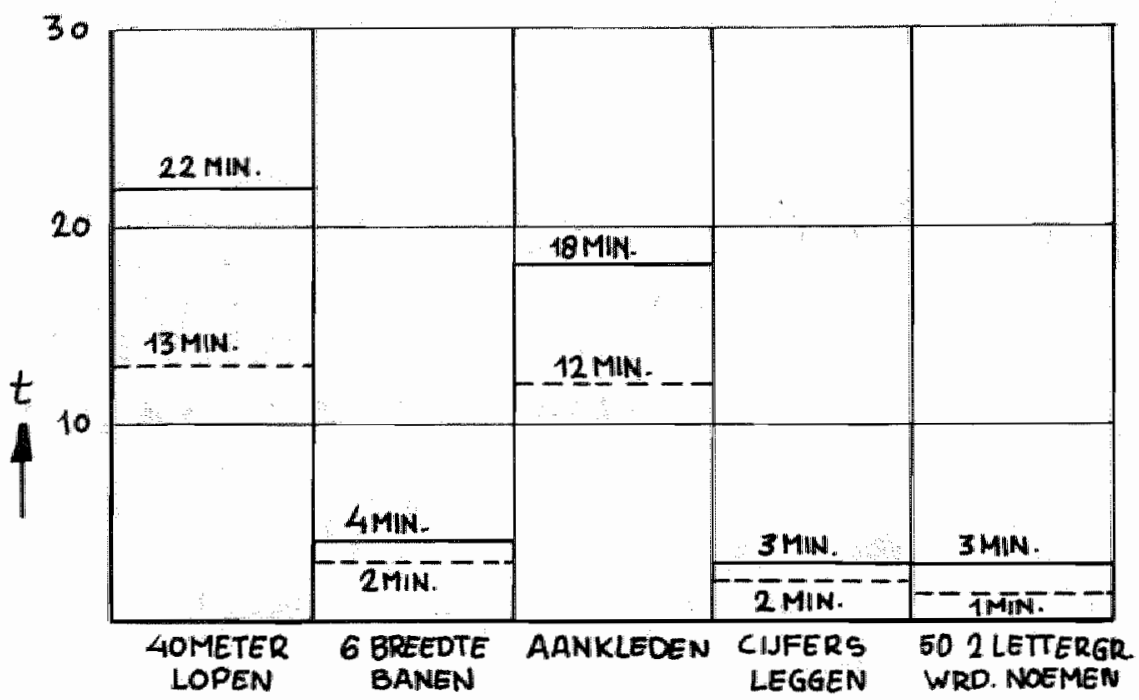

$1=$ benodigde tijd in minuten

De in kolommen geplaatste niveaus zijn gemiddelden van 3-5 metingen per week

- voor behandeling

- - na behandeling

(7) Procesassestment: (als voorbeeld logopedie, 50 tweelettergrepüge woorden noemen)

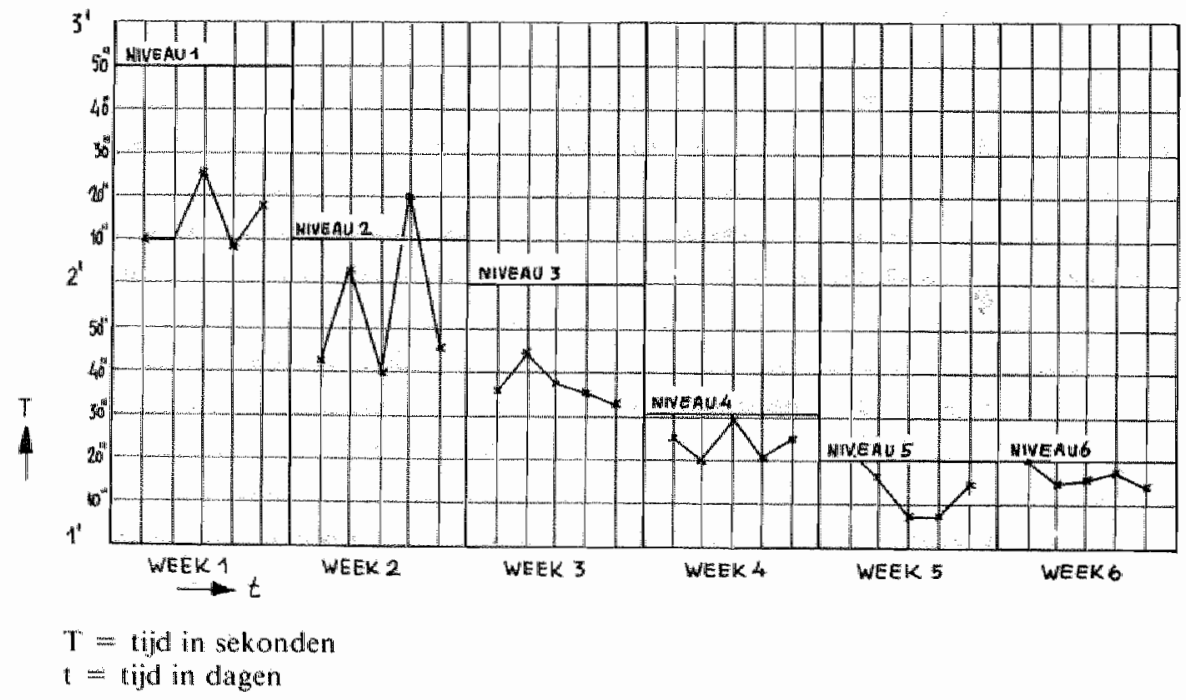




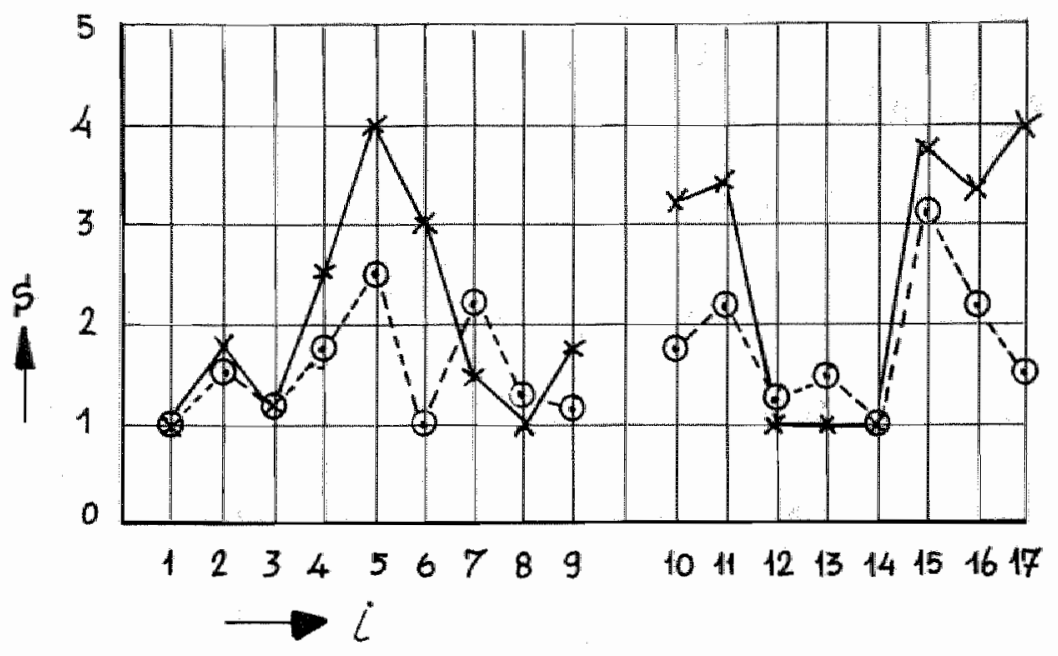

$$
\begin{aligned}
& \mathrm{i}=\mathrm{GOCC} \text {-item } \\
& \mathrm{s}=\mathrm{GOCC} \text {-score } \\
& \mathrm{x}=\text { voor behandeling } \\
& \mathrm{O}=\text { na behandeling }
\end{aligned}
$$

PO: geen of nauwelijks verandering in scores vór v.s. na behandeling (zie verzameltabel, bijlage 4)

\section{(9) Resulfatev:}

(a) Probleemassessment: Afname van benodigde tijd (tempoverhoging) voor alle aktiviteiten. Probleemassessment vond voor en behandeling plaats onder niet bekrachtigende kondities. Eindscore van de probleemassessment ligt echter hoger dan eindniveau der doelassessment. Algemene indruk bestond dat patiënt wèl sneller kon, indien hij hiertoe gestimuleerd werd ( $\pm 60 \%$ sneller).

(b) Procesassessment: Vrijwel alle aktiviteiten tonen een afname van benodigde tijd.

- 40 meter lopen van niveau 1 (op 16 minuten) natar niveau 4 (op 7 minuten)

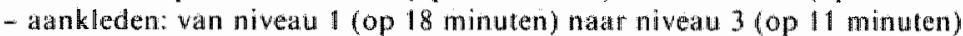

- 6 breedtebanen zwemmen: van basislijn op 4 minuten naar blijwend niveau wan 3 minuten - cijferleggen: van basislijn probleemgedrag op 3 minuten naar blijvend niveall van 2 minuten.

- 50 twee-lettergrepige woorden: van niweau 1 (op $\left.2^{\prime} 50^{\prime \prime}\right)$ naar nivea 6 (op $\left.1^{\circ} 20^{\prime \prime}\right)$.

(c) Effektassessment: Afname van 6 gedragsbelemmeringen nl. de observatie-items: 5-6-10-11-16 en 17 (resp. onzelfstandigheid, zich afzonderend, slordigheid, niet coopperatief, ongemotiweerd, gebrek atan zelfkritiek). 
(1) Patiëniggevent:

$-6,4$ jaur

- tija trauma tot opname in centrum: 6 weken

- duur coma: 10 dagen

- stamcontusio

- wolgens GOCC zjin er gedragsbelemmeringen; volgens PO zijn er hoordzakelijk concentratiestoornissen (zie effektassessment).

(2) Probleemgedrag. Patiènt is niet in staat langdurig met een bepalde opdracht bezig te zijn. De GOCC signaleerde met name on rustig, ontremd, gejaagd gedrag. Besloten werd geen aundacht te besteden aan het ontremde gedrag (in fieite hield dit dus reeds negatie in), maar het aksent te leggen op toename van .attentionspan" "m.a.w. hel langduriger bezig kunnen zijn met bepaalde aktiwteiten Dit betekent dus dat het zwartepunt der behandeling lag op toename van reeds bestaand gedrang en niet op de afname van probleemgedrag zoals bij de gedragsreduktic. Teneinde het probleemgedrag nader te specificeren werden per 4 disciplines (fysiotherapie, sport en spel, verpleging en ergotherapie) een aantal (5) spelaktiviteiten witgezocht als "balgooien" bij sport en spel "mens-erger-je niet" bij verpleging e.d. Uiteraard zal de interesse per spel, therapeut en situatie verschillend zijn. De basislijn werd wón de behandeling per discipline over dezelfde soorten spelaktiviteiten vastgesteld. Dit gebeurde eveneens na de behandeling.

(3) Doelgedrag: Toename van ,attentionspan" d.w.z. het langduriger bezig kunnen zijn met een bepalde aktiviteit.

(4) Behandelingsplam: ledere deelnemende discipline was per dag een half uur met patiënt bezig. In dit half uur werden de 5 (per discipline) geselekteerde spelaktiviteiten titgevoerd. Aangezien de basislijn per discipline verschillend lag werd het beginniveau van het doelgedrag per discipline apart bepaald op een halve minuut onder deze basislijn. Een elerwekker werd ingesteld op de tijdsspanne, waarin patiënt volgens het afgesproken doelniveau bezig moest blijven. Indien patiënt nog met het spel bezig was als de eierwekker alliep, volgde bekrachtiging in de vorm van snoep en aanhaling. Bij fallen werd geen bekrachtiging gegeven. ledere therapeut probeende de tijd in iedere volgende sessie telkens met een halve minuut op te voeren.

De doelassessment biestond uit de registratie van het percentage der aktiwiteüten dat patiènt gedurende de vastgestelde tijd had weten vol te houden.

(5) Uiwoering: Deze vond plaats in een relatief stimulusarme ruimte gedurende ca. 6 weken en wel ledere dag door leden van 4 a parte disciplines. Het plan leek in eerste instantie tot mislukken gedoemd, atugezien de bek rachtiging (snoep en lichamelijk kontakı) niet langer dan een week bleek te werken. Hierna werd echter overgega an op het gebruik van een .model" nl. een leeftijdsgenoot van patient. Dit bewerkstelligde uiteraard eveneens ", het samen kunnen spelen". Het model werd voor hat volhouden van het spel bek rachtigd door goedkeuring en als patient eveneens (zonder afleiding) had weten mee te spelen, volgde voor hem eveneens verbale goedkeuring. Na 2 weken werd overgegaan op "fading " $d . w . z$. de spelgenoot was als model niet meer anwezig. De therapeut nam de rol wan het "model" over en op deze wijze was de situatie gelijk aan de situatie in de eerste week.

Datrmee werd nog 2 weken voortgegaan warna onder afwezigheid van bekrachtiging werd bezien hoe lang patient nu met de desbetreffende aktiviteiten kon bezig zijn. 
(6) Probleemassessment:

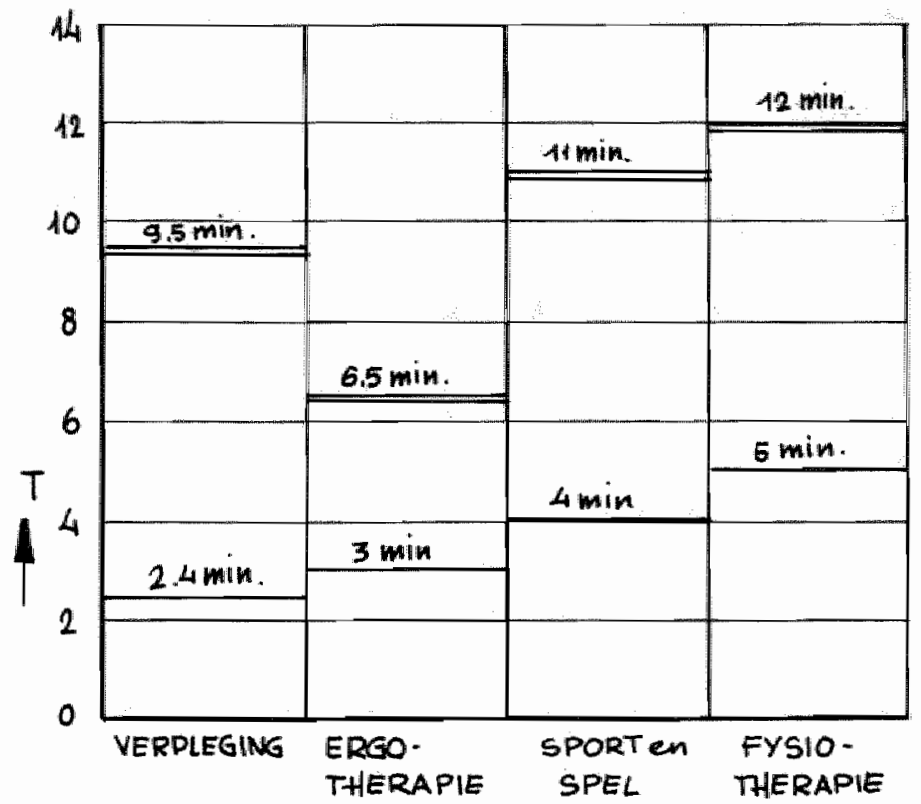

$T=$ attention span in minuten

- voor behandeing

$=$ na behandeling

De weergegeven niveaus zijn de gemiddelden wan 5 spelen genomen over 4 observatiedagen. (d.w.z. per discipline 20 spelaktiviteiten)

(7) Procesassessment: (geillustreerd aan behandelingsbijdrage door verpleegkundigen)

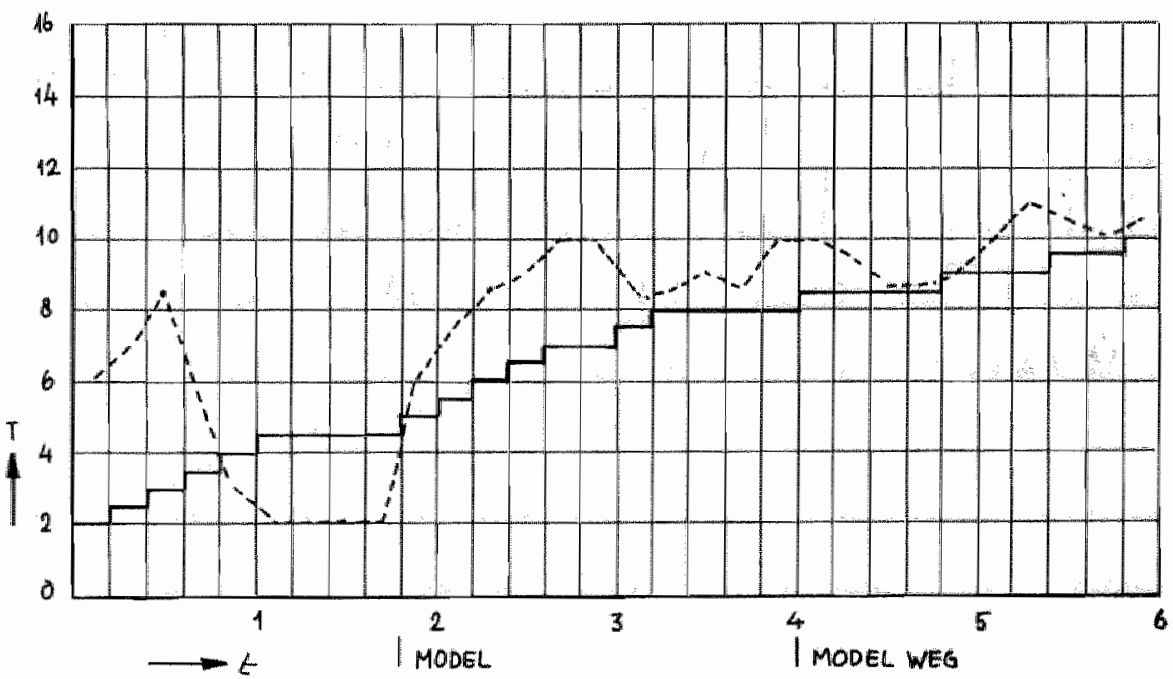

$T=$ attention span in minuten

$t=$ tijd in weken

. = doelniveau (verhoging)

.$--=$ gemiddelde attention span per $1 / 2$ uur training genomen over 5 spellen 


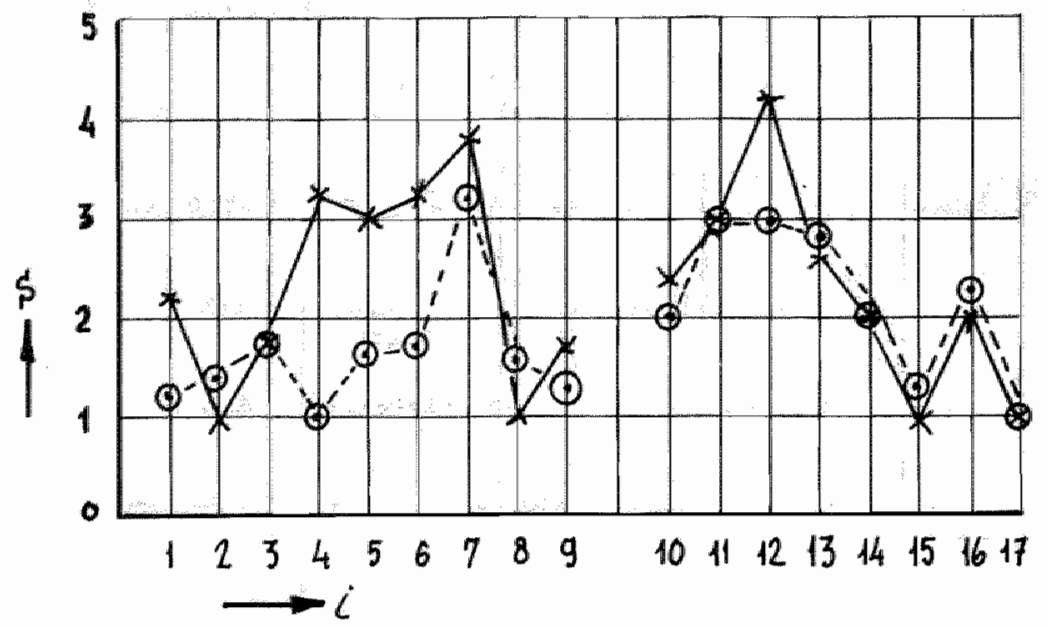

$\mathrm{GOCC}$

$\mathrm{s}=\mathrm{GOCC}$-score

$i=\mathrm{GOCC}$-item

$x=$ voor behandeling

$o=$ na behandeling

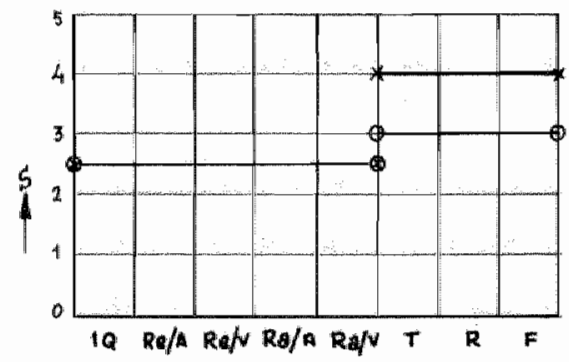

Psychologisch onderzoek PO

VOOR BEHAND $s=\mathrm{PO}$-score (in punt-score) $\| Q=$ intelligentiequotiènt NA BEHAND. $\mathrm{Re} / \mathrm{A}=$ Recognitie-auditief $\mathrm{Re} / \mathrm{V}=$ Recognitie-visueel $\operatorname{Ra} / A=$ Recall-auditief $\mathrm{Ra} / \mathrm{V}=\mathrm{Recall}$-visueel $\mathrm{T}=\operatorname{tempo}$

$\mathbb{R}=$ regelmadt

$F=$ fouten

(9) Resulfaten:

(a) Probleemassessment: Toename van attention span woor aktiviteiten met alle disciplines.

(b) Procesassessment: Verhoging van doelniveau kon voor hedere discipline in geplande tijd gerealiseetd worden. All grafieken tonen een wrijwel overeenkomstig beeld, d. w.z. een "dip" in tweede week, stijging bij inschakeling van model en stabilisering nat afwezigheid van model.

(c) Effektassessment: GOCC-afname op punten 4, 5,6,12 (resp. klagen, onzelfstandigheid, zich afzonderend, ontustig ontremd gedrag). PO enige verbetering van concentratie-items (tempo, regelmad, flouten). 
(1) Pariènigegevens:

- 9.4 jarar

- tijd trauma tot opname revalidatiecentrum: 2/2 maand

- durr coma: onbekend

- contusio cerebri

- geen psychologisch onderzoek mogelijk door motorische stoornissen en probleomgedrag. GOCC op 6 punten $\geq 3$

(2) Probleemgedrag: per dag moet patiënte verscheidene alstanden afleggen. Ze doet dit kruipend, terwijl het lopend zou kunnen. Als ze lopen moet, zeurt en huilt ze en valt neer. Door dat zeuren, builen en neervallen zijn fysiotherapic-oefeningen onmogelijk. Besloten werd de gedragingen, die gedragsvorming tegenwerkten volkomen te negeren, en het aksent te leggen op toeneming van het lopen, dat wel in het gedragsrepertoir aamwezig was. Als probleemgedrag, werd genomen het aantal malen dat ze tijdens een behandelingssessic van staande houding (gesteund door therapent) over wilde gaan op kruipen. Dit werd nagegaan wöór en na de gedragsmodifikatie.

(3) Doelgedrag: Patiente moet zelfstandig kunnen lopen met hulp wan een rollator. Dit kriterium was volgens fysiotherapie haalbaar en werd als doelgedrag gesteld.

(4) Behandelingsplan:

(a) Selektieve reinforcement bij iedere volgehouden looppoging onder negatie van niet-coöperatief gedrag (zeuren, op de grond vallen e.d.). Bekrachtiging moest direkt en snel zijn, daarom werd afgesproken dat zodra patiënte een eerste wankelend pasje zou zetten er onmiddellijk reinforcement zou komen. Bekrachtiging hield in; snoepje geven en lichamelijk kontakt (d.w.z. even aanhalen). Vooral in het begin leek dit nogal wat moeite op te leveren: stapje, snoepje, twee stapjes, snoepje enz. enz. De negatie hield in dat men patiënte ter plekke op de grond liet liggen, terwijl de therapeut zich verwijderde en pas weer aanstalte tol benadering toonde als patiente probeerde op te staan.

(b) Successieve aproximatie van het doelgedrag "Iopen met rollator". Er werden 4 betrekkelijk korte afstanden geselekteerd die door drie disciplines iedere dag getraind werden.

Verpleging: van kamer nat toilet en terug, van kinderkamer naat eetkamer en terug.

Fysiotherapie: van kamer naar oefenkamer (op dezelfde ardeling) en terug.

Ergotherapie: van kamer naar ergotherapiekamer en terug.

De aproximatiestappen:

le week: lopen met vasthouden van twee handen door therapeut die vóór patiènt loopt.

2e week: lopen met alleen vasthouden van rechterarm.

3e week: lopen met vasthouden van de linkerarm.

4e week: lopen met rollator, beide banden atan de handgrepen vasthouden, terwijl de rollator mee naar voren wordt gettrokken door therapeut.

Se week: Alleen de linkerhand wordt door therapeut vastgehouden, terwijl de rollat tor door therapeut mee natr woren wordt getrokken.

6e week: patiente houdt rollator wast, therapeut trekt rollator vooruit.

7 week: patiente duwt zelf rollator en loopt.

(5) Virvering: De diverse approximatie-stappen over de vier genoemde afstanden werden dagelijks door drie disciplines driemaal getraind ( 5 dagen per week). Hierbij werden nogal problemen ondervonden door het gedrag dat gedragsvorming tegen werkte. Het gebeurde vooral dat patiente zich op de grond liet vallen als ze tijdens de oefeningen op een plats $k$ wam walar meer of andere personen (dan therapeut) haar konden zien. Met name de route naar ergotherapie werd hierdoor werstoord. In een dergelijk geval werd afgesproken, dat therapeut patiënte zonder kommentaar zou oppakken, naar afdeling ergotherapie zou dragen en haar daar weer neerzetten. Tijdens de uitvoering ontwikkelde zich ook sttottergedrag". Dit gaf aanleiding tot diverse kritieken, die neerkwamen op eem te 
enerverend zijn wan de behandeling voor patiente. Het stottergedrag verdween echter toen ook dit werd genegeerd.

Deze kritiek werd met name geuit door personen, die meenden dat men spontane groe:, rijping of ontwikkeling diende af" te wachten en zeker niet moest proberen de zaak te forceren. Aangezien patiente reeds ca. 4 maanden in het centrum aanwezig was, waarbij voortdurend voorzichtig gepirobeerd was siets" te bereiken, werd van verder afwachten afgezien.

Kortom: een niet eenvovdige behandeling, die door allerlej kommentaar extra beladen en bemoetlijkt werd. Bovendien moest de behandeling 3 weken onderbroken worden, doordat patiente mazelen kreeg.

(6) Problecmassessmen: Geen kwantitatieve bepaling van frekwentie van voorkomen van het probleemgedrag per dag over een week. Mondelinge verslaggeving: neiging tot kruipen of vallen kwam voor de behandeling in $75-90 \%$ der looppogingen voor, na de behandeling kw wam dit niet meer voor.

Afname $100 \%$

(7) Procesassessment:
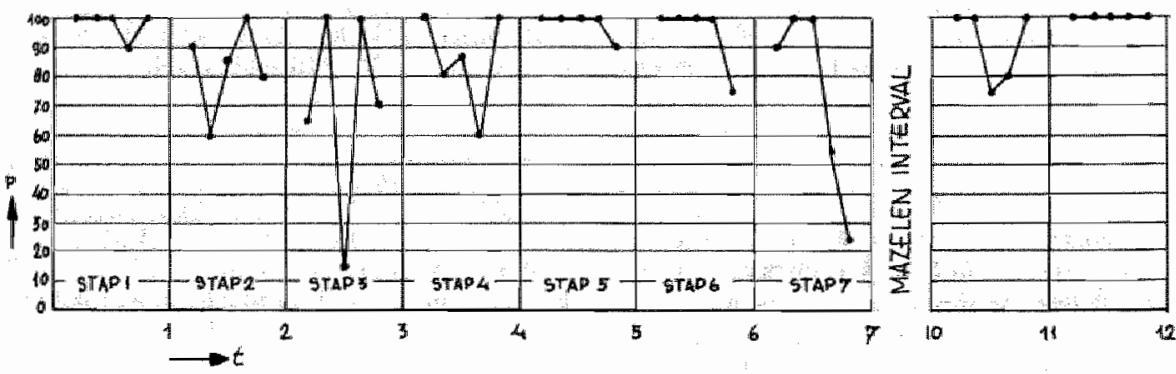

$t=t i j d$ in weken

$\mathbb{P}^{\prime}=$ percentage succesvolle trials per dag (maximaal $9 x$ per dag).

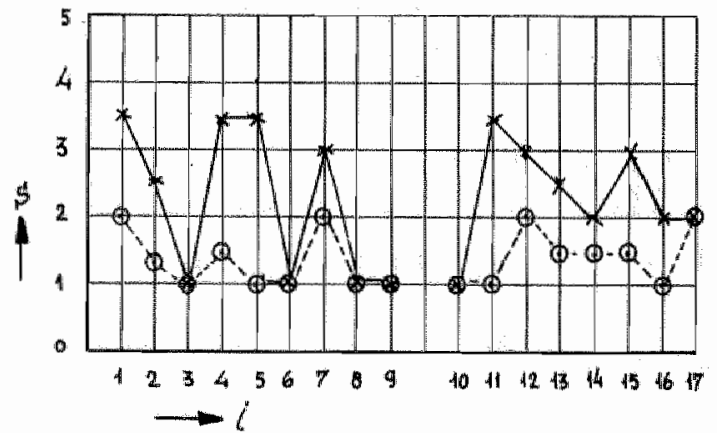

(8) Effectassessment:

$s=$ GOCC-score

$i=$ GOCC-items

$\mathrm{x}=$ voor behandeling

$o=$ nat behandeling.

PO: niet mogelijk voor en na behandeling (zie verzameltabel, bijlage 4)

(9) Resulraten:

(a) Probleemassessment: afname van probleemgedrag in de orde van grootte van 100 "y

(b) Procesassessment: ondanks vele bezwarende omstandigheden werd doelgedrag in 7 stappen gerealiseerd. Totale duur der behandeling bedroeg mede door ziekte wan patiente 13 weken.

(c) Effektassessment: 10 van de 17 observatie-items tonen afname van meer dan eán puntscore. Sterke afname van 4, 5 en 11 (resp. klagen, onzelfstandig en niet-coopperatief gedrag) 


\subsubsection{Gedragsreduktie}

\section{Pavient R-1}

(1) Patrentgegevens:

- 9.20 jaar

- duur trauma tot opname: 6 maanden

- duur coma: 2 maanden

- stamcontusio, hemiparese rechts, dysarthrie

- niet testbaar, verscheidene gedragsbelemmeringen.

(2) Probleemgedrag: Uit GOCC blijkt dat bij voortduring aanwezig blift: inaktiviteit, ongemotiveerdheid, zich afzonderend gedrag. niet coopperatief, gebrek an zelfkritiek, onzelfstandigheid.

Patiënte wordt door het thuismilieu beschreven alls zeer moeilijk opvoedbaar en niet coöperatief.

Nadere definiëring: Bij opdracht eerst niets zeggen, weigeren en bij aandringen verbale agressie (schelden). Ter bepaling van frekwentie van woorkomen werd woór en na de behandeling ieder eerste kwartier van elk wur vastgesteld of en hoe valak het niet-coopperatieve gedrag optrad.

(3) Doelgedrag: Reduktie van niet-coöperatief gedrag (zoals gedefinieerd in de GOCC), opdracht uitvoeren zonder protest.

(4) Behandelingsplan:

le. Het probleemgedrag modificeren door onthouding wan bekrachtiging (atandacht) bij niet-coöperatief gedrag en het geven van bekrachtiging bij coöperatief gedrag.

2e. Het geleidelijk aan werhogen van allerlei eisen, die door de omgeving aan patiènte kunnen worden gesteld eveneens door gebruik te maken wan bekrachtiging.

3e. Bektachtiging vindt in eerste instantie plaats door $\mathrm{zg}$ sociale bekrachtiging. Dit geschiedt op basis van een kontinu bekrachtigingsschema. Geleidelijk atan wordt overgegaan op andere vormen van bekrachtiging op intermitterende basis.

4e. Het ondernemen van generalisatiepogingen. Patiënte diende niet slechts coöpcratief te reageren op het direkte behandelend personeel, maar eveneens op het gedrag van andere personeelsleden en patiënten.

(5) Uitwering:-(Stap 1) Aangezien het probleemgedrag intermitterend werd bekrachtigd werd overgegaan tot "relatief isolement" d.w.z. isolering van patiënt op een éenpersoonskamer. Om her half uur werd patiente bezocht door een der lleden van thet behandelingsteam (dat ondertussen uit 15 personen bestond). Jeder wan hen presenteerde bij binnenkomst de diskriminatieve stimulus (opdracht, opmerking, kritick), Indien patiênte darop probleemgedrag manifesteerde werd direkt (zonder agressiel vertoon) de kamer verllaten. Indien patiënte de opdracht of kritiek aanvardde werd dit "beloond" met een kort gesprek ền een token.

N.B. Van the voren was aan patiënte de doelstelling uitgelegd, ongeveer alls volgt: "We vinden dat je je niet zo leuk gedraagt to.v. andere mensen, we willen je helpen anders te worden. Dat doen we op de volgende manier..."

(Stap 2) De eisen die alan patiènte gesteld werden, geraakten geleidelijk aan op een complexer of hoger niveau. In eerste instantie waren deze gericht op het bewerkstelligen van enige zelfverzorging, maar geleidelijk aan $k$ wam het onderhoud van de kamer erbij, inclusief allerlei laken die door onderwijs, arbeids- en bezigheidtherapie konden worden verstrekt.

(Stap 3) Sociale bekrachtiging werd op een gegeven moment wervangen door tokens, die op het eind der dag ingewisseld konden worden woor persoonlijk a antrekkelijke goederen of gebeurtenissen. Het kontinu bekrachtigingsschema maakte plaats voor een regelmatig en tenslotte een onregematig intermitterend bekrachtigingsschema.

(Stap 4) Eerst had patiënte alleen kontakt met de therapeuten in haar kamer. Geleidelijk. 
aan werd dit zowel qua aktieradius als ook qua werscheidenheid aan ,kontaktpersonen" uitgebreid. Als afsluiting van de behandeling volgde cen periode waarin patiente volledig bepalde wat zill zou gaan doen (afgezien van vaste therapieer ed.), de systematisch geplande bekrachiging bleef achterwege. Eveneens werd in deze periode de eindassess mert van hel probleemgedrag ondernomen.

(6) Problecmassessmen:

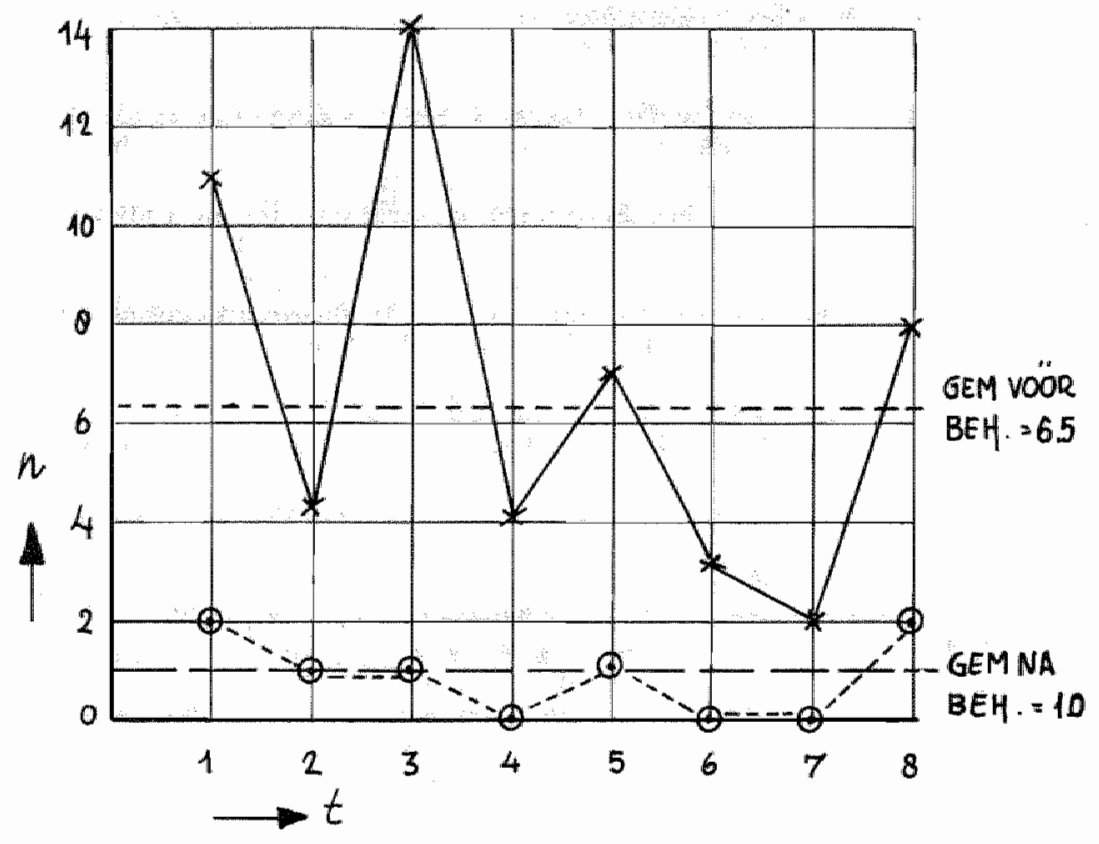

$\mathrm{n}=$ aantal malen probleemgedrag gesommeerd over 15 observatiekwartieren per dag

$t=$ tijd in dagem

$x=$ voor behandeling

$0=$ ma behandeling 
(7) Procesassessmen:

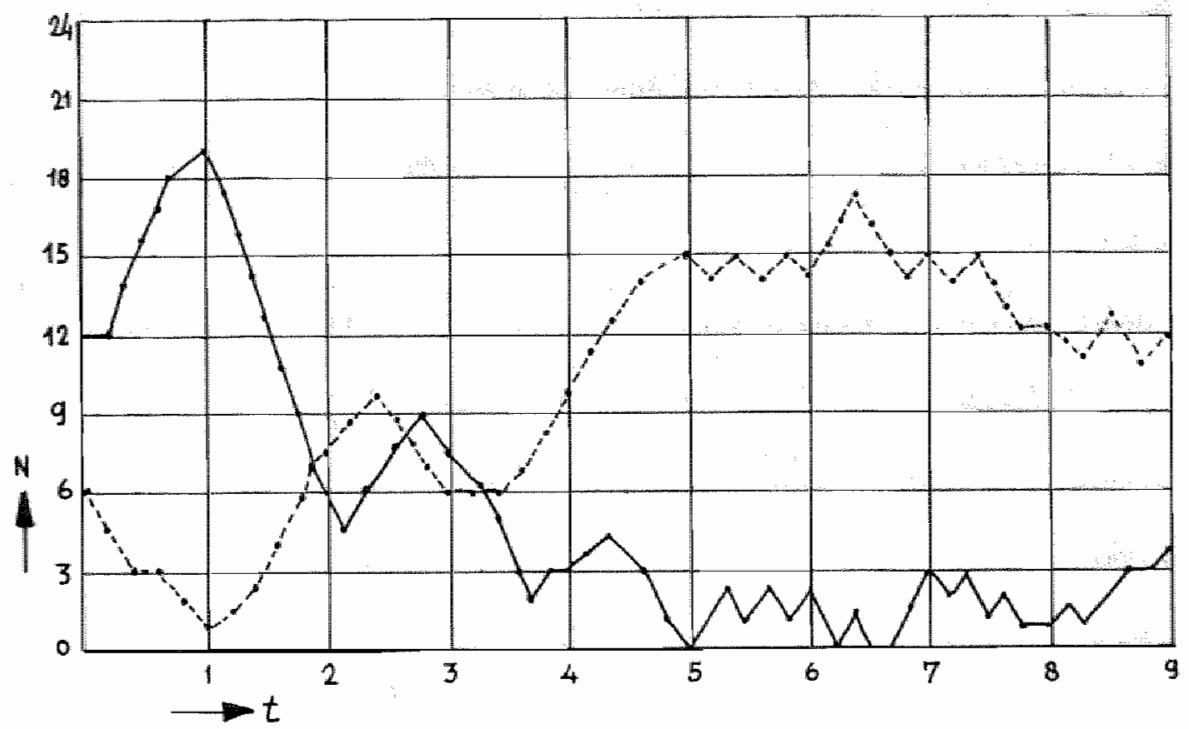

$n=$ aantal malen probleem, resp. aangepast gedrag over 28 kontakten per dag

$t=$ tijd in weken

- $=$ probleemgedrag

..... = aungepast gedrag

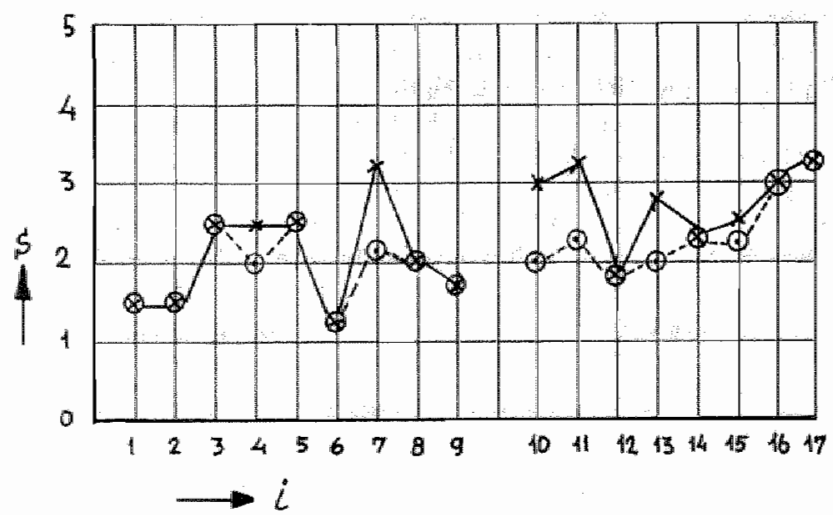

(8) Effektarsessment:

$s=\mathrm{GOCC}-\mathrm{score}$

$\mathrm{i}=\mathrm{GOCC}$-item

$x$ = voor behandeling

$0=$ na behandeling

$\mathrm{PO}$ : niet testbar (zie verzameltabel, bijlage 4)

19) Reshaten:

(a) Probleemassessment: Afname wan 6,5 natar 1,0 als gemiddelde wan 15 observatiek wartieren per dag, genomen over een week $( \pm 80 \%)$ :

(b) Procesassessment: andame probleemgedrag gerealiseerd in ca. 7 weken relatief isolement. Aangepast gedrag nam toe.

(c) Effektassessment: afname wan meer dan én puntscore op de items 7, 10 en 11 (resp. opdringerig gedrag, slordigheid, niet coöperatief). 
(1) Pariĕngegevens:

- Q, 20 jaar

- ijol trama tot opname revalidatiecentrum: 3 jaar en 9 maanden

- duur coma: 2 maanden

- stamcontusio

- gedragsproblemen volgens GOCC, geheugen- en concentratiestoornissen, intelligentie onder het geniddelde.

(2) Probleemgedrag; patiênte zou vroeger kleptomanie vertoond hebben. In het centrum werd deze kleptomanie geleidelijk an meer manifest. Tegelijkentijd hiermee presenteerde zich op de GOCC niet-cooperatief gedrag. De moeilikheid hierbij was dat (de frekwentie of intensiteit van) het kleptomane gedrag uiteraard niet 20 eenvoudig vast te stellen was. Patiente had direkt in de gaten als ze geobserveend werd en verdween dan.

Het was wel (enigszins) mogelijk de frekwentie van het niet-coöperatieve gedrag vast te stellen. Geteld werd het aantal malen dat een verzoek of opdracht werd geweigerd.

(3) Doelgedrag:

(a) Afname van niet-coöperatief gedrag, loename van akseptatie en uitvoering van opdrachten.

(b) Ten anzien van het kleptomane gedrang was het moeilijk het doelgedrag meetbaar vast te stellen. Als mogelijk doelgedrag werd geformuleerd thet ., onbelangrijk gaan vinden " wan de objekten waarvan werd aangenomen dat patiënte deze veelvuldig bijandere patienten wegnam. Dit waren voomamelijk sigaretten, snoep en koftie.

(4) Behandelingsplan: Aangezien het kleptomane gecrag volgens allerlei mededelingen vrï grote vormen aannam, was het niet goed mogelijk pattënte vrij te laten rondlopen. Met toestemming van har ouders werd patiènte onder relatief isolement gesteld.

(a) Het niet-coöperatief ged rag werd in het behandelingsplan betrokken doordat ieder hall uur een medewerker de kamer binnen ging. Patiënte kreeg dan een nieuwe opdracht waarvan de moeilijkheidsgraad geleidelijk aan werd verhoogd. Indien deze opdracht zonder kommentaar werd uitgevoerd, dan gold langer sociaal kontakt als bekrachtiging. Later zou dit vervangen worden door tokens, waarvoor patiente bepaalde genoegens of privileges kon "kopen". Bij niet-coôperatief gedrag werd de kamer direkt verlaten.

(b) Het onbelangrijk gaan vinden van snoep, sigaretten, koffie werd getracht te real liseren door deze goederen in werkelijk ongelimiteerde hoeveetheid in de kamer aanwezig te doen zijn. Er werd echter wel wan patiente verwacht, dat ze op een lijst zou aangeven hoeveel zij wan de desbetreffende artikelen geconsumeerd had. Deze consumptie werd (buiten de kamer van patiënte) eveneens bijgehouden door de verpleging. Indien het aantal door patiente aungegeven artikelen overeenkwam met het aantal dat door de verpleging werd gethoteerd, dan betekende dit voor patiente extra sociale bekrachtiging en/or tokens. Gehoopt werd dat hierdoor de patiente op den duur de consumptieartikelen op zich wat minder betangrijk zou gatan winden wn meer warde zou gaan hechten aan weerlijk" gedrag. dat werd bekrachtigd.

(5) Uinoering: Het niet-coopperatieve gedrag verdween vrijwel onmiddellijk. Moeilijkheden werchen echter ondervonden in de juiste vermelding wan de geconsumeerde artikelen. Het getal dat pationte angaf bleek steeds ver onder het getal te liggen dat de verpleging had aangegeven. In verband mel gekonstateerde geheugenstoornissen was het niet duidelijk in hoeverme dit verschil mede bepald werd door deze defekten. Er bleek een duidelijke afname te konstateren in de hoeveetheid snoepgebruik, echter de consumptie van siguretten en koftie ging gewoon verder. Tegelijkertijd manifesteerde zich onder medewerkers protest tegen zogenaamd manipuleren van mensen, hersenspoeling en dehumanisatie. Dit werd extra geaksentueerd doordat patiente op verzoek van een therapeut een opsitel had gemaak $\iota$, waturin met name concepten als "eenzaamheid", ,opsluiting" e.d. naar voren bleken te komen. Aangezien het niet-cooperatieve gedrag was argenomen en men zich 
geleideligk aan ging afvragen of de kleptomanie destijds wel inderdaad aanwezig was geweest, was er weinig reden om het zo zwaar beladen relatieve isolement nog langer te laten voortduren. Patiënte werd derhalve abrupt wederom bewegingsvrijheid teruggegeven. Dit betekende echter dat de frek wente bemoeien is met haar ook teneinde was, er werd geen of nauwelijks meer sociale bekrachtiging gegewen en snoep, sigaretten en koffie waren niet meer ongelimiteerd toegankelijk. Opnieuw manifesteerde zich diverse probleemgedragingen (zie effektassessment in verzameltabel, bijlage 4). Verwijzingen naar psychiatrische centra werden well overwogen, maar bleken - vermoedelijk door har dubbele handicap - niet te realliseren.

(9) Resultaten:

(a) Probleenassessment: werd vanwege abrupte beëindiging van het programma niet gerealiseerd.

(b) Procesassessment: Afname van niet-coöperatief gedrag binnen én week. Wegens onwoldoende definitie van en kontrole op "kleptomaangedrag" is hierover geen evaluatie mogelijk.

(c) Eftektassessment: (zie werzameltabel, bijlage 4): Heropleving van probleemgedrag in dezelfde en andere vormen.

Algeneen: totaal echèc. 
(1) Paheratgegeven:

$-\infty " 15$ jadar

- lijd trama tot opname revalidatiecentrum: 3 Ha mand

- duur coma: $5 / 2$ week

- stamcontusio en hemiplegie rechis

- redeljke intellgentie, enige geheugenstoornissen, mar voornamelijk concentratiestoornissen. Behoorlijke gedragsproblenaliek volgens GOCC.

(2) Probleemgedrag. Na herhadde GOCC-observatie bleek de meest hoge score (en subjektief meest hinderlike gedrag het zgn. .kleven" te zijn. D.w.z. frekwent aandacht vragen walutoriteiten anklampen" om vragen ie stellen watbij dan nogal veel moeite werd ondervonden om het onderhoud af te breken.

Dit probleemgedrag was tamelijk eenwoudig te objektiveren en te kwantificeren. Gedurende het eerste $k$ wartier van ieder uur werd gezorgd dat een observator zich in de buurt van patïnt bevond; waarbij deze naging hoe frekwent pateent het woord richtte tot een personeelshid. Deze observatie werd gedurende 5 dagen wóor en na de behandeling uitgevoerd (15 observatiek wartieren per dag).

(3) Doelgedrag: Aframe van "vrager stellend gedrag aan autoriteit" en toename van de ijd waran geen wragen gesteld worden. Nadere specifikatie: patiểnt moet in statat zijn vragenstellend gedrag 3 uur na te laten.

(4) Behandeling: Poging to beĭnvloeding van het , kleefgedrag" op basis van kontraktmanagement. Deze patiènt R-3 werd dus niet onder relatief isolement gesteld, matar wel bijzonder naw wlettend geobserweerd. Met de patient werd argesproken dat hij aan het eind van ieder uur 5 minuten de gellegenteid kreeg tot vragen stellen. Was hij het overige deel van het uur in slat geweest aan het werk te blijven zonder informaties te stellen, dan werd dit. bekrachtigd met een token. Bij een bepactd aantal kon an het eind der week inrailing platats vinden voor een meer specifieke bekrachiging. Het personeel van het behandelingsteam negeerde het kleefgedrag tijdens de afgesproken "nietwraagmeriode" door gewoon door te lopen (ook dit was aan patiènt meegedeeld). Tijdens de 5 minuten vraagperiode mocht het behandelingsteam antwoord geven, maar in elk geval kreeg patient ma 55 suksesvolle minuten zijn token en een kompliment. De niet-vaag-periode zou in vier niveaus omhoog gebracht worden tot het doelgedrag wan 3 uren was bereikt. Gesprekken met patiënten vielen uiteraard buiten het kriterium.

(5) Virvoung: Tijdens de behandeling werden geen problemen ondervonden. Patient kon overal vrij rondlopen. Er werd konsekwent genegeerd en bekrachtigd. Duur van do behanduling: 4 weken. Per dag werd patient gedurende zijn therapie-uren (5 uur per dag) geobserveerd. 
6) Probleemassessment:

$\mathrm{n}=$ aantal malen probleemgedrag (kleven) gesommeerd over 15 observatiek wartieren (per dag)

$1=$ tijd in dagen

$x$ = vó́r behandeling

o. = na behandeling

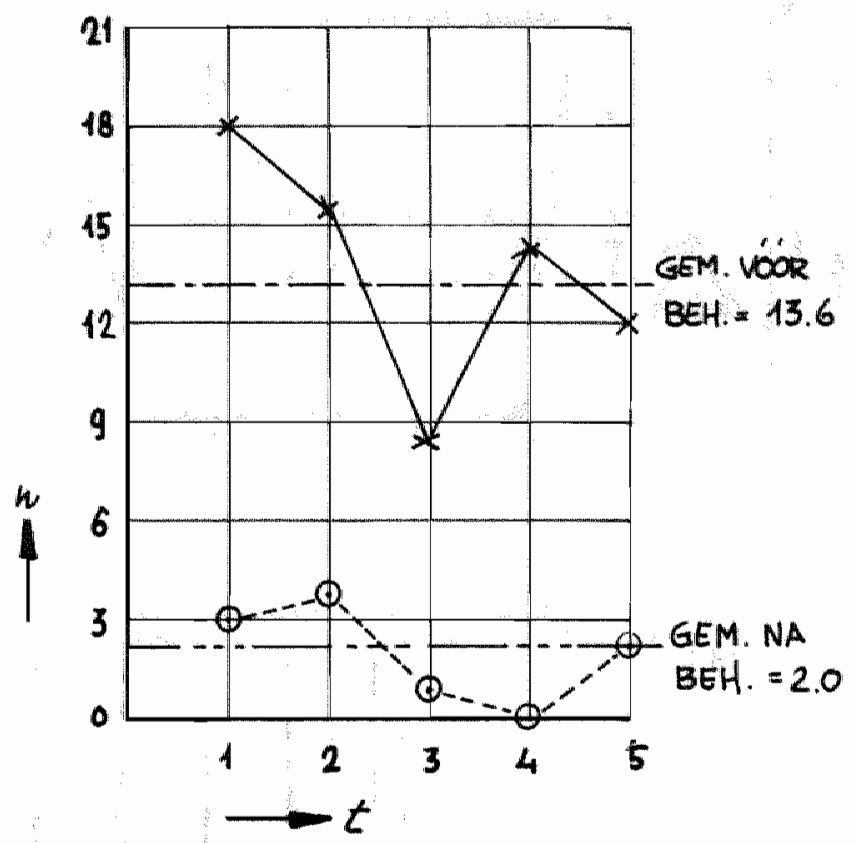

(7) Procesassessment:

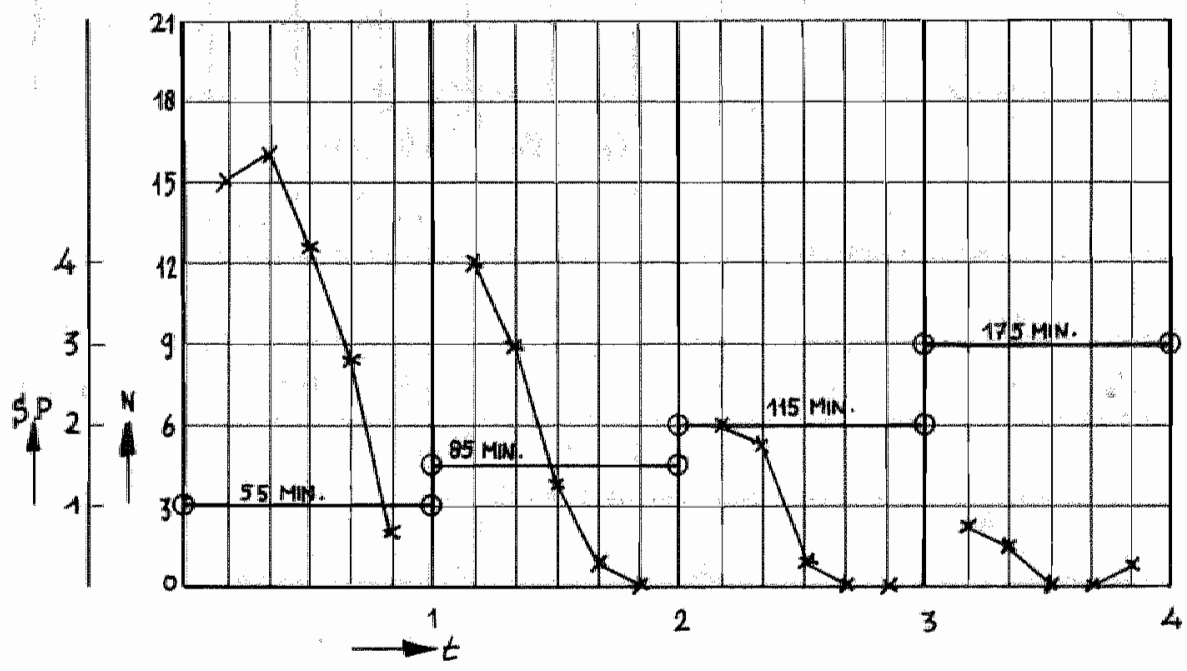

$1=t i j d$ in weken

$n=$ antal probleemgedrag $(x)$ gesommeerd over $S$ uren observatie per dag

$x=$ vragen gesteld in "verboden" periode

$0=$ niveau ,stille" periode

$s p=$ stille periode in uren 
(8) Effekrassessment:

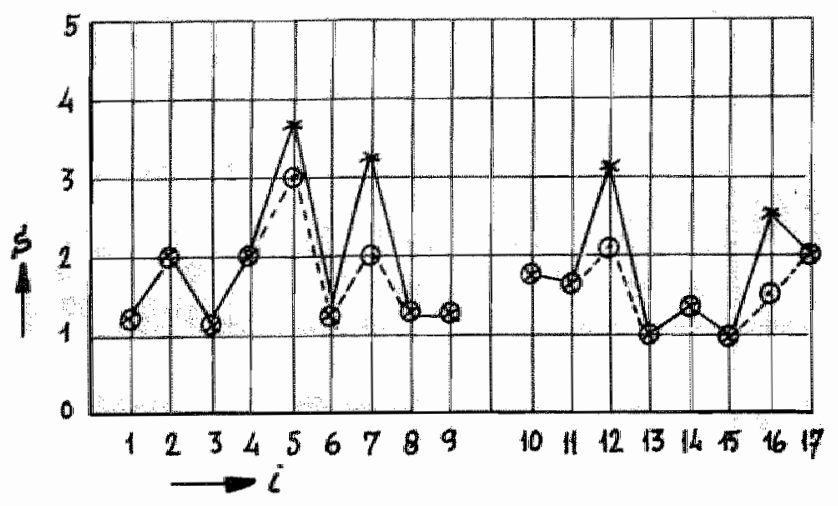

$$
\begin{aligned}
& i=\text { GOCC-ltem } \\
& s=\text { GOCC-score } \\
& x=\text { yoor behandeling } \\
& o=\text { na bethandeling }
\end{aligned}
$$
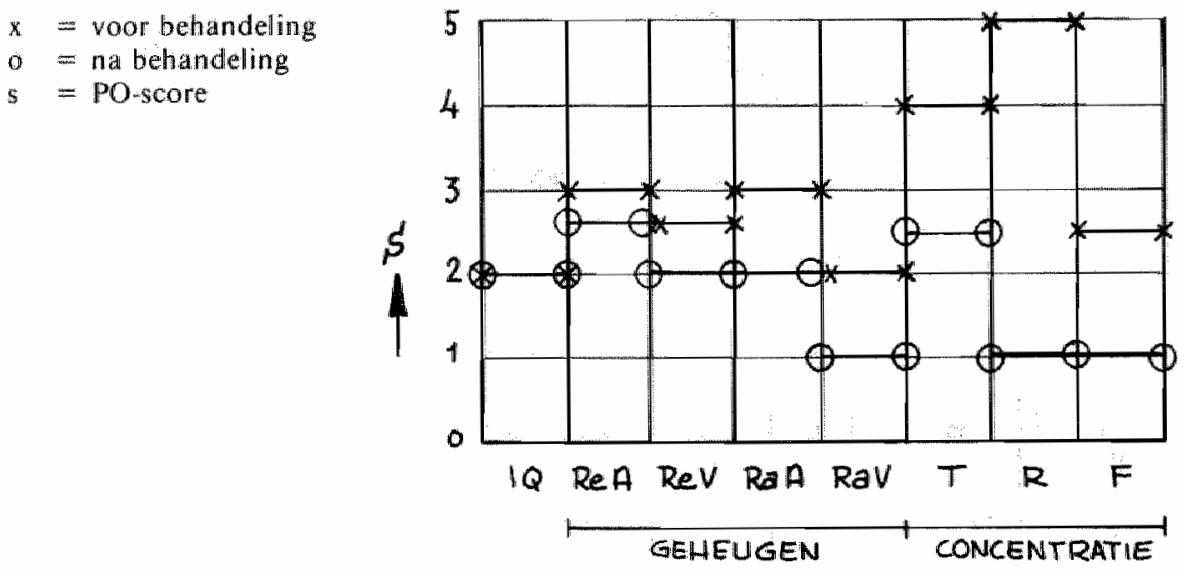

(9) Resullaten:

(a) Probleemgedrag: afname van 13,6 mas aandacht vragen aan , autoriteiten" (verpleeg. kundigen, therapeuten e.d.) alls gemiddelde over 15 observatiek wartieren per dag naar 2,0 $( \pm 85(1)$.

(b) Procesassessment: doelgedrag gerealiseerd in 4 weken.

(c) Ellektassessment:

GOCC: afname wan eérpuntscore op de items 5, 7, 12 en 16 (resp. onzelfstandigheid, zich opdringend gedrag, on rustig ontremd gedrag en ongenotiveerdheid).

PO: afhame van éen puntscore op geheugen (recall auditief en visueel) en concentratie (tempo, regelmat en fouten). 
(1) Patientgegenens:

- O", 3 jaar en 7 maknden

- tijd trauma tot opname revalidatiecentrum: 6 weken

- duur coma: 6 weken

- stamcontusio

- psychologisch onderzoek: gemiddeide intelligentie, geen witgesproken geheugenstoorn issen, enigsins verminderde concentratie GOCC: enige gedragsbelemmeringen.

(2) Probleemgedrag: Signalering van problemgedrag vord ad hoc plaats door ouders diverse therapeuten en verpleegk undigen. Het bestond wit weglopen van patient tijdens wandel in gen buiten het therapiegebouw en het ouderlijk huis. Dit leverde viteraard aanzienlijke problemen op, aangezien patiènt geen aandacht besteedde aan het verkeer. Het probleemgedrag werd door ouders en therapeuten kontinu bekrachtigd angezien deze bij dit weglopen patiênt eerst probeerden te roepen en hem vervolgens achterna liepen. Voor patiënt werd het een aantrekkelijk spelletje, echter met niet te onderschatten gevaren.

Objektivering van probleemgedrag: Het aantal malen dat patient wegliepen niet reageerde op "kom terug" gesteld over een vol uur wandelen met patiënt. Dit werd voór en na de behandeling vastgesteld.

(3) Doelgedrag: Afname van "wegloop-gedrag" en toename van "terugkom-gedrag" na opdracht hiertoe.

(4) Behandelingsplan:

Fase 1: Een uur wandelen per dag, waarbij patiënt in een soort tuigje liep. Patient mocht vrij rondlopen maar als de afstand tot de begeleider te groot werd (meer dan 10 meter) werd "kom terug" geroepen. Er werd gekeken of dal gebeurde en zo niet, dan werd patiênt teruggehaald. Indien patiënt na de opdracht terugk wam, ontwing hij sociale bekrachtiging en een snoepje. Fase 1 voltrok zich in de buurt van het rewalidatiecentrum en duunde ongeveer éen week.

Fase 2: Een uur wandelen per dag, waarbij tuigje ontbrak. Als patient zich meer dan 10 meter uit de buurt van begeleidster bevond werd énmaal "kom terug " geroepen. Deed hij dit dan volgde bekrachtiging. Deed hij dit niet, dan ging de therapeut weg en keek niet meer naar patiënt om. Therapeut liep naar binnen en bleef wanuit, niet voor patient zichtbare, plek naar patiënt kijken. Duur fase 2 ca. 3 weken.

Fase 3: Een uur wandelen in het weekend thuis, zonder tuigje echter in gevaarloze rustige omgeving. Bij weglopen reageerden de ouders overeenkomstig de therapeuten in fase 2 (twee weekenden en wel het voorlatste en het laatste weekend varu fase 2).

Fase 4: Identiek aan fase 3 echter in wat drukkere ongeving.

Fase 5: Afbouw d.m.v. intermitterende bekrachtiging.

N.B. De ouders werden in hun aktiviteiten begeleid door een non-professional, die als model voor de ouders fungeerde en op de hoogte was van de gedragstherapeutische principes.

(5) Vitvoering: De fasen werden volgens plan afgewerkt. Er traden geen buitensporige moeilijkheden op. De overdracht naar de thuissituatie was éèn der eerste pogingen om te werken met een non professional. Dat bleek sukseswol. 
(6) Problecmassessment:

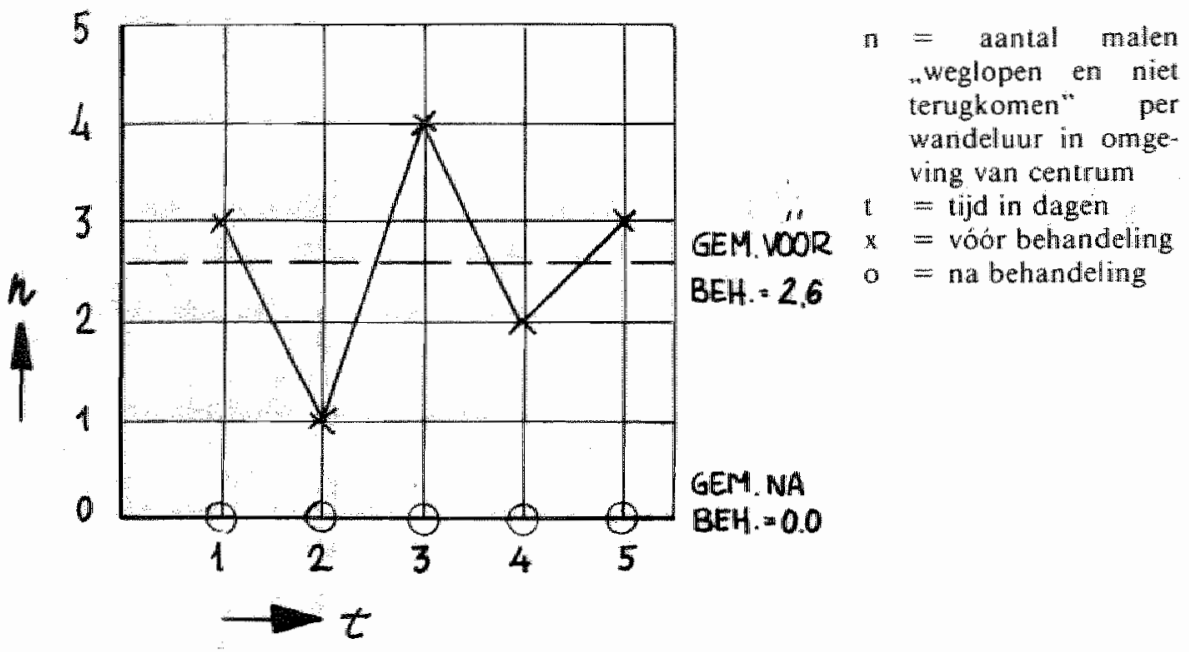

(7) Procesasseswint:

Werd niet uitgevoerd echter de fasen konden in de geplande volgorde en tijdsdur worden afgewerkt.

(8) Effektassessmen:

$\mathrm{i}=\mathrm{GOCC}$-item

$\mathrm{s}=\mathrm{GOCC}$-score

$x=$ voor behandeling

$o=$ na behandeling

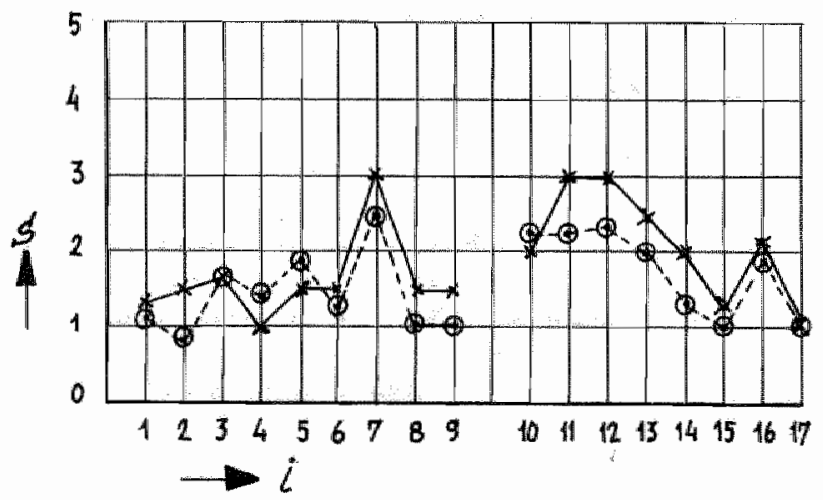

PO geen voor- of achteruitgang in psychologisch onderzoek (zie verzameltabell, bijlage 4)

(9) Resultaren:

(a) Probleemassessment: Afname van probleemgedrag van gem. 26 naar 0 (100\%)

(b) Procesassessment: Doelgedrag bimnen voorgenomen tijd gerealiseerd.

(c) Efektassessment: Geen afinames wan énpuntsscore warneembar.

Enige vermindering op GOCC-items 2, 7, 11, 12 en 14.

Enige toename op GOCC.items 4 en 5. 
1) Parientgegentens:

$-\sigma^{2}, \| 2$ ja ar

- Vijd trauma tot opname revalidatiecentrum: 4 maanden en 24 dagen

- duur coma: 4 malanden

- contusio cerebri

- psychologisch onderzoek: intelligentie onder het gemiddelde, ernstige geheugenstoornissen en concentratiestoornissen. Op meer GOCC-observatio-items hoge scores.

(2) Probleemgedrag: Ad hoc signalering. Er werden met name vanuit de verpleegkundige sektor diverse gedragsproblemen gesignaleerd zoals: bemoeizucht, agressiviteit inaktiviteilt, niet coöperatief, bemoeit zich storend met personen, stompen en slaan van andere kinderen. GOCC-observatie (zie effektassessment) ondersteunde deze gegevens.

Uit deze varieteit aan probleengedragingen werd "hinderlijk" gedrag geselekteerd, gedefinieerd als: (a). Het aantal malen per dag, geobserveerd ieder eerste kwartier van elk uwr, dat patient zich met woorden richt tegen personen die met iets bexig zijn met het doel dit te verstoren. (b). Het aantal malen dat patient met anderen begint te vechten wederom geobserveerd over 15 observatiek wartieren per dag.

(3) Doelgedrag: A frame van whinderlijk gedrag" zoals gedefinieerd. Toename van (x): Het zich niet bemoeien met twee personen, mar (zelstandig) alleen verder door spelen of lopen. (y): Aantal malen dat patiènt zich, zonder te vechten, bezighoudt met leeftijdsgenoten.

(4) Behandelingsplan: Aangezien patiënt de oudste was op een kinderafdeling en hierdoor o.a. moest aanzien dat de meeste aandacht naar jongere kinderen uitging, werd gemeend dat gemis aan aandacht mede een rol zou kunnen spelen in zijn gedrag. Vamuit de veronderstelling dat het hinderlijke gedrag een middel was on meer aandacht te krijgen werd hij na een observatieweek overgeplaatst natr een affdeling voor volwassenen, watr aam een ieder ongeveer evenveel aandacht wordt besteed.

$\mathrm{Na}$ een acclimatisatieperiode van 2 weken zou een nieuwe observatie komen.

(5) Uifvering. Deze vond plaats zoals in behandelplan genoend: 1 week probleem observatie (frekwentie) - 2 weken op wolwassen afdeling - 1 week probleenfrekwentie obserwatie op volwassenaldeling.

(6) Probleemassessment

$n=$ aantal malen prom bleengedrag over 15 observatiekwartieren per dag

$\mathfrak{t}=$ ijd in dagen

$x=$ vốr overplaatsing

$0=$ na overplaatsing

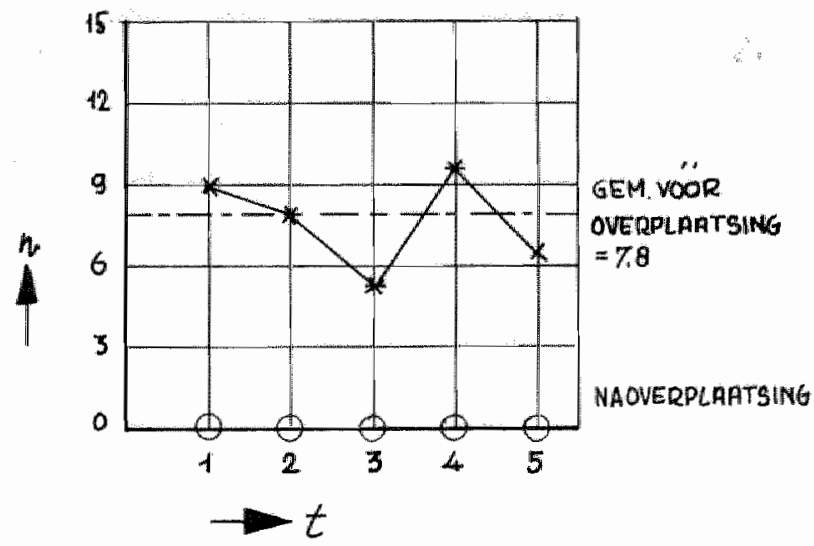


(7) Procesastessmen:

Niet uitgevoerd. Dit werd als tamelijk overbodig gezien, daar het (vooropige) plan alleen bestond wit overplatsing naar een andere afdeling d.w.z. in concreto het wegnemen vam de veronderstelde diskrminatieve stimulus.

(8) Effehassessmen

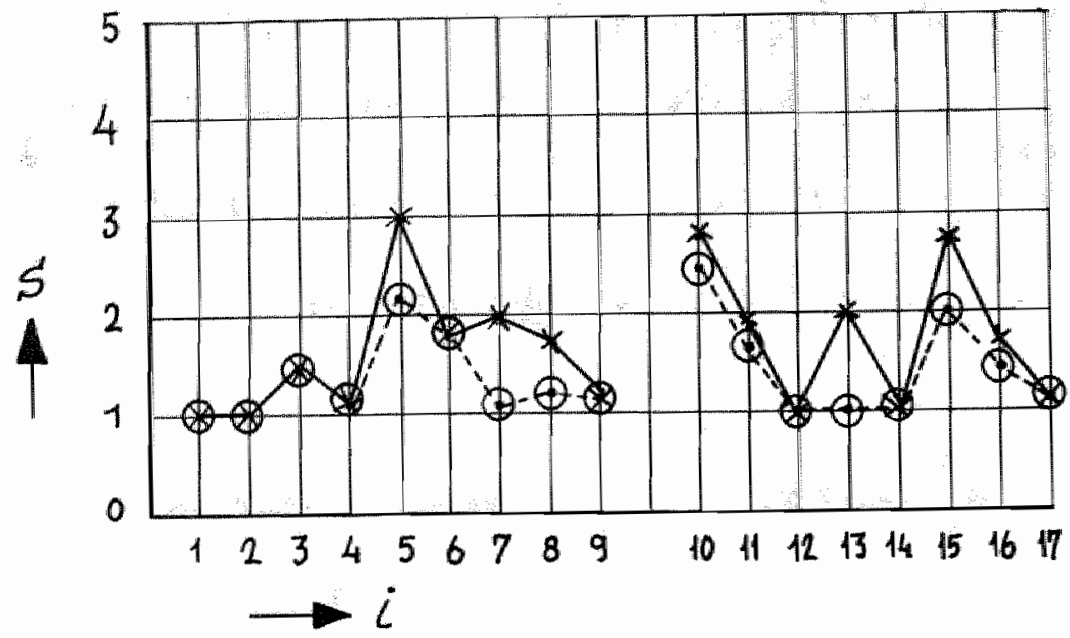

$$
\begin{aligned}
& i=\text { GOCC-item } \\
& s=\text { GOCC-score } \\
& x=\text { voor behandeling } \\
& 0=\text { na behandeling }
\end{aligned}
$$

PO geen veranderingen (zie verzameltabel, bijhage 4)

(9) Resullaren:

(a) Probleemassessment: Na overplaatsing nam probleemgedrag af tot 0 (100\%)

(b) Procesassessment: doelgedrag niet gekontrollerd. Er werd gelet op het probleemgedrag en mier op de toename van ander (incompatibel gedrag). Een en ander is niet verwonderlijk angezun men in een setting als een revalidatiecentrum al biti is wanneer alles een beetje rustig en soepel verloopt.

(c) Efektassesment: Aframe van éenpuntscore op 7 en 13 (resp. opdringerig en agressief gedrag).

Algemeen: Afname van probleemgedrag na wegname van de veronderstelde diskriminatieve stimulus. Of hierdoor meer sociaal gedrag gestimuleerd of angeleerd is kunnen worden, werd niet magegan. 
(1) Patienngegewens:

$-0,52$ jaar

- tijd trauma tot opname revalidatiecentrum: onbekend

- duur coma: onbekend

- contusio cerebri

- op 3 kriteria der GOCC vrij hoge scores. Psychologisch onderzoek: gemiddelde intelligentie, nawwelijks geheugen- en concentratiestoornissen.

(2) Problemgedrag: Een der revalidatiedoeleinden voor deze patiënte was het leren lopen met een ...wierpoot". Tijdens de training toonde patiènte de neiging om te vallen, warmee zij steeds tijdige opvang van de fysiotherapeut stimuleerde. Fysiotherapeutisch werd patiente echter wel in staat geacht dit lopen met vierpoot te realiseren.

Ook op de gangen en in hel dagverblijf manifesteerde zich hetzelfde gedrag. Patiente liet zich dan tegen de muur aanvallen - zo was althans de opvatting - en de betrefiende verpleegkundige haastte zich om haar op te wangen. Als probleemgedrag werd op advies der fysiotherapie geselekteerd "het aantal opvangpassen nat $\|$ inks, rechts en achter" dat patiënte uitvoerde teneinde haar balans weer te herkrijgen over een afstand van 250 meter (heen en terug).

Gedurende een week voór en na de behandeling werd ieder eerste kwartier van elk uur dit aantal opvangstappen vastgesteld.

(3) Doelgedrag: Het kunnen lopen van 250 meter theen en terug zonder opvangstappen.

(4) Behandelplam: Het negeren wan de walneigingen, zonder pogingen te ondernemen om patiënte op te vangen en bovendien zell's zonder enige notitiename van de ararzelende opvangpassen. Daarentegen zou getracht worden het normalle lopen regelmatig met belangstelling en warderende woorden te bekrachtigen. Als twee parallel lopende programma"s werden ontworpen:

a. fysiotherapie: looptraining gedurende 14 dagen, iedere dag $2 \times 10 \mathrm{~min}$. In deze 10 minuten zou patiënte de afstand van 250 meter moeten afleggen zowel heen als terug. De fysiotherapeut zou hierbij naast haar lopen, maar niet ingrijpen bij valneiging daarentegen wèl het aantal opvangpassen tellen.

b. Verpleegkunde: gedurende dezelfde 14 dagen zou eenmal in leder hall uur gekeken worden of patiènte zich verplaatste. Gedurende $10 \mathrm{~m}$ inuten zou de verpleegkundige naast of in de buurt van patiënte gaan lopen. $\mathrm{Zij}$ zou op geen enkele wijze reageren op valneigingen, maar haar darentegen wel bemoedigen als patiënte zich minstens 20 meter zonder valneigingen had voortbewogen. Ook door haar werd het antal opvangpassen gescoord.

(5) Uiwwering: Bij verpleging manifesteende zich de eerste dagen een sterke toename wan valneigingen. Het was uitermate moeilijk niet te reageren op de verwijten, het steunen en klagen van patiënte. Van werkelijk vallen was echter nimmer sprake. Degrafiek toonde een duidelijke afname na enkele dagen. Fystotherapie begon 4 dagen nadat de verpleging was begonnen. Hier toonde zich geen toename wan valneigingen, maar een gestage afname tot uiting komend in vermindering wan het aantal opvangpassen. Na 2 weken was de behandeling voltooid. 
(6) Probleenassessment:

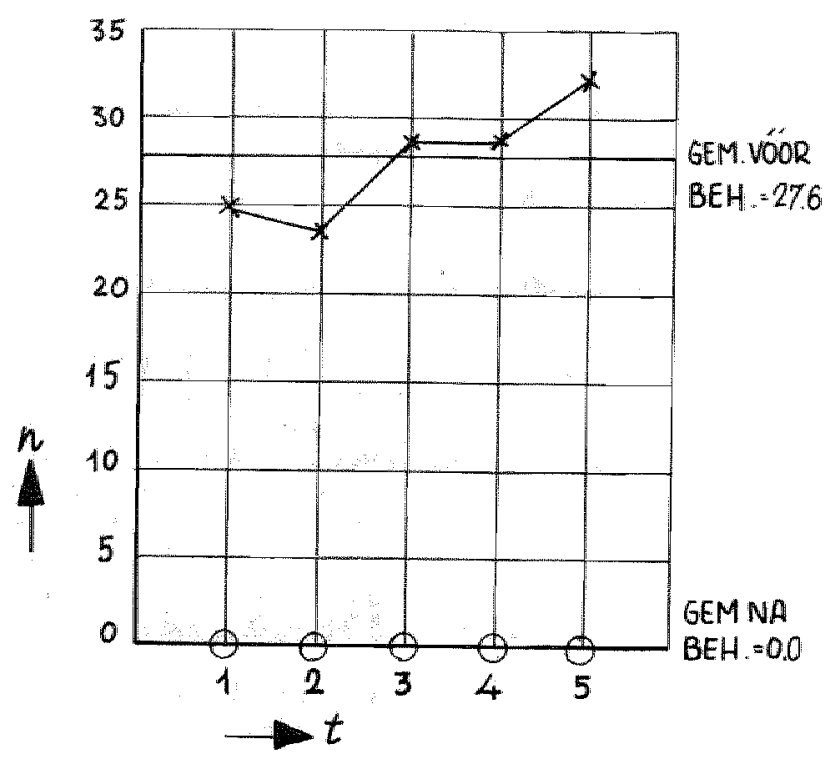

$n=$ aartal op vangstappen, geobserveerd ower 15 observatiekwartieren per dag en wel over cen lengte van ca. 250 meter

N.B. Patiente werd in deze obserwatiek wartieren slechts gemiddeld $4 \times$ lopende aangetroffen

1 tijd in dagen

$x$ - voór behandeling

$o=$ na behandeling:

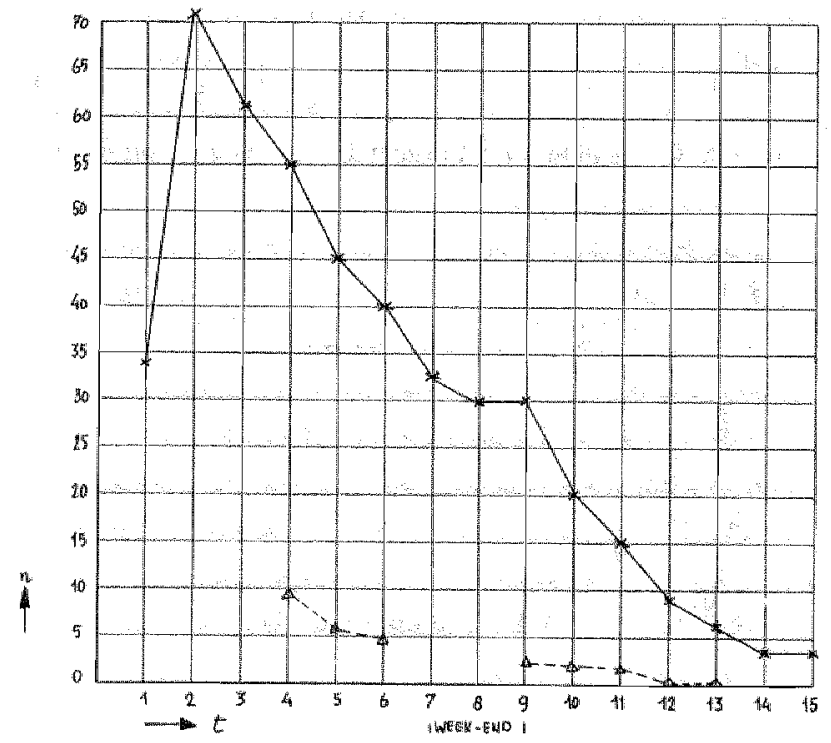

(7) Procesassessment:

i. = tijd in dagen

$n=$ aantal opvangstappen

$x$ = aantal opvangstappen per 10 observatieminuten, gemiddeld per dag wover \pm 250 meter geobserveerd door verpleging

$\Delta=$ aantal opvangstappen per 10 observatieminuten gemiddeld per dag over 250 meter, geob. serveerd door fysilotherapie 
(d) Effektassessmen:

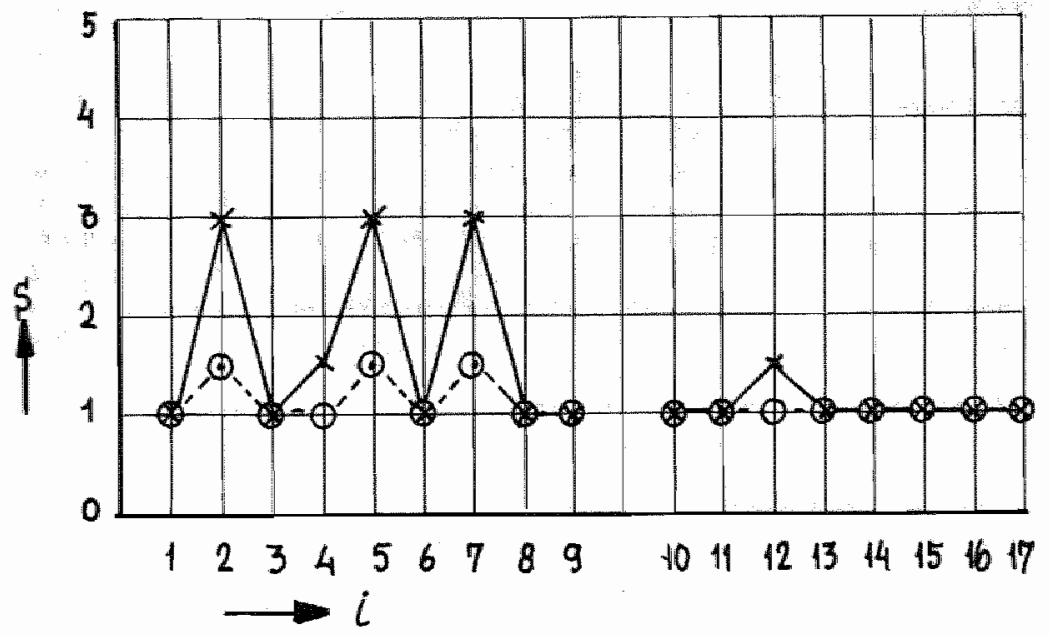

$$
\begin{aligned}
& i=\text { GOCC-item } \\
& s=\text { GOCC-score } \\
& x=\text { vóm behandeling } \\
& a=\text { na behandeling }
\end{aligned}
$$

PO geen verandering (zie verzameltabel, bijlage 4)

(9) Resuliaren:

(a) Probleemassessment: Afname probleemgedrag van gemiddeld 27.6 naar 0 opvangstap. pen, vastgesteld over 4 oservatiek wartieren per dag, waabij patiente ongeveer $250 \mathrm{~m}$ liep met vierpoot (afname van $100 \%$ ).

(b) Procesassessment: Doelgedrag gerealiseerd. Na 15 dagen werden vrijwel geen opvangstappen gek onstateerd over 10 minuten observatie, waarbij patiente dus 250 meter (bij benadering) aflegde.

(c) Effektassessment: Afname van 1 puntscore of meer bij de items 2, 5 en 7 (resp. angstig. gedrag, onzelfstandigheid, zich opdringend aan omgeving). De gehele GOCC is tamelijk normaal (dus , aangepast") te noemen. 
(1) Patienngegewens:

$-9,16$ jaren

- tijd trauma lot opname in centrum: $3 \frac{1 / 2}{2}$ mand

- duur coma: 1 week

- contusio cerebri, hemiplegie rechts en partiele afasie

- psychologisch onderzok: geheugenstoornissen GOCC: enkele gedragsbelemmeringen

(2) Probleengedrag: Opvallende kriteria wolgen $\mathrm{GOCC}$ slordigheid en ongemotiveerdheid. Vooral de slordigheid zou voor verpleging een tamelik probleemgedrag genoemd kunnen worden. Echter het was met name een opgave tot objektivering van dit probleemgedrag te komen. Er konden alleen enkele vage kriteria verzameld worden als: "lat kleren overail slingeren, trek thaar kleren maar half aan" e.d. Bovendien werd deze slordigheid niet direki als "revalidatiebelemmerend" ervaren. Toch bestond er behoefte dan gedragsmodifikatie in deze; omschrijwing en $k$ wantificering wan probleemgedrag werden echter niet witgewerkt.

(3) Doelgedrag: Afname van slordigheid, gedefinieerd als wet niet meer laten slingeren wan allerlei artikelen:"

(4) Behandelingsplan: Alle artikelen, die patiënte niet op de juiste plaats zou neerleggen, werden door de verpleging weggeborgen. Zij kon deze artikelen echter ,terug verdienen" door haar bed en kamer op te ruimen.

(5) Uivoering: Exacte definiëring en assessmentuitvoering van het probleemgedrag werden nagelaten.

(6) Probleemassessmem: Niet gerealiseerd. Men kan slechts afgaan op subjektieve beweringen.

(7) Procesassesment: Geen düdelijk gefaseerd plan, gericht op onduidelijk probleemgedrag, onbekende bekrachtiging enz. enz. Duur: bij benadering 3 weken.

(8) Effekrassessment: Zie verzameltabel, bijlage 4. Geen vooruitgang op GOCC en PO.

(9) Resultaren: Geen

Vermoedelijke oorzaken:

1.e. Geen duidelijke definitie en kwantificering wan probleemgedrag.

2e. Geen duidelijke doelstelling, mede doordat het probleemgedrag niet als arevalidatiebelemmerend" werd ervaren.

3e. De afwezigheid van een systematische planning en uitvoering. 


\subsection{Bespreking der resultaten}

De behandeling van niet contusio cerebrì patiènten had wat betreft de behandelingsstrategie betrekking op:

a. De Vorming van nieuw gedrag, 2 patiènten $(2 \mathrm{~V})$

b. Het doen Toenemen van reeds bestaand gedrag, 3 patiènten ( $3 \mathrm{~T}$ )

c. Reduktie van excessief gedrag, 7 patiënten ( $7 \mathrm{R})$

Het aantall (12) patiënten is beperkt.

Aan de voorwaarden voortvloeiend uit het principe van experimentele-versus kontrolegroep ter statistische toetsing kan niet voldaan worden.

Pogingen hiertoe zijn ondernomen, maar het bleek dat in het algemeen „probleempatiënten" te snel ontslagen werden om daaruit een kontrolegroep te kunnen vormen.

Eveneens was het gezien de algemeen ethische doelstelling van het behandelingsproces niet mogellijk een $\mathrm{A}$-B-A-design volgens de $\mathrm{N}=1$ methode te realiseren. Wellicht voldoet de benaming A-B-C-A-design.

A-konditie: Observatie gedurende ca. 4 weken d.m.v. GOCC, bepaling van het probleemgedrag en de frekwentie daarvan en het psychologisch onderzoek. In deze periode werd getracht behandelingspogingen door individuele werkers te voorkomen. Men kan aannemen dat in deze periode een intermitterende bekrachtigingsprocedure werd gehanteerd, zowel van gewenst als ongewenst gedrag.

B-konditie: Deze bestond uit selektieve bekrachtiging van nieuw te vormen gedrag en extinktie van probleemgedrag. Bij alle gedragsbehandelingen werden deze beide modifikatietechnieken gepraktiseerd, zij het met verschil in de mate van extinktie. Het sterkst werd deze extinktie toegepast bij de reduktie van gedragsbelemmeringen, welke immers eerst moesten worden genegeerd om "plaats te krijgen" voor het optreden van adekwaat gedrag, dat dan konsekwent moest worden bekrachtigd. De gehele procedure bij de gedragsreduktie was ook een aangelegenheid die min of meer 24 uur per etmaal moest worden volgehouden.

Bij de gedragsvorming en gedragstoename lag het aksent vooral op de selektieve bekrachtiging, waarbij ongewenst, "te kort schietend" gedrag niet werd bekrachtigd. De procedure strekt zich ook niet uit tot een "kontinue” behandeling, maar werd alleen uitgevoerd op regelmatige therapiesessies. Bij alle modifikaties werd doorlopend een konsekwent bekrachtigings-en extinktieschema toegepast.

C-konditie: Overgang van kontinue bekrachtiging van gewenst gedrag en extinktie van niet-gewenst gedrag naar intermitterende bekrachtiging van gewenst gedrag en blijvende kontinue extinktie van ongewenst gedrag.

A-konditie: Observatie gedurende 2 weken d.m.v. GOCC, bepaling van de frekwentie van het probleemgedrag en afsluitend psychologisch onderzoek. Voorzover er bekrachtiging werd gegeven voor het gewenste gedrag was dit op intermitterende basis. Er wordt verondersteld dat bekrachtiging van het eventueel optredend ongewenste gedrag in deze periode eveneens optrad op intermitterende basis.

Het enige verschil met het A-B-A-design is dus de introduktie van de C-konditie, waarbij a.h.w. "voorzorgen" werden getroffen dat het gewenste gedrag zou blijven voortduren, zonder optreden van ongewenst gedrag. Ter verdere bespreking der resultaten wordt derhalve uitgegaan van de volgende overwegingen: 
1e. Het A-B-C-A-design was aanwezig bij gedragsreduktie, gedragsvorming en de toename van gedrag (resp. de R-V-en T-patiëntengroep).

2e. Bijalle modifikatieptocedures werd gebruik gemaakt van extinktie en selektieve bekrachtiging.

Op grond van deze overwegingen zijn de drie subgroepen, totaal 12 patienten, als eén groep beschouwd ter statistische bewerking.

\subsubsection{Rekenkundige bewerking der resulttaten}

Een overzicht van de verkregen resultaten kan als volgt worden weergegeven (ze eventueel bijlage 4).

(a) Probleemassessment:

- D.m.v. nieuwe gedragswormingsprocedure: afname van probleemgedrag bij 2 van de 2 V-patiënten.

- D.m.v. gedragstoenameprocedure: alname wan probleemgedrag bij 3 van de 3 T-patiërnten.

- D.m.v. gedragsreduktieprocedure: aframe van probleemgedrag bij 5 van de 7 R-patiènten.

De percentages van de afneming van probleemgedrag zijn als volgt:

V 1:94\% V 2: $100 \%$

T 1:60\%; T 2:60\%; T 3: $100 \%$

R 1: $80 \% ;$ R 2: geen eind probleemassessment uitgevoerd; R 3: 85\%; R 4: $100 \%$; R 5: $100 \%$ : R 6: $100 \%$ : 7: mislukte behandeling.

Algemeen: Vermindering van probleemgedrag bij 10 van de 12 patienten met een gemiddelde afname bij de suksesvolle patiënten van circa $85 \%$ vanaf de beginwarde.

(b) Procesassessment.

De gemiddelde observatietijd per patiënt bedroeg vóór de behandeling 4 weken en na de behandeling 2 weken. De totale observatietijd bedroeg gemiddeld per patiënt 6 weken.

De gemiddelde behandelingsduur bij de suksesvolle patiënten bedroeg 6 weken. Dit betekent dus dat aan een suksesvol behandelde patiënt gemiddeld 12 weken observatie en bethandeling werd besteed.

\section{(c) Ellektassessment.}

Psychologisch onderzoek: geen afname van PO-scores (dus geen verbetering) bij 11 patienten. Alleen patiënt $R 3$ toont na afloop van de poging tot reduktie van het .vragenstellend gedrag" een duidelijke toename op de concentratietests.

Een verklaring voor de afwezigheid van verbetering bij de overige patienten zou kunnen bestaan uit de overweging dat de behandelinsprocedure niet expliciet gericht was op de verbetering van de prestaties, zoals deze diagnostisch werden bepaald.

GOCC: Alle patienten op een natonen een verbetering der GOCC-scores bij vergelijking vóór en $n$ a de behandeling. patiënt $R 2$ toont een toename, d.w.z. een verhoging van gedragsbelemmetingen wan +5.0 puntscores. De gemiddelde verbetering op de GOCC is voor de overige 11 patiènten 6,2 puntscores. Deze gemiddelde verbetering is het grootst bij de $3 \mathrm{~T}$ patiënten $\mathrm{nl}$. 11,5 ; bij de $6 \mathrm{R}$ patiënten (behalve $\mathrm{R} 2$ dus) is deze 4,4 ; bij de $2 \mathrm{~V}$ patiënten 3.8 puntscores. 


\subsubsection{Statistische bewerking der resultaten..}

(zie bijlage 4 )

Hoewel er geen statistische bewerking over een experimentele therapiegroep en een kontrole-, niet-therapiegroep, mogelijk was lenen de scores der patiènten vóór en na de behandeling zich wel voor statistische toetsing. Het zijn met name de GOCC. scores van de effektassessment, die voor zulk een toetsing in aanmerking komen.

Deze scores zijn - zoals dit ook bij de beoordelaarsbetrouwbarheid gebeurde - alan een antant voorbewerkingen onderworpen.

Deze voorbewerking bestaan uit enerzijds sommatie der GOCC-scores over de patient per GOCC-item apart, anderzijds sommatie der GOCC-score over de GOCC-items per patiënt apart.

In verband met de verschillende gedragsdeviaties en de daar op betrekking hebbende modifikatieprocedures is onderscheid gemaakt in drie verzamelingen:"

- Patiënten met gedragstekorten: de Patiënten V1, V 2, T 1, T 2 en T3.

- Patiënten met gedragsexcessen: De patiënten $\mathrm{R} 1 \mathrm{t} / \mathrm{m} \mathrm{R} 7$.

- Alle patiënten met gedragsdeviaties tesamen: de patiënten $\mathrm{V} 1, \mathrm{~V} 2, \mathrm{~T} 1, \mathrm{~T} 2, \mathrm{~T} 3$, R $1 \mathrm{t} / \mathrm{m}$ R 7.

De algemene verwachting, reeds vanuit de rekenkundige bewerking is, dat de GOCC-scores afnemen na de behandeling. Het is hierbij echter de vraag of het verschil vóór en na de behandeling signifikant is en zo ja, onder welke voorbewerking der scores en voor welke patiëntenverzameling. De volgende nul-hypothesen werden geformuleerd.

$\mathrm{H}_{0}-\mathrm{T}_{1}$ : Er bestaat geen verschil in de gemiddelden der [GOCC-scores] vóór en na de behandeling

- voor de patiëntenverzameling met gedragstekorten

- indien deze [GOCC-scores] tot stand zijn gekomen door sommatie der GOCC-scores over de patiënten met gedragstekorten per GOCC -item apart.

$\mathrm{H}_{10} \mathrm{E}_{\mathrm{I}}$ : Er bestaat geen verschil in de gemiddelden der [GOCC-scores] vóón en nat de behandeling

- voor de patiëntenverzameling met gedragsexcessen

- indien deze [GOCC-scores] tot stand zijn gekomen door sommatie der GOCC-scores over de patienten met gedragsexcessen per GOCC item apait.

$\mathrm{H}_{4}-\mathrm{D}_{1}$ : Er bestaat geen verschil in de gemiddelden der [GOCC-scores] vóor en nat de behandeling

- voor de patiëntenverzameling met gedragsdeviaties (d.w.z. gedragstekor. ten en gedragsexcessen)

- indien deze [GOCC-scores] tat stand gekomen zijn door sommatie der GOCC-scores over de patiënten met gedragsdeviaties per GOCC-item apart.

$\mathrm{H}_{0}-\mathrm{T}_{3}$ : Er bestaat geen verschil in de gemiddelden der [GOCC-scores] vóón en na de behandeling

- voor de patiëntenverzameling met gedragstekorten

- indien deze [GOCC-scores] tot stand zijn gekomen door sommatie der GOCC-scores over alle GOCC-items per patiẻnt met gedragstekorten. 
$H_{0}-E_{2}:$ Er bestaat geen verschil in de gemiddelden der [GOCC-scores] vóór en na de behandeling

- voor de patiêntenverzameling met gedragsexcessen

- indien deze [GOCC-scores] tot stand zijn gekomen door sommatie der GOCC-scores over alle GOCC-items per patiênt met gedragsexcessen.

$\mathrm{H}_{0}-\mathrm{D}_{2}$ : Er bestáat geen verschil in de gemiddelden der [GOCC-scores] vóór en na de behandeling

- voor de patientenverzameling met gedragsdeviaties

- indien deze [GOCC-scores] tot stand zijn gekomen door sommatie der GOCC-scores over alle GOCC-items per patiënt met gedragsdeviaties.

Toetsing van deze nulhypothesen zal plaats vinden aan de hand van de t-toets. woor het geval van een gepaarde steekproef (vór en na de behandeling) (Spitz $1968 \mathrm{p}$ 308).

Verwerping der nulhypothesen zal plaatsvinden indien de aldus berekende toetsingsgrootheid signifikant is bij $\alpha=0,01$ en een éénzijdige overschrijdingskans.

Ter verduidelijking van de toetsing zijn per nulhypothese de scores na voorbewerkingen per patiëntenverzameling alsmede met de verkregen resultaten in bijlage 5 samengevoegd. (De kritieke grenzen zijn betrokken van Pearson c.s. 1956.) Uit bijlage 5 blijkt dat 4 van de 6 nulhypothesen kunnen worden verworpen. Onder akseptatie van een signifikantieniveau van $\alpha=0,01$ eenzijdig getoetst geldt:

1e. Voor alle verschillende patiëntenverzamelingen is er een signifikant verschil wat betreft gemiddelden der [GOCC-scores] indien deze [GOCC-scores] tot stand zijn gekomen door sommatie der oorspronkelijke GOCC-scores per GOCC-item.

2e. Voor de patiëntenverzameling met deviant gedrag is er een signifikant verschil wat betreft de gemiddelden der [GOCC-scores] indien deze [GOCC-scores] tot stand zijn gekomen door sommatie der oorspronkelijke GOCC-scores over alle 17 GOCC-items per patiënt,

De nulhypothesen $\mathrm{H}_{0}-\mathrm{T}_{2}$ en $\mathrm{H}_{0}-\mathrm{E}_{2}$ kunnen niet worden verworpen, aangezien aan het gestelde signifikantieniveau $\alpha=0,01$ niet wordt voldaan. Dit wordt onder meer

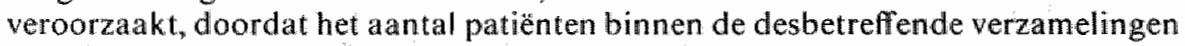
te klein is om aan de gestelde voorwaarden te voldoen.

Resumerend kan men tot de konklusie komen dat bij vergelijking der [GOCCscores] vóór en na de behandeling volgens gedragstherapeutische principes van extinktie en selektieve bekrachtiging bij de in deze studie beschouwde patiëntengroep een signifikante afname van deze [GOCC-scores] kan worden gekonstateend.

\subsubsection{Modifikatie van gedragsdeviaties bij patiënten die buiten de kategorie contusio cerebri vallen}

Naast de behandeling van, in de vorige paragrafen (3.3.4.,3.3.5. en 3.3.6.) genoemde patienten met contusio cerebri, werd eveneens getracht bij patiènten buiten deze kategorie gedrag te modificeren. Hoewel deze modifikaties buiten de opzet en uitvoering van deze studie vallen, zullen zij toch kort casuïstisch worden samengevat. 
- 9.34 jaar

- tijd trama tot opname revalidatiecentrum: $9 \mathrm{~W}$ jatar

- duur coma: eén dag

- hersentumor

- patiente was vón de gedragsvorming gedurende ca. 6 maanden in geheugen- en concentrathetraining. De resultaten hierwan waren zeer bevredigend. Hett probleemgedrag bestond uit het onvermogen boodschappen te doen door geheugen ", orientatiestoornissen en gebrek an woldoende zekerheid. Het doelgedrag, boodschappen kunnen doen in verschil: lende wirkels en platatsen met behulp van plattegrond, werd in 6 weken gerealliseerd. Sterke afname, dus verbetering van verhoogde GOCC-scores.

Patient T-4

- o", 10 jaar

- tijd trauma tat opname in revalidatiecentrum: 9 jaar

- duwr coma: onbekend (niet aranezig)

- post natala asfyxie bij praematuur

- PO: geheugen - en concentratiestoornissen, laag intelligentieniveau

- GOCC: sterk verhoogde scores

Het probleemgedrag: het gedrag bestaande uit diverse handelingen als anankleden lopen e.d. werd wel uitgevoerd, echter het bleef zeer traag, hetgeen niet volledig verklaard kon worden door een motorische stoornis. Hell doelgedrag, gedefinieerd als de toename van het tempo bij diverse handelingen werd in 12 weken gerealiseerd. Er bleek hiernaast een sterke afname, dus verbetering, der GOCC-scores.

Pavient R-8

$-\sigma, 35$ juar

- tijd trauma tot opname in revalidatiecentrum: (geen trauma)

- duur coma: niet aanwezig

- "konversiehysterie" volgens MMPI

- PO" geen geheugen of concentratiestoornissen, goed intelligentienivea u

- GOCC: sterk verhoogde scores op ..klaaggedrag".

Probleemgedrag werd gedefinieerd als het aantal malen klagen tegenover medepatiènten en personeelsleden per observatiekwartier genomen over een gehele week.

Doelgedrag: interaktie met patienten en personeelsleden zonder dat dit klaaggedrag optrad, Resultatat: de behandeling moest worden afgebroken wegens gebrek aan voldoende bek rachtigende kondities voor het "niet-klaag"-gedrag en vanwege voortgaande intermitterende bekrachtiging van het probleemgedrag.

Patienter R-9

- Q.58 jaar

- tija trauma tot opname: cal 3 jaar

- duur comar: ionbekend

- hersenbloeding

- PO: geheugen- en spraakstoornissen, goed intelligentieniveau

- GOCC-scores: vooral verhoogd op "klatagedrag".

Probleemgedrag: Dit werd in eerste imstantie volledig overeenkomstig thet GOCC.item ..klagen" gedefinieerd. In ean wat later stadium moesten een overvloed ann "paranoide" uitspraken aan het probleemgedrag toegewoegd worden.

Doelgedrag: Arname van klagen en paranoide uitspraken en toename van "normale" gesprekken over hobby"s, interesses en werkzaamheden.

Resultat: Sterke toename der GOCC-scores, m. a. w. verhoging van het klagen en de paranoide uitspraken. Over de mogelijke oorzaken hiervan kan slechts retrospektier worden gesproken. Enerzijds bestond de indruk dat tijdens de behandelingsperiode allen extinktie werd toegepast en de uitdrukkelijke noodzakelijke bekrachtiging voor gewenst gedrag total ontbrak. Anderzijds speelden allerlei niet kontroleerbare zaken een grote rol. 
Patient R-10

$-0,19$ jaar

- tijd trauma tot opname: geen traumgit

- duur coma: geen coma

- diplegia spastica t.g.v. partus praematurus

- PO. minder goede geheugenfunktie, tragg tempo, stechte concentratie, intelligentieniweau was zwak-begard

- GOCC: verhoogde scores op: klagen, niet-coopperatief gedrag en sterke motorische- en werballe agressie

Als probleemgedrag werd geselekteerd: klagen en agressiviteit in motorische en verbale zin Doelgedrag: afname van klagen en agressiviteit, toename wan cooperatief gedrag.

Resultaten: Volledige aframe van het probleemgedrag. Het gestelde doelgedrag werd in 10 weken gerealiseerd. Zeer sterke afname - dus verbetering - der GOCC-scores.

Patient R-11

- Q.2 21 jacar

- tijd tratuma tot opname revalidatiecentrum: 8 manden

- duur coma: 3 weken

- slikpneumonie met cardio-respiratoire stilsitand en cerebrale hypoxie.

Geen uitgesproken motorische beperkingen, hoge reflexen, extra pyramidale hypertone atactische gang

- $\mathrm{PO}$ niell lestbar

- GOCC: zeer aanzienlijke gedragsbelemmeringen

Problemgedrag: apathie, zeer onzelfstandig, motorisch-agressief gedrag.

Doelgedrag: afname van motorisch-agressief gedrag en toename van zelfstandigheid.

Resultaten: Na ca. 3 maanden was het doefgedrag gerealiseerd, echter er ontstond eer toenemende verbale agressiviteit en het afd wingen wan bekrachtiging. In verband met te lange duur der behandeling werd deze gestaakt.

Resumerend: V-3: succeswol; T-4: succesvol; R-8: niet succesvol; R-9: totaal echec; R-10: zeer succesvol; R-11: niet succesvol, m.a.w. $50 \%$ succesvol en $50 \%$ falen der behandeling.

\subsubsection{Samenvatting}

In de periode 1973-1976 werden patiënten met contusio cerebri en met een verscheidenheid aan gedragstekorten en gedragsbelemmeringen behandeld volgens ged ragstherapeutische methoden. Het betrof hier patiènten met cen totale afwezigheid an gewenst gedrag (2), pattënten warbij het gewenste gedrag wel anwezig was, matr in onvoldoende intensiteit (3) en patienten waarbij sprake was van gedrag dat nieuwe gedragsworming blokkeerde (7).

Als gedragstherapeutische methodieken werden gebruikt: extinktie en selektieve bekrachtiging, watrbij het aksent dat op extinktie gelegd werd per patient per probleemgedrag varieerde.

Gegeven de realiteitsgrenzen gesteld door de praktijk van behandeling in een klinische setting kon de empirische verifikatie alleen platswinden d.m.v. het A-B-C-A-design, watrbij in de A-konditie de observatie van het probleemgedrag zonder behandeling plaatsvond, in de B-konditie de behandeling werd gerealiseerd en in de $C$-konditie een overgang platswond van een kontinu maar een intermitterend bekrachtigingsschema.

Onder handhaving van dit onderzoeks- en behandelingsdesign konden d.m.v. probleemassessment, procesassessment en effektassessment de volgende resultaten worden gesignaleerd: 
1e. Afname van probleemgedrag bij 10 van de 12 patiênten. De gemiddelde afname bedroeg per patiënt $85 \%$ van het a anvankelijke probleengedrag.

2e. De gemiddelde observatieduur bedroeg vóo en na de behandeling resp. 4 en 2 weken per patiënt. De gemiddelde behandelingsduur bedroeg ca. 6 weken per patiënt.

3e. Het psychologisch onderzoek bestaande uit intelligentiebepaling, concentratiemetingen en geheugenonderzoek toonde bij 11 van de 12 patienten geen duidelijke verbeteringen.

4e. Daarentegen werd wel een verbetering der GOCC-scores na de behandeling gek onstateerd.

5e. Indien als effektkriterium deze GOCC-scores genomen worden, kan onder hantering van het A-B-C-A-design de nulhypothese: "Er is geen verschill in effektkriteria vóór en na de behandeling" worden verworpen.

\subsection{Evaluatie van de modifikatieprocedure ter gedragsbehoud onder toenemende stimuluscomplexiteit}

\subsubsection{Inleiding}

Wanneer een van de levensverrichtingen van de mens verstoord is, wordt in de diagnostiek t.b.v. de revallidatie in het algemeen en in de (psycho-) diagnostiek van psychologische syndromen in het bijzonder, gesproken over lichamelijke resp. psychische funktiestoornissen. Vooralsnog zullen in deze studie dergelijke stoornissen in gedragstermen worden aangegeven enwel als gedragstekorten in respons op specifieke teststimuli. Onder deze gedragstekorten wordt hier met name verstaan een inadekwate, een onvolledige respons op teststimuli gepresenteerd bij het geheugenen concentratie-onderzoek, welke niet kan worden toegeschreven aan een motorische handicap.

De scores van betreffende patient lagen m.a.w. ver onder de normen inzake gemiddelde prestaties bij gestandaardiseerde en op de Nederlandse bevolking genormeerde psychologische tests wat betreft geheugen en aandachtsaspekten.

Bij de konstatering wan deze tekorten werd een modifikatiestrategie ondernomen die hoofdzakeljk berustte op het al eerder genoemde "fading"-principe. Daartoe werden trainingsprogramma's zo ontworpen en gekonkretiseerd dat de modifikatie van deze gedragstekorten gestandaardiseerd kon worden uitgevoerd. Ook bij deze gedragsmodifikatie werd een meervoudige assessmentprocedure gehanteerd teneinde vór, tijdens en na de traming het effekt en verloop var deze training per individuele patiènt te kunnen nagaan.

Aan de voorwaarde van at random samengestelde steekproeven kon niet worden voldaan. Wel was het mogelijk een kontrolegroep samen te stellen die naar relevant geachte kriteria gematched was met de experimentele groep. Het effek van training versus niet-training kon zodoende aan de hand van een aantall hypothesen worden getoetist.

Deze paragraaf geeft verslag wan assessmentprocedure, modifikatiestrategle, de samenstelling der experimentele* en kontrolegroep, en van de kondities welke toepasbaar waren voor deze groeperingen. In een afsluitende subparagraaf zullen de resultaten van training versus niet-training worden besproken.

\subsubsection{Assessment en modifikatie}

De assessmentprocedure en modifikatiestrategie kwamen onder 2.3 .4 .3 . reeds in het kort aan de orde. Hier zal wat meer op deze onderdelen worden ingegaan waarbij 
de behandelingsvolgorde gelijk zal zijn aan die welke bij gedragsworming en gedragseduktie werd gehanteerd.

\section{(1) Effektarsessment.}

Voor de vaststelling van het behandelings- c.q. trainingseffekt werd ook bij de onderhavige groep patienten gebruik gemaakt van de Gedragsobservatieschaal Contusio Cerebri (GOCC) en het Psychologisch Onderzoek (PO). De GOCC werd vór de behandeling twee, maar ook vaak driemaal afgenomen. Voor het PO werden tests geselekteerd welke genormeerd waren op de Nederlandse populatie mar bovendien identiek waren an tests die door Guilford binnen zijn "Structure of Intellect" zijn opgenomen (zie Guilford c.s. 1971). Het PO vond voór de behandeling in de regel plaats tussen de 4 e en de $7 \mathrm{e}$ week na opname. Dit bestond uit:

a. Geheugenonderzoek; korte terminn (d.w.z. reproduktie na 5 sekonden voor zgn. "units". Het begrip "units" werd ontleend aan de terminologie van Guilford: "Relativily segregated or circumscribed items or "chunks" having "thing "character. May be close to Gestalt-psychology" figure on ground" (Guilford 1971 p. 20).

De geheugentests werden afgenomen binnen de visuele en auditieve modaliteit waarbij hel geheugen getoetst werd op de kenmerken van recognitie en recall. Wat betreft recognitie werd de capaciteit van inprenting en retentie bepaald d.m. $w$. het herkennen van vooraf gepresenteerde stimuli uit verscheidene tegelijkertijd aangeboden stimuli.

Wat betreft de recall werd deze geheugencapaciteit nagegaan d.m.v. de reproduktie van een aantal stimuli onafhankelijk van de volgorde van de presentatie.

De "inhoud" der stimuli was in de visuele modaliteit "figuraal" en in de auditieve madaliteit ${ }_{\text {w }}$ semantisch". Ook deze termen werden ontleend aan Guilford "Figural (F) Pertaining to information in concrete form as perceived or as recalled in the form of images" en "Semantic (M) Pertaining to information in the form of conceptions or mental constructs to which words are often applied, hence most notable in verbal thinking and verbal communication". (Guilford 1971 p. 20).

Het geheugenonderzoek bestond aldus uit: korte termijn - units:

a-1: Recognitie - visueel - figuraal

a-2: Recognitic - auditief - semantisch

a-3: Recall - visueel - figuraal

a-4: Recall - aduditief - semantisch

b. Ter bepaling van het concentratie-aspekt werd, zoals onder 2.2.2.1. gesteld, de zogenaamde Bourdon-Wiersma-test genomen. (zie Boeke P.E. 1962)

Deze concentratiemeting werd uitsluitend in de visuele modaliteit uitgevoerd. c. Naast geheugen- en concentraticonderzoek werd het intelligentieniveau bepaald. Aangezien IQ-scores van verschillende tests nogal kunnen verschillem en niet iedere intelligentietest bij motorisch gehandicapten (vooral i.v.m. subtests waar het tempo een rol speelt) afgenomen kan worden, werden steeds twee intelligentietests genomen warbij de betreffende handicap geen beperkend effekt had. Als kriterium voor het intelligentieniveau gold steeds het gemiddelde wan twee tests. Ter bepaling van het intelligentieniveau werd, rekening houdend met de handicap, een selektie gedaan uit WAIS-verbaal, WAIS-performance, volledige GIT, subtests van de GIT, volledige SON, subtests van de SON, de Raven Progressive Matrices, WISC-verbaal, WISC- 
performance. Bij grote diskrepantie tussen twee geselekteerde tests (meer dan 20 IQ-punten) werd overgegaan tot een tweede kombinatie van andere tests of subtests teneinde na te gaan in hoeverre het verschil in resultaten ook door deze kombinatie werd bevestigd.

$\mathrm{Na}$ de berekening der scores werden zowel bij de intelligentie - als bij de geheugen- en concentratietests, de ruwe scores eerst in decielen omgezet en vervolgens in $\mathrm{zgn}$. „punt-scores”. Door de omzetting in een schaal lopende van 1 tot 5 werden de bevindingen van het psychologisch onderzoek beter vergelijkbaar met die van de GOCC (zie 2.2.2.2.). Tenslotte zij nog vermeld dat de effektassessment (GOCC en PO) tijdens en na de behandeling om de drie maanden met een speling van \pm 14 dagen werd uitgevoerd.

\section{(2) Vaststelling van probleemgedrag}

Wat betreft gedragstekorten onder toenemende stimuluscomplexiteit werd het probleemgedrag als volgt gedefinieerd: Hoewel binnen een specifieke situatie (het psychologisch onderzoek) bij een eenvoudige stimulusconfiguratie wel wordt gereageerd met een adek wate geheugen- of concentratierespons, treedt dit gedrag niet of minder feilloos op indien deze konfiguratie meer complex wordt.

Het probleemgedrag dat voor modifikatie in aanmerking werd genomen had alleen betrekking op gekonstateerde geheugen- en/of concentratiekorten.

Van probleengedrag was sprake indien een patient met een IQ-puntscore $\leqslant 4$ op een der geheugen- en of concentratietests een punt-score behaalde $>3$. Alleen de patiënten die aan deze kriterïa voldeden, $k$ wamen woor geheugentraining in aanmerking.

\section{(3) Doelgedrag}

Behoud van adek wate geheugen-en/of concentratierespons onder toenemende stimuluscomplexiteit.

\section{(4) Behandelingsplan}

Voordat het geheugenbehandelingsprogramma in detail wordt beschreven diemen een aantal algemene lijnen ter verduidelijking te zijn vermeld.

a. De training vond plaats in de zgn. „korte termijn” - en ,lange termijn" - vorm. De "korte termijn"-training impliceerde dat na aanbieding van een aantal stimuli (die qua inhoud systematisch werden gevarieerd) de reproduktie na 5 sekonden moest optreden.

b. Het materiaal behoefde voor de ,lange termijn"-training geen verandering te ondergaan. De periode tussen presentatie en reproduktie werd stapsgewijs vergroot van 5 sekonden bij het ,korte termijn" naar resp. 1-3-5-7-10 minuten bij het "lange termijn"'-geheugen.

c. Bij de trainingen in de auditieve modaliteit werd naast de semantische inhoud der stimuli bestaande uit zinvolle woorden en woordkombinaties eveneens gebruik gemaakt van zgn. nonsens-woorden.

Deze nonsens-woorden kunnen volgens Guilford gerubriceerd worden als "symbolisch": "Pertaining to information in the form of denotative signs having no significance in and of themselves, such as letters, numbers, musical notations, codes and words (as ordered letter combinations)" (Guilford 1971 p. 20).

d. Bij de reproduktie in "recall" vorm behoefde de patiënt de gepresenteerde stimuli niet noodzakelijk in dezelfde volgorde als bij de presentatie te reproduceren. 
De uitbreiding van het geheugentrainingsprogramma met het zgn. "seriegeheugen", waarbij dezè volgorde wèl vereist werd, betekende eveneens geen noemenswaardige verandering in het materiaal. Volgens Guilford valt deze geheugenprestatie echter onder een totaal aparte kategorie n.l. „systems": "Organized or struçured aggregates of items of information, complexes of interrelated or interacting parts" (Guilford 1971 p. 20)

e. Bovenstaande uitbreidingen betekenen dus geen of geen noemenswaardige aanvullingen van het trainingsmateriaal. Voor het psychologisch onderzoek impliceerde dit echter dat er aanzienlijke testwoorzieningen getroffen moesten worden teneinde ook deze aspekten te kunnen meten. Deze voorzieningen konden slechts geleidelijk aan gerealiseerd worden, waardoor niet alle patiënten met de nieuw gekonstrueerde tests onderzocht werden. Voor de overzichtelijkheid zijn derhalve deze onderzoekings-procedures niet in het verslag betrokken, aangezien anders geen onderlinge vergelijking der testresultaten mogelijk was geweest.

f. Teneinde bij de training een toenemende complexiteit aan stimuli binnen de diverse onderdelen te realiseren, werden een aantal moeilijkheidsgraden geselekteerd. Als moeilijkheidsgraden werd bijvoorbeeld bij units, recognitie (auditief en visueel) gesteld: de herkenning van 2 stimuluskonfiguraties uit 6 stimuluskonfiguraties, 3 uit 9,4 uit 12,5 uit 15 , en 6 uit 18 . (2-6/3-9/4-12/ 5-15/6-18) Verwerking van bovenstaande algemen lijnen leidde tot het navolgende trainingsprogramma:

Visuele modaliteit:

Fase 1: unöts-recognitie - figuraal (korte en lange termijn)

Moeilijkheidsgraad: $2-6 / 3-9 / 4-12 / 5-15 / 6-18$.

Fase 2: units-recognitie-semantisch (geregistreerd) (korte en lange termijn). Moeilijkheidsgraad: $2(1)-6(1)$ d.w.z. twee éenlettergrepige woorden herkennen uit 6 éénlettergrepige woorden; $2(2)-6(2) ; 3(1)-9(1) ; 3(2)-9(2) ; 2(3)-6(3) ; 4(1)$ $12(1) ; 4(2)-12(2) ; 3(3)-9(3) ; 5(1)-15(1) ; 5(2)-15(2) ; 4(3)-12(3) ; 6(1)-18(1) ; 6(2)-$ $18(2) ; 5(3)-15(3)$.

Fase 3. Units-recall-semantisch (korte en lange termijn).

Moeilijkheidsgraad: 2(1); d.w.z. reproduktie van twee éénlettergrepige woorden, enz:; $2(2) ; 3(1) ; 3(2) ; 2(3) ; 4(1) ; 4(2) ; 3(3) ; 5(1) ; 5(2) ; 4(3) ; 6(1) ; 6(2) ; 5(3)$.

Fase 4. System-recall-figuraal (korte en lange termijn).

Moeilijkheidsgraad: $2 ; 3 ; 4 ; 5 ; 6 ; 7 ; 8$ figuren in volgorde.

Fase 5. System-recall-semantisch (geregistreerd) (korte en lange termijn)

Moeilijkheidsgraad: $2(1) ; 2(2) ; 3(1) ; 3(2) ; 2(3) ; 4(1) ; 4(2) ; 3(3) ; 5(1) ; 5(2) ; 4(3)$; $6(1) ; 6(2) ; 5(3)$.

Auditieve modaliteit:

Fase 1. Units-recognitie-semantisch (korte en lange termijn)

Moeilijkheidsgraad: $2(1)-6(1) ; 2(2)-6(2) ; 3(1)-9(1) ; 3(2)-9(2) ; 2(3)-6(3) ; 4(1)-$ 12(1); 4(2)-12(2):3(3)-9(3);5(1)-15(1);5(2)-15(2);4(3)-12(3);6(1)-18(1);6(2)$18(2): 5(3)-15(3)$.

Fase 2. Units-recall-semantisch (korte en lange termijn)

Moeilijkheidsgraad: $2(1) ; 2(2) ; 3(1) ; 3(2) ; 2(3) ; 4(1) ; 4(2) ; 3(3) ; 5(1) ; 5(2) ; 4(3)$; $6(1) ; 6(2) ; 5(3)$.

Fase 3: Units-recall-symbolisch (korte en lange termijn)

Moeilijkheidsgraad: $2(1) ; 3(1) ; 2(2) ; 4(1) ; 3(2) ; 5(1) ; 4(2) ; 6(1) ; 5(2)$.

Fase 4. System-recall-semantisch (korte en lange termijn)

Moeilijkheidsgraad: $2(1) ; 2(2) ; 3(1) ; 3(2) ; 2(3) ; 4(1) ; 4(2) ; 3(3) ; 5(1) ; 5(2) ; 4(3)$; $6(1) ; 6(2): 5(3)$. 
Fase 5. System-recall-symbolisch (korte en lange termijn)

Moeilijkheidsgraad: $2(1) ; 3(1) ; 2(2) ; 4(1) ; 3(2) ; 5(1) ; 4(2) ; 6(1) ; 5(2)$.

$\mathrm{Bij}$ de training werd getracht de visuele en auditieve modaliteit parailel met elkaar te realiseren waarbij de volgorde van fase 1 to 5 werd gehanteerd.

Patiënten die naast de geheugentekorten, op de Bourdon-Wiersma-test een puntscore hoger dan drie toonden, $k$ wamen in aanmerking voor concentratietraining.

Bij iedere oefening werd het tempo, de regelmaat en het aantal fouten geregistreerd. Het aantal fouten bleek bij iedere patient en bij iedere trainingseenheid zeer gering te zijn. Derhalve werd met name gelet op het verhogen van tempo en bewerkstelligen van regelmaat bij onderstaande oefeningen, die tevens een toename aan moeilijkheidsgraad representeren:

1. Twee-letier-diskriminatie $\mathrm{O}-\mathrm{Q} ; \mathrm{V}-\mathrm{W} ; \mathrm{M}-\mathrm{N}$ etc waarbij in cen horizontale rij van letters aangegeven moest worden of één der letters voorkwam of niet.

2. Drie-letter-diskriminatie.

3. Eenvoudige optelsommen.

4. Vergelijken van cijferkombinaties (bv. 548765 - 547765) eveneens in horizontale zinnen gepresenteerd.

5. Kombinaties van bovenstaande.

(5) Behandelingsuit woering

Van belang hierbij waren de volgende aspekten:

a. Relatie-opbouw met de patiënt. Hiertoe werd het doel en de werkwijze van het programma volledig met de patiënt besproken. De therapeut zette zich er met name duidelijk voor in een samenwerkingsrelatie en een stimulerende situatie te creëren.

b. Bekrachtigende kondities:

-1 - Vaststellen van streefijn: door therapeut werd aan patient gevraagd naar zijn schatting omtrent iedere volgende prestatie. Indien patiënt hiertoe niet in staat was, werd door de therapeut zelf een streefniveau aangegeven. Hierbij werd ervoor gezorgd, dat het eerste streefpunt ruim binnen de geschatte mogelijkheden van patiënt lag.

$-2-\mathrm{Na}$ iedere prestatie werd direkt informatie gegeven omtrent de resultaten wat betreft het aantal goede prestaties; mislukkingen werden niet genoemd.

-3- Bij hiervoor gevoelige personen werd bij het bereiken van het streefpunt bekrachtiging in de vorm wan ,tokens" gegeven. Deze tokens op zich boden dan weer de mogelijk heid tot een uitgebreide variatie in bekrachtiging, doordat de patiënt deze kon inruilen voor een door hem begeerd artikel of privilege.

-4- Daarnaast werden aan vrijwel alle personen de resultaten grafisch getoond. Deze grafische weergave der resultaten bleek bij een meerderheid der patiènten op zich reeds een goede bekrachtiger te zijn. De kombinatie van een in de grafiek aangeboden streeflijn en de bereikte resultaten gaf direkte en adekwate feedback omtrent de stand van zaken.

c. Processassessment.

De resultaten per sessie werden weergegeven in een blokdiagram. Horizontaal werden de aefeningen uitgezet. Per blokdiagram waren dit vijf verschillende oefeningen van dezelfde moeilijkheidsgraad. Vertikaal werden de aanbiedingen uitgezet die nodig waren om tot $100 \%$ goede reproduktie te komen (maximaal 5 aanbiedingen). Indien na 5 aanbiedingen nog geen $100 \%$ reproduktie bereikt was dan werd dit aangegeven met een vertikaal pijltje in het bovenste hokje. Bovendien werd in de kleine hokjes bij jedere trial het aantal juiste responsies genoteerd. Zie ter verduidelijking de volgende figuur. 


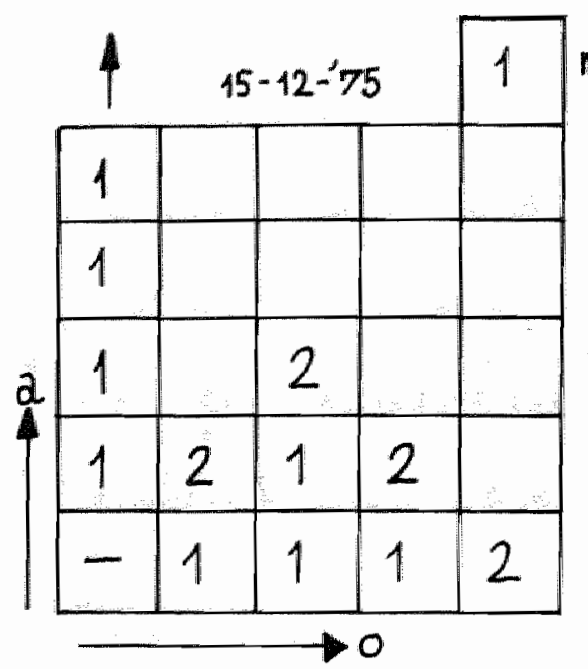

Fig. 2 Voorbeeld van een blokdiagram.

m.

$a=$ aanbieding $(1-5)$

$0=$ oefeningen $(1-5)$

Voorbeeld:

Recognitie van $2(2)$ uit $6(2)$

$\mathrm{M}=$ gemiddelde

shier $|(-)+1+1+1+2|: 5=1,0^{4 *}$

Teneinde tot een procesassessment te komen werd het gemiddelde berekend var de juiste responsen in de eerste aanbieding over 5 oefeningen van dezelfde moeilijkheidsgraad (zie voorbeeld bij $M$ )

Deze gemiddelden werden ingevuld op de procesassessmentgrafiek waarbij horizontaal de datum en vertikaal de scores en de moeilijkheidsgraad werden uitgezet. Zie onderstaande figur.

Fig. 3 Voorbeeld van procesassessment

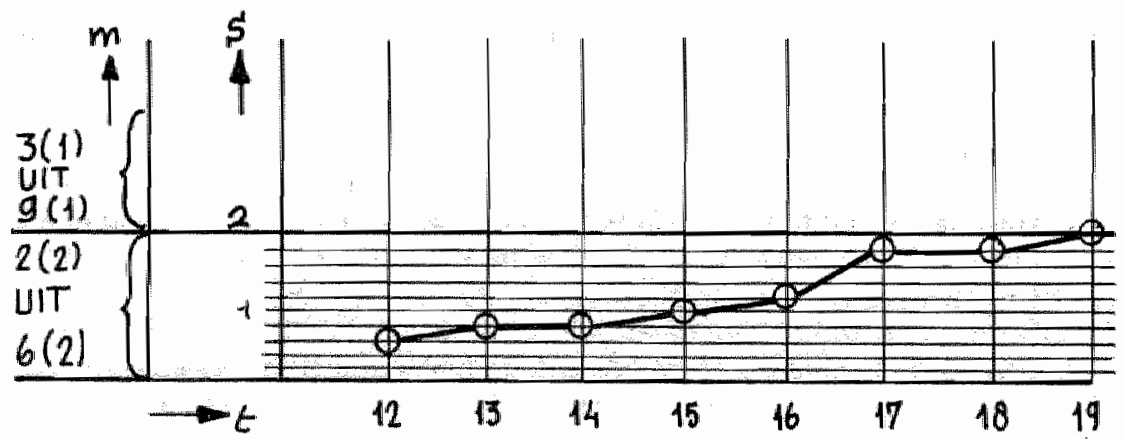

$m=$ moeilijkheidsgratad

$s=$ score in de moeiligheidsgratad

$i=$ lijd in dagen

De procesassessmentgrafiek diende ter feedback aan de patiënt en ter voortgangsevaluatie van de behandeling.

d. Basislijn, stijging in moeilijkheidsgraad en eindijn.

Tenslotte zij vermeld dat ten aanzien van bovenstaande kriteria vaste afspraken werden gemaakt. 
Basislijn: de moeilijkheidsgraad waarbij na 3 offeningen in een blokdiagram voor het eerst én maal een herhaling optrad. Bij iedere moeilijkheidsgraad werd dus bezien of patiënt drie verschillende oefeningen zonder foutieve reproduktie beheerste. Indien deze prestatie werd geleverd, werd overgegaan naar een volgende moeilijkheidsgraad. Bij falen binnen een bepaalde moeilijkheidsgraad gaf deze moeilijkheidssgraad de basislijn voor training aan. Score binnen de moeilijkheidsgraad was wederom het gemiddelde van de onderste blokjes in het blokdiagram.

Overgang naar volgende moeilijkheidsgraad: Indien de patiënt in de training 5 oefeningen van gelijke moeilijkheidsgraad in maximaal 7 herhalingen (waarbij de vertikale score in het blokdiagram maximaal $2 \mathrm{mag}$ zijn) voor $100 \% \mathrm{kan}$ reproduceren.

Eindijn: Na het doorlopen van een aantal moeilijkheidsgraden trad na enige tijd een "stabillisatie" van prestaties op. Indien deze stabilisatie 5 dagen voortduurde, werd aangenomen dat het maximale niveau voor de patiènt bereikt was.

6. Probleemassessment.

Eventuele toe- of afname van het probleemgedrag zoals gedefinieerd onder punt (2), werd vastgesteld door de scores op concentratie- en geheugentests, $>3$ punt-scores, vóór de behandeling te sommeren en te vergelijken met de somscores op dezelfde tests na de behandeling. Het verschil werd uitgedrukt in percentages van de beginwaarde. (zie 3.4.4.)

7. Procesassessment.

Per trainingseenheid werd eén procesassessmentgrafiek per patiënt samengesteld. Per patiënt ontstonden derhalve bij een volledig trainingsprogramma 10 van deze grafieken.

Deze zijn wat betreft hun omvang en aantal te groot om in dit verslag weer te geven. Er werd getracht in voorgaande figuur een indruk hieromtrent weer te geven.

8. Effektassessment.

De behandelingsduur was gemiddeld 5 à 6 maanden. Om vergelijkbare scores te verkrijgen werden zowel GOCC als $\mathrm{PO}$ om de 2 à 3 maanden gescoord, resp. afgenomen.

9. Resultaten:

Hiervoor wordt verwezen naar de verzamelstaat (bijlage 6) waarin de vermelde getallen de scores weergeven voor en na de \pm 6 manden durende behan. delingsprogramma's.

\subsubsection{Samenstelling en kondities van experimentele en kontrolegroep}

Vergelijking wan experimentele met kontrolegroep brengt het volgende kommentaar (zie tabell 8 en 9):

1e: Het aantal mannelijke en vrouwelijke patiënten is in beide groepen gelijk.

2e. De gemiddelde leeftijd bij mannen is in beide groepen gelijk; de vrouwelijke patiënten zijn in de experimentele groep gemiddeld $41 / 2$ jaar jonger dan diè in de kontrolegroep. De gemiddelde leeftijd van mannen en vrouwen tesamen is in de experimentele groep 3 jaar jonger in vergelijking met de kontrolegroep.

3e. De tijd tussen trauma en opname is bij de mannen in de experimentale groep ongeveer éen jaar langer in vergelijking tot de kontrolegroep. Bij de vrouwelijke patiënten is dit juist omgekeerd, namelijk ca. 4 maanden korter. De tijdsperiode 
verschilt voor beide groepen tesamen 8 maanden, d.w.z. de patienten uilt de experimentele groep werden 8 manden later na het trauma opgenomen dan die uit de kontrolegroep.

4. De gemiddelde comaduur was bij de mannelike experimentele groep langer (5 etmaten), bij de wrouwelijke experimentele groep korter ( 30 etmalen) in vergelijking met de kontrolegroep. Voor beide groepen tesamen geldt dat de experimentele groep een kortere comaduur had ( 7 etmalen) in vergelijking met de kontrolegroep.

5. De samenstelling wat betreft het type contusio is voor experimentele en kontrolegroep bij benadering gelijk.

6. De intelligentieniveaus zijn eveneens bij benadering gelijk te noemen.

7. De geheugen " concentratie en gekombineerde stoornissen zijn eveneens gelijk verdeeld in experimentele en kontrolegroep.

Tabell 8 Experimentele lgroep

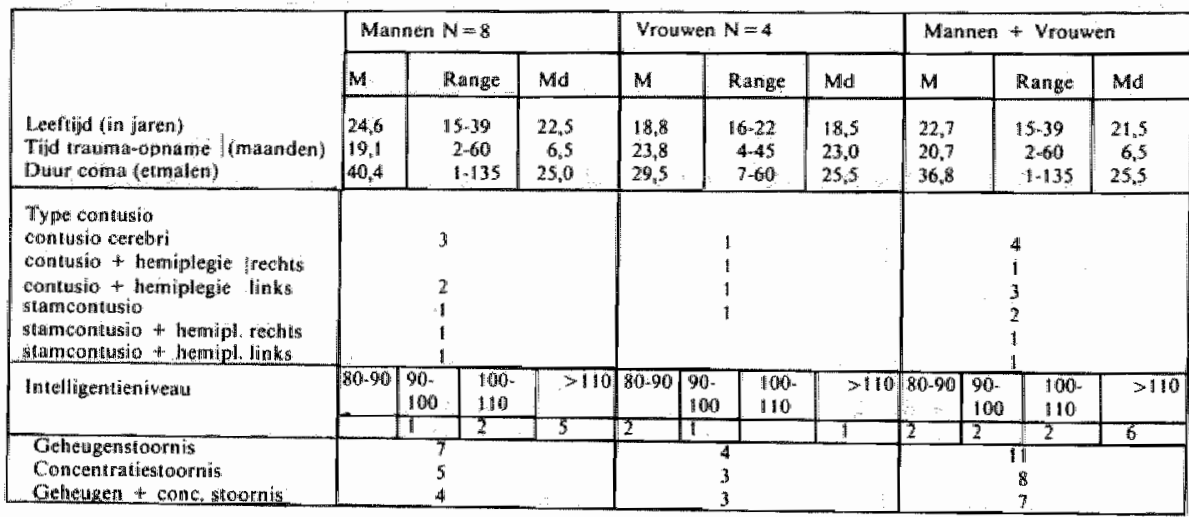

Tabet 9 Controle groep

\begin{tabular}{|c|c|c|c|c|c|c|c|c|c|c|c|c|}
\hline \multirow[b]{3}{*}{ 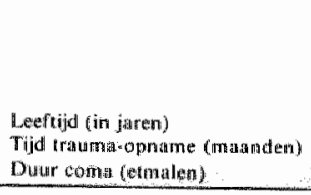 } & \multicolumn{4}{|c|}{ Mantaen $N=8$} & \multicolumn{4}{|c|}{ Vrow wen $N=4$} & \multicolumn{4}{|c|}{ Matrunen en Wroumen } \\
\hline & $M$ & \multicolumn{2}{|c|}{ Range } & $M d$ & $M$ & \multicolumn{2}{|c|}{ Range } & Mid & $M$ & \multicolumn{2}{|r|}{ Range } & Md \\
\hline & $\begin{array}{r}24,5 \\
5,3 \\
35,5 \\
\end{array}$ & \multicolumn{2}{|c|}{$\begin{array}{r}16-39 \\
0,5-14 \\
7,115 \\
\end{array}$} & $\begin{array}{r}25,0 \\
3,0 \\
24,5 \\
\end{array}$ & $\begin{array}{l}28,3 \\
27,5 \\
60,3 \\
\end{array}$ & \multicolumn{2}{|c|}{$\begin{array}{r}20-36 \\
3-84 \\
30-1120 \\
\end{array}$} & $\begin{array}{l}28,5 \\
17,5 \\
45,5 \\
\end{array}$ & $\begin{array}{r}25,8 \\
12,7 \\
43,8 \\
\end{array}$ & \multicolumn{2}{|r|}{$\begin{array}{r}16-36 \\
0,54-84 \\
7.135 \\
\end{array}$} & $\begin{array}{r}25,5 \\
3,5 \\
30,0 \\
\end{array}$ \\
\hline 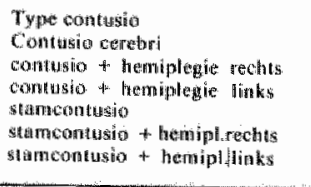 & \multicolumn{4}{|c|}{$\begin{array}{l}4 \\
1 \\
1 \\
2\end{array}$} & \multicolumn{4}{|c|}{1} & \multicolumn{4}{|c|}{$\begin{array}{l}6 \\
1 \\
2 \\
2 \\
3\end{array}$} \\
\hline \multirow[t]{2}{*}{ Intelligentieni weta } & 80.40 & $\begin{array}{l}90 \\
100\end{array}$ & $\begin{array}{l}100 \\
110\end{array}$ & $>110$ & $80-90$ & $\begin{array}{l}90 \\
100 \\
\end{array}$ & $\begin{array}{l}100 . \\
110\end{array}$ & 3110 & $80-90$ & $\begin{array}{l}90 . \\
100 \\
\end{array}$ & $\begin{array}{l}1000- \\
110\end{array}$ & $>110$ \\
\hline & 1 & & 4 & 3 & 2 & & 1 & $i$ & 3 & 0 & $\$$ & 4 \\
\hline 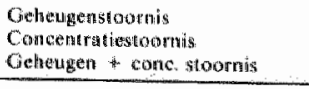 & \multicolumn{4}{|c|}{$\begin{array}{l}8 \\
6 \\
6\end{array}$} & \multicolumn{4}{|c|}{$\begin{array}{l}4 \\
1\end{array}$} & \multicolumn{4}{|c|}{$\begin{array}{r}12 \\
7 \\
7\end{array}$} \\
\hline
\end{tabular}

Indien de mannelijke en vrouwelijke deelgroepen tesamen genomen worden, dan zijn de experimentele en $k$ ontrolegroep redelijk gematched naar gemiddelde leeftijd, type contusio, intelligentie en gedragstekorten. 
Tijdens observatie der GOCC, het $\mathrm{PO}$ en de hïerboven beschreven modifikatie werden de betreffende patiënten in therapie genomen door de diverse revalidatiedisciplines. De invloed van medikatie werd niet in dit onderzoek betrokken. De betreffende medikatie werd overigens aan deze patiënten niet voorgeschreven met het oog op werbetering van geheugen en concentratie. Zowel behandelend geneesheer als medikatie wisselen per patiënt en per periode. Het was derhalve niet goed mogelijk om de medikatie voor iedere patiënt volgens een vaststaand onderling vergelijkbaar systeem te registreren.

De kondities van de kontrolegroep zouden idealiter gelijk moeten zijn aan de kondities van de experimentele groep met uitzondering van de modifikatie ter gedragsbehoud onder toenemende stimuiuscomplexiteit. Dit kon slechts ten dele gerealiseerd worden vanwege de volgende redenen:

1e. Wisseling van therapeuten, therapieën en medicijnen per patiënt en per periode voor patiënten in de experimentele groep. Het was niet mogelijk deze parameters gematched te krijgen met de kontrolegroep.

2e. Verbetering van de fysieke konditie resulteerde, vooral in de beginperiode van deze studie, in een vrij spoedig ontslag. De overtuiging dat ook psychische funktiestoornissen voor revalidatie in aanmerking komen, won slechts zeer langzaam terrein.

3e. Zowel om ethische als om pragmatische redenen was het niet mogelijk om bij patiënten die voor bovengenoemde modifikatie in aanmerking kwamen ter samenstelling van een kontrolegroep, deze trainingen op een latere datum te geven.

4e. Indien een patiënt geselekteerd was als kontrolepatiènt dan bleef zijn verblijf in hoge mate bepaald door het fysieke herstel. De vereiste verblijfsduur van een dergelijke kon rolepersoon kon dan ook op tamelijk onvoorspelbare momenten afgebroken worden.

De kontrolegroep kon dus slechts samengesteld worden uit patiënten met "funktiestoomissen", die hier echter niet voor in behandeling konden komen en waarbij de verblijfsduur niet bepaald werd door de fysiek-medische revalidatie.

Vooral dit laatste kriterium verschafte de doorslag in die zin dat uiteindelijk besloten werd kontrolepatiënten te selekteren uit de groep personen met funktiestoornissen, waarvan dankzij fysiek herstel het ontslag aanstande was.

De kontrolegroep werd samengesteld volgens onderstaande kriteria:

a. Bij ontslag van iedere patiênt werd d.m.v. psychologisch onderzoek nagegaan of hij geheugen- en/of concenteratiestoornissen toonde.

b. Indien dit zo was werd het observatieteam verzocht de GOCC te scoren $\mathrm{m}$. b.t. deze patiënt.

c. Na 5 à 6 maanden werd betreffende patiënt weer opgeroepen voor een herhatald psychologisch onderzoek.

d. De patiënt moest voldoen aan de matchingkriteria ten aanzien van de experimentele groep.

e. Gedurende zijn verblijf thuis mocht patient geen school hebben bezocht of andere vormen van leren hebben ondernomen.

f. De GOCC werd bij het herhalingsonderzoek, 6 maanden na ontslag, (volgens de synthetische beoordeling) afgenomen door de psychologisch assistenten op de afdeling psychologie. 
Op deze wijze werden in feite twee kondities vergeleken.

Experimenteel: Funktietraining, allerlei revalidathetherapieen en medikamenten bij verbliff in het revalidatiecentrum.

Kontrole: Geen funktietraining, geen revalidatietherapieen, wel enige medikatic, bij verblijf in het thuismilieu.

De kondities ter vergelijking van experimentele en kontrolegroep waren binnen de termijn en situatie warin dit onderzoek werd ondernomen niet verder te optímaliseren.

\subsubsection{Vergelijking van training versus geen trainingkondities}

\subsubsection{Formulering der bypothesen}

Voor statistische bewerking werd gebruik gemaakt wan:

1. Effektassessment: de GOCC- en PO-scores van de experimentele en kontrolegroep, vóór en na de experimentele, resp. kontroleperiode.

2. Probleemassessment: De probleemscores gedefinieerd als $\mathrm{PO}$-score $>3$ van de experimentele en kontrolegroep, vóor en na de experimentele, resp. kontroleperiode.

Voor de GOCC, PO-scores en PO $>3$ scores werd eenzelfde "voorbewerking" gebruikt als genoemd werd onder 3,2.3.2.

Deze voorbewerkingen bestaan uit:

a. Sommatie der GOCC-scores over alle patiënten per ieder GOCC-kriterium apart: $\Sigma 12$ pat $[\mathrm{GOCC}-\mathrm{sc}]$

b. Sommatie der GOCC-scores over alle GOCC-kriteria per patiënt apart $2: 7 \mathrm{GOCC}[\mathrm{GOCCsc}]$

c. Sommatie der PO-scores over alle patiënten per PO-kriterium apart $\Sigma, 12$ [POsc]

d. Sommatie der PO-scones over alle PO-kriteria per patiënt apart $\Sigma_{1}^{8}$ PO [POsc]

e. Sommatie der $\mathrm{PO}$-scores $\geqslant 3$ over alle $\mathrm{PO}$-kriteria per patient apart.

$\Sigma_{1}^{8} \mathrm{PO}[\mathrm{PO}>3 \mathrm{sc}]$

N.B. Sommatie der PO-scores $\$ 3$ over alle PO-kriteria per PO-kriterium werd niet uitgevoerd aangezien het betreffende probleemgedrag niet konsekwent bij ieder PO-kriterium optreedt, zoals blijkt uit de verzameltabel. (bijlage 6)

De betreffende rekenkundige bewerking der GOCC-scores wordt gerechtwaardigd, doordat de GOCC ontworpen is als een intervalschaal (zie 3.2.3.1.).

De rekenkundige bewerking der $\mathrm{PO}$-scores is alleen dan gerechtvaardigd voorzover het om globala vergelijking van gelijke groepen van scores gaat. leder PO-kriterium is immers een gegeven apart en derhalve moeilijk als schaal te interpreteren. Bij nauwkeuriger bewerking zullen de $\mathrm{PO}$-scores derhalve apart bezien worden.

A. Vergelijkbaarheid van de groepen

Voordat een uitgebreide toetsing zinvol is, dient bezien te worden in hoeverre experimentele en kontrolegnoep vóór de proefperiode (dit is experimentele resp. kontroleperiode) vergelijkbaar zijn.

Dat wil in dit geval zeggen dat de interesse in feite uitgaat naar het niet verwerpen van de nulhypothese. Deze nulhypothese dient dan geformuleerd te worden in de bewoordingen dat bij vergelijking van experimentele en kontrolegroep er geen verschillen zijn in de verkregen scores. In een dergelijk geval dient a extreem hoog te zijn. Het is hierbijgebruikelijk een signifikantieniverau $\operatorname{van} \alpha=0,25$ te nemen. Hier werd een $\alpha=0,50$ met tweezijdige overschrijdings kans voor de toetsing toegepast. 
Ho-A1: Experimentele en kontrolegroep verschillen niet wór de proefperiode in gemiddelden der $\Sigma ! 2$ pat [GOCC] scores.

Ho-A2: Experimentele en kontrolegroep verschillen niet vóor de proefperiode in gemiddelden der $\Sigma 17$ GOCC [GOCC] scores.

Ho-A3: Experimentele en kontrolegroep verschillen niet vóór de proefperiode in gemiddelden $\operatorname{der} \Sigma_{1: 2}^{12}$ pat $[\mathrm{PO}]$ scores.

Ho-A4: Experimentele en kontrolegroep verschillen niet vóór de proefperiode in gemiddelden der $\Sigma_{1}^{88} \mathrm{PO}[\mathrm{PO}]$ scores.

Ho-A5: Experimentele en kontrolegroep verschillen niet vóór de proefperiode in gemiddelden der $\Sigma{ }_{1}^{18} \mathrm{PO}[\mathrm{PO} \geq 3]$ scores.

Toetsing der nulhypothesen Ho-A1 $\mathrm{t} / \mathrm{m}$ Ho-A5 zal plaats vinden middels de $t$-toets inzake éen variabele en twee steekproeven. (Spitz 1968, p. 326).

Verwerping der nulhypothese zal plaatswinden indien de aldus berekende toetsingsgrootheid t, signifikant is bij $\alpha=0,5$ volgens een tweezijdige overschrijdingskans.

(Kritieke grenzen worden ontleend aan Lindguist 1953, p. 38)

B. Vergelijking der scores vóór en na de proefperiode

Indien aanvaarding van een of meer nulhypothesen akseptabel blijkt, is verdere toetsing zinvol en zal worden nagegaan in hoeverre er enig verschil is in scores bij de experimentele groep vóór en na de modifikatie, respektievelijk bij de kontrolegroep vóór en na de kontroleperiode.

Deze berekeningen zullen dan opnieuw uitgevoerd worden onder gebruikmaking van eerder genoemde "voorbewerkingen” der scores.

De volgende hypothesen zullen worden getoetst.

Ho-B1: In de experimentele groep bestaat geen verschil in de gemiddelden der $\Sigma \frac{12}{1}$ pat. $[G O C C]$ scores vóór en na de modifikatie.

Ho- $\mathbb{B} 2$ : in de experimentele groep bestaat geen verschil in de gemiddelden der $\sum_{1}^{17}$ GOCC [GOCC] scores vóór en na de modifikatie.

Ho-B3: In de experimentele groep bestaat geen verschil in de gemiddelden der $\Sigma_{i}^{12}$ pat. [PO] scores vóór en na de modifikatie.

Ho-B4: In de experimentele groep bestaat geen verschil in de gemiddelden der $\Sigma_{1}^{\&} \mathrm{PO}[\mathrm{PO}]$ scores vóo en na de modifikatie.

Ho-B5: In kontrolegroep bestaat geen verschil in de gemiddelden der

$\Sigma: 2$ pat. [GOCC] scores vóor en na de kontroleperiode.

Ho-B6: In de kontrolegroep bestaat geen verschil in de gemiddelden der $\Sigma 1_{1}^{17}$ GOCC [GOCC] scores vóór en na de kontroleperiode.

Ho-B7: In de kontrolegroep bestaat geen verschil in de gemiddelden der $\Sigma: 2$ pat. [PO] scores vóór en na de kontroleperiode.

Ho-B8: In de kontrolegroep bestaat geen verschil in de gemiddelden der $\Sigma_{1}^{*}$ PO [PO] scores voór en na de kontroleperiode.

Ho-B9: In de experimentele groep bestaat geen verschil in de gemiddelden der $\Sigma_{1}^{*} \mathrm{PO}[\mathrm{PO} \geqslant 3]$ scores voór en na de modifikatie. 
Ho-B10: In de kontrolegroep bestaat geen verschil in de gemiddelden der $\mathrm{z}_{1}^{*} \mathrm{PO}[\mathrm{PO}>3$ scores] vóó en na de kontroleperiode.

Toetsing der nulhypothesen $\mathrm{HO}-\mathrm{B} 1 \mathrm{t} / \mathrm{m}$ Ho-B10 zal plaats winden middels de t-toets voor éen variable en twee steekproeven paarsgewijs gematched. (afhankelijke steekproeven Spitz 1968 p. 308 )

Verwerping der nulhypothese zal plaats vinden indien de aldus berekende toetsingsgrootheid "t" signifikant is bij $a=0,01$ volgens een tweezijdige overschrijdingskans.

(Kritieke grenzen worden ontleend aan Pearson c.s. 1956)

C. Toetsing van aparte kriteria

Indien blijkt dat er bij een (of meer) wan onder B genoemde toetsingsprocedures verwerping van nulhypothese kan optreden zal er nagegaan worden in hoeverre er bij aparte $\mathrm{PO}$ - of GOCC-kriteria signifikante verschillen worden gevonden. Dit impliceert dat de PO- en de GOCC-scores in een dergelijk geval geen "voorbewerking* ondergaan zoals bij alle overige tot nu toe genoemde toetsingsprocedures.

Deze procedure lijkt voor Ho-B9 en Ho-B10 niet goed mogelijk aangezien de PO-kriteria waarop de $\Sigma_{1}^{*}$ PO [PO $\geqslant 3$ ] scores betrekking hebben gevarieerd zijn (zie verzameltabel). Een toetsing voor ieder $\mathrm{PO}$-kriterium apart wordt derhalve hierbij niet uitgevoend.

Ter toetsing van de verschillen per aparte kriteria werd uitgegaan van de volgende nulhypothesen.

Ho-C1: In de experimentele groep bestaat geen verschil in de gemiddelden van $\mathrm{GOCC}$-scores vóór en na de modifikatie indien deze per GOCC-kriterium apart worden bezien.

Ho-C2: In de experimentele groep bestaat geen verschill in de gemiddelden der PO-scores vóór en na de modifikatie, indien deze per kriterium apart worden bezien.

Ho-C3: In de kontrolegroep bestaat geen verschil in de gemiddelden der GOCC-scores vóó en na de kontroleperiode indien deze per GOCC-kriterium apart worden bezien.

Ho-C4: In de kontrolegroep bestaat geen verschil in de gemiddelden der PO-scores vór en na de kontroleperiode indien deze per PO-kriterium apart worden bezilen.

Toetsing der nulhypothesen Ho-C $1 \mathrm{t} / \mathrm{m} \mathrm{Ho-C4}$ zall plaats vinden door middel van de t-toets voor paarsgewijze matching (Spitz 1968, p. 308).

Aangezien door toetsing van de hypothesen onder B genoemd, de richting van de overschrijdingskans bekend wordt, zal bij de toetsing der C-hypothesen volstaan worden met een toetsing naar een eenzijdige overschrijdingskans.

Verwerping der nulhypothesen zal plaatsvinden indien de toetsingsgrootheid signifikant is bij $a=0,01$ éenzijdig.

\subsubsection{Toetsing der hypothesen}

Ter nadere verduidelijking van de toetsing der nulhypothesen worden de hiervoor gebruikte "voorbewerkte" getallen en de resultaten per toetsing in bijlage 7 
weergegeven. Alle hierin voorkomende getallen zijn de resultaten van de woorbewerking der cijfers uit de verzameltabellen (Bijlage 6) met uitzondering van de tabellen voor de C-hypothesen waarbij geen voorbewerking werd toegepast.

Het signifikantieniveau werd, evenals de kritieke grenzen, vermeld. Over het algemeen wordt in de sociale wetenschappen $\alpha=0,05$ gehanteerd, als zijnde voldoende voor toetsing der hypothesen. Aangezien uit de berekeningen bleek dat $\alpha=0,01$ een alleszins haalbaar niveau was, werd dit laatste kriterium gekozen.

\subsubsection{Bespreking der resultaten}

\section{Probleemassessment (Zie bijlagen 6 en 7)}

Vanuit de verzameltabel bijlage $6 \mathrm{kan}$ een globale indruk verk regen worden omtrent de afname van het probleemgedrag bij experimentele en kontrolegroep in procenten uitgedrukt. Als probleemgedrag werd gedefinieerd iedere score op een geheugen-en concentratietest van het psychologisch onderzoek welke groter was dan 3.0 punt-scores.

Gaande van patiënt 1 naar 12 blijkt bij de experimentele groep een afname van probleemgedrag in procenten van respektievelijk: $7,35,45,66,83,0,88,100,80,71$, 31, 50. Gemiddeld 48,5\%.

Bij de kontrolegroep blijkt in dezelfde volgorde een afname in procenten van 13 , $-11,40,-27,-25,-13,35,-25,-50,32,11,38$. Gemiddeld $10 \%$. („min"scores duiden op een toename van probleemgedrag.).

Globaal blijkt er bij de experimentele groep een ca. $5 \times$ zo grote afname van probleemgedrag in vergelijking tot de kontrolegroep. Het verschil tussen de probleemgedragscores van experimentele en kontrolegroep vóór en na de behandelings-resp. kontroleperiode komt eveneens tot uiting bij de statistische verwerking der resultaten (bijlage 7). Nadat gebleken is dat de Ho-A hy pothesen met verhoogd signifikantieniveau niet verworpen kunnen worden dus bij akseptatie van wergelijkbaarheid van experimentele en kontrolegroep, bleek dat de Ho-B9 hypothese kan worden verworpen. Dit impliceert akseptatie dat bij de experimentele groep de POscores, $\geqslant 3$, signifikant verschilden op de tijdstippen vóóren na de behandelingsperiode. De Ho-B 10 hypothese kan echter niet worden verworpen. Met andere woorden: het probleemgedrag verschilt bij de kontrolegroep niet signifikant indien men de scores vóór en na de kontroleperiode van 6 maanden vergelijkt.

\section{Procesassessment}

De procesassessment was bedoeld als voortgangsevaluatie van de gehele behandeling en ter feedback aan de patiënt en therapeut.

Zij levert ten aanzien van een statistische bewerking der resultaten geen extra informatie.

Hier wordt dan ook volstaan met de vermelding dat bij de 12 experimentele patiènten de totale modifikatiepoging in 6 maanden niet volledig was beëindigd. ledere patiënt toonde een verschillend tempo in het doorlopen van de training. Soms leek de visuele resp. de auditieve modaliteit sterker .aangetast". Dan weer bleek de recognitie-resp. de recall-training sneller te verlopen. Een aantal patiènten hadden zowell geheugen-als concentratietraining maar er waren eveneens patiënten die slechts een der beide programma "s hadden te doorlopen. Bovendien werd ook, juist bij deze langduriger behandelingen, de storende invloed ondervonden van ziektes, vakanties en personeelswisselingen. Al deze en andere faktoren maken onderlinge vergelijking inzake de duur van de behandeling en de doorlopen fasen niet goed mogelijk. In het algemeen echter hadden alle patiënten na genoemde 6 maanden de 
geheugentraining beeindigd woor korte termin, terwijl eveneens de concentratieoefeningen konden worden afgesloten.

\section{Efrektassessment (Zie bijlage 7)}

De statistische toetsing had met name betrekking op de effektassessment.

A. Hypothesentoetsing brachi als resultaat dat experimentele en kontrolegroep voor de behandeling resp. kontroleperiode vergelijkbat waren.

B- hypothesentoetsing bracht een zeer signifikant werschil naar voren tussen de scores van het psychologisch onderzoek bij de experimentele groep vór en na de behandeling. Dit verschil trad op, indien de $\mathrm{PO}$-scores gesommeerd werden over de patienten, mat eveneens indien de $\mathrm{PO}$-scores gesommeerd werden over de POkriteria zelf, per patient. De GOCC-scores tonen onder geen enkele voorwaarde een signifikant verschil hetgeen geinterpreteerd kan worden als het afwezig zijn van enige invloed van de betreffende training op gedragsexcessen. Deze interpretatie moet echter met de nodige omzichtigheid gehanteerd worden aangezien alle $\mathrm{GOCC}$-kriteria over het algemeen een betrekkelijke geringe score toonden voor alle groepen en kondities. Het genoemde verschil inzake PO-scores trad niet op bij de kontrolegroep. De sommatie van PO-scores over de $\mathrm{PO}$-kriteria per patiënt wettigt echter niet de uitspraak dat ieder $\mathrm{PO}$-kriterium voor het gekonstateerde verschil in gelijke mate mede aansprakelijk is. Deze sommatie op zich is trouwens op deze wijze alleen psychometrisch verantwoord, indien de resultaten slechts op beperkte wijze gebruikt worden, bijwoorbeeld ter verk rijging van een algeneen beeld, zoals bij de toetsing der B-hypothesen. Voor verdergatande konklusies dienen de scores per kriterium apart bezien worden.

C- hypothesentoetsing doef een uitsprak omtrent verdergaande konklusies. Drie van de getoetste zeven hypothesen kunnen onder handhaving van de gestelde kriteria niet verworpen worden.

Verwerping van de nuthypothese kon (onder soms zeer hoge signifikantieniveaus) optreden voor Hom C2 de kriteria RoV, RaV, T en $R$.

Met andere woorden visuele-geheugentests (recognitie en recall) en de tempoen regelmaat-kriteria van de concentratietraining leveren de hoogste bijdrage in het verschil in testscores bij de experimentele groep vergeleken voór en ma de behandeling.

\subsubsection{Samenvatting}

Ter evaluatie van de modifikantie procedure tot gedragsbehoud onder toenemende stimuluscomplexiteit werden een experimentele en kontrolegroep met elkaar vergelaken.

De groepen waren gematched naar zogenaamde „patiẻntengegevens" (als leeftujd, duur coma, tijd trauma tot opname, type contusio), 10 , geheugen en concentratiedelekten.

De experimentele groep werd aan het begin en het eind van de trainingperiode gescoord volgens de Gedragsobservatieschaal Contusio Cerebri (GOCC) en het psychologisch onderzoek ( $\mathrm{PO}$ ). De training duurde ca. 6 maanden en bestond unt de presentatio van "geheugenstimuli" en/ of "concentratiestimul" in toenemende complexiteit. De respons op deze presentatie werd per sessie geevalueerd.

De daruit verkregen gegevens fungeerden behalve als voortgangsevaluatie van de behandeling, als procesbegeleiding ter feedback aan de patiant en therapeut. 
De kontrolegroep werd samengesteld uit patiënten welke bij het ontslag geheugenen/of concentratiedefekten toonden. Beëindiging van fysieke revalidatie betekende voor patiënten uit de kontrolegroep, althans ten tijde van deze studie, eveneens beëindiging van het verblijf in het centrum.

Hoewel dit standpunt geleidelijkaan werd achterhaald, bracht deze positie met zich mee dat alleen op deze wijze een redelijk akseptabele kontrolegroep kon worden gevormd, die echter niet als gerandomiseerd mag worden beschouwd. Na verloop wan ca. 6 maanden na ontslag werden de patiënten uit deze kontrolegroep opgeroepen ter evaluatie van genoemde defekten.

Statistische bewerking van de GOCC-en PO-scores van experimentele en kontrolegroep van zowel vóór als na de behandelings resp. kontroleperiode, leidde tot de volgende bevindingen:

1e. De experimentele en kontrolegroep zijn vóór de behandeling wat betreft de GOCC- en PO-scores vergelijkbaar

2e. De experimentele groep als totaliteit bezien toont na de behandeling geen verbetering in GOCC-scores echter wel een duidelijke verbetering der $\mathrm{PO}$ scores

3e. De kontrolegroep als totaliteit bezien toont na de kontroleperiode geen verbetering in $\mathrm{GOCC}$ - en $\mathrm{PO}$-scores.

4e. De PO-kriteria, getoetst bij de experimentele groep, tonen een signifikant verschil (vóór en na de behandeling) bij de visuele geheugen tests en bij het tempo en regelmaataspekt der concentratietests. De owerige PO-kriteria tonen eveneens een verschil ündien de scores voór en na de behandeling worden vergeleken. Dit verschil is echter niet signifikant.

Op grond van deze bevindingen kan men konkluderen dat het in deze studie gepresenteerde onderzoek inzake het behoud van gedrag onder toenemende stimuluscomplexiteit bevredigende resultaten opleverde en perspektieven opent voor verdere research.

Bij twee groepen patiënten met contusio cerebri die wat betreft probleemgedrag en psychologische funktiestoornissen vergelijkbaar geacht kunnen worden, lijkt een geheugen- en concentratietraining effekt te sorteren. De groep waarop deze training gedurende 6 maanden werd toegepast toont in vergelijking met de niet getrainde groep betere prestaties op geheugen- en concentratietests.

In hoeverre deze verbeterde prestaties ook tot uiting zullen komen in gedrag buiten de trainings- en testsituatie zal door voortgaande research moeten worden aangetoond. 
HOOFDSTUK 4

\section{HERORIENTATIE}




\subsection{Assessment}

\subsubsection{Inleiding}

In hoofdstuk 3 werd de uitvoering van modifikatietechnieken getoetst. Deze toetsing kon in verband met de heperkte kontrole slechts betrekking hebben op de modifikatie van enkele gedragstekorten en excessieve gedragingen. Na de signalering van diverse hiaten in de assessment en de gebleken problemen bij de empirische toetsing zal nu bezien worden in hoeverre aanvullende literatuur andere of betere richtlijnen heeft te bieden.

De twee volgende vragen dienen hierbij als leidraad:

A. Is het mogelijk een verbetering te realiseren in assessmentprocedures? Hierbij wordt gedacht aan de eerder gesignaleerde lacunes, het benutten van verscheidene situaties welke informatie zouden kunnen opleveren en het streven naar met name een systematische exploratie aan de hand van een valide taxonomie.

B. Is het mogelijk een verbetering te brengen, in de tot nu toe toegepaste modifikatieprocedures? Kan modilikatie van gedragsdeviaties ook gerealiseerd worden in verschillende milieus?

Bij de weergave van deze publikaties zijn de volgende punten van belang:

1e. De specifieke literatuurgegevens betreffende contusio cerebri bleken slechts zeer beperkt aanwezig. Derhalve werd het te exploreren literatuurgebied uitgebreid tot cerebrale stoornissen met als deelgebieden: contusio cerebri, linker-hemisfeerstoornissen, rechter-hemisfeerstoornissen, de kombinatie van linker-en rechter-hemisfeerstoornissen, de „minimal brain damage” in relatie tot leerstoornissen, cerebral palsy, en mentaal geretardeerden.

Het krïterium voor deze samenstelling is dat alle genoemde patiëntengroepen gedragstekorten en gedragsstoornissen tonen tengevolge van een veronderstelde cerebrale aandoening. Het referentiekader hierbij was primair gedragspsychologisch en wel toegespitst op assessment en modifikatiemogelijkheden onafhankelijk van het feit of het defekt het gevolg is van aangeboren of verworven aandoening. Het samen nemen van een dergelijke populatie met een ogenschijnlijk zo gevarieerd beeld wordt door diverse auteurs onder zekere voorwaarden akseptabel geacht. Zo rechtvaardigt Rosinski zijn studie van een nog meer heterogene "severelly disabled" patiëntengroep bestaande uit o.a. hemiplegieën, epileptici en amputatiepatiënten, als volgt: .I am using the term disabled to allude a client's level of functional impairment not his disability cathegory e.g. paraplegic, amputee, epileptic. This category includes multiply handicapped persons usually manifesting a high degree of intellectual impairment because of organic damage who have problems with sensory input/output. Most of these clients would fall into the severe to moderate range of mental retardation as defined in the Diagnostic and Statistical Manual of Mental Disorder (DSM II 313-314) and have corresponding verbal, social and performance deficiencies" (Rosinkski 1975 p.302)

2e. De publikaties worden gerubriceerd volgens de in hoofdstuk 2 voorgestelde indeling naar "situatie", waarin de gedragsdevwaties werden vastgesteld en naar de „aard" van deze gedragsdeviaties zelf. Dat wil zeggen:

a. Naar situatie:

Premorbide situatie (situatie vóór opname).

Klinische testsituatie (gestandaardiseerde situatie).

Klinische observatiesituatie 
Nabehandelingssituatie (overgangssituatie van kliniek nat ontslag)

Thuissituatie (ook well "nazorg" genoemd)

b. Het onderscheid naar gedragsdeviaties bleef gehandhatd:

Gedragstek orten en Gedragsbelemmeringen.

Teneinde een indruk te geven van de frekwentie van voorkomen der artikelen per deelgebied wordt verwezen naar onderstaande tabel.

Tabel 10: Overzicht literatuur per deelgebied uit Rehabilitation Abstracts 1973-1976. Assessment/gedragstekort

\begin{tabular}{|l|r|r|r||l|l|l|r|}
\hline situatie & alg. & LH/RH & LH + RH & MBD & CP & MR & Tot. \\
\hline premorbide & 3 & & & & & & 3 \\
klinisch test & 18 & $5 / 0$ & 9 & 39 & 13 & 1 & 85 \\
klinisch obs. & 8 & $3 / 1$ & 2 & 3 & 3 & 4 & 23 \\
mabehandeling & 3 & & 1 & & 3 & 2 & 9 \\
thuis & & & & & & & \\
totalen & 32 & $8 / 1$ & 12 & 42 & 19 & 7 & 120 \\
\hline
\end{tabular}

Assessment/gedragsbelemmering

\begin{tabular}{|l|c|c|c|c|c|c|c|}
\hline situatie & alg. & LH $/$ RH & LH + RH & MBD & CP & MR & tot. \\
\hline $\begin{array}{l}\text { premorbide } \\
\text { klinisch test } \\
\text { klinisch obs. } \\
\begin{array}{l}\text { nabehandeling } \\
\text { thuis } \\
\text { totalen }\end{array}\end{array}$ & 4 & $2 / 1$ & 3 & 7 & 1 & 3 & 21 \\
\hline
\end{tabular}

Kodes:

alg = algemeen, d.w.z. onder alle kategorieèn te plaatsen

LH = linker-hemisfeerstoornis

$\mathrm{RH}=$ rechter-hemisfeerstoornis

$\mathrm{LH}+\mathrm{RH}=$ zowel toepasbar op linker-als rechter-hemisfeetstoornis

$\mathrm{MBD}=$ minimal brain damage

CP $\quad=$ cerebral palsy

MR = mental retardation

Voor eenzelfde overzicht inzake modifikatie wordt verwezen naar 4.2.1.

Uit voorafgaande literatuurtabel blijkt:

1e Het merendeel der beschikbare literatuur heeft betrekking op de assessment van gedragstekorten in klinische test-en klinische obserwatiesituaties.

2e. Slechts een klein aantal heef betrekking op de assessment van gedragsbelemmeringen in de klinische observatiesituatie.

3e. De overige deelgebieden komen in de literatuur nauwelijks voor.

Niet alle publlkaties zullen in deze rapportage worden opgenomen. Slechts die artikelen welke een duidelijke eigen en toepasbare strategie tonen en aansluiting bieden tot het in deze studie voorgestelde leertheoretisch denkkader zullen worden gepresenteerd en van enig kommentaar worden voorzien. 


\subsubsection{Assessment van gedragtekorten in de premorbide situatie}

Tijdens het revalidatieproces zal het beeld van het nog aanwezige gedrag en het nieuw aan te leren gedrag langzaam duidelijker worden. Het is van belang om na te gaan welke gedragsveranderingen de patiènt moet gaan leren en op welke wijze dit het best kan worden gerealiseerd.

Volgens Fordyce (1971-1) zal iedere handicap meebrengen dat bepaalde gedragsaspekten van de patiënt gekenmerkt zullen gaan worden door lage frek wentie, lage sterkte en lage waarde. Naarmate het vroegere gedrag meer lijkt op datgene wat hem na de handicap nog resteert, des te minder groot is de aanpassing die vereist wordt, des te minder is de kans op gedrag van lage frekwentie, sterkte en waarde en des te kleiner is de kans op gedrag dat nieuwe gedragsvorming tegengaat.

Het is daarom van belang om voor diverse situaties in het verleden (rekreatie, vrijetijdsbesteding, school, studie, werk) na te gaan:

1e. welk gedrag patiënt in al deze situaties regelmatig uitvoerde.

2e. welk gedrag patiënt niet of zelden ten uitwoer bracht.

$3 \mathrm{e}$ welk gedrag door patiënt in de toekomst moet worden gerealiseerd.

4e. hoever dit nieuwe gedrag "verwijderd" ligt van het oorspronkelijke gedrag vóór de handicap wat betreft frekwentie, intensiteit en waardering.

5e. welke bekrachtigers er nodig zijn om het opnieuw aanleren van gewenst doelgedrag mogelijk te maken.

De manier om bekrachtigers te vinden kan bestaan uit observatie van het gedrag van de patiënt in de kliniek, bij het psychologisch onderzoek of indirekt door observatie en navraag bij ramilieleden.

Fordyce (1971-1. p. 183) wijst erop dat er bovendien aanvullende informatie verkregen moet worden van vroegere modellen (ouders en vroegere vrienden) om gedragstekorten c.q. mogelijke blokkeringen bij ged ragsworming en bekrachtigende kondities vast te stellen. Persoonlijkheid en wijze van zelfexpressie zijn - aldus Fordyce - geleerd door een kombinatie van invloeden van (a) konsek wenties vanuit de ongeving, waarin het gedrag optrad, en (b) van het sociaal imitiatieleren. Veel van het gedrag van ouders en vrienden zal in het gedragsrepertoir van de patiënt opgenomen zijn, maar ook zullen zij bepaalde gedragingen van de patiënt bekrachtigd hebben. De keuze van hobby's, werk, boeken etc. van ouders en vrienden van patiënt zal datgene reflekteren wat zij bekrachtigend vinden voor zichzelf. Als er redelijk kontakt heeft bestatan tussen patiënt en zijn modellen, kan men aannemen, dat het gedrag van de patiënt veel van het gedrag of de stijl van de modellen zal reflekteren. Het verdient derhalve aanbeveling de vrijetijdsbesteding en het werk van degenen, die als achtergrond van de patiênt hebben gefungeerd mede in het vooronderzoek van de behandeling te betrekken.

Er is een systeem nodig om de informatie van patiênt en modellen te organiseren en te synthetiseren. De methode die Fordyce daartoe presenteert laat vrijetijdsaktiviteiten en beroepsaktiviteiten in drie klassen uiteenvallen:

1e. Symbool-gecentreerde aktiviteiten betrokken op ideeẽn, conceptgebruik, getallen en woordgebruik.

Vrijetijdsvoorbeelden: lezen, gokspelen, politieke diskussies e.d.

Beroepsvoorbeelden: boekhouden, administratief werk, komputerprogrammering.

2e. Motorisch manipulatief gecentreerde aktiviteiten betreffende de interesse en vaardigheid in de manipulatie van objekten en fysieke bewegingen.

Vrijetijdswoorbeelden: atletiek, tuinieren, aktiviteiten op het platteland.

Beroepsvoorbeelden: fysieke arbeid, werken met gereedschap en machines. 
3e. Interpersoonlijk gecentreerde aktiviteiten betreffende belangstelling en vaardigheid in allerlei sociale kontakten en werkzaamheden.

Vrijetijdsvoorbeelden: visites afleggen, club-bezoek, kaarten e.d.

Beroepsvoorbeelden: verkoper, onderwijzer, counselor, receptionist.

Het organiseren van informatie over patiènt en zijn modellen in termen van relatieve beklemtoning van deze kategorieën zal - aldus Fordyce - voor het behandelingsteam bruikbare gegevens leveren.

In concreto betekent dit dat vóor, maar vooral ook tijdens de opname van patiënt, zowel van hemzelf als van zijn modellen gegevens moeten worden verzameld van frekwentie van voorkomen, intensiteit en waardering van alle bovengenoemde aktiviteiten.

Uiteraard moet een dergelijk systeem verder worden uitgewerkt, maar het lijkt in principe mogelijkheden te bieden voor het verkrijgen van informatie inzake gedragstekorten en bekrachtigende kondities. In hoofdstuk 5 zulien deze ideeën nader worden uitgewerkt tot een werkmodel.

\subsubsection{Assessment van gedragstekorten in de klinische testsituatie}

\subsubsection{Probleemstelling}

Het onderzoek van gedrag in de testsituatie leidt er vrij snel toe gekonstateerde gedragstekorten te relateren aan hypothetische konstrukties die afhankelijk van het desbetreffende referentiekader „funkties", „systemen", „, operaties", ., leervoorwaarden" e.d. genoemd worden. Men komt echter voorlopig niet veel verder dan hypothetische konstrukties. Dit wordt door Ross alsvolgt omschreven:

.The moment the psychologist departs from a description of the observable stimulus respons events, and draws inferences about mediating processes, he is dealing with hypothetical constructs which are no more than explanatory devices, adressed to how a patient's central nervous system might operate. These hypothetical constructs however, based as they are on correlations between input and output, permit inferences about functions and not about structure. We know far too little about the anatomical basis of these functions to permit generalizations from for example disturbed integration to the presence of braindamage" (Ross 1966)

Deze bescheiden gedachtengang geeft aanleiding tot de volgende owerwegingen:

1e. Kan men uitgaande van leertheorie met name vanuit het operante paradigma verantwoord en vruchtbaar gaan werken met deze hypothetische konstrukties onder negatie van het anatomisch substraat?

2e. Indien het antwoord bevestigend is, $k$ an men dan een keuze doen uit de diverse hypothetische konstrukties? Hierbij zal een belangrijk kriterium moeten zijn in hoeverre het mogelijk is om vanuit het gekozen systeem een praktische diagnostiek op te bouwen.

3e. Dit laatste leidt tot de vraag: Is het noodzakelijk binnen het eenmaal gekozen konstruktiemodel nog aanvullingen te verrichten? Moeten er binnen dit model nog keuzen gemaakt worden? Zijn de hypothetische konstrukties vanuit het model voldoende operationeel gedefinieerd en instrumenteel realiseerbaar?

4e. Is het mogelijk vanuit de diagnostiek rond defekten in hypothetische konstrukties wan psychisch funktioneren, defekten te signaleren waarop een werkbare modifikatiestrategie toepasbaar is, die toch blijft uitgaan van de manipulaties volgens operante principes?

Dit zijn slechts enkele vragen, die men automatisch gepresenteerd krijgt, indien men de euvele moed heeft de Black Box binnen te gaan. Er zijn er meer denkbaar. 
In het onderstaande zal getracht worden op de $1 \mathrm{e}, 2 \mathrm{e}$ en $3 \mathrm{e}$ vraag antwoord te geven. De vierde overweging lijkt meer thuis te horen in die paragraaf (4.2) waar de modifikaties aan de orde komen.

Vraag 1. Kan men vanuit het operante leermodel zich verantwoord bezig houden met de hypothetische konstrukties?

Ullman en Krasner (1969 p. 573-585) stellen dat hersenstoornissen behoren tot onderzoek en behandeling vanuit het ziektemodel waarbij men zich dan heeft af te vragen in hoeverre het hier voorgestelde operante model enige inbreng heeft bij assessment en modifikatie hiervan.

Uit de kontakten met Fordyce W.E. kwam zijn visie inzake funtierestauratie en-assesment duidelijk naar voren: "I don"t think of our restoring a patient memory functioning! I think of it as restoring his recall of how to do such and such a task. In the context of braindamage, memory for example is not in my opinion a general trait or function. Ir you help a patient to get better at one kind of memory task, that improved skill is not likely to generalize to other memory tasks, unless those other tasks are virtually identical to the one about which you trained him. Therefore "functional restauration" consists of identifying functions or tasks to be performed and then setting up precision teaching programs to help them master those tasks". Diller L. veageerde in deze als volgt: "Your approach based on the combination of behavior modification, skill training and functional restauration is realistic. Behavior modification in itself is often insufficient in the care of brain damaged people".

De weinig Nederlandse onderzoekers die zich met dit gebied enigermate bezighouden waren, althans in 1976, niet veel verder dan enkele globale ideeën inzake diagnostiek, therapie of programmaformulering zonder overigens een duidelijke basis, inzake methodieken ten behoeve van fundamentele research. Deelman was reeds in 1970 de mening toegedaan dat gedragstherapie in kombinatie met neuropsychologie een ideale aanpak zou kunnen vormen voor de behandeling van hersenstoornissen. Een verdere specificatie wordt hierbij echter niet gegeven. „Het raaiste zou een integratie van neuropsychologische en gedragstherapeutische inzichten zijn" (Deelman 1970 p. 30)

Ook Schuerman komt in 1975 niet veel verder dan tamelijk globale konklusies: „Er bestaat een dringende noodzaak tot uitbreiding van de revalidatiediagnostiek. Indien een volledig in kaart brengen der funkties volgens een cybernetisch model niet mogelijk blijkt, zal het wellicht toch goed dienst kunnen doen als referentieframe. Voorlopig lijkt echter een fragmentarische aan pak het enige haalbare (...). Inzake therapeutische interventies kan gesteld worden dat kontrakt-management en in het algemeen gedragstherapeutische benadering volgens het operante paradigma duidelijke mogelijkheden bieden in de revalidatie" (Schuerman 1975 2 pg. 227-251).

Diamant (1976) als een der weinigen in Nederland die trachten gestoorde .funkties" bij psychiatriepatiënten te diagnosticeren en te revalideren stelt: „We zijn wel met Schuerman van mening, dat het cybernetisch model en de leertheorie waardevolle bijdragen kunnen leveren tot de funktiediagnostiek en funktietraining"."

Zoals uit bovenstaande citaten blijkt, zijn er zowel voor-als tegenstanders t.a.v. de mogelijke toepassingen van het operante model te signaleren. Het standpunt dat hier ingenomen wordt is, dat de leertheorie en met name het operante model, wel degelijk mogelijkheden biedt, mits het nog nader te bepalen hypothetische konstruktiemodel leidt tot in de praktijk toepasbare operante technieken, met name wat betreft de te presenteren stimuli, o.a. inzake hun aard, inhoud en volgorde van presenteren. Door 
deze manipulaties dient het hypothetische model in zijn totaliteit getoetst en eventueel herzien te worden.

Wraag 2. Is het mogelijk tot een keuze te komen inzake het model resp. inzake de hypothetische konstrukties binnen dit model?

Yates (1976) heeft getracht een overzicht samen te stellen van de bijdragen van psychologen in de diagnostiek van hersenstoomissen. Hij komt tot de konklusie dat in de jaren 1960-1964 meer dan 700 referenties te vinden zijn, die betrekking hebben op het psychologisch onderzoek van de effekten van hersenbeschadiging bij kinderen en volwassenen.

ilndien men een gemiddelde van 200 per jaar aanneemt, dan $z i n$ er, extrapolerend tot 1976, ca. 2000 publikaties bijgekomen. Ook hier rijst de vraag waar te beginnen en hoe het kaf van het koren te scheiden.

Diller (1971 - p. 1) spreekt in dit verband dan ook over "sensory cognitive and motor performance cover many fields of inquire. They are in themselves interdisciplinary fields in a state of fux being swept along in the present information explosion!" Hij besluit echter (p. 26) „The translation of the traditional neurlogical and psychological concepts into information processing systems in just around the corner".

Hieruit spreekt toch een zekere hoop, zij het dat deze gerealiseerd moet worden door een „informatieverwerkend systeem".

Diamant (1975) komt eveneens op een informatieverwerkend systeem uit: „In order to come further in the behavior analysis of the underlying brain functioning a more systematic approach is needed based on the general information theory".

Yates (1970) geeft aan hoe een informatieverwerkend systeem van invloed kan zijm op een adek wate feedback en als zodanig bekrachtigend $k$ an werken op een bepaald gedrag.

Van der Linden (1975 p. 614) stelt in zijn artikel over de diagnostiek van leerstoornissen bij kinderen: „De vergelijking met een cybernetisch model dringt zich aan ons op".

Fordyce (1971 p. 190 e.v.). The most likely functional consequence of braindamage is reduction of learning efficiency. Functional impairment in learning resulting from braindamage may occur at any of a number of points in the cyclus of mental processes going into learning". Hij noemt achtereenvolgens" „difficulties in receiving and processing information, in assimilating or retaining that information, in association it with previously acquired information or in retrieving it as effective memory to influence subsequent behavior ${ }^{\prime \prime}(\ldots)$. . These diffoulties in exercising quality control on their own behavior seem to be related to deficits in processing informational feedback from their own behavior or in maintaining alertness" (p. 192)

Schroots (1972-1 p. 334): Verlat men een ogenblik het idee dat gedrag dinekt te vertalen zou zijn in neuro-anatomische strukturen, dan stuit men direkt op een benadering welke in de experimentele psychologie zeer vruchtbata is gebleken, $n$. het CZS opgevat als een Information Processing System".

Snelbecker (1974): "This study is one of a series in which operant research equipment and techniques combined with in lormation theory findings are used in an experimental analys"s of human information processing of auditory stimuli."

Uit bovenstaande moge duidelijk zijn, dat althans een aantal auteurs perspektief zien in "een informatieverwerkend systeem". Met het noemen van deze welluidende betiteling is echter nog geen oplossing geboden. Dit blijkt pas mogelijk indien binnen dit systeem een aantal operaties genoemd kunnen worden, die een goede 
inhoudsvaliditeit bezitten, redelijk testbaar zijn en aansluiting bieden voor gedragsvorming geindiceerd vanuit de testsituatie.

Pas dan kan met recht gesproken worden van "funkties" en eventueel "funktierestauratie".

Hierdoor wordt in feite de derde probleemstelling onder de aandacht gebracht.

Vraag 3: Zijn de in het model genoemde hypothetische konstrukties voldoende operationeel gedefinieerd zodat instrumentele realisering mogelijk is?"

Deze laatste vraag zal in de navolgende paragrafen worden behandeld. Uit de literatuur inzake assessment van gedragstekorten in de testsituatie werden twee "Wijnen" geselekteerd. De auteurs in deze zijn afkomstig uit verschillende disciplines, nl. de neuropsychologie (Mark H. J.) en de cognitiepsychologie (Guilford). Meer dan anderen gaan zij gedetailleerd in op hun hypothetische konstrukties en dragen zij empirische toetsing aan. Dat wil niet zeggen dat de bijdragen van andere scholen minder waardevol zijn. Men denke bijwoorbeeld aan Luria (1966) „grand old man" van de Russische neuropsychologie, revalidatiepsycholoog van het eerste uur en Reitan $(1966,1968,1969)$ met de ont wikkeling van de Hallstead-Reitan neuropsychologische testbatterij, die vanuit het prediktie-uitgangspunt (testuitslaghersenstoornis) onovertroffen mag heten. Ook de publikaties vanuit de orthopedagogische hoek, zoals Dumont (1973), Kephart (1971), Cruickshank (1972) en vele anderen kunnen in dit kader genoemd worden. Het zijn alle pogingen een antwoord te vinden op dezelfde problematiek $\mathrm{nl}$. een poging tot overzichtelijkheid in diagnostiek.

Niet alle auteurs kunnen binnen deze studie behandeld worden. Overigens dient hier uitdrukkelijk en vooraf gesteld te worden, dat ook de theorieën van Mark en Guilford niet uitputtend vermeld kunnen worden, hetgeen wellicht in zeker opzicht afbreuk doet aan hun totale gedachtengang.

Vanuit de gestelde noodzaak tot en interesse in operationele definitie en instrumentele realisering zullen de ideeên van Mark en Guilford slechts weergegeven worden voorzover deze betrekking hebben op de konkretisering van de onderdelen van het informatieverwerkende proces:

Input- Hypothetische konstrukties in de Black Box-Output.

Wat de overige auteurs betreft: $B$ ij alle genoemde theoretici treft men denkbeelden aan, die de ideeèn van Mark en Guilford partieel ondersteunen.

Binnen het kader van deze studie, die niet meer pretendeert dan het signaleren van een beperkt atantal der mogelijke benaderingen, is de behandeling van andere stromingen eigenlijk niet goed mogelijk.

\section{4,1.3.2. De neuropsychologische benadering wan Mark}

Een belangrijke reden voor het geringe sukses dat men bij de psychodiagnostiek van leerstoornissen geboekt heeft, is - aldus Schroots (1974 p. 8) - het feit dat men het CZS vaak met een te simpel ".input-black box-output-model" benaderd heeft en dientengevolge de geweldige complexiteit van kommunikatiekanalen (modaliteiten) en systemen (funkties binnen elk kanaal, die tesamen het informatieverwerkend systeem vormen, de zgn. black box), ernstig heeft onderschat. Men liep te argeloos voorbif aan het feit dat een specifieke leerstoornis door een verscheidenheid aan disfunkties in het informatieverwerkende systeem veroorzaakt kan worden. Aksepteert men eenmal dat de hersenen het meest complexe orgaan vormen en dientengevolge een informatieverwerkend systeem als model hiervan, eveneens zeer complex van aard moet zijn, dan zal men op zoek gaan naar een theorie of model, welke recht doet an deze complexiteit". 
Luria (1966) bepleit, alls voorloper, het onderscheid en de bestudering van een drietal hoofdsystemen"

a. De regulering en stabilisatie van het energie-niveau (arousal). Concepten als sinhibitie-zwakte" en "excitatie" hiken hierin te kunnen passen (zie o.a. Ansink 1974),

b. Het funktionele systeem dat betrekking heeft op de regulering van de andacht. c. Het systeem dat zorgt voor de analyse, kodering en opslag van de informatie.

Deze uitganspunten van Luria zijn zeer verhelderend. De reden waarom Luria minder dan Mark en Guilford in deze studie zal worden betrokken, wordt gevormd door het feit dat Luria bezig is met de ontwikkeling van nieuwe onderzoeksinstrumenten, terwijl Mark en Guilford uitgaan van bestaande en derhalve beschikbare tests. Bovendien ligt bij Luria hel aksent op het substraat d.w.z. op de anatomie en de fysiologie van het CZS. Bij Mark en Guilford daarentegen op het gedrag, hetgeen derhalve betere aanknopingspunten biedt voor het therapeutisch handelen. Om dit laatste is het in de diagnostiek tenslotte begonnen.

In deze studie wordt mede door de gedachtengang van Luria, Mark en Guilford het standpunt ingenomen dat er ter nadere bestudering der informatieverwerking minimaal twee ,indelingen” denkbaar zijn.

1.e. De indeling, die betrekking heeft op gedragsregulatic: het tot gedrag komen, gedragsstabilisatie, gedragsafremming, maar ook gedragskontinuering en ged ragstempo.

2e. De indeling die betrekking heeft op de organisatie, de analyse de kodering en opslag van de gedragsinformatie.

Aangezien noch Mark noch Guilford zich, voorzover bekend, uitputtend bezig houden met de gedragsregulatie en Luria met zijn nieuwe testontwikkeling niet gereed is, dient deze taxonomie verder te worden afgewacht.

In het onderstaande valt derhalve het aksent op de organisatie van informatie.

Henry Mark's leertheorie richt zich met name op deze organisatie en doet volledig recht aan de complexiteit (Mark 1962) zoals hierna volgend zal worden aangetoond. Voor het , lerende" organisme, d.w.z. voor het leergedrag postuleert Mark een a antal noodzakelijke leervoorwatarden, welke hij "operaties" noemt. Onder operatie verstaat Mark de aktiviteit van de zenuwcellen, die in zijn simpele vorm bestaat uit het met elkaar in verband brengen van afzonderlijke informatie-eenheden. De mate nu waarin deze verbanden tot stand kunnen worden gebracht, dus het aantal en de snelheid van relatievorming, zou het leervermogen van het organisme bepalen. Ahankelijk van de plalats van het organisme op de phylogenetische ladder en/of het ontwikkelingsstadium, watarin het zich bevindt, zujn ingewikkelder en snellere operaties mogelijk. Mark onderscheidt de volgende operaties:

1e. Het tot aktiviteit komen van het organisme (het eerste indelingsprincipe)

2e. De mogelijkheid om nieuwe informatie te organiseren inzake uitwendige omgeving, alsook omtrent eigen handelen.

3e. Het vermogen om georganiseerde informatie te gebruiken bij het zoeken naar "antwoorden" op deze stimuli, vragen of problemen welke door de omgeving gesteld worden of binnen het organisme rijzen.

4e. Het in staat zijn tot het verzamelen, resp. het herinneren van antwoorden en oplossingen t.a.v. onder punt 3 genoemde probleemstellingen.

se. Het vermogen beschikbare informatie (over eigen omgeving of eigen funktioneren) te gebruiken tijdens een proces warbij nieuwe kombinaties beschikbare informatie uitgevonden worden of beschikbaar komen. 
Deze vif verchillende soorten operaties worden door Mark in 34 verschillende suboperaties onderscheiden. Kenmerk van een goede theorie is, dat zij de mogelikheden schept tot toetsing wan gedrag gepresenteerd in de hypothetische konstrukties. Voor Mark s leertheorie betekent dit dat de verschillende operaties c.q. neurofysiologische processen vertaalbaar moeten zijn in temen van toetsbaar of observeerbar gedrag. Deze gedragstermen worden door Mark systemen" genoemd en gepresenteerd in een matrix bestaande wit 34 systemen, gezamenlijk aangeduid met de term "kontrolesysteem" (zie fig. 4).

Fig. 4 Kontrole-systeem Hierarchie

\section{OPERATIES}

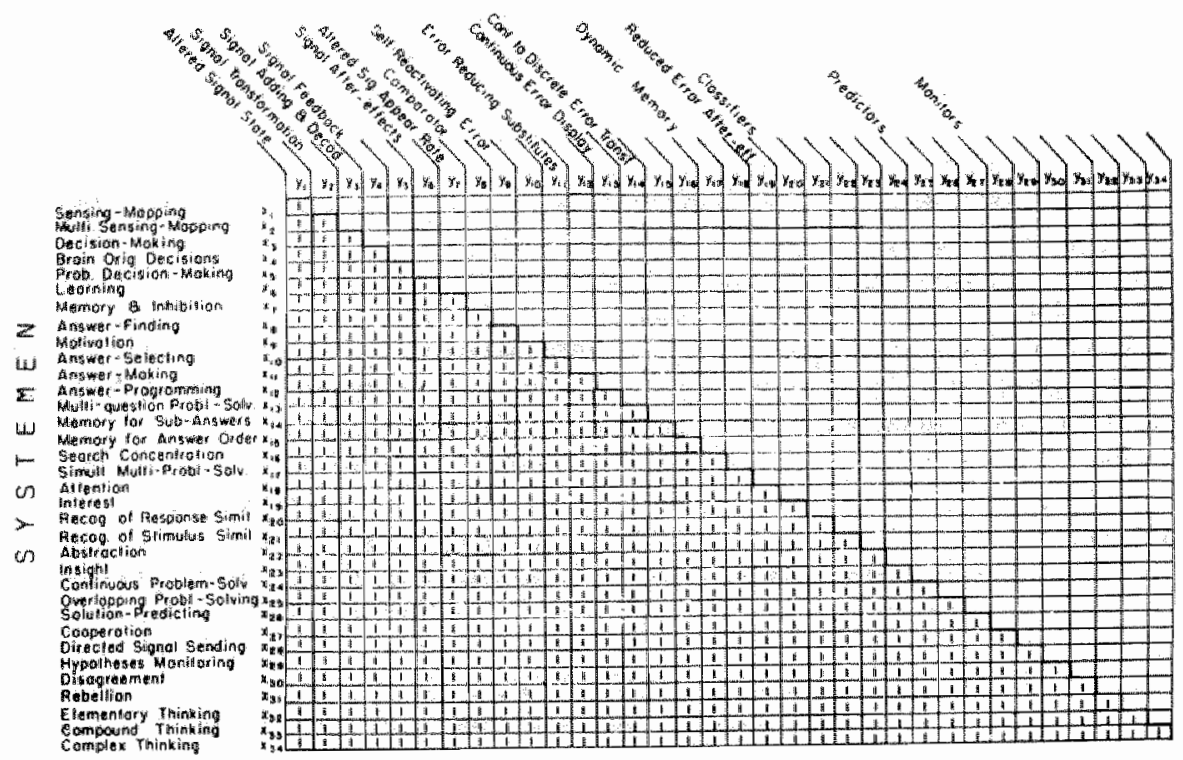

Hierbij wordt verder aangegeven dat er geen specifieke input/output modaliteit vereist is, d.w.z. binnen elk leerkanaal treft men dezelfde verzxmeling van systemen an. Een leerkanaal is ieder receptor, effector systeem zoals bijvoorbeeld: auditieve input - informatieverwerking - anditieve output - auditieve feedback.

Een verder kenmerk van het kontrolesysteem volgens Mark is zijn hiërarchische opbouw. Indien een systeem $x_{1}$ met operatie $y_{1}$ korrespondeert; systeem $x_{2}$ met operatie $y_{1}$ en $y_{2}$ : systeem $x_{3}$ met operatie $y_{1} y_{2}$ en $y_{3}$; dan kan door kontrole van $x_{3}$ nagegatan worden of operatie $y_{1} y_{2}$ en $y_{3}$ funktioneren. Indien dit niet juist is volgt kontrole van $x_{2}$ die dan informatie geeft omtrent operatie $y_{1}$ en $y_{2}$ enz.

Sukses op niveau $x_{n+1}$ is hierbij ook afhankelijk van de output, gegenereerd door het laatste $y$-as mechanisme ook wel "brain factor" genoend van $x_{13}$ Onder een mechanisme verstat Mark de verzameling operaties, waarbij de output van de eerste operatie gevoed wordt in de tweede operatie (input), de output van de tweede in de derde enz. 
Het voordeel van een dergelijke hiërarchie is dat zeer snel gekontroleerd zou kunnen worden of een bepaald systeem naar behoren funktioneert. Men toetst daartoe door middel van een zgn. gedragstest, het systeem in een bepaald kanaal en op een bepaald niveau. Treft men daarbijeen disfunktie aan dan kiest men een lager niveau. Als het getoetste systeem goed funktioneert zouden - aldus Mark - alle hièrarchisch woorafgaande systemen eveneens goed funktioneren. Indien met de theorie tegenstrijdige resultaten gevonden worden is herziening van de hiërarchie noodzakellijk. Wat dat betreft vormen de testresultaten tevens een kontrole op de validiteit van de betreffende hiërarchie. Bij het menselijk organisme kan men een groot aantal receptor-effektor-systemen of kombinaties daarvan onderscheiden. Binnen ieder receptor-effektor-systeem, door Mark aangeduid met de term "kanaal" funktioneert het eerder beschreven kontrolesysteem (van 34 systemen in relatie met 34 neurofysiologische operaties).

De informatie-input wordt volgens Mark gekenmerkt door de modaliteit en de context.

Modaliteiten zijn: auditief, visueel, kinestetisch, taktiel enz. In termen van Mark is die context in een ontogenetische hiërarchische volgorde te onderscheiden in "picture language", "gesture language”, „spoken language”, ,recorded language” en "mathematical language". Er zou in principe rekening mee moeten worden gehouden dat in een bepaalde modaliteit verschillende context "soorten" kunnen worden gepresenteerd. Er is bijvoorbeeld sprake van "visueel picture" - language, "visueel gesture" - language en "visueel recorded" - language, e.d.

De output wordt door Mark onderscheiden naar Gross-Motor, Fine Motor en Speech Motor responsies.

De kombinatie input-modaliteit, input-context en output vormt dan een kommunikatiekanaal. Mark onderscheidt op deze wijze 24 kanalen waarbij hij overigens wel aangeeft dat het ene kanaal belangrijker is dan het andere.

De verzameling van kanalen en systemen binnen deze kanalen wordt door Mark aangeduid met de term gedragsklassifikatieschema.

Naast de mogelijkheid tot gedetailleerde operationalisatie van zijn theorie kunnen aan Mark's gedragsklassilikatie drie belangrijke aspekten worden onderkend.

a. Een eindige verzameling van stoornissen.

b. Iedere stoornis uit deze verzameling kan beschreven worden in termen van de theorie zelf.

c. Door Mark werd een tijdschaal toegevoegd die aangeeft wanneer een bepaald systeem in chronologische volgorde tot ontwikkeling komt. Wanneer een kind van bepaalde leeftijd deze ontwikkeling niet toont, zou van een leerstoornis sprake kunnen zijn.

Wanneer men de eerste publikaties van Mark (1962) vergelijkt met zijn latere (1969) en tenslotte met zijn lezingen voor TNO (Schroots 1972) dan blijkt dat in de loop der jaren het aantal systemen aanzienlijk werd gereduceerd en geleidelijk aan meer en meer een terminologie werd gebruikt die aan de psychologie is ontleend i.p.v. aan de informatica. Ook het aantal belangrijke kanalen blijkt gereduceerd te zijn.

Vraagt men zich af wat in de loop der tijd van de theorie van Mark is overgebleven, dan blijkt dat bij hemzelf de belangrijkste elementen hebben stand gehouden.

1e. De aanwezigheid van systemen, hiërarchisch geordend, wat betreft hun ontogenese, alsook wat betreft hum bijdrage aan operaties tot uiting komende in het gedrag.

2e. De aanwezigheid wan de hiërarchische systeemstruktuur in ieder kanaal zowel unimodaal als bimodaal. 
3e. Een pogen tot onderscheid maken in de context van de input alsook in de context naar output.

\subsubsection{De cognitief-psychologische benadering van Guilford}

Mark lijkt zich voornamelijk bezig te houden met de disfunkties wan jonge kinderen tot circa 45 jaar. Ongeweer tot het niveau warop het kind toe is a an drie-woordzinnen. Voor inzicht in de cognitieve funkties zoals deze worden aangetroffen bij de volwassenen biedt het werk van Guifford meer perspektief. Zijn langdurige en intensteve faktoranalytische bewerking wan honderden psychologische onderzoekmethoden leverde gedegen grondmaterial woor de konstruktie van een taxonomie van cognitieve funkties.

In zijn, Analysis of Intelligence" (1971) bracht hij met Hoepfner de bevindingen wan deze 20 jatar research (1949-1969) tesamen. Hier zullen daarvan speciaal zijn taxonomie van psychische funkties ter sprake komen.

Guilford baseert zich op een groot aantal psychologische tests. Door middel van faktoranalytische bewerking komt hij tot een rubricering van deze tests. De populatie waarop zijn gegevens betrekking hebben, is overigens moellijk vergelijkbaar met die van Mark. De populatie die Guilford gebruikt bestaat namelijk merendeels uit volwassenen met een ithtelligentie boven het gemiddelde die niet gestoord zijn in de "psychische funkties". Mark gaat uit wan kinderen met leerstoonmissen.

Evenals Mark lijkt Guilford het organisme, de black box, op te vatten als een informatieverwerkend systeem, dat voor deze informatieverwerking een aantal operaties ter beschikking heeft. Een belangrijk verschil tussen Mark en Guilford is echter dat bij het konstruktiemodel van Mark diverse hierarchieẽn gepostuleerd worden, terwill Guilford daarentegen zijn model hierarchieloos d.w.z. morfologisch presenteert.

De term "operation" wordt door Guilford gedefinieerd als "Major kinds of intellectual activities or processes; things that the organism does in the processing of information, information being defined as "that which the organism discriminates".

Door Guilford worden 5 aperaties onderscheiden:

1e. Cognition (C). "Immediate discovery, awareness, rediscovery or recognition of information in its various forms; comprehension or understanding."

2e. Memoly (M). Fixation of newly gained information in storage*

3e. Divergent Production (D) ,Generation of logical alternatives from given information where the emphasis is upon variety, quantity and relevance of output from the sitme source".

4e. Convergent Production (N), Generation of logical conchsions from given information where the emphasis is upon achieving unique or conventionally best outcomes"*.

5e. Evaluation (E): "Comparison of items of information in terms of variables and making judgements concerning criterion satisfaction".

Guilford onderscheidt naast "Operation" een zestal "Products"

Onder "Products" verstaat Guilford: "Basic forms that information takes in the organism "s processing of it"

1e. Units (U): "Relatively segregated or circumscribed items or "chunks" of information having ,thing" character. May be close to Gestalt psychology"s "figure on a ground". 
2e. Relations ( $R$ ): "Connections between items of information based upon variables or points of contact that apply to them. Relational connections are more definable than implicational connections".

3e. Implications (I) „Circumstantial connections between items of information, as by virtue of contiguity, or any condition that promotes "Belongingness".

4e. Systems (S): „Organized or structured aggregates of items of information complexes of interrelated or interacting parts".

Se. Classes (C): "Conceptions underlying sets of items of information grouped by virtue of their common properties".

6e. Transformations (T): "Changes of various kinds (redefinitions, shifts, transitions, or modifications) in existing information."

Zowel Guilford als Mark geven aan dat verschillende zintuigmodaliteiten in acht moeten worden genomen, zoals visuele, auditieve, kinesthetische en eventueel ook kombinaties daarvan (Guilford p. 20; Mark zie 4.1.3.2)

Een dimensie die Guilford verder toevoegt is de "Content" der stimuli en wel onderverdeeld in:

1e. Figural (F): „Pertaining to information in concrete form as perceived or as recalled in the form of images".

2e. Symbolic (S): „Pertaining to information in the form of denotative signs having no significance in and of themselves: such as letters, numbers, musical notations, codes and words (as ordered letter combinations)".

3e. Semantic (M) „Pertaining to information in the form of conceptions or mental constructs to which words are often applied, hence most notable in verbal thinking and verbal communication".

4e. Behavioral (B): "Pertaining to information essentialy nonfigural and nonverbal, involved in human interactions, where the attitudes, needs desires, moods, intention, perception, thoughts etc. of others and ourselves are involved.

De visie van Guilford wordt weergegeven in de .structure of intellect" (zie onderstaand figuur).

fig. 5. The siruchure of intellect - naar Guilford.

CONTENTS

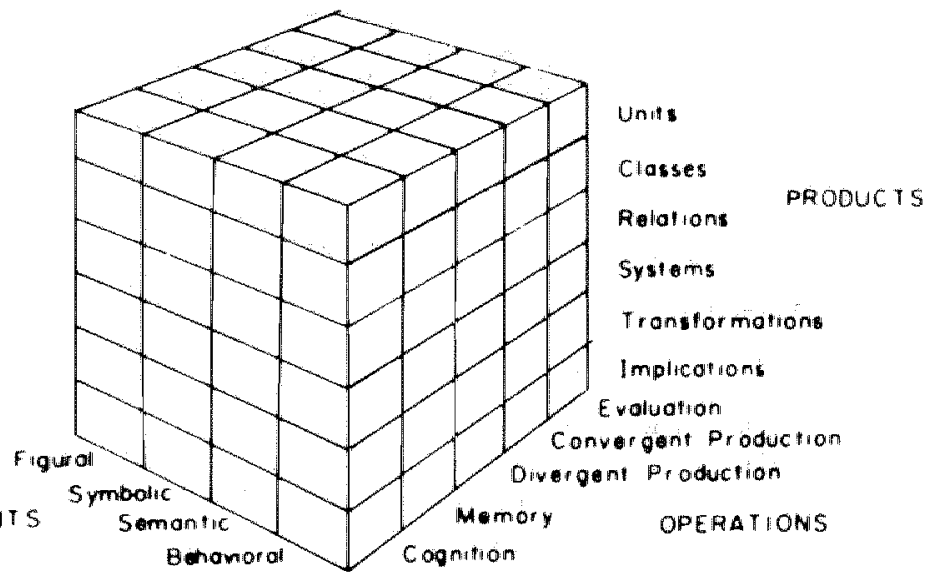




\subsubsection{Ontwikkelingspsychologische benaderingen}

Uit de veelheid van informatie betreffende neuropsychologische en cognitief psychollogische konstruktiemodellen werden in het voorgaande twee auteurs geselekteerd watarbij als kriterium gold de poging tot invulling, operationalisatie en instrumentele realisering van de hypothetische konstrukties in de black box. Hoewel een benadering vanuit ontwikkelingspsychologische zijde zeker de moeite waard is, leek deze voor de onderhavige studie iets minder relevant. De interesse in deze studie gaat uit naar een momentane toestand van een volwassen patiënt met cerebrale stoornissen. Het is hierbij de vraag in hoeverre een ontogenetische ontwik kelling bij assessment en modifikatie van belang is. (Voorzover een ontogenese, hoe plausible dan ook, op dit moment reeds ondersteund wordt door een hecht empirisch fundament)

Ontwik kelingspychologische en orthopedagogische publikaties getuigen weliswaar van een rijkdom aan denkbeelden, maar aan een konkretisering van een "taxonomie"s naar hypothetische konstrukties overeenkomstig Mark of Guilford, lijkt nog geen gestalte te zijn gegeven. (voor zover bekend hier) Niettemin wordt er door een groot aantal ontwikkelingspsychologen en orthopedagogen in hun praktische benaderingswijze (van bijvoorbeeld het leergestoorde kind) gewerkt onder ogenschijnlijk impliciete aanname van een reeds empirisch ondersteunde „funktietaxonomie".

De hiërachie naar ontwikkeling zoals door Dumont (1973) weergegeven (bewegen, verinnerlijkt bewegen, gesproken taal, geschreven taal, mathematische taal) doet zeer sterk aan de indeling van Mark denken. Hoewel een dergelijke analogie (vermoedelijk ontleend aan Osgood) tussen Dumont en Mark uitermate stimulerend werkt, is de daaropwolgende serie in zijn boek gepresenteerde tests enigszins pover te noemen. Hierin representeert zich op geen enkele wijze een diagnostiek naar gel aagdheid of hiërachie, terwijl ook de door Mark zo beklemtoonde kanaal-specificiteit ontbreekt.

Onder de inspiratie van o.a. Piaget, Osgood en vele anderen wordt door logopedisten voorlopig gesproken over o.a. evokatie, imitatie en prediktie (zie o.a. Dumont 1973); door speltherapeuten van bewegingsspel, konstruktiespel en fantasiespel (persoonlijke mededeling); door fysiotherapeuten inzake het opdoen van bewegingservaring, bewuste bewegingservaring en stabilisatie van de beweging. (zie Kugel 1976 en Koolen 1974). Eveneens wordt onder hantering van dit soort en andere begrippen veelvuldig een hiërachie in ontogenese als bewezen geacht. Hoewel al deze concepten (en waarschijnlijk meer) uitermate zinvol kunnen zijn, zou een empirisch wetenschappelijke ondersteuning van deze ideeën gewenst zijn. Aangezien deze ondersteuning vooralsnog tamelijk onzeker lijkt te zijin, wordt van een verdere bespreking afgezien.

\subsubsection{Overzicht.}

Zoals eerder werd opgemerkt is het binnen het kader van deze studie onmogelijk om alle stromingen te behandelen. Volstaan werd met de "lijnen" welke niet slechts qua theoretische konstruktie maar eveneens wat betreft konkrete realisering in de vorm van een funktietaxonomie, enige betekenis leken te hebben. Hoewel het systeem van Mark wel degelijk perspektief schijnt te bieden moet gezegd worden dat zijn denkbeelden tamelijk speculatief zijn. Met name de veronderstellingen inzake een hièrarchische struktuur en ontwikkeling (naar ortogenese) worden op welhaast intuïtieve wijze als "bewezen" gepresenteerd. De gebruikte terminologie in zijn literatuur is op diverse punten tamelijk onduidelijk en vaag te noemen. De praktisch te realiseren diagnostiek lijkt niet eenwoudig uit te voeren en dit is des te meer 
belangrijk, indien men de eis stelt dat vanuit deze diagnostiek mogelijkheden voor therapietoepassing moeten voortkomen.

De konstruktie van Guilford wordt gefundeerd door een circa 20-jarige research, hetgeen niet van Mark gezegd kan worden, Daarentegen "beweegt" Guilford zich op (louter) cognitief "niveau", terwijl Mark eveneens pretendeert de sensomotorische koppeling binnen zijn konstruktiemodel een plaats te kunnen geven. Een tekort in de benadering van Guilford is het feit dat hij zich, in tegenstelling tot Mark, niet occupeert met een onderscheid naar tests in de diverse modaliteiten en responsmon gelijkheden. Het onderscheid naar ". kanaalspecificiteit" lijkt bij het onderzoek naar cerebrale stoornissen een tamelijk reëel uitgangspunt te moeten zijn. Tenslotte wijst Guilford iedere hiërarchische gelaagdheid af en zijn zijn tests dusdanig ontwikkeld dat interkorrelatie grotendeels afwezig is.

Resumerend kan gesteld worden dat de ter beschikking statande informatie geen uitzicht biedt voor het opzetten van een goed gefundeerde taxonomie. Dit is des te meer klemmend, aangezien de revalidatie van cerebraal gestoorden niet kan wachten op een empirisch getoetste benadering. Een eventueel te konkretiseren taxonomie zal dus opnieuw gekenmerkt worden door grote onzekerheden. Niettemin zal in hoofdstuk 5 een poging gedaan worden met de ter beschikking staande gegevens een voorlopige taxonomie op te stellen. Een eventueel te konkretiseren taxonomie zal gepaard dienen te gaan met zeer omvangrijke en gedegen researchak. tiviteiten.

\subsubsection{Assessment van gedragstekorten in de klinische observatiesituatie}

\subsubsection{Probleemstelling}

In 2.3.2.1. werd reeds een omschrijving gegeven van het hier geintroduceerde begrip ".klinische observatiesituatie" en wel als een soort intermediair tussen de "test= situatie" en de "nabehandelingssituatie" met als doel een betere prediktie van het gedrag. In allerlei situaties ook buiten de testsituatie zijn d.m.v. gedragsobservatie diverse gedragstekorten te signaleren, die niet noodzakelijk behoeven te korreleren met gedragstekorten in de testsituatie. Deze signalering van gedragstekorten zijn meestal een signalering-per-toevalligheid, dat wil zeggen zonder systematische screening. Teneinde een eventuele modifikatiepoging meer gestruktureerd te kumnen realiseren werd overwogen een systematische observatie te introduceren. Aangezien de tot nu toe vervaardigde observatieschalen betrekking hadden op andere populaties en bovendien op een beperkt gedragsarsenaal, werd naar andere mogelijkheden gezocht.

Het observeren van gedrag met het voorbijzien van zowel de hypothetische konstrukties in de black box, als ook van de relatie met het anatomisch substraat sluit uitdrukkelijk aan bij het operante model. Ook Fordyce toont zich een aanhanger van direkte observatie en modifikatie van gedragstekorten, met voorbijgaan van de hypothetische konstrukties. Des te meer merkwaardig is het dat Fordyce (zie 4.1.3.1. en 1971 - 1 p. 190) zich desondanks toch ook uitlat in termen ontleend aan een cybernetisch model. Dit dualisme wordt bij verscheidene auteurs aangetroffen, waardoor het probleem blifft bestaan vanuit welke positie men in de praktijk der revalidatie dient te kiezen. Zo te zien zijn er drie mogelijkheden: Het aksent valt wolledig op de black box en de daarin veronderstelde systemen; men richt zich alleen op de gedragsobservatie onder voorbijgaan van intervenièrende variabelen; men doet zowell het één als het ander.

Kiest men, gezien de onzekerheid der hypothetische konstrukties en mogelijk in verband met de irrelevantie hiervan, voor beperking tot gedragsobservatie, dan zal 
men toch moeten zoeken naar een of ander observatiesysteem. Signalering ad hoc blift immers onbevredigend. Het alternatief is te streven naar een struktuur of overzicht wat betreft de soorten gedragingen, die men wil observeren en de wijze waarop dit gaat gebeuren. Wellicht zal het eveneens mogelijk of zelfs noodzakelijk zijn te zoeken naar een opbouw of hiërarchie van gedragingen naar complexiteit. Dit lijkt een algemeen ethologisch probleem te zijn. Een extra moeilijkheid hierbij is dat de bestaande literatuur weinig informatie levert over de opzet van een dergelijk systeem, zodat men geheel moet drijven op eigen kreativiteit.

Kiest men er voor in de assessment voorzichtigheidshalve zowel tests als observeerbaar gedrag in de niet-testsituatie te laten meetellen, dat staat men eveneens voor een moeilijk dilemma. Men kan beide gegevenheden los van elkaar hanteren en zet dan ook bij gebleken gedragstekorten vanuit de testsituatie en observatiesituatie allerlei modifikaties, onafhankelijk van elkaar op. Men gaat er dan vanuit dat de twee uitgangspunten afkomstig zijn uit twee verschillende systemen, die niet noodzakelijk met elkaar in verband hoeven staan. Het alternatief voor eerstgenoemde keuze bestaat uit een poging om toch weer aansluiting te zoeken tussen beide systemen. Een eerste aansluiting lijkt te bestaan uit het zoeken naar korrelaties en/of generalisaties tussen beide methoden van onderzoek en modifikatie. Een andere aansluiting kan gezocht worden in het "afstemmen " wan beide onderzoeksystemen en modifikatiestrategieën op elkaar. De opgave die dan onvermijdelijk wordt is om aan te geven, waar de assessment van hypothetische konstrukties (systeem- of funktieassessment) overgaat in gedragsobservatie en waar men bezig is met "funktierestauratie" danwel "gedragsvorming"

De gerezen vragen kunnen samengevat worden onder de volgende probleemstellingen:

1e. Is het mogelijk om een keuze te doen tussen: alleen gedragsobservatie of gedragsobservatie èn psychologisch (test)onderzoek?

2e. Indien beide systemen relevant lijken, moet men deze dan afzonderlijk bezien of in rela tie tot elkaar? Hoe liggen de korrelatieve verbanden tussen (test)onderzoekbevindingen en gedragsobservaties?

3e. Bestaat er enige infomatie inzake struktuur of opbouw van de gedragsobservatie?

4e. Indien beide systemen in acht genomen moeten worden is het dan duidelijk waar het ene systeem "overgaat" in het andere of is een dergelijke grens niet te trekken?

Probleemstelling 1. De keuze tussen alleen gedragsobservatie danwel de kombinatie van gedragsobservatie en assessment van hypothetische konstrukties.

In de literatuur wordt dit keuzeproblieem op verschillende wijzen en op verschillende gebieden gesignaleerd. Als voorbeelden van door diverse onderzoekers/auteurs in deze gemalakte keuze zijn te noemen:

Feschbach C.S. (1974)..Two alternative models for identifying Kindergarten age children with a high risk of becoming reading failures are compared. One model places primary emphasis on psychometric test procedures assessing linguistic and perceptual - motor skills related to reading readiness. The alternative strategy is based upon the kindergarten teacher's evaluations of child's skills and behavior..." Diller L. (1976): „Two basic paradigms are currently popular (1) Shaping a behavior which is inadequate in a real life situation e.g. Goodkin speeded up the performance of a patient who moved slowly in a wheelchair. (2) Improving performance in a test situation e.g. Zane and Goldman trained a patient to pass the face-hand test. 
Both approaches have their limitations... In the case of shaping real life behaviors in brain damaged people, generalization may be limited. The patient may speed up in the hospital corridor, but not in a different setting. The same can be said about performances in testsituations (... . $)^{\circ}$.

Poor C. c.s. (1975): „.... there are differences of opinion among professional evaluators as to which approach, or approaches, are the most meritorious. The four principle approaches are (a) Mental testing (b) Work sampling (c) Situational analysis (d) Job try-outs". (Dit citaat is afkomstig uit een artikel dat probeert aan te geven hoe arbeidsmogelijkheden beoordeeld kunnen worden, (a) is analoog aan de "testsituatie”, (b) komt overeen met de „klinische situatie”. (c) lijkt een overgang naar de werksituatie, de nabehandelingssituatie (d) is duidelijk de werksituatie).

Dumont (1973 p. 244): „Lezen en rekenen zijn geen ontwikkelingspsychologische produkten, dat kan niet genoeg herhaald worden, maar vaardigheden, die het kind moet verwerven op grond van on twikkelingswoorwaarden, die dat mogelijk maken. Daarbij is het zich ontwikkelende en lerende kind afhankelijk van de didaktische aanbieding ( . . .). Didaktiek is het a anbieden van de leerstof, rekening houdend met het al dan niet vervuld zijn van de leervoorwaarden in het kind". Hier wordt dus een onderscheid gemaakt in twee ...systemen" nl. leervoorwaarden als resultaat van ontwikkeling en vaardigheden als resultaat van een goede didak tische aanbieding. Gunzberg (1973 p. 26): „Te veel word" nog een onmiddellijk verband gelegd tussen een te laag IQ en een onvoldoende sociale aanpassing bij zwakzinningen". p. 33: "Een vergelijking van leeftijdgenoten met ongeveer dezelfde intelligentie-uitslagen vestigt de aandacht op verschillen in sociale aanpassing (...) een verschil van enkele IQ-punten kan zeker niet als reden gelden; ervaring, rijping, onderwijs en opvoeding zijn de belangrijkste aspekten.

p.75: .... verstandelijke achterstand is slechts in een enkel geval verantwoordelijk voor het gebrek aan elementaire sociale vaardigheden".

Uit bovenstaande literatuurvoorbeelden kan minstens de konklusie getrokken worden, dat het aanbeweling verdient zowel tests, alsook gedragsobservatie in de assessmentprocedures te betrekken.

Probleemstelling 2: Welke gegevens zijn er voorhanden wat betreft het verband tussen de twee modellen.

Feshbach c.s. (1974) vindt in zijn studie over leesgestoorde kinderen korrelaties die variëren van .46 tot .52 , tussen enerzijds tests als WPPSI, Otis, de Hirsch en anderzijds gedragsobservaties volgens de Student Rating Scale en Kohn Social Competence Scale. De psychologische tests v.s. kriterium "leesprestatie" en gedragsobservatieschalen v.s. .leesprestatie" vergelijkend konkludeert hij: „For the present we are encouraged by the finding that Kindergarten teacher's rating can predict first grade reading achievement at least as efficiently as a psychometric battery that has been designed for this purpose".

De interkorrelatie tussen tests en gedragsobservatie als ook de korrelatie testkriterium en observatiekriterium zijn volgens Feshbach bevredigend.

Diller (1970) vergelijkt prestaties op de "Digit Cancellation Task", met het aantal ongelukken, dat patiënten met rechter-en linker-hemisfeerstoornis vertonen in hun vaardigheid bij het omgaan met hun rolstoelen. Bij deze tests worden tijd en aantal korrecte pogingen gemeten. De linker-hemisfeergestoorden variëren t.o.v. de "normalen" in nauwkeurigheid. De rechter-hemisfeergestoorden zijn nauwkeuriger, maar langzamer op deze test dan linker-hemisfeergestoorden $(\mathrm{p}<.01)$.

Het aantal ongelukken staat in relatie met de mate van nauwkeurigheid en niet met de tijd $(p<.01)$. M.a.w. linker-hemisfeergestoorden, die laag scoorden op de test 
hebben meer ongelukken bij het zich verplaatsen naar en het rijden in een rolstoel. Gunzberg (1973 p. 190 e.v.) vergelijkt in een goed gekontroleerd onderzoek twee groepen zwakbegaafden met eenzelfde intelligentieniveau, kalenderleeftijd en sociaal niveau. Intelligentie werd bepaald door de Terman-Merrill-schaal en het sociale niveau door de Vineland-schaal. De experimentele groep kreeg training in allerlei vaardigheden als winkelen, gebruik van openbaar vervoer, boodschappen doen etc. $\mathrm{Na}$ afloop van de training bleek het intelligentieniveau niet veranderd, echter de score op de Vineland was voor de experimentele groep signifikant hoger dan voor de kontrolegroep. ( $\mathrm{p}<.01$ niveau).

Palker (1972) komt tot een enigszins andere konklusie als Gunzberg (p. 35) „Results indicate that hyperactive children have an intellectual (lower WISC IQ's) as well as behavioral handicap (scores on school achievement) but that they do learn schoolwork at the rate normall for their level of intelligence."

Loney (1972), Reed (1967) en Larsen (1973) komen uit hun onderzoekingen eveneens tot de konklusie dat, althans bij de door hen onderzochte populatie van leesgestoorde kinderen, een lage intelligentie niet of nauwelijks korreleert met leesprestaties.

De konklusie kan voorlopig zijn, dat een intelligentieonderzoek niet noodzakelijk hoeft te korreleren met sociale vaardigheden of leesvaardigheden, maar dat er gezien Feschbach's resultaten misschien betere tests bestaan, die dat wel doen.

Aangezien via literatuuronderzoek (Rehabilitation Abstracts 1973-1976) voorshands geen andere studies werden gevonden, blijit de probleemstelling inzake de relatie testged rag - gedragsobservatie voorlopig onopgelost. Rond de probleemstelling "struktuur der obserwatieschalen" blijken meer gegevens voorhanden waarop in de hierna volgende sub-paragraaf zal worden ingegaan.

\subsubsection{Samenstelling yan enkele gedragsobserwatieschalen}

Teneinde probleemstelling 3 nader te bestuderen zal nagegaan worden of er observatieschalen bestaan, welke gericht zijn op het gedrag van cerebraal gestoorde patiènten en of het mogelijk is hierin enige struktuur of systematiek te ontdekken. In het navolgende zullen enkele informaties hieromtrent worden gepresenteerd.

Fordyce (persoonlijke mededeling) blijkt zich in zijn gedragsmetingen te richten op: gedragsverandering, beroepsprestaties, sociale vaardigheden, vrijetijdsbesteding en zelfverzorging.

Zijn doelstellingen en ideeën lijken voor een deel overeenkomstig te zijn aan de gedachtengang, die in deze studie wordt verwoord.

Het geheel is in een researchstadium.

Diller (persoonlijke mededeling) onderscheidt op zijn beurt drie globale hoofdgebieden, nl: Aktiviteiten Dagelijks Leven (ADL), sociaal gedrag, beroepsprestaties. ledere hoofdgebied lijki onderverdeeld te zijn. Het geheel is in researchstadium. In de reeds eerder genoemde studie van Feshbach c.s. (1974) werden potentiële leergestoorde kinderen geobserveerd m.b.v. de Student Rating Scale en de Kohn Social Competence Scale. Eerstgenoemde schaal bevat items, die betrek king hebben op het cognitieve, affektieve en sociale funktioneren van het kind in de klas. Laatstgenoemde observatieschaal heeft twee subschalen betreffende respectievelijk sociaal en emotioneel funktioneren. De publikatie van Feschbach geeft geen verdere informatie omtrent de samenstelling der schalen.

Rosinsky (1975) verschaft uitgebreidere informatie inzake een instrument dat door hem gebruikt werd ter bepaling of een patiênt geschikt zou zijn voor plaatsing in een beschutte werkplaats. De gedragsgebieden welke hij hanteert hebben niet slechts 
betrekking op het kunnen omgaan met gereedschap ed,, maarook op gedragsvoorwaarden voor plaatsing in een werkplaats. Rosinsky onderscheidt in de uiteindelijk konstruktie van zijn CELE (Controllend Environmental Laboratory Evaluation): cognitieve, psychomotorische, en affektieve aspekten en verder een kategorie "andere gedragsmogelijkheden".

Wehman (1975) en Rosinsky (1975) dwingen a.h.w. tot een uitspraak inzake terminologie en positiebepaling. Beide auteurs betrekken in hun observatiesyteem, gedrag, dat vereist wordt om in de toekomst op een (beschute) werk plaats arbeid te kunnen verrichten. De observaties worden bij beide auteurs uitgevoerd in een "voorstation". dat voorafgaat aan een eventuele plaatsing. De soorten gedragstekorten die door beiden genoemd worden, werden echter in deze studie eveneens gekonstateerd in de klinische situatie bijwoorbeeld het dagverblijf, de gangen, op arbeidstherapie etc.

Om der wille van de overzichtelijkheid en efficiëntie in werkwijze wordt hier het standpunt ingenomen, dat het geven van speciale cursussen (metaalbewerken, autogeen lassen, administratieve cursussen e.d.) beoordeeld en gegeven moeten worden in de „nabehandelingfase". In de klinische fase dient het aksent te liggen op observatie en modifikatie van gedrag, dat voor het volgen van een dergelijke cursus een voorwaarde is. Volgens deze visie behoort bijvoorbeeld "het leren klokkijken", "het omgaan met geld", "gebruik kunnen maken van publiek vervoer" in een mogelijk wat meer te kontroleren situatie, de klinische fase te geschieden. Dit soort vaardigheden worden niet slechts gezien als voorwaarden voor werkaanpassing, maar integendeel en meer omvattend, als voorwaarden om de gehele complexe leefruimte in fysiek en cultureel opzicht te kunnen hanteren.

Aangezien ook het merendeel der gedragsobsevaties van Wehman en Rosinsky op laatstgenoemde "vaardigheden" betrekking hebben, worden beide auteurs hier onder de „klinische situatie" behandeld.

Wehman (1975) is de eerste, die naast het noemen van een aantal observatiegebieden een mogelijke hiërarchie persenteert.

Hij noemt zijn observatieschaal "Curriculum for Social Skills in Vocational Setting". ( De schaal heeft betrekking op mentaal geretardeerden.) Hij meent dat een dergelijke schaal aan drie voorwaarden moet voldoen:

"(1) Provide behavioral objectives as training goals, (2) provide an approximate sequence or direction in which skills should be trained and (3) provide a basis for periodic evaluation and accountability".

Zijn hiërarchie bestaat uit vier niveaus van toenemende complexiteit (zie ook figuur

6).

1e Personal Care level, which is made-up of selected self-help skills.

2e. Primary Interaction Level, a level encompassing certain remedial communication skills..

3e. Job and Community Survival Level, made-up of critical survival skills necessary to exist in the job.

4e. Advanced Interaction Level, this level deals with the more subtle and sophisticated forms of human interaction, i.e. trust, cooperation."

Enige belangrijke opmerkingen van Wehman zijn de volgende:

a. ,Skills are described behaviorally rather than as constructs.

b. An easy-to-hard learning sequence is established; that is, it is presumed that learning takes place more readily at the lower stages of the model.

c. Where appropriate, skills in the curriculum are broken into subcomponents and discussed".

Ook Wehman stelt dus, conform het standpunt ingenomen in deze studie (zie 
2.2.3.1.), dat in een obserwatieschaal "vaardigheden" meer funktioneel te beschrijven zijn in gedragstermen dan in termen van konstrukties. Voorts onderstreept thi de warde van successieve approximatie en het opdelen van een taak in komponenten, hetgeen opnieuw de aandacht vestigt op de bekende leertheoretische principes.

Fig. 6

Hierarchische opbouw wan het .Curriculum for Social Skills in Vocational Setings" volgens Wehman.

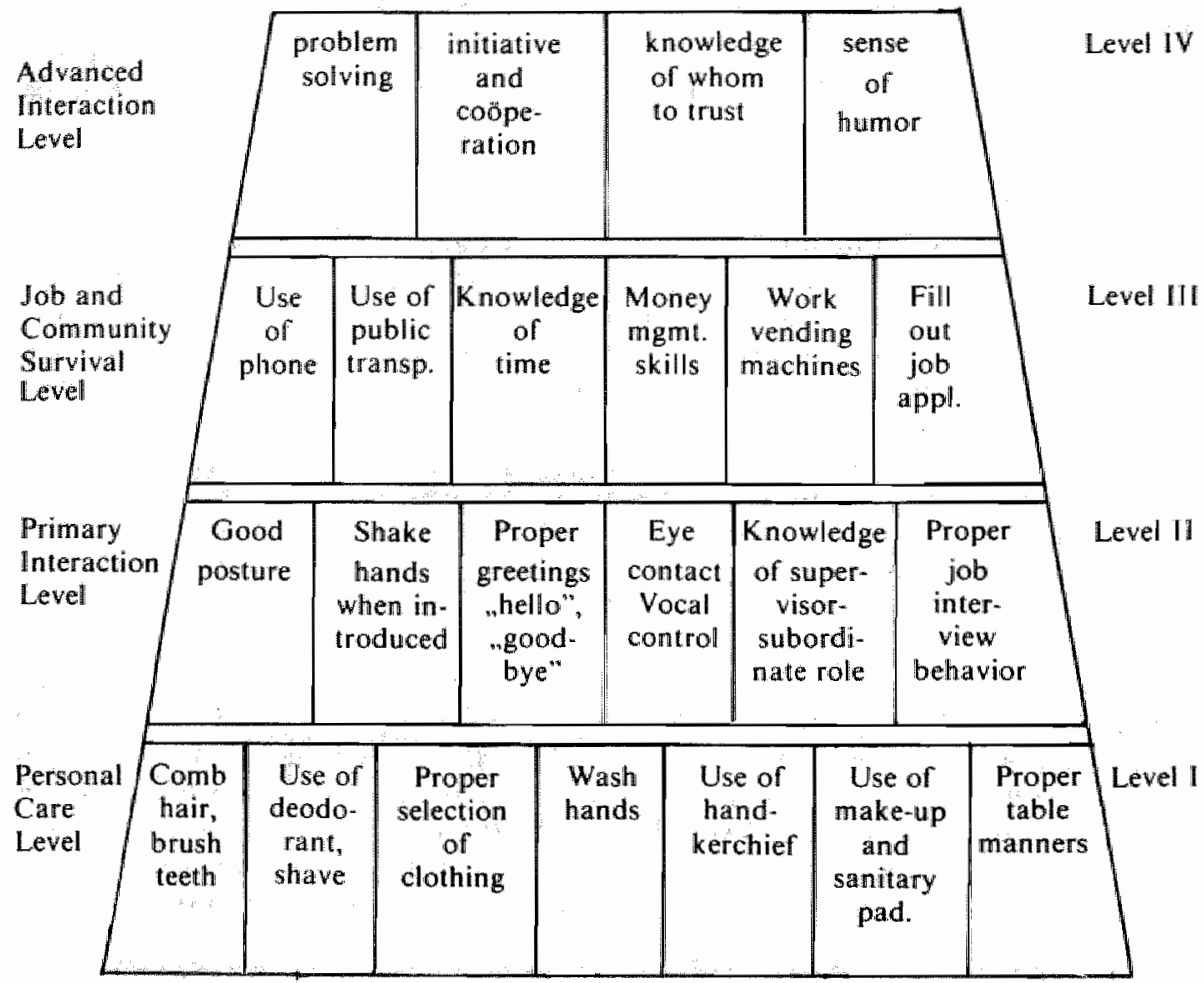

Gunzberg (1974) onderscheidt in zijn Progress Assessment Chart (PAC) een groter aantal observatiegebieden en deelgebieden dan voorgaande auteurs.

De samenstelling der PAC is gekenmerkt door:

le. Differentiatie naar diverse leeftijdsgroepen van mentaal geretardeerden $n l$ : P.PAC 0-7 jaar, PAC-1 vanaf 6.16 jaar, PAC-1a een aanvulling van $P A C-1$ mell name gericht op sociale ontwikkeling, PAC-2 volwassenen.

De $\mathrm{M} / \mathrm{PAC}-1$ is een versie van de PAC-1 bestemd voor de evaluatie van mongolöde kinderen van 6-16 jaar.

2e. Voor iedere leeftijdsgroep wordt het te observeren gedrag onderverdeeld in "gebieden" nl. zelfstandigheid, kommunikatie, socialisatie en bezigheden.

3e. De ,gebieden" worden elk weer onderverdeeld in "deelgebieden", warvan de terminologie per leeftijdsgroep enigszins varieert. Globaal worden de volgende deelgebieden onderscheiden:

Zelfstandigheid: eten en tafelmanieren, wassen en hygiëne, aankleden, zorg voor kleding, bewegen, gezondheidszorg. 
Kommunikatie: laalverwerving, rekenen en geldhantering, tijd en maten onderscheiden, schrijwen, lezen.

Socialisatie: winkelen, omgangsvormen, huishouden, omgaan met gell, sociaal bewustzijn en initiatief.

Bezigheden: handvaardigheid, vrijetijdsbesteding, behendigheid en nauwkeurigheid, snelheid, stiptheid.

4e. leder deelgebied bestaat uit een antal obserwatie-items, warbij de wize van afname en het kriterium voor scoring redelijk nauwkeurig worden aangegeven. Een aantal hierarchieên zijn hierbij ingebouwd:

A. Een globale hiërarchie in leeftijdsgroepen.

B. Een meer gedifferentieerde opbouw van deelgebieden bij de hogere leeftijden.

C. Een toename van moeilijkheidsgraad bij ieder deelgebied.

De scoringsgegevens worden uiteindelijk gegroepeerd in een cirkel, ingedeeld in 4 $\mathrm{kwadranten}$ (de hoofdgebieden). Ieder kwadrant is ingedeeld in 2-5 sektoren (de deelgebieden). ledere sektor betaat wit een aantal vakjes, die vanuit het middelpunt in concentrische cirkels geplaatst zijn. Deze vakjes zijn genummerd volgens de volgorde der observatie-items, waarbij de meer gemakkelijke itemvakjes dicht bijhet middelpunt liggen en de moeilijkere items meer naar buiten zijn geplaatst.

Ter verduidelijking wordt verwezen nar de volgende figuur. Een goede behandeling van het observatiesysteem van Gunzberg zou vele bladzijden vergen. Voor een nauwkeuriger bestudering moet derhalve verwezen worden naar de literatuur. In vergelijking met de overige genoemde auteurs lijkt Gunzbergs observatiesysteem het meest gedifferentieerd.

Fig 7: Gunzbergs observatie/rapportage-systeem

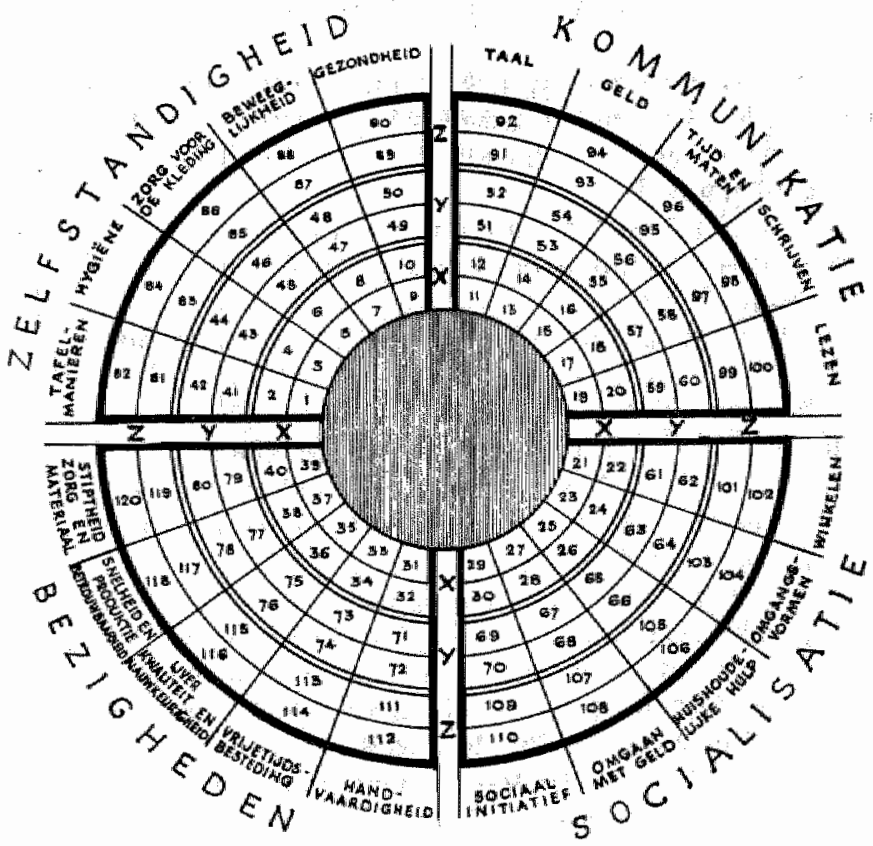


Resumerend leidt een andyse wan diverse observatieschaalkonstrukties rot de volgende conclusies:

le. In de schaalkonstrukties worden onderling verschillende observatiegebieden onderscheiden. Deze zijn voor zover vergelijkbaar in onderstaande tabel weergegeven.

\section{TABEL 11}

\begin{tabular}{|c|c|c|c|c|}
\hline Fordyce & Diller & Rosinsky & Wehman & Gunzberg \\
\hline \multicolumn{5}{|l|}{$\begin{array}{l}\text { gedrags } \\
\text { verandering }\end{array}$} \\
\hline $\begin{array}{l}\text { beroeps- } \\
\text { prestaties }\end{array}$ & $\begin{array}{l}\text { beroeps: } \\
\text { prestaties }\end{array}$ & & $\begin{array}{l}\text { Job } \\
\text { Survival }\end{array}$ & \\
\hline $\begin{array}{l}\text { sociale } \\
\text { vaardigheden }\end{array}$ & $\begin{array}{l}\text { sociaal } \\
\text { gedrag }\end{array}$ & affectie & $\begin{array}{l}\text { Pr. en Sec. } \\
\text { Interaktie }\end{array}$ & Sociallisatie \\
\hline \multirow{3}{*}{$\begin{array}{l}\text { vrijetijds } \\
\text { besteding }\end{array}$} & & & & Bezigheden \\
\hline & A.D.L. & & $\begin{array}{l}\text { Personal } \\
\text { Care }\end{array}$ & Zelfstandigheid \\
\hline & & $\begin{array}{l}\text { Cognitieve } \\
\text { Vaardigheid }\end{array}$ & & kommunikatie \\
\hline
\end{tabular}

2e. Er is bij sommige auteurs sprake van de onderverdeling van observatiegebieden in deelgebieden. De Progress Assessment Chart van Gunzberg is hierbij het meest genuanceerd.

3e. Alleen Wehman spreekt zich expliciet uit inzake een voorkeur voor een hiërarchie in observatiegebieden. Bij Gunzberg is deze hiërarchie aanwezig in de differentiatie naar leeftijdsgroep en in de volgorde der "moeilijkheid" van de items in de deelobservatiegebieden.

4e. Bij Rosinsky is niet duidelijk sprake van een gekonstrueerde observatieschaal. Hij doet een beroep op bestaande (deel) schalen. Bij Fordyce en Diller zijn de schalen nog in een researchstadium.

Se. In feite biedt alleen de PAC van Gunzberg een overzichtelijk gestruktureerd observatic-netwerk.

\subsubsection{Aansluiting tussen test en gedragsobservatieschaal}

Voorgaande in formaties werden ontleend aan publikaties welke werden angetrofCon in de Rehabilitation Abstracts 1973-1976 en vanuit informatie uit diverse toonalangevende centra in de USA.

Indien deze verzameling van gegevens representatief is voor de stand van zaken inzake de gedragsobservatie t.b.v. revalidatiepatienten en meer in het bijzonder de cerebraal gestoorden onder hen, dan levert deze situatie weinig op om op voort te bouwen. Er bestaat eigenlijk geen schaal, die rekening houdt met de gesignaleerde diversiteit aan gedragstekorten en de specifieke kriteria inzake observatie en gedragsscoring ten behoeve van deze patiëntenkategorie. Hoewel er in diverse centra aan systematische gedragsobservatie gedacht en gewerkt wordi, heeft dit 
vooralsnog geen voldoende gefundeerde toepasbare resultaten opgeleverd. Zelfs Fordyce en Diller, die toch in deze als "koplopers" beschouwd kunnen worden, zijn niet veel verder dan een researchstadium, hetgeen overigens veel verder is dan enig onderzoeker of revalidatiecentrum in Nederland.

De huidige stand van zaken maakt een poging gedragstekorten in de testsituatie te relateren aan gedragstekorten, gebleken uit observatie, tot ontwikkelingswerk op een achter gebleven gebied van de gezondheidszorg. Hiermee wordt niet primair bedoeld eventuele berekening van korrelaties, die trouwens eveneens schaars zijn, maar het oplossen van probleemstelling 4: ,Waar gaat het ene model in het andere over", dan wel, "bestaat er een analogie tussen het conceptual frame work "testprestatie versus gedragsobservatie" naar gepresenteerde stimulusconfiguraties en responssoorten. Een dergelijke analogie zou immers aanzienlijk bijdragen tot overzichtelijkheid en systematiek in de wijze van assessment. Het zou wenselijk zijn, door middel van factoranalyse, empirisch na te gaan of, en zo ja, hoe de verschillende meetsystemen samenhangen. Het zou dan zelfs kunnen blijken dat één der systemen gemist kan worden, namelijk indien het andere systeem een gedragstekort net zo goed meet en beter aansluit op een modifikatiestrategie. De enige persoon, die hieromtrent een boodschap lijkt te hebben is Diller, wiens publikatie (winter 1976) de meest recente in de lijst is.

Diller begint met de vier langzamerhand overbekende probleemstellingen te signaleren.

.(1) Wat is het probleem van de patiënt? (2) Hoe en wat tracht men te diagnosticeren? (3) Wat omvat de behandeling? (4) Is deze behandeling effektief?" Vervolgens gaat hij over tot de presentatie van zijn assessmentprocedure, die weergegeven wordt in onderstaande figuur, tabel en begeleidende tekst.

Fig. 8

A model for Remediation of Perceptual / Cognitive Problems in Brain Damaged People (naar Diller)

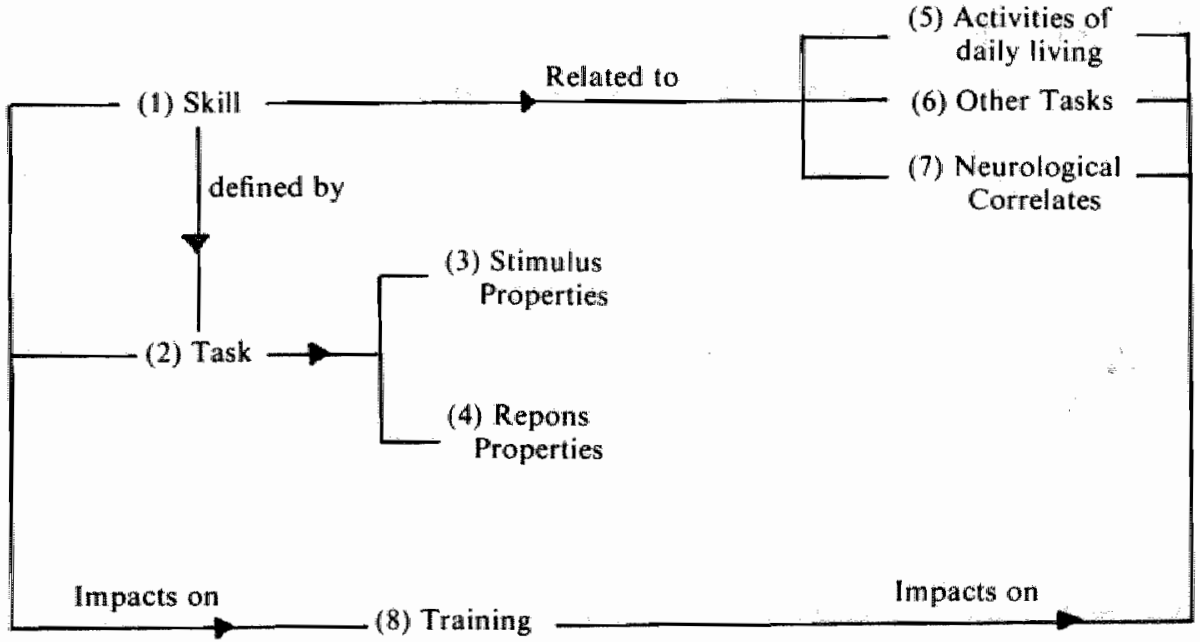

Dit model lijkt samengesteld te zijn uit de volgende elementen: (1) Vaststelling van de defekte vaardigheid. (2) Vaststellen van een taak of test, die de vaardigheid representeert. Deze test moet geanalyseerd worden in (3) stimuluseigenschappen en (4) responseigenschappen. Zowel vaardigheid als test moeten gerelateerd worden 
aan (5) aktivituiten van het dagelijks leven (6) andere taken (7) neurologische verbanden. (8) Tenslotte wordt er een training uitgevoend (welke, is hierbij niet dwidelijk).

Tabel 12

\begin{tabular}{|c|c|c|c|}
\hline \multicolumn{4}{|c|}{$\begin{array}{l}\text { Factors which have been varied in Training Brain Damaged People } \\
\text { Stimulus Characteristics }\end{array}$} \\
\hline $\begin{array}{l}\text { 1. Speed of presentation } \\
\text { 2. Singlly or simultaneous } \\
\text { 1y } \\
\text { 3. Density or context } \\
\text { 4. Orientation } \\
\text { 5. Locus in space } \\
\text { 6. Load }\end{array}$ & \multicolumn{2}{|c|}{$\begin{array}{l}\text { 7. Type materials } \\
\text { 8. Sensory modallities } \\
\text { 9. Sensory context } \\
\text { 10. Three v.s. two dimen- } \\
\text { sions } \\
\text { 11. Anchoring } \\
\text { 12. Concrete v.s. } \\
\text { Abstract }\end{array}$} & $\begin{array}{l}\text { 13. Options for responding } \\
\text { 14. Size } \\
\text { 15. Color } \\
\text { 16. Relationship to } \\
\text { other stumuli } \\
\text { 17. Familiarity } \\
\text { 18. Interest } \\
\text { 19. Moving v.s. Still }\end{array}$ \\
\hline \multicolumn{4}{|c|}{ Respons Characteristics } \\
\hline \multicolumn{2}{|c|}{$\begin{array}{l}\text { 1. Speed } \\
\text { 2. Duration } \\
\text { 3. Feedback } \\
\text { 4. Type Error-Omission/Commission }\end{array}$} & \multicolumn{2}{|c|}{$\begin{array}{l}\text { 5. Rate } \\
\text { 6. Initiation } \\
\text { 7. Nature of the Error }\end{array}$} \\
\hline
\end{tabular}

„We can illustrate our model by its application to a concrete instance.

(1) The problem of spatial neglect associated with damage to the right hemisphere.

(2) An excellent task for eliciting problems of spatial neglect is visual cancellation which requires an active search of the environment.

(3) Visual cancellation can utilize a variety of stimuli (letters, numbers words, pictures, shapes) which can be distributed on the right and, or left-side of the page and which may also differ in how densely they are placed (...).

(4) It is sensitive to errors of omission as well as commission. It shows what part of the page elicits more errors. Finally performance can be timed.

(5) Performance on wisual cancellation is correlated with a number of features in activities of daily living, including accidents, difficulties in reading and learning to transfer from a wheelchair to a regullar chair and back (...).

(6) Respons to visual-cancellations also has a number of neurological correlates among then are damage to the right as opposed to the left hemisphere and the presence of visual feeld defects".

(7) Training (wordt niet genoend).

Toegepast op een wan de konkrete valardigheden waarvoor Dillers werkmodel is ontworpen, blijkt de volgende procedure te worden gevolgd (nummering is identiek arit bovenstaande volgorde).

(1) (2) Bij die patiênten, waarbij via neurologisch onderzoek o.a. is aangetoond, dat de patiẻnt hemianopsie heeft. gaat men over tot assessment in de klinische testsituatie.

(3) (4) Hierbij gebruikt men een antal instrumenten onder variatie van stimulus inhouden en limit testing, warvan bekend is dat deze hemianopsie kunnen diagnosticeren, en onderzoekt de respons. 
(5) (6) Er wordt gekeken in hoeverre ook observeerbaar gedrag in andere situaties wordt beïnvloed. (Indien men zulks, zonder meer onderneemt, dan is er sprake van korrelatie op basis van "face validity" en meer niet.)

(7) Er wordt (nogmaals) onderzocht wat de gewolgen zijn op neurologische basis.

(8) De invalshoeken voor therapie zijn niet duidelijk.

Deze werkwijze behoeft het volgende kommentaar:

1e. De verwachte aansluiting tussen test en gedragsobservatie komt hier enigszins aan de orde.

2e. Van een systematische screening met behulp van psychologische tests, danwel van gedragsobservatie is echter geen sprake. Het lijkt wat op een benadering in de vorm van de "single case study" (zie Shapiro 1966), watarbij t.b.v. de individuele patiènt een individuele assessment en therapieprogramma wordt opgezet.

Deze benadering van Shapiro is efficiënt gebleken in de situatie waarin een beperkt aantal symptomen via de individuele patient-therapeut relatie moet worden gemodificeerd.

In deze studie wordt vooralsnog beoogd, dat er dankzij een systematische assessment d.m.v. tests en/of gedragsobservatie een modifikatie mogelijk is, die gerealiseerd wordt door een multidisciplinaire aanpak.

De aanpak van Diller is van niet te onderschatten waarde en komt in hoofdstuk $V$ opnieuw ter sprake. Zij is vrijwel analoog aan de benaderingswijze die in deze studie wordt voorgestaan..

\subsubsection{Assessment van gedragstekorten in de nabehandelingssituatie}

Terugkeer vanuit de kliniek naar huis stelt de patiënt min of meer definitief voor bepaalde taken, bezigheden of aktiviteiten. Het woord "taak" wordt hier verkozen, enerzijds om niet direkt te belanden in de arbeidssfeer, maar anderzijds omdat de patiënt toch een verantwoorde taak voor zichzelf en zijn omgeving zal willen nastreven. Het wordt hoe langer hoe duidelijker, dat revalidatie niet slechts gericht dient te zijn op het weer kunnen vervulien wan een bepaald beroep en eveneens dat zuiver fysieke revalidatie slechts éen, hoewel belangrijk, onderdeel is van het totale revalidatieproces. Hawryluk (1974) spreekt zich wat dit betreft zeer duidelijk uit: "Rehabilitation increasingly has become to mean more than placing a disabled client back in a job and adapting him to a work environment, laudable as this accomplishment may be (...). Disabilities are also changing. More and more clients are receiving services because of psychological, psychiatric, character or behavior disorders and proportionately fewer are being referred for physiological causes. Rehabilitation for these types of disability by its mature has to be broadly oriented and not solely concerned with occupational preparations".

Met het groeiend besef dat de doelstelling van de revalidatie niet bepaald dient te zijin door arbeidshervatting en fysiek herstel, wordt het expliciteren van andere, nieuwe doelstellingen des te meer urgent. De hierna volgende publikaties leveren hiertoe een bijdrage:

Hawryluk (1974) ontwikkelde een instrument bestaande uit 5 dimensies:

(1) Hours per week gainfully occupied (also included are hours per week spent as a student at school or in a training program).

(2) Weekly earnings (gross wage and salary income). 
(3) Work status (the relative value of the clients status in comparison with a range of statuses clients frequently hold before, during and after their rehabilitation experience).

(4) Economic dependency (Support funds received from either public or private sources).

(5) Psychological well being (Responses to a 10 item self percept instrument).

Scherzer A. L. (1973) onderzocht kinderen met cerebral palsy na een intensief therapieprogramma wat betreft hun plaatsing op school, prestaties op het gebied van onderwijs en sociale ontwikkeling. (Hoewel dit hier met het oog op assessment misschien minder relevant is, $k$ wam Scherzer tot de konklusie dat een hoge sociale status, stabiliteit in de familie en goede medische begeleiding een belangrijke bijdrage leverden in de ontwikkeling wat betreft bovengenoemde dimensie.)

Er van uitgaande dat revalidatie is: "Coping with a disability, a sliding scale of goals", ziet Trieschmann (1974) als achtereenvolgende doelstellingen:

(1) "Prevention of medical complications and utilization of ADL-mobility skills (2) Maintenance of a stable living environment (3) Productivity". Toelichting: (ad. 1) "These behaviors are appropriate whether he resides at home or in an institute" (ad. 2) "If he lives alone he must be able to deal with the world to maintain his residence and physical needs. If he lives at home, his family interactions should not be disruptive to the extent that they interfere with his functioning" (ad. 3) "Productivety may entail vocational endeavours, education, social interactions and avocational pursuits".

Mede op grond der uitspraken van deskundigen als Hawryluk, Scherzer en Trieschmann laten zich de revalidatiedoelstellingen in de situatie waarin patiënt voorbereid wordt op een hernieuwde konfrontatie met de maatschappij alsvolgt omschrijven:

1e. Het kunnen onderhouden van gedrag dat de patiënt tijdens het verblijf in het centrum heeft geleerd, d.w.z. het gebruiken van medicijnen, rolstoel, prothesen e.d. in die zin dat de patiènt tot op aanzienlijke hoogte tot zelfverzorging in staat is.

2e. Het kunnen onderhouden van sociaal kontakt. (Zowel Hawryluk, Scherzer als Trieschmann schijnen dit aspekt als zeer belangrijk te ervaren).

3e. Het kunnen ondernemen van aktiviteiten welke betrekking kunnen hebben op (a) arbeid (b) hobby's (c) onderwijs. De aansluiting met Trieschmann lijkt duidelijk: na ontslag heeft de cliënt tot "taak" gedrag te ontwikkelen of te kontinueren dat gericht is op zelfverzorging, sociaal kontakt en ..produktiviteit". Het is de opgave der revalidatie hem hier op voor te bereiden en na te gaan in hoeverre dit wordt gerealiseerd.

\subsubsection{Assessment van gedragstekorten in de thuissituatie}

Dit gebied wordt als „pro memorie" genoemd. Er is nauwelijks of geen literatuur beschikbaar hetgeen op zichzelf een teken aan de wand is voor de evaluatie en toepassing van de nazorg.

Als „taakgedrag” werd genoemd: zelfverzorging, sociaal kontakt, produktiviteit. De basis voor het onderhouden van dit taakgedrag dient gelegd te worden in het revalidatiecentrum, echter de revalidatie eindigt niet op het moment van ontslag, maar gaat verder als de persoon de opnieuw aangeleerde aktiviteiten inderdaad effektueert en kontinueert vanaf zijn rentree in zijn eigen leef wereld. Hoewel een en 
ander niet in het ziekenfondspakket is inbegrepen, dient de revalidatie met name oog te hebben woor de omgeving, waarin de revalidant na ontslag terecht komt, de doeleinden die de persoon wenst te ontwikkelen en de vaardigheden die hiervoor vereist zijn. Alle inspanning tijdens het klinisch revalidatieproces is zinloos, als de patiënt thuis gekomen terug valt in revalidatie-inadek waat gedrag: bijvoorbeeld het niet gebruiken van prothesen, het niet toekomen aan sociaal gedrag, het niet verder ont wikkelen van zichzelf in de zin van arbeid, hobby"s of onderwijs. Om deze zinloze inspanning van het revalidatieteam te voorkomen dient juist extra aandacht besteed te worden aan de "beklijving" van nieuw aangeleerd gedrag in de thuissituatie.

"One of the major reasons for failure" - aldus Trieschmann (1974) -" is the lack of attention to what the person will $d o$ after discharge. Living with a disability is difficult, frustrating, of ten painful and sometimes humilitating. Unless an individual receives some rewards and satisfaction in life, he will not perform all the activities necessary to prevent medical complications. Mobility and ADL skills entail hard work and will be practiced inconsistently unless they meet the persons needs. These needs can be defined as some reward, some satisfaction (. . .)" Het sleutel woord voor het onderhouden van revalidatie-adekwaat gedrag is leertheoretisch bezien uiteraard „reinforcement".

De ondersteuning van ,revalidatie-adek waat gedrag" zal in de volgende paragraaf (4.1.7.) aan de orde komen. De beoordeling of het in de kliniek aangeleerde gedrag inderdaad wordt uitgeoefend in de thuissituatie, is wel degelijk mogelijk en wel aan de hand van de gegevenheden uit klinische en nabehandelingssituaties. Dankzij uitgebreide en systematische assessment krijgt men de beschikking over cruciale check points ter evaluatie van het gedrag van de patiënt in zijn thuissituatie.

\subsubsection{Assessment van gedragsbelemmeringen}

\subsubsection{Probleemstelling}

In hoofdstuk 2 werd na een exploratief onderzoek vastgesteld dat een meerderheid aan pogingen tot gedragsvorming bij de patiënt met contusio cerebri mislukte door revalidatiebelemmerend gedrag. Deze blokkeringen zijn niet alleen te signaleren in hun belemmerend effekt op fysiotherapie, arbeidstherapie, logopedie, maar ook werd dit gedrag als hinderlijk ervaren door de verpleging en door andere patiënten, in hun dagelijkse omgang met elkaar. De patiënt was niet langer "hanteerbaar" en "verdween naar elders", tenzij er een poging kon worden ondernomen om dit storende gedrag te elimineren of te reduceren. Van deze pogingen werd in hoofdstuk 3 verslag gegeven. De GOCC ontwikkeld n.a.v. patiëntenstatussen van ontslagen patiënten met contusio cerebri, was bedoeld om deze gedragsbelemmeringen bij de patiënten met contusio cerebri te signaleren. De vraag is echter of deze schaal woldoende voorziet in de observatie van deze patiëntenkategorie, d.w.z. worden alle deviante gedragingen hierdoor gesignaleerd. Bovendien werd het zoekveld all lengs uitgebreid tor gedragsdeviaties op basis van cerebrale stoornissen zowel van congenitale als van traumatologische oorsprong. Indien een dergelijke uitbreiding reëel is dan moeten de diverse patiënten gediagnosticeerd volgens medische kriteria een soortgelijke problematiek presenteren.

Hiernaast dient te worden nagegaan of er in de literatuur reeds observatieschalen aanwezig zijn, die gericht zijn op de konstatering van ., probleemgedrag” optredende bij de patiëntengroep, die als cerebraal gestoord kan worden aangemerkt. 


\subsubsection{Gedragsaspekten ter observatie}

In de beschikbare literatuur bleek geen specifieke observatieschaal inzake probleemgedrag bij cerebraal gestoorden voorhanden. Wel konden er een redelijk aantal gedragsobservatieaspekten voor diverse patièntenpopulaties vanuit enkele publikaties worden opgespoord. In de volgende tabel wordt een overzicht gegeven van observatie-items ten aanzien van gedragsdeviaties per auteur. Hierbij werden de persoonlijke koderingen van de auteur zoveel mogelijk gehandhaafd. In de eerste kolom werden de GOCC-items opgenomen, zodat vergelijking hiermee mogelijk wordt.

Tabel 13 Overzicht obseryatie-items uit diverse bronnen inzake gedragsbelemmeringen

\begin{tabular}{|c|c|c|c|c|c|c|c|c|c|c|c|c|c|}
\hline $\begin{array}{l}\text { Gedragsdeviatie } \\
\text { bij patiënt }\end{array}$ & $\begin{array}{l}\text { Bro } \\
1.1\end{array}$ & $\begin{array}{l}\text { inver } \\
2 \mid\end{array}$ & $\begin{array}{r}\text { rme } \\
3.1\end{array}$ & 4. & & 6. & 7. & 18.1 & & & 11. & 12. & tot. \\
\hline $\begin{array}{l}\text { Huilen } \\
\text { Angstig } \\
\text { Neerslachtig/depressief } \\
\text { Klagen } \\
\text { Onzelfstandig } \\
\text { Zich afzonderen } \\
\text { Opdringerig } \\
\text { Dwangmatig } \\
\text { Euphorie } \\
\text { Slordig } \\
\text { Niet-coöperatief } \\
\text { Onrustig/ontremd } \\
\text { Prikkelbaar/agressief } \\
\text { Dominerend } \\
\text { Inaktief/traag } \\
\text { Ongemotiveerd } \\
\text { Gebrek aan zelfkritiek }\end{array}$ & $\begin{array}{l}x \\
x \\
x \\
x \\
x \\
x \\
x \\
x \\
x \\
x \\
x \\
x \\
x \\
x \\
x \\
x \\
x\end{array}$ & $\begin{array}{l}x \\
x \\
x \\
x\end{array}$ & $\begin{array}{l}\times \\
\times\end{array}$ & $\begin{array}{l}\times \\
\times\end{array}$ & $\begin{array}{l}x \\
\times \\
\times\end{array}$ & $x$ & $x$ & $\mid \begin{array}{l}x \\
\times \\
x\end{array}$ & 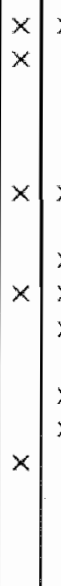 & 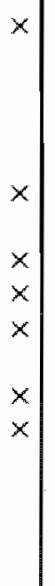 & $\begin{array}{l}x \\
\times\end{array}$ & $\begin{array}{l}\times \\
\times\end{array}$ & $\begin{array}{l}8 \\
8 \\
3 \\
2 \\
1 \\
7 \\
1 \\
6 \\
6 \\
3 \\
2 \\
7 \\
7 \\
2 \\
4 \\
1 \\
1\end{array}$ \\
\hline $\begin{array}{l}\text { Praten over schuld en bestraffing } \\
\text { Uit willen praten } \\
\text { Impulsief } \\
\text { Verandering in persoonlijkheid } \\
\text { Stemmingsstoornissen } \\
\text { Fobieèn } \\
\text { Koppigheid } \\
\text { Morbide konfabulaties }\end{array}$ & & $\mid \begin{array}{l}x \\
x\end{array}$ & $x$ & & & $x$ & $x$ & $x$ & $\begin{array}{l}x \\
x\end{array}$ & & & & $\begin{array}{l}1 \\
1 \\
2 \\
2 \\
1 \\
1 \\
1 \\
1\end{array}$ \\
\hline Totalen: & 17 & 7 & 5 & 71 & 3 & 4 & 6 & 8 & 8 & 7 & 5 & 2 & \\
\hline
\end{tabular}

1. GOCC-samenstelling.

2. Ibbotson (1975): Algemene Fysieke handicap, opmerking over CVA.

3. Mordock (1971): Minimal Cerebral Dysfunction.

4. Cohn (1961): Lees en schrijfgestoorde kinderen.

5. Craft (1974): Kinderen met hersentraumata.

6. Thornson (1974): Volwassenen met hersentrauma-contusio.

7. Hogg (1974): Autisme, kinderen.

8. Mitchell (1971): Hersenbeschadiging, volwassenen. 
9. Linden, v.d. (1975): Kinderen met minimal braindysfunction.

10. Dumont (1973): Kinderen met leerstoornissen.

11. Bijou c.s. (1969): Kinderen met hydrocephallus.

12. Haring c.s. (1971): Mentaal geretardeerde kinderen.

Uit deze tabel blijkt:

1e. Volwassenen en kinderen welke verschillend gediagnosticeerd werden, lijken vanuit het referentiekader inzake gedragsbelemmeringen gelijkelijk te beoordelen te zijn.

(Uiteraard werden door de diverse auteurs nog meer aspekten genoemd. Deze behoorden echter tot de kategorie "gedragstekorten" zoals in deze studie gedefinieerd. Zij werden derhalve in deze tabel niet opgenomen.)

2e. De GOCC (als schaal) heeft t.o.v. alle andere verzamelingen een veelvoud a an observatie-items.

3e. De meerderheid der observatie-items van iedere auteur worden eveneens in de $\mathrm{GOCC}$ aangetroffen.

4e. Vier GOCC-observatie-items worden niet aangetroffen bij de genoemde auteurs nl.: onzelfstandigheid, opdringerigheid, ongemotiveerdheid en gebrek aan zellfkritiek.

\subsubsection{Samenvatting}

In het voorgaande werd een overzicht gegeven van de literatuurinformatie inzake de assessment van gedragstekorten en gedragsbelemmeringen. In eerste instantie werd uitgegaan van literatuur welke verband hield met de patiëntenpopulatie van deze studie, nl. patiënten met contusio cerebri. Aangezien het aantal bronnen betreffende deze kategorie patiënten vanuit gedragspsychologisch uitgangspunt zeer beperkt bleek, werd het zoekveld verruimd tot dat van patiënten met cerebrale stoornissen van zowel congenitaal als traumatologische aard. Als ingang tot de literatuurgegevens bleef het thema gedragstekorten en gedragsbelemmeringen hierbij gehandhaafd. Het op deze wijze verruimde terrein leverde een tamelijk verwarrende hoeveetheid literatuur op.

De resultaten van deze heroriëntatie kunnen als volgt worden samengevat:

A. Gedragstek orten:

1e. Het verdient aanbeveling om ter begeleiding van de gedragsvorming in de klinische situatie rekening te houden met mogelijke premorbide gedragstekorten. Enkele richtlijnen voor thet verzamelen van dergelijke gegevens werdien verstrekt.

2e. De assessment van gedragstekorten in de klinische setting dient volgens twee procedures te geschieden, namelijk zowel door de assessment van "testgedrag" als door "gedragsobservatie". De relatie tussen beide modellen werd tot nu toe onvoldoende onderzocht via statistische toetsing met behulp van korrelatieberekeningen.

3e. Twee assessmentsystemen, namelijk die van Guilford en Mark, werden ten behoeve wan de klinische testsituatie gepresenteerd. Het bleek niet mogelijk uit deze systemen een valide taxonomie van psychische funktiestoomissen ten behoeve van de patiënt met cerebrale stoornissen te destilleren. Een eventueel in de toekomst te realiseren taxonomie zal rekening moeten houden met vrij omvangrijke researchaktiviteiten. 
4e. Voor de toepasing van de assessment volgens de tweede procedure, de gedragsobservatie, werden diverse schalen vergeleken. Enerzijds bleek dal deze merendeels nog in researchstadium verkeren, terwijl anderzijds nawwelijks aansluiting bij de revalidatie-populatic werd gevonden. De Progress Assessment Chart (PAC) van Gunzberg bood in deze het meeste perspektief.

Se. De assessment van gedragstekorten in de nabehandelingssituatie dient gericht te zujn op de mogelijkheden, die de patient heeft, zgn. "levenstaken" na ontslag naar behoren te kunnen verrichten. Als mogelijke "taken" werden genoemd zelf verzorging, sociale kontakten en produktiviteit in de zin van hobby"s, studie of arbeid.

\section{B. Gedragsbelemmeringen.}

De observatie-items van een aantal auteurs werden met elkaar en met de GOCC vergeteken. Uit deze vergelijking bleek dat de GOCC wat betreft de algemene "dekking" van het probleemgedrag bij de patienten met contusio cerebri en bij cerebral gestoonden relatief de grootste volledigheid toont.

\subsection{Modifikatie}

\subsubsection{Inleiding}

De hierna volgende beschrijving van modifikatieprocedures beoogt een inventarisatie te presenteren van mogelijke strategieën, die vanuit de literatuur naar voren komen en tevens aansluiting bieden aan het operante leermodel. Evenals bij de assessment is deze inventarisatie gebaseerd op publikaties inzake gedragsdeviaties ap basis van organisch cerebrale aandoeningen van congenitale en traumatologische aard.

Een overzicht van de frekwentieverdeling der publikaties per ziektebeeld wordt gegeven in de onderstaande tabel.

TABEL 14 Overzicht literatuur per deelgebied uit Rehabilitation Abstracts 1973-1976 (kodes zie 4.1.1.)

Modifikatie/gedragstekorten

\begin{tabular}{|l|r|c|c|c|c|c|c|}
\hline situatie: & Alg. & LH/RH & LH + RH & MBD & CP & MR & Tot. \\
\hline preklinisch & & & & & & & \\
klinisch test & 6 & $10 / 0$ & 2 & 13 & 1 & 2 & 34 \\
klinisch obs. & 10 & $6 / 1$ & 4 & 10 & 7 & 30 & 67 \\
nabehandeling & 4 & & & & & 5 & 9 \\
thuis-werk-school & 11 & & 3 & 6 & 1 & 6 & 27 \\
totalen & 31 & $16 / 1$ & 9 & 29 & 9 & 43 & 137 \\
\hline
\end{tabular}

Modifikatie/gedragsbelemmeringen

\begin{tabular}{|l|c|c|c|c|c|c|c|}
\hline situatie: & Alg. & LH $/$ RH & LH + RH & MBD & CP & MR & Tot. \\
\hline $\begin{array}{l}\text { preklinisch } \\
\text { klinisch test } \\
\text { kliniseh obs. }\end{array}$ & 7 & $4 / 0$ & 2 & 11 & 3 & 5 & 32 \\
nabehandelling & & & & & & & \\
thu is-werk-school \\
totalen
\end{tabular}




\subsubsection{Modifikatie van gedragstekorten uit de premorbide situatie}

Naast het gedrag dat een persoon door ziekte of trauma heeft verworven kan zijn gedrag vóót opname in een revalidatiecentrum mede beïnvloed zijn door ervaringen in de behandelings-verzorgingssituatie tussen trauma c.q. uitbreking van de ziekte en de opname in dit centrum.

Het zal bekend zijn dat in een algemeen ziekenhuis door de daar aanwezige medische specialisten, arbeids/ergotherapeuten, fysiotherapeuten, logopedisten en verpleegkundigen diverse aktiviteiten ondemomen worden ter reduktie van gedragstekorten, resp. de vorming van nieuw gedrag. Een van de doeleinden van deze studie is aan te geven dat de vorming van nieuw gedrag, met name doordat het aksent op het opnieuw leren valt (en de daarmee samen hangende complexiteit), een uitgesproken specialisme representeert warin dan revalidatiegeneeskunde, -psychologie en -techniek participeren. In het algemeen ziekenhuis lijkt voorshands nog niet voldoende besef anwezig omtrent de reikwijdte en toepassing van leerwetten, terwijl over het opzetten van een revalidatie-leerproces en de moeizame uitwoering hiervan het eerste woord aldaar nog uitgesproken dient te worden.

Terecht waarschuwt De Ruyter (1974 p. 92) dan ook voor de toepassing van de revalidatie in zjekenhuizen:" .Te vaak wordt nog beweerd dat de revalidatie een onderdeel is van de curatieve geneeskunde. Nog steeds wordt verdedigd dat de gehele revalidatie thuis hoort in het pakket voorzieningen van het algemeen ziekenhuis, terwijl men voorbij ziet aan de zeer belangrijke verschillen tussen deze ziekenhuizen en revalidatiecentra".

Uiteraard zijn er ziektebeelden denkbaar waat de hier naar voren gebrachte problematiek niet of nauwelijks een rol speelt. Bij die patiëmten echter waar het opnieuw leren van gedrag (voor patient en thuismilieu) met de reeds meermalen genoemde voorwaarden inzake geringe rrekwentie, intensiteit, lage waarde, aversieve beleving etc. etc. naar voren komen, is een speciale benadering gewenst. Deze kan alleen uitgevoerd worden door een multidisciplinair team, dat gesteund door eenzelfde grondgedachte, eenzelfde leerstrategie weet te hanteren.

Ondertussen blijft het algemeen ziekenhuis het eerste en belangrijkste ontwangststation voor o.a. de traumapatiënt. Hier zullen de handelingen verricht moeten worden die noodzakelijk zijn om een krisissituatie in eerste aanzet te hanteren. Informatie omtrent deze handelingen heeft zeer grote waarde m.b.t. assessment en modifikatie in het revalidatiecentrum. Het lijkt derhalve wel van belang, dat het algemeen zickenhuis in de eerste diagnostiek en behandeling zou kunnen anticiperen op de krïteria die in het revalidatie-leerproces relevant worden geacht.

\subsubsection{Modifikatie van gedragstekorten vanuit klinische testsituatie}

\subsubsection{Probleemstelling}

Teneinde gedragsmodifikatie te kunnen kontroleren, toetsen, korrigeren etc. moet vamuit empirisch standpunt iets wezenlijks ingebouwd worden, namelijk begeleidende assessmentprocedures, die bestaan uit meting vooraf, minstens én meting tijdens de gedragsmodifikatie en een meting na afloop. Het woord meting word hier bedoeld als de meting m.b.v. een geijkt instrument, ter uitsluiting van subjektieve (voor)oordelen.

Indien men vanuit deze invalshoek, de bril van het empirische kriticisme opzet, dan kunnen de volgende vragen gesteld worden.

1. Hebben de vele trainingen, therapieën, begeleidingen, ondersteuningen, die ter 
verbetering van gedragstekorten in de testsituatie ondernomen worden inderdaad sukses en worden er pogingen tot objektieve evaluatie ondernomen?

2. Bestaat er een mogelijkheid om een overzicht te krijgen inzake de vele vormen van trainingen? Is er een logisch indelingsprincipe denkbaar uitgaande van een theoretische of praktische invalshoek, dat bij voorkeur uitgaat van, rekening houdt met, of aansluit op een voorafgaande assessment?

3. Tenslotte: Is het haalbaar een koers te bepalen welke uitgaat van een duidelijke assessment, modifikatiepogingen konsekwent toepast en een mogelijkheid tot empirische toetsing toelaat?

\subsubsection{Het effekt van funktietrainingen}

Zowel in Nederland alsook in het buitenland zijn er wrijwel geen objektieve evaluerende onderzoeken uitgevoerd over het effekt van de verschillende methoden en over de indikaties voor toepassing ervan. Strikt genomen is de mogelijkheid voor de verbetering van gedragstekorten, gekonstateerd in de klinische testsituatie, niet aangetoond.

Ten aanzien van herstel van zgn. "funkties" (de hypothetische konstrukties van de black box) zijn er, bezien vanuit neuropsychologisch standpunt, volgens Deelman (1970 - 1 p. 27), twee uiteenlopende meningen:

A. Wanneer er een hersencel vernietigd is, dan resulteert dit in een onherstelbaar defekt.

B. Wanneer er een hersencel vernietigd is, dan resulteert dit in een herstelbaar defekt, dat namelijk kan worden gekompenseerd of worden opgeheven."

Volgens Deelman (1970-1 p.27) zijn er tegen het therapeutische nithilisme enige bedenkingen aan te voeren:

1e. "Er kunnen "funktiestoornissen” optreden (bijw. bij afasie) zonder dat er hersencellen vernietigd zijn. De cellen kunnen ook tijdelijk niet in staat zijn hun normale funktie te verrichten.

2c. Wanneer een bepaalde funktie uitvalt, dan is het niet gezegd dat alle cellen van het gebied dat die funktie verzorgt, uitgeschakeld zijn.

3e. De hersencellen kunnen ook door zich elders afspelende processen geïrriteerd of pathologisch beïnvloed worden.

4e. Spontaan herstel lijkt soms reeds na korte tijd mogelijk."

Deze overwegingen samen laten, aldus Deelman, nogal wat ruimte voor herstelmogelijkheden.

Deze hoopgevende gedachtengang wordt, zoals eerder aangegeven, ondersteund of begeleid door een veellheid en variēteit aan trainingsprogramma's die op een diversiteit aan defekten wordt losgelaten. Of de funktietrainingsprogramma"s werken is voorlopig onzeker.

Dumont (1973 p.187): „De overtuiging dat de programma"s helpen is vooral op klinische observatie gefundeerd. Wetenschappelijke bewijsvoering is hierbij nog een wens".

Sarno (1970-1): .Does speech therapy help aphasics? There is an element of natural recovery present but proper therapy at the time helps more. Most of the studies reporting gatin in this field are based on retrospective reports and are subjective in nature. Among these techniques that have been used are drug therapy, grouptherapy, social therapy and role playing".

Sarno c.s. (1970 -2): .C Controversy exists on the benefits of an auditory stimulation 
versus a structured instructionall approach. There is no hard evidence for either: There is evidence that psychosocial factors have little consequences for the learning process in aphasics".

Cohen C.s. (1970): "Physical therapy techniques have not yet undergone systematic comparison (...) the published evidence does not support the enthousiastic claims that have been made for it. The current wave of physical therapy derived from the growth of interest in neuropsychology has given rise to considerable controversy. Many of the methodological problems of psychotherapy appear in physical therapy as well".

Diller (1971 p.13): "There are still many problems with regard to ADL scaling that should be briefly noted (a) What items are selected and how are they grouped? Studies range from single-items scales to scales with over 100 items. (b) How are utems to be scored? (c) How are the date to be treated, different treatments of the same date yield markedly different results (. . . )"

Deelman (1970 -2 p.648): "Naar mijn mening is het een uitzichtloze situatie voor de solitaire onderzoeker. Een interdisciplinair team evenwel, zal stellig in staat moeten zijn een begin te maken met een objektieve evaluatie van op zijn minst een enkele variant van de afasiebehandeling".

Door de citering van deze twee Nederlandse en vier buitenlandse publikaties is de gehele aangelegenheid natuurlijk niet afgehandeld. De vooflopige indruk uit de betreffende literatuur is, dat er onvoldoende aandacht - tot nu toe - besteed werd aan de evaluatie van trainingen en dat het niet mogelijk is op basis van deze informatie een uitspraak ten gunste of ten nadele van deze aktiviteiten te formuleren.

\subsubsection{Indeling naar theoretische uitgangspunten}

$\mathrm{Na}$ bovengenoemde onzekere toestand inzake het effekt van funktietrainingen $z o a l$ aanwezig, lijkt het toch van bellang enigszins te weten welke training woor welke patiênt (syndroom, symptoom etc.) van belang wordt geacht. Een eerste vraag hierbij is in hoeverre bepaalde theoretische verklaringsmodellen een indikatie verstrekken woor het uitvoeren van een duidelijk omschreven handelingssekwentie, waarbif dan gehoopt wordt op herstel van een defekt.

M.a.w. een theorie zal ter hypothesetoetsing gebruik maken van een bepaalde verzameling van tests, wervolgens zal een bepaald resultaat aanleiding geven tot een geïndiceerde training. Dit lijkt althans plausibel. Op de genoemde handelingssekwentie ,theorie-test-therapie" bij bepaalde scholen zal hier exemplarisch worden ingegaran.

De Subcorticale Sensorische Integratie (Ayres 1974) is gebaseerd op de gedachte dat kerproblemen het gevolg zijn van inadek wate sensorische integratie op subcortical niveau. Bij de daaruit door Ayres afgeteide assessmentprocedures ligt het aksent op o.a. visuele watrneming, taktiele waarneming, kinesthetische waarneming, het taktiele bewegen, kinesthetische bewegingen en de integratie wan het watnemen en bewegen naar diverse modaliteiten en responsies. De op deze onderzoeken aanslutende therapie bestaat uit het stimuleren van die gebieden warin tekorten werden vertoond, waarbij het aksent vooral lijkt te liggen op de taktiele en vestibulaire stimulatie in toenemende moeilijkheidsgraden.

De theorie der Phylogenetic Recapitulation (Doman c.s. 1960) ook wel theorie der optimale neurologische organisatie genoemd, gaat er wan uit dat: (1) De neurologische organisatie van het individu een herhaling is van de fylogenese, de on wikkeling 
diz de mens als soort gedurende de evolutie heeft doorgemakt. (2) De laatste ontwikkelingsstap die de mens van het dier doet verschillen stat in verband met een specifieke specialisatie van de hersenschors (taalcentra). (3) Deze specialisatie treed op doordat en nadal de hersenen georganiseerd worden in een dominante an subdominante hemisfeer. Optimale neurologische organisatie is de organisatie der hersenen in een strikt dominante en subdominante hemisfeer. Het is niet duidelijk of Domanen Delacato een eigen testserie ontwikkeld hebben. Als dit zo is dan lijken deze tests o.a. gericht te moeten zijn op dominantiebepaling van oog, oor, voet en hand. Therapie is gericht op het verkrijgen van unilaterale dominantie (dus of links of rechts) en kruisdominantie moet vermeden worden. De praktische oefeningen bestaan uito.a. rollen, schuiven, kruipoefeningen, hetgeen lijkt op passieve oefeningen waarbij de bewegingen die men laat uitvoeren geleidelijk moeilijker worden.

In het zgn. "Frostig programma" (Frostig 1968) wordt ervan uitgegaan dat het sukses van het $k$ ind in de beheersing van allerlei taken afhangt van $z$ ijn perceptuele ontwikkeling, waarbij de visuele perceptie het belangrijkst is. Frostig beklemtoont ook het belang van de sensomotorische fase zoals beschreven door Piaget en ze erkent de waarde van Ayres in de verschaffng wan kinesthetische, taktiele en visuele stimuli, maar ze warschuwt tegen bewegingsopvoeding, als deze tot basis van al de andere ontwikkelingen wordt gemaakt. Eigen testontwikkeling is aanwezig. Deze is gericht op de bekende Gestalt-principes als!figuur-achtergrond, vormkonstantie, maar toch ook op visuex-motorische coördinatie of oog-hand coördinatie. De training is gericht op het ambieden wan stimuli overeenkomstig de testseries in opklimmende moeilijkheidsgraden al of niet in de vorm van spelletjes.

Het Kephart programma „Step by step" (Kephart 1971 en 1973) gaat ervan uit dat men bij de bestudering van de ontwikkeling twee scholen in hun gedachtengangen moet kombimeren. De eerste lijn is de zgn. normatieve benadering waarin mem het opgroeiende kind geleidelijk meer en meer gekompliceerde taken ziet verrichten. Het akkumuleert vaardigheden en vermogens en zijn voortgang volgt een langzaam stijgende kurve. De tweede benadering gaat uit van Piaget, die stelt dat de ontwikkeling ontstaat via een serie van stadia die essentieel andere methoden kenmerken in de verwerking van informatie. Kephart suggereert dat het leren optreedt door eerst volgens de normatieve weg een hoeveel heid vaardigheden en wermogens te akkumuleren tot een voldoende kwantiteit aan informatie is opgeslagen. Op dit punt ontstaat een total nieuw patroon en het leren toont een spiongsgewijze mutatie naar een nieuw stadium. Op deze wijze wordt on twikkeling. gezien alls een serie „step by step"-processen. Als een proces wordt overgeslagen gaat het kind nieuwe problemen oplossen met oude methoden van informatieverwerking. Kephart heeft een eigen testontwikkeling en obserwatieschaal met nanke gericht op sensomotorische prestaties (evenwichtsbalk, springen, identifikatie van lichaamsdelen, imitatie van bewegingen, maar ook het kunnen uitroeren van spelletjes, ritmische oefeningen etc. etc.) (Zie Kephart c.s. 1973). De training is gericht op input, (perception) and output (motor ability) en de feedback tussen deze twee aktiviteiten. Hierbij wordt gebruik gemaakt van allerlei oefeningen die overeenkomst vertonen met de prestaties die ook in de test geleverd moeten worden.

Voor nadere informatie over warianten van deze "theorie-test-training"-cycli kan o.a. verwezen worden naa.r Dumont (1973) als een van de overzichtwerken.

Van belang wordt toch op een gegeven moment de vraag, wat al deze ideeèn en 
programma's te bieden hebben naast uitgebreide publikaties van de auteur, kritieken van de vele opponenten, allerlei verschillende tests en trainingen en weinig empirisch onderzoek wat dan ook nog eens een keer wordt weerlegd.

Het lijkt niet eenvoudig om een overzicht van allerlei gemeenschappelijke punten hier weer te geven. Een poging hiertoe zou als volgt kunnen luiden:

a. De meeste "theorie-test-programma"-cycli in de literatuur hebben betrekking op leergestoorde kinderen (of welke andere omschrijving hiervoor ook gebruikt mag worden).

b. De theorieèn proberen meestal aansluiting te zoeken bij een gepostuleerde neurologische ontwikkeling. Hierbij wordt dan gesuggereerd dat er tijdens de ontwikkeling "iets" niet goed is gegaan. Er is een bepaalde laag of niveau of anatomisch deel niet volgroeid. Het heeft geen aansluiting gevonden bij andere parallele ontwikkeling etc. De meeste theorieën oriënteren zich op de sensorische, op de motorische of op de sensomotorische ontwikkelingsachterstand. Andere theorieën stel.len daarentegen dat er toch nog ",iets meer" of ",iets later" optreedt bijp. de taalontwikkeling. Vaak wordt dan toch wel genoemd, dat eer er een goede taalontwikkeling kan plaatsvinden eerst de dlaaraan voorafgaande groei of ontwikkelingsprocessen goed moeten zijn werlopen.

c. Sommige theoretici hebben tests ontwikkeld watwan wordt aangenomen dat deze aansluiten op de theorie. Ze zijn er dus op gericht om tekorten te meten die, bij een eventuele leerachterstand, door de theorie worden gesuggereerd. Bij andere theoretici is het wat moeilijker om deze relatie tussen theorie en diagnostiek te leggen. Er wordt dan eenvoudigweg een aantal tests gepresenteerd waarbij het niet duidelijk is waarom juist deze test en geen andere wordt gebruikt. De psychometrische eigenschappen van de tests worden vaak niet genoemd. Een volgorde of taxonomie van tests werd in geen enkele publikatie duidelijk alangetroffen. Naast de tests bestaan ook een groot aantal opdrachten die door de therapeut en patiënt of alleen door de patiënt moeten worden uitgevoerd.

d. De therapieën lijken soms aan te sluiten bij de tests, echter in een groot aantal gevallen staat merkwaardigerwijs de training reeds bij voorbaat vast. Het is een pakket van aktiviteiten dat door de patiënt moet worden uitgevoerd, waarbij men zich kan afvragen waarom er eigenliik een moeizame testprocedure werd ondernomen. Zie bv. Zaad (1975 p.20); "Vooraf moet gezegd worden dat de pedagogische en orthodidaktische strategie ons inziens niet ontstaat uit een logische deduktie van de psychologische diagnose. Veeleer zien we de strategie als het plan dat reeds ter beschikking staande orthopedagogische methoden tol éen (?) effektief (?) geheel maakt, veelal met binnen dat plan zelf ontstane nieuwe orthopedagogische orthodidaktische methoden" (Zaad schijnt reeds a an te nemen dat dit de enige juiste weg is, waarwan reeds lang werd aangetoond dat ze effektief zijn zou).

Sarno (1970): "There is a tendency to apply a given technique without regard to the degree of impairment" or even assessment of the impairment" (uit deze opmerkingen van Sarno spreekt toch wel enige ongerustheid omtrent de gang van zaken). De trainingen lijken in een beperkt aantal gevallen wel aan te sluiten bij de theorie. Bijv. Als het aksent der theorie op de sensomotorische ontwikkelingsstoornis valt dan worden allerlei bewegingsoefeningen gedaan. Valt dit aksent der theorie op de visuele sensoriek (Frostig) dan ziet men hoofdzakelijk training in de visuele perceptie, met een waarschuwing van Frostig zich niet al te zeer bezig te houden met de motoriek.

e. De inhoud der oefeningen bestaat uit passief bewegen (therapeut beweegt patiënten), verrijken van de omgeving (omgeving wordt meer gedifferentieerd) 
aktief bewegen (zingen, spelletjes), het geven van opdrachten die een toenemende mate van complexiteit vertonen. Vaak en erg vaag bestond er de indruk dat vele oefeningen vanuit verschillende theoretische visies elkaar overlappen. Hierbij wordt het theoretisch uitgangspunt wel enigszins irrelevant.

Bij geen enkele, tot nu toe bestudeerde, publikatie was duidelijk sprake van een evaluatie in de zin wan herhaalde, tussentijdse diagnostiek m.b.v. parallel tests. Hoewel er nog meer opmerkingen geplaatst kunnen worden, lijkt het op dit moment nuttig om te bezien of er nog andere invalshoeken bestaan.

\subsubsection{Indeling naar praktische uitgangspunten}

In de vorige sub-paragraaf werden allerlei aktiviteiten (schijnbaar)gedetermineerd door de theoretische vooronderstellingen inzake de relatie "hersenen-gedrag”. Een theorie leidde in de gunstige gevallen tot een test en na gebleken tekorten op de test werden er therapeutische aktiviteiten uitgevoerd die overeenkomst vertoonden (direkt of indirekt) met de testopgaven. Een effektevaluatie in de vorm van her-testen werd nimmer aangetroffen. Vanuit praktisch standpunt geldt zeker nu de zeer reële vraag "wat doet men nu precies" ongeacht de theorie of misschien zelfs ondanks de theorie.

Het operante model is a.h.w. a-theoretisch d.w.z. het ziet theorievorming als minder relevant en richt zich dus niet op de theorievorming inzake „hersenen-gedrag” maar op het waarneembare gedrag. Blijkt in het waarneembaar gedrag een deviatie dan presenteert dit model een aantal technieken tot gedragsmodifikatie. Deze technieken werden met name genoemd in 2.3.3.

Het theoretisch en a-theoretisch uitgangspunt kunnen symboolsgewijs als volgt met elkaar vergeleken worden:

Uitgangspunt theorie:

$\mathrm{O} \rightarrow \mathrm{S}_{1} \rightarrow \mathrm{R}_{1}$ vervolgens $\mathrm{S}_{2} \rightarrow \mathrm{R}_{2}$

Over de black box wordt een theorie gevormd; deze geeft bij de testsituatie aanleiding tot het gebruik van bepaalde stimuli $\left(\mathrm{S}_{1}\right)$, waarbij gekeken wordt of het gedrag $\left(\mathbb{R}_{1}\right)$ meer of minder adek waat is. Bij de therapie wordt een enigszins andere stimuluskonfiguratie gepresenteerd $\left(S_{2}\right)$ waarbij $S_{2}$ overigens direkt of indirekt $S_{1}$ benadert. Vervolgens wordt getracht bij $\mathrm{S}_{2}$ een adek wate respons te doen optreden $\left(\mathrm{R}_{2}\right)$

Uitgangspunt operant model:

$S_{1} \rightarrow R_{1}$ vervolgens $S_{x} \rightarrow R_{y} \rightarrow \mathbb{K} \rightarrow C$

Vanuit een nog nader te bepalen presentatie van stimuli wordt bezien of de daaruit voortvloeiende respons adek waat is. In de therapie kan onder systematische variatie van stimuluskonditie $\left(S_{x}\right)$ gekeken worden of de optredende respons $\left(R_{y}\right)$ adek wat is. Vervolgens wordt volgens vastgestelde bekrachtigingsschema"s de juiste respons versterkt. Het operante model legt dus, meer dan bij de "theoretische modellen", het aksent op systematische presentatie van stimuli en op de kontrole van bekrachtiging en kontingenties. Over het algemeen worden in de trainingprogramma's bij .. leergestoorde kinderen" voorwaarden als goedkeuring ed. wel genoemd, maar niet systematisch gehanteerd.

De presentatie van stimuli tijdens test- en trainingsituatie is hierbij een probleem apart. Indien volgens een nauwkeurig vastgestelde volgorde de diverse mogelijkheden aan stimuluskombinaties zijn gepresenteerd dan zal bij een gekonstateerd tekort in de respons volgens de methode van "limit testing" moeten worden 
nagegaan welke methodiek er geschikt is on responsverbetering te doen optreden. Limit testing is de techniek, waarbij men onder systematische variatie van stimuluskondities tracht na te gaan in hoeverre een vereiste respons verbetert. (zie hoofdstuk 5 inzake limit testing).

Bovenstaande overweging gaat er nog steeds vanuit, dat herstelmogelijkheden aanwezig zijn. Zoals eerder gesteld, zijn er naast herstel van defekten alternatieven (o.a. kompensatie van defekten) denkbaar.

Voor er op de diverse methodieken binnen het operante model ingegaan wordt, moet aandacht besteed worden aan bovengenoemde alternatieven.

Deelman (1970-1 p.29 en 30) vergelijkt twee vormen van training:

1e. Het trachten te herstellen van de funktie als zodanig, zodat pritient weer op dezelfde wijze funktioneert als vóo het defekt. Hiertoe rekent hij alle mogelijke vormen van aktiveren of stimuleren (zoals deze o.a. naar voren komen bij de trainingsprocedures voor het leergestoorde kind).

2e. Het laten verlopen van de funktie langs $\mathrm{k}$ walitatief andere weg: het reorganiseren als therapeutische mogelijk heid die vooral door Luria zou worden gebezigd. Deelman stelt verder: "Wanneer wij nagaan wat er aktueel gebeurt bij de behandeling dan wordt het echter erg moeilijk om allerlei methoden duidelijk van elkar te blijven onderscheiden. Om dat te kunnen doen moet men precies weten wat zich allemaal bij een bepaalde behandeling afspeelt". Deze laatste uitspraak sluit volledig aan bij de mening die hier gepresenteerd wordt: Men komt er niet achter wat er precies gebeurt, aangezien de handelingen nergens duidelijk geëxpliciteerd worden.

Diller (1971 p.25) onderscheidt in vergelijking met Deelman drie modellen nl. „ability model, process model and the engineering model”.

„1e. The Ability model suggests that abilities can be taught by beginning at the level of competence of the individual and gradually increasing the tasks demands. There are several wariations of abilities models. One includes an enrichment material model that argues in favor of some type of stimulation approach. The basic idea is that atypical behavior is due in part to an absence of proper experience or as a result of environmetal deprivation or neurological impairment.

2e. The process model argues that lack of competence is not a function of lack of experience and that competence does not arise from repetition enrichment or even reinforcement. Competence may arise by changing the nature of the task demands

3e. The engineering model suggests that the development of prosthetic devices, prosthetic environments and aids are helpfull."

Aan de hand van de twee bovenvermelde auteurs werd het volgende indellingsprincipe gekozen:

1e. Gedragsrestauratie m.b.w. operante technieken.

Nadat door middel wan limit testing (zie Hoofdstuk 5) nagegaan is welke techniek bij de patiënt de grootste kans heeft, wordt een keuze gemaakt uit de volgende procedures:

a. Toename van gedrag in frekwentie en in intensiteit d.m.v. selektieve reinforcement.

b. Handhaving wan gedrag bij toenemende complexiteit der stimuluskondities d.m.v. fading. 
c. Shaping van gedrag indien er totaal geen respons of onvolledige respons volgt bij een teststimulus. Hierbij kan gebruik gemaakt worden van "verbal cues, modeling, prompting, suksessieve approximatie, back ward chaining e.d." Al deze technieken zijn er dus op gericht "funktie" herstel te realiseren. Zijzullen in het navolgende met enkele literatuurvoorbeelden worden toegelicht.

2e. Gedragskompensatie.

Indien blijkt dat bovengenoemde technieken wel in staat zijn het gewenste gedrag te realiseren onder introduktie van bepaalde kondities dan wordt getracht deze ondersteunende konditie geleidelijk aan te verminderen. Als deze fadingsprocedure mislukt dan is de patiënt aangewezen op handhaving van de faciliterende kondities. Aangezien het niet mogelijk zal zijn dat een begeleider voortdurend de kondities zo arrangeert dat er facilitatie optreedt, zullen er hulpmiddelen moeten worden ingebouwd. Dit kan geschieden d.m.v. ..gedragsprothesen".

3e. Gedragsreorganisatie.

Indien gedragsmodifikatie en -kompensatie niet voldoende mogelijkheden bieden wordt overgegaan tot een wat meer ingrijpende aktiviteit "de gedragsreorganisatie". Voorzover bekend is deze benadering nimmer in Nederland en zeer zelden in het buitenland toegepast.

Niettemin verdient zij de aandacht.

Voorbeelden uit de literatuur ter verduidelijking:

1. Gedragsrestauratie m.b.v. operante technieken.

1a. Toename van intensiteit en frekwentie van gedrag onder ondersteuning van selektieve reinforcement.

Hiervan is dus alleen sprake als de patiënt een prestatie moet leveren waarbij de moeilijkheidsgraad bij benadering gelijk blijft. Een bepaalde prestatie wordt te weinig uitgevoerd of niet intensief genoeg. Deze prestatie is op zich wel goed, maar moet toenemen.

De principes van regelmatig voortgaande herhalingen in kombinaties met selektieve bekrachtiging komen naar voren bij de traditionele logopedische behandeling, perceptietraining e.d., zoals uit onderstaande voorbeelden blijkt.

- Leche (1974 p. 347) "Constant repetition and reinforcement help to reestablish the language patterns."

- Underwood (1974 p. 343) „perception is largely an acquired skill and should be treated by providing the opportunity for the patient to re-learn through repeating experience which he may have forgotten".

- Sarno (1970 p. 50): „one of the first steps in treating a patient with global aphasia according to a traditional approach is to present him with a group of pictures of common objects. While the therapist names the pictured objects, the patient is directed to point to the picture named (...)"

- Savage (1971 p. 41) „The patients are seated at the table with the therapist opposite them. One item is taken from the box with the right hand and held out sideways. Ask the patient to look at the object and name it (...) Continue until the patient becomes quicker at eye movements".

1b. Handhaving van gedrag onder toenemende complexiteit der stimuluskonditie d.m.v. fading.

De "fadingprocedure" is hierbij vaak impliciet ingebouwd. Het principe is dat het gedrag wel beheerst wordt in situatie of stimuluskonditie A, maar nog niet in situatie 


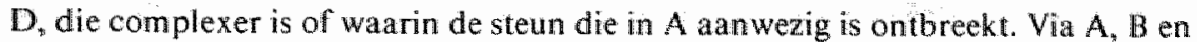
$\mathrm{C}$, die geleidelijk qua stimuluskonditie verschillen wordt $\mathrm{D}$ bereikt.

Het bekende voorbeeld uit de gedragstherapie is de leerling die wel bepaalde prestaties verricht indien de moeder aanwezig is, en niet indien leraar en leerlingen aan wezig zijn. Fading behelst hier het geleidelijk aan verwijderen van de faciliterende kondities en vervangen door minder faciliterende, marar gewenste kondities.

- Indien een patiënt een bepaald gedrag beheerst in een stille omgeving dan is de stilte, het geordend zijn van de ruimte een faciliterende konditie. Het geleidelijk aan brengen van patient in een meer stimulusrijke of meer complexe stimuluskonditie betekent werlies van ondersteuning onder (hopelijk) behoud van gedrag.

- Men kan iedereen leren bepaalde (zonderlinge) woordparenkombinaties te onthouden door bv. visualizering wan de kombinaties. Dit kan zelfs een "tweede natuur" worden, hetgeen dan gaat lijken op een "prothese". Naarmate echter de stimuli complexer worden of minder gemakkelijk te visualizeren, wordt het gebruik maken wan deze ,steun" moeilijker. Het geleidelijk aan "afbouwen" van deze steun, hulpmiddel of ezelsbrug, die iedere patient tracht te vinden bij geheugentrainingen e.d. valt per definitie onder fading.

In principe vallen alle "verrijkingsprocedures" en "stimulatietrainingen met toenemende moeilijkheidsgraad" die genoend werden bij therapieèn voor leergestoorden onder fading.

- Gibson c.s. (1955) „Two point discrimination may be effected by a few hours traning so that the distance after four weeks, may change from $30 \mathrm{~m}$. $\mathrm{m}$. to $5 \mathrm{~m} . \mathrm{m}$." - Kales (1971 p.32), Once a relationship of confidence and trust is established the patient visits the occupational therapy department for tea. The first visit is always short. If he cannot tolerate the different environment and the noise, we have tea in a quiet room. On subsequent visits mental and physical activity are gradually increased and he is encouraged to mix with other patients (...) The patient is praised for achievement and if he fails after a second attempt the activity is simplified". (Hier ziet men dus duidelijk drie essentiële elementen: (1) het leggen van een goede relatie, teneinde te realiseren dat de arbeidstherapeute een "reinforcing agent" wordt. (2) het geleidelijk verhogen van de moeilijkheidsgraad onder behoud van "theegedrag" en (3) het toedienen van de bekrachtiging).

- Holland (1974 p.542), Then the experimenter initially performed the respons and subsequently faded out relevant cues until the subject was able to perform the specific action on command". (Dit lijkt een kombinatie van modeling en fading.) - Hogg (1974) .Funktierestaunatie wordt geprobeerd d.m.v. stimulatie onder verhoging van intensiteit en van aflectief kontakt. Eerst moet het kind de therapeut gewaarworden. Bij het hyperaktieve kind, dat steeds heen en weer loopt, zorgt de therapeut dat het tegen haar arinrent. Bij het hypoaktieve kind gaat de therapeut nawst het kind zitten en rakt het aan. Naarmate de gewarwording toeneemt worden er meer stimuli aangeboden."

Inzake een der weinige Nederlandse publikaties, die vermoedelijk eveneens op deze plats genoemd moet worden, kan verwezen worden naar Saan c.s. (1973).

1c. Shaping van gedrag bij volledige of gedeeltelijke afwezigheid van een respons. Bij deze methodiek is de limit testing een vereiste. Er zijn witeratard meer mogelijkheden om deze procedure te hanteren. Men kan uitgaan van de hypothese dat een ontwikkeling volgens een zekere volgorde zal ontstaan en dan met deze rangorde rekening houden in de aan te bieden stimuli (zie Sarno c.s. 1970). Men kan een taak zoals Ozer (1974) in komponenten onderverdelen of de modaliteit van de input variëren. Men kan ingrijpende veranderingen in de omgeving trachten te 
realiseren (licht, donker) of bewust gaan manoeuwreren met het aantal afleidende stimuli. Er bestaat op dit moment nog geen frame work van mogelijke variaties hoewel Mark (1969) er zich wel op schijnt te beroepen. De techniek der limit testing wordt uitgebreider besproken onder 5.1.2.3. Het principe zal hierbij altijd bestaan wit het (systematisch) uitproberen van veranderingen in stimuluskondities, het nagaan of de patiënt een taak onder een bepaalde konditie wel beheerst, geleidelijke overgangen van kondities. (licht-donker, meer taakkomponenten invoeren) en tenslotte bezien hoever de patiënt in het uitvoeren van de taak kan komen. Het residu aan gedragstekorten bepaalt de prothese. De principes der shaping, zoals reeds meer malten genoemd, lijken volledig te beantwoorden aan het principe dat door Diller werd geformuleerd in zijn "proces-approach": "Competence may arise by changing the nature of the task demands" (1971 p. 25)

Ter illustratie van limit testing en diverse vormen van shapingsprocedures werden de volgende publikaties geselekteerd.

- Sarno c.s. (1970) lijkt zich bewust te zijn van de noodzaak tot suksessieve approximatie. "Language recovery: In the analysis of these assumptions it became clear to us that in order to use a programmed approach it would be necessary to revise our traditional approach. It was apparent that pre-verbal skills such as imitation and visual recognition had to be mastered before auditory comprehension and speech could be introduced (...) Language recovery was viewed as a continuum or hierarchy of skills: imitations, visual recognition, auditory comprehension and finally speech. After determining the sequence of modalities for the programmed curriculum it was necessary 10 grade skills within each modality (. . .). The number of steps in each program varied according to the complexity of the task (...). (Hier wordt dus uitgegaan van een conceptual frame work, dat een volgorde in kanaalsystemen aangeeft en een onderverderdeling in taakkomponenten).

- Yoder c.s. (1974) geeft een voorbeeld van modeling: "It has been only a recent trend to examine the effects of modeling on the acquisition of abstract cognitive respons patterns (...) adding verbalizations to overt behavioral modeling cues is one way to increase the number and salience of cues".

- Rosenthal c.s. (1972) noemt eveneens het faciliterend effekt van modeling. "Concept acquisition of children is facilitated by observation of a modelperforming the task prior to the subject performance"

- Leche (1974) „The programmed instruction approach views language rehabilitations as an educative process and applies operant conditioning techniques drawn rrom learning theory and principles from psycholinguistic analyses to guide the content and order of the presentation of the linguistic taught"

- Reissenweber (1953 p. 27) "Performance with block designs may sometimes be appreciably improved when such factors as the angle of display "position of the materials are understood (...) Variations in training are necessarily dependent upon capabilities of individual patients".

- Ben Yishay c.s. (1970) "To cross-validate previously reported findings which suggest that improvement in block design performance of left hemiplegics as a function of cueing is lawfull and quantifiable (...). The uniformly high correlations between competence and cues which where obtained for all three groups (left and right hemiplegics and normals) are clearly in line with previous findings. Furthermore the data suggest that these relationships apply in normal and brain injured "ndividuals.

- Schubert (1969) .What we are in effect suggesting is that the diagnostic process be viewed as a learning one (...). Because of these considerations the order of tests was not uniform (...). The child was helped toward the solution of these problems 
according to a standardized procedure which was aimed to direct his conscious attention upon his mode of work (limit testing).

- Silver c.s. (1969).. Sequin emphasized the importance of isolating and stimulating single modalities in a manner inkeeping with the present information-processing theory".

- Diller (1967 p. 14): "Goldstein and Schurer (1941) and Luria (1961) have advocated varying conditions of stimulus presentation for the purpose of assessment. Such variations could be used also for treatment".

Verscheidene trainingsprogramma*s blijken impliciet gebruik te maken van een kombunatie van diverse operante technieken. Een representatief voorbeeld van een dergelijke kombinatie - ongeacht de theorie - is de behandelingswijze van Holland. - Holland c.s. (1974 p. 592) "Throughout the program the patient was seated at a table with the program cards and tokens facing him. Following each command he was given 10 seconds to point to the correct answer. If he responded correctly then the tester said "good" "fine" or "that's right" (selectieve reinforcement). If he still failed to respons the experimenter demonstrated the correct answer (modeling) (....). If the subject was asked, show me green" from an array of green, red and blue and he selected blue he heard "No you show me blue, show me green" (verbal cues) (. . . .). The the experimenter initially performed the response (modeling) and subsequently faded out rellevant cues until the subject was able to perform the specified action on command (fading)".

\section{Gedragskompensatie.}

Met name het gedragsrestauratie-model waarbij nagegaan wordt onder welke kondities een gedrag in de testsituatie wel tot stand kan komen (shaping e.d.) levert informatie op inzake mogelijke hulpmiddelen. Hoewel prothesen alleen of hoofdzakelijk bekend zijn ter kompensatie van een gedragstekort tengevolge van zintuigelijke of lichamelijke defekten is het ook denkbaar dat deze ontworpen kunnen worden woor de meer psychische systemen.

Aan deze "psycho-prothesen" is behoefte, indien - overigens na een moeizame procedure - wastgestelde faciliterende kondities niet meer door fading kunnen worden weggenomen.

Indien men bijvoorbeeld een patiënt tijdens geheugentraining leert dat het gebruik maken van allerlei rangschikkingen en visualizeringen van het materiaal to betere geheugenprestaties voert, dan is hijgaandeweg in staat met deze hulpmiddelen meer materiaal te onthouden. Op zichzelf is dit te zien als het stap voor stap bereiken van een doel d.m.v. een hulpmiddel, zonder dat dit hoeft te betekenen dat de geheugen $_{4,}$ funktie" op zich verbeterd is. Dit kan pas nagegaan worden indien de persoon een geheugenprestatie levert zonder wan deze methode gebruik te maken. Indien dit afbouwen langzaam verloopt, kan wan fading gesproken worden. Blijkt echter dat de persoon bij voortduring gebruik moet maken van de aangeleerde methode dan is er een hulpmiddel ontstaan dat blijvend moet worden "te hulp" geroepen. Aangezien het hierbij gaat om de verbetering van gedrag als een reaktie op teststimuli warbij verondersteld wordt "hypothetische konstrukties" te modificeren, wordt deze vorm van prothese hier behandeld. Er zijn - zoals zal blijken andere vormen van hulpmiddelen mogelijk die meer complexe gedragstekorten in de klinische observatiesituatie kompenseren. (zie 4.2.4.2).

Toepassing van "psycho-prothesen" ter kompensatie van tekorten in specifieke hypothetische konstrukties zijn tamelijk schaars. Slechts enkele literatuurvoorbeelden kunnen worden genoemd. 
Diller (1971 p.25), The formalations of the brain injured child as baving problems due to ligure ground is based on the idea that the ground interferes with the figure and the way to correct the situation was to minimize the distraction".

Aan de hand wan hel volgende voorbeeld kan het hier geintroduceerde onderscheid tussen "restauratie, kompensatie en reorganisatie" geilllustreerd worden:

Deelman (1970 p.29) .Sommige leesstoornissen ontstaan door visuele moeilijkheden. Deze patienten zien de letters well duidelik, maar kunnen ze toch niet goed identificeren. Het is mogelijk om door gebruik te maken van taktiele stimuli deze patienten met hun leesproblemen te helpen. Er worden letters gebruikt met een ruw oppervlak dat alsteekt tegen de gladde achtergrond. De patiënt leert dam lezen door de letters te betasten".

Het is hier de opvatting dat deze informatie door limit testing werd ontdekt. Het proces van het leren lezen d.m.v. taktiele indrukken kan geplaatst worden onder het werschaffen van een hulpmiddel. Indien door oefening gaandeweg de taktiele prikkels een steeds geringer rol gaan spelen, kan men ook van fading spreken. Blijven deze vormen van letters vereist als "ondersteuning", dan is hier sprake van een prothese en wordt het kompensatiemodel van kracht. Gaan echter de taktiele indrukken het gehele leerproces beheersen (zoals bij blinden) dan is sprake van reorganisatie.

\section{3e. Reorganisatie van gedrag.}

Het cerebrum hoeft niet altijd op dezelfde wijze bij een handeling betrokken te zijn. Men kan niet van een gefixeerde bijdrage spreken. De konsek wentie hiervan is dat, wanneer door een cerebale stoornis een bepaalde prestatie niet meer kan worden geleverd, men kan proberen die prestatie langs kwalitatief andere weg tot stand te laten komen.

Reorganisatie kan ook spontaan verlopen. Een voorbeeld hiervan zijn ademhalingsstoornissen. Wanneer door een trauma een gedeelte van de muskulatuur niet goed meer funktioneert worden bepaalde spiergroepen bij de ademhaling betrokken die daar normaal geen rol bij spelen.

In Rusland legt men op dit reorganisatieprincipe de meeste nadruk. Het aksent ligt hierbij echter op de vorming van meer complex samengesteld gedrag en niet specifiek op de reorganisatie van "funktiestoornissen" zoals hier bedoeld. Derhalve wordt voor de behandeling der publikaties verwezen naar modifikatie van gedragstekorten in de klinische observatiesituatie (4.2.4.2.)

\subsubsection{Modifikatie van gedragstekorten wanuit de klinische observatiesituatie}

\subsubsection{Probleemstelling}

De modifikatiepogingen van gedragstekorten vanuit de testsituatie hadden alle betrekking op relative enkelvoudig gedrag: het verbeteren van een respons op een specifieke tesistinulus. Bij de konstatering van gedragstekort in een observatiesituatie heeft men doorgans te maken met een complex samengesteld gedrag waarvan de gepresenteerde stimuli niettemin qua inhoud en modaliteit overeenkomst tonen met de stimuli in de testsituatie.

De inventarisatie van modifikatiepogingen voortkomende uit de testassessment trachtte vanuit theoretisch en praktisch standpunt een overzicht te presenteren. Het ligt dus voor de hand om een dergelijke poging eveneens te ondernemen bij de gedragsmodifikatie wanuit de observatie in de kliniek. Het is een betrekkelijk vereenvoudigde zaak om reeds hier vast te stellen, dat er, althans in de geraadpleegde 
literatuur, geen duidelijk omschreven principes konden worden gevonden, anders dan de principes der operante konditionering.

Anderzijds blijkt de hoeveelheid publikaties waarin melding gemaakt wordt van operante toepassingen in de revalidatie zo omvangrijk dat het moeilijk is een overzichtelijke indeling te geven. De reden hiervan is dat diverse methodieken meestal niet apart maar in kombinatie door diverse disciplines worden toegepast, waarbij men overigens zelden blijk geeft van bekendheid met en hantering van leerwetten.

Toch zal getracht worden om ook hier de indeling te volgen, die bij de "funktietrainingen" bezien vanuit het operante model, werd gevolgd:

1. Gedragsrestauratie.

a. Toename van gedrag d.m.v. selektieve reinforcement

b. Handhaving van gedrag onder toenemende stimuluscomplexiteit

c. Shaping

2. Gedragskompensatie.

3. Gedragsreorganisatie.

Bij literatuurinventarisatie worden voor het eerste ook tamelijk frek went empirische studies aangetroffen. Het empirisch design is hierbij het A-B-A-principe d.w.z. (A) Konstatering van uitgangswaarde (B) Het introduceren van een onathankelijke variabele welke gekontroleerd gemanipuleerd wordt en waarbij het effekt gemeten wordt. (A) Eliminatie van de variabele om te zien of de uitgangswaarde weer terugkeert. Indien zulks gebeurt, wordt verandering in de afthankelijke variabele toegeschreven aan manipulatie van de onathankelijke variabele.

\subsubsection{Gedragskorrektie naar methodiek}

Aangezien de principes bij de gedragskorrektie dezelfde zijn als bij de funktietraining zal hier volstaan worden met een ordening van literatuurvoorbeelden naar aard van de methodiek met zonodig toelichtend kommentaar.

\section{Gedragsrestauratie.}

1a. Toename van gedrag d.m.v. selektieve reinforcement.

Meyerson c.s. (1967) geven hun training in typevaardigheid als volgt weer: ..Typing skill was increased in an eighteen year old boy with traumatic quadriplegia. Before the behavior modification program, the patient did not persist in the job of typing. $\mathrm{He}$ frequently sought the therapist's attention and was reinforced for this by obtaining it. The behavior modification program consisted of placing him in a quiet room for typing, ignoring his demands for attention and reinforcing him for thirty minutes of typing. The reinforcement was five minutes of conversation on a topic, that interested him. As the program progressed he was required to type a certain number of lines to be reinforced (...). After twelve sessions his rate increased from five to twelve lines in thirty minutes and errors decreased from three per line to one every other line" (reduktie van excessief gedrag d.m.v. extinktie en toename van gewenst gedrag door selektieve reinforcement).

Hogg C. (1974 p. 62): Inzake toename van sociaal gedrag „Operant conditioning wwas aimed at eliciting the respons patterns or attitudes indispensable for social interaction and teaching appropriate behavior. The program involved reinforcement to increase the probability of the desired responses" (toename van sociaal gedrag d.m.v. sellektieve bekrachtiging).

Betreffende de training van spreekvaardigheid bericht Goodkin (1966): .Mrs. S., who following a CVA had suffered a speach disturbance of 3 years duration. The patient used many words, but she tended to shift very quickly from one topic to 
another and spoke quite mappropriately in terms of questions asked of her. Recelving all sorts of stimulus questions such as . Tell me about this room; what are some of the things you see in the room; tell me about your clothes; describe the clothes you are wearing" and responding $2 \mathrm{~min}$. this patient was reinforced verbally and with a blue poker chip for each $15 \mathrm{sec}$. period which included some material relevant to the questions. She was told that she was off the topic and received a red chip after each $15 \mathrm{sec}$. period, that failed to include any relevant material. In fewer than 15 sessions Mrs. $S$. had shown a marked progress in relevant responses to the stimulus guestions.

Walker c.\$. (1968) inzake de training van ,aandacht" vermeldt: „Attending behavior had been trained frequently in retarded persons and emotionally disturbed children. The general procedure followed is reinforcement of each period of eye contact with the experimenter (...). Initially, werbal prompting might be required but could be faded as interaction, becomes the discriminative stimulus for looking at the person being talked to".

16. Handhaving van gedrag onder toenemende complexiteit der stimulussituatie of afname van steun.

Bij elk modifikatieprogramma is het de doelstelling zo ver te komen dat de persoon het gedrag, dat eerst d.m.v. reinforcement en shapingsprocedures werd verkregen, gat vertonen zonder deze en andere ondersteuningen. Sommige programma"s leggen iets meer het aksent op deze fading dan andere.

Harris (1974): ${ }_{3}$ A new approach to treatment of children with athetoid cerebral palsy has been developed using electronic sensory aids to improve kinesthetic monitoring of the head and the limbs (...). The children are automatically reinforced for using signals to establish control during postural and movement activities (...). The use of these substitutes of course raises the question of whether the child tanght to control his movements using electronic sensory aids can maintain his improved function without them subsequently. The answer is probably "Yes, but you've got to explicitly prowide for the transition in the training program". That is the child must be slowly weamed from dependence on the devices after he has learned to function well using them". (Harris volgt derhalve het schema van aanleren van gedrag door feedback als positieve reinforcement, daarna wordt het aksent op fading-out gelegd).

Ten anzien van de korrektie van eetgedrag bericht Fingado's c.s. (1970): "The patient, a five year old severely retarded hydrocephalic child has developed many eating problems as a result of his condition. He did not feed himsell, did not take liquids from aldss and refused to eat any place other than special child's eating table. Thus the main focus of the behavior modification program was the establishment of appropriate eating skills (...). The nurse began by leading Steve's hand and partially filled spoon to his mouth (prompting). She gradually faded our her assistance initially removing her hand just before the spoon reached his mouth and finally removing her hand as he drew his spoon from the dish. All prompts were subsequently withdrawn. Training Steve to drink from a glass involved a similar fading procedure. Because a glass was aversive to Steve the nurse began by presenting chocolate pudding in the glass. Steve was initially permitted to use al spoon to eat the pudding. The spoon was removed after he had learned to hold the glass and thus he had to bring the glass to his mouth in order to consume the pudding. The pudding was gradually thinned with more and more milk untill he was drinking milk without assistance. After three weeks Steve's major eating problems has been removed". 
Een wolgend voorbeeld in Garber's studie over de behandeling van "k wijlgedrag" Garber (1971): "Little research has been applied to the modification of deviant responses secondary to known physical inwolvement. The present study was concermed with the elimination of drooling behavior in a cerebral palsied adolescent. R. M. is a 14 year old male with choreoathetotic cerebral palsy and right hemiparesis. His speech is dysarthric, characterized by excessive nasality and omissions, distortions and substitutions of consonant and vowel sounds. Constant drooling appears to be consequent to the oral paresis (...). A behavior modification program to reduce drooling was executed during speech therapy for articulatory disorders (...). The first was to instruct R. M. to swallow prior to the initiation of each verbal utterance. Because of this tendency to drool during sentence production the speech therapist would raise his hand in order to prompt $R$. M. to perform the swallowing act. After several sessions the boy was able to remember this pattern and the prompt was eliminated (rading). The second way was verbal praise for swallowing (...) after some period also this action was eliminated. The third way was to give $R$. M. pennies at the appropriate time. Only the penny reward system was used throughout the entire speech therapy program".

\section{1c. Shapingprocedures.}

Het aksent op de shapingsprocedures in hun diverse vormen lijkt te liggen in de volgende studies:

Hogg. C. (1974): "Reinforcement therapy has been devided into three phases: (1) the occupational therapist tries to gain eye to eye contact so that automatic rapport is established and the child can follow verbal directions (succ. appr. tot verbal cues), step by step rituals and gestures are eliminated (fading); (2) the second phase involves giving and receiving body contact, execution of simple tasks, recognition of spatial concepts of the face and body and physical features of the class-room. Speech is also reinforced or any attempts to verbalize; (3) The third phase is a combination of the simple behaviors of the other phases into more complex patterns. Speech is particularly encouraged with initiation coming from the child, not the therapist (fading van model). In this way the child experencies mastery (selfreinforcement) resulting from succesfull control and prediction of the environment. This lessens anxiety and increases the ability to learn".

Kolderie (1971): "A three year eight month old boy who seldom engaged in physical activity but who was not physically handicapped was conditioned to play on a large climbing-frame to engage in other forms of physical activity. The experimenters shaped the behavior by using reinforcers when the boy came near the frame. Verbal approval, smiling and physical contact were used as reinforcers. After nine days of continuous reinforcement, the contingencies were reversed and climbing-framebehavior dropped nearly to zero. The author concluded that the behavior modification program was tesponsible for the increase in physical activity" $(A-B-A$ design)

Wehman (1975): "Proper selection of clothing is another personal care skill that may have to be trained (. .). Proper selection of clothing can be subdivided in to several related clothing steps and assessed in the following way: shoes on correct reet; fine motor-dressing skills completed" shirt tucked in pants etc".

\section{Gedragskompensatie d.m.v. prothesenmodel.}

Fordyce (persoonlijke mededeling) verhaalt inzake de behandeling van een patient met geheugenstoornissen: D.m.v. successieve approximatie werd een .geheugengedrag" ontwikkeld: polshorloge met belmechanisme afstellen - op tijdstip loopt 
wekker af-hand in broekzak - notitieboek pakken en kjken waar men maar toe moet - wekker opnieuw arstellen op volgend uur - notitieboek in zak - opdracht witvoeren. Fading lukte niet helemaal, patient bleek reder uur het notitieboekje nodig te blifuen lhebben. Wat dat betreft is een zakagenda langzamerhand een even normal hulpmiddel ter gedragsbepaling als een bril. Hier wordt gemeend dat deze vorm wan prothese onder "gedragsvorming" valt en niet zozeer onder "funkterestauratie", angezien het hier gaat om het onthouden of aanleren van een handelingssek wentie van complex gedrag. Het volgende woorbeeld illustreent dit eveneens.

Gassel c.s. (1963): .Patients with homonymous hemianopia can by paying attention make better use of residual vision in the "blind" side. Some of the patients were no more aware of their blind half-fields than most of us are of our blind spot. They compensate as we do by learned eye movements or head movements".

Ten aanzien van de interaktietraining delen De Villiers C.S. (1974) mee: ${ }_{n} \mathrm{~A}$ strict-training procedure was used to advance language in two language-deficient children. A "particle language" consisting of English words printed on magnetic particles placed on magnetic board, was used to map the interaction between subject and experimenter, which led to food reinforcement. The area of this interaction was expanded to include the comprehension and production of simple commands, description and question". Aangezien het artikel niet vermeldt dat dit instrument op een gegeven moment overbodig werd, wordt aangenomen dat dit als permanente prothese tot communicatie werd gebruikt. Dergelijke interaktie- of communicatie prothesen worden in Nederland reeds enige tijd toegepast (zie Van Mierlo 1976).

\section{Reorganisatie van gedrag.}

Bijliteratuuronderzoek werden slechts beperkte aantallen publikaties gevonden, die voorbeelden gaven van gedragsreorganisatie van complex samengesteld gedrag. Deelman (1970-1 p. 30$)$ noemt enkele voorbeelden: "Patiënten die erg traag en schuifelend lopen en soms in het geheel niet meer vooruitkomen worden behandeld door het "automatisch lopen" te reorganiseren tot een cognitief geleide vorm van lopen. De patiënten moeten hun voeten steeds zetten op strepen, die op de vloer zijn aangebracht. Van lopen wordt zodoende een visueel gekontroleerde handeling gemaakt, die op een andere wijze verloopt dan vóór de behandeling".

Een ander voorbeeld van reorganisatie is de werk wijze van Farnham - Diggory (1967): "Brain injured children cannot complete a task when presented in sentence lontm but can when asked to enact it".

Prins (1975 p. 208 ) geeft een samenvatting van de therapie van Luria. Hij onderscheidt een viertal principes. ,a. De reorganisatie van het funktionele systeem als geheel door gebruikmaking wan de nog intakte schakels van het systeem. b. Uitgebreide programmering van de te reorganiseren aktiviteit met behulp van een reeks externe thulpmiddelen. c. Vila korrekte feedback moet de patiënt uiteindelijk leren om eventuelle foute impulsen a.h.w. vooraf te onderdrukken. d. Simplifikathe van de te verrichten aktiviteiten door deze zoveel mogelijk onbewust te maken wia inkorporatie in grotendeels automatische handelingssekwenties".

Over het algemeen lijkt de aanpak van Luria een boeiend uitgangspunt. Vanuit praktisch (operant) referentiekader lijken er toch allerlei elementen als shaping, gebruik van hulpmiddelen ed. door elkaar gebruikt te worden. Het laatste woord is hier nog niet over gezegd. Dit geldt eveneens en im het algemeen t.a.v. de restauratie van hypothetische konstrukties gekonstateerd in de testsituatie. Uiteindelijk zal toch een synthese tussen de theoretische- en a-theoretische denkwijzen moeten worden 
verworpen of nagestreefd. Binnen het kader van deze studie kan hiertoe slechts een aanzet worden gevormd.

In dit overzicht werd bewust naar beperking gestreefd. Het antal publikaties, vooral wat betreft de toepassingen van de shapingsmethodiek is bij de vorming van complex samengesteld gedrag aanzienlijk groter dan hier kon worden vermeld.

Er lijkt echter te zijn atangetoond, dat de indelingsprincipes, zoals gebruikt buj de vorming van gedragstekorten, gekonstateerd in de testsituatie, eveneens toepasbaar zijn op die gedragstekorten, welke d.m.w. observatie worden vastgesteld.

Gedragsrestauratie, gedragskompensatie en gedragsorganisatie, gesteund door leerprincipes vanuit het operante paradigma lijken toepasbaar op het aanleren van „,enkelvoudig" en "samengesteld" gedrag.

\subsubsection{Modifikatie van gedragstekorten in de nabehandelingssituatie}

Als revalidatiedoelstellingen inzake de situatie na ontslag zijn in 4.1.5. vastgesteld:

1. Het onderhouden van, "revalidatie-adek waat gedrag" (medicijngebruik, gebruik van rolstoel, prothesen) in die zin, dat de patiënt in staat wordt gebracht tot zelfwerzorging in de thuis-, werk- of schoolsituatie.

2. Mogelijkheden tot het onderhouden wan sociale kontakten.

3. Mogelijkheden tot produktiviteit, waarbij dit niet slechts verstaan dient te worden als "waarde op de arbeidsmarkt", maar eveneens of veel meer als "zelfreallisering".

In de klinische situatie wordt zoveel mogelijk als doelstelling het eerste punt algemeen gerealiseerd. Voor zover dit niet het geval is, zal daar natuurlijk ook nog in de nabehandelingssituatie aandacht aan besteed dienen te worden.

In de nabehandelingssituatie ligt derhalve het aksent op: Het voorbereiden van de patient op de thuissituatie in kombinatie met het onderhouden van goede sociale kontakten en het veilig stellen van zelfverzorgende aktiwiteiten. Over het algemeen is er moeilijk een exacte grens te trekken tussen klinische en nabehandelingssituatie. Deze grens zal per centrum verschillen.

De vraag waar het in dit verband om gaat is, of de leerprincipes vanuit het operante model enige bijdrage in dit "voortgezet leren" kumnen leveren. Heystek (1975) adstrueert deze gedachte an een aantal voor zichzelf sprekende voorbeelden, waarbij zij zich voornamelijk oriënteert op shapingsprocedures. "Als een patiënt op de aldeling Arbeidstherapie aktiviteiten wil uitvoeren, dan kan dat gebeuren door middel van verbale opdracht, imitatietechniek, prompting, fading, successieve approximatie". Zij bevind $z$ ich bij het uiten van deze mening in gezelschap van meer autteurs, die in het onderstaande in het kort zulten worden genoemd. Hierbij wordt niet opnieuw stil gestaan bij een bespreking van de verscheidenheid der technieken. Zoals uit 4.2.4. naar voren $\mathrm{k}$ wam, worden de diverse methoder vaak in kombinatie met elkar gebruikt en er is soms uit een publikatie niet overduidelijk te distilleren welke methode er nu precies gebruikt werd. Een en ander impliceert niet dat bij de aktuele toepassing hiervan verwarring moet bestaan. Bij het opzefter van een programma zal wel degelijk met diversiteit in techniek, presentatic en opbouw moeten worden rekening gehouden.

Hierna volgend zullen toepassingen van gedragstherapeutische technieken voor dit voortgezette leerproces onderverdeeld worden volgens genomde onderscheiding: Arbeid, Onderwijs, Hobby, Sociaal kontakt. In tegenstelling tot de revalidatie bij cerebraal gestoorde patiënten wordt bij de mentaal geretardeerde personen veel meer en steeds vaker gebruik gemaakt van gedragstherapeutische technieken. 
Onderstande publikaties gelden slechts als voorbeelden.

\section{Arbeid}

Gold (1972) onderzoekt de stimulusfaktoren die een rol spelen bij de training van mental geretardeerde volwassenen bij een "Complex Assembly Task" waarbij hij tot de konklusie komt dat de wijze van stimuluspresentatie een rol speelt in snell heid van leren en niveau waartoe de getrainde kan worden opgeleid.

Gold (1973-1). Vervolgens toont Gold aan dat mentaal geretardeerden tijdens hun opleiding in staat zijn tot verwerving, transfer en retentie van tamelijk complexe motorische taken zoals samenstelling van een fietsrem e.d.

Gold (1973-2). Tenslotte konkludeert Gold dat er een grote diskrepantie bestaat in datgene wat mentaal geretardeerden doen vergeleken met datgene waartoe zij dankzij een goede leermethodiek - in staat blijken.

Daniel (1973) beschrijft de invloed van het gebruik van ,token reinforcement" toegepast bij mentaal geretardeerden op vier gedragsgebieden: aanwezigheid op het werk, nauwkeurigheid bij het werk, $k$ waliteit en kwantiteit, sociale responsiviteit.

\section{Hobby's}

Winkelstein c.s. (1973) beschrijven een cursus voor de training in zgn. „kunstzinnige vaardigheden" bij mentaal geretardeerde kinderen.

Katz (1974) beklemtoont de waarde van het instellen van een trainingsprogramma, waarbij aan mentaal geretardeerden via modeling en andere operante principes geleerd zou moeten worden hoe zij hun vrije tijd zouden kunnen doorbrengen.

\section{Sociale vaardigheden}

Keil c.s. (1973) attenderen erop hoezeer het van belang is wanneer een mentaal gehandicapte ook (opnieuw) leert een sollicitatiegesprek te voeren. Hij presenteert een gedragsmodifikatieprogramma, waarbij aan de hand van "social learning"procedures, dit gedrag gevormd wordt.

Wehman (1975) stelde een programma samen, waarmee aan gehandicapten geleerd wordt om in een toekomstige werksetting tot sociaal gedrag te komen en dit te onderhouden.

Bij sociale vaardigheden is het niet alleen van belang om te kunnen omgaan met andere mensen, maar eveneens om te kunnen diskrimineren in de mate en de wijze van persoonlijk kontakt. Perske c.s. (1973) geven aan dat het over het algemeen zeer moeilijk is (en niet alleen voor de gehandicapte) om te leren, wie er te vertrouwen is: Ze beklemtonen echter dat het met name voor de gehandicapte van belang is om in vertrouwen om te kunnen gaan met verkopers, taxichauffeurs en andere leden van de gemeenschap.

\section{Onderwijs}

Resnick c.s. (1973) ontwikkelden een introduktiecursus voor de verrichtingen van mathernatische operaties waarbij leertheoretische principes een belangrijke rol spelen.

Edmonson (1974) stelt dat probleemoplossend gedrag en planning, belangrijke cognitieve vaardigheden zouden zijn die als uiteindelijke voorwaarden gelden voor persoonlijke onafhankelijkheid.

Ross c.s. (1973) voerden twee experimenten uit die pretendeerden probleemoplossend gedrag en „planning skills" in emotioneel, mentaal geretardeerde kinderen te trainen d.m.v, het simuleren van situaties (social learning). Het doel van het programma is hierbij: het laten luisteren naar en het begrijpen van datgene waar het 
omgat bij de probleemstelling, het aanleren van de gewoonte een probleem in onderdelen te verdelen, die de moeite ward zijn om op te lossen, de waarneming dat vele problemen verschillende oplossingen hebber.

Ross c.s. (1974) presenteren een effektief trainingsprogramma ter modifikatie wan probleemoplossend gedrag t.b.W. mentaal geretardeerden.

Het nabehandelingsgebied vormt tesamen met de overige genoende gebieden in assessment en modifikatie een groot terrein. Elk gebied en deelgebied zijn nog niet volledig geëxploreerde terreinen, die zeer waarschijnlijk aansluiting bij elkatr moeten en kunnen vinden, indien men in staat is met eenzelfde kompas deze onderzoekingsreis door verscheidene personen te laten ondernemen.

Dit kompas is, althans volgens het standpunt dat hier wordt ingenomen, de leertheorie uitmondend in het operante paradigma.

\subsubsection{Modifikatie van gedragstekorten in de thuissituatie}

Vanuit het perspektief van de klassieke en operante leertheorieèn mag het een wonder heten, dat welke patiënt dan ook door therapie in zijn funktioneren verbetert. De voorwaanden die noodzakelijk zijn voor de generalisatie wan gedragsveranderingen van de therapeutische situatie naar de situatie in het alledaagse leven, zijn volgens deze theorieên niet altijd aanwezig. Dit geldt niet alleen bij psychotherapie, maar ook bij gedragsmodifikaties zoals die in revalidatiecentra worden nagestreefd. De therapeut is in het algemeen niet in staat om de reakties .,buiten de therapiesituatie" te kontroleren. Ook al is een patient in staat om tijdens de therapiesituatie adekwat te reageren, dan nog kan de miet-therapie. omgeving voorzover zijgedrag niet ondersteunt, niet goedkeurt of bestraft alle werk en inspanning ongedaan maken. Hierbij moet dan nog toegevoegd worden, dat de therapiesituatie over het algemeen zo totaal verschillend is van datgene wat de patiënt ontmoet in zijn „eigen wereld", dat er weinig transfer of overdracht verwacht mag worden. De twee situaties "therapie" versus "niet therapie" bevatten zelfs grote diskrepanties: veel van het gedrag van de therapeut is gericht op het vergroten van het verschil tussen gedrag in therapie en niet-therapiesituatie. In de psychotherapie wordt de patient aangemoedigd om vrijuit te praten, hetgeen daarbuiten veelal wordt afgeleerd. Voor iedere goede prestatie wordt de patiënt ondersteund, terwijl deze ondersteuningen meestal ontbreken in de situaties van het dagelijkse leven.

Inadekwaat gedrag wordt opzettelijk geëxtingeerd terwijl daar in de maatschappij veelal juist uitdrukkelijk op wordt ingegaan. Met weinig mogelijkheden om de reinforcementkonsekwenties en -kontingenties te hanteren buiten de therapie en met weinig overeenkomst tussen therapie en niet-therapiesituatie kan men zich afvragen hoe het mogelijk geacht wordt dat er zoiets als generalisatie optreedt. De impliciete veronderstelling is, dat als de omgeving van de patiént vóo de therapie aversief reageerde, deze dit na de theraple plotseling niet meer doet en dat als de patient zich anders gaat gedragen, dit automatisch door de omgeving geaksepteerd en bekrachtigd wordt.

Sukses in therapie is dan tot op zeer grote hoogte afhankelijk wan de welwillendheid en tolerantie van de omgeving en mogelijk is dit een van de redenen, watardoor het overall-effekt van psychotherapie zo slecht aantoonbaar blijkt.

De therapeut en ook de persoon die zich op gedragsmodifikatie richt, moet in staal zijn om meèr te doen dan alleen het bewerkstelligen van gedragswerandering in de therapiesetting, de klinische of nabehandelingssituatie. Langzaam groeit het besef dat het noodzakelijk is om een gedrag dat een begin van verandering toont verder te ondersteunen. 
Dit is alleen mogel ijk indien de therapeut het totale milieu kan kontroleren, hetgeen ondenkbar is, of - en dat likt een meer reele propositie - als de therapeut in staat is om in de omgeving van de patiënt de voor deze patiënt relevante personen (ruinforcing agents) zodang te instrueren m.b.t. het geven of onthouden van bekrachtiging dat hierdoor de gedragsmodifikatie in het eigen milieu wordt gekontinueerd. Deze "significant others" dienen wooral gezocht te worden bij familielleden, leraren, werkgevers, vrienden etc.

Een andere voorwaarde is, zoals gesteld, dat de generalisatie wan therapie naar niet-therapienilieu geleidelijk verloopt. Dit lijk mogelijk door de uiterlijke verschijningsworm van de therapie omgeving heel langzam om te buigen naar de thuissituatie.

Bij de reduktie van excessief gedrag werd dit (zie Hoofdstuk 3) gerealiseerd door geleidelijke deelname van famillieleden aan het modifikatieproces, door de patient eerst te isoleren en daarna de toegankeljke omgeving te vergroten etc. In de revalidatie in zijn totaal, die zich tot nu toe slechts hoofdzakelijk occupeerde met nieuwe, "rysicke" gedragsvorming, zit deze geleidelijkheid a.h.w. ingebouwd in de diverse oefensituaties, klinische, mabehandelingssituatie en thuismilieu.

Hoewel bovenstaande overwegingen vooral betrekking hebben op de gedragsmodifikatie van excessief deviant gedrag, gelden zij ook voor de ondersteuning van gedrag dat in de kliniek opnieuw a angeleerd werd. Het probleem hierbij is de opgave om ouders, leraren, werkgewers zover te krijgen, dat ze bereid en in staat zijn mee te doen aan een proces dat ook in de kliniek niet tot de meest eenvoudige opgaven behoort. Dat de realisering hiervan wel degelijk tot de mogelijkheden behoort, moge blijken uit enkele publikaties die hieronder worden genoemd. De indeling naar thuis, school en werksituatie werd hierbij gehanteerd.

\section{Thuissituatie}

Clement (1971) gaat in zijn artikel eerst in op de vele voordelen die verbonden zijn aan het trainen van ouders tot gedragstherapeuten. Een van de voordelen is dat de begeleiding 24 uur per etmaal zou kunnen duren. Deze $z g n$. mediatie-therapievorm vergroot in belangrijke mate de aktieradius van de behandeling in vergelijking tot de traditionele therapieën. Dit geld niet alleen wat betreft de tijd, maar ook wat betreft aantal en intensiteit van konditionerende faktoren. Het belang van het maken van een gedragsanalyse wordt gesteld en de ouders moeten er in opgeleid worden om gedrag te analyseren in de aspekten die in deze studie voortdurend naar voren kwamen: excessief gedrag, gedragstekorten en het onderhouden van gewenst gedrag. Clement stelt dat er drie doeleinden zijn, die ook door ouders kunnen worden nagestreef:

a. "To reduce the behavioral excesses

b. To increase the frequency of desirable behavior which occur at low rates prior to intervention

c. Maintain and strengthen the behavioral assets."

Grazlano (1975) is ervam overtuigd dat gestoorde kinderen nieuw complex sociaal aangepast gedrag geleerd kan worden. Indien hiermee begonnetz zou worden in het centrum, dan zouden "non-professionals" getraind als gedragstherapeutische medehelpers, nieuwe gedragsvorming verder voort kunnen zetten. Ook bepleit hij dat er systematische gedragsmodifikatieprogramma"s voor groepen opgezet zouden moeten worden in buurtcentra, waarbij ouders samen met non-professionals modifikatieprocedures realiseren.

Fingtdo (1970) reeds eerder genoemd bij de gedragsworming in de klinische situatie, 
presenteert drie cases waarbij ouders geleerd wordt via videobanden, thoe ze de behandeling die uitgevoerd werd in de kliniek, thuis moeten voortzetten.

De gevallen hebben betrekking op het aanleren van eetgedrag, het toenemen van spreken bij een autistisch kind en het aanleren van een geretardeerde jongen om te reageren als hij bij de naam werd geroepen. Fingado stelt dat deze ogenschijnlijk tamelijk "simpele" gedragingen eerst aangeleerd moeten worden door een opname van 30 dagen in een kliniek, die daartoe speciat werd gestruktureerd.

Bragg (1975) beschrijft een onderzoek naar gedragsworming bij kinderen met cerebral palsy, die geleerd werden thuis in een betere houding te zitten. Het ging er hierbij wooral om, na te gaan in hoeverre er generalisatie optrad van kliniek naar thuissituatie door voortzetting van bekrachtigingsprocedures. Bij 4 van de 6 kinderen leidde dit tot goed resultaat.

\section{Schoolsituatie}

Mc Kenzie c.s. (1970) behandelt een programma waarin onderwijzers in het gewone lagere onderwijs geleerd worden hoe ze in hun kllas om moeten gaan met cerebraal gestoorde jongeren. Het lijkt misschien enigszins merkwaardig, maar het is een realiteit: "Forty-Sixty percent of handicapped children" - aldus Mc Kenzie - .are projected as not receiving adequat special education services. A reasonable assumption is that a sizable proportion of these children are being educated in regular classes." In zijn publikatie noemt Me Kenzie slechts 3 van de 47 succesvolle - zoals hij stelt - toepassingen van gedragstherapie. Hierbij wordt reduktie van excessief gedrag (destruktie, interrupties, agressie e.d.) en toename van te weinig gedrag (te weinig aandacht, weinig korrekte rekenprestaties) behandeld. Al deze behandelingen werden gerealiseerd door lagere-schoolonderwijzers, die eerst onderwezen werden in de principes van ged ragstherapie, waarma zij onderwijzers die niet getraind waren in de leertheorie begeleiden.

D'Annunzio c.s. (1974) adstrueert in feite de waarde van limit testing. Hij begint met het signaleren van twee methoden, die tot nu toe werden toegepast, welke hij minder bevredigend vindt (1). .Intensification of activities in an effort to compensate for the children's deficiencies (2) a wide range of remedial procedures (...). Neither approach appears to have been succesfull, as both tend to be too amorphous and to neglect the learners specific inadequacies. The present study was made to determine the efficacy of an approach which stresses differential diagnosis, a description of each child abillities and deficits for learning, followed by prescriptive remedial procedures". In zijn assessment noemt D'Annunzio methoden, die overeenkomst vertonen met datgene wat in deze studie onder limit testing wordt verstaan: .Carelul screening of the way the child responds to the presentation of specific stimuli to specific modatities will allow clinical inferences to be made about the child"s operational strength and weakness".

Waar D'Annunzio zich meer schijnt te richten op gespecialiseerd onderwijs richten Ozer c.s. (1974-2) zich weer evenals Mc Kenzie op woorzieningen in het gewone lager onderwijs ......) Many children who are having difficulty, learning in the regular classroom. The goal is to help the teacher respons more effectively to the variety of needs within the classroom". Het programma dat Ozer presenteert bestat uit drie strategieèn, waarbij limit testing herkend wordt en modifikaties die aansluiten op indikaties vanuit deze limit testing. De wijze van modifikaties verdiskonteert kennis van leertheorie:

(1) The first strategy is that of segmenting a task across time.

(2) Using different combinations of modalities of input.

(3) Limiting the numbers of stimuli. 


\section{Arbeid}

Wat de werksituatie betreft levert de bestudeerde literatuurveramelling slechts weinig publikaties op inzake de toepassing van leertheoretische principes bij cerebraal gestoonde patienten. Opvallend is eveneens, dat voorzover er hieromtrent publikaties zijn verschenen, deze betrekking hebben op toepassingen in de zwakzinnigenzorg.

Zimmerman (1969) vestigt de andacht op de warde wan bek rachtigende kondities indien getracht wordt de "produktiviteit" van mental geretardeerden in een beschutte werkplatis te verhogen.

Tate c.s. (1976) bevestigt de mogelijkheid om ook zwak begafde personen vrij complexe taken te doen uitvoeren, indien men voldoende acht slaat op leertheoretische principes.

Bovenstaande vermelding van literatuurgegevens moest wederom beknopt zijn. Ook hier was het de intentie aan te tonen dat hulpverleners in thuis-, school-, of werksituatue die qua aard of mentaliteit weinig rekening kunnen houden (of willen houden) met systematische ondersteuning van gedrag, deze mogelijkheden toch in principe zouden kunnen gebruiken. Dat deze mogelijkheden uitdrukkelijk en noodzakelijk moeten worden aangewend voor de „beklijving" van nieuw aangeleerd gedrag, werd reeds werschillende malen met klem naar woren gebracht. M.a.w. de zogenaamde "nazorg" verdient bijzondere aandacht.

\subsubsection{Modifikatie van gedragsbelemmeringen}

\subsubsection{Probleemstelling}

Hoewel dit in hoofdstuk 3 niet expliciet werd genoemd, bestonden er diverse omstandigheden waardoor met name de reduktie van excessier ongewenst gedrag als een bijzonder moeilijke opgave werd ervaren. In hoofdstuk 5 wordt hier verder op ingegaan.

Gedragstherapeutische behandelingsprogramma's ter reduktie van excessief ongewenst gedrag bleken alleen opgezet en voltooid te kunnen worden, wanneer komplicerende faktoren een minimale rol speelden. Echter ook dan moest bij voortduring bijgestuurd, gekorrigeerd en gekontroleerd worden. Zelfs onder gunstige omstandigheden bleek nog vaak ondanks bijsturen de gehele procedure niet of moeizaam te lopen. Het is dan ook de vraag of voor sommige kategorieèn patiênten ter gedragsreduktio geen bijzondere matregelen genomen moeten worden. On dit na te gaan werd opnieuw gezocht naar literatuur war met name "probleemgedrag" bij cenebraal gestoorden d.m.V. gedragstherapeutische principes werd behandeld.

\subsubsection{Reduktie vam excessiefgedrag in de diverse situaties}

\section{Thuissittuatie}

De mogelikheden ter reduktie van excessiefgedrag in de thuissituatie zijn uiteraard afhankelijk, enerzijds van het soort patienten en hun probleemgedrag, en anderzijds van de mogelijkheden in de thuissituatie wat betreft huisgenoten en omstandig. heden.

Volgens Geller (1972) is de belangrijkste opgave bij het gebruik maken van ouders als mediator van gedragstherapie, hun de bekrachtiging van dewiant gedrag te leren stoppen en in de plaats daarvan in te gaan op aangepast gedrag. Geller heeft getracht het gedrag van $k$ inderen te veranderen wat betreft d wangmatig herhalingsgedrag 
zoals het verplaatsen van voorwerpen, wrijwen van plekken op vloeren en muren, woor-en achterwarts schommelen, mar ook inzake agressief gedrag als het slaan wan jongere broertjes, ernstige driftbuten en pogingen tot zelfbeschadiging. Bij het leren wan het gebruik van gedragstherapie aan ouders als non-professionals bleken de volgende moeilik heden voor te komen, aldus Geller:

(1) Having the parents define objectively the behavior under study,

(2) identifying what constitutes reinforcement for their child.

(3) providing the reinforcement as soon as the appropriate behavior occurs.

(4) stop paying attention if the child behaves in a disruptive way,

(5) in general: hesitance on the part of the parents to use operant techniques".

Deze moeilijkheden konden echter worden overwonnen, doordat de bereikte gedragsverbetering van het kind de ouders in hun mieuwe aanpak versterkten. Desondanks bleek, dat als de belangrijkste problemen waren opgelost, de geneigdheid der ouders om de gebruikte technieken te blijven hanteren, verminderde. Dit betekent in feite dat de procedure vroegtijdig werd gestopt of niet meer konsekwent werd toegepast. Er bleken regelmatige bekrachtigingen nodig voor de ouders om deze te motiveren met de begonnen technieken voort te gaan en bijvoorbeeld een systematische afbouw van kontinue naar intermitterende bekrachtiging te realise ren.

Naast Geller berichten Wiltz (1973), Philage (1975) en Koekkoek (1977) goede resultaten inzake de betrekking van ouders als mediator in de gedragstherapie.

Wiltz (1973) geeft aan dat het bij ernstige gevallen van excessief ongewenst gedrag noodzakelijk is, ter observatie van gedragsinterakties als ook ter instruktie van de huisgenoten, het gehele gezin gedurende enkele weken in een speciaal centrum op te nemen.

Betreffende de behandeling van perceptueel disfunktionerende kinderen biedt Philage (1975) nieuwe perspektieven door een kombinatie van gedrags- en Gestalttherapeutische principes met gebruikmaking van de ouders als mediatoren. De enige publikatie welke in dit verband specifiek betrekking heeft op de revalidatie van cerebraal gestoorden hier te lande, is afkomstig van Koekkoek (1977). Hierin vermeldt hij de begeleiding van twee patienten met cerebrale stoornissen in de leeftijd van 4 en 14 jaar, onder gebruikmaking van een hiertoe speciaal opgeleide assistent-gedragstherapeut. De begeleiding vond plaats in het thuismilieu doot middel van de ouders als mediator onder supervisie van deze gedragstherapeut. De behandeling duurde 2 maanden en had betrekking op de beklijving van gedrag, dat de patiënten eerst in het revalidatiecentrum hadden aangeleerd (zij werden eveneens in deze studie, hoofdstuk 3 naar voren gebracht). Koekkoek signaleert - naast een bevredigend resultat - onder meer het belang van modeling, gedrags voorschrften, konsek wente uitvoering van extinktie en bekrachtiging en het geven van informatie inzake gedragstherapeutische principes aan de ouders. Hij beklemtoont de noodzaak tot wijziging van de tot nu toe geldende opvattingen inzake de "nazorg".

\section{Schoolsituatie}

Als een der probleemgedragingen, welke voor "reduktie" in anmerking komen, wordt bij herhaling hyperaktiviteit van schoolgaande kinderen vermeld.

Bower (1975) geeft eerst een overzicht van de methodieken welke tot nu toe ter reduktie werden aangewend. Vervolgens vestigt hij de aandacht op de aanhangers van de reinforcementheorie. Door zich te beperken tof de hantering van overt gedrag zouden - aldus Bower - een groot aantal onderzoekers de warde van gedragsmodifikatie hebben aangetoond. Door middel van omgevingsmanipulatie- 
technieken blykt o.a. gebruik van psychofarmaca te kunnen worden voorkomen. Als gebrukte mahoden zijn te vermelden:

a. Vermijding van afleidende stimuli.

b. Verhoging van de stimuluswarde van het leenateriaal.

c. Het gebruik maken van rustig lerende leefijdsgenoten als model.

d. Negatie van hyperaktief gedrag en aandacht bij rustig gedrag.

Cull (1974 p.108) beschrijft de behandeling wan een tweetal jongens, die in gezelschap van elkaar zeer grote onrust wisten te kreèren, maar die, indien zij niet met elkar optrokken, de rust zelve waren. Het probleem was echter dat zujaltijd met elka a optrokken. De begeleiding bestond uit de konsek wente bek rachtiging (d.m.v. aandacht), indien de jongens apart of met andere kinderen speelden en de onthouding van aandacht, indien zij met elka optrokken. Binnen drie dagen aldus Cull - speelden de beide jongens slechts $15 \%$ van de totale observatiet ijd met elkar en $75 \%$ met andere kinderen. Het datarop uitgevoerde A-B-A en A-B-A-Bdesign ondersteunde de warden van de leerprincipes. Van belang is het om hierbij op te merken dat er wee leerkrachten nodig waren voor een konstante begeleiding, hetgeen een voorwarde is die niet eenwoudig te realiseren valt in de traditionele schoolsituatie.

Allen c.s. (1970) beschrijven een casus van het meisje Eleanor, 5 jaar oud, die geen schoolworderingen zou maken en warbij het meest opvallende was, dat zij zich nooit met andere kinderen bemoeide en alijd alleen speelde. Bij observatie van de klas viel op dat de algemene teneur gekensehetst kon worden als autoritair, weinig vrij spell met frekwente reprimandes.

Het kind werd geplaatst in een "Behavior Modificationclass (!)", met als programma:

(1) "No adult reinforcement when she was playing alone.

(2) She would receive adult reinforcement when she was interacting with other children with or without verbal accompaniment.

(3) She would receive additional adult attention when she was verbalizing".

Allen geeft in deze studie an hoe gewenst gedrag i.c. sociaal contacf door middel van bovenstaand programma kan toenemen, maar eveneens weer afneemt en omslaat in apathie en isolement indien de betreffende leerkracht na terugplaatsing uit de gedragsmodifikatieklas, niet kan worden "ingetraind".

Van belang lijkt te konstateren:

(a) Het bestaan van een speciale klas gericht op gedragsmodifikatie.

(b) De gedragsbelemmering (apathisch gedrag) werd gereduceerd door onthouding van reinforcentent voor dit gedrag.

(c) Verbaal en interaktie gedrag bleken wel degelijk in het gedragsrepertoir aranwezig echter zij traden alleen infrekwent op.

(d) Toename van incompatibel gedrag werd gerealiseerd door bekrachtiging hiervan.

(e) Het A-B-A-B-design werd uitgevoerd.

(1) Het afwezig zijn van adekwate voortzetting resp. de poging tot beklijwing van het aangeleerde gewenste gedrag leidt tot terugval in het probleemgedrag.

\section{Kliniek}

Uit voorgaande citering van publikaties lijkt duidelijk te zijn dat de reduktie van excessief ongewenst gedrag in thuis-en schoolmilieu - zij het door bijzondere voorzieningen - in principe tot de mogelijkheden behoort. De ervaringen inzake de uitwoeringen van gedragsreduktie in Hoensbroek geven enerzijds de informatie dat reduktie wan probleemgedrag in een klinische setting tot de mogelijkheden behoort, 
anderzijls vestigen zij de aandacht op de noodzaak tot het treffen van speciale voorzieningen. Een andere uitermate belangrijke gedachtengang in deze studie is de overweging dat eerst eventueel excessief gedrag moet worden gereduceerd, voordat nieuwe gedragsvorming mogelijk wordt. Vanuit deze achtergrond kunnen de volgende probleemstellingen ta.v. de literatuurinformatie worden gesteld:

(1) Wordt in de literatuur de volgorde van reduktie van problemgedrag en vervolgens de vorming van nieuw gedrag eveneens gesignaleerd?

(2) Zijn er woor deze reduktie speciale voorzieningen in de kliniek noodzakelijk?

(3) $1 \mathrm{~s}$ er iets bekend omtrent een eventuele noodzaak tot voorselektie van patienten (-groepen), die hiervoor al dan niet in aanmerking komen?

Hoewel de literatuurverzameling niet omvangrijk genoemd mag worden, konden toch een aantal auteurs worden gevonden die omtrent deze probleemstellingen een (deel)antwoord lijken te verstrekken.

In een uitgebreide studie vestigt West (1975) er allereerst de aandacht op, dat er talrijke pogingen werden ondernomen teneinde, hetzij excessief ged rag te reduceren, hetzij toename wan gedrag te realiseren, hetzij een specifieke leerstoornis te trainen. In zijn kritiek stelt West dat nimmer of zelden werd getracht deze drie aspekten tesamen in éen behandelingsprogramma te vervatten. Het door West gepresenteerde programma houdt een poging in deze drievoudige anan ak gestalle te geven.

"Phase 1: Reducing student's desruptive behavior in a group contingency situation. Phase 2: To increase student attention to and participation in the class activities by offering membership in a status group for attending and participating.

Phase 3: Was directed toward improving the home-work aspect of the academic competence of the students by paying wages for home-work completed.

(N.B.): The procedures were implemented by personal employed by the learning disabilities school".

Hoewel dit vrij omvangrijke gedragsmodifikatieprogramma werd gerealliseerd in een niet-klinische setting toont het een grote overeenkomst met de programmauitwoering zoals in deze studie wordt voorgestaan.

Enkele herkenningspunten zijn hierbij:

(a) Voordat er met het anleren van nieuw gedrag begonnen kan worden, wordt reduktie van excessief ongewent gedrag ondernomen.

(b) Nadat deze reduktie van excessief gedrag is gerealiseerd wordt a andacht besteed aan de vorming van nieuw gedrag èn de verdere voortzetting resp. beklijving van dit gedrag in de thuissituatie.

(c) Onder alle drie de kondities wordt gebruik gemaakt van wbekrachtiging".

(d) Een speciale setting is vereist.

Leibowitz c.s. (1974) presenteert een studie wa arbij eveneens het aksent valt op het aanleren van nieuw gedrag nadat een grote varięteit an storend gedrag was gereduceerd of geëlimineerd. De gedragsmodifikatie werd uitgevoerd op een 5 -3arig meisje met een Cattel IQ van 41, dat niet in staat was zichzell le voeden en dardoor reeds jaren op zeer moeizame wijze gevoed moest worden met special voedsel. Pogingen om een variëteit in het voedsel te brengen, alsmede hat te leren tot het zelfstandig nuttigen van de maaltijd te komen, resulteerden in ernstige gedragsproblemen (gillen, schoppen, slaan, handbijten, zelfdestruktief gedrag etc.).

De procedure bestond uit een kombinatie van reduktie van probleengedrag en successieve approximatie: "During session 1, the psychologist placed the spoon near $S$ 's face. When resistance was encountered, such as screaming etc the psychologist praised $S$ and withdrew the spoon, but only when the screaming teased. Severe head-banging and screaming resulted in time-outs until $S$ was quiet, but the spoon remained near $S$ 's face. In 23 minutes the psychologist was able to move the spoon 
gradually closer and closer to S's mouth, until S licked and finally accepted the ice cream (...). When ice cream was accepted, the same procedure was used for three sessions with small quantities of two other foods. However these small quantities of food were placed toward the back of the spoon while the ice cream was placed at the tip of each spoonful. In addition, each spoonful accepted resulted in ice cream on a one tot one basis, that is continuous reinformcement".

Van sessie 5-14 nam een arbeidstherapeut met gedragstherapie-ervaring de procedure over. Zij had wan te voren d.m.v. een "one way screen" alle voorgaande aktiviteiten waargenomen (modelling) en voerde in dezelfde kamer dezelfde procedure uit. De psycholoog bleef wel in de buurt. Een en ander was bedoeld om generalisatie naar een ander persoon te realiseren. Van sessie 15-37 nam de arbeidstherapeut de leiding geheel over. De voedingssessies vonden nu driemaal per dag plaats en bovendien in andere kamers. Tenslotte nam een arbeidstherapeut zonder gedragstherapie-ervaring de gehele procedure over.

Tijdens elke sessie werd opnieuw optredend agressief gedrag genegeerd of bestraft (time-out), elke toenadering tot de gewenste eetrespons werd beloond. Daarna werd op soortgelijke wijze kleed-en wasgedrag gevormd.

Alabiso (1973) presenteert een uitgebreid verzamelartikel waarin researchgegevens worden genoemd inzake reduceren van hyperaktiviteit. Eerst worden allerlei therapieën behandeld als chemotherapie en speciale onderwijstrainingen. Vervolgens wordt gedragsmodifikatie aan de orde gesteld, waarbij er van uitgegaan wordt dat "aandachtig bezig zijn" gezien kan worden als „inkompatibel met hyperaktiviteit". Tenslotte wordt de reduktie van hyperaktiviteit behandeld. Dit wordt gerealiseerd door het enerzijds onthouden van positieve reinforcements aan hyperaktief gedrag, anderzijds door het toedienen wan bekrachtiging aan het geleidelijk vergroten van ,attention span”. Het aksent bij deze studie ligt op de positieve bekrachtiging van de aandacht en minder op de extinktie procedures. De te leveren prestaties worden langs de weg der suksessieve approximatie geleidelijk aan groter gemaakt.

\section{Speciale „settings"}

In het voorgaande werden verscheidene malen studies genoemd, waarbij sprake was van bijzonder uitvoerige maatregelen, gedragsmodifikatieklassen e.d. Het lijkt de moeite waard aandacht te besteden aan de eventuele aanwezigheid van speciale teams, klinieken e.d., die zich ten doel gesteld hebben zich alleen of hoofdzakelijk te richten op de hier genoemde reduktie van extreem ongewenst gedrag.

Uit ervaringen met excessief gedrag bij kinderen, zoals driftbuien, destruktief gedrag, huilen etc. blijken diverse onderzoekers als Allen (1972) en Cull c.s. (1974) tot de konk\|usie te komen, dat er inderdaad speciale settings nodig zijn, wil men effektiel dit gedrag kunnen modificeren.

Het is hierbij opvallend, dat de desbetreffende studies steeds gepresenteerd worden als ,the case of ...", alsof de behandeling een waar ,projekt" zou zijn geweest. Dit nu is ook de indruk, die bij de behandelingen in Hoensbroek steeds weer gewekt werd: De modifikatie van werkelijk storend gedrag is een veelomvattende langdurige angelegenheid, die de naam projekt wel degelijk verdient.

\section{Allen (1972): „The case of Julie":}

"Julie was 4 years old, an unusually small child for her age though there were no untoward medical signs except that of arrested hydrocephalus during early infancy. Developmentally she exhibited poor large motor skills and infantile speech patterns. In addition she displayed an extensive repertoire of inappropriate and maladaptive 
behaviors toward children and adults. With children her most conspicuous responses were avoidance or attack. With adults she was totally noncompliant: Sthe screamed "no" to any request, any insistence by an adult (parent or teacher) provoked a full-fledged tantrum in which she threw herself face down on the floor, kicking and screaming hysterically (...). Two members of the Experimemal Education Unit (EEU) in the Child Development and Mental Retardaton Center preschool staff observed Julie and they agreed to enrolli her in a preschool-class at the EEU.

Procedure: Six days of baseline data were collected on several criteria. During one sixty minute observation period: fysical attack $68 \%$ of the time; throwing and dumping $74 \%$; disruptive behavior $48 \%$; a mount of time not engaged in purposefui activities $88 \%$; amount verbalizing to peers $6 \%$; cooperative interplay $30 \%$; amount of time spent alone $77 \%$ :

phase 1: time out for physical attacks (...)

phase 2: activity decision required (...)

phase 3: time out for throwing and dumping (...)

phase 4: structuring cooperative play (. . .)".

ledere fase op zich bestaat uit een voortdurend samenspel tussen verscheidene groepsleiders gedurende enkele weken. De studie besluit met: "This study, as well as several others in progress seem to indicate that children with severe problem behaviors are not likely to improve without specific behavior mamagement interwention in special instimutes".

Cull c.s. (1974 p.110-116): Een andere studie is . The case of Townsend". (discruptive, agressive, retarded, tantrum behavior etc.)

"This child was $41 / 2$ years old, when he was transferred from a Head start classroom to a Behavior Modificationciass. This study demonstrates with great specificity the many and varied contingency arrangements required for this ty pe of child - a child who is all too frequently "written off" or rellegated at a very early age to institutional care for predelinquents. On Townsend's eleventh day in the new classroom a first step in behavior modification was initiated. All tantrums regardless of duration or intensity were to be ignored, that is put on extinotion. Absolute disregard of the tantrum, no matter how severe it might become, had to be thoroughly agreed upon among the teachers in as much as there are data, which indicate that when tantrums are put on extinction, extremes of tantrum behavior may temporarily ensue. Townsend's first tantrum under the nonattending contingency lasted twenty-seven minutes (average duration of previous tantrums had been five minutes) becoming progressively more severe. The classroom was cleared of all children and adwis when it became obvious that the tantrum was going to be lengthy. The children were taken to the play ground by a teacher and a non-professional, while the other teacher was stationed immediately outside the classroom door. When Townsend quieted the teacher opened the door to ask in a matter of factvoice if he was ready to go to the play ground. Before the teacher had a chance to speak, Townsend recommenced his tantrums. The teacher stepped back outside to wait for another period of calm (. . .). Each time the episodes were shorter (six, three and one minute respectively). Finally the teacher was able to suggest going out of doors. This she did in a thoroughly neutral fashion (...). On the second day of tantrum intervention there was one tantrum of 15 minutes with two-minute follow-up tantrums. On the third day there was one mild four minute tantrum. No further tantrum occured.

Deze twee studies vestigen de aandacht op extreem probleemgedrag (in diverse vormen) bij kinderen. 
Men kan zich woorstellen welke moeilijkheden er ontstaan als een dergelijk programma bij een cerebradal gestoorde volwassene met excessief gedrag in eem revalidatiecentrum moet worden gerealiseerd. Alle patiënten op een zaal zouden op cruciale momenten in de therapie moeten meewerken ten behoeve van éen persoon, die juist door zijn ged ragsstoornissen niet tor de meest sympathieke behoort. Mutatis mutandis geldt hetzelfde voor vele personeelsleden, die ieder op hun eigen wijze bij de verzorging wan een bijzondere groep patiënten betrokken zijn. De patiënten zijn geen therapeuten, maar personen die allen in meer of mindere mate door hun handicap medebepaald zijn en eveneens gedragsdeviaties kunnen tonen. Tenslotte kan men zich voorstellen, dat een gedragsmodifikatieprogramma (met eventueel 24 uur begeleiding) relatief eenvoudig is bij, en ook makkelijker geaksepteerd wordt door kinderen en hun familie, maar dat dit in verscheidene opzichten totaal anders ligt bij de volwassenen. Het is trouwens zeer opmerkelijk dat de literatuur geen casuistiek presenteert inzake de behandeling van volwassenen met excessief gedrag.

Resumerend kan gesteld worden, dat uit ervaring en (beperkte) literatuurstudie blijkt, dat alleen na speciale maatregelen getracht kan worden iets aan gedragsmodilikatie te doen. Deze noodzakelijke voorzieningen houden in: speciaal opgeleid personeel, een geëigende omgeving, een patiëntenselektie en niet te vergeten een ondersteunend thuismilieu.

\subsubsection{Samenvatting}

In deze paragraaf werd gepoogd een inventarisatie te presenteren inzake de modifikatie van gedragstekorten en gedragsbelemmeringen. Het uitgangspunt hierbij was wederom de leertheoretische visie hoewel op sommige punten een welwillend oor geleend werd aan gezichtspunten vanuit andere bron.

1e. Het werd van belang geacht dat personen werkzaam in de situatie die voorafgaat aan de revalidatie een open kommunikatie voeren met het personeel in het revalidatiecentrum. Nogmaatls werd beklemtoond dat revalidatie een leerproces is dat alleen maar efficiënt te realiseren valt door een hierop georiënteerd team.

2e. Bij de modifikatie van gedragstekorten, gekonstateerd in een klinische testsituatie, zijn twee principieel verschillende uitgangspunten te signaleren:

a. Men gaat uit van een theorie inzake de relatie tussen hersenen en gedrag, er wordt een testprocedure ontwikkeld en er volgt een training waarbij de trainingsstimuli direkt of indirekt overeenkomst vertonen met de teststimuli. Het principe der training lijkt terug te voeren op stimulering, verrijking of , weer naar boven brengen".

b. Vanuit praktische overwegingen kan men zich ook afvragen wat de aktuele behandelingsaktiviteiten zijn, ongeachı de theorie "hersenen - gedrag". Wanneer men dit praktisch uitgangspunt hanteert, blijken de bestaande trainingsprocedures te herleiden tot drietal direkte pogingen gedrag te modificeren, nl. gedragsrestauratie (herstel wan gedragstekorten), gedragskompensatie (d.m.v. prothesen) en gedragsreorganisatie (het ont wikkelen wan een k walitatief ander gedrag om tot eenzelfde resultaat te komen).

3e. Ter modifikatie van gedragstekorten gekonstateerd via gedragsobservatie werden, althans in de literatuur, alleen operante konditioneringstechnieken aangetroffen.

4e. Inzake voortzetting van de revalidatie in de nabehandelingssituatie werden literatuurstudies gepresenteerd, die alle gebruik maken van de leertheoretische 
principes teneinde een der revalidatiedoeleinden nl. "produktiviteit" te ondersteunen of te realiseren. Produktiviteit dient in deze opgevat te worden als een mogelijkheid om een bevredigende taak woor zichzelf en/of gemeenschap te realiseren d.m.\%. arbeid, hobby, studie en sociaal kontakt.

5. De literatuurstudie gericht op de behandeling in de thuissituaties wees erop dat het ook in deze milieus wel degelijk mogelijk is om nieuwe gedragsvorming te realiseren of, indien deze reeds enigszins aanwezig was, verder te ondersteunen.

6. Tenslotte is de belangrijikste bevinding, dat extreem ongewenst gedrag dat gedragsvorming belemmert, niet of nauwelijks gereduceerd of geëlimineerd kan worden in de huidige revalidatiecentra hier te lande. Gegeven de resultaten elders blijkt het echter wel degelijk mogelijk ook excessief gedrag welke vorming van nieuw adekwaat gedrag belemmert te reduceren, zij het alleen indien specifieke voorzieningen in de zin van getraind personeel werkzaam in speciale instituten worden getroffen. 
HOOFDSTUK 5

NAAR EEN REVALIDATIE-LEERPROCES 


\subsection{Overwegingen inzake assessment}

\subsubsection{Inleiding}

In hoofdstuk 4 werd literatuur inzake de assessment en modifikatie voor toepassing in de diverse kriteriumsituaties behandeld.

Gekonkludeerd werd dat uit deze literatuurstudie enkele lijnen inzake assessment en modifikatie natar voren $\mathrm{kwamen}$, die een steun kunnen bieden voor een (eventueel) te realliseren revalidatie-leerproces. Een revalidatie-leerproces impliceert niet, dat de medisch-verpleegkundige aspekten in waarde en betekenis behoeven in te boeten, maar wel dat minstens evenveel mogelijkheden worden gegeven om in het total van revalidatie-aktiviteiten ook het leren in zijn vele aspekten te betrekken. Dat een persoon leert - het werd reeds vele malen benadrukt - is niet altijd een vanzelfsprekende zaak. In de revalidatie dient expliciete aandacht geschonken te worden aan het optimaliseren van voorwaarden die dit leren mogelijk maken. Het vereist, zoals. Fordyce stelt, in eerste instantie een herziening van de revalidatiegedachte, die vermoedelijk reeds zou moeten aanvangen bij de revalidatie-opleidingen.

Een verandering van stand punt of visie van medewerkers a an een instelling is, zoal realiseerbaar, geen eenvoudige zaak. De konkretisering wan aktiviteiten, die voortwloeien uit zulk een veranderde visie is eveneens geen geringe opgave. Hier kan dan ook alleen gewezen worden op een aantal richtlijnen die de literatuur en praktijk verstrekken. In deze eerste paragraaf komen overwegingen inzake de assessment aan de orde Bij deze presentatie is afgezien van de behandeling per kriteriumsituatie, aangezien de te behandelen richtlijnen in alle situaties van kracht zijn. Het onderscheid naar gedragstekorten en gedragsbelemmeringen blift echter well gehandhaafd.

\subsubsection{Assessment van gedragstekorten in de klinische testsituatie}

\subsubsection{Algemene zienswijze}

Bij gedragstekorten is een goede assessment de onmisbare basis voor het uitvoeren van handelingen welke gericht zijn op nieuwe gedragsvorming. Zowel in de pre-opname situatie, klinische testsituatie, klinische observatiesituatie, nabehandelingssituatie en thuissituatie moet uitgegaan kunnen worden van een netwerk van items, inzake gedragstekorten. Deze netwerken zullen noodzakelijkerwijs een steekproef zijn uit een universum van items, maar zij zullen toch voldoende representatief moeten zijn om het totaal aan tekorten inzake, ,gedrag-noodzakelijk-in-de-leefruimte" te kunnen representeren. Een andere voorwaátde hierbij is dat de netwerken niet zo gekompliceerd moeten zijn, dat ze onhanteerbaar worden. Teneinde een totaalbeeld aan gedragstekorten te verk rijgen zou het bovendien de algemene werkbaarheid ten goede komen, indien de diverse netwerken op elkaar aansloten en elkaar aanvulden. Het zou nog prettiger zijn, indien de diverse netwerken aan te beoordelen items elkaar zouden overlappen, d.w.z. één netwerk voor diverse situaties. De voordelen van een dergelijk systeem zijn ontellbaar, echter het is alleen realiseerbaar indien er een begrippenkader gevonden kan worden dat in staat is de diverse eisen van de diverse leefwerelden te dekken. Met andere woorden bij bedoelde assessment gaat het niet slechts om een taxonomie van "funkties", maar een taxonomie van gedragstekorten in de diverse "situaties".

De visie van deze studie is dat een dergelijk begrippenkader uit moet gaan van de vergelijkbaarheid van stimuluskonfiguraties en responsies in de diverse kriterium- 
situaties. Ter konkretisering van een dergeljke assessment zal een poging onderno. men worden tot nadere precisering van de externe stmulusituatie en vereiste respons. (De , $S$ " en "R" uit de gedragswergelijking $\mathrm{S}-\mathrm{O}-\mathrm{R}-\mathrm{K}-\mathrm{CH}$. De algemene zienswijze hierbij is, dat het wellicht mogelijk is om in elke situatie het externe milieu te specificeren naar stimulusinhoud: figuraal, gedragsmatg, symbolisch en semantisch en kombinaties hiervan. Hierbij zal dan ook rekening moeten worden gehouden met de modaliteit(en) warin de stimuli worden geptesenteerd. De respons zou dan onderverdeeld kunnen worden naar bijwoorbeeld een spraak - en verplaatsingsrespons.

Allereerst zal deze indeling naar stimulus en respons-aspekten ondernomen worden bij de instrumenten, die gebruikt worden in de klinische testsituatie:

Het is opvallend dat deze visie die a.h.w. aangereikt wordt door Mark en Guilford (4.1.3.2. en 4.1.3.3.) wat betreft de klinische testsituatie ook aansluit bij zienswijzen van andere onderzoekers in de onderscheiden kriteriumsituaties in deze studie.

In de pre-opname situatie word deze visie tendele door Fordyce (4.1.3.1.) gebezigd, wanneer hij suggereert allerlei aktiviteiten die de patiènt vón de opname bezigde in te delen naar "symbool. motorisch-manipulatief en interpersoonlijk gecentreerd".

In de gedragsobservatieschallen (4.1.4.2.) werden regelmatig onderscheidingen aangetroffen die doen denken aan bovengenoemde indeling. Bijvoorbeeld de indeling van Gunzberg (socialisatie, kommunikatie) of Rosinsky (cognitieve sektie, affektie) e.d.

Bij de taakobservatie in de nabehandelingssituatie wordt door Poor (1975 p.34) uitgegaan van de analyse van werksituatie naar overeenkomstige "kwaliteiten" in zijn .Work Sample Approach": "The Work Sample Approach utilizing a sample of work from an actual job to be found in the community. The same material, tools and equipment are used in a different setting". Het lijkt niet al te geforceerd om ook hier een analyse van gepresenteerde stimuli naar inhoud voor mogelijk te houden. Tenslotte zou nog aangevoerd kuninen worden, dat een testsituatie een gestandaardiseerde steekproef is uit de totaliteit van het leven en dat men poogt vanuit de testsituatie generalisaties naar deze grotere, meer complexe werkelijkheid te ondernemen, m.a.w. er wordt steeds uitgegaan van de mogelijkheid tot generalisatie vanuit gereduceerde stimulussituaties naar meer complexe.

\subsubsection{Ontwerp van een funktietaxonomie}

In het onderstaande zal getracht worden, vanuit de literatuurinformatie, tot een ramwerk inzake een funktietaxonomie te komen. Ondanks vele onzekerheden wordt hierbij uitgegaan van de volgende vooronderstellingen:

1e. Het gedrag wordt in iedere situatie en op elk leeftijdsniveau tot stand gebracht door een informatieverwerkend systeem, bestaande uit input zijde, centrale verwerking met feedback kontrollemogelijkheid en een output zijde.

2e. Het centraal informatieverwerkend systeem wordt hierbij twee taken toebe dacht nl: a. Gedragstegulatie d.w.z. het tot gedrag komen, gedragsafremming, gedragstempo, gedragskontinuering ed. en b. Gedragsorganisatie d.m.v. een aantal hypothetische konstrukties (operaties en produkten naar Guilford).

3e. De output d.w.z. de respons op de gepresenteende stimuli kan onderscheiden worden naar motorisch-sprekende (vocaal en subvocaal) en motorischverplaatsend (grof en fijn).

4e. De input d.w.z. de gepresenteerde samengesteldheid a stimuli kan op cognitief niveau onderschelden worden nar:

a. Inhoud (Guilford): figuraal, gedragsmatig, semantisch, symbolisch. 
b. De diverse modaliteiten: auditief, visueel, taktiel, kinesthetisch.

c. Wijze van presentatie (aantal, volgorde, intensiteit e.d.).

Se. Een belangrijke, maar onzekere gedachtengang in deze is of het onderscheid naar stimulusinhouden inzake cognitie ook van kracht zou zijn op het, niveau" wa ar de zgn. sensomotorische koppeling ontstaat. De indruk bestaat, dat er ook op dit riveau sprake zou kunnen zijn van de formatie wan wnits, relaties, implikaties etc." Ook kan aangevoerd worden dat de wereld" warin het kind zich begeeft gevuld is met fenomenen, die in eerste instantie een figurale indruk zullen geven en dat figuur-grond-differentiatie een vereiste is om tot verdere ontwikkeling in deze te komen. Niettemin past de definitie van Guilford niet geheel voor dit type van stimuli: "Fugural, pertaining to information in concrete form as perceived or as recalled in the form of images ${ }^{* *}$.

Voorlopig moet derhalve gekonkludeerd worden dat het althans op dit moment niet mogelijk is de indeling van Guilford op verantwoorde wijze eveneens op het "sensomotorische niveau" toe te passen. Hiervoor is hij in feite ook nooit bedoeld.

6e Door uit te gaan van modaliteit en stimulusinhoud worden de hypothetische niveaus en hiërarchieèn buiten beschouwing geplaatst, relatief minder belangrijk; en kunnen onderliggende konstrukties bij het informatieverwerkend proces toch onderzocht worden.

7e. Deze onderliggende konstrukties zijn:

a. De operaties: cognition, memory, evaluation, convergent production, divergent production.

b. De produkten: units, relation, implication, system, transformation, classes. (zie Guilford c.s. 1971 pag. 21).

Aangezien er vermoedelijk niet voldoende modaliteitsspecifieke tests bestaan, die iedere operatie-produkt-cel per stimulusinhoud, per responssoort vullen, zal genoegen moeten worden genomen met een benadering.

8e. Het lijkt in ieder geval mogeljk om in de klinische testsituatie per stimulusinhoud, modaliteit en responstype de aparte operaties te onderzoeken. In de zogenaamde klinische observatiesituatie is dit niet goed mogelijk, angezien door het daar gevraagde complexe samengestelde gedrag de diverse operaties moeilijk te onderscheiden zijn. Bovendien lopen daar stimulusinhouden, modaliteiten, wijzen van presentatie en responstypen te veel door elkaar. Overigens leent zich een goede observatiesituatie beter voor prediktie van gedrag in de complexe werkelikheid, dan de testsituatie.

9e. Deze latatste overweging leidt tot een nieuwe afgrenzing van "funkties" en "vaardigheden".

Funktes: Hypothetisch konstrukties, ingedeeld volgens de taxonomie van Guilford in specifieke operaties en produkten, per stimulusinhoud, modaliteit, presentatie wijze en responstype.

Funktleassessment: De beoordeling wan deze hypothetische konstrukties door presentatie van tests, welke volgens Guilford deze konstrukties meten onder systematische variatie van stimulusinhoud, modalliteit, presentatiewijze en verwacht responstype.

Vaardigheden: Handelingssekwenties die samengesteld zijn uit een voorlopig (onbekend) aantal hypothetische konstrukties. Zijzijn als zodanig handelingen, die typisch voortkomen uit de socio-culturele fysieke context en een appël doen op de persoon zelf om zichzelf in zijn leefsituatie te handhaven.

Vaardigheidsobservatie: De beoordeling van het vermogen van een persoon inzake het kunnen bean woorden aan de eisen die vanuit de leefsituatie aan hem 
gesteld worden Teneinde een aansłuiting te kunnen vormen met de funktieassessment dient ook bij deze vaardigheidsbeoordeling zoveel mogelijk rekening gehouden te worden met stimulusinhoud, modaliteit, presentatiewijze en responstype.

Bovenstaande uitgangspunten leiden tot een hypothetische taxonomie van funkties die in onderstaande tabel worden weergegeven. Aangezien deze tabel een indeling naar niveaus lijkt te suggereren, moet hier nogmaals gesteld worden dat dit zeker niet de bedoeling is. Het is slechts de intentie om in deze studie zoveel mogelijk uit de taxonomie van Guilford te halen. Door een indeling van de tests van Guilford naar kanaalspecificiteit wordt getracht deze „structure of intellect" in de revalidatie te introduceren. Verdergaande research dient, op vermoedelijk vrij lange termijn, na te gaan in hoeverre deze introduktie een reële bijdrage gaat leveren in de assessment van gedragstekorten bij cerebraal gestoorde patiënten.

Tabel 15 Taxomomieschema.

\begin{tabular}{|c|c|c|c|c|c|c|}
\hline $\begin{array}{l}\text { Stumulus } \\
\text { inhoud }\end{array}$ & $\begin{array}{l}\text { Input } \\
\text { materi } \\
\text { Mod. }\end{array}$ & Inth. & $\begin{array}{l}\text { Centrale Verwerking } \\
\text { Operaties: C/M/E/N/D } \\
\text { Produkt: U/R/W/S/C/T } \\
\text { (Zie Gullford } 4.13 .3 .)\end{array}$ & $\begin{array}{l}\mathrm{O} \\
\mathrm{R}\end{array}$ & $\begin{array}{l}\text { Voorbeelden van } \\
\text { (culturete) } \\
\text { mogelijkheden }\end{array}$ & Uni of Bimodas \\
\hline \multicolumn{7}{|l|}{$\$$} \\
\hline symbolisch & $\begin{array}{l}\mathrm{V} \\
\mathrm{V} \\
\mathrm{A} \\
\mathrm{A} / \mathrm{V} \\
\mathrm{A} / \mathrm{V}\end{array}$ & $\begin{array}{l}\mathrm{s} \\
\mathrm{s} \\
\mathrm{S} \\
\mathrm{S} \\
\mathrm{M} / \mathrm{s} \\
\mathrm{M} / \mathrm{s} / \mathrm{S}\end{array}$ & $\begin{array}{l}\text { Mathematische } \\
\text { cial verwerving }\end{array}$ & $\begin{array}{l}\text { Ms } \\
M v \\
M s \\
M v \\
M s\end{array}$ & $\begin{array}{l}\text { schriftelijke rekenopdrachi } \\
\text { net gesproken art woord } \\
\text { schriftelijk rekenen } \\
\text { hoofdrekenen } \\
\text { mondiel inge rekenopdr. op } \\
\text { papier witrekenen } \\
\text { M-S koppelling } \\
\text { M-S koppeting }\end{array}$ & $\begin{array}{l}\text { Bii } \\
\text { Uni } \\
\text { Uni } \\
\text { Bi } \\
\text { Bi } \\
\text { Bi }\end{array}$ \\
\hline$\frac{-}{M r}---$ & -- & +-1 & ------- & - & $-------\cdots$ & $-m--$ \\
\hline $\begin{array}{l}\text { semaintiseh } \\
\text { geregistreerd }\end{array}$ & $\begin{array}{l}W \\
W \\
A \\
A N W \\
A N W\end{array}$ & $\begin{array}{l}M^{r} \\
M^{r} \\
M^{s} / M^{r} \\
M^{n} / M^{r}\end{array}$ & $\begin{array}{l}\text { Geregistreexde } \\
\text { taglverwerving } \\
\text { 1) }\end{array}$ & $\begin{array}{l}\text { Ms } \\
M v \\
M v \\
M s\end{array}$ & $\begin{array}{l}\text { hardop lezen } \\
\text { naschrijuer } \\
\text { diktee } \\
\text { M-Mr koppeling } \\
\text { M-Moppeling. }\end{array}$ & $\begin{array}{l}\text { Bi } \\
\text { Uni } \\
\mathrm{Bi} \\
\mathrm{Bi} \\
\mathrm{Bi}\end{array}$ \\
\hline$m-\cdots--$ & -- & $t-\cdots$ & $-------\cdots$ & -- & --------- & $----\cdots$ \\
\hline $\begin{array}{l}\text { setrialin tisch } \\
\text { gesprokent }\end{array}$ & $\begin{array}{l}W \\
A / A \\
W / A\end{array}$ & $\begin{array}{l}\text { P*: } \\
\mathbb{F} / \mathbf{M}^{s}\end{array}$ & $\begin{array}{l}\text { Gesproken } \\
\text { taalverwerving } \\
\text { 1) }\end{array}$ & $\begin{array}{l}\text { Ms } \\
\text { Ms } \\
\text { Mv }\end{array}$ & 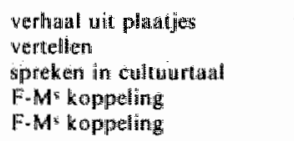 & $\begin{array}{l}\text { Bi } \\
\text { Uni } \\
\text { Bi }\end{array}$ \\
\hline----- & $-\infty$ & --- & $-------\infty$ & -- & --------- & $-\infty-\infty-\infty$ \\
\hline figuraal & w & $\mathbb{F}$ & $\begin{array}{l}\text { Verinnerlijkle } \\
\text { bewegingen }\end{array}$ & $\mathrm{Mv}$ & $\begin{array}{l}\text { figurale manipulaties } \\
\text { (in gedachten) }\end{array}$ & $\begin{array}{l}\text { Unal } \\
\text { Unili }\end{array}$ \\
\hline $\begin{array}{l}--\infty-1 \\
\text { biohavioral }\end{array}$ & 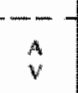 & $\begin{array}{c}--- \\
B \\
B\end{array}$ & $\begin{array}{l}\text { Toekennen van infoud } \\
\text { anth bewegingen }\end{array}$ & $\mathrm{Mv}$ & $\begin{array}{l}\text { auditiel initren } \\
\text { wisueel imiteren }\end{array}$ & $\underset{\substack{\text { Uni } \\
\text { Uni }}}{---\infty}$ \\
\hline $\begin{array}{l}\text { Betekenis: } \\
F=\text { Figuraal } \\
B=\text { Behavior } \\
M=\text { Segmanti } \\
M=\text { Semant }\end{array}$ & ger & treend & $\begin{array}{l}A=\text { auditief } \\
V=\text { wistieel }\end{array}$ & $\begin{array}{l}M s \\
M v \\
\mathrm{R}=\end{array}$ & $\begin{array}{l}\text { Motioriscth-spralak } \\
\text { Motorischn verplatsend } \\
\text { Sutput } \\
\text { Respons }\end{array}$ & $--m-\infty$ \\
\hline
\end{tabular}

$\mathbf{S}=$ Symboliseh

y Kome nier voor bij Gualord 


\section{A. Invulling der cellen in de taxonomie.}

Een theoretisch model zal, will dit praktische warde kriggen, moeten unkristallliseren in een geoperationaliseerd frame, bruikbaar woor assessment. Vanuit de denkbeelden van Guilford is een global werkframe an te geven, terwijl zijn praktische testwoorbeelden toepabbar zinn voor een deel der psychische funkliediagnostiek.

Cuilfords systeem is echter niet voor alle cellen ( C-U, C-R, C-I enz. D-U, D-R enz) te vullen met genormeerde tests met een enkelwoudige faktorlading, geschikt voor de revalidatiepatient, die bijvoorbecld niet kan schrijven of spreken. Enerzijds hebben vele tests op het onderhavige gebied een meerwoudige faktorlading. anderzijds zin diwerse tests met een enkel woudige faktorlading of weinig brükbaar ôf niet genormeerd woor het Nederlandse taalgebied. De tests die Guilford in zijn model presenteert zijn bovendien niet geselekteerd op kanaalspecificiteit. Dit geldt trouwens voor 99 \% der verkrijgbare tests, aangezien deze meestal intermodaal (auditief-visueel) moeten worden verwerkt, hetzij qua input, hetzij qua input-output modaliteiten. Tenslotte houdt Guilford geen rekening met de soort motorische respons en dus ook niet met de modaliteit watrin de respons kan worden wargenomen.

Voor de koppeling wan twee verschillende stimulusinhouden als bijv. figuraal-semantisch biedt Mark perspektief in zijn "Detection of psycholinguistic disorders" (zie Schroots 1972 pag. 43). Bij deze naspeuring is echter geen sprake meer wan tests wat betreft het kriterium, normering. Het betreft meer systematische kontrole van alanwezigheid en funktioneren van de verschillende systemen. Door middel van het "sukses falen" principe wordt namelijk herhaald gekeken of de patiënt een specifieke opdracht aan kan of niet. De gegeven taken blijken eigenlijk alleen cognitief qua "operatie". waarbij andere operaties onduidelijk blijven. Wel worden alle systemen afgetast binnen het auditief-visuele (bi-modale) kommunikatiekanaal, met zorgvuldige manipulatie van de in put. Hoewel onvolledig biedt deze aanzet van Mark een perspektief tot verdere exploratie. Veel moeilijker lijkt het onderzoek te worden bij het niveau "sensomotoriek". Weliswar bestaan er enkele tientallen tests, gekontroleerde opdrachten en observatieschalen, maar deze instrumenten zijn niet zondermeer binnen het hier voorgestelde framework te passen. Evenals bij de meeste "cognitieve" tests zijn tests of gekontroleerde opdrachten met een enkelvoudige faktorlading onvoldoende ontwikkeld. Deze studie wil dan ook geen uitspraak doen inzake het onderzoek van zogenaamde sensomotorische koppelingen.

Per stimulusinhoud en per kommunikatiekanaal dient iedere „operatie“ apart te worden onderzocht. Daar voorlopig nog niet ledere operatie-produkt-cell per stimulusinhoud en per kanaal gevuld is, kan per stimulusinhoud, per kommunikatiekanaal iedere operatie bij benadering slechts door twee tests worden beoordeeld, d.w.Z. 10 onderzoeken per kanal en stimulusinhoud. Indien op deze wijze alle kommunikatiekanalen zouden kunnen worden onderzocht, betekent dit c.a. 200 onderzoeken in totaal.

Aangezien ledere test, indien hij enigszins adekwaat wordt uitgevoerd, minstens 10 minuten zal vergen, betekent dit ca. 4 dagen onafgebroken onderzoek. Dit is uiteraard een ondoenlijke a.angelegen heid, zowel voor patiënt als voor onderzoeker, derhalve moet in eerste instantie gewerkt worden met een vrij grove benadering. Deze benadering kan bestaan uit het waststellen van de stimulussoort waarmee de patiènt de meeste moeite heeft door per kommunikatiekanal een aantal .gang- 
bare" mogelijkheden als rekenen, lezen, diktee etc. na te gaan (zie integratie 5.1.5.). Hierna kan voor één kanaal ten aanzien van de veronderstelde meest gestoorde stimulussoort worden bezien welke operaties het meest zijn aangetast. Een andere mogelijkheid is na te gaan of de cruciale koppelingen (Figuraal-Semantisch), (Semantisch gesproken-Semantisch geschreven) e.d. wel kunnen worden gemaakt: Geleidelijkaan kan zo het onderzoeksfocus worden versmald, waardoor het mogelijk wordt in ca. 2 dagen tot een redelijk beeld te komen van de psychischio funktiestoornissen ten gevolge van een cerebrale aandoening.

Een volgend probleem is de limit testing-procedure. Pas indien enige zekerheid is verkregen dat het defekt binnen het taxonomiemodel lokaliseerbaar is en zich bijvoorbeeld niet uitstrekt tot, of doorwerkt op een veelvoud van kommunikatiekanalen, operaties en produkten, kan met limit testing begonnen worden. Dit concept dat in hoofdstuk 4 terloops werd genoemd vergt een nadere uiteenzetting.

\section{B. Limit testing-procedure.}

Guilford presenteert in zijn complex systeem uiteindelijk toch een sterk gereduceerd extern milieu. De realiteit is in feite complexer en de test is slechts een gestandaardiseerde situatie waarvan gehoopt wordt, dat er enige overlap bestaat met de realiteit.

De gestandaardiseerde test elimineert elke afwijking van de voorgeschreven test procedure. Dit vermindert zijn bruikbaarheid, met name voor de revalidatiepatiënt. De revalidatiepatiënten zijn immers zeer gevarieerd in hun resterende gedragsmogelijkheden. Het probleem om ook van de gehoorgestoorde patiënt de intelligentie te bepalen vond hier té lande zijn oplossing door de konstruktie van de „Snijders en Oomen Niet-Verbale Intelligentietest" ( $\mathrm{SON}$ ). Naast de gehoorgestoorde bestaat echter ook nog de motorisch gestoorde patiënt die b.v. zijn hoofd voortdurend laat zakken tijdens het onderzoek, de patiënt met "inhibitiezwakte" " die moeilijk langdurig met een taak bezig kan zijn, de afasiepatiënt die ,ja" zegt, maar "nee" bedoelt. De mogelijkheden en kombinaties hiervan zijn legio en tevens zeer reëel. Indien men bij dergelijke patiënten op gekontroleerde wijze zou mogen afwijken van de standaardregels, b.v. het hoofd opbeuren, bij tempotests geen acht geven op de tijd, regelmatig proberen de aandacht vast te houden enz, dan lijkt men een meer reëel beeld te kunnen krijgen en in elk geval winst te boeken ten aanzien van de assessment, mits men iedere afwijking van de standaardisatie van het onderzoek registreert. Indien men geen rekening houdt met mogelijke faciliterende of bemoeilijkende stimuluskondities, wordt er met de gangbare testprocedure zo'n veelvoud aan lage uitslagen verkregen, dat daarmee onvoldoende indikaties voor benodigde therapie worden werstrekt.

Zowel de praktijk der revalidatie als de „beperktheid" van het model-Guilford maken aanvulling van de gebruikelijke assessment met andere methodieken noodzakelijk. Dit additionele aspekt wordt o.a. door Mark, Ozer en Diller gepresenteerd in de "limit testing-procedure". Dit is het systematisch en gekontroleerd variëren van de "wijze" waarop de stimuli gepresenteerd naar inhoud worden aangeboden. In feite wordt de test hierbij al s basis voor een leerexperiment gebruikt, waarbij de verschillende experimentele kondities (onafhankelijke variabelen) en stimulusinhoud binnen operatie/produkt (interveniërende variabele) systematisch gevarieerd worden, teneinde te zien hoe de respons (afhankelijke variabele) wordt beinvloed. Het is een leerexperiment met als doel de score op de diverse tests te verhogen.

Het probleem is hierbij echter dat met name bij de revalidatiepatiënt niet bekend is 
waaruit deze limit testing zou moeten bestaan. Uit de literatuur kunnen enige gegevens worden betrokken.

Ozer (1974) noemt deze procedure „process diagnosis" waarbij hij drie kriteria onderscheidt, $\mathrm{nl}$. (a) een taak in komponenten verdelen (b) de modaliteit van de in put variëren (c) afleidende stimuli beperken.

Diller (1976) verschaft vanuit een andere optiek eveneens informatie. De ideeèn die Diller verschaft werden onder 4.1.4.3. tabel 12 behandeld en lijken bij te kunnen dragen aan ".limit testing".

Aangezien dus momenteel nog niet duidelijk is welke variaties er zoal mogelijk zijn wat betreft de uitwoeringswijze van limit testing kan bij leder gedragstekort op een specifieke teststimulus de betreffende taak worden geanalyseerd. Een dergelijke analyse is al wel gedar wat betreft de uitvoering van de "Block Design Taak” (Reisenweber 1953 en Ben-Yishay 1970). Een andere mogelijkheid is, om volgens een van te voren opgestelde manier de wijze van presentatie systematisch te variëren waarbij o.a. gebruik gemaakt kan worden van de gegevens van Diller en eigen improvisatie en kreativiteit. De eerste methode lijkt wetenschappelijk meer verantwoord maar kost tijd en energie. De tweede methode is een "trial and error"aangelegenheid, waarbij men de kans loopt iets over het hoofd te zien.

Dankzij het leerexperiment worden gegevens verk regen hoe een eventuele modifikatiepoging zou kunnen worden opgezet. Indien blijkt dat de patiënt onder bepaalde kondities in reaktie op een teststimulus meer adekwaat ged rag presenteert dan onder andere kondities, kunnen daraan duidelijke gegevens worden ontleend voor modifikatieplanning.

Ongeacht de methode zal het resultaat van limit testing moeten zijn, informatie inzake het opzetten van trainingsprogramma's, leidend tot gedragsrestauratie, -kompensatie of -reorganisatie.

\subsubsection{Assessment van gedragstekorten in de klinische observatiesituatie}

Observatie van gedragstekorten dient gericht te zijn op de konstatering of de persoon in staat is om met zijn lichaam, met de ruimte en de tijd waarin hij zich bevindt en met de objekten en subjekten, die hij daarbij ontmoet op "adekwate" wijze om te gaan. Het woord ,adekwaat" is voor een deel een waarde-oordeel. In deze studie blijven daarbij de uitgangspunten der leertheorie gehandhaafd. Volgens deze visie heeft de mens twee soorten drijfveren, $\mathbf{n l}$. de aangeboren en aangeleerde drijfveren. Deze aangeboren drijfveren (reduktie van honger, dorst, etc.) zijn voor alle mensen gelijk. De aangeleerde drijfveren worden gezien als gekonditioneerd aan de aangeboren drijfveren en zullen per cultuur, subcultuur, groep en persoon verschillend kunnen zijn.

Afhankelijk van het waardepatroon kunnen per cultuur, subcultuur etc. andere driffveren aangeleerd worden. De reduk tie van deze aangeleerde drijfveren betekent de ontwikkeling van alangeleerd gedrag. Welk soort gedrag er aangeleerd moet worden, de wijze en het moment waarop dit gedrag moet worder geëffektueerd is tevens cultuur-bepaald. Realiseert de persoon het gedrag op de door de cultuur aangeleerde wijze, moment en plaats, dan volgt positieve (sociale of andere) bek rachtiging. Doet hij dit niet, dan volgt straf (sankties of negatie). Op deze wijze houdt de samenleving zichzelf en het individu hierin zich tot op zekere hoogte in stand. "The good society is one in which all people are positive social reinforcers. The important value is to behave so as to please others and to contribute (as assessed by others) to the general welfare of all men and society". (Krasner 1969 p. 544). Enerzijds zal een gedragsobservatieschaal dus gedrag beoordelen, waarbij het gaat 
om de ,adekwate" handhaving van de persoon inzake het (fysiek) voortbestaan. Anderzijds zal de gedragsbeoordeling betrekking hebben op het uitoefenen van gedrag, waarbij adekwaatheid ontleend wordt aan de (sub) culturele norm. Deze twee lijken vaak in kombinatie voor te komen.

Voorbeeld: De mens wordt op zekere leeftijd geacht zelfstandig voedsel tot zich te kunnen nemen (ter reduktie van de aangeboren drijfveren). De wijze waarop dit gebeurt is cultureel bepaald, waarbij het gebruik van mes en vork meestal, maar niet allijd door iedere sociale context gewaardeerd wordt.

Een andere overweging heeft betrekking op de struktuur der observatieschaal. Een duidelijk onderscheid tussen de assessment van gedragstekorten d.m.v. psychologische tests versus de assessment wan gedragstekorten d.m.v. observatie is, dat eerst genoemde benadering wèl hypothetische konstrukties inzake de black box postuleert, laatstgenoemde niet. Het gaat immers om de beoordeling van gedrag van de persoon in zijn leefsituatie, in relatie tot zichzelf, de ruimte, tijd, objekten en subjekten, die de persoon daarin ontmoet. Dit alles gericht op de reduktie van aangeboren en aangeleerde drijfveren. Welnu, al hetgeen de persoon in zijn levenssituaie on tmoet is waarneembaar ook zonder vooronderstelling van hypothetische konstrukties: De persoon ",beheerst" het gedrag dat vereist wordt wel, niet, of ten dele. De eventuele vraag naar "het waarom" is binnen het operante model minder relevant. Wel relevant blijft de wraag welke aspekten van de uitwendige wereld de persoon wel en niet beheerst en onder welke omstandigheden hij dit wel of niet kan en of de respons meer of minder adekwaat is (volgens de eerder genoemde kriteria).

Te onderscheiden blijven:

a. Stimulusaspekten: hoe presenteert zich de levenssituatie.

b. Responsaspekten: hoe reageert de persoon op de levenssituatie, hoe lost de persoon "het probleem" van de stimulusconfiguratie op, teneinde zelfhandhaving via de nodige (sociale) bekrachtiging te bereiken.

Het lijkt hierbij evident dat de mens krachtens zijn konstitutie op de zich presenterende levenssituatie alleen waarneembaar kan responderen middels een motorische-en/of een spraakrespons.

Het lijkt eveneens mogelijk om de onderscheidingen welke gehanteerd werden ten aanzien van de stimuli ( = inputzijde van de black box) zoals modaliteit en inhoud op hun toepasbaarheid te bezien. Bij gedragsobservatieschalen dringt zich derhalve een analogie op met de konstatering van gedragstekorten in de testsituatie, zij het dat de samengesteldheid der stimuluspresentatie naar modaliteit, inhoud en context wararschijnlijk veel complexer is in de leefruimte dan in de testsituatie.

Een andere analogie tussen de assessment in de testsituatie en die in de "life"-situatie doet zich voor in de gesuggereerde limit testing-procedure van de te verwerken stimulusaspekter.

Resumerend blijkt het van belang na te gaan in hoeverre bij de gedragsobservatie eenzelfde model te hanteren is als bij de psychologische tests.

De poging tot konstruktie van een vaardigheidsobservatieschaal gaat ervan uit, dat thet mogelijk moet zijn de diverse opdrachten, taken of eisen wat betreft hun inhoud in te delen naar stimuli. Daarmee is een relatie gegeven met de onder 5.1.2.2. behandelde funktie-assessement, zodat het wellicht mogelijk wordt korrelatieberekeningen tussen "funkties" en "vaardigheden" uit te voeren.

Bij de vaardigheidsobservatie is het in tegenstelling tot de funktie-assessment niet goed mogelijk operaties en produkten apart te onderzoeken.

Ook de limit testing-procedure heeft bij de vaardigheidsobservatie beperkingen. 
Wel is het goed mogelijk om een tak in delen te verdelen, een instruktie op diverse wijen te presenteren e.d. Een dergelike nuancering in limit testing, zoals mogelik lijkt bij de funktie-assessment, valt echter niet te realiseren bij de varardighedenobservatie. Hiertegenover staat dat de geven opdrachten een meer direkte aansluting met de realiteit van het dageliks leven bieden.

In het hiernavolgende concept voor een gedragsobservatiesysteem wordt getracht een antal elementen te verenigen (zie eveneens 4.1 .42 ).

Tabel 16 Concept Gedrate-observatieschad

\begin{tabular}{|c|c|c|}
\hline Hoordgroep (naar Wehman) & Deelgroep (nanar Ciurnzberog) & Subgroep (ngar Cunztuerg) \\
\hline 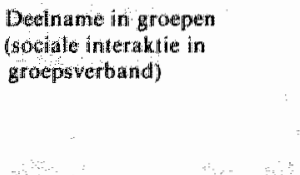 & 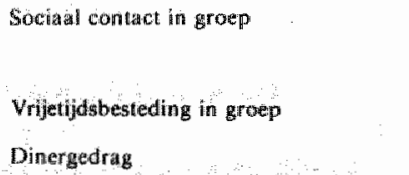 & 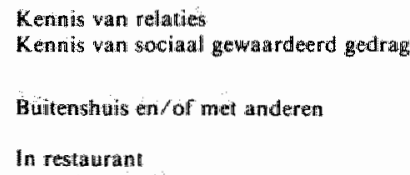 \\
\hline 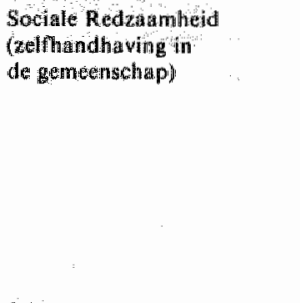 & 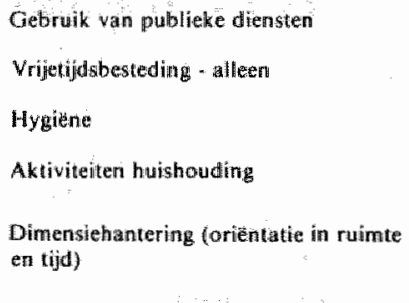 & 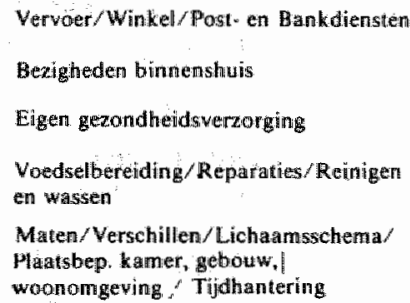 \\
\hline $\begin{array}{l}\text { Plimatire Interaktie } \\
\text { (contact met anderen) }\end{array}$ & 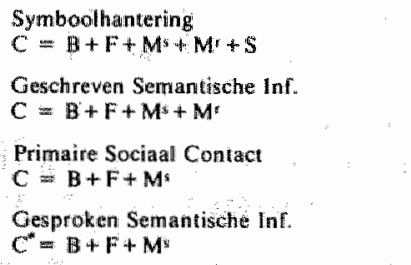 & $\begin{array}{l}\text { Rekenen met geld } \\
\text { Rekenen met getallen } \\
\text { Lezen } \\
\text { Schrijwen } \\
\text { Sociale orientatie } \\
\text { Expressier Taralgebrutk } \\
\text { Receptivef Taalgebruilk }\end{array}$ \\
\hline Zalf vonocrging (ADL) & 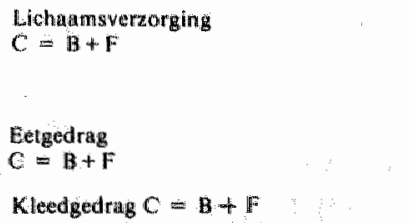 & 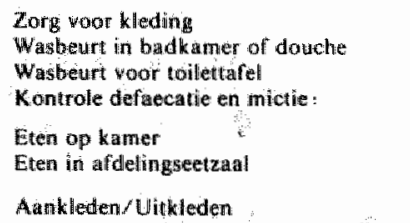 \\
\hline Motoriete & $\begin{array}{l}\text { Motorisch, sprask } \\
\text { Motorisch, werplatatsend } \\
\text { M }\end{array}$ & 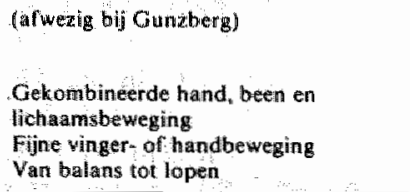 \\
\hline
\end{tabular}

$C=$ stimullusimhoud

$B=$ Behminioral

$M^{\prime}=$ Geregistreerde semantiek

\section{$F=$ Figuraal $\quad M^{\mathrm{s}}=$ Gesproken semanuisch}

$S=$ Symbolisch 
In tabel 16 zijn de volgende elementen verenigd:

1e. De observatieschal zoals deze gepresenteerd werd door Wehman (1975), wat betreft zijn indeling naar "hoofd observatiegroepen".

2e. De indeling naar Gunzberg (1974) wat betreft zin onderscheid in deetgroep en subgroepen. (De items van de subgroepen van Gunzberg lijken voor een redelijk deel toepasbaar op de cerebraal gestoorden. Deze zijn niet in de voorafgaande tabel gepresenteerd.)

3e. Een poging werd ondernomen om in iedere deelgroep het te beheersen stimulusaspekt naar inhoudelijkheid aan te geven.

Ook hierbij lijkt wederom dat er sprake zou moeten zijn van een hierarchische of niveausgewijze ontwikkeling. Hoewel deze gedachtengang misschien plausibell is, wordt deze hier niet gesuggereerd.

\subsubsection{Assessment van gedragstekorten in andere kriteriumsituaties}

Een doelstelling van deze studie is de ordening van alle beoordelingsinstrumenten volgens én referentieframe, nl. de analyse naar inhoud der gepresenteerde stimuli. Hierdoor wordt de mogelijkheid geboden een netwerk toe te passen, dat (zij het enigszins gemodificeerd) per situatie telkens weer terugkeert. Het ligt voor de hand na te gaan in hoeverre deze assessment van gedragstekorten ook zou kunnen plaatsvinden in nabehandelings- en thwissituatie:

Diverse publikaties bieden mogelikheden in die richting, o.a. Poor (1975 p. 34), Rosinski (1975) en de in Nederland verknijgbare meetinstrumenten als „Afname van handvardigheidsproeven voor zwakbegaafden" (Beekers 1968). Het lijkt hier wiet de plats om nogmaals op de uitwerking van de algemene visie terug te komen, aangezien de optiek waarmee gedragstekorten kumnen worden bezien voldoende werd behandeld en er ter verduidelijking twee mogelijke toepassingen (in test en observatiesituatie) werden gepresenteerd. Gedragstekorten zullen zich in verscheidene (kriterium)situaties presenteren in ogenschijnlijk zeer witeenlopende gedaantes. Ter voortgaande evaluatie, maar ook ter voortga nde modifikatie lijkt het nuttig om per situatie eenzelfde begrippenkader te hanteren of althans te bezien of dit mogelijk is. Analyse naar Input (stimulusinhoud, wijze van presentatie en modaliteit) rekening houdenda met de Output (responssoorty lijk teen niet ona an trek kelijke invalshoek te zijn.

\subsection{Integratie van funkties en vaardigheden ter assessment}

De huidige stand van wetenschappelijk kennis lat (nog) niet toe datogenschijnlijk plasibele hypothesen inzake niveaus van on wikkeling en hièrarchische strukturen zonder meer als vaststatand en bewezen worden geaksepteerd. Als in het vooraf. gatande wellicht een idee hieromtrent nat voren gekomen is, dan is dit het resultat van de dwingende behoefte een perspectief te ontdekken vanuit het labyrint van lunktie- en vaardigheidsstoornissen.

Het is denkbaar dat dankzij gedegen onderzoek de reeds lang getianteerde gedachterigang wan niveausgewijze en hiërarchisch gelaagde ontwikkeling wordi bevestigd.

Voorlopig echter heeft men te maken met de patient die op diverse tasts en beoordeeld langs diverse observatietechnieken en deficiet toont in "test en 
observatiegedrag". Het nomologiseh netwerk van Guilford en de gemodificeerde observatieschaal van Gunzberg is slechts een poging meer systematiek in de gehele situatie te brengen, waarbij gehoopt wordt dat beide instrumenten een representatieve steekproef van gedragstekorten zullen vertegenwoordigen in een tweetal kriteriumsituaties.

Het lijkt erop alsof test- en observatie-assessment zich vooralsnog als twee onafhankelijke benaderingen zouden moeten ontwikkelen. Vanuit minstens twee bronnen is ondertussen echter bekend dat er pogingen worden ondernomen tests en vaardigheden met elkaar in verband te brengen. De eerste informatie hieromtrent is afkomstig wan Diller (1976) (4.1.4.3), waarbij aangegeven wordt dat bij de assessment van gedragstekorten, tot uiting komende in gestoorde vaardigheden, gezocht wordt naar tests of taken welke geacht worden in relatie te staan met deze vaardigheden. De tweede informatie is afkomtig van Nieuwenhuyse (persoonlijke mededeling) waaruit blijkt dat o.a. de Gemeentelijke Universiteit van Amsterdam zeer recentelijk bezig is d.m.v. "multiple regressie"-technieken vaardigheden te relateren aan de tests van Guilford.

Indien deze informaties juist zijn lijkt het mogelijk een tweevoudige assessment (naar funkties en vaardigheden) op elkaar af te stemmen.

\subsubsection{Assessment van ged ragsbelemmeringen}

De gedragsbelemmeringen werden in hoofdzaak gekonstateerd onder omstandigheden, waarbij de persoon in interaktie was met een ander (therapeut, verpleegkundige, andere patiënt). De daaruit voortgekomen observatieschaal (GOCC) werd derhalve in eerste instantie, interaktiediagnostiek" genoemd en de daaruit voortvloeiende interventies ,interaktiemodifikatie. Gekonstateerd werd dat bepaalde patiënten nergen anders aan toe kwamen dan aan het vertonen van een bepaald gedrag, dat zich doorgaans overal en vrijwel de gehele dag manifesteerde. Verondersteld werd dat reduktie van dit gedrag in eerste instantie ruimte voor therapie en interaktiemogelijk heden zou bieden. Het is echter onvoorzichtig, indien men aan een patiënt die bijvoorbeeld agressief of passief is, zonder meer een gebrek aan sociale vaardigheid gaat toeschrijven. Hoewel dit niet is wit te sluiten, is deze konklusie vanuit een "deficiet-model" te eenzijdig en te voorbarig om te dienen tot het ontwerpen van een revalidatieprogramma voor de betreffende patiënt. Het is heel goed mogelijk, dat in het potentiële ged ragsrepertoir van de patiënt wel degelijk een goede en vriendelijke omgangsvorm aanwezig is. Door de aanwezigheid van op dat moment - incompatibel gedrag komt het echter niet naar voren. Eerst na reduktie van het gedragsbellemmerend in casu agressief gedrag, kan blijken dat de persoon niet in staat is zich in de interaktie op cultureel akseptabele wijze te gedragen. Hij heeft het nooit geleerd of is het "ontleerd" en de opgave wordt dan om parallel axn reduktie van agressief gedrag, een nieuw gedrag te gaan vormen $n$. socitile vaardigheid. Als blijkt dat na of tijdens de reduktie van gedragsbelemmerend gedrag wel degelijk een sociale vaardigheid bij de persoon aanwezig is, kan men overwegen om dit sociale gedrag als incompatibel met het agressieve gedrag te gaan ondersteunen, waardoor gehoopt wordt dat de frek wentie van het agressieve gedrag (door extinktie) afneemt en de frekwentie van het sociale gedrag (door bekrachtiging) toeneemt.

Het is uitermate belangrijk drie denkwijzen duidelijk ten opzichte van elkaar af te grenzen en naast elkaar te stellen:

1e. Bij het „excessief model” is sprake van excessief gedrag dat een poging tot nieuwe gedragsworming in wat voor opzicht dan ook, tegengaat. Het is hierbij 
niet vanzelfsprekend, dat het gedrag dat incompatibel is met het excessieve gedrag, niet tot het gedragsrepertoir behoort. Integendeel, men hoopt en verwacht dat het juist wël aanwezig is en gaat dit incompatibele gedrag, indien het zich voordoet, bekrachtigen onder extinktie van de gedragsbelemmering. De agressieve patiënt met goede sociale interaktiemogelijkheden kan, zoals in het bovenstaande werd aangegeven, als voorbeeld dienen.

2e. Bij het "deficiet-model" is sprake van gedragstekorten die met behulp van de assessment in de klinische testsituatie of klinische observatiesituatie konden worden vastgesteld. Er treden hierbijgeen excessieve gedragsbelemmeringen op en men kan overgaan tot nieu we gedragsvorming volgens de diverse gedragstherapeutische principes. Voor een dergelijke benadering van uit het „deficietmodel " komt de patiënt in aanmerking die bijvoorbeeld rustig en benaderbaar is, maar waarbij gebleken is, dat hij zich in allerlei situaties niet volgens de sociaal-culturele normen kan gedragen of andere gedragstekorten toont.

3e. Bij de kombinatie van „excessief en deficiet"model is er sprake van excessieve gedragsbelemmeringen èn gedragstekorten, welke tot dezelfde gedragskategorie behoren. Als voorbeelden:

De agressieve persoon onderhoudt dit gedrag dankzij een hieraan ontleende bekrachtiging, maar is tevens niet in staat in de niet-agressieve perioden sociaal gedrag te stellen. Danwel: het agressieve gedrag wordt in alle situaties onderhouden, aangezien de persoon in kwestie nooit iets anders heeft geleerd. Een dergelijke situatie vereist een tweevoudige opdracht nl. extinktie van excessief gedrag in kombinatie met het stapsgewijs aanleren van een nieuw (sociaal)gedrag, hetgeen eventueel als incompatibel met het excessieve gedrag gezien kan worden. In een aantal gevallen zal dit niet goed mogelijk zijn en zal men derhalve naar een ander incompatibel gedrag moeten omzien teneinde reduktie van het excessieve gedrag te realiseren. Pas na deze reduktie kan dan getracht worden de sociale vaardigheden door middel van modeling en successieve approximatie op te bouwen.

Het zal uit bovenstaande duidelijk zijn dat, indien deze drie denkmodellen niet van elkaar onderscheiden worden, spraakverwarring en ook een inefficiënte vermenging van benaderingswijzen en modifikaties een reëel gevaar gaan betekenen.

Ook een andere terminologische aangelegenheid verdient de aandacht. Onder gedragsbelemmeringen werden die gedragingen verstaan, die nieuwe gedragsvorming tegengaan, belemmeren of blokkeren. Vanuit gedragstherapeutisch en revalidatiestandpunt werd dit gedrag ook wel excessief genoemd. De frek wentie van voorkomen van dit excessieve gedrag dient, teneinde nieuwe gedragsvorming mogelijk te maken, in feite gelijk aan nul te zijn. Ten onrechte neigt men er toe om de term „excessief" gedrag te reserveren voor overmatig aktiel gedrag, zoals ontremming, agressiviteit, prikkelbaarheid, bewegingsdrang, onrust etc. Hoewel het vreemd aandoet om bijvoorbeeld passiviteit, inertie e.d. excessief te noemen, is dit gerechtvaardigd aangezien dit trage, ongemotiveerde, apathische gedrag kontinu aanwezig is en dus ongelijk is aan nul, hetgeen vanuit het gedragsvormende standpunt gewenst zou zijn.

Dit excessieve gedrag kan worden getoond door de pattiënt, maar eveneens door zijn "tegenspelers" of ",medespelers" in het therapeutisch-, thuis- of werkmilieu m.a.w. in de premorbide, klinische, nabehandelings- en thuissituatie. De GOCC was een eerste poging om dit gedrag bij de patiënt vast te stellen. Met opzet wordt hier gesproken over "nieuw-gedrag-belemmerend" en niet van "revalidatie-belemmerend gedrag". De reden hiervoor is dat het aksent bij de revalidatie, althans in 
Nederland, nog voornamelijk valt op de "lichamelijke revalidatie”. Gehoopt wordt dat langzamerhand meer ruimte en aandacht zal ontstaan woor de vorming van een breder gedragsscala.

Het voorkomen van dit excessieve gedrag, dat nieuwe gedragsvorming tegengaat, word" vanuit leertheoretisch stand punt verklaard door aanwezigheid van externe of interne ongewenste bek rachtigende kondities bij patiënt en/of zijn omgeving of de afwezigheid van voldoende gewenste bekrachtigende kondities. Onder 1.3.5. werden de ongewenste resp. gewenste bekrachtigende kondities onderkend. De presentatie hervan vond plats aan de hand van de zogenaamde ,revalidatiefasen" namelijk: kriseshantering, assimilatie van de handicap (aversief beleefde revalidatie, rouwproces, premorbide gedrag) het motivatieconcept en de beklipwing van handicap-adek waat gedrag. Bij de behandeling van het excessieve gedrag in deze fasen zal dezelfde volgorde worden gevolgd:

le Krises. De ervaring van de leefruimte, het lichaam, het denken etc. lijkt gekenmerkt te zijn door onbekendheid, onzekerheid, chaos, pijn. Voorzover er enig gedrag is, zal dit ongericht zijn. De persoon moet weer gaan leven, maar heeft voorlopig slechts de beschikking over een partieel gedragsrepertoir. Zoals het pasgeboren kind moet de patiènt opnieuw leren welk gedrag in zijn wereld mogelijk is, waarde heeft (d.w.z. bekrachtigend voor hemzellf en omgeving) welke doeleinden er zijn etc. Het gedrag lijkt in deze fase gekenmerkt te kunnen zijn door geringe frekwentie of juist zeer hoge frekwentie van persevererende aard. Er is sprake van geen of onvoldoende bekrachtiging voor welk gedrag dan ook.

2e Aversief beleefde revalidatie. Als de behandeling door patiënt en/of omgeving geassocieerd wordt met het ondragelijk leven met handicap, of de therapie een pijnlijke aangelegenheid blijkt te zijn, of indien gehoopt herstel slechts gedeeltelijk kan worden gerealiseerd, wordt aversief reageren op de behandeling daandoor versterkt. Reakties hierop kunnen zijn, vermijdingsgedrag (zich onttrekken aan de behandeling), niet meewerken uit gemis aan "motivatie" en/of agressief gedrag, waarmee men zich teweer stelt tegen de als bedreigend ervaren therapeut. Als dit gedrag door thuis- of therapiemilieu wordt ondersteund bijv. door het geven van extra aandacht, kan het lang duren eer er aan vorming van nieuw gedrag begonnen kan worden.

3e. Rouwproces. Het besef van de handicap, van het verlies en van het gemis aan toekomstperspektief, kan leiden tot geanticipeerde deprivatie bij patiënt en thuismilieu. Het gemis atan geanticipeerde, zinvolle, levensvullende aangelegenheden kan leiden tot reaktiewijzen, welke veelal beschreven worden als depressie en apathie.

4e. Tegenwerking door premorbide gedrag. Tijdens de revalidatie moet de patiënt viak nieuw gedrag aanleren dat strijdig kan zijn met het vroegere gedrag. Het vasthouden aan dit vroegere gedrag, hetzij in gedachten of in de realiteit, gaat nieuwe gedragsvorming tegen, vooral indien het thuismilieu dit ook nog eens ondersteunt of anmoedigt.

$5 e$. Revalidatiegedrag is in eerste instantie veelal niet persé zelfbek rachtigend, hier wordt in het algemeen onvoldoende bij stil gestaan. Bij afwezigheid van bekrachtiging moet de therapeut zelf deze bekrachtigende funktie vervullen door de relatie tussen patiënt en therapeut zo te struktureren dat de patiënt het op zichzelf niet bekrachtigende gedrag toch uitvoert, om van de therapeut de goedkeuring te verkrijgen. Bij afwezigheid van deze houding bij de therapeut kan opnieuw ontsnappings- en/ of vermijdingsgedrag in allerlei vormen het resultaat zijn. 
Met voorgenoemde bewoordingen lijkt het begripgedragsbelemmeringen voldoende toegelicht te zijn.

De poging enige informatie omtrent deze gedragsbelemmeringen te verk rijgen werd - zoals eerder gesteld - gekonkretiseerd in de zogenaamde GOCC.

De GOCC werd ten tijde van deze studie slechts gehanteerd in de klinische observatiesituatie. Het verdient aanbeveling na te gaan in hoeverre de assessment van excessief gedrag eveneens uitgevoerd kan worden in de premorbide, klinische test- nabehandelings- en thuissituatie. De wijze van informatieverzameling in deze situaties verdient hierbij een bijzondere aandacht, aangezien het niet te verwachten walt dat bijwoorbeeld in de thuissituatie een synthetische beoordeling $\mathrm{kan}$ worden gerealiseerd. Het frekwente voorkomen wan gedragsexcessen in de premorbide situatie geeft echter informatie over en is mogelijk een duidelijke (contra-)indikatie voor de uitvoering van gedragsmodifikatie in de $k$ liniek. Het werd ook verscheidene malen beklemtoond dat het van belang is om na te gaan, in hoeverre een geslagade reduktie van excessief gedrag in de kliniek inderdaad gekontinueerd wordt in nabehandeling- en thuissituatie.

Het bovenstaande in aanmerking genomen kan gekonkludeerd worden, dat de systematische observatie wan excessief gedrag in de $k$ liniek noodzakelijke uitbreiding verdient in andere kriteriumsituaties. Pas nadat gegevens hieromtrent verzameld zijn, lijkt het zinvol te bezien in hoeverre voor de diverse situaties een begrippenkader kan ontstaan dat, ewenals bij gedragstekorten, voorziet in een kontinue „over-all"-evaluatie van gedragsdeviaties in alle kriteriumsituaties.

\subsubsection{Samenvatting}

Vanuit praktijkervaringen (hoofdstuk 3) en literatuurstudie (hoofdstuk 4) werd getracht een onderlinge afstemming te bewerkstelligen t.a.v. assessment van gedragstekorten en gedragsbelemmeringen.

1le. Assessment van gedragstekorten in de premorbide, klinische testsituatie, klinische observatiesituatie, nabehandelingssituatie en thuissituatie wint door gebruik te maken van éen begrippenkader. Een dergelijk begrippenkader is te funderen op de gepresenteerde stimuluskonfiguraties, nader bepaald naar stimulusinhoud, modaliteit en wijze van presentatie.

De begrippen "funktie", "vaardigheden" en ,taken" werden gerelateerd aan de situaties waarin gedragstekorten in deze konden worden vastgesteld, te weten: de test - observatie - en nabehandelingssituaties.

Voor een tax onomie naar funkties en vaardigheden werd een ont werp gemaakt.

2e. Door middel van ,multiple regressie"-technieken is het mogelijk een specifieke vaardigheid te relateren aan een verzameling van Guilford-tests. Hierdoor wordt het eveneens mogelijk een relatie te leggen of te zoeken tussen defekten in gekonstateerde vaardigheden èn tekorten in bepaalde hiermee in verband staande testprestaties.

3e. De assessment van gedragsbelemmeringen kan uiteraard gerealiseerd worden door diverse beoordelingsinstrumenten. De tot nu toe gebruikte ..gedragsobservatieschaal voor contusio cerebri" bleek in vergelijking tot andere schalen zeker geen ongunstige positie in te nemen. Van belang werd geacht dat de gedragsbelemmeringen niet slechts in de klinische observatie moesten worden nagegaan, maar dat ook andere kriteriumsituaties hiervoor in aanmerking komen. Het lijkt mogelijk om - analoog aan de konstatering van gedragstekorten - een begrippenkader te ontwerpen inzake gedragsbelemmeringen optredende in verscheidene situaties. 


\subsection{Overwegingen inzake modifikaties}

\subsubsection{Inleiding}

Ook wat betreft de modifikatie kunnen uit literatuurstudie èn praktijkervaringen enkele richtlijnen betrokken worden welke een mogelijk perspektief bieden inzake de behandeling van patiënten met cerebrale stoornissen. De modifikatie van gedragstekorten werd in de literatuurstudie tamelijk uitvoerig behandeld. In de praktijksituatie werden geen klemmende problemen gekonstateerd. Het is wan belang in deze de aandacht te vestigen op een mogelijke integratie tussen funktierestauratie en vaardigheidstraining. Aangezien dit een zeer recente ontwikkeling is, kan hierover slechts exemplarisch enkele voorlopige suggesties worden gedaan. De modifikatie van gedragsbelemmeringen $\mathrm{kwam}$ vanuit de literatuurgegevens ë̀n de praktijksituatie als een moeilijke en vaak zwaar (ethisch) beladen behandeling naar voren. Aangezien de revalidatie vermoedelijk doorlopend gekonfronteerd zal worden met blokkades bij de nieuwe gedragsvorming werd gemeend in het nawolgende extra aandacht aan deze problematiek te moeten besteden.

\subsubsection{Modifikatie van gedragstekorten}

In de literatuurstudie (4.2.) werd getracht na te gaan welke handelingssekwenties bij het herstel van gedragstekorten te herleiden zijn tot leertheoretische methodieken. Een aantal programma's bleek terug te voeren tot aktiviteiten welke vanuit het leertheoretisch operante paradigma bekend staan als fading, selektieve bekrachtiging, en shapingsprocedures. In diverse kriteriumsituaties werden dlezelfde operante handelingssek wenties aangetroffen. Dit bleek het geval in de $\mathrm{zgn}$. klinische testsituatie (4.2.3.4) de klinische observatiesituatie (4.2.4.2), maar ook in de nabehandelings- (4.2.5.) en thuissituatie (4.2.6.) werd de leertheorie en haar toepassingen bij voortduring ontmoet. Het operante paradigma (S-R-K-C) presenteert dus een aantal technieken, die aangewend kunnen worden om gekonstateerd gedragstekort in elke willekeurige situatie op te heffen. Onafhankelijk van een theorie inzake "hersenen-gedrag" blijkt het, gegeven de literatuur, mogelijk gedragstekorten in iedere situatie op te heffen volgens gedragstherapeutische methoden. De moeilijk heid was echter tot nu toe, dat men geen adkwaat raster bezat aan input-variabelen om een systematische en representatieve steekproef te trekken uit alle mogelijke gedragstekorten. Een mogelijk raster van te onderzoeken inpul-variabelen werd in voorgaande paragrafen aangeboden: Voor iedere kriteriumsituatie eenzelfde netwerk uitgaande van de gepresenteerde stimulus naar inhoud, modaliteit en presentatiewijze.

De mogelijke eenheid in benadering welke dus aanwezig wordt geacht bij de assessment van gedragstekorten, kondigt zich nu eveneens aan bij de behandeling van deze gedragstek orten: De gedragsrestauratie, gedragskompensatie en gedragsreorganisatie d.m.v. fading (stimulusfacilitatie-reduktie), selek tieve reinforcement (stimulatie met bek rachtiging van adekwaat gedrag) en shaping. De mogelijkheden voor deze benadering zijn niet alleen aanwezig bij gedragstekorten als respons op teststimuli, maar eveneens bij observatie in klinische, nabehandelings- en thuissituatie.

Opgave is tot nadere specificatie van gedragstekorten in de nader gespecificeerde situaties te komen. Hierna kan volgens bovenstaande opsomming een poging ondernomen worden tot gedragsrestauratie, -kompensatie, of -reorganisatie. 
Uit de prakijkervaring $\mathrm{kwam}$ zoals hoofdstuk 3 illustreerde eveneens de nodige informatie nat voren.

Er werden alleen pogingen ondernomen tot gedragsrestauratie in de vorm van: le. fading (bij gedragstekorten gebleken in de testkriterium situatie). 2e. toename van gedrag (d.m.v. selektieve bekrachtiging van reeds bestaand gedrag ad hoc gekonstateerd d.m.v. observatie) en 3 e, shaping van gedrag (d.m.v. successieve approxima(iic).

De gedragskompensatie en gedragreorganisatie k wamen bij de voorlopige revalidatilestrategie niet aan de orde. Inzake de gedragsrestauratiepogingen kan gekonkludeerd worden, dat de fadingprocedures bij funktiestoornissen voldoende material opleverden om voor statistische bewerking in aammerking te komen. De resultaten hiervan werden in hoofdstuk 3 besproken. De pogingen tot toename van gedrag en de vorming van nieuw gedrag waren alle sukseswol, echter de abntallen ter behandelling aangeboden patiënten waren helaas te gering voor statistische bewerking.

Diverse malen kwam in de literatuurstudie naar voren, dat in vele behandelingen leertheoretische principes verdisk onteerd zijn. Het blijkt tevens uit de literatuur, dat de fysiotherapeut, onderwijskracht etc. dankbaar gebruik maken van de principes die vanuit de leertheorie worden angereikt.

De leerpsychologie pretendeert hierbij niet, dat het een fundamentele wijziging zal brengen in alle tot nu toe gehanteerde revalidatiemethoden. Zij presenteert slechts een aanvullende, maar een zeer essentiële bijdrage aan het revalidatie-leerproces. Zij stelt zich hierbij kwetsbaar op, aangezien de methoden die zij aanbiedt dusdanig geformuleerd en geoperationaliseerd zijn dat een toetsing mogelijk wordt. Zijbepleit zelfs een objektieve evaluatie en verschaft tegelijk de realisatie hierwan.

Een dergelijke instelling kan de patiënt, de revalidatie in het algemeen en de individuele medewerker alleen maar ten goede komen.

Hèt toekomstperspektief wordt echter gezien in de poging tot integratie van funktierestauratie en vaardigheidstraining. Deze ontwikkeling schijnt in Amerika (zie Diller 1976) en in Nederland nog niet of nauwelijks van de grond te zijn gek omen.

Diller lijkt op een door hem niet nader geexpliciteerde wijze tekorten in vaardigheden in verband te brengen met een taak of tests, die met deze vaardigheid in verband staan.

In Nederland worden pogingen ondernomen d.m.v. "multiple regressie"-Hechnieken na te gaan welke tests van Guillord met een bepaalde vaardigheid korreleren. Er worden echter nergens publikaties aangetroffen inzake systematische ged ragsobservatie en/of testprocedures. Kennelijk bevindt men zich hier op een nog te exploreren terrein warin nog geen koersbepaling en research van enige omvang heeft plats gevonden. Ideeën omtrent verdere ontwikkelingen moeten dan ook met de grootste omzichtigheid worden gepresenteerd:

Vanuitt de ter beschikking staande gegevens en de algemene ontwikkelingslijnen die zich, hoewel vaag, laten bespeuren wordt hier een integratie van zowel funktie- èn wardigheidstraining voorgestaan.

1e. Vanuit de in deze studie gepresenteerde vaardigheidsobservatieschaal lijkt het mogelijk vast te stellen welke gebieden de grootste stoornissen tonen. Na de selektie van éen of meer vaardigheidstekorten dient m.b.v. „, multiple regressie" technieken vastgesteld te worden welke tests van Guillford in verband gebracht kunnen worden met deze vaardigheden. 
2e. Vanuit de in deze studlie gepresenteerde taxonomie wan funkties moet het eveneens mogelijk zijn per stimulusinhoud, per kommunikatiekanaal de meer defekte "operaties" te lokaliseren. Na deze vaststelling dient omgekeerd een relatie te worden gelegd met hiermee in werband staande mogelijke vaardigheidsdefekten.

3e. Vanuit ad. I en 2 dient gezocht te worden naar elkaar overlappende defekten tot uiting komende in tests èn vaardigheden.

4e. Limit testing-procedures, toegespitst op de gelokaliseerde tests en vaardig. heden zouden invalshoeken kunnen werschaffen inzake de te realiseren funktierestauratie en vardigheidstraining.

5e. D.m.v. fadingprincipes kan getracht worden werbetering te brengen in testgedrag (funktierestauratie).

6e. Dim.v. shapingsprocedures, selektieve bekrachtiging en fading wordt verbetering van meer complexe gedragingen ondernomen (vaardigheidstraining). Zowel funktierestauratie als vaardigheidstraining dienen zich hierbij gemeenschappelijk te richten op het gekonstateerde defekt in funkties en vardigheden.

7e. De gehele aanpak dient aan de hand wan beginassessment, begeleidende assessment en afilluitende assessment gecoördineerd en bijgestuurd te worden.

8e. Deze assessment moet gericht zijn op testonderzoek, gedragsobservatie en neurofysiologische gegevens.

Hierop gebaseerde en nader uit te werken research zou wellicht informatie kunnen verschaffen inzake de - in diverse publikaties zo veelwuldig gepresenteerde ontwikkelingsniveaus en hiërarchieën. Het spreekt vanzelf dat deze meervoudige, tamelijk complexe aanpak alleen realiseerbaar is door een multidisciplinair team dat uitgaande van eenzelfde grondgedachte de leerprincipes in theorie en praktijk volkomen beheerst. Een pleidooi voor een opzichzelfstand team, resp. afdeling ligt hierbij voor de hand. Eenzelfde gedachtengang zal ook naar voren komen bij de nu te behandelen , reduktie van gedragsbelemmeringen".

\subsubsection{Modifikatie van gedragsbelemmeringen}

\subsubsection{Terugblik}

Uit praktijkervaring en literatuurinformatie blijkt dat men bij de pogingen tot reduktie van excessief gedrag te maken krijgt met de volgende gegevenheden:

a. Een methodiek (operante konditionering) waarvan de wetenschappelijke geldig. heid enigszins bewezen kan worden geacht voor sommige populaties (meestal in de vorm van $n=1$ studies volgens het $A-B-A$-design).

b. Voordat men operante konditionering kan toepassen ap een ,nieuwe" populatie dient men eerst de relevante kenmerken van deze populaties in relatie tot de methodiek te kennen. Twee van deze kenmerken zijn konditioneerbaarheid (indien dit eem a parte faktor is en meetbaar zou zijn) en de bepaaldheid van dit gedrag door omgevingskontingenties.

c. Operante konditionering moet uitgevoerd worden door een „instrument" Dit "instrument" is hier samengesteld uit een aantal elementen $\mathrm{nl}$. een veelvoud aan personen en een veelvoud a an handelingssekwenties, die op een strikt konsek wente wijze over een langdurige periode moeten worden gebezigd. Het instrument is uiterst kwetsbaar, want het falen van éen onderdeel binnen de elementen kan mislukking der behandelinsmethode betekenen. Door de complexiteit van het instrument is bovendien moeilijk na te gaan op welk moment en waardoor er iets mis is gegaan. d. Het "instrument" is alleen toepasbaar indien bepaalde behandelingsvoorwaar- 
den zijn vervuld. Deze voorwaarden hebben betrekking op de indikatiestelling, patiëntenselektie en de kennis en bereidheid van velen in het therapie- en net-therapiemilieu.

e. De uitvoering van operante konditionering kan alleen plaatsvinden in een bepaald ,klimaat". Kenmerken van het klimaat zijn:

- strikte uitvoering van het behandelingsplan ter operante konditionering.

- de mentaliteit van de gedragstechnikus die o.a. bepaald lijkt te zijn door de "mensvisie", het "geloof" dat deze persoon ondersteunt.

- een financieel-ekonomische basis, die het mogelijk maakt bepaalde voorzieningen te treffen.

- bekrachtigingen voor de gedragstechnikus bij suksessen, maar vooral bij falen van de gedragsbehandeling.

f. Een mogelijkheid tot evaluatie van sukses of falen d.m.v. gekontroleerde A-B-A-B-design, de methode van gepaarde analyse of het gebruik maken van experimentele en kontrolegroep door medewerking van verschillende centra.

\subsubsection{Beslissingsprocedure}

Voordat men met een behandeling begint, dient er een beslissingsprocedure te zijn vastgesteld aan de hand waarvan het mogelijk is te bepalen in welke gevallen men een behandeling begint en tot hoever men deze voortzet op bepaalde cruciale momenten. Teneinde een aanzet te vormen tot het ontstaan van dergelijke beslissingsprocedure wordt in het onderstaande een flow-diagram weergegeven tan de hand waarvan een beslissingsstrategie kan worden opgezet.

Hierbij wordt ervan uitgegaan dat alle partners: patiënt, familie en behandelingsteam indien patiënt hiermee akkoord gaat volledig omtrent het programma worden geïnformeerd. Het komt dus neer op een kontrakt dat met al deze partijen gesloten gaat worden en voortdurend moet kunnen worden herzien of afgebroken indien een der partijen niet verder wil participeren. Zie tig. 9 op pg. 214 en 215.

Het schema lijkt in grote lijnen toepasbaar te zijn op de operante dekonditionering van probleemgedrag (zoals meer keren gedefinieerd) d.m.v. medewerking van patiënt, familie en team. Een belangrijke uitgangsvoorwaarde is hirbij dat met name patiënt, familie en team. Een belangrijke uitgangsvoorwaarde is hierbij dat mer name de patiënt volledig wordt geïnformeerd en participeert in de behandeling.

participeren. Dit probleem deed zich bij herhaling voor bij de verbaal gestoorde patiënt, de konversiehysterie-patiënt of bij die patiënten die gedragsbelemmeringen kontinueren, tengevolge van bekrachtigende kondities die het wrobleem "gedrag aantrekkelijker maken dan het "aangepaste" gedrag. Volgens dit schenn komen dergelijke patiënten niet voor behandeling in aanmerking, tenzij het thusmismes son het behandelingsteam bereid en in staat is konditionering te realiseren wouten de patiënt" om. Dit is echter, zoals de ervaring heeft geleetd, geen eenvoudige aangelegenheid en kan alleen gerealiseerd worden in een volkonen aparte afdeling met een kleine groep van gespecialiseerd personeel.

Indien bijgaand flow-diagram (fig. 9) zou zijn toegepast op de patiènten zoals deze in hoofdstuk 3 vermeld werden, dan zou een aantal patiëntenbehandelingen met de bestaande ak komodatie niet gerealiseerd zijn.

Ter illustratie:

a. Vaak was het niet mogelijk het probleemgedrag exact te omschrijven. Voortdurend moest ten gevolge van onvolledige observatie en/of informatie tot herformulering worden overgegaan. Daar de deelnemende personeetsleden per bespreking varieerden was het mogelijk dat een deel bezig was met extinktie van 
1. FAOBLEEM KOMSTATEFING

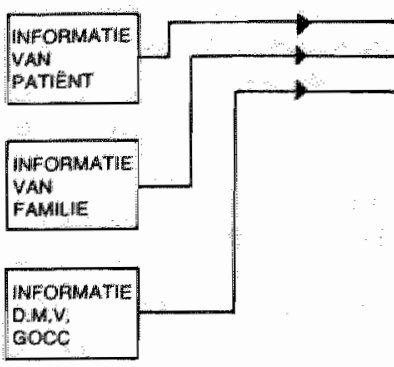

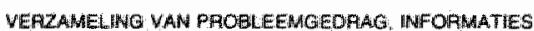
VANUIT PATTENT "FAMULIE EN GOCC

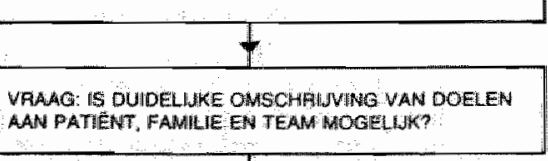

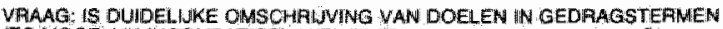
ZO MOGELUUK INCOMATABEL WET PAOBLEEMGEOFIAGI AAN PATENT FAMHLE TEAM NOGELWK?

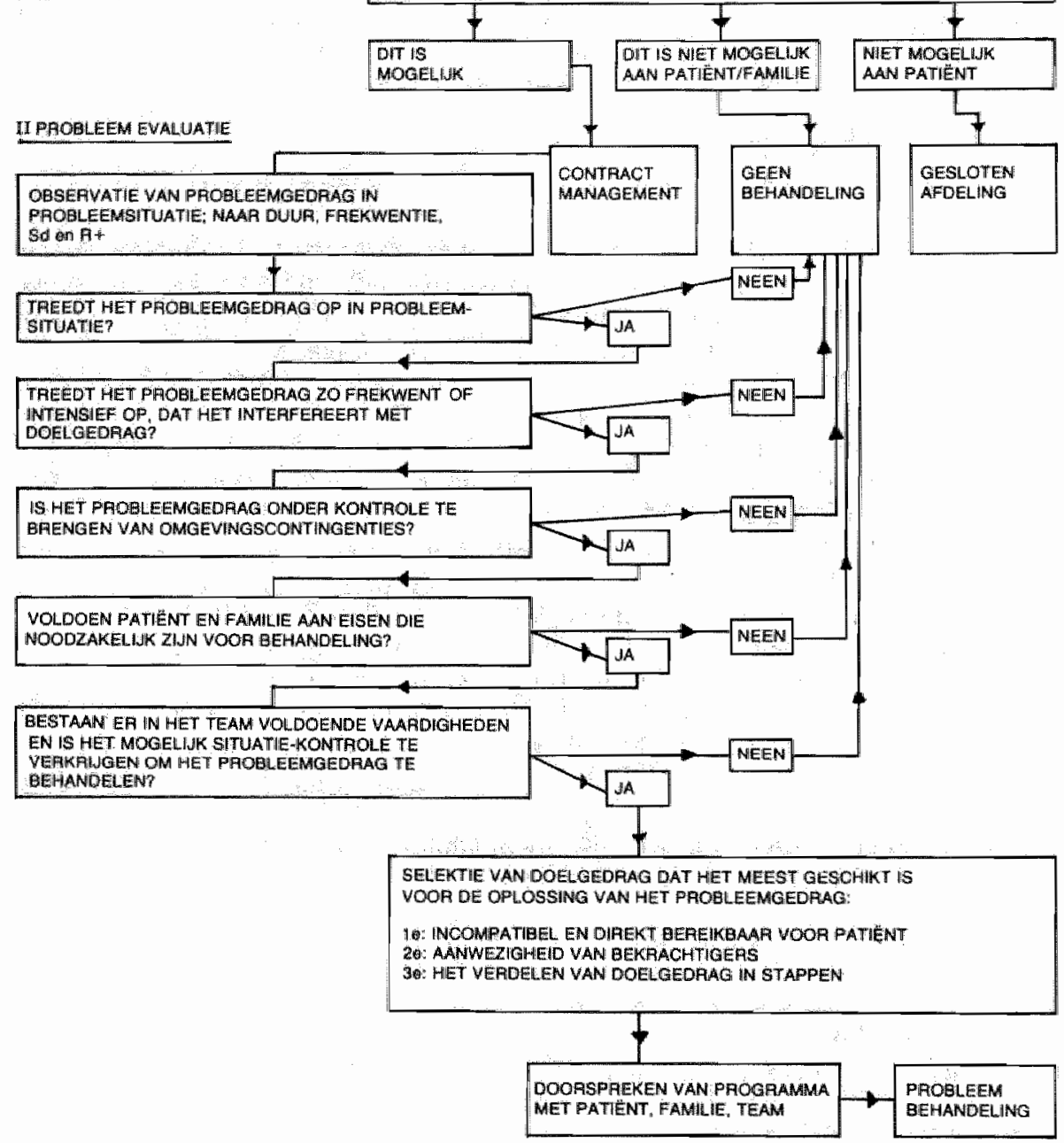




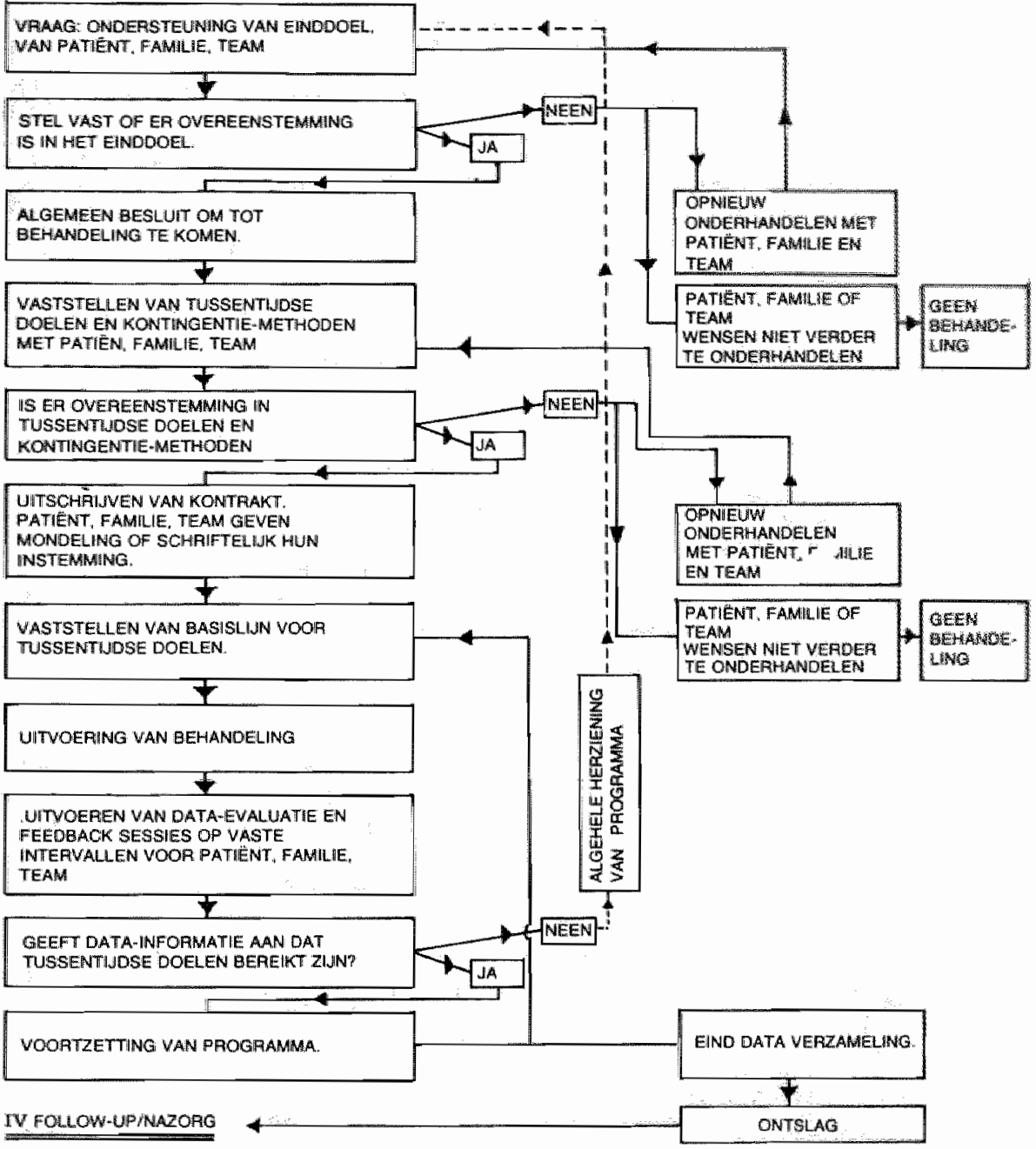

probleemgedrag $Y$ en een ander deel zich nog steeds richtte op probleemgedrag $X$. b. Het alternatieve, incompatibele gedrag kwam eveneens onvoldoende exact naar voren. Er ontbrak inzicht in diskriminatieve situaties en vaak waren onvoldoende bekrachtigende kondities aanwezig.

c. De medewerking van patiënt was in vele gevallen niet geheel duidelijk. Weliswaar werd de patiënt in vrijwel alle gevallen volledig geïnformeerd, maar het was vaak onzeker in hoeverre deze informatie werkelijk tot de patient doordrong.

d. Het thuismilieu werd in alle gevallen volledig geïnformeerd. Het was echter niet altijd duidelijk in hoeverre de familie inderdaad voldoende inzicht en steniciteit opbracht om daadwerkelijk met de behandeling mee te werken en deze thuis voort te zetten. 
e. Inzake de konsekwentie en konsistente werking wan het ,instrument" bestond grote onduidelijkheid.

All met al zou onder hantering van woorgaand beslissingsschema een anat malen niet met behandeling begonner zijn. Onder druk der omstandigheden, de anticipatie van een onantrekkeligk toekomst voor de patient en thuismillieu werd toch operante konditionering ondemomen. Achteraf bezien was deze behandeling door onduidelijke informatie, onzekerheid inzake de konsekwente toepassing e.d. echter soms bij woorbaat tot mislukking gedoemd. Herbij kwam nog dat het gehele behandelingsteam onder extra stress stond door de vele onzekerheden en de kritiek van andere personeelsleden die niet direkt bij de behandeling betrokken waren.

Tracht men hel gehele proces van gedragsreduktie objektief te analyseren dan komt men tot de volgende uitspraken:

1e. Een der doelstellingen wan revalidatie is nieuwe gedragsvorming.

2e. Deze nieuwe gedragsvorming kan bij een aantal patiènten belemmerd worden door gedrag dat door bepalde bekrachtigende kondities zo sterk aanwezig blifft dat niewwe gedragsvorming niet mogelijk wordt.

3e. Dit gedrag, dat nieuwe gedragsworming tegengaat, kan op zichzelf eveneens als "storend" door patient of omgeving worden ervaren.

4e. Men kan trachten dit gedrag te reduceren of te elimineren.

5e. Indien men eenmaal besluit dat revalidatie ook een taak heeft in reduktie wan dit storend gedrag, dan impliceert dit een aantal niet te onderschatten aktiviteiten.

Deze atktiviteiten worden veelal in revalidatiecentra niet ondernomen en als psychiatrische taken gezien. Vandaar dat revalidatiemedewerkers deze aktiviteiten koderen als psychiatrische interventie en vervolgers volstaan met verwijzing van de patiènten naar psychiatrische ziekenhuizen. Vanuit leertheoretische visie kan wellicht beter geen onderscheid worden gemakt tussen patienten volgens de medisch-specialist ische indeling. Een indeling vanuit gedragsgezichtspunt biedt een nieuw referentiekader daar, waar ook uit andere hoofde, de wenselijkheid van herindeling van kategorieèn patienten naar huidige specialismen wordt bepleit. Revalidatiecentra kunnen, gesteund door deze herindeling vanuit de leertheorie, pogingen ondernemen deze reduktie van gedragsbelemmeringen zelf ter hand te nemen. Indien tot laatstgenoemde keuze wordt overgegaan, betekent dit echter een aanzienlijke verzwaring en een herorièntatie inz:ke revalidatie. Deze heroriètatie kan alleen gerealiseerd worden door een speciasl team op een speciale afdeling of paviljoen. Deze keuze is volgens schrijver dezes de enige en enig juiste keuze. Het is een keuze met een duidelijke konsekwentie, $\mathrm{nl}$. het treffen van voorzieningen watardoor uitvoering van gedragsbehandelingsprogramma's mogelijk wordt: Een afdeling warin leertheoretische principes binnen de rewalidatie kunnen worden toegepast en geëvalueerd.

Op de ethische problematiek, verbonden met de toepassing wan gedragstherapeutische methoden in de hulpverlening en met name in een gedragstherapeutische afdeling, $k$ an hier niet worden ingegaan. De wetenschappelijke en beroepsethische discussie is gande sinds de opkomst van deze vorm van therapie. Zijzal zich dienen voprt te zetten in samenhang met die van andere geavanceerde therapievormen en wel afgestemd op het normen-en waardesysteem in de hulpverlening in het algemeen. Binmen het bestek van deze studie kan alleen verwezen worden naar. overigens uitstekende, diskussies en publikaties hieromtrent. Zie hiervoor o.a. Van Geel (1975), Fokkens (1976) en Krasner (1969). 


\subsubsection{Samenvatting}

Vanuit praktijkervaringen (hoofdstuk 3) en literatuurstudie (hoofdstuk 4) werd getracht een mogelijk toek omstperspektief ta.v. modifikatie van gedragstekorten en gedragsbelemmeringen te presenteren.

1e. De pagingen om gedragstekorten te herstellen werden in feite ontkoppeld aan de diverse theorievormingen inzake de relatie ,hersenen-gedrag". Nagegaan werd wat er in de praktijksituaties gebeurde wat betreft aktuele handelings. sekwenties. Deze bleken te herleiden tot:

a. Gedragsrestauratie

b. Gedragskompensatie

c. Gedragsorganisatie

Vanuit leertheoretische perspektief bleek de gedragsrestauratie verwezenlijkt te kunnen worden d.m.v. fading, toename van gedrag d.m.v. selektieve reinfor. cement en de vorming van nieuw gedrag door diverse shapingsprocedures.

De gedragskompensatie werd verwezenlijkt door diverse ,hulpmiddelen "., Ook ter gedragsreorganisatie bleken leertheoretische principes bruikbaar.

2e. Onder voorlopige afwezigheid van een betrouwbare taxonomie van funkties en systematische gedragsobservatieschalen lijkt een oplossing gezocht te kunnen worden in een integratie van funktierestauratie en vaardigheidstraining. Zowel de ontwikkeling van genoemde instrumenten alsook een voortgaande coördinatie van modifikatietechnieken behoeven uitgebreide research.

3e. De overwegingen inzake de pogingen tot reduktie van gedragsbelemmeringen bij fysiek gehandicapten leidden tot de konklusie dat hierin alleen voorzien kan worden door de formatie van een gedragstherapeutische unit apart van de traditionele revalidatiecentra echter wel witdrukkelijk gelieerd met een revalidatiecentrum.

\subsection{Conceptual frame work}

\subsubsection{Inleiding}

In hoofdstuk 2 werd vermeld dat het vooralsnog niet mogelijk bleek onder de toen geldende stand van kennis en praktijkerwaring een theoretisch model t.a.v. een revalidatie-leerproces te ontwikkelen. Er werd derhalve gewerkt met een experimenteel opgezette revalidatiestrategie. Dit experimentele mode» werd in hoordstuk 3 op zijn bruikbaarheid getoetst, zodat op deze wijze een redeljike hoeveelheid praktische informatie kon worden vergaard. In hoofdstuk 4 zorgde een literatuurstudie voor de noodzakelijke aanvulling. In de vorige paragrafen werd getracht de aansluiting tussen theorie en praktijk te formuleren.

Het lijkt op dit moment mogelijk vanuit een leertheoretisch referentiekader een theoretisch taamwerk te presenteren waabinnen de assessment en modifikatie van gedragstekorten en gedragsblokkades in de diverse kritemumsituaties op meer gesystematiseerde wijze zijn te plaatsen. Dit theoretisch raamwerk heeft, indien dit kan worden gerealiseerd, duidelijke praktische konsekwenties. Hoewel deze konsekwenties niet in detail geanticipeerd kunnen worden zullen wel enige denkbeelden hieromtrent worden gegeven.

Het is tenslotte niet slechts noodzakelijk wit te gaan van theorie en praktijk, maar het is eveneens een eis dat theorieen en werkwijzen worden getoetst. Omtrent research in het algemeen en ook inzake de toepassingen hiervan in de revalidatie vallen enkele gedachten te formuleren. 


\subsubsection{Praktische realiseringsmogelijk heden}

\subsubsection{Poging tot konkretisering van leermodel}

Ter konkretisering van een te realüseren revalidatieleerproces kunnen de volgende richtlijnen wellicht als leidraad fungeren.

\section{Observatie wan gedrag dat het anleren van wieuw gedrag belemmert}

Premorbide situatie (thuismillieu): Gegevens omtrent reeds vroeger bestaand probleemgedrag, mogelijk alternatieve gedragingen; bekrachtigende kondities; informatie inzake "modellen" en modelgedrag.

Klinische observatie: Gedragsobservatie d.m.v. geêigende schalen zoals de GOCC door speciaal hiertoe opgeleide medewerkers.

\section{Reduktie van gedragsobstakels}

Klimische simatie: Operante dekonditionering bij woorkeur d.m.v. kontraktmanage. ment. Noodzakelijke voorwaarden: adek wate patièntenselektie, medewerking door patient en thuismilieu en special hiertoe opgeleide medewerkers, aparte afdeling. Postopname situatie (thuismilieu): Voorzorgen treffen dat het probleemgedrag niet apnieuw optreedt in thuissituatie door dit milieu eveneens ander gedrag aan te leren wat betreft de interaktie met de patient. Reeds in de kliniek dienen de nodige maatregelen getroffen te worden ter realisering van een nazorg welke het gedrag van het thuismilieu en van de (ontslagen) patiënt ondersteund volgens gedragstherapeutische principes.

\section{Assessment van gedragstekorten}

Premorbide simatie (thuismilieu), klinische restsifuatie en klinische abservatiesituaie: Het verzamelen van gegevens inzake gedragstekorten volgens analyse van externe stimuluskonfiguraties naar inhoud, modaliteit en presentatiewijze.

Premorbide situatie: Vragenlijst die de interviewer een indruk geeft inzake schoolen werkprestaties in het hanteren van gedragsmatige, figurale, gesproken semantische, geschreven - semantische en symbolische stimuli.

Klimische tesisiruatie: Onderzoek naar gedragsregulatie en- organisatie. Hierbij is het onderzoek naar gedragsregulatie nog een te exploreren terrein waarbij de neurologische gegevens zijn aan te vullen met reaktie- en aandachtsproeven. Het onderzoek nar gedragsorganisatie kan op cognitief niweau nu reeds grotendeels uitgevoerd worden met kanaalspecifieke tests volgens de principes van Guilford. Inzake de gedragsorganisatie op "sensomotorisch niveau" staan verscheidene psychologische onderzoeksmethoden ter beschikking, ook al is op dit moment nog niet duidelijk in hoeverre deze overeenkomen met de taxonomie van Guilford. Binnen de testsituatie dient eveneens "limit testing" gerealiseerd te worden volgens de in deze studie verschafte (globale) richtlijnen.

Klinische obserwatiesimatie: Observatie van gedrag volgens gekontroleerde opdrachten. Op het moment dat deze studie wordt geschreven is de ontwikkeling van een dergelijke gedragsobserwatieschaal inzake gedragstekorten volgens voornoemde princupes gerealiseerd (in de vorm van de $\mathrm{zgn}$. VOS, vaardighedenobservatieschaal). Limit testing-procedures lijken in de klimische observatiesituaties minder genuanceerd wit te voeren dan in de klinische testsituatie.

Integratie wan gegevens uit lest- en obserwatiesimatie. 


\section{Het aanleren van nieuw gedrag}

\section{Integratie wan funktierestawatie en vaadigheidsfraining}

Funktierestauratie beoogt het aanleren van gedrag als respons op specifieke stimuli natar aanleiding van tekorten, gebleken tijdens de testkriteriumsituatie. In de testkriteriumsituatie werden deze gedragstekorten vastgesteld aan de hand van systematische exploratie d.m.w. kanaalspecifieke tests volgens het model Guilford. Hiernaast werden gegevens verkregen d.m.v. limit testing.

Het begrip "funkties" werd in 5.1.2.2. gedefinieerd. Funktierestauratie impliceert de poging het gekonstateerde deficiet in de "verwerking" van de stimuluskonfiguratie (naar inhoud, modaliteit) te verbeteren d.m.v. de leertheoretische principes: fading, toename van gedrag in frekwentie en intensiteil d.m.v. selektieve bekrachtiging en diverse shapingsprocedures.

In de praktijk blijkt nogal eens overlap op te treden tussen de aktiviteiten van de arbeidstherapeut, logopedist, fysiotherapeut, ergotherapeut en onderwijskracht. Via afstemming van de aktiviteiten van de diverse disciplines zal tot een gezamenlijke systematische modifikatie binnen deze funktierestauratie moeten worden gekomen.

Vaardigheidsvorming beoogt het aanleren van gedrag als respons op stimuli m.a.v. tekorten, gebleken in de klinische observatiesituatie.

Bovenstaande overwegingen gelden op dezelfde wijze voor de vaardigheidstrainig. Het begrip „vaardigheid" werd eveneens in 5.1.2.2. gedefinieerd. Met het ananleren van nieuw gedrag kan begonnen worden in de funktierestauratie (training in vitro) en dit kan worden voortgezet in de vaardigheidsvorming (in vivo-trainingssituatie). De mogelijkheden voor het variëren der trainingskondities lijken bij de vaardig. heidsvorming beperkter, echter de aansluiting met de realiteit is veel direkter. Eien afstemming van funktierestauratie op de waardigheidsvorming is hierbij essentieel.

\section{Taakassessment en modifikatie}

Nabehandelingssituate: Bij de voorbereiding tot de inschakeling in het arbeidsproces en vrijetijdsbesteding kan gebrük gemaakt worden van de gegevens zoals aangegeven onder $1 \mathrm{t} / \mathrm{m}$ 4. Het ligt voor de hand dat de voorbereiding tot de terugkeer in de maatschappij als complexe leefwereld logischerwijs zou kunnen en moeten gebruik maken van deze gegevens. Ter reduktie van excessief gedrag, zo belemmerend voor nieuwe gedragsvorming dient de moeizame poging tot aanleren van nieuw gedrag op een systematische wijze te worden voortgezet in dit intermediair tussen kliniek en maatschappij.

\section{Gedragsbeklijwing}

Postopname situatie: Door nauwkeurig voorbereide nazorg dient voorkomen te worden dat wederom probleemgedrag ontstaat en dat nieuwe gedragsvorming ongedaan wordt gemaakt. Terzake geinstrueerde professionele gedragstherapeuten maar ook non-professionele medehelpers kunnen hilerbij, ind uen althans voldoende gedragstherapeutisch getraind, goede hulpmogelijkheden bieden. Informatie aan hen vanuit het klinisch team gedurende de opname van patiënt is daarvoor uiteraard wel een vereiste. Na ontslag van patient dient een speciale deskundige (gedragstherapeut) zich exclusief te kunnen richten op de begeleiding van de nazorg werkers in hun voortgaande ondersteuning van patiënt en thuismilieu gedurende minimaal 6 maanden. Dit laatste verschaft eveneens mogelijkheden voor de zo noodzakelijke follow-up studies.

Voorzover dit uit het woortgaande nog niet duidelijk genoeg naar voren is gekomen 
dient iedere interventie begeleid te worden door hetzij probleem-, hetzij proces-, hetzil effektassessment of kombinaties hiervan, zoals in hoofdstuk 2 en 3 werd besproken. Bij het gehele revalidatieprogram van cerebraal gestoorde patiënten zal steeds, "het assessment-behandelingscircuit"gevolgd moeten worden.

Onder assessment wordt datarbij verstaan het vaststellen van een uitgangswaarde en een voortgaande meting hetzij tussentijds aan de hand van een modifikatieproces, hetzij aan het eind wan (een onderdeel) van het modifikatieproces. Assessment in deze zin wijst dus op een regelmatige meting, die vooruitgang of achteruitgang aangeeft.

Op basis van probleem, effekt- en procesassessment wordt vervolg van dezelfde behandelingsstrategie, wijziging in behandeling of beëindiging hiervan bepaald.

Dit assessmentbehandelingscircuit lijkt opgebouwd te zijn uit de volgende momenten:

$\mathrm{Na}$ het verzamelen van algemene gegevens d.m.w. observatie, meting, informatie:

1e. Specifieke of meer gerichte assessment (Probleem en/of effekt).

2e. Strategiebepaling aan de hand der assessment in teamoverleg.

3e Uitvoering van strategie onder voortgaande procesassessment.

4e. Elfekt-en/of probleemassessment.

5e. a. Bepaling van resultaat van strategie aan de hand van de diverse vormen van assessment, in de vorm van overleg.

b. Verdere strategiebepaling enz. enz.

Aangezien er nogal eens diverse typen behandelingen (herleidbaar tot interventies vanuit ziekte- en leermodel) dwars door elkaar of parallel aan elkaar verlopen, lijkt het nuttig een algemeen beeld te verschaffen inzake de diverse assessment behandelingscircuits, die vanuit het leermodel en ziektemodel kunnen optreden. Dit geeft wellicht mogelijkheden om tot een overzicht te komen inzake een relatief breed beeld der revalidatie-aktiviteiten.

\subsubsection{Poging tot integratie van ziekte- en leermodel}

In het voorgande werd een onderscheid gemaakt naar de diverse kriteriumsituaties waarin gedragsdeviaties (excessen en tekorten) konden worden vastgesteld. Het lijkt ook mogelijk een indeling te maken naar "fasen" waarin de diverse gedragsmodifikatiepogingen geplaatst kunnen worden. In het onderstaande schema is getracht deze te ordenen waarbij tevens de aktiviteiten vanuit het ziektemodel zijn geïntegreerd. De algemene en de specifieke asessment alsook de daarbij behorende strategieën zijn inhoudelijk verschillend wan elkaar. Het assessmentbehandelingscircuit is bij alle aanwezig.

De fasen warin getracht wordt tot het aanleren van nieuw gedrag te komen worden in volgend flow-diagram (fig. 10) weergegeven. Voor de verklarende tekst wordt verwezen naar pagina 222

Dit flow-diagram pretendeert niet meer dan een algemeen overzicht te geven inzake de aktiviteiten vanuit het ziekte- en het leermodel en uiteraard de diverse wissel werkingen hiertussen. Het spreekt vanzelr dat in een dergelijk beknopt schema niet de totaliteit van het complexe revalidatie-gebeuren kan worden samengevat. iedere aktiviteit, iedere assessment, modilikatie en onderlinge relatiewerking zal op zijn beurt verder moeten worden uitgewerkt. Het geïntegreerde funktioneren van ziekte-en leermodel zal aan de praktijk moeten worden getoetst. 
FISS TO FASEN-OVERTRCHT

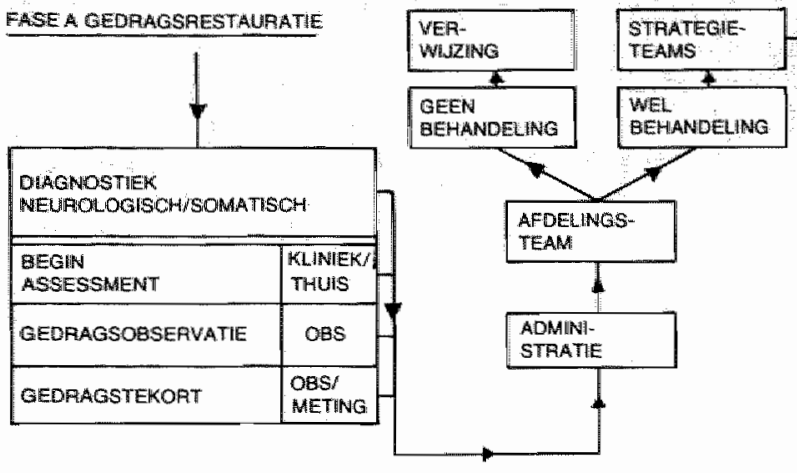

ASSESSMENT BEHANDEUING cincults

GEDRAGSMODIFIKATHE

KLINEKK THULS

GEDARAGSORMING

KKLINIIEK

\section{FASE G GEDRAGSHEAIORIENTATIE}

\begin{tabular}{|c|c|}
\hline \multicolumn{2}{|l|}{ DIAGNOSTIEK } \\
\hline $\begin{array}{l}\text { SOMATISCH } \\
\text { PESTDEFEKT }\end{array}$ & METTMG \\
\hline $\begin{array}{l}\text { NEUAROLOGHSOH } \\
\text { AESTDEFEKT }\end{array}$ & METING \\
\hline MATERIELLE VOORZ. & MNF. \\
\hline \multicolumn{2}{|l|}{$\begin{array}{l}\text { BEGIN } \\
\text { ASSESSMENT }\end{array}$} \\
\hline PROTHESE-GEORAG & OBS. \\
\hline ASSIHALATIE & GIBS. \\
\hline TAAKGEDAAG & $\begin{array}{l}\text { ALGEMEEN } \\
\text { B.K.A. }\end{array}$ \\
\hline
\end{tabular}

\section{MEDISCH}

SPEC GROEP

MAT VOORZ

MAT.VOOR

VOORZIENIIN-

GEN HULP.

MIDDEEILEN

MMDDEFLEN

AFOELLNGS.

TEAMM

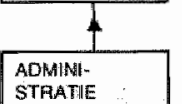

STRATEGIE TEAMS

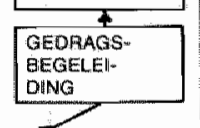

ASSESSMENT BEHANOELINO CHRCUITS

VESTIGING PUIOTHESE GEDAAG KLIINIEK/THUISS

ASSIMIILATIE VAN MAANNDICAP KRLINIEKRTHUIS

TAAK GEDRAG BEGELEIDING KLINIEK/THUIS/SCHODU/WERKK
FASE C. GEDRAGSBEKLIJWING

\begin{tabular}{|c|c|}
\hline \multicolumn{2}{|c|}{$\begin{array}{l}\text { DRAGNOSTIEK } \\
\text { HUISAATS IMEDISCH }\end{array}$} \\
\hline \multicolumn{2}{|c|}{$\begin{array}{l}\text { DEGIN ASSESSMENT THUIS } \\
\text { M.W. GEPREKODEERDE LUSTEN }\end{array}$} \\
\hline MAT" VOOAZ & $\mathbb{N} \mathbb{N F}_{0}$ \\
\hline $\begin{array}{l}\text { PFOTHESE } \\
\text { GEDRAG }\end{array}$ & obs: \\
\hline ASS瞳WLATLE & $\begin{array}{l}\text { MNAF J } \\
\text { OOSS. }\end{array}$ \\
\hline TAAKKSEORAG & INF: \\
\hline
\end{tabular}

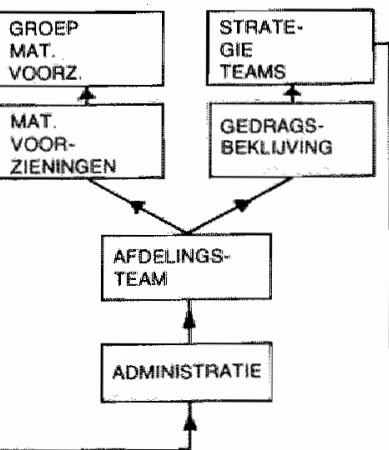

ASSESSMENT BEFHANDDEEINO OlFCults

NESTIGING PAOTHESE GEDHAO THUtS

ASSSMMLATE VAN HANDDICAP

THUIS

TAAK GEDRAG BEGELEIDINO THUUIS/SCHOOLWEPK

EVENTUUEP FASEA 


\section{A. Herstelfase of gedragsrestauratie}

In deze fase is de gedragsassessment en modifikatie gericht op:

1e. Vaststelling van gedragsobstakels en de verwijdering hiervan d.m.v. extinktie van probleemgedrag en de bekrachtiging van incompatibel gedrag.

2e. Vaststelling van gedragstekorten (vanuit premorbide situatie, testsituatie, klinische observatiesituatie) en het aanleren van nieuw gedrag d.m.v. gedragsvormende technieken.

3e. Ondersteunende informatie vanuit medisch-neurologische gegevens t.b.v. gedragsreduktie en het aanleren van nieuw gedrag.

\section{B. Gedragsheroriëntatie: kompensatie of reorganisatie}

In deze fase wordt vastgesteld welke restdefekten er zullen blijven bestaan, welke hulpmiddelen er moeten worden aangepast, welke medikatie er blijvend zal moeten worden verstrekt en welk. gedrag er in diverse opzichten moet ontstaan met of zonder hulpmiddelen. In deze fase dienen de nodige materiële en technische voorzieningen te worden getroffen. Gedragsassessment en - modifikatie zal in deze fase gericht zijn op:

1e. Vaststelling van de aard of soort der prothesen, nagaan van eventueel incompatibel prothesegedrag en de verwijdering hiervan.

2e. Vaststelling van de wijze waarop verwerking van het revalidatieprogramma optreedt en mogelijke ondersteuning hiervan d.m. $v$. medikatie en gedragstherapeutische technieken (cognitieve herstrukturering, verwerking van depressies enz.).

3e. Vaststelling welke beroeps-, omscholings-, vrijetijdsaktiviteiten mogelijk zijn en begelleiding van de eerste aanzet hiertoe in de nabehandelingsfase.

De strategieën zijn derhalve:

1e Vestiging van prothesegedrag en gereorganiseerd gedrag.

2e. Het ondersteunen van de assimilatie van de handicap.

3e. Begeleiding van taakgedrag.

\section{Gedragsbeklijving (nazorg)}

In deze fase moet ervoor gezorgd worden dat het nieuwe gedrag dat geleerd werd in fase A en B blijft voortbestaan en dat materiële voorzieningen gebruikt blijven worden.

De gedragsassessment en modifikatie is gericht op:

1e. Vaststelling van de gebruikmaking van hulpmiddelen in thuis- en werksituatie en eventuele ondersteuning van dit gebruik.

2e. Vaststelling in hoeverre de omscholings-, beroeps-, vrijetijdsaktiviteiten worden geeffektueerd. Verdere begeleiding hiervan, indien nodig.

\subsubsection{Research in de revalidatie}

\subsubsection{Algemene overwegingen.}

„Het invoeren van een nieuwe en hopelijk juiste strategie zal elk centrum, altijd met een welhaast onoplosbaar dilemma konfronteren: Enerzijds verplicht de dagelijkse praktijk patiënten met de ter beschikking staande middelen optimaal te behandelen, anderszijds vraagt wetenschappelijke benadering van de problematiek om grondig onderzoek, woorbereiding van personeel, betere of andere hulpmiddelen om met meer inzicht en een hechter fundament assessment en modifikatie te verbeteren. M.a.w. het onmisbare wetenschappelijke onderzoek komt in konflikt met de direkte 
praktische hulpverlening aan patiènten" (Te Riele H.F.W., ongepubliceerde nota), Men krijgt hier de neiging om aarzelend te zeggen: "Was het maar waar"! Was het maar waar, dat er inderdaad gesproken zou kunnen worden van een dergelijk konflikt want in dat geval zou er sprake zijn van gelijke tendenties. Bovenstaande uitspraak terecht waarschuwend bedoeld geeft de realiteit niet volledig weer. De research in psychiatrische centra, ziekenhuizen en revalidatie-instituten (met uitzondering misschien van akademische ziekenhuizen) lijdt een kommervol bestaan. Het is een hoge uitzondering indien hier sprake is van enig wetenschappelijk onderzoek om over een mogelijk konflikt tussen research en praktische gezondheidszorg maar niet te spreken. Dit is dè realiteit. Geldt deze stand van zaken al inzake biochemische, fysische en medische research in de niet-akademische gezondheidszorgcentra, research vanuit andere modellen zoals bijvoorbeeld psychologische research is nog zeldzamer. Het is zelfs zeer de vraag of deze ooit goed van de grond zal komen in centra die de direkte hulpverlening aan patiënten als een eerste doelstellingen in hun vaandel voeren.

Barendregt (1975) stelt niet voor niets dat de psychologen, andragogen, funktiepsychologen en verder alle mensen therapeuten worden. Hij bepleit het belang van research zijnde van grotere importantie dan de therapeutische vloedgolf die momenteel de patiënten lijkt te overspoelen.

Van Dam (1974) krijgt op zijn oproep om vooral research in het ziekenhuis niet te vergeten te horen, dat hij een tamboer-maitre is zonder korps (Benders 1974)

Raven (1966) spreekt over de moeilijke inpasbaarheid van die psychologen die rationeel trachten te werken, in het psychiatrische ziekenhuis.

Vanwaar deze moeizame - of beter - nauwelijks bestaande positie van de psycholoog, die tracht empirisch toetsend te werken in de individuele praktijk danwel in gezondheidszorg-instellingen?

Men kan ten aanzien hiervan slechts enkele opmerkingen maken:

1e. $\mathrm{Er}$ is onder psychologen nogal eens verschil van mening omtrent welke vorm van wetenschap er toegepast zou moeten worden op psychische fenomenen. De wetenschappelijke cyclus zoals De Groot (1966 p. $29 \mathrm{t} / \mathrm{m}$ 36) deze beschrijft zou niet altijd toepasbaar zijn.

2e. Niet alle psychologen huldigen het standpunt dat psychologie een wetenschap zou moeten zijn. Men zou minimaal een onderscheid moeten maken tussen "metende, objektiverende psychologie" en de "verstehende psychologie".

3e. Naast deze algemene verdeeldheid die het vormen van een meer gecoördineerde pressure group in vele opzichten onmogelijk maakt, bestatat er de indruk dat de mogelijkheden tat het verrichten van onderzoek erg klein zijn.

Het moeizaam doorploegen van moeilijke literatuur moet veelal in de vrije tijd geschieden. Het aantal personen (ook niet psychologen) dat eigen vakliteratuur bijhoudt (zonder daaraan gekoppelde research) uit de behoefte om binnen eigen vak op de hoogte te blijven, lijkt niet groot. Research veronderstelt eigenlijk veel meer of beter, iets anders $\mathrm{nl}$. dat men op een beperkt terrein gedurende een korte tijd tot nieuwe gedachtenvorming komt op basis van tamelijk geavanceerde publikaties.

Indien het bijhouden van eigen vakliteratuur door wat voor omstandigheden dan ook niet mogelijk is, dan lijkt een literatuurstudie als basis op voorbereiding tot research een utopie.

4e. Niet alleen de mogelijkheden zijn beperkt, maar ook de behoefte tot onderzoek lijkt niet indrukwekkend groot te zijn.

Vanuit leertheoretisch standpunt zou men de vraag kunnen stellen of het bezig zijn met de patiênt, het houden van lezingen, het mogen deelnemen aan 
belangrijke stafvergaderingen, besprekingen ete, wellicht een aantrek kelijker bekrachtigingsschema inhoudt dan het eenzaam zitten op de kamer met als enige gesprekspartners een aantal auteurs en een onzekere bekrachtiging over enkele jaren.

Se. Een psycholoog die nastreeft in een praktijksituatie zo rationeel mogelijk te werken ondervind allerle" weerstanden in zijn omgeving: Over het algemeen lijkt men onvoldoende doordrongen van het belang van een optimale opzet van het onderzoek, voorzover men al doordrongen is van de noodzaak tot onderzoek op zich. Naast de eerder genoemde oppositie wanuit alternatieve ,psychologieën", alternatieve ,wetenschappen ", allerlei ethische overwegingen inzake het dehumaniserende van een onderzoek krijgt men ook nog eens te maken met de moeilijke samenstelling van experimentele en kontrolegroepen, de medewerking van het personeel, het konstant houden van een strategie enz. enz, waarbij het uiteindelijk de wraag wordt wat men door al deze alternatieve invloeden en de moeizame konstruktie van een elementair onderzoek, nog wel meent te kunnen meten.

6e. Het bepleiten en stimuleren van onderzoek lijkt totaal overbodig in die situaties waar gesteld wordt dat men op , wetenschappelijke" wijze werkt. Nog afgezien van de mogelijkheid dat men aan versleten routine doet is in de (geestelijke) gezondheidszorg met zijn steeds fluctuerende probleemgebieden en steeds vernieuwende methodieken en visies een kritische, objektieve en kwantitatieve evaluatie en hieruit voortvloeiende bijsturing een blijvende noodzaak.

Bovenstaande overwegingen kunnen in dezelfde of andere vorm in diverse publikaties worden aangetroffen. Ze z̈jn voor een deel herleidbaar tot de algemene gedachtengang dat naast, overigens waardevolle, vernieuwende denkbeelden en praktijktoepassingen plaats geboden moet worden aan een rationele inbreng in een organisatie.

Rationele inbreng in een organisatie kan echter alleen maar enigszins gerealiseerd worden, indien de organisatie als geheel gemotiveerd is voor rationallisatie: dat wil zeggen dat de individuen, die tot de organisatie behoren, allen minstens het belang inzien van meer systematische, op toetsing gerichte, meer produktieve, meer efficiënte, meer rendabele wijze van werken. Het belang inzien is echter niet voldoende, maar het is wel een begin. Deze inzichtsverandering zal gevolgd moeten worden door een wijze van denken en handelen, waardoor er een gunstig klimaat ontstaat en praktijkvernieuwing, theorievorming en research tot de mogelijkheden gaan behoren.

\subsubsection{Nabeschouwing}

Het tot stand komen van deze studie binnen het Revalidatie Centrum "Hoensbroeck " toont aan dat het in principe wel degelijk mogelijk is in revalidatie instituten het vereiste rationele denk- en werk klimaat te kreëren nodig voor de uitvoering van revalidatieresearch. Of deze mogelijkheid in andere revalidatiecentra in den lande bestatat, valt uiteraard iets moeilijker vast te stellen. De belangstelling welke ondervonden werd tijdens de colloquia-serie „cerebrale traumata" 1975/1976, doet echter veronderstellen dat een bereidheid hiertoe zowel bij revalidatie-artsen, -psychologen en paramedisch personeel aanwezig is.

Deze veronderstelling wettigt het standpunt dat het mogelijk moet zijn deze studie in zijn kwetsbaarheid, in vertrouwen ter diskussie te stellen.

Vanuit de presentatie der leertheorie en de problematiek aangeboden vanuit de patient met contusio cerebri werd de vraag gesteld of leertheoretische principes een antwoord zouden kunnen bieden, dat zou bijdragen tot de oplossing van gedragste- 
korten en excessief gedrag. De algemene konklusie van dit betoog is dat dit inderdaad, onder zekere dringende voorwaarden, tot de mogelijkheden behoort.

Tegelijkertijd zijn er echter opnieuw vragen gesteld die beantwoord dienen te worden, aleer verdere vooruitgang te realiseren is. Voortgaande research zal het mogellijk maken dat de hier geformuleerde ideeën kunnen worden bijgesteld. De relatie tussen theorie en praktijk die alleen in het revalidatiecentrum gelegd kan worden, zal er toe bijdragen dat ideeên inzake assessment en modifikatie ook doorwerken in een beter gekonkretiseerde hulpverlening. Uiteindelijk zullen wellicht hulpverlener en gezondheidszorg, dankzij de erkenning en akseptatie van het leermodel naast het ziektemodel, ervaren dat het wel degelijk mogelijk is om patiënten die tot voorheen als onbehandelbaar werden afgeschreven toch tot op redelijke hoogte te revalideren.

En hier was het uiteindelijk om begonnen.

\subsubsection{Samenvatting}

In deze paragraaf werd aangegeven welke konsekwenties de realisering van het theoretische framework in praktisch opzicht zou hebben, indien hierbij bovendien leer-en ziektemodel zouden worden geïntegreerd.

Vervolgens werd ingegaan op de moeilijkheden inzake research in een praktisch hulpverlenende setting, waarbij echter toch de noodzaak van wetenschappelijk onderzoek werd beklemtoond.

De studie besluit met de hoop uit te spreken, dat zowel patiënt, hulpverlener en gezondheidszorg het belang zullen gaan ervaren van de wisselwerking tussen het ziekte- en het leermodel in de revalidatie. 
HOOFDSTUK 6

Algemene Samenvattingen 


\subsection{Summary}

This study represents the result of an experience gained in a rehabilitation centre over a period of about 5 years. This experience centered around patients suffering from brain damage, concentrating particularly on those with contusio cerebri. In these five years a meeting took place between staff concerned with clinical psychology on the one hand and rehabilitation staff on the other hand. Experts in clinical psychology had to conclude that because of its still short development phase the rehabilitation process suffers from many limitations, but offers at the same time many possibilities. To these possibilities belongs also the development and application of achievements in the field of learning theories. In order to achieve this, one needs an interdisciplinary approach, since one is confronted with the exceptionally multi-faceted task of having to provide an answer or part-answer concerning the treatment of patients with brain contusion.

The development of learning theory concepts with regard to theoretical and working models in the treatment of the brain injured, was set out as follows:

Chapter 1 contains as introduction an overview of the situation which gave rise to the present study. Based on the idea that at least a section of rehabilitation is concerned with "behaviour modification" and consequently with "learning", this "relearning of behaviour" is seen as one of the vital elements of rehabilitation. In dealing with learning principles as they are applied in the field of rehabilitation, a basic knowledge of learning theory becomes a pre-requisite. Discussed is how different learning paradigms are applied in rehabilitation, though in a concrete situation and on pragmatic grounds preference is given to the operant learning paradigm as explanatory and treatment model. This perspective is used to examine up to what extent the various stages of the rehabilitation process may not only be examined but also explained with the aid of the operant learning paradigm. The first chapter ends with the conclusions which can be drawn from this learning paradigm; conclusions with regard to the practical application of rehabilitative action in general up to and including the so-called "rehabilitation learning model."

After dealing with the introduction of learning theory in rehabilitation, Chapter 2 turns to the group of patients suffering from brain contusion. An analysis is made as to what extent it is possible to define more precisely the problems of these patients laking a behavioural structure as baseline. On the basis of information regarding the "status", a decision is made as to what statements are made by team members to describe the behaviour of patients. This content analysis in describing the status leads us to differentiate between:

A. Behaviour deficits, ascertained by means of a standardized test situation, but also with the aid of non-structured behaviour monitoring. This is generally the behaviour to which - seen from the rehabilitation standpoint - the various behaviour training programmes orient themselves. An attempt is made to remove or compensate behaviour deficits.

B. Excessive behaviour, in short called "behavioural obstacles", which hampers efforts at behaviour modification or behaviour compensation. In general, one has to do here with a type of behaviour which in the long term can lead to a discharge from the rehabilitation centre. In such a case the patient is often considered as incapable of being rehabilitated. 
Assessment procedures are developed for both types of behavioural deviations:

1. The combination of a series of psychological examination methods (tests) in order to measure at least part of the different behaviour deficits.

2. The setting up of a temporary assessment scale to show up especially behavioural obstacles: the behaviour monitoring scale in the case of patients with brain contusions, abbreviated to $\mathrm{GOCC}$ (Gedragsobservatieschaal van Contusio Cerebri).

Also in the case of learning theory one differentiates between excessive behaviour and behaviour deficits, so that theory and practice can be joined together. The distinction between excessive behaviour and behaviour deficits is, thus, backed up not only by theory but also by praxis.

As far as excessive behaviour is concerned, the learning theory offers the method in the form of differential reinforcement aimed at reducing the problem behaviour. As far as behaviour deficits are concerned, the learning theory mentions three methods whose aim it is to achieve a new or improved behaviour repertoir. These are: a selective reinforcement concerning the increase of an already existent behaviour, shaping procedures for forming a totally new behaviour, and fading for maintaining the behaviour while increasing the stimulus complexity.

The common aim of all these procedures is the extinction of inadequate behaviour and the reinforcement of desired behaviour.

The developed assessment procedures and corresponding modification techniques borrowed from the learning theory form together the "temporary rehabilitation strategy". Although in the present study this temporary rehabilitation strategy refers only to the clinical phase, it must be pointed out that ideally the home environment should definitely play a part in the treatment. In order to achieve an effective integration and a consolidation of the new, acquired or reduced behaviour these strategies, moreover, should not be restricted to the clinical stage, but should be continued and supplemented in the home environment.

The theoretical construction of this multiple approach seems to be applicable not only in the case of patients with brain traumas. There is the possibility that such a theoretical construction could be an effective model in other fields and for other groups of patients in rehabilitation.

The temporary rehabilitation strategy described is a starting point for the development and realisation of different rehabilitation programmes. In order to test these programmes by empirical means, chapter 3 deals first of all with an experimental method for carrying out and evaluating of this rehabilitation strategy. Since we are dealing here with an experimental strategy with possibly far reaching consequences for later developments, special attention must be paid to the assessment. The extinction of excessive behaviour and the build-up of a new behaviour are subjected to a triple assessment:

1. Problem assessment which orients itself to the problem behaviour and the possible increase or decrease thereof, and where the situation prior and after treatment is examined.

2. Result assessment which is formed by means of scores achieved according to the behaviour monitoring scale and the psychological examination compiled, preand post-treatment.

3. Process assessment which orients itself to the target behaviour, frequently at behaviour which is incompatible with the problem behaviour: the scores reached are obtained by means of an almost constant monitoring and recording during treatment. 
Since an important part of the assessment procedure is based on the $\mathrm{COCC}$, the scalle undergoes a statistical analysis in order to ascertain the reliability of evaluations made by different people involved in the case. Based on the results obtained, one can say that as far as the item compilation and the construction of the scale are concerned, the GOCC is quite a reliable measurement instrument as behaviour monitoring scale for the assessment of behaviour deviations in patients with contusio cerebri.

The ewaluation of behaviour modifications takes its cue mainly from the results obtained by the techniques for the reduction of excessive behaviour, the build-up of new behaviour, and the increase of already existing behaviour. The importance of the testing of these techniques, however, is reduced due to the absence of a control group; in addition, it was not possible to form the experimental group according to the randomisation principle. The problem behaviour consisting of excessive behaviour, non-existent behaviour, and the low intensity of existent behaviour is reduced by a good $85 \%$ in treated patients in relation to the initial value. The target behaviour consisting in the reduction of excessive behaviour, the build-up of new behaviour, and the increase in the intensity of existent behaviour is reached by the majority of patients in approximately 6 weeks. The result assessment reveals, with the use of the methods described, no change in the scores according to the psychological examination. In contrast, the GOCC scores reveal a significant improvement when comparing them before and after treatment.

The evaluation of behaviour modifications which orient themselves to the maintenance of bethaviours under an increasing stimulus complexity is to be given particular relevance, since in the case of such a strategy it was possible to form an experimental and a control group. However, also in this case it proved impossible to form the experimental and the control group according to the randomisation principle. The problem behaviour of the two groups consists of considerable memory and concentration disturbances which were ascertained by means of the psychological testing procedures compiled. The treatment of the experimental group extended over a period of about 6 months. The treatment itself consisted of stimuli presented in ever increasing complexity. This approach can be traced back to the "fading" principle of learning theory, in which the gradual reduction of stimulus facilitation plays the main role. The retention of a corresponding memory and/or concentration response under an increasing stimulus complexity could then be attributed to an improvement in memory and/or concentration behaviour during training situations. The control group consisted of patients who displayed unmistakable memory and/or concentration disturbances one month prior to their discharge. This group was called back five months after discharge for a repeat examination. The general conclusion that can be drawn from the examination is that the test performances with regard to memory and concentration showed a considerable improvement due to the training described in this study compared to people who had not been subjected to such training. A reply to the question whether "the memory" and "the concentration" are being influenced also in a positive sense outside a test situation requires further examination.

After testing the application of principles of learning theory in the treatment of patients with contusio cerebri, Chapter 4 deals with analysis of literature to determine the next steps. Although it was first attempted to limit the collection of unformation to patients suffering from brain contusion, it soon transpired that there was a paucity of publications which dealt with this category of patients. For this reason the literature analysis was enlarged to cover several categories of patients 
whith brain damage such as patients with a left or right hemiplegia, a combination of these, minimal brain damage, cerebral palsy patients, and the mentally retarded. Arguments are advanced which justify the inclusion of such mixed groups of patients. The premise is that of a wehaviour therapy type $e^{\mathrm{n}}$, and from this perspective approaches and modification possibilities are examined which literature offers patients suffering from behaviour deviations caused by brain damage independently of whether such a damage is congenital or was acquired at a later stage. The results of this new orientation may be summarized as follows:

1. Several authors underline the necessity of analysing behaviour deficits under different conditions such as the premorbid, clinical, after-care situation, and the home environmental situation. The study of behaviour deficits under clinical conditions should be carried out basically according to two procedures, that is to say by means of standardized test procedures and behaviour monitoring scales. Various models are compared not only in the case of test procedures but also in the case of behaviour monitoring. As far as the clinical test situation is concerned, the "Structure of Intellect of Guilford" has the greatest support. As

far as behaviour monitoring is concerned, the .Progress Assessment Chart of Gumzberg" seems to offer the more favourable prospectives.

2. In order to obtain an impression of the studies on "behavioural disorders" "the monitoring criteria of several authors are compared with each other and with the behaviour monitoring scale (GOCC) developed for this study. The result was that the GOCC does most justice to the problem behaviour of patients with a contusio cerebri and those with other cerebral damage.

3. Conditioning principles of learning theory and especially operant conditioning principles can be found in a number of publications dealing with efforts to modify behaviour deficits. It can be seen that these principles are used by representatives of different disciplines always under different names and in various combinations.

4. Finally, the most important finding may lie therein that exireme, unwanted behaviour which impedes a behaviour build-up cannot or can hardly be reduced or extinguished in the rehabilitation centres of today. However, based on results from abroad we know that it is quite possible to reduce such excessive behaviour even if only with the use of specially trained staff and in institutions with special facilities.

In Chapter 5 an attempt is made at combining the information extracted from the analysis of literature with the practical experience obtained. If one ignores in the practical situations for the time being the theoretical obstacle with regard to the relation "brain-behaviour" without, though, falling to orientate oneself to the "input-output" relation - in expectation of further developments in this field -, it is possible to detect the beginnings of a clearly defined approach to assessment. By attempting to specify more clearly the stimulus situation and the resulting response through behaviour monitoring scales, in combination with standardized test procedures, it is possible to obtain information on complex behaviour and simple behaviour related thereto. This approach opens up the possibility of analysing determined behaviour deficits from two different perspectives co-ordinated with each other. Moreover, this method appears to offer possibilities for badly needed research in this field.

Practical experience and the literature analysis showed that there exists a similar situation with regard to the question of modification. It has been proved that the attempt at balancing behaviour deficits can be separated from the various 
theoretical constructions with regard to the relation ,brain-behawiour". In examining what is happening in practice with regard to current action sequences, the latter can be attributed to behaviour reestablishment, behaviour compensation and behaviour reorganization.

The aim of this study is basically the concretisation of the rehabilitation learning process. By a rehabilitation learning process it is meant, in fact, that the medical and paramedical work need not lose its vallue but that there are just as many possibilities open in onder to include also "learning", with its many aspects, in the comprehensive rehabilitation activities. It must be pointed out at this point that it is not always to be taken for granted that a person learns. Learning is an implicit rehabilitation pre-tequilsite which makes it necessary to pay particular attention to circumstances promoting the learning of new behaviour. In patients with learning inhibitions the efforts should be concentrated on the reduction of behaviour disturbances. If this cannot or cannot adequately be done in a rehabilitation centre, alternatives to implement these methods should be sought outside the centre. After reducing excessive behaviour an attempt can be undertaken to build up a new behaviour at the rehabilitation centre. The permanent interaction and integration between the so-called "disease model" and the "learning model" should and could be given a chance in the rehabilitation learning process. In order to concretize this, particular attention is given in the last part of Chapter 5 to the application of "medical learning models" in the practice of the rehabilitation centre. A rehabilitation centre lends itself ideally to the amalgamation of theory and practice in this field.

Learning theory and behaviour therapeutic practice supplement and support the conventional work of rehabilitation medicine, and offer, in addition, rehabilitation possibilities to a considerable number of patients suffering from cerebral damage and probably also to those patients suffering from behaviour disorders who up to now were considered unfit for rehabilitation.

The aim of this study was to contribute to developments leading in this direction. 


\subsection{Zusammenfassung}

Diese Studie ist das Ergebnis einer etwa funfjährigen Erfahrung innerhalb eines Rehabilitationszentrums, in deren Mittelpunkt die Bemülangen um Patienten mit Hirnschädigungen, insbesondere um Patienten mit Hirnquetschungen standen. In diesen fünf Jahren fand eine Begegnung zwischen Mitarbeitern der klinischen Psychologie einerseits und der Rehabilitation andererseits statt. Die Fachleute der klinischen Psychologie mußten dabei feststellen, daß das Rehabilitationsgeschehen wegen seiner noch kurzen Entwicklungsphase micht nur vielen Einschränkungen unterliegt, sondern auch viele Möglichkeiten bietet. Zu diesen Möglichkeiten gehört die Entwicklung und Anwendung lerntheoretischer Errungenschaften. Dazu ist die Zusammenarbeit vieler Disziplinen erforderlich, die mit der außerordentlich vielschichtigen Aufgabe konfrontiert werden, eine Antwort oder Teilantwort in Bezug auf die Behandlung won Patienten mit einer Hirnquetschung zu geben.

Die Entwicklung lerntheoretischer Ideen zu Denk- und Arbeitsmodellen zur Behandlung von Hirngeschädigten wurde wie folgt wiedergegeben:

In Kapitel 1 wird als Einführung eine Übersicht über die Situation, woraus die vorliegende Studie entstehen konnte, gegeben. Aufgrund der Idee, daß wenigstens ein Teil der Rehabilitation "Verhaltensänderung" und deshalb ..Lernen" beinhaltet, wird dieses „erneutes Lernen von Verhalten” als einer der wesentlichen Elemente der Rehabilitation betrachtet. Bei der Behandlung yon Lerngrundsätzen in ihrer Anwendung im Rehabilitationsbereich werden Grundkenntnisse über die Lerntheorie vorausgesetzt. Dargestellt wird wie verschiedene Lernparadigmen in der Rehabilitation anwendbar sind, aber da $\beta$ in der konkreten Situation, auch aus pragmatischen Gründen das operante Lemparadigma bevorzugı wird, als Erklärungs- und Behandl ungsmodell. Aus dieser Perspektive wird untersucht, inwiefern die verschiedenen Phasen im Rehabilitationsablauf gleichfalls mit Hille des operanten Lernpardigmas untersucht und erklärt werden können. Das erste Kapitel wird mit den Schlußfolgerungen, die aus diesem Lernparadigma gezogen werden, beendet; Schlußfolgerungen in Bezug auf die praktischen Anwendungen des rehabilitativen Handelns im allgemeinen bis zum sogenannten "RehabilitationsLermmodell".

Nach der Einführung der Lerntheorie in die Rehabilitation befaßt sich Kapitel 2 mit den Patienten mit einer Hirnquetschung. Es wird untersucht, inwieweit es möglich ist, die Problematik dieser Patientengruppe - ausgehend won einem Verhaltensrahmen - näher zu präzisieren. Aufgrund von Informationen über den „Status” wird restgestellt, welche Aussagen durch die Teammitglieder gemacht werden, um das Verhatten der Patienten zu beschreiben. Diese Inhaltsanalyse bei der Statusbeschreibung führt zur Unterscheidung in:

A. Verhaltensdefizite, festgestellt in einer standardisierten Testsituation, aber auch mit Hilfe nichtstrukturierter Verhaltensbeobachtungen. Im allgemeinen ist dies das Verhalten, an dem sich - vom rehabilitativen Standpunkt aus gesehen - die verschiedenen Verhaltenstrainingsprogramme orientieren. Es wird versucht, die Verhaltensdefizite auszuräumen oder zu kompensieren.

B. Exzessives Verhalten, das diese Bemühungen zu Verhaltensänderungen oder Verhaltenskompensationen behindert, kurz "Verhaltensbehinderungen" genannt. Im allgemeinen handelt es sich dabei um jenes Verhalten, das längerfristig zu einer Entlassung aus dem Rehabilitationszentrum führt, wobei der Patient dann oft als nicht rehabilitationsfähig bezeichnet wird. 
Für beide Arten von Verhaltensabweichungen weiden Bewertungsverfahren entwickell:

1. Die Zuismmenfassung einer Reihe psychologischer Untersuchungsverfahren (Tests), um wenigstens ein Teil der verschiedenen Verhaltensdefizite zu messen.

2. Die Konstruktion einer vorläufigen Bewertungsskala, die vor allem Verhaltensbehinderungen signalisieren soll: die Verhattensbeobachtungsskala bei Patienten mit Hirnquetschungen, abgekurzt GOCC genannt (= Gedragsobservatieschaal wan (Contusio Cerebri).

Auch in der Lerntheorie wird ein Unterschied zwischen exzessivem Verhalten und Verhaltensdefiziten gemacht, so daß Theorie und Praxis miteinander verbunden Werden können. Die Unterscheidung zwischen exzessivem Verhalten und Verhaltersdefiziten wird also sowohl durch die Theorie, als auch durch die Praxis unterstützt.

In Bezug auf das exzessive Verhalten bietet die Lerntheorie die Methodik der differentiellen Verstärkung zur Abschwächung des Problemverhaltens. In Bezug auf Verhaltensdefizite nennt die Lerntheorie drei Methoden, die alle die Verwirklichung eines neuen oder besseren Verhaltensrepertoire zum Ziel haben, und zwar die selektive Verstarkung bezüglich der Zunahme eines bereits vorhandenen Verhaltens, „shapings" - Verfahren zum Aufbau eines grundlegend neuen Verhaltens und "fading" zur Beibehaltung des Verhaltens unter zunehmender Reizkomplexi. tait.

Allen Verfahren gemeinsam ist die Beseitigung unangemessenen Verthaltens und die Verstârkung des gewünschten Verhaltens.

Die entwickelten Vorgehensweisen und die der Lerntheorie entnommenen entsprechenden Modifkationstechniken bilden zusammen die ,vorläufige Rehabilitationsstrategie". Obwohl sich diese worlaufige Rehabilitationsstrategie in der vor liegenden Studie nur auf die klinische Phase bezieht, nuß betont werden, da 3 im Idealfall die hausliche Umgebung ausdrücklich an der Behandlung teilhaben sollte. Um eine gute Integration und die Konsolidierung des newer, gelernten oder reduzierten Verhaltens zu erreichen, sollten diese Strategien auBerdem nicht auf die klinische Phase beschränkt bleiben, sondern in der häuslichen Umgebung weitergeführt und ergänzt werden.

Die theoretische Konstruktion dieser mehrfachen Vorgehensweise scheint nicht nur für Hirntraumatiker anwendbar. Die Möglichkeit, daß sie Modellwirkung für weitere Bereiche und andere Patientenkreise in der Rehabilitation haben könnte, scheint durchaus gegeben zu seim.

Die dargestellte vorläufge Rehabilitationsstrategie bietet Ansätze zur Entwicklung und Realisierung verschiedener Rehablitationsprogramme. Um diese Programme empirisch zu erproben, behandelt Kapitel 3 zunächst die experimentelle Methode zur Ausfuhrung und Evaluierung dieser Rehabilitationsstrategie. Da es sich hier uri eine experimentelle Strategie mit möglicherweise weütreichenden Konsequenzen für spatere Entwicklungen handelt, ist der Evalunierung besondere Aufmerksamkeit gewidmet. Sowohl die Reduzierung exzessiven Verhaltens, als auch der Aufban neten Verhaltens werden einer dreffachen Bewertung unterzogen:

1. Problembewertung, die sich am Problemverhalten und der eventuellen $\mathrm{Zu}$ - oder Abnahme dieses Verhaltens orientiert, wobei die Situation vor und nach der Behandiung untersucht wird.

2. Ergebnisbewertung, die durch die erreichten Punktzahlen nach der entwickelten Verhaltensbeobachtungsskala und die zusammengestellte psychologische Untersuchung gebildet wird, - vor und nach der Behandlung. 
3. ProzeBbewertung, die sich am Zielverhalten oriantiert, oft jenes Verhalten, das nicht mit dem Problemverhalten kompatibel ist, wobei die erreichten Punktzahlen durch eine nahezu permanente Beobachtung und Registrierung wahrend der Behandlung zustande kommen.

Da ein wichtiger Teil des Bewertungsverfahrens auf der $\mathrm{OOCC}$ basiert, wird diese Skala einer statistischen Bearbeitung unterzogen, um die Zuverlassigkeit von Wertungen der verschiedenen Personen zu bestimmen, die mit dieser Aufgabe befaßt sind. Aufgrund der Ergebnisse kann festgestellt werden daB die GOCC als Verhaltensbeobachtungsskala sowohl was die Itemzusammenstellung, als auch die Konstruktion der Skala angeht ein ziemlich zuverlässiges Meßinstrument darstell um Verhaltensabweichungen bei Patienten mit Hirnquetschungen zu bewerten. Die Evaluierung der Verhaltensmodifikationen orientiert sich hauptsächlich am Ergebnis der Techniken zur Reduzierung exzessiven Verhaltens, dem Aufbau neuen Verhaltens und der Zunahme bereits vorhandenen Verhaltens. Die Bedeutung der Erprobung dieser Techniken wird durch das Fehlen einer Kontrollgruppe jedoch etwas geschmälert, außerdem konnte die experimentelle Gruppe nicht nach den Randomisierungsprinzipien zusammengestellt werden. Das Problemverhalten, bestehend aus exzessivem Verhalten, nicht vorhandenem Verhalten und der niedrigen Intensität vorhandenen Verhaltens nimmt bei den behandelten Patienten um rund $85 \% \mathrm{im}$ Verhältnis zum Ausgangswert ab. Das Zielverhalten, bestehend aus der Reduzierung exzessiven Verhaltens, dem Aufbau neuen Verhaltens und der Zunahme der Intensität bestehenden Verhaltens, wird bei der Mehrzahl der Patienten in etwa 6 Wochen erreicht. Die Ergebnisuntersuchung ergibt bei den genamnten Methoden keine Änderung der Punktzahlen bei der psychologischen Untersuchung. Die Punktzahlen nach der GOCC zeigen jedoch eine spürbare Verbesserung, wenn man sie vor und nach der Behandlung vergleicht.

Die Evaluierung der Verhaltensmodifikationen, die sich an der Beibehaltung des Verhaltens unter zunehmender Reizkomplexitat orientieren, soll besonders dargestellt werden, da es bei dieser Strategie wohl möglich war, eine experimentelle und eine Kontrollgruppe zu bilden. Aber auch in diesem Falle konnte wowoll die experimentelle, als auch die Kontrollgruppe nicht nach den Randomisierungsprinzipien zusammengestellt werden. Das Problemverhalten besteht bei beiden Gruppen aus erheblichen Gedächtnis- und Konzentrationsstörungen, die mit Hilfe der zusammengestellten psychologischen Untersuchungsverfahren festgestellt wurden. Die Behandlungsdauer der experimentellen Gruppe umfaßte etwa 6 Monate. Die Behandlung selbst bestand aus einem Reizangebot in zunehmender Komplexitat. Diese Vorgehensweise kann auf das lerntheoretische "fading"-Prinzip zurickge führt werden, wobei die allmahliche Verringerung der Reaktionsbequemlichkeit die zentrale Rolle spielt: Die Beibehaltung einer entsprechenden Gedachtnis-und/oder Konzentrationsreaktion bei zunehmender Relzkomplexität konnte dann auf eine Verbesserung des Gedächtnis-und/oder Konzentrationsverhaltens wahrend der Trainingssituation zurückgefuhrt werden. Die Kontrollgruppe bestand aus Patienten, die einen Monat wor der Entlassung deutliche Gedăchtnis- und/oder Konzentrationsstörungen zeigten. Diese Gruppe wurde fül Monate nach der Entlassung zur Wiederholungsuntersuchung einbestelt. Die allgemeine SchluBfolgerung, die aus der Untersuchung gezogen werden kann, lautet: die Testleistungen bezüglich Gedachtnis und Konzentration durch das in dieser Studie dargestelltes Training zeigen eine erhebliche Verbesserung im Vergleich zu Personen auf, welche diesem Training nicht unterzogen wurden. Eine Antwort auf die Frage ob "das Gedachtnis" und "die Konzentration" auBerhalb der Untersuchungssituation auch in positivem Sinne beeinfluBt werden, erfordert nähere Untersuchungen. 
Nach der Erprobung von Anwendungen lerntheoretischer Grundsätze bei der Behandlung von Patienten mit Hirnquetschungen wird in Kapitel 4 über ein Literaturstudium zur Festlegung des weiteren Vorgehens berichtet. Obwohl zunächst versucht wurde, die Informationssammlung auf Patienten mit Hirnquetschungen zu beschränken, ergab sich allmählich, daß Veröffentlichungen über diese Patientenkategorie auBerst selten waren. Deshalb wurde das Literaturstudium auf mehrere Patientenkategorien mit Hirnschädigungen ausgedehnt und zwar auf Patienten mit einer Hemiplegie rechts oder links, Kombinationen davon, ,minimal brain damage". Cp-Patienten und geistig Behinderte (Retardierte). Es werden Argumente aufgefuhrt, die das Zusammennehem solcher gemischter Patientengruppen rechtfertigen. Die Ausgangsbasis ist dabei "verhaltenstherapeutischer Art", wobei von dieser Perspektive aus gesehen Vorgehens- und Modifikationsmöglichkeiten untersucht werden, welche die Literatur für Patienten mit Verhaltensabweichungen bietet, die durch eine angenommene Hirnbeschädigung entstanden sind, unabhängig davon ob diese Schädigung angeboren ist oder später erworben wurde. Die Ergebnisse dieser Neuorientierung können wie follgt zusammengefaßt werden:"

1. Mehrere Autoren betonen die Notwendigkeit; Verhaltensdefizite in verschiedenen "Situationen" wie die prämorbide-klinische-Nachbehandlungssituation und die der häuslichen Umgebung zu untersuchen. Die Untersuchung von Verhaltensdefiziten in der klinischen Situation sollte grundsätzlich nach zwei Verfahren ablaufen und zwar durch standardisierte Testverfahren und Verhaltensbeobachtungsskalen. Sowohl für das Testverfahren, als auch die Verhaltensbeobachtung werden verschiedene Modelle miteinander verglichen. Was die klinische Testsituation angeht findet die "Structure of Intellect von Guilford" die meiste Unterstützung. Was die Verhaltensbeobachtung angeht scheint die "Progress Assessment Chart von Gunzberg" die meisten Perspektiven zu bieten.

2. Um einen Eindruck bezüglich der Untersuchungen von „Verhaltensbehinderungen" zu erhalten, werden die Beobachtungskriterien einer Reihe von Autoren miteinander und mit der in dieser Studie entwickelten Verhaltensbeobachtungsskala (GOCC) verglichen. Dabei stellt sich heraus, daß die GOCC dem Problemverhalten von Patienten mit einer Hirnquetschung und von Patienten mit anderen Hirnbeschädigungen am umfassendsten gerecht wird.

3. Bei einer Vielzahl der Veröffentlichungen können bei den Bemühungen, Verhaltensdefizite zu modifizieren, lerntheoretische und vor allem operante Konditionierungsgrundsätze festgestellt werden. Es stellt sich heraus, daß diese Grundsätze durch die Vertreter verschiedener Disziplinen - immer unter anderen Bezeichnungen und in verschiedenen Kombinationsformen - verwendet werden.

4. Schließlich besteht die vielleicht wesentlichste Erkenntnis darin, daß extremes, unerwünschtes Verhalten, das Verhaltensaufbau behindert, nicht oder kaum in den heutigen Rehabilitationszentren in unserem Lande reduziert oder beseitigt werden kann. Aufgrund der Ergebnisse im Ausland wissen wir jedoch, daß es durchaus möglich ist, auch dieses exzessive Verhalten zu reduzieren, wenn auch nur mit ausgebildeten Fachkräften in speziell eingerichteten Institutionen.

In Kapitel 5 wird versucht die Information, die aus dem Literaturstudium gewonnen wurde, mit den Praxiserfahrungen zu kombinieren. Wenn man in der Praxissitation vorläufig vom theoretischen Hindernis bezüglich der Relation „Gehirn-Verhalten” absieht, aber sich - in Erwartung weiterer Entwicklungen auf diesem Gebiet - an der .input-output" Relation orientieren könnte, scheinen Ansätze zu einer ü- 
bersichtlichen Vorgehensweise möglich. Durch den Versuch, die Reizsituation und die damit in Zusammenhang stehende Reaktion näher aufzuschlüsseln, anlyand von Verhaltensbeobachtungsskalen in der Kombination mit damit in Zusammenhang gebrachten standardisierten Testuntersuchungen, erhält man Informationen über komplex zusammengestelltes tind dazu in Beziehung stehendes einfaches Verhalten. Diese Vorgehensweise eröffnet die Möglichkeit festgestellte Verhaltensdefizite aus zwei verschiedenen aufeinander abzustimmenden Perspektiven anzugehen. Außerdem scheint diese Methode Möglichkeiten zur dringend erwünschten Forschung in diesem Bereich zu bieten.

Die Praxiserfahrung und das Literaturstudium hat ergeben, da 3 man bezüglich der Modifikation eine ähliche Situation feststellen kann. Der Versuch, Verhaltensdefizite auszugleichen, kann - so hat sich ergeben - von den verschiedenen theoretischen Konstruktionen bezüglich der Relation "Gehirn-Verhalten” losgelöst werden. Wenn man untersucht, was in der Praxis in Bezug auf die aktuellen Handlungssequenzen geschieht, so sind diese auf Verhaltenswiederherstellung, Verhaltenskompensation und Verhattensreorganisation zurückzuführen.

Die Zielsetzung dieser Studie ist im Grunde die Konkretisierung des RehabilitatonsLernprozesses.

Unter einem Rehabilitations-Lernprozeß wird tatsächlich verstanden, daß das medizinische, paramedizinische Handeln nicht an Wert einzubüßen braucht, aber daß genau so viele Möglichkeiten gegeben werden, um auch das "lernen" mit seinen vielen Aspekten, in die Gesamtheit der rehabilitativen Aktivitäten einzubeziehen. Daß eine Person lernt, es sei an dieser Stelle betont, ist nicht immer eine selbstverständliche Angelegenheit. Lernen ist eine implizite Rehabilitationsvoraussetzung und deshalb ist es notwendig, der Schaffung von Umständen, welche das Lernen neuen Verhaltens ermöglichen, besondere Aufmerksamkeit zu widmen. Bei Patienten, die beim lernen gehemmt sind, sollten sich die Bemühungen zunächt auf die Reduzierung von "Verhaltensbehinderungen" konzentrieren. Wenn dies nicht oder nicht ausreichend innerhalb des Rehabilitationszentrums erfolgen kann, sollte auß3erbalb des Zentrums nach Möglichkeiten, die vorliegenden Methoden anzuwenden, gesucht werden. Nach der Reduzierung exzessiven Verhaltens kann dann versucht werden im Rehabilitationszentrum ein neues Verhalten aufzubauen. Die permanente Wechselwirkung und Integration zwischen dem sogenannten „Krankheitmodell" und dem "Lernmodell" sollte und könnte im Rehabilitations-Lernproze 3 ihre Chance erhalten. Um dies zu konkretisieren wird im letzten Teil des 5. Kapitels der Anwendung des "medizinischen-Lernmodells" in der Praxis des Rehabilitationszentrums besondere Aufmerksamkeit gewidmet. Ein Rehabilitationszentrum ist naturgemäß zur Integration von Theorie und Praxis in diesem Bereich prädestiniert.

Eine Ergänzung und Unterstützung des üblichen rehabilitationsmedizinischen Handelns durch Lerntheorie und verhaltenstherapeutische Praxis bietet Rehabilitationsmöglichkeiten für eine erhebliche Zahl von Patienten mit Hirnschädigungen und wahrscheinlich ebenso für andere Patienten mit Verhaltensabweichungen, die bisher als nicht rehabilitationsfähig abgeschrieben wurden.

Es, war das Ziel dieser Studie, zu Entwicklungen in diese Richtung beizutragen. 


\subsection{Résumé.}

Cette étude est le résultat d "une ex périence d"environ cinq annẻes au sein d'un centre de rééducation, où on s'occupait principalement d'handicapés cérébraux, et plus spécialement de mallades à lésion cérébrale.

Pendant ces cinq années il y a eu collaboration entre médecins et psychologues d'une part et réeducateurs d'autre part. Le personnel médico-psychologique a du faire l'expêrience des nombreuses possibilités, à côté des nombreuses limites, qu'offre la rééducation par le fait qu'elle est encore à une phase débutante de son dévelop. pement. Font partie de ces possibilités: le déweloppement et l'adaptation des acquis de la théorie de l'apprentissage. Pour cela une collaboration entre un grand nombre de disciplines est nécessaire, lesquelles sont confrontées avec le devoir extrêmement complexe de donner une réponse ou une réponse partielle au sujet du traitement des malades souffrant de lésion cérébrale.

Le développement des idées de la théorie de l'apprentissage servant de modèles de travail et de réflexion pour le traitement des handicapés cérébraux se présente comme suit:

Dans le chapitre 1 on a esquissé en manière d'introduction la situation qui a permis cette étude. En se fondant sur l'idée que du moins une partie de la rééducation implique "nouvelle forme de comportement" et par conséquent "apprentissage", ce "nouvel apprentissage đu comportement" est considéré comme un des piliers sur lesquels la réducation devrait s'appuyer. L'utilisation des principes d'apprentissage dans leur a pplication au domaine de la réeducation, suppose une connaissance fondamentale de la theorie.

On traite de la façon dont les divers paradigmes d'apprentissage s'appliquent à la rééducation, mais que concrètement, également à partir de considérations prag. matiques, on préfère en ce moment le paradigme d'apprentissage actif, comme modèle d'explication et de traitement. Dans cette optique on regarde dans quelle mesure les différentes phases du processus de rééducation peuvent être également approchées et expliquées par le paradigme actif. Le premier chapitre se conclut par le prolongement des conséquences de ce paradigme; en ce qui concerne les applications pratiques de l'activité de rééducation en général, à ce qu'on appelle "le modèle d'apprentissage de réeducaton".

Aprés l'introduction de la théorie de l'apprentissage dans la rééducation, le chapitre 2 porte sur le groupe de patients souffrant de lésion cérébrale.

On y vérifie dans quelle mesure il est possible de préciser plus a vant la problématique de ce groupe de patients à partir d'un cadre de "comportement”.

Sur la base d"informations à partir du "statut", on considère quelles expressions sont utilisées par les membres de l'équipe, pour indiquer le comportement du patient. Cette analyse du contenu des dossiers conduit à distinguer:

A. Les déficits du comportement, déterminẻs dans une situation-test standardisée, mais également å l"aide d"observations de comportement non structurées. En général il s'agit du comportement sur lequel portent, du point de vue de la rééducation, les divers programmes de formation du comportement. On tente de supprimer ou de compenser les déficits du comportement:

B. Le comportement excessif, lequel bloque ces tentatives pour une nouvelle formation du comportement ou sa compensation, en bref appelé ,inhibitions du comportement". En général il s'agit du comportement qui, lorsqu'il dure trop 
longtemps, amène à renvoyer le patient du centre de rëeducation. Le patent est allors souvent décrit comme non rééducable.

Pour ces deux sortes de déviations du comportement on a mis au point des procedés d"evaluation:

1. La réunion d"un certain nombre de méthodes d"investigation psychologique (tests), afin de mesurer au moins une partie des différents déficits du comportement.

2. La construction d'une échelle provisoire d'évaluation, spécialement destinè ả signaler les inhibitions du comportement: L"echelle d'observation du comportement de la lésion cérébrale, communément appelée GOCC (Gedrags Observatieschaal van Contusio Cerebri).

Aussi en partant de la theorie de lapprentissage on distingue le comportement excessif et les déficits du comportement, de sorte qu'on peut faire la jonction entre la theorie et la pratique. L'évaluation des excès et des déficits dans le comportement des patients trouve donc un appui dans la théorie comme dans le pratique.

En ce qui concerne le comportement excessif, la theorie de l'apprentissage présente la méthode de la validation différentielle pour réduire le comportement à problèmes. En ce qui concerne les défcits du comportement la théorie de l'apprentissage cite trois méthodes ayant toutes comme but de réaliser un répertöre de comportement nouveau et meilleur, c'est-å-dire une validation sélective en ce quï concerne l'augmentation du comportement déjà existant, des procédés pour former un comportement totalement nouveau et une atténuation pour réaliser une préservation du comportement avec l'augmentation de la complexité des stimuli.

Tous ces procédés ont comme caractéristiques communes l'extinction du comportement inadequat et la validation du comportement souha"té.

Les procédés d'évaluation développés et les techniques de modification tirées de la thérie de l'apprentissage forment ensemble la wtrategie provisoire de réducation". Bien que cette stratégie provisoire de réducation porte dans cette étude seulement sur ce qu'on appelle la phase clinique, il faut insister que lidéal serait que le milieu familial puisse participer explicitement au traitement. Afun de créer une bonne intégration et consolidation du comportement nouvellement appris et réduit, ces stratégies ne doivent pas se limiter en plus à la phase clinique, mais ont besoin d"être poursuivies et complétées dans le milieu familial. On estime que la structure théorique de cette façon multiple d'aborder la question ne s'applique pas seulement aux patients ayant des traumatismes cérébraux. La possibilité de servir de modele a des domaines plus vastes et d'autres groupes de patients dans lat réducation semble bien exister.

La stratégie provisoire de rééducation décrite presente des points communs en ce qui concerne la conception et la réalisation de divers programmes de réducallion. Afin d'essayer ces programmes de façon empirique, on s intéresse tout d'abord dans le chapitre 3 au schéma expérimental concernant l'exécution et l'évaluation de cette stratégie de rééducation. Etant donné qu'il s'agit ici d"une stratégie expérimentale avec des conséquences importantes possibles pour l'évolution ultérieure, on a porté une attention particulière a l"évaluation. Aussi bien la réduction du comportement excessif que la formation d"un nouveau comportement sont soumises a une triple evaluation:

1. Evaluation des problèmes, portant sur le comportement à problèmes constatés et l'éventuelle augmentation ou diminuation de ce comportement si la situation est considérée avant et après le traitement:

2. L'évaluation des résultats, constituée par les scores dans l'ěchelle d'observation 
du comportement mise au point et la réunion des investigations psychologiques, avant et aprés le uraitement.

3. Evaluation des processus, portant sur le comportement vise, souvent le comportement qui est incompatible avec le comportement a problemes, où l'établissement des scores peut être effectué grâce à une observation et un enregistrement presque continu pendant le traitement.

Etant donné qu"une partie importante des procédés d'évaluation est basée sur le GOCC, cette échelle est soumise un traitement statistique, pour déterminer la fabilité des inter - et intra-juges. Sur la base des resultats on peut conclure que le GOCC, en tant qu'echelle d'observation du comportement, constitue en ce qui concerne la composition du sujet et la structure de l'échelle, un instrument de mesure assez frable pour évaluer les déviations du comportement chez les patients soufrant d'une lesion cérébrale.

L'évaluation des modifications du comportement porte tout d'abord sur le résultat des techniques concernant la reduction du comportement excessif, la formation du nouveau comportement et l'augmentation du comportement déjà existant. La signification qu'on peut attribuer à la mise à l'épreuve de ces techniques est limitée par le fait qu'aucun groupe de contrôle n"a pu être constitué et d'autre part par le fait que le groupe expérimental n'a pas pu ètre constitué selon les principes du hasard. Le comportement à problèmes comportant le comportement excessif, l'absence de comportement et la faible intensité du comportement existant, diminue chez les patients traités d'environ $85 \%$, en calculant par rapport à la valeur de départ. Le comportement visé, comportant la réduction du comportement excessif, la formation du nouveau comportement et l'augmentation de lintensité du comportement existant, est réallisé chez la plupart des mallades en 6 semaines environ.

L'évaluation des résultats ne s'exprime pas pour les méthodes citées dans le changement des scores de l'investigation psychologique. Par contre les scores du GOCC présentent une nette amélioration si ces scores sont comparés avant apt après le traitement.

L'evaluation des modifications du comportement portant sur la préservation du comportement sous augmentation de la complexité des stimuli mérite d"être traitée séparément, étant donné que pour cette stratégie on a pu cette fois former un groupe expertimental ainsi qu'un groupe de contrôlle. Ici aussi d'allleurs le groupe experimental et le groupe de contrôle n"ont pas pu être constitués au hasard. Le comportement a problemes comporte pour les deux groupes des déficiences de concentration et de mémoire assez considérables, déterminées grâce aux procédés d'investigation psychologique mis au point. Le groupe experimental a subi un traitement d"environ 6 mois, comportant la présentation de stimuli de complexilé croissante. Cette approche peut être ramenée au principe du "fading" (de l'attenuation) de la théorie de l"apprentissage, centré sur la diminution progressive de la facilité de stimuli. La conservation d*une mémoire adéquate et/ou d'une réponse au niveau de la concentration avec l'augmentation de la complexité des stimuli pourrait alors être attribuée à une amélioration du comportementi de la memoire tou de la concentration pendant les situations de l'entrainement. Le groupe de contrôle était composé de patients ayant présenté un mois avant leur renvoi de très nets troubles de la mémoire et/ou de la concentration. Ce groupe a été convoqué cinq mois après leur renvoi pour un examen de contrôle. La conclusion générale qu'on peut tirer de cette recherche est que les résultats des tests concernant la mémoire et la concentration gràce à l'entrainement decrit dans cette étude, montrent une nette amélioration, contrairement aux personnes qui n'ont pas subi 
cet entraimement. La question de savoir sî "la mémoire" et "la concentration" sont egallement influencées dans un sens favorable en dehors du cadre de la techerche, exige un étude plus approfondie.

Après la mise à l'épreuve des principes de la theorie de l'apprentissage dans le traitement des patients souffrant de lésion cérébrale, le chapitre 4 rend compte dune étude de la littérature pour déterminer la suite de l'évolution. Bien qu'on ait tout d'abord essayé de baser les informations rassemblées sur les patients ayant une lésion cérébrale, il s'est avéré peu à peu que les publications concernant cette catégorie de patients étaient extrèmement limités. Par conséquent on a étendu l'étude de la littérature aux diverses catégories d'handica pés cérébraux, c'est-a-dire les patients ayant des troubles de l'hem isphère droite ou gaviche, des combinaisons des deux, un "minimal brain damage", les patients paralysés cérébraux et les retardés mentaux. Les arguments allégués justifient l'assemblage d'un groupe de patients ainsi mêlés. Le cadre de référence est ici . la psychologie du comportement", tout en s'attachant dans cette optique aux possibilités d'évaluation et de modification, présentées dans la littérature chez les patients présentant des déviations du comportement à la suite d'une attein te cérébrale supposée, indépendamment du fait que cette déficience soit la conséquence d'une atteinte congénitale ou acquise.

Les résultats de cette réorientation peuvent être rẻsumés de la façon suivante:

1. Différents auteurs accentuent la nécessitê d'évaluer les déficits du comportement dans diverses "situations" comme la situation "prëmorbide”, clinique, de post-traitement et a la maison. Lévaluation des déficits du comportement dans la situation clinique devrait se faire en principe selon deux procédés, cest-à-dire à l'aide de tests standardisés et à l'aide d'échelles d'observation du comportement. Pour le procédé par tests comme pour l'observation du comportement on compare différents modèles. En ce qui concerne la "situation" de test clinique, la „Structure of Intellect de Guilford" a l"appui le plus empirique. En ce qui concerne l"observation du comportement le "Progress Assessment Chart de Gunzberg" s"avère offirir le plus de perspectives.

2. Afin de se faire une impression concernant lévaluation des inhibitions du comportement, les critères d'observation d"un certain nombre dauteurs sont comparés entre eux ainsi qu"avec l'échelle d'observation du comportement développée dans cette étude (GOCC). Il en ressort que le GOCC domine au mieux le comportement à problèmes des patients souffrant de lésion cérébrale et des autres handicapés cérébraux.

3. Dans un grand nombre de publications on reconnait dans les tentatives de modification des déficits du comportement des principes de conditionnement selon la théorie de l'apprentissage et essentiellement actifs. Ceux-ci s'avèrent être utilisés par les membres de diverses disciplines, a chaque fois sous d'autres termes, et dans différentes formes de combinaisons.

4. Enfin la constatation la plus importante est peut-être le fait qu'un comportement indésirable, extrême, qui empéche la formation d'un comportement ne peut pas ou à peine être réduit ou éliminé dans les centres de rééducation actuels ici dans notre pays. Etant donné les résultats ailleurs il semble toutefois parfiaitement possible de réduire également ce comportement excessif, mais seulement avec du personnel entraïné dans des instituts aux structures spécifiques.

Dans le chapitre 5 on essaie d'intégrer l'information sélectionnée a partir de la littérature avec les expériences de la pratique. Sï, en travaillant dans la pratique, on weut éliminer provisoirement l"obstacle théorique, concernantla relation ,cerveau- 
comportement" et si on pouvail s'orienter, dans l'attente des développements ultérieurs dans ce domaine, vers la relation , input-output*, la mise en marche d"une évahurion claire semble possible. En tentant de specifuer plus avant les stimuli et la réponse qui en résulte a l"aide d'echelles d'observation du comportement, combinees avec une recherche par tests standardisee qui $s^{*} y$ rapporte, on obtient une unformation concernant le comportement simple constitué de façon complexe et qui y est lie. Cette evaluation donne la possibilité d'approcher les déficits du comportement constatés, â partí de deux angles d'incidence diférents à adapter I"un a l'autre. De méme elle semble offrir des possibilites pour une recherche très souhaitée dans ce domaine.

Il ressort de la pratique et de letude de la littérature, qu'on peut également constater une situation similaire en ce qui concerne la modification. La tentative de guérir des défictis du comportement semble pouvoir être découplée des différentes structures théoriques concernant la relation "cerveau-comportement". Sï on vérifie ce qui se passe dans la pratique en ce qui concerne les séquences de traitement actuelles, celles-ci peuvent être ramenès à un rétablissement du comportement, une compensation du comportement et une réorganisation du comportement.

Le but final de la présente étude est la concrétisation d'un processus d'a pprentissage de réeducation. On entend en fait par processus d'apprentissage de rééducation que l'action médicale et para-médicale n'a pas à y perdre en valeur, mais qu"il y autant de possibilités d'offertes pour impliquer dans l'ensemble des activités de la réeducation également „l'apprentissage" dans ses nombreux aspects. Le fait qu'une personne apprenne, que ce soit clair ici, n'est pas toujours une chose évidente. Apprendre constitue une condition implicite pour la rééducation et par conséquent il faut s'y intéresser de façon explicite pour créer des circonstances rendant possible cet apprentissage d'un nouveau comportement. Chez les patients chez qui l'apprentissage est bloquế, il faut par conséquent s'attacher d'abord à la réduction des "inhibitions du comportement". Si cela n'est pas ou est insuffisamment réalisable ă l'intérieur du centre de rééducation, il faut rechercher à l'extérieur du centre des possibilités permettant de mettre en cuvre les méthodes existantes. Après réduction du comportement excessif, on peut alors essayer d"entreprendre dans le centre de rééducation la formation d'un nouveau comportement. L'interaction continue et l'intégration continue entre ce qu'on appelle le "modèle de maladie" et le "modele d"apprentissage" semble devoir et pouvoir avoir sa chance dans le processus d"apprentissage de rééducation. Afin de donner une forme plus concrète a ceci, on sintéresse dans la derniere partie du chapitre 5 a l"application du , modele d"apprentissage médical" dans la pratique du centre de réducation. Un centre de réeducation se prête par essence et par excellence à l'intégration de la théorie et de la pratique dans celui-ci.

Le fait de complêter et de soutenir l'action médicale de réducation courante a partir de la theorie de l"apprentissage et la praxis de la thérapeutique du comportement, offre des possibilites de réducation pour un groupe important de patients souffrant de troubles cérébraux et probablement également pour d'autres patients ayant des déviations du comportement, lesquelles ont été classés jusque là comme intraitables.

Cétai le but de cette étude de contribuer aux développements dans cette direction. 


\subsection{Samenvatting}

Deze studie is het resultaat van een circa vijfjarige ervaring binnen een revalidatiecentrum, waarin hoofdzakelijk bemoeienis bestond met cerebraal gestoorde patiënten en met name patiënten met contusio cerebri. In deze vijf jaren vond een ontmoeting plaats tussen medewerkers vanuit de medische psychologie enerzijds en wanuit de revalidatie anderzijds. De werkers vanuit medisch-psychologisch denkkader hebben hierbij ervaren dat het revalidatiegebeuren vanwege de daaraan eigen jeugdige onwikkelingsfase, naast vele beperkingen ook vele mogelijkheden biedt. Tot deze mogelijkheden behoort de ontwikkeling en toepassing van leertheoretische verworvenheden. Daartoe is een samenwerking nodig tussen een veelheid aan disciplines, die gekonfronteerd worden met de uitermate complexe opgave een antwoord of deelantwoord te geven inzake de behandeling van patienten met contusio cerebri.

De ontwikkeling van leertheoretische ideeën tot denk- en werk modellen ten behoeve van de behandeling van cerebraal gestoorden is alsvolgt weergegeven:

In hoofdstuk 1 wordt als introduktie een schets gegeven van de situatie van waaruit deze studie kon ontstaan. Op grond van de gedachte, dat althans een deel der revalidatie "nieuwe gedragsvorming" en derhalve "leren" impliceert, wordt dit "Opnieuw leren van gedrag" als een der pijlers gezien waarop revalidatie zou moeten berusten. Bij de behandeling van leerprincipes in hun toepassing op het gebied van de revalidatie wordt een basiskennis inzake leertheorie voorondersteld. Besproken wordt hoe diverse leerparadigmata in de revalidatie toepasbaar zijn, maar dat in concreto, mede vanuit pragmatische overwegingen, op dit moment de voorkeur wordt gegeven aan het operante leerparadigma als verklarings- en behandelingsmodel. Vanuit deze optiek wordt bezien in hoeverre de diverse fasen in het revalidatiegebeuren eveneens benaderd en verklaard kunnen worden door het operante paradigma. Het eerste hoofdstuk wordt besloten met het doortrekken wan de konsekwenties van dit paradigma wat betreft de praktische toepassingen van het revaliderend handelen in het algemeen tot het zo genoem de "revalidatie-leermodel".

Na de introduktie van de leertheorie in de revalidatie richt hoofdstuk 2 zich op de groep van patiënten met contuso cerebri.

Er wordt nagegaan in hoeverre het mogelijk is de problematiek van deze pätiëntengroep vanuit een .gedrags"kader nader te preciseren.

Op basis van informatie vanuit de "status" wordt bezien welke uitspraken er door teamleden worden gebezigd, teneinde het gedrag van de patiènt aan te geven. Deze inhoudsanalyse van de statussen leide tot het onderscheid in:

A. Gedragstekorten, vastgesteld in een gestandaardiseerde testsituatie maar ook wel door middel vam niet gestruktureerde gedragsobservaties. Over het algemeen is dit het gedrag waa rop vanuit revalidatiestandpunt diverse gedragsvormende programma's worden gericht. Er wordt getracht de gedragstekorten op te heffen of te kompenseren.

B. Excessief gedrag, dat deze pogingen tot niewwe gedragsworming of kompensatie hiervan blokkeert, in het kort ..gedragsbelemmeringen" genoemd. Over het algemeen is het gedrag dat, bij langdurig voortbestaan, aanleiding geeft de patiënt uit het revalidatiecentrum te ontslaan. De patiënt wordt dan vaak als niet revalideerbaar omschreven. 
Voor beide soorten van gedragsdeviaties worden assessmentprocedures ontwikkeld: 1e. De samenvoeging van een aantal psychologische onderzoekmethoden (tests) om althans een deel van de diverse gedragstekorten te meten.

2e. De konstruktie van een voorlopige assessmentschaal welke met name bedoeld is om gedragsbelemmeringen te signaleren: De gedragsobservatieschaal van contusio cerebri, in de wandeling GOCC genoemd.

Ook vanuit de leertheorie wordt onderscheid gemaakt in excessief gedrag en ged ragstekorten zodat een aansluiting tussen theorie en praktijk gelegd kan worden. De assessment naar excessen en tekorten in het gedrag van patienten vindt aldus vanuit theorie è praktijk ondersteuning. Ten aanzien van excessief gedrag presenteert de leertheorie de methodiek van differentiële bekrachtiging ter reduktie van het probleemgedrag. Ten aanzien van gedragstekorten noemt de leertheorie een drietal methodieken welke alle ten doel hebben een nieuw of beter gedragstepertoir te realiseren, $\mathrm{nl}$. selektieve bekrachtiging inzake toename van reeds bestaand gedrag, shapingsprocedures voor de vorming van totaal nieuw gedrag en fading ter bewerkstelliging van gedragsbehoud onder toenemende stimuluscomplexiteit.

Alle procedures hebben als gemeenschappelijke kenmerken de extinktie van adek waat gedrag en de bekrachtiging van gewenst gedrag.

De ontwikkelde assessmentprocedures en de uit de leertheorie betrokken modifikatietechnieken vormen tesamen de "voorlopige revalidatiestrategie”. Hoewel deze voorlopige revalidatiestrategie in deze studie slechts betrekking heeft op de zogenaamde klinische fase, moet wel worden benadrukt, dat idealiter het thuismilieu expliciet zou moeten kunnen participeren in de behandeling. Teneinde een goede integratie en konsolidatie van nieuw aangeleerd of gereduceerd gedrag te doen ontstaan, dienen deze strategieën bovendien niet beperkt te blijven tot de klinische fase, maar behoeven zij een woortzetting en aanvulling in het thuismilieu. De theoretische konstruktie van deze meervoudige aanpak wordt niet slechts toepasbaar geacht voor patiënten met cerebrale traumata. De mogelijkheid dat zij model zou kunnen staan woor bredere gebieden en andere patiëntengroepen in de rewalidatie lijkt zeer wel aanwezig.

De beschreven voorlopige revalidatiestrategie biedt aanknopingspunten wat betreft het ontwerpen en realiseren van diverse revalidatieprogramma"s. Teneinde deze programma's empirisch te toetsen wordt in hoofdstuk 3 in eerste instantie aandacht besteed aan het experimenteel design inzake uitvoering en evaluatie van deze revalidatiestrategie. Aangezien het hier om een experimentele strategie gaat met mogelijk verreikende konsekwenties voor latere ontwikkelingen, is extra aandacht besteed aan de evaluatie. Zowel de reduktie van excessief gedrag alsook de vorming van nieuw gedrag worden aan een drievoudige assessment onderworpen:

1e. Probleemassessment, gericht op het gekonstateerde probleemgedrag en de eventuele toe- of afname van dit gedrag, indien de situatie vóór en na de behandeling wordt bezien.

2e. Effektassessment, gevornd door de scores op de ontwikkelde gedragsobservatieschaal en het samengevoegde psychologisch onderzoek, vóór en na de behandeling.

3e. Processasessment, gericht op het doelgedrag, veelal het gedrag dat incompatibel is met het probleemgedrag, waarbij de scoring tot stand komt door een vrijwel kontinue observatie en registratie tijdens de behandeling. 
Aangezien een belangrijk deel der assessmentprocedure gebaseerd is op de GOCC, wordt deze schaal ter bepaling van de inter-en intrabeoordelaarsbetrouwbaarheid aan een statistische bewerking onderworpen. Op grond van de resultaten kan gekonkludeerd worden, dat de GOCC als gedragsobservatieschaal wat betreft item-samenstelling en schaalkonstruktie, een redelijk betrouwbaar meetinstrument is ter assessment van gedragsdeviaties bij patiënten met contusio cerebri.

De evaluatie der gedragsmodifikaties is in eerste instantie gericht op het effekt der technieken inzake de reduktie van excessief gedrag, de vorming van nieuw gedrag en de toename van reeds aanwezig gedrag. De betekenis die aan de toetsing van deze technieken is toe te kennen wordt beperkt doordat geen kontrolegroep kon worden gevormd en bovendien de experimentele groep niet volgens randomisatie-principes kon worden samengesteld. Het probleemgedrag, bestaande uit excessief gedrag, afwezigheid van gedrag en lage intensiteit van bestaand gedrag, neemt bij de behandelde patiënten af met circa 85 procent gerekend ten opzichte van de begin waarde. Het doelgedrag, bestaande uit reduktie van excessief gedrag, vorming van nieuw gedrag en toename der intensiteit van bestaand gedrag wordt bij het merendeel der patiënten in circa 6 weken gerealiseerd. De effektassessment komt bij genoemde methodieken niet tot uiting in verandering der scores in het psychologisch onderzoek. Daarentegen tonen de GOCC-scores een duidelijke verbetering indien de scores vóór en na de behandeling worden vergeleken.

De evaluatie der gedragsmodifikaties gericht op gedragsbehoud onder toename van stimuluscomplexiteit verdient een aparte behandeling aangezien bij deze strategie wel een experimentele- en kontrolegroep kon worden gevormd. Ook hier kon overigens de experimentele en kontrolegroep niet at random worden samengesteld. Het probleemgedrag bestaat voor beide groepen uit vrij aanzienlijke geheugen- en concentratiedefekten vastgesteld door middel van de samengestelde psychologische onderzoekprocedure. De experimentele groep kreeg een behandeling van circa 6 maanden welke bestond uit het aanbieden van stimuli in toenemende complexiteit. Deze benadering kan herleid worden tot het leertheoretische "fading"-principe, waarin geleidelijke vermindering van stimulusfacilitatie centraal staat. Het behoud van een adek wate geheugen- en/of concentratierespons onder toenemende stimuluscomplexiteit zou dan toegeschreven kunnen worden aan een verbetering van geheugen- en/of concentratiegedrag tijdens de trainingsituaties. De kontrolegroep werd samengesteld uit patiënten die een maand voor ontslag duidelijke geheugenen/of concentratiestoornissen toonden. Deze groep werd 5 maanden na ontslag opgeroepen voor een herhalingsonderzoek. De algemene konklusie die uit het onderzoek kan worden getrokken is dat de testprestaties inzake geheugen en concentratie van patiënten die aan de in deze studie beschreven training deelnamen een duidelijke verbetering vertonen in vergelijking met die personen weike deze training niet ondergingen. De vraag of "het geheugen" en "de concentratie" buiten de onderzoeksituatie ook in gunstige zin worden beïnvloed vergt voortgezet onderzoek.

Na de toetsing van toepassingen der leertheoretische principes in de behandeling van patiënten met contusio cerebri geeft hoofdstuk 4 verslag van een literatuurstudie ter verdere koersbepaling. Hoewell in eerste instantie getracht werd de informatieverzameling te baseren op de patiënten met contusio cerebri, bleek gaandeweg dat publikaties inzake deze kategorie patiènten uitermate beperkt waren. Derhalve werd de literatuurstudie uitgebreid tot verscheidene kategorieên van cerebraal gestoorden, namelijk patiënten met rechter- of linker-hemisfeerstoornissen, kombinaties hiervan, ,minimal brain damage”, cerebral palsy pătiènten en 
mental geretardeerden. Er worden argumenten a angevoerd die het samenwoegen van een dergelijk gemeleerde patientengroep rechtvardigen. Het referentiekader is hierbij "gedragspsychologic", warbij vanuit deze optiek gel wot word op assessmenten modifikatiemogelijkheden, die vanuit de literatuur gepresenteerd worden bij patienten die gedragsdewaties tonen tengevolge van een veronderstelde cerebrale aandoening, onafhankelijk of dit defekt het gevolg is van aangeboren of verworven aandoening.

De resultaten van deze herorientatie kunnen alsvolgt worden samengevat:

1e. Verscheidene auteurs beklemtonen de noodzaak tot assessment van gedragstekorten in diverse "situaties" zoals de premorbide, klinische, nabehandelings-, en thuissituatie. De assessment naar gedragstekorten in de klinische situatie zou in principe volgens twee procedures moeten geschieden nl. d.m. v. gestandaardiseerde testprocedures en gedragsobserwatieschalen. Zowel voor de testprocedure en gedragsobservatie worden diverse modellen met elkaar vergeleken. Wat betreft de klinische testsituatie heeft de "Structure of Intellect van Guilford" de meeste empirische ondersteuning. Ten aanzien van de gedragsobservatie blijkt de "Progress Assessment Chart wan Gunzberg" het meeste perspelktief te bieden.

2e. Teneinde een indruk te verkrijgen inzake de assessment van gedragsbelemmeringen worden de observatiekriteria van een aantal auteurs met elkaar en met de in deze studie ontwikkelde gedragsobserwatieschaal (GOCC) vergeleken. Hieruit blijkt dat de GOCC het probleemgedrag van patienten met contusio cerebri en van anderszins cerebraal gestoorden het meest volledig bestrijkt.

3e. In een groot aantal publikaties kunnen bij de pogingen tot modifikatie wan gedragstekorten, leertheoretische en met name operante konditioneringsprincipes worden herkend. Deze blijken door de leden wan diwerse disciplines, steeds onder andere bewoordingen, en in diverse kombinatievormen, gehanteerd te worden.

4e. Tenslotte is wellicht de belangrijkste bevinding dat extreem, ongewenst gedrag dat gedragsvorming belemmert nielt of nauwelijks gereduceerd of geellimineerd kan worden in de huidige revalidatiecentra hier te lande. Gegeven de resultaten elders blijk het echter wel degelijk mogelijk ook dit excessief gedrag te reduceren, zij het alleen met getraind personeel in specifiek gestruktureerde instituten.

In hoofdstuk 5 wordt getracht de informatie uit de literatuur te integreren met de praktijkervaringen. Indien men, werkende in een praktijksituatie, voorlopig wil afzien van het theoretische obstakel inzake de relatie , hersenen-gedrag", maar zich - in afwachting van verdere ontwikkelingen op dit gebied - zou kunnen orienteren op de „input-output"-relatie dan lijkt er een aanzet tot een overzichtelijke assessment mogelijk. Door een poging de stimulussituatie en de resulterende respons nader te specificeren an de hand van gedragsobservatieschalen, in kombinatie met hiermee in verband gebracht gestandaardiseerd testonderzoek, krijgt men informatie omtrent complex samengesteld en hiermee gerelateerd enkelvoudig gedrag.

Deze assessment verschaft de mogelijkheid gekonstateerde gedragstekorten vanuit twee verschillende op elkar af te stemmen invalshoeken te benaderen. Tevens lijkt zij mogelijkheden te bieden voor zeer gewenste research op dit gebied.

Vanuit praktijk en literatuurstudie blijkt dat ook ten aanzien van de modifikatie een soortgelijke situatie kan worden gekonstateerd. De poging om gedragstekorten te herstellen blijkt losgekoppeld te kunnen worden van de diverse theoretische konstrukties inzake de relatie "hersenen-gedrag". Indien men nagaat wat er in de praktijk gebeurt wat betreft de aktuele handelingssekwenties, dan zijn deze te herleiden tot gedragsrestauratie, gedragskompensatie en gedragsreorganisatie. 
De uiteindelijke doelstelling van deze studie is de konkretisering van een revalidatieleerproces. Met een revalidatie-leerproces wordt in feite bedoeld, dat het medischparamedisch handelen niet in waarde behoeft in te boeten, maar dat evenveel mogelijkheden worden gegeven om in het tota al der revalidatie-aktiviteiten ook het "leren" in zijn vele aspekten te betrekken. Dat een persoon leert, het zij hier duidelijk gesteld, is niet altijd een vanzelfsprekende zaak. Leren is een impliciete voorwaarde ter revalidatie en derhalwe dient expliciet aandacht te worden besteed an het scheppen van omstandigheden die dit leren van nieuw gedrag mogelijk maken. Bij patiënten waar het leren geblokkeerd wordt, dient derhalve eerst aandacht te worden besteed aan de reduktie van ..gedragsbelemmeringen". Indien dit niet of onvoldoende te realiseren valt binnen het revalidatiecentrum dan moet buiten het centrum naar mogelijkheden gezocht worden on de voorhanden liggende methodieken aan te wenden. Na de reduktie van het excessieve gedrag kan dan getracht worden in het revalidatiecentrum de vorming van nieuw gedrag te ondernemen. De voortdurende wisselwerking en integratie tussen het zogenaamde "ziektemodel" en "leermodel" lijkt in het revalidatie-leerproces zijn kans te moeten en kunnen krijgen. Teneinde hieraan meer konkreet gestalte te geven wordt in het laatste deel van hoofdstuk. 5 aandacht besteed aan de toepassing van het "medisch-leer-model" in de-praktijk van het revalidatiecentrum. Een revalidatiecentrum leent zich uiteraard bij uitstek tot de integratie van theorie en praktijk in deze.

Aanvulling en ondersteuning van het gangbare revalidatiegeneeskundig handelen vanuit de leertheorie en gedragstherapeutische praktijk bieden revalidatiemogelijk heden voor een belangrijke groep patiënten met cerebrale stoornissen en waarschijnlijk eveneens voor andere patiënten met gedragsdeviaties welke tot voorheen als onbehandelbaar werden afgeschreven.

Het was de doelstelling van deze studie bij te dragen tot ontwikkelingen in deze richting. 


\section{REFERENTIES}


Alabiso F. (1972) - Inhibitory functions of attention in reducing hyperactive behavior. American Jr. of Mental Deficiency, 77,3 (p. 259-283).

Allen K. E., Turner K. E., Everett P. M. (1970) - A bethavior modification classroom for Head Surt children with problem behawiors. Exceptional Children. 37.2 (p. 119-129).

Alten K. E. (1972) - Jutie: a case study. Presented at the third annual conference on behavior analysis in education. University of Karsas. Lawrence, Kansas.

Anderson N. (1961) - Scales and statistics: parametric and nonparametric. Psychological Bulltin LVIII.

Anderson T. P. (1975) - An altermative rrame of reference for rehabilitation. The helping process versus the medical model. Arch. Phys. Med. Rellab. 56 (p. 101-104).

Ansink B. J. J.(1974) - Klinisch lessen. Inhibitie en keerproces. Ned. Tijdschrift Geneeskunde $118,35(\mathrm{p} .1321-1323)$.

Asch S. E. (1956) - Studies of the dependence and conformity. A minority of one against a unanimous majority. Psychol. Monogr. 76,9 (whole no. 416 ).

Ayllon T., Azrin N. H. (1968) - The token economy. A motivational system for therapy and rehabilitation. Appleton - Century - Crofts - New York.

Ayres J. E. (1974) - Sensory integration and learning disorders. Western Psychological Services; Los Angelos.

Bakker P. (1974) - Samen watting der werkzaamheden van de confusio werkgroep. Revalidatie Centrum "Hoensbroeck". Interne rapportage.

Bakker P. (1976) - Behandeling wan contusio cerebri in de revalidatie. Voordracht gehouden op het colloquium: voor revalidatie-artsen en psychologen, Utrecht (in press).

Bandura A. (1970) - Interpretations of causal processes. 7n: Principles of behavior modification (p. 19-45). Ed. Bandura A. Standford University, Holt Reinhart and Winston, London.

Barendregt J. T. (1974) - Klinische psychologie is meer dan therapie bedrijwen. De Psycholoog $1 \mathrm{X}, 4 .(\mathrm{p}, 127-136)$

Beekers L. J. P. M. (1968) - Afname van handvaardigheidsproeven voor geestelijk 2 wakbegaafden. Test en trainingsafdeling van de Prinses Wilhelminastichting, Utrecht.

Benders H (1974) - Reakties n.a.x. "Psychologie in het algemeen ziekenhuis". De Psycholoog $X .8($ p. $402-410)$.

Ben Yishay Y.(1970) - The ability to profit from cues as a function of initial competence in normal and brain damaged adults: A replication of previous findings. Ir. of Abnormal Psychology, 76, (p. 378-379).

Berni R., Dressler J., Baxter J. C. (1971) - Reinforcing behavior. American Journall Nursing. (p. 2180-2183).

Berni R., Fordyce W. E. (1973) - Behavior modification and the nursing process. The C. V. Mosby Company, Saint Louis 1973.

Boeke P. E. (1962) - Psychodiagnostische problemen wan de epilepsie. Dissertatie. Groningen, van Gorcum. Assen.

Boneau G.(1961) - A note on measurement scitles and statistical tests. American Psychologist XVI.

Bowes K. B. (1975) - Hyperactivity: Etiology and interwention techniques. Jr. School Health $45,4$ (p. $195-202)$.

Bragg J. H. (1975)-Behavior modification: effects on reverse tallor sitting in children with cerebral palsy. Physical Therapy 55,8 (p. $860-868$ ).

Burger A. W. (1966) - De superioriteit van de synthetische beoordelaar. Voordrachtenteeks wan de Nederlandse vereniging van psychiaters in dienstverband.

Burgen A. W., de Waard, Wilde (1966) - Graffelschaal. Psych. inr, "Het Groot Graffel" Warnsfeld.

Burger A. W., Hofman R., Peters N. J., Wolters F. J. (1971) - Warnsveldse aanpassingsschaal voor de verpleegafdeling. .Het Groot Graffel", Warnsfeld.

Byou S. W. Peterson R. F., Harris F. R., Allen K. E., Johnson M. S. (1969)-Methodology for experimental studies of young children in natural settings. The Psychological Record. $19,2(p .177-210)$.

Cartwright D., Zander $\mathbb{R}$, (1960) - Group dynamics research and theory. Tavistock, Publications Limited, London. 
Cllose D. W.(1973) - The use of token reinforcement whth trainable mentally retarded in a work activity setting. Vocational Evaluation and Work Adjustment. 6.4 (p. 6-13).

Clemment P. W. (1971) - Please mother I'd rather you did it yourself. Traming parents to treat their own children. Jr. of School Health, febr. (p. 65-69).

Cofer C. N., Appley M. (1967) - Toward an unifed theory of motivation. In: Motivation, theory and research (p. 808-838), Ed: Cofer C. N., Appley M., John Wiley and Sons Inc. New York.

Cohen H.J., Birch H. G., Taft L. T. - Evaluation of the Doman-Delacto .patterning" method. Pediatrics 45 (p. 302-314).

Cohn R. (1961) - Delaying acquisition of reading and writing disabilities in children: $A$ neurological study. Archives of Neurology, 4 (P. 153-164).

Craft A. (1974) - Children with head injuries. Special Education: Forwand Trends 1,3 (p. $11-12)$.

Cruickshank W. M. (1972) - Buitenbeentjes. Kinderen met hersenbeschadigingen thuis, op school en in de groep. Lemniscaat, Rotterdam.

Cull J. G., Hardy R. E. (1974) - Behavior modification in rehabilitation settings, applied principles. Charles $C$. Thomas, Publishers, Springfield.

Dam F. van (1975) - De psycholoog in het algemeen ziekenhuis. Psycholoog $X, 7$ (p. 349-353) en de Psycholoog $X, 8$ (p. 402-410).

Daniel $C$. W. (1973) - The use of token reinforcement with tramable mentally retarded in a work activity setting. Vocational Ev and Work Adj. 6.4 (p. 6-13)

D'Annunzio A., Steg D. R. (1974) - Effects of individualized learning procedures on children with specific learning disabilities. Develop. Med. Child. Neurol. 16 (p. $507-512$ ).

Deelman B. G. (1970-1) - College diktat neuropsychologie. Rijks Universiteil Groningen. (niet gepubliceerd).

Deelman B. G. (1970-2) - Kanttekeningen bij de behandeling wan arasie. Nederlands Tijdschrift voor de Psychologie. XXV, $10($ p. 637-648).

Deese J., Hulse S. H. (1967) - Patterns of reinforcement. In: The psychology of learning (p. 142-169). Ed: Deese J.. Hulse S. H., Mc. Graw Hill Book Company. New York.

Diamant J. J., Vermeulen H. W. M. (1976) - "Closed Circuit" benadering van het funktie-revalidatie proces by psychiatrische patiënten mett organische hersenbeschadi. ging. De Psycholoog XI, 5 (p. 215-222).

Diller L. Weinberg J. (1970) - Evidence for accident prone behavior in hemiplegic patients. Archives of Physical Medicine and Rehabilitation, june (p. 358-363).

Diller L. (1971) - Cognitive and motor aspects of handicapping conditions in the neurologically impaired. In.: Rehabilitation psychology; procedings of the national conference in the psychological aspects of disability, held at the Asilomar Conference Center, Monterey, California. October 25-28, (p. 1-33). American Psychological Ass. Ed: Neft W. S. Washington D. C.

Diller L. (1976) - A model for cognitive retraining in rehabilitation. The Clinical Psychologist. $29,2(0.13-25)$

Dollard I., Miller N. E. (1950) - Personality and psychotherapy. An analysis in terms of learning, thinking and culture. Mc. Graw Hill New York.

Doman R. J., Spitz E. Zucman E. Delacato C. and Doman 0 . (1960)-Children withsevere brain injuries. Ir. of the American Medical Associations, 174 (p. 257 e.v.).

Drenth J. P. (1966) - De psychologische test. Een inleiding in de theorie van de psychologische test en zijn toepassngen. Van Loghum Slaterus, Arnhem.

Dumont J. J. (1973) - Leerstoornissen, corzaken en behandelingsmethoden. Orthorecks, Lemniscatat Rotherdam.

Edmondson B. (1974) - Arguing for a concept of competence. Mental Retardation, 12,6 (p. 14-(15.)

Ellis M. J. (1973) - Why people play. Englewood Clifs, N. J. Prentice Hall.

Farnhan-Diggory S. (1967) - Symbol and synthesis in experimental ureading". Child Development 38 (p. 221-231).

Feshbach A. Ademan H., Fuller W. W. (1974)-Early identification of childrem with high risk of reading failure Ir. of Learning Disabilities. 7,10 (p. 49-54). 
Fingado (1970) - A thirty day residential traming program for retarded children. Mental Retardationi, dec. (p. 42-45).

Fokkens W. (1976) - Pleidooi voor een praktische voepassing van leerprincipes in bedrijuen. Intermediair 12e jaargang. nr. 9 (p. 45-49).

Fordyce W. E. (1971-1) - Psychologicall assessment and management. In: Handbook of rehabilitation and medicine (chapter 6). Ed: Krusen, Kottke and Elwood, New York.

Fordyce W. E.(1971-2) - Behaviorall methods in rehabilitation. In: Rehabilitation Psychology (p. 74-108). Ed: Neff W. S. American Psychological Association Inc. Washington D. C.

Fordyce W. E., Sand P. L., Trieschman R. B., Fowler R. S. jr (1971) - Behawioral systems analyzed. Medical Retabilitation Facilities, March, April (p. 29-33).

Fordyce W. E. (1974-1) - Chronische pijn als operant gedrag. Gedeelten wit voordracht gehouden t.b.v. workshop revalidatie psychologen, september 1974. Revalidatie Centrum "Hoensbroeck". (niet gepubliceerd)

Fordyce W. E. (1974-2) - Chronische ziekte als operant gedrag. Gedeelten uil lezing tb.w. workshop rewalidatie psychologen, september 1974. Revalidatie Centrum "Hoensbroeck". (niet gepubliceerd)

Frostig. M. (1968) - Sensory motor development. Special Educiation, 57 (p. 18 e.w.).

Garber (1971) - Operant procedures to eliminate drooling behavior in a cerebral palsied adolescent. Develop. Med. Child. Neurol, 13 (p. 641-644).

Gassel M. M., Williams (1963) - Visual function in patiens with homonymous hemianopia. The contemplation phenomenon; insight and attitude to the defect and visual functional efficiency. Brain, 86 (p. 229).

Geel C.A.A. wan (1975) - „De tegenstelling tusseri de visie van Pr. Dr. P. Leenhouwers over writheid en het Behaviorisme". Skriptie M.O. pedagogiek, Sittard. (niet gepubliceerd).

Geller J. (1972) - The development of behavior therapy with autistic children: A review. Jr. Chron. Disease, 25 (p. 21-31).

Gibson J.J. en Gibson E.J. (1955) - Perceptual training. Psychol. Review, 62 (p. 32)

Gilenn E., Snelbecker E., Mason J. (1970) - Cross discipline comparison of practitioners objectives and strategies concerning braindamage and rehabilitation/ educational planning. Prepublication Draft American Psychological Association Convention, Miamy Beach.

Goffman E. (1961) - Asylums, essays on the social situation of mental patients and other inmates. Anchor Books Double Day and Company Inc., Garden City New York.

Gold M.W. (1972) - Stimulus factors in skill training of retarded adolescents on a complex assembling task. Acquisition, transfer, retention. Am. Jr. Mental Deficiency 76,5 (p. $517-526)$

Gold M.W. (1973-1) - Research in the vocational habilitation of the retarded. The present and the future. In: International review of research in mental retardation. Ed: Norman E.R. Academic Press. New York.

Gold M.W. (1973-2) - Factors affecting production by lihe retarded. Mental Retardation 11,6 (p. $41-45$ ).

Goodkin R. (1966) - Case studies in behavioral research in rehabilitation. Perceptual and Motor Skills. 23 (p. 171-182)

Grazanio A.M. (1975) - Child without tomorrow. Rehabilitation Literature 36.5 (p. 151)

Groot A.D. de (1959) - Wetensehap en leven. Volksuniversiteitsbibliotheek No.62. De Erven F. Bohn N.V. Haarlem.

Groot A.D. de (1966) - Methodologie, grondslagen van onderzoek en denken in gedragswetenschappen. Mouten en co "s Gravenhage.

Guilford J.(1954) - Psychometric methods 2d ed. Mc. Graw Hill New York

Guilford J.P., Hoepiner R. (1971) - The analysis of intelligence. Mc. Graw Hill series in Psychology, Mc. Graw Hill Book Company, New York.

Gunzberg H.C. (1973) - Sociale vaardigheden voor geestelijk gehandikapten. Orrhoreeks, Lemnisoat, Rotterdam.

Gunzberg H.C. (1974) - P.A.C. Manual progress assessment chart of social and personal development. Manual 3rd Edition. Sefa Publications L.T.D., Burmingham.

Haring N.H., Hayden A.H., Allen K.E. (1971) - Programs and projects: Intervention in early childhood. Educational Technology febr. (p. 52-61). 
Harris F.A. (1974) - Electronic sensory aids as treatment for cerebral palsied children. Physical Therapy 54,4 (p. $354-365)$.

Hawryluk A. (1974) - Rehabilitation gain. A new criterion for an old concept. Relhabilitation Literature $35,11(\mathrm{p}, 322-328)$.

Hefferline $R F_{n}(1962)$ - Learning theory and clinical psychology - An eventual symbiosis. In : Experimental foundations of clinical psychology (p. 97-128) Ed: Bachrach A.J., Basic Books, Inc. Publishers New York.

Heystek W. (1975) - Vardigheidsdiagnostiek en modifikatie. Voordracht gehouden op het colloquium voor revalidatie geneeskunde. Utrecht (in press).

Hilgard E.R. (1956) - Theories of learning. Appleton Century Crofts. New York.

Hogg C. (1974) - Early infantile autism. Canadian $\mathbb{I r}$. Occ. Ther. 41, 3 (p. 58-64).

Holland A.L., Sonderman J.C. (1974) - Effects of a program based on the token test for teaching comprehension skills to aphasics. Jr. Speech and Hearing Research. 17,4 (p. 589-598).

Hollon T.H. (1973) - Behavior modification in a community hospital rehabilitation unit. Arch. Phys. Med. Rehabil. 54 (p. 65-68).

Hooft F. van het (1975) - Schedeltraumata. De Nederlandse Bibliotheek der Geneeskunde. Deel $92($ p. 48-73)

Ibbotson J. (1975) - Psychological effects of physical disability. British Jr. of Occupational Therapy 38,1 (p. $5-6$ ).

Katales I.M. (1971) - The role of accupational therapy in the early stages of rethabilitation of the head injury. Occupational Ther., febr. (p. 30-35).

Kanfer F.H., Philips J.S. (1970) - The behavioral learning model in clinical psychology. In: Learning Foundations of Behavior Therapy (p. 54-74). Ed: Kanfer F.H., Philips J.S. University of Cincinnati and Massachussets. John Wiley and Sons Inc. New York.

$\mathbb{K}$ atz.P.A., Deutch M. (1964) - Modality of stimulus presentation in serial learning for retarded and normal readers. Perceptual and Motor Skills 19 (p. 627-633):

Katz S. (1974) - Leisure time problems of metally retarded graduates of training programs. Mental Retardation 12,3 (p. $54-57$ ):

Kazdin A.E. (1973) - Issues in behavior modification with mentally retarded persons. American Journal of Mental Deficiency, 78,2 (p. 134-140).

Kerlinger F.N. (1972) - Foundations of behavioral research, educational and psychologicall enquiry. Holt, Rinehart and Winston, London.

Keil E.C., Barbec J.R. (1973) - Behavior modification and training the disadvantaged job interviewee. Vocational Guidance Quarterly 22, (p. 50-56).

Kephart N.C. (1971) - The slow learner in the classroom. Charles E. Merril U.S.A.

Kephart N.C. (1973) - Hekkesluiters 1,2 en 3. Sensomotorische ontwikkeling van moeizaam lerende kinderen. Lemniscaat., Rotterdam.

Koekkoek J. (1977) - Mediatie therapie in de revalidatie: Begeleiding in en door het thuismilieu. De Psycholoog XII Nr. 4 (p. 133-156).

Kolderie M.L. (1971) - Behavior modification in the treatment of children with cerebral palsy. Physical Therapy $51,10(\mathrm{p}, 1083-1091)$.

Koolen H.J. (1974) - Basisbewegingstherapie, theorie. Agon-Elsevier, Amsterdam.

Klages L. (1928) - Die Grundlagen der Charakterkunde, funfte und sechste Auflage, Johann Ambrosius Barth, Leipzig:

Krasner L. (1969) - Behavior modification, values and training. The perspective of a psychologist. In: Behavior Therapy: Appraisal and status. Ed: Franks C.M., Mc. Graw-Hill Book Company, New York.

Krech D., Crutchfield R.S., Ballachey E.L. (1962) - Individual in sociaty: a textbook of social psychology. Mac. Graw Hill Book Company Inc. New York.

Kugel J. (1976) - Psychologie van het lichaam. Aula 488.

Larsen J.J. (1973) - Factors in reading achievement; an interdisciplinary approach. Jr. Learning Disabilities 6,10 (p. 636-644)

Leche P.M. (1974) - The speech therapist and hemiplegia. Physiotherapy 60,11 (p. 346-349).

Leibowitz J. M. Holcer P. (1974) - Building and maintaining self-feeding skills in a retarded child. American Jr. of Occupational Therapy 28.9 (p. 545.548 ). 
Lindeboom J. (1976) - Geheugentraiming. Lezing gehouden onder auspicien der Ned. Vereniging voor Neuro-psyclologic: Utrecht. (niet gepubliceerd)

Linden E. v.d.(1975) - Kinderen met minimal brain disfunction. Ned. Tijdschrifo Psychologie $29(601-630)$

Linquisti E. F. (1953) - Design and analysis of experiments in psychology and education. Houghton Miffin Company, Boston.

Linschoten J. (1964) - Gedrag. In: Udolen van de psycholoog (p. 396-399), Bijleveld, Litrecht

Loney J. (1974) - The intellectual functioning of hyperactive elementary school boys. A cross-sectional investigation. Am. Jr. Orthopsychiatr. 44,5 (p. 754-762).

Lord F. (1954) - Further comments on "football numbers". American Psychologist IX.

Lundin R.W. (1967) - Personality theory in behavioristic psychology. In: Concepts of Personality (p. 257-290). Ed: Wepman J.M. and Heine R. W. Aldine Publishing Company, Chicago.

Luria A.R. (1966) - Higher cortical functions in man. Basic Books, New York.

Marinkelle A.B. (1969) - Experimentelle schaal voor de gedragsbeoordeling in de psychiatrie. Assen (niet gepubliceerd).

Mark HJ. (1962) - Elementary thinking and the classification of behavior. Science 135, (p. $75-87$ ).

Mark H.J. (1969) - Psychodiagnostics in patients with suspected minimal brain dysfunction. In: Minimal brain dysfunction in children. Dept. of Health, Education and Wellfare. P.H.S. Publ no $2015 \mathrm{~N}$ and SDCP Monograph. Bethesda Md, U.S.A.

Mc. Kenzie H.S., Egner A.N., Knight M., Perdman P.F., Schneider B.M., Gawin J.S. (1970) - Training consulting teachers to assist elememtary teachers in the management and education of handicapped childien. Exceptional Children, okt (p. 137-144).

Meel J.J.M. - stamensteller(1975) - De ontwikkeling van temporalle integratie. (Heyden A.H.C. van der - lonken naar lezen. Schroots J.J.F. - temporele orde in het lees leerproces. Feltzer M.J.A. - ontwikkeling van temporele integratie in de warneming). Nederlands Tijdschrift voor de Psychologie, 30/4-5.

Meyerson L. Kerr N. Michael J.L. (1967) - Behavior modification in rehabilitation. In; Child development readings in experimental analysis, (p. 214-239), Ed: Byou W., Bear D.M., Appleton Century - Crofts, New York.

Mierlo J.M.A. van (1976) - Communicatology (the choice peeper). A new technical approach to communicational problem solving. Son, the Netherlands.

Mitchell A.R.K. (1971) - Psychiatric consequences of head injuries. Occupational Therapy, febr. (p. 25-29).

Moor W. de, Orlemans J. W.G. (1972) - Inleiding tot de gedragstherapie. Van Loghum Slaterus, Deventer.

Mordock J.B. (1971) - Behavioral problems of the child with minimal cerebral dysfunction. Physical Therapy, 51,4 (p. 398-404).

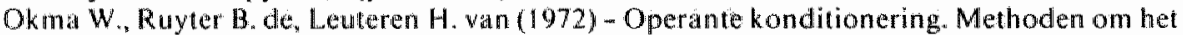
gedrag van zwakzinnigen te veranderen. De Tijotstroom, Lochem.

Ozer M.N., Richardson H.B. (1974 - I) - The diagnostic evaluation of children with learning problems. A "Process Approach". Jr. of Learning Disabillitiles 7,2 (p. 30-34)

Ozer M.N., Dworkin N.E. (1974-2) - The assessment of children with learning problems: an in-service teacher training program. Jr. Learning Disabilities, 7,9 (p. 539-544).

Pearson E.S., Hartley H.O., (1956) - Biometrika tables for statisticians. Volume I (p. 138). Canbridge.

Perske $R_{n 4}$ Marquis J. (1973) - Learning to live in an appartment: Retarded adults from institutions and dedicated citizens. Mental Retardation, 11,5 (p. 18-19).

Philage M.L. Kuna J.D. (1975) - The therapeutic contract and L.D. families. Academic Therapy 10,4 (p. 407-411).

Poor $C$., Filtcher $C$., Thielgens $\$$., Gutknecht $G$., Morgan $C .,(1975)$ - Vocational potential assessment. Arch. Psych. Med. Rehabo, 56 (p. 33-36).

Prins R.S., Wagenaar E. (1975) - Op bezoek bjjprof. Luria. Een overzicht van zijn opvattingen over afasie in theorie en praktijk. Logopedie en Foniatrie, 47 (p. 206-222). 
Raven E. (1966) - Vraagstellingen bij het psychologisch onderzoek in de Tweede Psychiatrsche Universiteitskliniek te Utrecht. Mededelingen van het instituut woor klinisch en industriele psychologie van de Rijksuniwersiteit ie Utrecht, nr. 10, Utrecht.

Reed $\mathrm{LC}$. (1967) - Reading achievement as related to differences between WISC verbal and performance 1Q's. Child Development 38, 3 (p. 836-839).

Reissenweber M. (1953) - The use of modified block design in the evalwation and training of the brain injured. Psychological Monographs, voll. 67.

Reitan R.M. (1966) - A research program on the psychological effects of brain lesions in human beings. In: International review of research in mental retardation. vol. 1 ( $\mathrm{p}$. 153-218) Ed: Ellis N.R, Academic Press, New York.

Reitan R.M. (1968) - Manual for administration of neuropsychological testbatteries for adults and children. Neuropsychological laboratory, University of Washington. Seattle, Washington.

Reitan $\mathbb{R}$.M. (1969) - Examples of children with brain lesions and children with neuropsychological diagnostic problems: Neuropsychology Laboratory. University of Indiana, Medicall Center, Indiana.

Resnick L., Wang M.C., Kaplan J. (1973) - Task analysis in curriculum design: A hierarchically sequenced introductory mathematics curriculum. Jr. Applied Behavior Analysis $6,4,(p .679-709)$.

Riele H.F.W. te (1975-2) - Huisarts en revalidatie. Revalidatie, 21, 7/8 (p. 7-9). stabesprekingen in het Rawalidatie Centrum "Hoensbroeck", (niet gepubliceerd).

Riele H.F.W. te (1975-2) - Huisarts en revalidathe. Revalidatie, $21,7 / 8$ (p. 7.9).

Rooyen P.J.A. van (1976) - .Het revalidatie centrum": een proeve van een typologie van het revalidatie centrum als instituut voon gezondheidszorg. VRIN-rapport.

Rosenthal T.I., Zimmerman B.J. (1972) - Modeling by exemplification and instruction in training conversation. Developmental Psychology, 6 (p. 392-401).

Rosinsky R.W. (1975) - Evaluating the severely disabled. The Controlled Environmental Laboratory Evaluation. Rehabilitation Literature, 36, 10 (p. 302-305).

Ross A.O. (1966) - Conceptal issues in the evaluation of brain damage In: Brain damage and mental retardation; a psychological evaluation (p. 20-43). Ed: Khanna J.L., Springfield, III.

Ross D.M. and Ross S.A. (1973)-Cognitive training for the E.M.R. child: situational problem solving and planning. Am. Ir. Mental Deficiency 78,1 (p. 20-25).

Ross D.M. and Ross S.A. (1974) - The pace-maker: primary curticulum, Belmont Calif.

Rümke H.C. (1951) - In leiding tot de karakterkunde, derde herziene druk. De Erven F. Bohn N.V. Haarlem.

Ruyter C.W. de (1974) - Revalidatie, een multidisciplinaire opgave. Metamedica 5, (p. 92-94).

Saan R.J., Schoonbeek H.R. (1973) - Problemen bij de behandeling en de evaluatie van een patient met rekenstoormissen. In: Klimische Psychologie in Nederland II (p. 223-256). Ed: Cassee A.P. Boeke P. Barendregi J., Deventer.

Sand P.L., Trieschmann R. B. Fordyce W.E., Fowler R.S., (19\%0)-Behavior modification in the medical rehabilitation setting. Rational and some applications. Rehabilitation Research and Practice Review 1,2 (p. $11-24)$.

Sarno M.T., Sands E. (1970-1) - An objective method for the evaluation of speech therkp in aphasia. Archives of Physical Medicine and Rehab., 51 (p. 49-55).

Sarno M.T., Silverman M., Sands $\mathbb{E}_{.4}(1970-2)$ - Speech therapy and language recovery in severe aphasia. Ir. of Speech and Hearing Research, 13 (p. 607-623).

Savage A. (1971) - Perception and perceptual training activities. Occupational Therapy, frobr. (p. $36-41$ ).

Schef T.J. (1966) - Being mentally ill: a sociological theory. Aldine Publishing Company. Chicago.

Scherzer A.L. (1973) - Educational and social development among intensively treated young patients having cerebral palsy. Arch. Phys. Med. and Rehab. 54, 10 (p, 478-484).

Schroots J.J.F. (1972-1)-Prediktie, inferentie en decisie, een evaluatie van de neuropsychologische test. Nederlands Tijdschrift voor de Psychologik, 27, 6 en 7 (p. 309-340).

Schroots J.J.F., Hecht Ponger S.D. (1972-2) - Psycho-diagnostics in brain dysfunctions. A seminar organized by the Netherland Institute for Preventive Medicine T.N.O. Leidien. 
Schroots I.J.F. (1974) - Vroegtijdig herkenning van leerstoonissen, Leidse Diagnostische Test: konstruktie en prychometrische verkenning. Nederlands Instituut voor Preventieve Geneeskunde T.N.O. Leiden.

Schubert J. (1967) - Effects of training on the performance of the WISC, blocik design subtest. British Jr. of Social and Clinical Psychology, 6 (p. 144-149)

Schuernan 1. A (1974) Psychologische diagnostiek en behandelingsmogelikheden bij hersentraumata. Meta Medica 5 (p. 98-102).

Schuerman I.A. (1975-1) - Perspektief van de contusio cerebrie in de revalidatie. De Psycholoog 10,3 (p. 83-95).

Schuerman J.A. $(1975-2)-$ Perspectief van de contusio cerebri in de revalidatie (slot). De Psycholongig, 10,5 (p. 227-251).

Shapiro M.B. (1966) - The single case in clinical psychological research. Jr. of General Psychology, 74 (p. 3-23).

Silver A.A., Hagin R.A., Hersch M.S. (1967) - Reading disability, teaching through stimulation of deficit perceptual areas. American Jr. of Orthopsychiatry 37, (p. 744-752).

Snelbecker G.E. Fullard W., Reiling $A_{\text {. }}$ Love G. (1974) - Auditory information processing by normal and CVA hemiplegic adults. Perceptual and Motor Skills, 38 (p. 855-860).

Spitz J.C. (1968) - Statistiek voor psychologen, pedagogen, sociologen. 3e druk. NoordHollandse Uitgeversmatschappij, Amsterdam.

Tate B.G.,Baroff G.S. (1976) - Training the mentally retarded in the production of a complex product: a demonstration of work potential. Exceptional Children 33,6 (p. 405-408).

Thomson I. V. (1974) - The patient with severe head injury and his family. A follow-up study of 50 patients. Scandinavian Jr. Rehab. Med. 6,4 (p. $180-183$ ).

Trieschmann R.B. (1974) - Coping with a disability. A sliding scale of goals: Arch. Phys. Med. Rehabil. 55. dec. (p. 556-560).

Ullman L.P., Krasner L. (1965) - Case studies in behwvior modification. Holt, New York.

Uliman L.P. Krasner L. (1969) - A psychological approach to abnormal behavior. Prentice Hall Inc. Englewood Cliffs, New Yersey.

Underwood C.S. (1974) - Occupational therapy in the early stages of hemiplegia. Physiotherapy, 60, 11 (p. 343-345).

Vester F. (1976) - Hoe wij denken, leren en vergeten. Bosch en Kenning, Baarn, De Fontein, Bilthoven.

Villiers J.G. de, Naughton J.M. (197.4) - Teaching a symboll language to autistic children. Jr. Consulting and Clinical Psychol. 42,1 (p. 111-117).

Walker H.M. Buckley N.K. (1968) - The use of positive reinforcement in conditioning attending behavior. $\mathrm{M}$. Applied Behavior Analysis 1,3 (p. 245-250).

Wehman P.H. (1975) - Toward a social skill curriculum for developmentally disabled clients in vocational settings. Rehabilitation Literature 36,11 (p. 342-384).

West M.G. (1975) - A 3-D program for L.D. children. Academic Therapy, 10, 3 (p. 309-319).

Wilt N.A. (1973) - Behavior therapy techniques in treatment of emotionally, disturbed children and their family Child Welfare $11,8(\mathrm{p} .4834491)$.

Winkelstein E., Shapiro B.J., Bernard J., Shapiro P.P., (1973) - Art, curricula and mental retarded preschoolers. Mental Retardation 11,3 (p. 6-9).

Wright B. (1960) - Physical disability - a psychological approach. Harper, New York.

Yates A.J. (1966)-Psychological deficit. In : Annual Review of Psychology, 17 (p. 111-144).

Ed: Farnsworth P. R. Me. Nemar O. and Mc. Nemar Q. Palo Alto, Calif:

Yates A.J.(1970) - Servo mechan istic control of behavior. In: Behavior therapy. (p. 37-41) Ed: Yattes A.J. University of Western Australia, John Wiley and sons Inc. New York.

Yoder P. Forehand R. (1974) - Eflects of modeling and verbal cues upon concept acquisition of retarded and non retarded children. American Jr. of Mental Deficiency 78,5 ( $p$. $566-570)$.

Zaad Ch.P.M. (1975) - Opvoeding en behandeling van kinderen na een ernstig schedelletsel. Tijdschrift voor Orthopedagogiek. 1 (p. 20-29).

Zimmerman J. (1969)-Operant conditioning in a sheltered workshop. Rehab. Lit. 30,11 (p. $326-334)$ 


\section{BIJLAGEN}




\section{GEDRAGSOBSERVATIESCHAAL CONTUSIO CEREBRI (GOCC)}

\section{Aanwijzingen voor de beoordelar}

Ie. Op elk van de hiverna wolgende bladzjdem vindt u een serie gedragsomschrijvingen. ledere serie bestaat uit altijd 5 omsehrijvingen van war te nemen gedrag.

20. Het is de bedoeling dat u niet meer dan één patient tegetijk beoordeelt. $U$ wordt verzocht telkens een bladzijde voor u te nemen, de serie beschrijingen op deze bladzijde door te lezen en dan datait die omschrijving te kiezen, die het meest op het gedrag van patient van toepassing is. Het nummer var de gekozen omschrijving omcirkelt $u$ op het andwoordformulier. Hierna doet u hetzelf de an de hand van de wolgende bladzijden met de volgende serie omschrijwingen.

3e. U vult dus het gehele antwoordformulier in voor éen patiënt. Pas daarna gaat u over op de beoordeling van ean eventueel volgende patient.

4e. Het zal weleens gebeuren dat het moeilijk is een keuze te doen. Het kan gebeuren dat geen van de omschrijwingen van een serie precies het gedrag van deze patient weergeeft of dat u verscheidene omschrijuingen van toepassing windt. In dat geval moet u toch éen omschrijving kiezen en dus slechts één nummer op het antwoordformulier omcirkelen. In de rubrick ..opmerking" op het antwoordformulier kunt u dan aangeven in welk opzicht de omschijijing niet voldoet.

5e. De invulling der antwoordformulieren moet steeds plaatsvinden op de $2 \mathrm{e}$ en $4 \mathrm{e}$ donderdag van de maand. De daaropvolgende dag ( 2 e en $4 \mathrm{e}$ vrijdag van de maand) moeten de antwoordformulierem per interne post verzonden worden naar de afdeling psychologie.

6e. S.v.p. geen onderling overleg tussen beoordelaars, en ook niet met het overige personeel.

7e. De beoordeling moet tot stand komen op grond van eigen observavie van de patient. Hiertoe moet de beoordelaar in de betrefende periode van $\$ 4$ dagen driemaal gelegenheid tot observatie nemen. Pas indien eigen observatie niet gerealiseerd kan worden mag de beoordelaar "indrukken verzamelen" van het behandelend personeel. Deze indrukken moeten echter met voorzichtigheid gewogen en met elkaar vergeleken worden.

\section{VERVOLG BIJLAGE I}

\section{Irems}

\section{Huilen}

5. Huilt zonder aanleiding en half uur achter elkat of langer.

4. Huilt dikwijls, ook wel zonder anleiding.

3. Huilt soms, maa eigenlijk alleen bij het spreken over, het zien van sentimentele onderwerpen, of het spreken over eigen probleem.

2. Huilt zelden, en dan alleen bij zeer verdrietige gebeurtenissen of verwelende behandelingen.

1. Huilt nooit.

\section{Angstig gedrag}

5. Voortdurend angsten aanwezig, het gesprek wordt voortdurend door angst beheerst, er is vrees en wanhoop, eventuel zijn er fobieën.

4. Patient is snel in paniek en in consternatie; op zulke momenten beheerst de angst hem volledig: hij is niet instaat op zulke momenten angst te verbergen.

3. Er is weliswaar over het algemeen angst aanwezig maar patiënt kan zich van deze angstgevoelens losmaken; hij doet moeite ze te verbergen en hij kan over gewone onderwerpen praten.

2. Van angsten merkt men alleen onder bepaalde omstandigheden iets; in een normaal gesprelk merkt men van angsten niet veel.

1. Van angsten bemerkt men niets. 
III Neerslachtige stemming/depressief

5. Vrijwel altijd erg neerslachtig, prat over stuicide (Het leven heeft geen zin meer voor patiënt).

4. Erg neerslachtig, lijkt suicidaal, matar prat er niet spontaan over.

3. Alleen "smorgens of alleen "s avonds somber gesterid, stil en erg teruggetrokken.

2. Slechts een enkele maal in zichzelf getrokken, still en in zichzelf piekerend.

1. Van een sombere stemming of van een downstemming blijkt niets.

\section{Klagen}

5. Patiènt klaagt vrijwel altijd over van alles en nog wat; zeurt ontzettend; moppert over een heleboel dingen en mensen.

4. Patiënt klaagt regelmatig, zeurt nogal veet.

3. Patient klaagt spontaan slechts een enkele mal, maar bij nawrag dikwijls over allerlei zaken.

2. Patient klaagt nooit spontaan maur bij novraag blijkt er toch een enkele maal iets niet te deugen.

1. Patiënt klasgt spontaan niet, maar bij navraag ook niet.

\section{Onzelfstandig gedrang}

5. Patient is slaafs en te volgzaam. Kan geen eigen besluiten nemen. Is onzeker, weifelend in iedere aktiviteit die hij onderneemt.

4. Patient komt zelden tot eigen besluitworming. Vraagt daarom regematig advies en beslissingen van anderen.

3. Afwisselend momenten van onzekerheid en advies vragen met momenten waarin well tot gericht handelen en besluitvorming wordt overgegaan.

2. Over het algemeen een wat onzelkere opstelling, maar komt over het algemeen toch tot gericht handelen en besluitvorming.

1. Van onzekerheid, twijfelen, blijkt niets. Patient regelt zijn eigen zaken en heeft geen advies nodig.

\section{Zich afzonderen}

5. Patiënt schenkt in het geheel geen aandachl aan verpleging/therapeuten/patiënten. Vermijdt ieder kontakt. Pogingen tot het leggen van kontakten lopen op niets wit. Lijkt in zichzelf opgesloten, ook al dringt men erop alan dat hij meedoet.

4. Kontakt tol stand brengen lukt met verpleging/therapeuten/patienten slechts voor korte tijd ( $\pm 5 \mathrm{~min}$.) en dan alleen bij aandringen of gebruik van veel takt, doet patiënt eventjes mee en prait eventjes.

3. Patiënt zoekt een enkele maal uit zichzelr kontakt met verpleging/therapeuten/patiènten. Hij trekt zich snel terug op zichzelr, er gitat verder weinig van hem wit.

2. Patiënt zoekt uit zichzelf wel kontakt met verpleging, therapeuten/patienten, mar is wat te bedeesd of verlegen. Patiènt is toch in stat het gesprek of bezigheden enige tijd gatande te houden.

1. Van te grote geremdheid, bedeesdheid, verlegenheid, blijkt in het kontakt met verpleging/therapeuten/patiênten niets.

\section{Aandacht vragend, opdringerig}

5. Patiënt is voortdurend hinderlijk of opdringerig en last verpleging/therapeuten/pattienten bijna "geen moment met rust". Is een klever, wil altijd haantje de voorste zijn, maakt altijd opmerkingen, wil het centrum van atandacht zijn. Dringt hulpwardigheid op.

4. Patient is zelden in stat tot een rustig kontakt. Hij vraagt dikwijls aandacht door zijn houding of vertoont overdreven jovial gedrag. Is een uitslover, wil op overdreven wijze iedereen helpen, probeert andacht te trekken door grappig te zujn.

3. Patiënt neigt tot druk, joviaal, opdringeriggedrag, maar als men hem laat merken dat men rustiger kontakt op prijs stelt, dan is patient hiertoe in staat. Er is toch nog wel duidelijke kontaktbehoefte, 
2. Er is af en toe sprake wan dudelijke konaktbehoefte, maar er zijn sporadisch momenten vat druk, overdreven gedrag.

1. Var opdringerigheid of sterke kontak tbehoefte is geen sprake. Patiënt gaat gewoon zijn garige

\section{VIllla Dwangmatig gedrag in werk}

5. Werkt veel te precies, mawgezet en pietepeuterig. (1s wel steeds bezig, toch blifit hij steken en er komt wrijwel niets uit zijn handen).

4. Werkt te perfektionistisch (maar wat klaar komt is perfekt en af, het duurt echter wel te lang).

3. Werkt erg zorgvuldig wardoor hij meestal onvoldoende produceert en te traag is.

2. Wat hij affevert, is meestal prima. Door de iets te grote preciesheid produceert hij meestal nog net voldoende.

1. Van te precies of te nauwgezet werk blijkt niets.

\section{Dwangmatig gedrag in zelfverzorging}

5. Pattiént is dagelijks zeer lang en eventueel op rituele wijze bezig met de verzorging van zijn lichaam, uiterlijk, kleding, leefruimte. Hij kan geen wanorde, wuil e.d. om zich zien. Zonder hulp of aansporing komt hij niet klaar.

4. Pationt is langdurig en vaak dwangmatig bezig met de lichamelijke verzorging en andere verzorging, mar kan er tenslotte zelf wel een eind aan maken.

3. Patiënt vertoont bij de verzorging varn lichaam en kamer een overdreven aandacht. zorgultigheid of pietepeuterigheid en is daardoor steeds te laat klaar.

2. Patient besteedt een wat overdreven aandacht aan verzorging van lichaam en ruimte waarin hij leeft.

1. Patient is niet overdreven neljes, noch dwangmatig in zelfwerzorging.

\section{Euphorie}

5. Voortdurend llacherig, opgewekt en blij, zelfs indien de omstandigheden (handicap) eerder een downstemming zouden doen vermoeden. Dwanglachen en overdreven lang doorisacheri.

4. Landurig perioden van opvallende opgewektheid en blijheid. Lacht op onevenwichtige wijze vaak te vel (lachbuien eventueel waak afgewisseld met huilbuien).

3. Lacht verscheidene malen in zichzelf. Lacht verscheidene malen te opgewekt.

2. Lacht een enkele maal in zichzelf. Glimlacht nogal vaak of lacht dikwijls als enige. lets te overdreven lachen.

1. Van overdrewen lachen blikt niets. Lacht niet op abnormale wijze, noch abnormaal veel.

Xal Slordigheid in werk, met gereedschap ed.

5. Wat patiem aflevert zit vol fouten, het is niet af. Patient laat allijd gereedschap slingeren. ondarhoudt het niet, rumt niets op.

4. Als men ei nawlettend op toeziet of andringt neemt de slordigheid al en ruimt hij wat op. Mar aan zichzelf overgelaten neemt het slordige gedrag weer toe.

3. Patient let in het algemeen zell op alwerkung, kwaliteit en fouten. Hij ruimt ook meestal alles wel op, matar men moet een oogje in het zeil houden en ansporing is nog wel nodig.

2. Putient zorgi grotendeels uit eigen beweging voor goede kwaliteit en woor opruiming. Slechts af en toe hapert er wat aan.

1. Varn slordigheid in werk en opruming van materiaal en gereedschap blijkt niets.

\section{Xb Slordigheid in zelfverzorging, lleefruimte}

5. Bekommert zich in het geheel niet om orde en netheid. Patient is totdal onverschillig la.v. lichamelijke verzorging. Een ander moet er steeds op letten of kleding en leefruimte netjes zijn.

4. Is er mel veel takt toe te krijgen wat op te ruimen. Verzorgt zichzelf alleen als men er numwlettend op toeztet. 
3. Met een kleine aansporing ruimt patiênt rommel op. Patiënt heeft wel enige aandacht voor lichaam en kleding, maar men moet toch een oogis in het zell houden, anders gaat her met de franse slag.

2. Is meestal netjes thit zichzelf. Er hapert slechis af en toe wat aan.

1. Van onzorgvuldigheid in de verzorging wan kleding, witerlijk en leefruinte blijk niets.

\section{Niet coöperatief gedrag}

5. Patiênt ontrekr zich voortdurend aan de voorschriften en afspraken. Zijn onverzettelijkheid en weerspanmigheid maken hem niet korrigeerbaar. Hij helpt nooit mee, zelfs niet bij de grootste atandrang.

4. Patient ontrekt zich aan afspraken en voorschriften als hij er de kans toe krijgt. Hij helpt alleen bij zeer sterke aandrang mee.

3. Patiènt houdt zich aan de regels zij het niet altijd even gewillig en hij zal zich niet spontaan voor ardeling en werpleging inzetten. Helpt alleen als het om lets prettigs gatat en fils hem hierom gevraagd wordt.

2. Patiënt helpt spontaan, vooral bij prettige aangellegenheden. Hij houdt zich aan de regels en dikwijls woelt hij zich ook verantwoordelijk voor de gang van zaken.

1. Patiënt zet zich in voor afdeling en andere patiënten.

\section{Onrustig, ontremd gedrag}

5. Patent toont zich voortdurend onrustig, gespannen, gejagd en heftig geemotioneerd. Er is een overmatige bewegingsdrang. Patient is voortdurend bezig en overmatig aktief. Maakt rusteloze, altijd gehaaste indruk en kan zelden stilzitten.

4. Gelaatsuitdrukking is gespannen (broeierig). Bij perioden ook uiterlijk onrustig. gejaagd en rusteloos (bv. ijsberen op de gang)

3. Gespannenheid en on rustige gejaradheid zijn wel dik wijls merk baar, doch vooral wanneer men met patient praat (er zijn dus perioden dat het niet opvallend is).

2. Vun enige onrust en gespannentheid merkt men alleen in het gexprek iets. Over het algemeen is patient aktief bezig, hij loopor wat versneld" hij zit niet lang op dezelfde plaats. Men zou zeggen: "lets meer vlotheid dan gewoon".

1. Van onrust, gespannenheid, geja adheid, bewegingsdrang of gehaste beweging en overmatige aktiviteit, blijkt niets.

\section{Agressief gedrag/geprikkelheid}

5. Patiënt is openlijk vijandig zonder duidelijke reden. Slaat andere patienten, verplegenden of therapeuten (motorisch agressief).

4. Patiènt slatat zelden, maar is snel verbaal agressief. Hij kan dan schelden en tieren of zich dreigend opstellen en raakt voortdurend in een konfliktsituatie met patiënten, verplegenden of therapeuten.

3. Patiènt gedraagt zich alleen bij vriendelijke en taktvolle benadering door omgeving wriendelijk en beleefd. Anders reageerl hij gauw geprikkeld en geïrriteerd.

2. Patient gedragat zich meestal vriendelijk en beleerd, maar is een enkele keer iets onistemd en kan dan weinig hebben.

1. Pewtient is bijna nooit boos, alleen als er een goede reden voor is en dan waak zelfs ook niet eens.

\section{Agressief gedrag in de zin van domineren, sfeer bederven}

5. Patient tracht woortdurend andere patienten ongunstig te beînvloedem. Hij tracht ook verpleging en/of therapeuten te intimideren en zells te overheersen.

4. Patiènt tracht zijn omgeving voornamelijk te overheersen d.m.v. intrigeren, opstoken tegen elkaar, ageren en protesteren.

3. Patient stelt zich to.v. medepatiënten vaak bedillerig, bemoeizuchtig of baasspelerig op. Hij heeft altijd zijn mening klaar en verkondigt die als enige watheid.

2. Patiënt heeft wel iswar dik wijls zijn "mening" klaar doch hij tracht deze slechts af en toe atu anderen op te dringen.

1. Van ongunstige beïnvloeding, overheersen of sfeerbederr blijkt bij patiënt niets. 


\section{Inaktiviteit/traagheid}

5. Patient zit voortdurend op dezelfde plaats. Als hij zich eens een keer beweegt, gaat dat allijd largzam. Hij reageert vrijwel niet op aansporingen. Patient makt een willoze, llevensiloze indruk.

4. Patient blijft lang op dezellde plats zitten, beweegt zich over het algemeen weinig en tratan madr yeageert wel op aansporingen.

3. Patiants alktiviteit is over het algemeen niet groot, hij loopt betrekkelijk traag mat hij is op verzoek tot vergrote of versnelde aktiviteit te $\mathrm{kriljgen.}$

2. Patient is eigenlijk wel voortdurend spontaan aktief bezig. 2 kn handelingen en bewegingen zijn voldoende alwisiselend, maar over het algemeen zijn zij nog iets te traag.

I. Van enige tratagheid, onbeweeglijkheid, starheid of te geringe aktiviteit is geen sprake.

\section{Ongemotiverdheid}

5. Patient gedragt zich willoos, passief, initiatiefloos. Toont weerstand of geen lust woor wrijwel alle therapieèn en aktiviteiten. Trach zich op alle mogelijke manieren aan deze zaken te ontrekken. Verschint niet of weel te laat op afspraken.

4. Patient oppert een enkele maal ideeen of plannen, maar ze worden nooit uitgevoerd. Toont in het algemeen weel weerstand tegen therapieën. Alleen met weel takt is patient ergens toe te krijgen of bezig te houdten.

3. Brengt alleen maar aandacht op voor het werk dat hij zelf wil. Zet ideeên soms om tot daden. Komt op therapie, mat doet matig zijn best.

2. Doet mee met de meeste soorten varn werk en therapie. Hij heeft nog wall moeite zich te schikken en zijn best te doen in werk of therapie als dit hem niet alanstaat.

1. Doet ijverig mee, van weerstand of ageren blijkt niets. Patiënt is aktief. Doet zelf suggesties, heeft er echt zin in.

\section{Gebrek aan zelfkritiek}

5. Maakt de meest fantastisehe plannen voor de toekomst. Bagattelliseert zijn gehandicapt zijn: is zeer zelfwerzekerd. Is impullsief, resoluut, roekeloos. Kom bij kritiek niet tot korrectie wan zijn ziens. en handelswijze.

4. Maakt allerlei plannen, die well reěel zijn voor gezonde, maar minder voor de gehandicapte mensen. Is wel impulsief, roekeloos of resoluut, maar komt bij a ansporingen, kritiek toi korrektie.

3. lets te zel lverzekerd en te snelle besluit worming. Kan echter wel naar anderen luisteren. Het is mogelijk met hem het probleem te bespreken, maar meestal worden reële verwachtingen en ideeën door hem tegengesproken.

2. Overweegt in het algemeen eerst rustig en komt vervolgens tot een gericht besluit en tot reëel handelen. Toch blijkt een enkele matal de zelfkritiek te gering.

1. Van overmatige impulsiviteit of te grote zelfverzekerdheid is geen sprake. Pariënt overweegt betrekkelijk nuchter zijn mogelijk lieden. 
VERVOLG BIJLAGE

\section{ANTWOORDFORMULIER GOCC}

naam van de patient:

man/vrouw/kind afd.:

naam van de observator: vd. discipline

dagen en tijdstip waarop geobserveerd:

van tot van tot wan tot

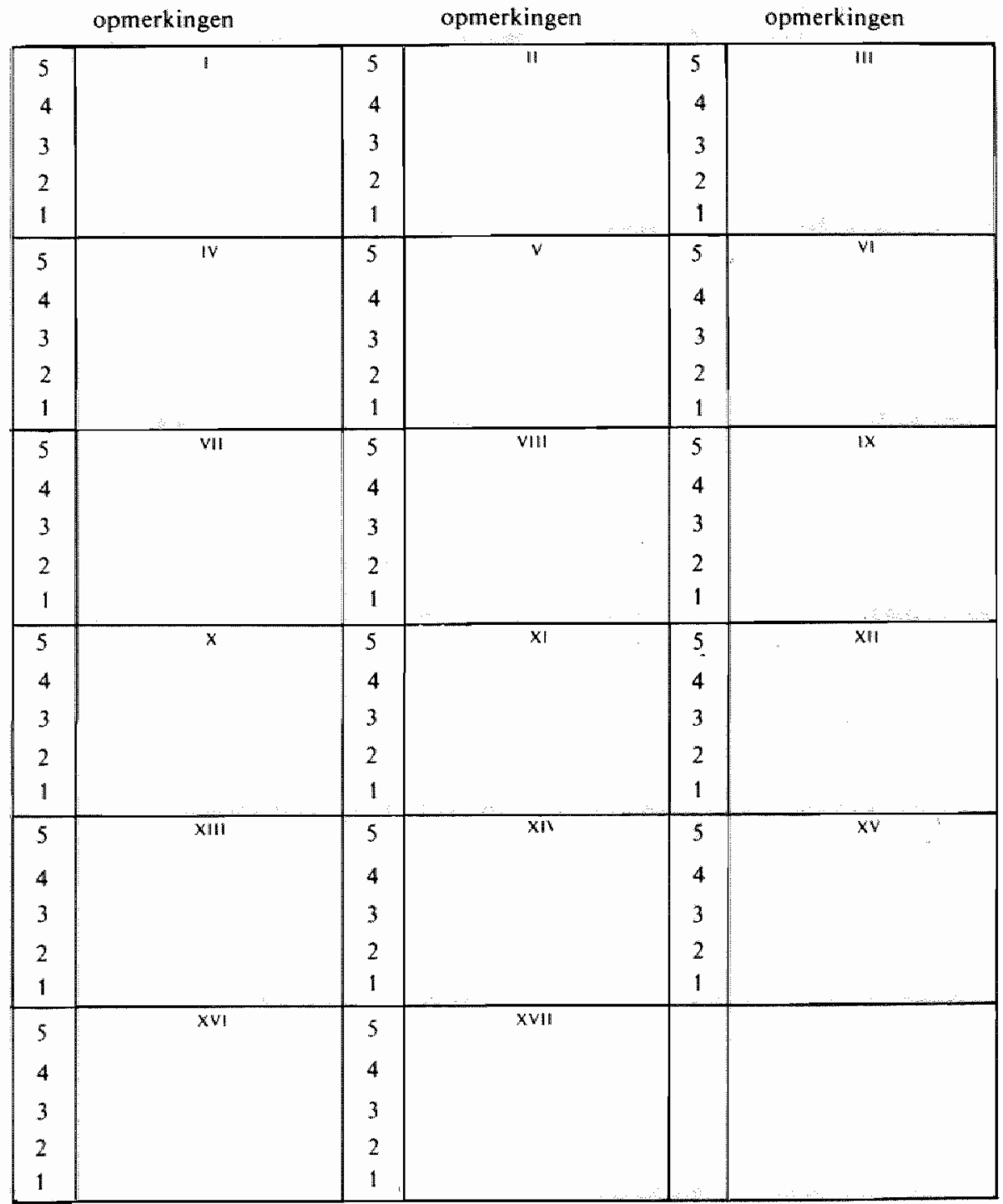


BIJLAGE 2:

VOORBEWERKINGSTABELLEN INZAKE GOCC scores.

verzameling I (dec. 1975)

\begin{tabular}{|c|c|c|c|c|c|c|c|c|c|c|c|c|}
\hline & & & A)ti & tip & mati & owerk & \multicolumn{6}{|c|}{ (C)tigdstip $\mathrm{l}_{2}$} \\
\hline ltem & \multicolumn{6}{|c|}{ Observator nr } & \multicolumn{6}{|c|}{ Observator $\mathrm{nr}$} \\
\hline $\mathbb{N} R$ & 1 & 2 & 3 & 4 & 5 & $M$ & 1 & 2 & 3 & 4 & 5 & $\mathrm{M}$ \\
\hline 1 & 22 & 24 & 24 & 19 & 23 & 22,4 & 20 & 21 & 24 & 17 & 23 & 21,0 \\
\hline 2 & 28 & 30 & 30 & 28 & 32 & 29,6 & 22 & 28 & 33 & 24 & 28 & 27,0 \\
\hline 3 & 31 & 32 & 33 & 23 & 28 & 29.4 & 25 & 29 & 30 & 21 & 27 & 26,4 \\
\hline 4 & 32 & 29 & 32 & 34 & 38 & 33,0 & 34 & 36 & 35 & 36 & 44 & 37,0 \\
\hline 5 & 42 & 40 & 38 & 41 & 42 & 40,6 & 32 & 41 & 42 & 43 & 46 & 40,8 \\
\hline 6 & 33 & 27 & 37 & 30 & 31 & 31,6 & 32 & 30 & 37 & 26 & 31 & 31,2 \\
\hline 7 & 35 & 29 & 30 & 24 & 24 & 28,4 & 32 & 31 & 35 & 30 & 40 & 33,6 \\
\hline 8 & 21 & 21 & 24 & 23 & 32 & 24,2 & 19 & 23 & 20 & 23 & 35 & 24,0 \\
\hline 9 & 24 & 22 & 24 & 24 & 24 & 23,6 & 23 & 23 & 24 & 28 & 28 & 25,2 \\
\hline 10 & 29 & 27 & 32 & 27 & 34 & 29,8 & 27 & 29 & 34 & 38 & 33 & 32,2 \\
\hline 11 & 40 & 36 & 37 & 40 & 39 & 38,4 & 35 & 43 & 35 & 35 & 4.1 & 37,8 \\
\hline 12 & 29 & 23 & 34 & 21 & 26 & 26,6 & 30 & 33 & 30 & 26 & 33 & 30,4 \\
\hline 13 & 33 & 28 & 32 & 22 & 30 & 29.0 & 29 & 28 & 28 & 24 & 31 & 28,0 \\
\hline 14 & 23 & 21 & 26 & 23 & 28 & 24,2 & 21 & 23 & 21 & 21 & 29 & 23,0 \\
\hline 15 & 33 & 32 & 38 & 40 & 43 & 37.2 & 35 & 32 & 34 & 37 & 44 & 36,4 \\
\hline 16 & 32 & 33 & 36 & 33 & 30 & 32,8 & 33 & 40 & 34 & 33 & 35 & 35,0 \\
\hline 17 & 29 & 28 & 28 & 28 & 32 & 30,8 & 30 & 33 & 29 & 40 & 40 & 34,4 \\
\hline
\end{tabular}

\begin{tabular}{|c|c|c|c|c|c|c|c|c|c|c|c|c|}
\hline & & & $E) t$ & $\begin{array}{l}\text { So } \\
\text { tip }\end{array}$ & 0 & er de & $\mathrm{OC}$ & $\mathrm{em}$ & G)ti & tip & & \\
\hline Pat & & & bse & tor: & & & & & bse & tor $\mathrm{r}$ & & \\
\hline$N R$ & $\mathbb{1}$ & 2 & $\overline{3}$ & 4 & 5 & $\mathrm{M}$ & 1 & 2 & 3 & 4 & 5 & $\bar{M}$ \\
\hline 1 & 35 & 34 & 44 & 40 & 53 & 41,2 & 28 & 31 & 34 & 39 & 46 & 35,6 \\
\hline 2 & 21 & 20 & 21 & 32 & 23 & 23,4 & 32 & 21 & 21 & 33 & 26 & 26,6 \\
\hline 3 & 26 & 29 & 28 & 34 & 36 & 30,6 & 27 & 30 & 30 & 36 & 38 & 32,2 \\
\hline 4 & 32 & 26 & 30 & 30 & 42 & 32,0 & 27 & 29 & 29 & 30 & 37 & 30,4 \\
\hline 5 & 35 & 42 & 45 & 30 & 44 & 39,2 & 28 & 49 & 32 & 33 & 52 & 38,8 \\
\hline 6 & 40 & 40 & 30 & 19 & 30 & 31,8 & 28 & 45 & 23 & 35 & 45 & 35,2 \\
\hline 7 & 26 & $3 \|$ & 37 & 20 & 35 & 29,8 & 30 & 25 & 39 & 19 & 26 & 27,8 \\
\hline 8 & 19 & 17 & 22 & 17 & 17 & 18,4 & 17 & 17 & 17 & 17 & 17 & 17,0 \\
\hline 9 & 27 & 20 & 30 & 20 & 19 & 23,2 & 26 & 21 & 24 & 38 & 41 & 30,0 \\
\hline 10 & 31 & 30 & 40 & 31 & 30 & 32,4 & 31 & 30 & 42 & 23 & 39 & 33,0 \\
\hline 11 & 54 & 25 & 30 & 37 & 50 & 39,2 & 29 & 33 & 44 & 34 & 33 & 34,6 \\
\hline 12 & 28 & 27 & 21 & 17 & 29 & 24,4 & 25 & 26 & 22 & 18 & 28 & 23,8 \\
\hline 13 & 26 & 30 & 25 & 49 & 25 & 33,0 & 41 & 41 & 41 & 49 & 43 & 43,0 \\
\hline 14 & 36 & 37 & 3.4 & 37 & 30 & 34,8 & 37 & 36 & 36 & 35 & 35 & 35,8 \\
\hline 15 & 35 & 28 & 36 & 19 & 24 & 28,4 & 32 & 34 & 38 & 18 & 27 & 29.8 \\
\hline 16 & 19 & 24 & 23 & 31 & 25 & 24,4 & 18 & 31 & 30 & 23 & 36 & 27.5 \\
\hline 17 & 26 & 22 & 29 & 21 & 29 & 25,4 & 23 & 24 & 23 & 22 & 19 & 22,2 \\
\hline
\end{tabular}


VERVOLG BIJLAGE 2

Verzameling ( 6 dec. 1976 )

\begin{tabular}{|c|c|c|c|c|c|c|c|c|c|c|c|c|}
\hline \multirow{3}{*}{$\begin{array}{l}\text { Ittem } \\
\text { NR }\end{array}$} & \multicolumn{6}{|c|}{ (B)tijdstip $t_{1}$} & \multicolumn{5}{|c|}{ (D)tijdstip t? } & \\
\hline & \multicolumn{6}{|c|}{ Observator $\mathrm{nr}$} & \multicolumn{6}{|c|}{ Observator $\mathrm{nr}$} \\
\hline & 1 & 2 & 3 & 4 & 5 & $M$ & 1 & 2 & 3 & 4 & 5 & $M$ \\
\hline 1 & 43 & 38 & 41 & 34 & 38 & 38,8 & 43 & 36 & 37 & 32 & 38 & 37,2 \\
\hline 2 & 51 & 47 & 47 & 49 & 54 & 49,6 & 50 & 41 & 49 & 44 & 53 & 47.4 \\
\hline 3 & 52 & 50 & 49 & 42 & 45 & 47,6 & 54 & 46 & 53 & 42 & 45 & 48,0 \\
\hline 4 & 53 & 57 & 51 & 55 & 61 & 55,4 & 58 & 55 & 61 & 57 & 70 & 60,2 \\
\hline 5 & 66 & 76 & 75 & 69 & 76 & 72,4 & 72 & 59 & 61 & 70 & 81 & 68,6 \\
\hline 6 & 56 & 57 & 56 & 51 & 54 & 54,8 & 56 & 61 & 57 & 48 & 54 & 55,2 \\
\hline 7 & 50 & 55 & 49 & 43 & 52 & 49,8 & 54 & 54 & 55 & 45 & 57 & 53,0 \\
\hline 8 & 37 & 37 & 35 & 37 & 52 & 39,6 & 34 & 34 & 36 & 37 & 54 & 39,0 \\
\hline 9 & 42 & 41 & 42 & 42 & 50 & 43,4 & 43 & 39 & 46 & 51 & 47 & 45,2 \\
\hline 10 & 62 & 56 & 51 & 44 & 60 & 54,6 & 64 & 54 & 56 & 55 & 62 & 58,2 \\
\hline 11 & 63 & 71 & 68 & 63 & 66 & 66,2 & 70 & 64 & 73 & 58 & 70 & 67,0 \\
\hline 12 & 51 & 44 & 43 & 35 & 48 & 44,2 & 46 & 47 & 55 & 49 & 49 & 49,2 \\
\hline 13 & 49 & 54 & 46 & 37 & 51 & 47,4 & 51 & 53 & 52 & 42 & 51 & 49,8 \\
\hline 14 & 40 & 41 & 41 & 38 & 47 & 41,4 & 36 & 36 & 40 & 35 & 46 & 38,5 \\
\hline 15 & 64 & 63 & 65 & 70 & 71 & 66,6 & 59 & 66 & 57 & 67 & 78 & 65,4 \\
\hline 16 & 61 & 65 & 63 & 54 & 52 & 59,0 & 62 & 64 & 67 & 54 & 63 & 62,0 \\
\hline 17 & 51 & 53 & 48 & 59 & 65 & 55,2 & 54 & 57 & 56 & 61 & 71 & 59,8 \\
\hline
\end{tabular}


VERVOLG BUILAGE 2

Verzamelling 2 (6 dec. 1976)

\begin{tabular}{|c|c|c|c|c|c|c|c|c|c|c|c|c|}
\hline \multicolumn{13}{|c|}{$\begin{array}{l}\text { Sommatie over de GOCC-items } \\
\text { (F)tijdstip } 4\end{array}$} \\
\hline Pat & \multicolumn{6}{|c|}{ Observator in } & \multicolumn{6}{|c|}{ Observator $\mathrm{nr}$} \\
\hline NR & 1 & 2 & 3 & 4 & 5 & $\mathbf{M}$ & 1 & 2 & 3 & 4 & 5 & $M$ \\
\hline 1 & 32 & 40 & 40 & 19 & 28 & 31,8 & 23 & 28 & 43 & 35 & 45 & 34,8 \\
\hline 2 & 22 & 19 & 17 & 17 & 17 & 18,4 & 17 & 17 & 17 & 17 & 17 & 17,0 \\
\hline 3 & 28 & 28 & 28 & 22 & 37 & 28,6 & 34 & 32 & 33 & 27 & 36 & 32,4 \\
\hline 4 & 23 & 27 & 25 & 24 & 34 & 26,6 & 26 & 33 & 29 & 26 & 31 & 29,0 \\
\hline 5 & 33 & 36 & 41 & 28 & 41 & 35,8 & 50 & 49 & 57 & 22 & 40 & 43,6 \\
\hline 6 & 31 & 26 & 37 & 20 & 35 & 29.8 & 39 & 30 & 27 & 19 & 25 & 28,0 \\
\hline 7 & 30 & 54 & 25 & 37 & 50 & 39,2 & 44 & 29 & 33 & 34 & 33 & 34,6 \\
\hline 8 & 40 & 31 & 30 & 30 & 30 & 32,2 & 42 & 31 & 30 & 23 & 39 & 33,0 \\
\hline 9 & 26 & 22 & 26 & 21 & 29 & 24,8 & 23 & 24 & 23 & 22 & 19 & 22,2 \\
\hline 10 & 35 & 26 & 30 & 49 & 25 & 33,0 & 43 & 41 & 40 & 49 & 43 & 43,2 \\
\hline 11 & 44 & 35 & 32 & 40 & 53 & 40,8 & 34 & 28 & 31 & 39 & 46 & 35,6 \\
\hline 12 & 30 & 32 & 26 & 30 & 42 & 32,0 & 29 & 29 & 26 & 30 & 37 & 30,2 \\
\hline 13 & 21 & 21 & 20 & 32 & 23 & 23,4 & 21 & 30 & 21 & 33 & 25 & 26,0 \\
\hline 14 & 21 & 30 & 21 & 33 & 25 & 26,0 & 23 & 30 & 24 & 32 & 39 & 29,6 \\
\hline 15 & 28 & 26 & 29 & 34 & 36 & 30,6 & 30 & 27 & 30 & 36 & 38 & 32,2 \\
\hline 16 & 30 & 27 & 20 & 20 & 19 & 23,2 & 24 & 26 & 21 & 38 & 41 & 30,0 \\
\hline 17 & 31 & 28 & 26 & 21 & 22 & 25,6 & 32 & 29 & 32 & 21 & 31 & 29,0 \\
\hline 18 & 33 & 26 & 30 & 17 & 30 & 27,2 & 31 & 26 & 28 & 24 & 26 & 27,0 \\
\hline 19 & 31 & 34 & 31 & 25 & 32 & 30,6 & 34 & 34 & 27 & 28 & 29 & 29,8 \\
\hline 20 & 22 & 22 & 22 & 21 & 26 & 22,6 & 18 & 20 & 21 & 27 & 24 & 22,0 \\
\hline 21 & 23 & 19 & 24 & 31 & 25 & 24,4 & 30 & 18 & 31 & 23 & 36 & 27,6 \\
\hline 22 & 34 & 36 & 37 & 37 & 30 & 34,8 & 36 & 37 & 36 & 35 & 35 & 35,8 \\
\hline 23 & 36 & 35 & 28 & 19 & 24 & 28,4 & 40 & 32 & 34 & 18 & 27 & 30,2 \\
\hline 24 & 27 & 29 & 23 & 33 & 41 & 30,6 & 25 & 22 & 17 & 29 & 30 & 24,6 \\
\hline 25 & 28 & 32 & 32 & 28 & 30 & 30,0 & 25 & 23 & 28 & 30 & 26 & 26,4 \\
\hline 26 & 24 & 30 & 34 & 19 & 30 & 27,4 & 27 & 27 & 33 & 18 & 29 & 26,8 \\
\hline 27 & 45 & 35 & 42 & 30 & 44 & 39,2 & 29 & 28 & 49 & 33 & 52 & 38,2 \\
\hline 28 & 44 & 47 & 45 & 38 & 28 & 40,4 & 34 & 41 & 46 & 29 & 29 & 35,8 \\
\hline 29 & 21 & 28 & 27 & 17 & 29 & 24,4 & 22 & 25 & 26 & 18 & 28 & 23,8 \\
\hline 30 & 18 & 24 & 22 & 30 & 27 & 24,2 & 21 & 23 & 18 & 32 & 33 & 25,4 \\
\hline
\end{tabular}


BIJLAGE 3:

INTER- en INTRABEOORDELAARSBETROUWBAARHEIDSCOËFFICIËNT INZAKE GOCC SKORES

GOCC skores gesommeerd over de patiënten (17 GOCC items).

Verzameling $\|$ (december 1975 )

Interbeoordelarabetrouwbaarheidscoefficiènten

Intrabeoordelaars -

\begin{tabular}{|c|c|c|c|c|}
\hline & \multicolumn{2}{|c|}{ (A) $t_{1}$} & \multicolumn{2}{|c|}{ (C) $\mathrm{t}_{2}$} \\
\hline & $\mathbb{r}_{\text {uzutst. }}$ & t-toets & 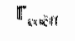 & -toets \\
\hline$r_{1.2}$ & .884 & 7.32 & .845 & 6.12 \\
\hline$r_{H-3}$ & .848 & 6.20 & .786 & 4.92 \\
\hline$r_{1-4}$ & .718 & 4.00 & .706 & 3.86 \\
\hline$r_{11-5}$ & .563 & 2.64 & .753 & 4.43 \\
\hline$r_{2-3}$ & .768 & 4.69 & .787 & 4.94 \\
\hline$r_{2-4}$ & .780 & 4.83 & .729 & 4.12 \\
\hline$r_{2.5}$ & .635 & 3.18 & .733 & 4.17 \\
\hline$r_{3-4}$ & .697 & 3.76 & .667 & 3.47 \\
\hline$r_{3.5}$ & .582 & 2.77 & .595 & 2.87 \\
\hline$r_{4-5}$ & .887 & 7.44 & .844 & 6.09 \\
\hline
\end{tabular}

betrouwbaarheidscoêfificienten

\begin{tabular}{|l|l|l|}
\hline \multirow{2}{*}{} & \multicolumn{2}{|c|}{$(\mathrm{A}-\mathrm{C}) \mathrm{t}_{1}-\mathrm{l}_{2}$} \\
\cline { 2 - 3 } & $r$ & $\mathrm{r}_{\mathrm{H}}$ \\
\hline$r_{1}$ & .834 & 5.85 \\
$r_{2}$ & .820 & 5.55 \\
$r_{3}$ & .844 & 6.09 \\
$r_{4}$ & .811 & 5.37 \\
$r_{5}$ & .776 & 4.77 \\
\hline
\end{tabular}

Student"s t-toets éénzijdig $a=.01$ $\mathrm{df}=15$

Kritieke grens: 2.60

* = niet signifikant

GOCC skores gesommeerd over de items ( 17 patiènten). Eerste verzameling (dec. 1975 )

Interbeoordelaarsbetrouwb.h.cosfficiënten

\begin{tabular}{|c|c|c|c|c|}
\hline & \multicolumn{2}{|c|}{$(E) i_{1}$} & \multicolumn{2}{|c|}{ (G) $t_{2}$} \\
\hline & $r_{\max }$ & t-toets & $r_{\text {surer }}$ & t-toets \\
\hline$r_{\ln 2}$ & .476 & $2.10^{*}$ & .448 & $1.94^{*}$ \\
\hline$r_{1-3}$ & .416 & $1.77^{*}$ & .606 & 295 \\
\hline$r_{1 / 4}$ & .201 & $.79^{*}$ & .558 & $2.16^{*}$ \\
\hline$r_{i .5}$ & .650 & 3.31 & .330 & $1.35^{*}$ \\
\hline$r_{i-m}$ & .741 & 4.28 & .724 & 4.06 \\
\hline$i_{2-3}$ & .684 & 3.64 & .433 & $1.86 \%$ \\
\hline $\mathbb{1}_{2.4}$ & .250 & $1.00^{*}$ & .447 & 1.94 \\
\hline$r_{2-5}$ & .487 & $2.16^{6 *}$ & .732 & 4.16 \\
\hline$r_{2-m}$ & .740 & 4.26 & .813 & 5.40 \\
\hline$r_{3-4}$ & .333 & $1.37^{*}$ & .226 & $.90^{*}$ \\
\hline $\mathbb{r}_{3.5}$ & .537 & $2.46^{\text {* }}$ & .329 & 1.35 \\
\hline$r_{3-m}$ & .768 & 4.65 & .651 & 3.33 \\
\hline$r_{4-5}$ & .4117 & $1.78^{*}$ & .690 & 3.70 \\
\hline$r_{4-m}$ & .616 & 3.03 & .779 & 4.81 \\
\hline$r_{5 \cdot m}$ & .854 & 6.36 & .844 & 6.08 \\
\hline
\end{tabular}

Intrabeoordellaars betrouwb.h.coëfficiëmten

\begin{tabular}{|l|l|l|}
\hline & \multicolumn{2}{|c|}{$(\mathrm{E}-\mathrm{G}) \mathrm{t}_{1}-\mathrm{t}_{2}$} \\
\cline { 2 - 3 } & $r_{\text {exin }}$ & \multicolumn{1}{|c|}{$\mathrm{t}_{\text {toet. }}$} \\
\hline$r_{1}$ & .331 & $1.36 *$ \\
$r_{2}$ & .859 & 6.50 \\
$r_{3}$ & .645 & 3.27 \\
$r_{4}$ & .730 & 4.25 \\
$r_{5}$ & .450 & $1.95 *$ \\
$r_{m}$ & .810 & 5.35 \\
\hline
\end{tabular}

Studeni"s \#-toets éênzijjüg $\alpha=.01$ $\mathrm{df}=15$

Kritieke grens: 2.60

* = niet signifikant 
BIJLACE 3 (NERVOLG):

INTER-EN INTRABEOORDELAARSBETROUWBAARHEIDSCOEFFICIENT INZAKE GOCCSKORES

GOCC skores gesommeerd over de patienten (17 GOCC items) Tweede verzameling (dec. 1976)

Interbeoordetarabetrouwbatheidscoeff.

\begin{tabular}{|c|c|c|c|c|}
\hline & \multicolumn{2}{|c|}{$(B) \iota_{\|}$} & \multicolumn{2}{|c|}{ (D) 13} \\
\hline & $P_{\text {watifly }}$ & toloets & $r_{\text {wive }}$ & i-loets \\
\hline$r_{1-2}$ & 915 & 8.78 & .857 & 6.44 \\
\hline$r_{1,3}$ & 916 & 8.84 & .889 & 7.52 \\
\hline$r_{1-4}$ & .776 & 4.56 & .781 & 4.84 \\
\hline$r_{1.5}$ & .719 & 4.01 & .744 & 4.31 \\
\hline$r_{2-3}$ & 963 & 13.84 & .896 & 7.81 \\
\hline$r_{2-4}$ & .833 & 5.83 & .776 & 4.76 \\
\hline$r_{24}$ & .781 & 4.84 & .765 & 4.60 \\
\hline$r_{1,4}$ & .870 & 6.83 & .737 & 4.22 \\
\hline$r_{3.5}$ & .755 & 4.46 & .682 & 3.61 \\
\hline$r_{4-5}$ & .901 & 8.04 & .913 & 8.67 \\
\hline
\end{tabular}

Intrabeoordelaarsbetrouwb h coeff.

\begin{tabular}{|l|l|r|}
\hline \multirow{2}{*}{} & \multicolumn{2}{|c|}{$(\mathrm{B}-\mathrm{D}) \mathrm{t}_{1}-\mathrm{t}_{\mathrm{t}}$} \\
\cline { 2 - 3 } & $\mathrm{r}_{\text {tuen }}$ & $\mathrm{t}$-toets \\
\hline $\mathrm{r}_{1}$ & .950 & 11.78 \\
$\mathrm{r}_{2}$ & .897 & 7.86 \\
$\mathrm{r}_{3}$ & .812 & 5.39 \\
$\mathbb{r}_{4}$ & .884 & 7.32 \\
$\mathbb{r}_{5}$ & .964 & 14.04 \\
\hline
\end{tabular}

Student's t-toets éénzijdig $a=.01$ $\mathrm{df}=15$

kritieke grens: 2.60

* niet signifikant

GOCC skores gesommerd over de items (30 patiènten). Tweede verzameling (dec. 1976).

Interbeoordelaarsbetrouwbartheidscoeff.

\begin{tabular}{|c|c|c|c|c|}
\hline & \multicolumn{2}{|c|}{$(F) t_{1}$} & \multicolumn{2}{|c|}{ (H) $t_{2}$} \\
\hline & $r_{t, \mathrm{x}: \mathrm{s}}$ & t-toets & $r_{\text {wandit: }}$ & l-toets \\
\hline$r_{1.3}$ & .570 & 3.67 & .723 & 5.54 \\
\hline$r_{1,3}$ & .699 & 5.17 & .635 & 4.35 \\
\hline$r_{1-4}$ & .344 & $194^{*}$ & .876 & $.40^{*}$ \\
\hline$r_{1.5}$ & .405 & $2.34 *$ & .329 & 1. $84 *$ \\
\hline$r_{1, \text { rib }}$ & .804 & 7.14 & .752 & 6.03 \\
\hline$r_{3 \cdot x}$ & .566 & 3.63 & .725 & 5.57 \\
\hline$r_{24}$ & .316 & 1.76 & .227 & $1.23^{*}$ \\
\hline$r_{2-9}$ & 513 & 3.16 & .344 & $1.94^{*}$ \\
\hline$t_{2}$. - rit & .802 & 7.11 & .808 & 7.26 \\
\hline rind & 158 & $.85^{* 4}$ & .129 & $.69^{*}$ \\
\hline$r_{1.5}$ & .357 & $.202^{*}$ & .542 & 3.41 \\
\hline$r_{i-m}$ & .734 & 5.71 & .837 & 8.09 \\
\hline$r_{4.6}$ & .360 & $.204^{*}$ & .612 & 4.09 \\
\hline$r_{4+t|H|}$ & .607 & 4.04 & .533 & 3.33 \\
\hline$r_{5-1 н \text { i }}$ & .743 & 5.88 & .768 & 6.34 \\
\hline
\end{tabular}

Intrabeoordelaarsbetrouwb.h.coëf.

\begin{tabular}{|c|l|l|}
\hline \multirow{2}{*}{} & \multicolumn{2}{|c|}{$(F-H) t_{1}-t_{2}$} \\
\cline { 2 - 3 } & $r_{\text {uzit }}$ & $t$-toets \\
\hline$r_{1}$ & .605 & 4.02 \\
$r_{2}$ & .483 & 2.92 \\
$r_{3}$ & .833 & 7.97 \\
$r_{4}$ & .729 & 5.64 \\
$r_{3}$ & .409 & 2.37 \\
$r_{m}$ & .789 & 6.80 \\
\hline
\end{tabular}

Student's t-toets éénzijdig $\alpha=.01$ $\mathrm{d} \mathrm{ff}^{\mathrm{n}}=28$

kritieke grens: 2.47

* = niet siginifkant 
BULAGE 4: VERZAMELTABEL INZAKE GEDRAGSVORMING, GEDRAGSTOENAME EN GEDRAGSDEVIATIES

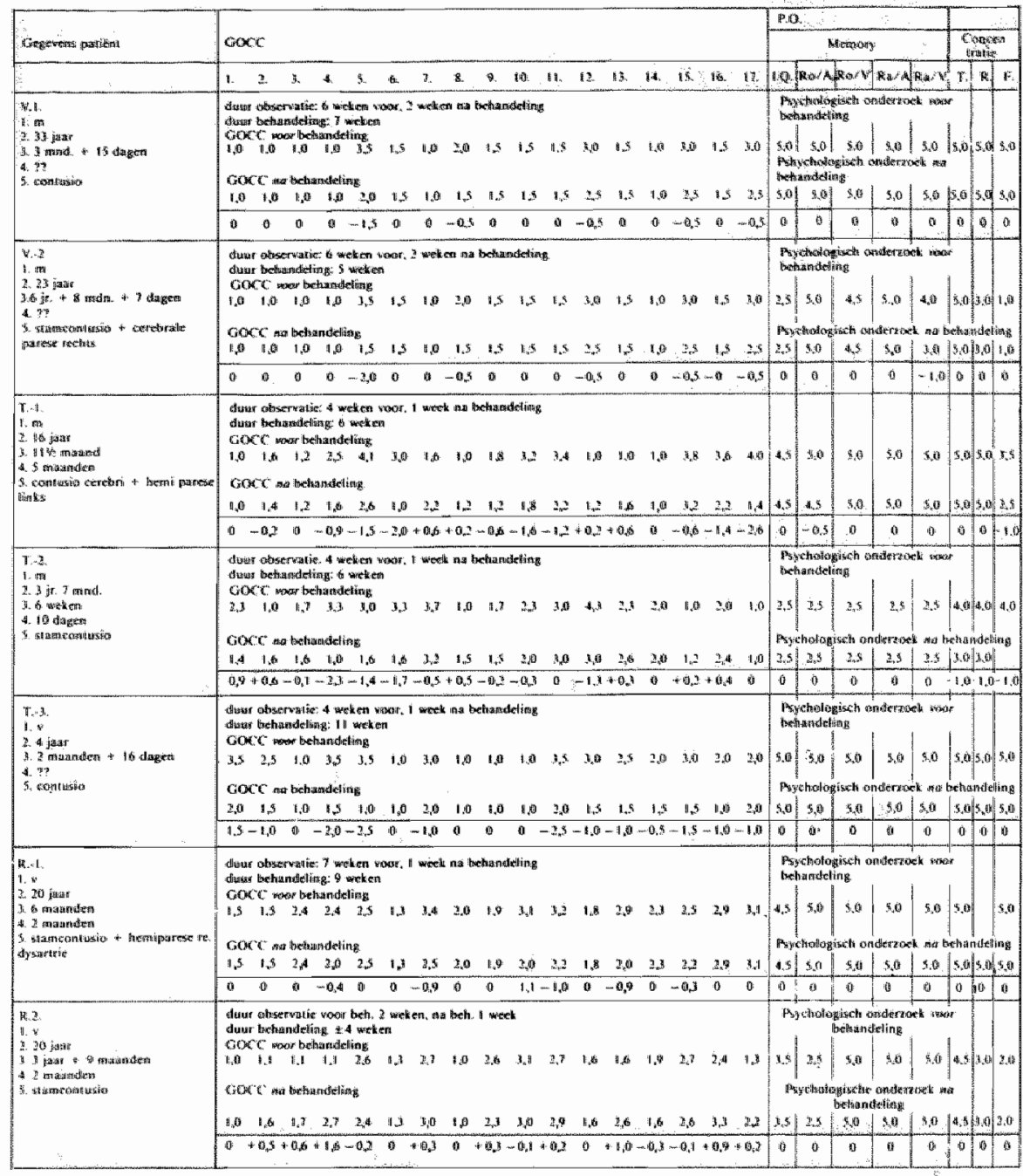


VERVOLG VAN BIJLAGE 4

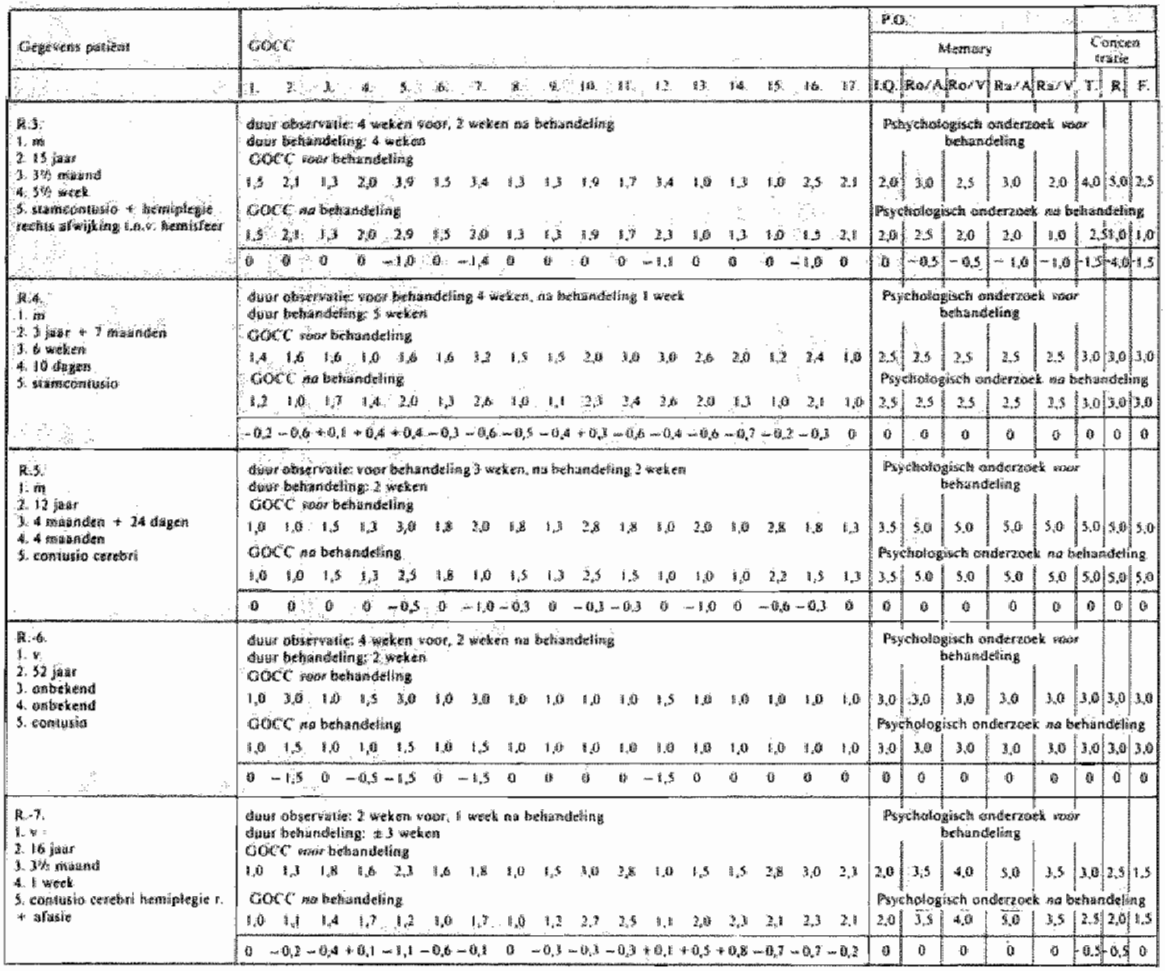


BIJLAGE 5:TOETSING VAN DE PROCEDURES TER GEDRAGSVORMING, GEDRAGSTOENAME EN GEDRAGSREDUKTIE.

\begin{tabular}{|c|c|c|}
\hline \multicolumn{3}{|c|}{$H_{0}-T_{1}$} \\
\hline GOCC & \multicolumn{2}{|c|}{$\mathbf{E}$ pat. $[\mathrm{Gocc}$ sel] } \\
\hline items & Voor & $\mathrm{Na}$ \\
\hline 1 & 8,8 & 6,4 \\
\hline 2 & 7,1 & 6,5 \\
\hline 3 & 5,9 & 5,8 \\
\hline 4 & 11,3 & 6,1 \\
\hline 5 & 17,6 & 8,7 \\
\hline 6 & 10,3 & 6,6 \\
\hline 7 & 10,3 & 9,4 \\
\hline 8 & 7,0 & 6,7 \\
\hline 9 & 7,5 & 6,7 \\
\hline 10 & 9,5 & 7,8 \\
\hline 11 & 12,9 & 9,2 \\
\hline 12 & 14,3 & 11,2 \\
\hline 13 & 8,8 & 8,7 \\
\hline 14 & 7,0 & 6,5 \\
\hline 15 & 13,8 & 10,9 \\
\hline 16 & 10,6 & 8,6 \\
\hline 17 & 13,0 & 9,4 \\
\hline \multicolumn{3}{|c|}{$\begin{array}{l}\mathrm{t}=4,344 \\
\alpha=0,01 \text { éénzijdig } \\
\mathrm{df}=16 ; \mathrm{Kr} \cdot \mathrm{gr} .=2,583 \\
\text { Sign. Verw. } \mathrm{H}_{0}\end{array}$} \\
\hline
\end{tabular}

\begin{tabular}{|c|c|c|}
\hline \multicolumn{3}{|c|}{$\mathrm{H}_{0}-\mathrm{E}_{\mathrm{t}}$} \\
\hline $\mathrm{GOCC}$ & \multicolumn{2}{|c|}{$\Sigma$ pat. $100 \mathrm{cc}-\mathrm{sc}$. } \\
\hline items & Voor & $\mathrm{Na}$ \\
\hline 1 & 8,4 & 8.2 \\
\hline 2 & 11,6 & 9,8 \\
\hline 3 & 10,7 & 11,0 \\
\hline 4 & 10,9 & 12,1 \\
\hline 5 & 18,9 & 15,0 \\
\hline 6 & 10,1 & 9,2 \\
\hline 7 & 19,5 & 14.3 \\
\hline 8 & 9,6 & 8,8 \\
\hline 9 & 11,1 & 10,1 \\
\hline 10 & 16,9 & $\| 5,4$ \\
\hline 11 & 16.2 & 14,2 \\
\hline 12 & 13,3 & 11,4 \\
\hline 13 & 12,6 & 11,6 \\
\hline 14 & 11,0 & 10,8 \\
\hline 15 & 14,0 & 12,1 \\
\hline 16 & 16,0 & 14,6 \\
\hline 17 & 12,1 & 12,8 \\
\hline \multicolumn{3}{|c|}{$\begin{array}{l}t=3,421 \\
\alpha=0,01 \text { éenzijdig. } \\
\mathrm{df}=16 ; \mathrm{Kr.gr} .=2,583 \\
\text { Sign. Verw. } \mathrm{H}_{0}\end{array}$} \\
\hline
\end{tabular}

\begin{tabular}{|c|c|c|}
\hline \multicolumn{3}{|c|}{$H_{\sharp !}-D_{\sharp}$} \\
\hline $90 \mathrm{CC}$ & \multicolumn{2}{|c|}{$\Sigma$ pat $\| \mathrm{GOCC}-\mathrm{se}$} \\
\hline itenns: & Voor & $\mathrm{Na}$ \\
\hline 1 & 17.2 & 14,6 \\
\hline 2 & 18.7 & 16,3 \\
\hline 3 & 16.6 & 16,8 \\
\hline 4 & 22,2 & 18,2 \\
\hline 5 & $36 ; 5$ & 23,7 \\
\hline 6 & 20,4 & 15,8 \\
\hline 7 & 29,8 & 23,7 \\
\hline 8 & 16,6 & 15,5 \\
\hline 9 & 18,6 & 16,8 \\
\hline 10 & 26,4 & 23,2 \\
\hline 11 & 29,1 & 23,4 \\
\hline 12 & 27,6 & 22,6 \\
\hline 13 & 21,4 & 20,3 \\
\hline 14 & 18,0 & 17,3 \\
\hline 15 & 27,8 & 23,0 \\
\hline 16 & 26,6 & 23,2 \\
\hline 17 & 25,1 & 22,2 \\
\hline \multicolumn{3}{|c|}{$\begin{array}{l}t=4,983 \\
\alpha=0,01 \text { eenzijdig } \\
\mathrm{df}=16 ; \mathrm{Kr}, \mathrm{gr} .=2,583 \\
\text { Sign. Verw. } \mathrm{H}_{0}\end{array}$} \\
\hline
\end{tabular}

\begin{tabular}{|c|c|c|c|c|c|c|c|c|}
\hline \multicolumn{3}{|c|}{$H_{0}-T_{2}$} & \multicolumn{3}{|c|}{$\overline{H_{0}-E_{2}}$} & \multicolumn{3}{|c|}{$\overline{H_{0}-D_{2}}$} \\
\hline \multirow{2}{*}{$\begin{array}{l}\text { Pa- } \\
\text { tieient } \\
\mathrm{Nr} \text {. }\end{array}$} & \multicolumn{2}{|c|}{ [": Goce $\| \mathrm{Gocc} \mathrm{se}]$} & \multirow{2}{*}{$\begin{array}{l}\mathrm{Pa}- \\
\text { tiënt } \\
\mathrm{Nr} \text {. }\end{array}$} & \multicolumn{2}{|c|}{$\sum: \mathrm{GOCC}$ [GOCC-se] } & \multirow{2}{*}{$\begin{array}{l}\text { Pa- } \\
\text { tient } \\
\text { Nr. }\end{array}$} & \multicolumn{2}{|c|}{$\sum: \operatorname{GOCC}\left[\mathrm{GOCC}-\mathrm{sc}_{1}\right]$} \\
\hline & Voor & $\mathrm{Na}$ & & Voor & $\mathrm{Na}$ & & Voor & $\mathrm{Na}$ \\
\hline $\mathrm{V}_{1}$ & 29,5 & 26,0 & $\mathrm{R} 1$ & 40,7 & 36,1 & $V_{1}$ & 29,5 & 26,0 \\
\hline$\sqrt{2}$ & 29,5 & 25,5 & R2 & 31,8 & 36,8 & $V_{2}$ & 29,5 & 25,5 \\
\hline $\mathrm{T} 1$ & 38.8 & 27,6 & R3 & 33,2 & 28,7 & $\mathrm{~T} 1$ & 38,8 & 27,6 \\
\hline $\mathrm{T} 2$ & 38,9 & 32,2 & R4 & 32,2 & 28,0 & $\mathrm{~T} 2$ & 38,9 & 32,2 \\
\hline $\mathrm{T} 3$ & 39,0 & 22,5 & R5 & 29,2 & 24,9 & $\mathrm{~T} 3$ & 39,0 & 22,5 \\
\hline \multirow{6}{*}{\multicolumn{3}{|c|}{$\begin{array}{l}t=3,436 \\
\alpha=0,01 \text { Eénzijdig } \\
\mathrm{df}=4: \mathrm{Kr} \cdot \mathrm{gr}=3,747 \\
\text { niet sign. op } \alpha=0,01 \\
\text { niet verw. Ho }\end{array}$}} & R6 & 24,0 & 18,5 & $\mathrm{R} \|$ & $40 ; 7$ & 36,1 \\
\hline & & & R7 & 31,8 & 28,4 & $\mathrm{R} 2$ & 3,8 & 36,8 \\
\hline & & & & & & $\mathrm{R3}$ & 33,2 & 28.7 \\
\hline & & & \multirow{4}{*}{\multicolumn{3}{|c|}{$\begin{array}{l}t=2,251 \\
a=0,01 \text { eenzijdig } \\
\mathrm{d} r=6 ; \mathrm{Kr} \cdot \mathrm{gr} .=3,143 \\
\text { niet sign. op } a=0,01 \\
\text { niet verw. } \mathrm{H}_{0}\end{array}$}} & R4 & 32,2 & 28,0 \\
\hline & & & & & & R5 & 29,2 & 24,9 \\
\hline & & & & & & R6 & 24,0 & 18,5 \\
\hline & & & & & & \multirow{2}{*}{\multicolumn{3}{|c|}{$\begin{array}{l}t=3,631 \\
a=0,01 \text { eénzijdig } \\
d r=11 ; \mathrm{Kr}, \mathrm{gr} .=2,718 \\
\text { Sign. Verw. } \mathrm{H}_{0}\end{array}$}} \\
\hline & & & & & & & & \\
\hline
\end{tabular}




\section{BIJLAGE 6: VERZAMELTABEL INZAKE BEHOUD VAN GEDRAG ONDER TOENEMENDE STIMULUS-COMPLEXITEIT.}

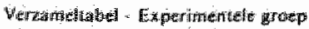

\begin{tabular}{|c|c|c|c|c|c|c|c|c|c|}
\hline 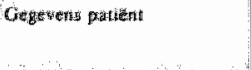 & 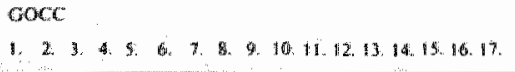 & 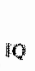 & Men & $f y$ & A & Wat & $\cos$ & Reegett & tratie \\
\hline 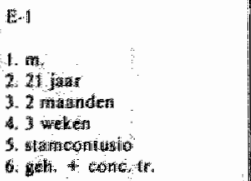 & 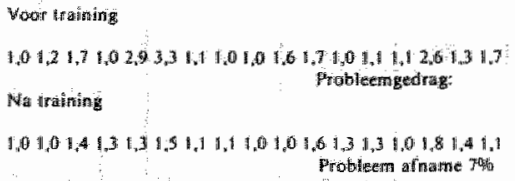 & $\begin{array}{c}3,0 \\
-\end{array}$ & $\stackrel{1,6}{-10}$ & $\begin{array}{l}4,03 \\
1_{n} 01\end{array}$ & $\begin{array}{l}5,0 \\
2,0\end{array}$ & $\begin{array}{l}4,5 \\
1,0\end{array}$ & $\prod^{4}$ & 1.0 & $\begin{array}{l}3.5 \\
4.5 \\
-10.5\end{array}$ \\
\hline 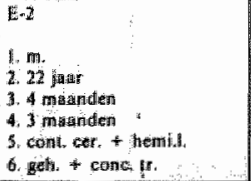 & 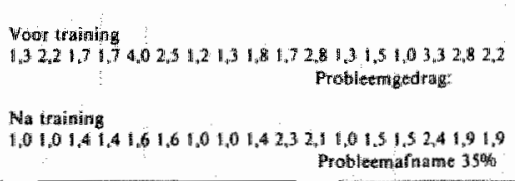 & $\begin{array}{l}2,0 \\
2,0\end{array}$ & $\begin{array}{l}1,5 \\
-\end{array}$ & $\begin{array}{l}5.0 \\
2.0\end{array}$ & $\begin{array}{l}5,0 \\
2,0\end{array}$ & $\begin{array}{l}3,5 \\
0,5\end{array}$ & 18,5 & $\left|\begin{array}{l}A_{4} 0 \\
H_{n} 0\end{array}\right|$ & 1,0 \\
\hline 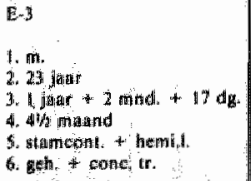 & 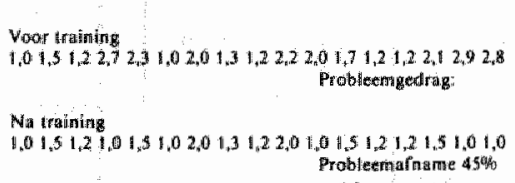 & - & $\frac{1,0}{-}$ & $\begin{array}{l}2.3 \\
-\end{array}$ & $\begin{array}{c}5,0 \\
0\end{array}$ & $\begin{array}{r}1,5 \\
0.5\end{array}$ & $\mid \begin{array}{l}0,5 \\
1 i, 0\end{array}$ & $\begin{array}{l}40 \\
10\end{array}$ & $\begin{array}{l}2,0 \\
2,0 \\
-\end{array}$ \\
\hline 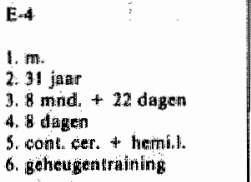 & 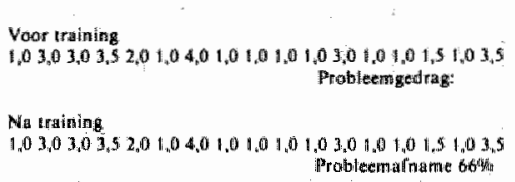 & - & $\begin{array}{l}5,00 \\
2,19\end{array}$ & $\begin{array}{l}2,5 \\
2,0\end{array}$ & 5,04 & $\frac{3,00}{-}$ & $(5,0)$ & $\left(\begin{array}{c}3.0 \\
-\end{array}\right.$ & 30 \\
\hline
\end{tabular}

\begin{tabular}{|c|c|c|c|c|c|c|c|c|c|}
\hline 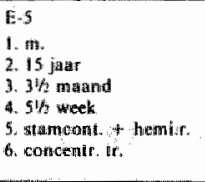 & 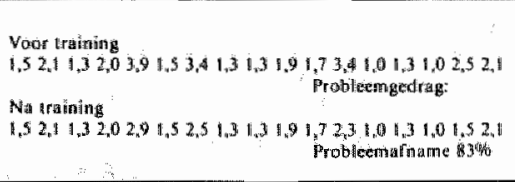 & $\begin{array}{c}2,0 \\
- \\
2,0 \\
-\end{array}$ & $\begin{array}{c}3,8 \\
-\end{array}$ & $\begin{array}{c}2.00 \\
-\end{array}$ & $\begin{array}{c}3,0 \\
-\end{array}$ & 2,0 & $\begin{array}{l}3,5 \\
0.5\end{array}$ & $\begin{array}{r}1,0 \\
2,0\end{array}$ & $\begin{array}{l}2,5 \\
- \\
1.0 \\
-\end{array}$ \\
\hline 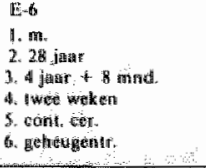 & 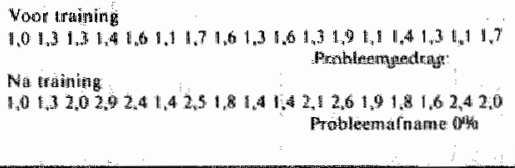 & $\begin{array}{l}2,0 \\
2,0 \\
-\infty\end{array}$ & 1,0 & $\begin{array}{l}5,00 \\
3,00\end{array}$ & $\mid \begin{array}{c}50 \\
20 \\
-0 \\
90 \\
0\end{array}$ & 8.0 & $\begin{array}{c}1.0 \\
2\end{array}$ & $\begin{array}{c}\mathrm{H}: 0 \mathrm{i} \\
-\end{array}$ & $\begin{array}{c}1, n \\
- \\
2.0 \\
-\end{array}$ \\
\hline 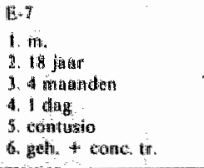 & 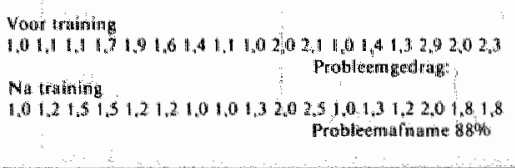 & 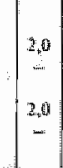 & $\begin{array}{l}2: 0 \\
= \\
2: 0 \\
-\end{array}$ & $\begin{array}{l}3,5 \\
0.5 \\
3 \\
3,0 \\
0.5\end{array}$ & $\begin{array}{l}5.0 \\
2.0 \\
3.5 \\
1.5\end{array}$ & 1.5 & $\begin{array}{l}2: 5 \\
0,5\end{array}$ & $\begin{array}{l}4,0 \\
1,0 \\
2,5 \\
1,0\end{array}$ & $\begin{array}{l}\$, 0 \\
1,0 \\
-\infty\end{array}$ \\
\hline 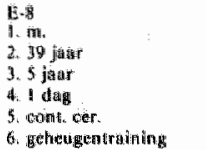 & 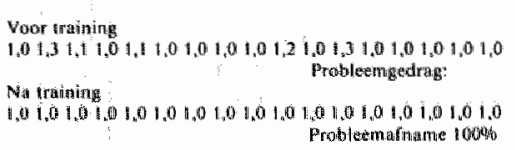 & $\begin{array}{l}2,0 \\
20 \\
20\end{array}$ & $\frac{1,5}{1,3}$ & $\left(\begin{array}{l}5,0 \\
2,0 \\
1,5 \\
2,0\end{array}\right.$ & $\begin{array}{l}4,5 \\
1,5 \\
1,0 \\
1,5\end{array}$ & $\begin{array}{c}1,0 \\
1,0 \\
i=\infty \\
1,0 \\
-\infty\end{array}$ & $\stackrel{-1,0}{-1,0}$ & $\operatorname{lin}_{-\infty}$ & $\begin{array}{l}1,6 \\
-6 \\
1,0 \\
-\end{array}$ \\
\hline
\end{tabular}


VERVOLG BIJLAGE 6

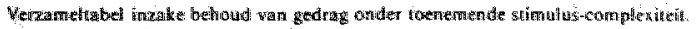
Verzansetisabel-Experimeniele groep.

\begin{tabular}{|c|c|c|c|c|c|c|c|c|c|}
\hline 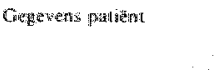 & 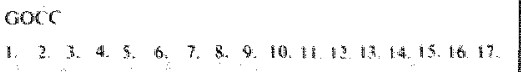 & 40 & Ran & myis & Fu:A & Rus & ton & Whent & int \\
\hline 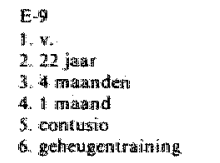 & 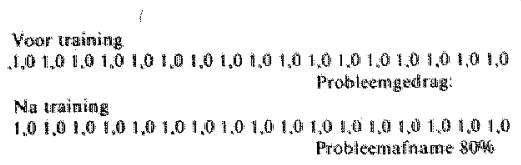 & $\begin{array}{l}3,0 \\
- \\
3,0 \\
-6\end{array}$ & $\begin{array}{c}2.0 \\
- \\
1.0 \\
-\end{array}$ & $\begin{array}{l}5,0 \\
2,0 \\
1,0 \\
2,0\end{array}$ & $\begin{array}{l}1,0 \\
2,80\end{array}$ & $\begin{array}{l}10 \\
-\end{array}$ & $\mid \begin{array}{c}3,5 \\
0,5 \\
3,5 \\
0\end{array}$ & $\begin{array}{c}3.5 \\
0,8 \\
3.5 \\
0\end{array}$ & $\begin{array}{l}20 \\
- \\
1,0 \\
-\end{array}$ \\
\hline 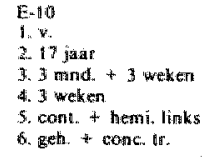 & 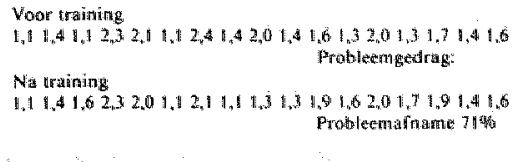 & $\begin{array}{l}3,5 \\
0,5 \\
3.5 \\
0.5\end{array}$ & $\mid \begin{array}{l}1,5 \\
4 \\
2,3 \\
-\end{array}$ & $\left|\begin{array}{l}5,0 \\
2.0 \\
\\
3.0 \\
2.0\end{array}\right|$ & $\begin{array}{c}x, 5 \\
-5 \\
20 \\
-\end{array}$ & $\begin{array}{l}3,5 \\
0,5 \\
3,5\end{array}$ & $\begin{array}{c}200 \\
- \\
20\end{array}$ & $\begin{array}{l}5,0 \\
2,0 \\
4,0 \\
1,0 \\
\therefore\end{array}$ & $\begin{array}{l}5,0 \\
2,0 \\
1,0 \\
2,0\end{array}$ \\
\hline 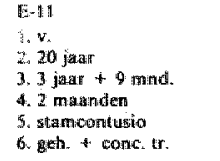 & 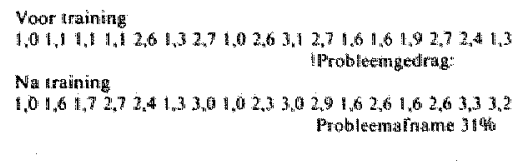 & $\begin{array}{l}3,5 \\
0,5 \\
3,5 \\
45\end{array}$ & $\begin{array}{l}2,5 \\
2,5 \\
-5\end{array}$ & $\mid \begin{array}{c}5,0 \\
2,0 \\
5,0 \\
0\end{array}$ & $\begin{array}{c}5,0 \\
2,6 \\
5,0 \\
0\end{array}$ & $\begin{array}{c}5,9 \\
2,0 \\
2,5 \\
3,5 \\
1.5\end{array} \mid$ & $\begin{array}{l}4,5 \\
1,5 \\
3,5 \\
1,1,1\end{array}$ & $\begin{array}{c}3,0 \\
- \\
2,0 \\
-\end{array}$ & $\begin{array}{c}2,0 \\
- \\
1,0 \\
-1\end{array}$ \\
\hline 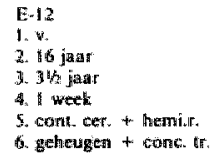 & 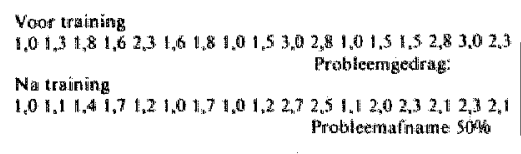 & $\begin{array}{l}20 \\
20 \\
= \\
20 \\
-\end{array}$ & $\begin{array}{l}1,5 \\
0,5 \\
2,5 \\
0,5\end{array}$ & $\begin{array}{c}4,0 \\
1,0 \\
1,0 \\
1,0\end{array}$ & $\begin{array}{c}5,0 \\
2,0 \\
5,0 \\
0\end{array}$ & $\begin{array}{c}3,5 \\
0,5 \\
1,5 \\
0,5\end{array}$ & $\begin{array}{c}3,0 \\
- \\
1,5 \\
-\end{array}$ & $\begin{array}{c}25 \\
- \\
2,4 \\
-\end{array}$ & $\begin{array}{l}1,5 \\
- \\
1,5 \\
-\end{array}$ \\
\hline
\end{tabular}

Verangeltatet - controle groep

\begin{tabular}{|c|c|c|c|c|c|c|c|c|c|}
\hline 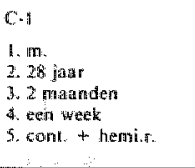 & 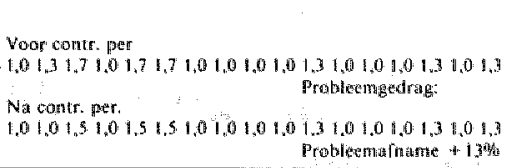 & $\begin{array}{c}2.9 \\
- \\
2,8 \\
-\end{array}$ & $\begin{array}{c}4,0 \\
1,0 \\
4,0 \\
0\end{array}$ & $\begin{array}{c}4,0 \\
0,0 \\
4,5 \\
-0,5\end{array}$ & $\mid \begin{array}{c}5,0 \\
2,0 \\
5,0 \\
0\end{array}$ & $\begin{array}{c}3.5 \\
0.5 \\
3.5 \\
0\end{array}$ & $\begin{array}{l}5,0 \\
2,0 \\
4,0 \\
4,0 \\
1,0\end{array}$ & 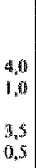 & $\begin{array}{l}1,0 \\
0 \\
1,0 \\
-\end{array}$ \\
\hline 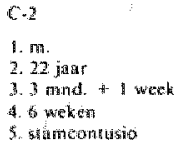 & 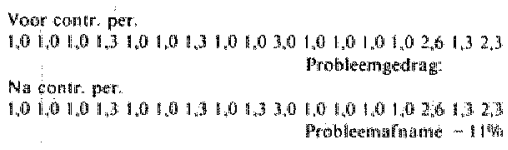 & $\begin{array}{c}2,5 \\
- \\
2,5 \\
-n\end{array}$ & $\mid \begin{array}{c}1.5 \\
- \\
4,0 \\
-1,0\end{array}$ & $\left|\begin{array}{l}4,5 \\
1,5 \\
5,0 \\
0,5\end{array}\right|$ & 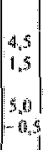 & $\begin{array}{c}39_{9} 0 \\
- \\
1,6 \\
-2\end{array}$ & $\mid \begin{array}{l}3 ; 0 \\
-5 \\
2,5 \\
4 \infty\end{array}$ & $\begin{array}{l}4,0 \\
1,0 \\
3,0 \\
1,0\end{array}$ & $\begin{array}{l}3,5 \\
0,5 \\
2,0 \\
0.5\end{array}$ \\
\hline 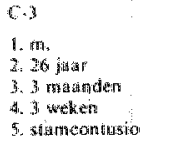 & 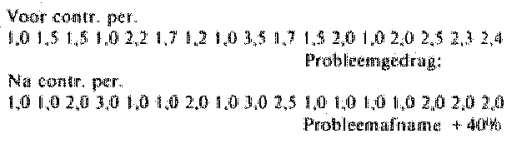 & $\begin{array}{c}2,0 \\
- \\
3,0 \\
3 \\
-\end{array}$ & $\left|\begin{array}{c}1,5 \\
-5 \\
3,5 \\
-0,5\end{array}\right|$ & $\begin{array}{l}4,0 \\
80 \\
2,0 \\
1,0\end{array}$ & $\mid \begin{array}{c}5,40 \\
2,0 \\
5,4 \\
6\end{array}$ & 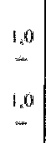 & $\begin{array}{l}50 \\
20 \\
4,5 \\
6,5\end{array}$ & $\begin{array}{l}50 \\
3,0 \\
3,5 \\
4,5 \\
0,5\end{array}$ & $\begin{array}{l}5,0 \\
2,0 \\
2,0 \\
2,0\end{array}$ \\
\hline 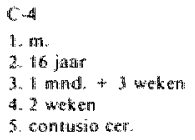 & 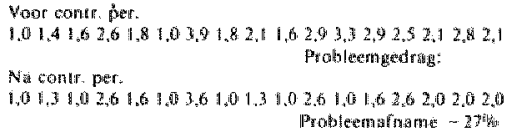 & $\begin{array}{c}2,5 \\
- \\
3,0 \\
-1\end{array}$ & $\mid \begin{array}{c}1,0^{4} \\
- \\
1,0 \\
-\end{array}$ & $\begin{array}{c}2,5 \\
- \\
d, 0 \\
+1,0\end{array}$ & $\begin{array}{c}5,0 \\
2,0 \\
5,0 \\
0\end{array}$ & $\begin{array}{c}2,0 \\
- \\
3,5 \\
-0,5\end{array}$ & $\begin{array}{l}5,0 \\
2,0 \\
2,0 \\
5,0 \\
0\end{array}$ & $\begin{array}{c}4,5 \\
1,5 \\
4,5 \\
0\end{array}$ & $\begin{array}{c}2,0 \\
\ldots \\
2,0 \\
\cdots\end{array}$ \\
\hline
\end{tabular}


VERVOLG BIJLAGE 6.

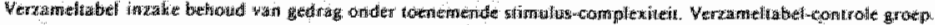

\begin{tabular}{|c|c|c|c|c|c|c|c|c|c|}
\hline Getgevens putant & 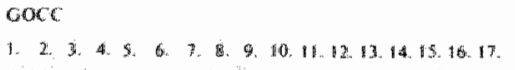 & 10 & Matian & nory & & Pais & $\operatorname{Con}$ & R. & ratise \\
\hline 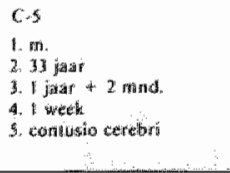 & 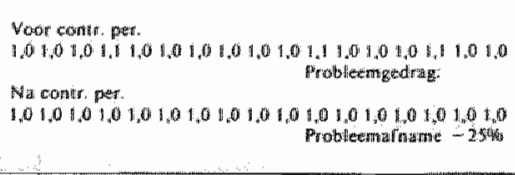 & $\left|\begin{array}{c}20 \\
-6 \\
20\end{array}\right|$ & $\begin{array}{c}4.90 \\
.0 .0 \\
4.0 \\
0\end{array}$ & $\left(\begin{array}{c}4,0 \\
1.0 \\
4,5 \\
-0,5\end{array}\right.$ & $\begin{array}{c}50 \\
50 \\
-0 \\
-\end{array}$ & $\begin{array}{c}1,5 \\
-\infty \\
15 \\
-\end{array}$ & $\left\{\begin{array}{l}1,5 \\
-5 \\
1,5 \\
-\end{array}\right.$ & $\begin{array}{c}1,0 \\
- \\
1,0 \\
-\end{array}$ & $\begin{array}{l}1.0 \\
- \\
1.0 \\
-0\end{array}$ \\
\hline 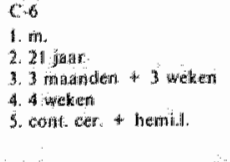 & 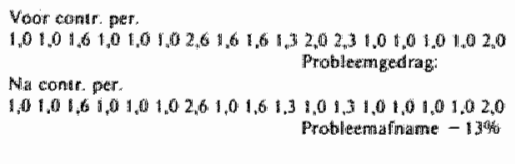 & $\begin{array}{c}2.5 \\
- \\
3,0 \\
-\end{array}$ & $\begin{array}{c}20 \\
- \\
40 \\
0 \\
0\end{array}$ & $\begin{array}{l}5,0 \\
7,0 \\
4,5 \\
0,5\end{array}$ & $\begin{array}{c}5,0 \\
2,0 \\
50 \\
0\end{array}$ & $\begin{array}{c}2,5 \\
- \\
30 \\
-\end{array}$ & $\mid \begin{array}{l}2,0 \\
\cdots \\
2,0 \\
-\end{array}$ & $\begin{array}{c}2,5 \\
- \\
2.5 \\
-\end{array}$ & $\begin{array}{c}2,01 \\
- \\
2,9 \\
-\end{array}$ \\
\hline 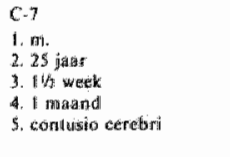 & 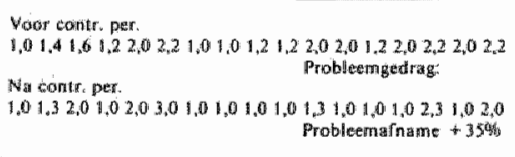 & $\begin{array}{c}-4,3 \\
0,5 \\
3,5 \\
0\end{array}$ & $\begin{array}{l}3.5 \\
n_{0} .5 \\
1.0 \\
0.5\end{array}$ & $\begin{array}{c}5,0 \\
2,0 \\
5,0 \\
0\end{array}$ & $\left(\begin{array}{c}5,0 \\
2,0 \\
5.0 \\
0\end{array}\right)$ & $\begin{array}{l}3,5 \\
0,5 \\
3,0 \\
0,5\end{array}$ & $\begin{array}{l}4,5 \\
1,5 \\
4,0 \\
0,5\end{array}$ & $\begin{array}{c}4 ; 0 ; \\
1,0 \\
y, 0 \\
1,0\end{array}$ & $\begin{array}{l}5,80 \\
2,0 \\
4,0 \\
1,0\end{array}$ \\
\hline 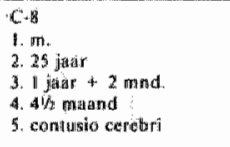 & 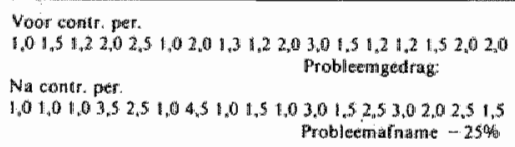 & $\left|\begin{array}{c}2,0 \\
-0,0 \\
-\infty, 0\end{array}\right|$ & $\left|\begin{array}{c}1,0 \\
1,0 \\
-\end{array}\right|$ & $\begin{array}{c}1,5 \\
- \\
5,0 \\
-2,0\end{array}$ & $\mid \begin{array}{l}5,0 \\
2,0 \\
4,5 \\
0,5\end{array}$ & $\begin{array}{c}1,5 \\
- \\
2,0 \\
-\end{array}$ & $\begin{array}{l}2,5 \\
- \\
2,5 \\
-\end{array}$ & $\begin{array}{l}5,0 \\
2,0 \\
3,5 \\
1,5\end{array}$ & $\begin{array}{c}2.0 \\
- \\
4,8 \\
-1,0\end{array}$ \\
\hline
\end{tabular}

\begin{tabular}{|c|c|c|c|c|c|c|c|c|c|}
\hline $\begin{array}{l}\text { C }-9 \\
\text { 1. v. } \\
\text { 2. } 23 \text { jast } \\
\text { 3. } 7 \text { jaar } \\
\text { 4. } 4 \text { mantent } \\
\text { 5. cont cer. heani.l. }\end{array}$ & 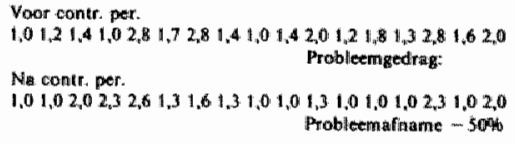 & $\begin{array}{c}2,5 \\
- \\
3,10 \\
-\end{array}$ & $\begin{array}{c}2,0 \\
- \\
2,0 \\
-\end{array}$ & $\mid \begin{array}{c}5,60 \\
2,0 \\
5,0\end{array}$ & $\begin{array}{c}5,0 \\
2,0 \\
5,0 \\
0\end{array}$ & $\begin{array}{c}3,0 \\
- \\
5,0 \\
-2,0\end{array}$ & $\left\{\begin{array}{l}1.5 \\
- \\
1.5 \\
-\end{array}\right.$ & $\begin{array}{l}1,0 \\
- \\
1,0 \\
-\end{array}$ & $\begin{array}{l}1.0 \\
- \\
1.0 \\
-\end{array}$ \\
\hline $\begin{array}{l}\text { C. } 10 \\
\text { 1. } . \\
\text { 2. } 34 \text { jaar } \\
\text { 3. } 3 \text { maanden } \\
\text { 4. } 1 \text { maand } \\
\text { 5. convusio cerebri }\end{array}$ & 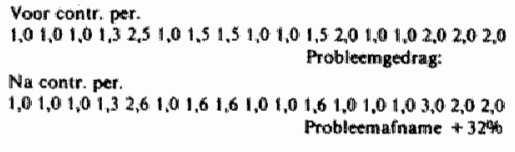 & $\begin{array}{c}3.5 \\
0.5 \\
0.5 \\
0 \\
0\end{array}$ & $\begin{array}{c}2.5 \\
- \\
1.0 \\
-\end{array}$ & $\begin{array}{c}5,0 \\
2,0 \\
5,0 \\
5,0 \\
0,4\end{array}$ & $\begin{array}{c}5,0 \\
2,0 \\
5,0 \\
0\end{array}$ & $\begin{array}{l}5,01 \\
2,0 \\
3,5 \\
1,5\end{array}$ & $\left|\begin{array}{l}4,5 \\
1,5 \\
4,6 \\
0,5\end{array}\right|$ & $\begin{array}{l}4,5 \\
1,5 \\
3,5 \\
1,0\end{array}$ & $\begin{array}{c}1,0 \\
-0 \\
1.0 \\
-\end{array}$ \\
\hline 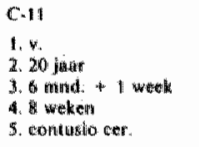 & 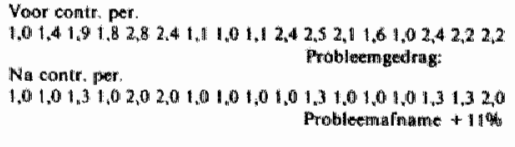 & $\begin{array}{c}1,0 \\
- \\
7_{n} 0 \\
-\end{array}$ & $\begin{array}{c}1,0 \\
\cdots \\
1,0 \\
-\end{array}$ & $\begin{array}{r}4,0 \\
+, 0 \\
5,0 \\
-1,0\end{array}$ & $\begin{array}{c}5,0 \\
2,0 \\
5,0 \\
0\end{array}$ & $\begin{array}{l}4,5 \\
1,5 \\
3,0 \\
1,5\end{array}$ & $\left|\begin{array}{c}3,6 \\
=-\infty \\
2,6 \\
=\end{array}\right|$ & $\begin{array}{l}4,5 \\
- \\
1,0 \\
-\end{array}$ & $\begin{array}{l}\frac{1.00}{10} \\
- \\
-\end{array}$ \\
\hline 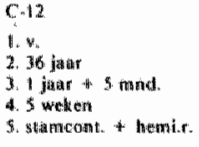 & 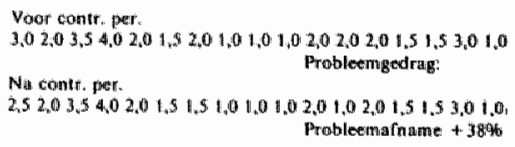 & $\begin{array}{c}3,5 \\
0,5 \\
3,5 \\
0\end{array}$ & $\begin{array}{c}2,0 \\
- \\
1,0 \\
\end{array}$ & $\begin{array}{c}5,0 \\
2,04 \\
50 x \\
6\end{array}$ & $\begin{array}{l}4,0 \\
1,0 \\
2,0 \\
1,0\end{array}$ & $\begin{array}{l}3,5 \\
0,5 \\
3,0 \\
0,5\end{array}$ & $\mid \begin{array}{c}1,5 \\
- \\
1,5 \\
-\end{array}$ & $\begin{array}{c}2,0 \\
- \\
2,0 \\
-\infty\end{array}$ & $\begin{array}{l}2,5 \\
-\end{array}$ \\
\hline
\end{tabular}


BULAGE 7: TOETSING VAN DE PROCEDURE TOT GFIRAGSBEHOUD ONDER TOENEMENDE STIMULUSCOMPLEXITEIT.

A. TOETSING DER A-HYPOTHESEN.

\begin{tabular}{|c|c|c|c|c|c|c|c|c|}
\hline \multicolumn{3}{|c|}{$H_{0}-A 1$} & \multicolumn{3}{|c|}{$\mathrm{H}_{0}-\mathrm{A} 2$} & \multicolumn{3}{|c|}{$H_{0}-A$} \\
\hline \multirow{2}{*}{$\begin{array}{l}\text { GOCC } \\
\text { item. }\end{array}$} & \multicolumn{2}{|c|}{$x: 7$ pal $[\mathrm{Gocc} \mathrm{sk}]$} & \multirow{2}{*}{$\begin{array}{l}\text { pat. } \\
\text { Nr. }\end{array}$} & \multicolumn{2}{|c|}{ I, Gocc looce sk] } & \multirow{2}{*}{$\begin{array}{l}\text { PO } \\
\text { itern }\end{array}$} & \multicolumn{2}{|c|}{ E: pula [Posk] } \\
\hline & Exp. & Contr. & & Exp. & Contr. & & Exp. & Contr. \\
\hline 1. & 12.9 & 14.0 & 1. & 26.3 & 20.3 & 10 & 30.0 & 30.0 \\
\hline 2. & 18.5 & 15.7 & 2. & 34.4 & 22.8 & RoA & 31.0 & 26.0 \\
\hline 3. & 17.4 & 19.0 & 3. & 30.3 & 30.8 & RoV & 52.5 & 49.5 \\
\hline 4. & 21.0 & 19.3 & 4. & 32.5 & 37.4 & $\operatorname{RaA}$ & 55.0 & 54.5 \\
\hline 5. & 27.7 & 23.3 & 5. & 33.2 & 17.3 & Rav & 34.5 & 34.5 \\
\hline 6. & 18.0 & 17.2 & 6. & 23.7 & 24.0 & $\mathrm{~T}$ & 40.0 & 39.0 \\
\hline 7. & 23.7 & 21.4 & 7. & 26.9 & 27.4 & $\mathrm{R}$ & 42.0 & 39.0 \\
\hline 8. & 14.0 & 14.6 & 8. & 18.0 & \multirow{2}{*}{$\begin{array}{l}20.1 \\
28.4\end{array}$} & $F$ & 26.5 & 27.0 \\
\hline \multirow{2}{*}{$\begin{array}{r}9 . \\
10 .\end{array}$} & 16.7 & 16.7 & 9. & 17.0 & & \multirow{2}{*}{\multicolumn{3}{|c|}{ 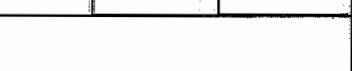 }} \\
\hline & 21.7 & 18.6 & 10 & 27.2 & $\begin{array}{l}28.4 \\
24.3\end{array}$ & & & \\
\hline 11. & 21.7 & 22.8 & 11. & 21.8 & 30.9 & \multirow{2}{*}{\multicolumn{3}{|c|}{$\mathrm{t}=0,288$}} \\
\hline 12 & 19.5 & 21.4 & 12 & 31.8 & 34.0 & & & \\
\hline 13 & $\begin{array}{l}15.4 \\
150\end{array}$ & $\begin{array}{l}16.7 \\
16.5\end{array}$ & & $=0,28$ & & $\alpha=$ & 80 twe & dig \\
\hline 15. & 23.9 & 23.0 & & $\mathrm{df}=2$ & & & ke gr. & \\
\hline 16. & 22.4 & 22.2 & $\alpha=$ & 50 twe & $\mathrm{dig}$ & & niet s & \\
\hline 17. & 23.5 & 22.5 & & $\begin{array}{l}\text { eke gr. } \\
=\text { niet si }\end{array}$ & & & pen & A 3 \\
\hline & & & & & & & & \\
\hline & $\begin{array}{l}=0,400 \\
\mathrm{c}=32\end{array}$ & & & $\mathrm{H}_{00}-\mathrm{A}$ & & & $0 \times A$ & \\
\hline$\alpha=$ & 50 twee & & pat & $\Sigma_{1}^{\alpha} P O$ & O $\mathrm{kkl}$ & pat & $\overline{\Sigma_{1}^{*}} \mathrm{PO}$ & $>3 \mathrm{sk}]$ \\
\hline & gr. 0,6 & & Nr. & Exp. & Contr. & $\mathrm{Nr}$. & Exp. & Contr. \\
\hline$t=$ & te signif & ant & 1. & 31.5 & 29.0 & 1. & 5.0 & 7.5 \\
\hline niet ve & erpen 1 & A 1 & 2 & 29.5 & 26.5 & 2 & 7.0 & 4.5 \\
\hline & & & 3. & 25.5 & 28.5 & 3 & 8.0 & 9.0 \\
\hline & & & 4. & 29.5 & 24.5 & 4. & 4.0 & 2.0 \\
\hline & & & 5. & 24.0 & 16.0 & 5. & 3.0 & $2.0^{\circ}$ \\
\hline & & & 6. & 21.5 & 23.5 & 6 & 4,0 & 4,0 \\
\hline & & & 7. & 23.0 & 34.0 & 7. & 4.0 & 10.0 \\
\hline & & & 8. & 18.0 & 20.5 & 8. & 3.5 & 4.0 \\
\hline & & & 9. & 25.5 & 21.0 & 9. & 7.5 & 4.0 \\
\hline & & & 10 & 28.0 & 31.0 & 10. & 8.5 & 9.5 \\
\hline & & & 11. & 30.5 & 21.0 & 11. & 5.5 & 4.5 \\
\hline & & & 12. & 25.0 & 24.0 & 12. & 6.0 & 4.0 \\
\hline & & & $\begin{array}{r}a \\
k \\
\text { niet }\end{array}$ & $\begin{array}{l}\mathrm{d}=0,5 \\
\mathrm{df}=2 \\
0,50 \mathrm{tw} \\
\text { ieke gr. } \\
=\text { niet } \\
\text { werpen }\end{array}$ & $\begin{array}{l}\text { jdig } \\
86 \\
-A 4\end{array}$ & $\begin{array}{c}a \\
k \\
\text { niet }\end{array}$ & $\begin{array}{l}=0,2 \\
\text { If }=2 \\
50 \mathrm{iw} \\
\text { ke gr. } \\
\text { niet } \\
\text { verper }\end{array}$ & $\begin{array}{l}\text { jdigg } \\
86 \\
\text { A } 5\end{array}$ \\
\hline
\end{tabular}

De H-A hypothesen kunnen voor alle bewerkingen worden aanvaard. Dit impliceert akseptatie dat experimentele groep en kontrole-groep, althans vór de behandeling-resp. kontroleperiode aan elkaar gelijk kumnen worden gesteld.

Deze konklusie wettigt verdere toetsing van de B-hypothesen "Er bestaat (voor meedere kriteria) gen erschil in experimentele groepsskores vóor en na de behandeling en er bestaat geen verschil in kontrole groepsskores vór en na de kontroleperiode." 
VERVOLG BUILACE 7.

B.TOETSING DER B-HYPOTHESEN

\begin{tabular}{|c|c|c|c|c|c|c|c|c|}
\hline \multicolumn{3}{|c|}{$H_{0}-B$} & \multicolumn{3}{|c|}{$\mathrm{H}_{0}-\mathrm{B}^{3}$} & \multicolumn{3}{|c|}{$H_{0}-B 5$} \\
\hline $\begin{array}{l}\mathrm{GOCC} \\
\text { item }\end{array}$ & \multicolumn{2}{|c|}{ Li past [GOCC sk] } & $\begin{array}{r}P O \\
\text { item }\end{array}$ & $E_{1}^{\prime 2}$ patt $\{\mathrm{fO}$ sc & $\begin{array}{c}0 \mathrm{scl} \\
\text { na }\end{array}$ & $\begin{array}{c}\text { GoCC } \\
\text { item }\end{array}$ & 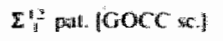 & $\begin{array}{c}\mathrm{CCl}_{\mathrm{na}} \\
\mathrm{na}\end{array}$ \\
\hline $\begin{array}{l}1 . \\
2 . \\
3 . \\
4 . \\
5 \\
6 . \\
7 . \\
8 . \\
9 . \\
10 . \\
11 . \\
12 . \\
13 . \\
14 . \\
15 . \\
16 . \\
17 .\end{array}$ & $\begin{array}{l}12.9 \\
18.5 \\
17.4 \\
21.0 \\
27.7 \\
18.0 \\
23.7 \\
14.0 \\
16.7 \\
21.7 \\
21.7 \\
19.5 \\
15.4 \\
15.0 \\
23.9 \\
22.4 \\
23.5\end{array}$ & $\begin{array}{l}12.6 \\
17.2 \\
18.5 \\
22.3 \\
20.5 \\
14.6 \\
22.9 \\
13.6 \\
15.4 \\
20.6 \\
21.3 \\
19.0 \\
17.8 \\
16.6 \\
20.4 \\
20.0 \\
22.3\end{array}$ & $\begin{array}{l}\text { IQ } \\
\text { RoA } \\
\text { RaV } \\
\text { RaA } \\
\text { RaV } \\
\text { T } \\
\text { R } \\
\text { F }\end{array}$ & $\begin{array}{r}30.0 \\
31.0 \\
52.5 \\
55.0 \\
34.5 \\
40.0 \\
42.0 \\
26.5 \\
=5.5 \\
\text { df }= \\
01 \text { in } \\
\text { ens }= \\
\text { iifikar } \\
\text { rpen }\end{array}$ & $\begin{array}{l}29.5 \\
19.0 \\
34.5 \\
44.5 \\
22.5 \\
32.0 \\
29.0 \\
19.5 \\
\text { jidig } \\
199 \\
133\end{array}$ & $\begin{array}{c}1 . \\
2 . \\
3 . \\
4 . \\
5 . \\
6 . \\
7 . \\
8 . \\
9 . \\
10 . \\
11 . \\
12 \\
13 \\
14 \\
15 \\
16 . \\
17 .\end{array}$ & $\begin{array}{l}140 \\
15.7 \\
19.0 \\
19.3 \\
23.3 \\
17.2 \\
21.4 \\
14.6 \\
16.7 \\
18.6 \\
22.8 \\
21.4 \\
16.7 \\
16.5 \\
23.0 \\
22.2 \\
22.5\end{array}$ & $\begin{array}{l}13.8 \\
13.6 \\
18.9 \\
23.0 \\
20.8 \\
16.3 \\
22.7 \\
12.9 \\
15.7 \\
15.8 \\
18.4 \\
12.8 \\
15.1 \\
16.1 \\
22.3 \\
19.1 \\
21.1\end{array}$ \\
\hline \multicolumn{3}{|c|}{$\begin{array}{c}\|=1,74\| \\
d r=16 \\
a=0,01 \text { weezijdig } \\
\mathrm{kr}, \text { grens: } 2,921 \\
\text { niet sign. } \\
\text { geen verw. } \mathrm{H}_{0}-\mathrm{B}\end{array}$} & $\begin{array}{c}\text { pat. } \\
\text { nr. } \\
1 . \\
2 . \\
3 . \\
4 . \\
5 .\end{array}$ & $\begin{array}{l}2.80 \\
\text { voor } \\
31.5 \\
29.5 \\
25.5 \\
29.5 \\
24.0\end{array}$ & 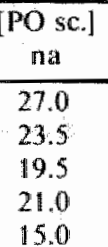 & \multicolumn{3}{|c|}{$\begin{array}{c}c=2,510 \\
d r=16 \\
a=0,01 \text { weerijdig } \\
\mathrm{kr} \text {. grens } 2,92 \\
\text { niet sign. } \\
\text { geen verw. } H_{0 .} \text {. }\end{array}$} \\
\hline \multicolumn{3}{|c|}{$\mathrm{H}_{0}-\mathrm{B} 2$} & $\begin{array}{l}6 \\
7\end{array}$ & $\begin{array}{l}21.5 \\
23.0\end{array}$ & $\begin{array}{l}18.0 \\
18.0\end{array}$ & \multicolumn{3}{|c|}{$H_{0}-B \cdot 6$} \\
\hline $\begin{array}{l}\text { pat.. } \\
\text { nr. }\end{array}$ & $\begin{array}{r}2: 00 C \\
\text { yoor }\end{array}$ & $C$ skl & $\begin{array}{c}8 \\
9 \\
10 \\
11\end{array}$ & $\begin{array}{l}18.0 \\
25.5 \\
28.0 \\
30.5\end{array}$ & $\begin{array}{r}9.5 \\
15.0 \\
21.0 \\
26.0\end{array}$ & $\begin{array}{l}\text { pat. } \\
\text { nr. }\end{array}$ & $27 \mathrm{GOC}$ & $\begin{array}{c}\text { OCC sikj } \\
\text { na }\end{array}$ \\
\hline $\begin{array}{c}1 . \\
2 . \\
3 \\
4 \\
5 \\
6 \\
7 \\
8 \\
9 \\
10 \\
11 \\
12\end{array}$ & $\begin{array}{r}26.3 \\
34.3 \\
30.3 \\
32.5 \\
33.2 \\
23.7 \\
26.9 \\
18.0 \\
17.0 \\
27.2 \\
31.8 \\
31.8 \\
\text { t }=0.9 \\
\text { dr }=1 \\
0.01 \text { tw } \\
\text { r. grens } \\
\text { niet sig } \\
\text { verw. H }\end{array}$ & $\begin{array}{l}21.2 \\
26.0 \\
22.1 \\
32.5 \\
29.2 \\
32.5 \\
24.5 \\
17.0 \\
17.0 \\
27.4 \\
37.8 \\
28.4\end{array}$ & 12 & $\begin{array}{l}=5_{y} \\
\mathrm{df}= \\
01 \mathrm{tw} \\
\text { grens } \\
\text { gnifik } \\
\text { rpen }\end{array}$ & 16 & $\begin{array}{c}1 . \\
2 . \\
3 . \\
4 . \\
5 . \\
6 . \\
7 . \\
8 . \\
9 . \\
10 . \\
12 . \\
\mathrm{t}=1 \\
\alpha= \\
\mathrm{k} \\
\mathrm{n} \\
\text { geer }\end{array}$ & $\begin{array}{l}20.3 \\
22.8 \\
30.0 \\
37.4 \\
17.3 \\
24.0 \\
27.4 \\
28.1 \\
28.4 \\
24.3 \\
30.9 \\
981 \\
0.01 \text { tw } \\
\text { grens: } \\
\text { t signifi } \\
\text { verw. }\end{array}$ & $\begin{array}{l}19.4 \\
23.1 \\
27.5 \\
29.2 \\
17.0 \\
21.4 \\
23.9 \\
24.0 \\
24.7 \\
24.7 \\
21.2 \\
=11 \\
\text { ijdig } \\
06 \\
\text { nt } \\
\text { B } 6\end{array}$ \\
\hline
\end{tabular}


VERVOLG BIJLAGE 7. Toetsing der B-hypothesen

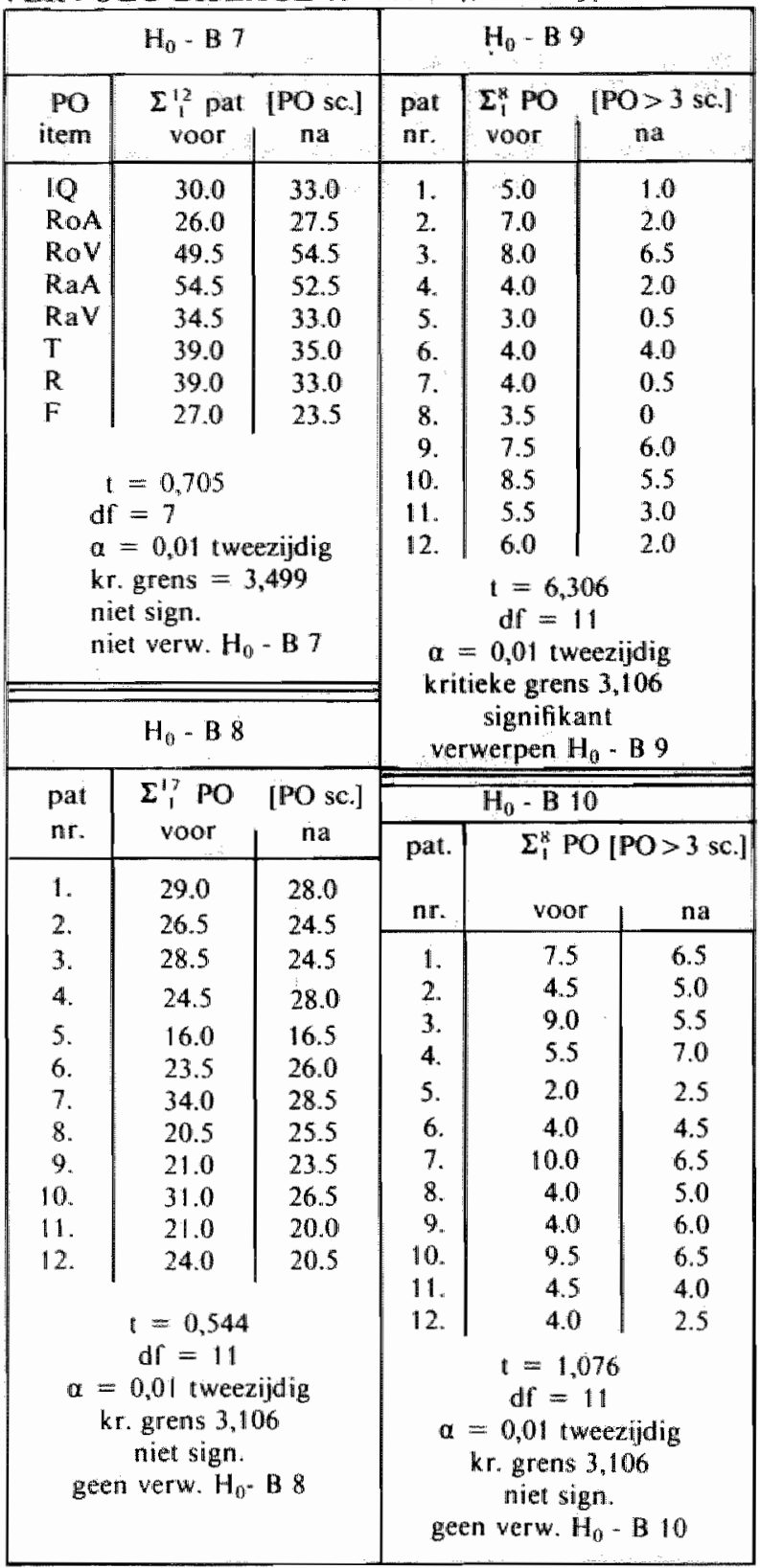

Uit bovenstaande toetsingsbevindingen kan gekonkludeerd worden:

le. Er bestaal geen verschill in gemiddelden der GOCC-scores vóot en na de bethandeling, zowel bij experimentele als kontrolegroep.

2e. Er bestaat geen verschil in gemiddelden der $\mathrm{PO}$-scores vóo en na de kontroleperiode bij de kontrolegroep.

3e. Er bestaat wel verschil in gemiddelden der PO-scores váö en nat de behandeling bij experimentele groep.

Bij deze konklusie wordt een fout van 0,01 geaksepteerd. 
VER VOLG BIILAGE 7.

Toetsing der C-hypothesen.

Alleen Hypothese $\mathrm{H}_{\sigma}-\mathrm{C} 2$ kont voor verdere toetsing in aanmerking.

Per apan PO-kriterium zal worden bezien in hoeverre deze mulhypothese kan worden werworpen.

Uit de verzameltabel blikt dat de $1 \mathrm{Q}$-skores bij de experimentelle groep voór en na toetsing gelijk zijn. Derhalve lijk took toetsing voor dit PO-kriterium overbodig en kan de nulhypothese wat betreft $1 \mathrm{Q}$ niet worden verworpen:

\begin{tabular}{|c|c|c|c|c|c|c|c|c|}
\hline$H_{\mathrm{sit}}<2$ & \multirow{2}{*}{$\begin{array}{l}\text { WoA } \\
\text { Po-shloriag } \\
\text { voor }\end{array}$} & \multirow{2}{*}{ 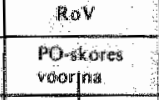 } & \multirow{2}{*}{ 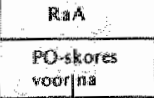 } & $\mathbb{R a V}$ & & $\mathrm{R}$ & \multicolumn{2}{|l|}{$\mathrm{F}$} \\
\hline 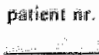 & & & & $\begin{array}{l}\text { PO-fkorex } \\
\text { vonr na: }\end{array}$ & $\begin{array}{l}\text { Po-skorea } \\
\text { roordnat }\end{array}$ & $\begin{array}{l}\text { Polmikotes } \\
\text { woonina }\end{array}$ & $\begin{array}{l}\text { POLG } \\
\text { Rotr }\end{array}$ & ortes \\
\hline $\begin{array}{l}1 \\
2 . \\
3 \\
4 . \\
5 \\
6 \\
7 . \\
8 \\
9 . \\
10 . \\
11 . \\
12 .\end{array}$ & 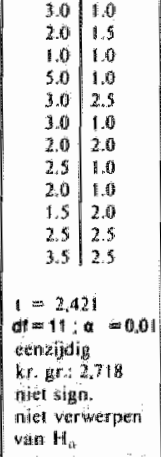 & 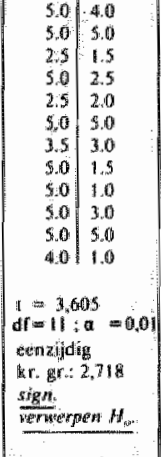 & 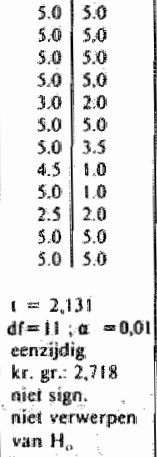 & 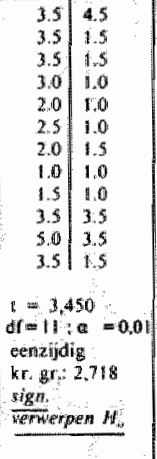 & 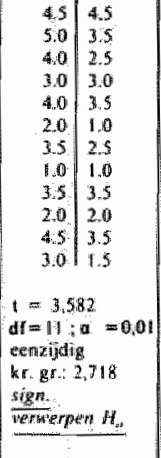 & 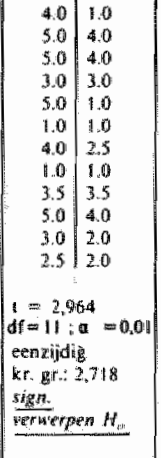 & $\begin{array}{r}3.5 \\
2.0 \\
2.0 \\
3.0 \\
2.5 \\
1.0 \\
1.0 \\
1.0 \\
2.0 \\
5.0 \\
2.0 \\
1.5\end{array}$ & 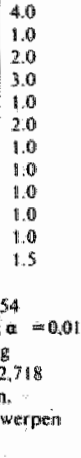 \\
\hline & 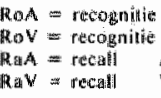 & $\begin{array}{l}\text { Wisueel } \\
\text { Aluditicf } \\
\text { Wisued }\end{array}$ & $\begin{array}{l}=\text { Regelmat } \\
=\text { Fouthat }\end{array}$ & & & & & \\
\hline
\end{tabular}




\section{CURRICULUM VITAE}

J. A. Schuerman, geboren 4-12*1931 te Goes, volgde na het eindexamen H.B.S.-B aldaar de H.T.S. te Amsterdam. Met een onderbreking van twee jaar militaire dienst, werkte hij bij het Nationaal Lucht- en Ruimtevaart Laboratorium te Amsterdam, alwaar hij in 1962 aan de Gemeentelijke lniversiteit tevens begon met de studie psychologie. Met als hoofdrichting persoonlijkheidsleer behaalde liij in 1970 het doktoraalexamen psychologie, waama hijzich specialiseerde in de gedragstherapie. Als psycholoog werd hij aangesteld in het psychiatrisch centrum "Licht en Kracht" te Assen ten behoeve van de klinische psychodiagnostiek en psychotherapie van psychiatrische patiënten.

In 1972 werd hij aangesteld als hoofd van de afdeling psychologie van het Revalidatie Centrum ..Hoensbroeck”. Als medewerker van de capaciteitsgroep Medische Psychologie van de Medische Faculeit Maastricht werkte hij o.a. als opleider en supervisor mee aan de opleiding van gedragstherapeuten en psychotherapeuten in het kader van het Instituut voor Multidisciplinaire Psychotherapie van de Stichting Geestelijke Gezondheidszorg te Mastricht. Vanaf 1973 werkte hij in het Revalidatie Centrum "Hoensbroeck" aan de ontwikkeling van de revalidatiepsychologie met name wat betreft de toepassing van leertheoretische verworvenheden en gedragstherapeutische methodieken ten behoeve van cerebraal gestoorden. In een specifiek daarop toegespitst researchproject zal hij aan deze ontwikkeling de eerstkomende jaren blijven werken.

Publicaties:

- Psychologische diagnostiek en behandelingsmogelijkheden bij hersentraumata Meta Medica 1974, 5 (p. 98-102)

- Perspektief voor de Contusio Cerebri in de Revalidatie I en II. De Psycholoog 1975, resp. 10/3 (p. 83-95) en 10/5 (p. 227-251).

- Gedragsverandering. Ned. Tijdschrift voor Fysiotherapie 1977, 7/8. 